\title{
Evaluación de una intervención formativa y de apoyo social "INFOSA-DEM» dirigida a cuidadores informales de personas con demencia en relación con la sobrecarga y el bienestar emocional
}

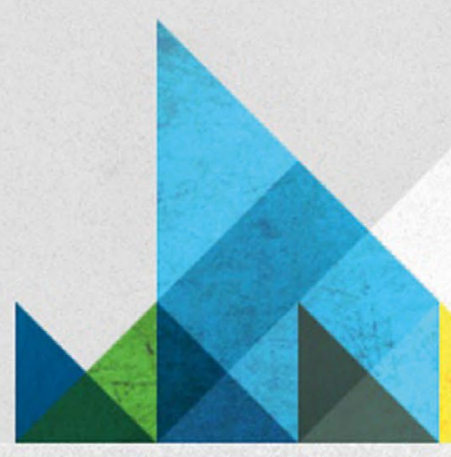

TESIS DOCTORAL

Autora:

Doctoranda Cindy E. Frías Torres

Directora de la tesis:

UNIVERSITAT

JAUME•I Adelaida Zabalegui Yárnoz 



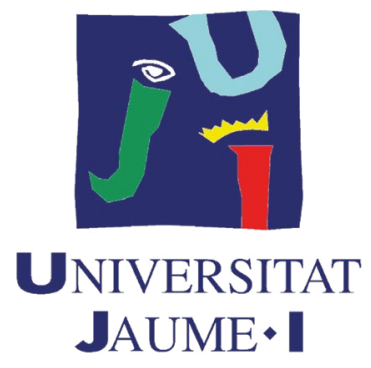

Programa de Doctorado en Ciencias de la Enfermería

Escuela de Doctorado de la Universitat Jaume I

\section{Evaluación de una intervención formativa y de apoyo social "INFOSA-DEM» dirigida a cuidadores informales de personas con demencia en relación con la sobrecarga y el bienestar emocional}

Memoria presentada por Cindy E. Frías Torres para optar al grado de doctor/a por la Universitat Jaume I

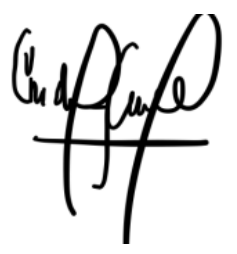

Doctoranda

Cindy E. Frías Torres

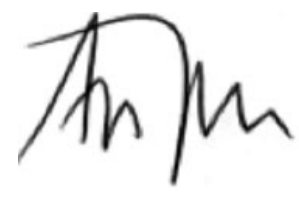

Directora de tesis Adelaida Zabalegui Yárnoz 


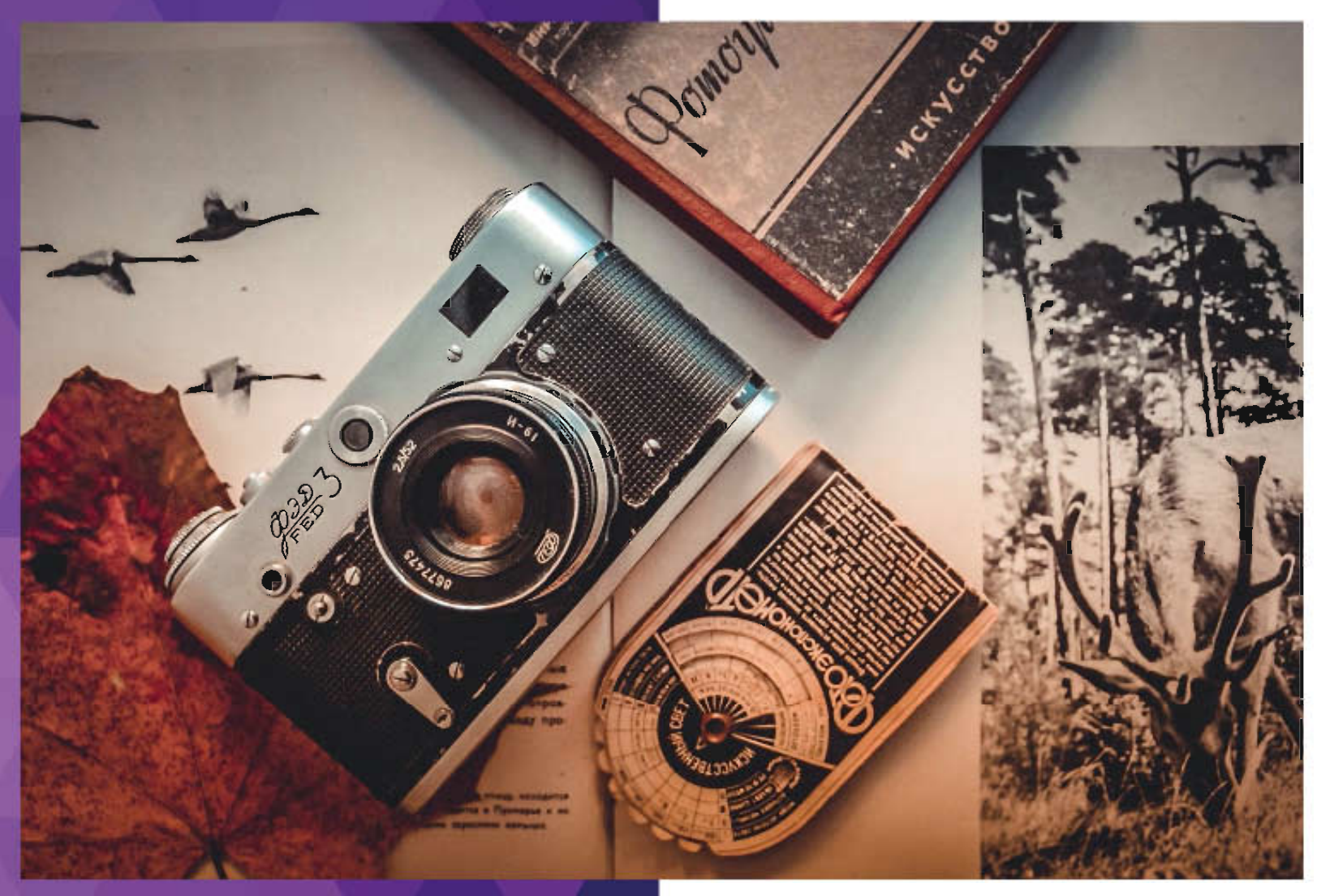




\section{Evaluación de una intervención formativa y de apoyo social «INFOSA-DEM » dirigida a cuidadores informales de personas con demencia en relación con la sobrecarga y el bienestar emocional}

Programa de Doctorado en Ciencias de la Enfermería Escuela de Doctorado de la Universitat Jaume I

Memoria presentada por Cindy E. Frías Torres para optar al grado de doctor/a por la Universitat Jaume I

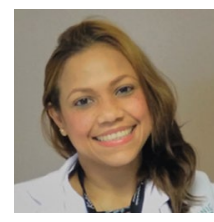

Doctoranda:

Cindy E. Frías Torres

Directora de tesis:

Adelaida Zabalegui Yárnoz

Castelló de la Plana, Mayo 2021 
El estudio INFOSA-DEM ha sido financiado por la Fundació La Marató de TV3.

Subvención número: 20144410. 
"Se supone que los desafíos de la vida no están para paralizarte; están para ayudarte a descubrir quién eres.»

Bernice Johnson Reagon

«Son nuestras decisiones las que muestran quiénes somos realmente, más que nuestras habilidades.» 


\section{Tesis por compendio de publicaciones científicas}

\section{Artículo 1}

Effectiveness of a psychoeducational intervention for caregivers of People With Dementia with regard to burden, anxiety and depression: A systematic.

Autores: Cindy E. Frías, Marta García-Pascual, Mercedes Montoro, Nuria Ribas, Ester Risco, Adelaida Zabalegui.

J Adv Nurs. 2020; 76(3): 787-802. https://doi.org/10.111/jan.14286.

Factor de Impacto: 2.561. Quartil: Q1.

\section{Artículo 2}

Psychoeducational intervention on burden and emotional well-being addressed to informal caregivers of people with dementia.

Autores: Cindy E. Frias, Ester Risco, Adelaida Zabalegui.

Psychogeriatrics. 2020; 20(6): 900-909. https://doi.org/10.1111/psyg.12616.

Factor de Impacto: 1.75. Quartil: Q2.

\section{Artículo 3}

Informal Caregivers' Roles in Dementia. The Impact on Their Quality of Life.

Autores: Cindy E. Frias, Ester Cabrera, Adelaida Zabalegui.

Life (Basel). 2020; 10(11): 251. https://doi.org/10.3390/life10110251.

Factor de Impacto: 2.991. Quartil: Q1. 


\section{Artículo 4}

INFOSA-DEM: programa dirigido a figuras cuidadoras de personas con demencia.

Autores: Cindy E. Frías, Marta García-Pascual, Estela Solbes-Pina, Teresa Jordi-Ferran, Irene Torrero-Capilla, Ester Risco, Ana Ma Rodríguez-Lavandeira, Elisabeth Calvo-Fernández, Adelaida Zabalegui.

Metas Enferm. 2020; 23(4): 16-24. https://doi.org/10.35667/

MetasEnf.2019.23.1003081581.

\section{Artículo 5}

The INFOSA-DEM programme. An intervention for caregivers.

Autores: Cindy E. Frías Torres, Ester Risco, Adelaida Zabalegui.

Enviado a Psychogeriatrics

Factor de Impacto: 1.75. Quartil: Q2. 


\section{Agradecimientos}

Durante los años que he empleado en el desarrollo de esta tesis doctoral, ha sido fundamental el apoyo incondicional de personas que me han regalado parte de su tiempo para despejar dudas, añadir comentarios o simplemente darme apoyo emocional para seguir adelante. Por ello, es importante para mí dedicarles unas líneas, que realmente se quedan cortas para agradecerles su ayuda.

A la Dra. Adela Zabalegui, mi directora de tesis, a quien quiero agradecer su confianza desde el primer momento y la oportunidad de ser parte de su equipo y de participar en su proyecto. Quiero darle las gracias por su cercanía y su sinceridad en todo momento, por transmitirme su conocimiento y por el soporte en los momentos duros.

A la Dra. Ester Risco, porque siempre me ha brindado su ayuda en cualquier momento, por desenmarañar mis ideas investigativas y por transmitirme su conocimiento. A mi anterior cap de Enfermería, que más que mi «jefa» ha sido una madre y me ofreció su apoyo laboralmente en una de las etapas más duras de mi vida. Gracias igualmente a mi actual cap de Enfermería, Laura Cardete, por haber confiado en mí y por haberme dado la oportunidad de trabajar a su lado en este nuevo proyecto asistencial.

Gracias a la Dra. Zuleima Cogollo, quien desde mis estudios de pregrado ha sido un ejemplo para mí, como enfermera y como docente. Gracias, querida Zuleima Cogollo, por darme la oportunidad de ser parte del equipo de docencia de mi casa académica, la Universidad de Cartagena.
Gracias a las enfermeras Elisabeth Calvo y Ana María Rodríguez por ayudarme en el reclutamiento de los participantes. Gracias a Marta García, Irene Torrero, Teresa Jordi y Estela Solbes por vuestra ayuda en las entrevistas y en los seguimientos.

Quiero hacer una mención especial a todos los cuidadores y pacientes entrevistados durante la investigación, sobre todo por haber aceptado compartir vuestras experiencias y emociones durante las semanas que estuvimos reunidos formando los grupos de cuidadores para la intervención.

Gracias a mis compañeros y amigos del hospital (Azahara López, Noelia Alcaraz, Soraya Sabater, Isabel Agasi, Marina Garriga...) y a todos los que se convirtieron en la «familia COVID».

Por último, y no menos importante, quiero dar las gracias infinitamente a mi familia, especialmente a mi pequeño Santi, mi motor, mi hijo adorado, mi príncipe, mi todo...

Gracias a mis amados padres, Vidal y Nury, quienes me han transmitido los genes de la templanza, del positivismo y de la lucha por conseguir lo que te propones; quienes me han apoyado incansablemente y no me han dejado desfallecer. Sin ustedes nada hubiese sido posible, los amo muchísimo. Gracias también a mis queridos hermanos, Shirley, Ariel y Óscar, quienes desde China y desde Colombia me han trasmitido su alegría y su energía positiva, ¡los amo!

A Dios, gracias por tanto. 


\section{Tabla de contenido}

Tesis por compendio de publicaciones científicas

Agradecimientos

Índice

1.Listado de siglas y acrónimos

2. Resumen

3. Introducción

3.1. El envejecimiento

3.2. Concepto de demencia

3.2.1. Demencias de tipo degenerativo

3.2.1.1. La enfermedad de Alzheimer

3.2.1.2. La demencia vascular

3.2.1.3. La demencia de cuerpos de Lewy

3.2.1.4. La demencia frontotemporal

3.2.2. Otras causas de demencia

3.2.3. Diagnóstico de la demencia

3.2.4. Síntomas psicológicos y conductuales de la demencia

3.2.5. Tratamiento de la demencia

3.2.5.1. Tratamiento farmacológico

3.2.5.2. Tratamiento no farmacológico

3.3. La demencia y la familia

3.3.1. El cuidador informal

3.3.2. Necesidades del cuidador informal

3.3.3. Impacto del rol de cuidador en la sobrecarga y en el bienestar emocional

3.4. Intervenciones de enfermería basadas en la psicoeducación

3.4.1. Impacto de la psicoeducación en el cuidador informal 
4. Objetivos 42

4.1. Objetivo general $\quad 44$

4.2. Objetivos específicos

5. Hipótesis 46

6. Publicaciones científicas $\quad \mathbf{5 0}$

6.1. Artículo $1 \quad 52$

$\begin{array}{ll}\text { 6.2. Artículo } 2 & 70\end{array}$

6.3. Artículo $3 \quad 82$

6.4. Artículo $4 \quad 96$

6.5. Artículo $5 \quad 108$

$\begin{array}{lr}\text { 7. Discusión } & 132\end{array}$

$\begin{array}{ll}\text { 8. Limitaciones } & 140\end{array}$

9. Conclusiones 144

10. Implicaciones para la práctica 148

11. Futuras investigaciones 152

12. Referencias bibliográficas 156

$\begin{array}{lr}\text { 13. Anexos } & 168\end{array}$ 


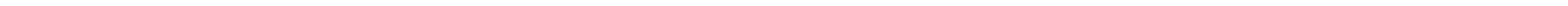


1. Listado de siglas y acrónimos

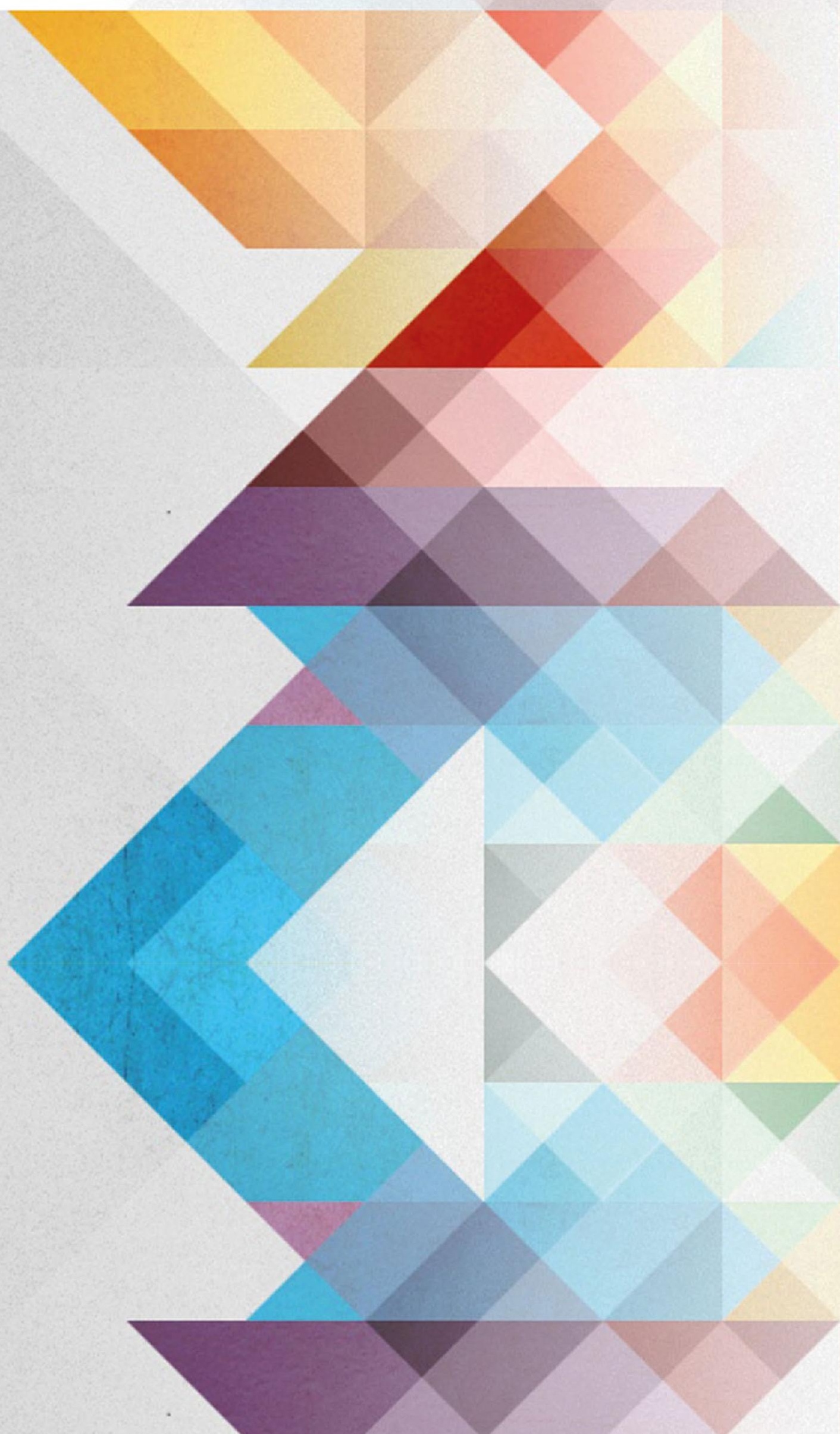




\section{Listado de siglas y acrónimos}

ABVD: actividades básicas de la vida diaria

CCI: Índice de Comorbilidad de Charlson

CdV: calidad de vida

Cl: cuidador informal

CIE-10: Clasificación Internacional de Enfermedades (10.a edición)

CRA: Cuestionario de Aspectos de Reacción

DV: demencia vascular

EA: enfermedad de Alzheimer

GC: grupo control

Gl: grupo intervención

GDS: Escala de Deterioro Global

MMSE: Mini-Mental State Examination

NPI: Inventario de Síntomas Neuropsiquiátricos

OCDE: Organización para la Cooperación y el Desarrollo Económico

OMS: Organización Mundial de la Salud

PcD: persona con demencia

QoL-AD: Quality of Life in Alzheimer's Disease

RUD: Escala de la Utilización de Recursosen Demencia

SPCD: síntomas psicológicos y conductuales de la demencia

TIC: tecnologías de la información y la comunicación

TNF: tratamiento no farmacológico

VIH: Virus de inmunodeficiencia humana

ZBI: Entrevista de Zarit Burden 


\section{Resumer}




\section{Resumen}

\section{Antecedentes}

En nuestro entorno, como en otros países europeos, la atención a las personas con demencia sigue siendo un reto muy grande, ya que constituye una de las principales causas de discapacidad debido a la pérdida progresiva de la autonomía, por lo que es necesario el acompañamiento de un cuidador informal durante el curso de la enfermedad.

A partir de ello, se evidencia que las principales necesidades de los cuidadores son recibir información con respecto a la evolución y el progreso de la enfermedad, obtener formación específica, con el objetivo de adquirir habilidades y poder afrontar actividades cotidianas, y la necesidad de recibir apoyo social para poder minimizar el riesgo que pueda suponer el rol de cuidador en su propia salud. De esta manera, se podría fomentar la autonomía de la persona con demencia y evitar su institucionalización, al mismo tiempo que se refuerza el autocuidado de los cuidadores informales.

\section{Objetivo}

Con el fin de orientar el proceso y encaminar el afrontamiento y las habilidades de los cuidadores, este estudio presenta el desarrollo, la implementación y la evaluación del impacto de un nuevo enfoque psicoeducativo del programa INFOSA-DEM (Información, Formación y Apoyo Social) en cuidadores informales de personas con demencia en relación con la sobrecarga y el bienestar emocional.

\section{Método}

La investigación se realizó en tres etapas. En la primera etapa, el estudio recogió los datos mediante una revisión de la literatura y del balance of care, con la participación de cuidador informal, en relación con las mejores prácticas para cada tipo de situación paciente-cuidador, los recursos comunitarios con que se cuenta en la actualidad y las necesidades principales del cuidador informal para la construcción y el desarrollo del programa psicoeducativo INFOSA-DEM, por medio del trabajo multidisciplinar de profesionales expertos en la atención de personas con deterioro cognitivo. Los datos se recopilaron durante siete meses en el año 2017.

En la segunda etapa de construcción del programa, para comprender mejor el contexto de la implementación del programa INFOSA-DEM, se realizó una prueba piloto para analizar la aplicabilidad y llevar a cabo las modificaciones pertinentes a partir de las conclusiones del pilotaje del programa. Así mismo, se elaboró un análisis de la población para iniciar el reclutamiento, la implementación del programa y el seguimiento de la muestra. En la tercera etapa se evaluó el impacto del programa INFOSA-DEM a partir de visitas domiciliarias y de la evaluación de las variables estudiadas.

El estudio fue aprobado por el Comité de Ética de Investigación Clínica. Se trata de un estudio longitudinal multicéntrico con observaciones (pre y post intervención I a los tres meses y post intervención II a los seis meses) en el domicilio de los participantes, de diseño semi experimental, no aleatorizado, con grupo intervención y grupo control. El estudio se ha desarrollado en el área metropolitana de Barcelona y se seleccionó a 160 personas con demencia y sus cuidadores informales, distribuidos en el grupo control, que recibió el cuidado estándar, y en el grupo intervención, que recibió el programa INFOSA-DEM.

La eficacia de la intervención INFOSA-DEM se ha evaluado mediante instrumentos válidos y fiables en el contexto del estudio, dirigidos a cuidadores informales y personas con demencia. En la persona con demencia se ha evaluado el grado de deterioro mediante la Escala Mini-Mental; la calidad de vida mediante la Quality of Life in Alzheimer's Disease (QoL-AD) y la presencia de comorbilidades con el Índice de Comorbilidad de Charlson (CCI) y la Escala de Deterioro Global (GDS). En el Cl se evaluó el grado de sobrecarga utilizando la versión española de la Entrevista de Zarit Burden (ZBI); el bienestar emocional se evaluó mediante el Cuestionario de Salud General (GHQ-12); la reacción del cuidador en relación con su rol, con el Cuestionario de Aspectos de Reacción (CRA); la calidad de vida del cuidador, mediante la Quality of Life Scale (EQ-5D); la atención formal e informal en la demencia, con la Escala de la Utilización de Recursos en Demencia (RUD) y los síntomas neuropsiquiátricos en las personas con demencia, con el Inventario de Síntomas Neuropsiquiátricos (NPI).

Para el análisis estadístico de los datos se utilizó la prueba t pareada o prueba t de muestras independientes para 
comparar los resultados entre la visita inicial y el seguimiento a los tres meses. Se empleó La prueba de tendencia monótona de Jonckheere-Terpstra, equivalente a la prueba de Kruskal-Wallis, para las categorías ordenadas, para verificar la posible existencia de tendencia entre visitas sucesivas (línea de base, tres meses y seguimiento a los seis meses). Se analizaron las diferencias medias entre el grupo intervención y grupo control y se calcularon sus intervalos de confianza del $95 \%$. Todas las pruebas de significancia fueron de dos colas y los valores de $p<0,05$ se consideraron significativos.

\section{Resultados}

La revisión previa de la literatura científica sugiere que las intervenciones con un enfoque psicoeducativo son intervenciones prácticas que pueden tener efectos protectores en el cuidador mediante el suministro de información sobre la enfermedad y los consejos sobre cómo responder a determinadas situaciones, que pueden mejorar la autoeficacia y reducir la ansiedad y los síntomas de depresión. Teniendo en cuenta lo anterior, se diseñó el programa INFOSA-DEM, que consiste en cinco sesiones informativas-formativas y de apoyo emocional y social impartidas de manera consecutiva durante una semana, con una duración aproximada de 90 minutos/sesión/día, para grupos reducidos de 8 a 10 cuidadores. Los temas principales fueron conceptos básicos de la demencia, nutrición, descanso, medicación, alteraciones físicas y cognitivas y manejo de síntomas conductuales, así como problemas afectivos en el paciente y en el cuidador informal, técnicas de comunicación verbal y no verbal, autocuidado del cuidador e información sobre recursos y servicios comunitarios disponibles. Además, se elaboraron cuatro vídeos explicativos y una guía práctica para cuidadores.

El 68\% de los cuidadores informales manifestaron en la entrevista basal tener un buen estado de salud y un bienestar psicológico dentro de los valores normales y el 32\% presentaban un nivel bajo de bienestar psicológico. El $45 \%$ manifestaron tener una sobrecarga de leve a moderada, y el 49\% un nivel elevado de sobrecarga. Se observó un efecto positivo de la intervención en la sobrecarga y en el estado psicológico, con mejoras no significativas. Se observó un empeoramiento de la sobrecarga y del bienestar emocional en los cuidadores informales del grupo control. Teniendo en cuenta las tres visitas, la mejora de la sobrecarga y del bienestar emocional se mantuvieron en el grupo intervención después de seis meses, aunque las diferencias no fueron estadísticamente significativas. Así mismo, se observó un empeoramiento a lo largo del tiempo estadísticamente significativo en el grupo control $(p<0,017)$ en lo que respecta a la autoestima y en las interferencias en las actividades diarias.

\section{Conclusiones}

Este estudio representa un nuevo enfoque con una intervención psicoeducativa eficaz para cuidadores informales de personas con demencia en el ámbito comunitario que respalda la importancia de la orientación como medida de apoyo social, con el fin de ir encaminando el estilo de afrontamiento del cuidador informal a partir del desarrollo de habilidades y de la reestructuración cognitiva. Además, se describe la importancia proporcionar a los cuidadores informales programas de formación, información y apoyo emocional y social para poder satisfacer las necesidades expresadas por los cuidadores para mejorar la calidad del cuidado que se brinda a personas con demencia en el contexto domiciliario y mejorar también su propio bienestar.

\section{Implicaciones para la práctica}

Esta intervención puede implementarse en la práctica diaria de la atención domiciliaria formal en los Centros de Atención Primaria, con el fin de ayudar a los profesionales de la salud a mejorar la gestión de la atención de la demencia en la comunidad y para mejorar la calidad de la atención y la calidad de vida de las personas con demencia y sus cuidadores informales.

Palabras claves: Cuidadores informales, demencia, cuidado domiciliario, intervención psicoeducativa, sobrecarga, bienestar emocional, distrés. 


\section{Background}

In our environment, as in other European countries, caring for people with dementia continues to be a very great challenge, since it constitutes one of the main causes of disability due to the progressive loss of autonomy, which is why accompaniment is necessary informal caregiver during the course of illness.

From this, it is evident that the main needs of caregivers are to receive information regarding the evolution and progress of the disease, obtain specific training, with the aim of acquiring skills and being able to face daily activities, and the need to receive social support in order to minimize the risk that the role of caregiver may pose to their own health. In this way, the autonomy of the person with dementia could be promoted and their institutionalization avoided, at the same time that the self-care of informal caregivers is reinforced.

\section{Objective}

In order to guide the process and direct the coping and skills of caregivers, this study presents the development, implementation and evaluation of the impact of a new psychoeducational approach of the INFOSA-DEM program (information, training and social support), in informal caregivers of people with dementia in relation to their burden and emotional well-being.

\section{Method}

The investigation was carried out in three phases. In the first phase, the study collected the data through a review of the literature and the balance of care, with the participation of the informal caregiver, in relation to the best practices for each type of patient-caregiver situation, the community resources with which It currently addresses the main needs of the informal caregiver for the construction and development of the INFOSA-DEM psychoeducational program, through the multidisciplinary work of professionals who are experts in caring for people with cognitive impairment. The data was collected over seven months in 2017.

In the second phase of program construction, to better understand the context of the INFOSA-DEM program implementation, a pilot test was carried out to analyze the applicability and carry out the pertinent modifications based on the conclusions of the program piloting. Likewise, a population analysis was carried out to initiate recruitment, program implementation, and sample monitoring. In the third phase, the impact of the INFOSA-DEM program was evaluated based on home visits and the evaluation of the variables studied.

The study was approved by the Clinical Research Ethics Committee. This is a multicenter longitudinal study with observations (pre and post intervention I at three months and post intervention II at six months) in the homes of the participants, with a semi-experimental, non-randomized design, with an intervention group and a control group. The study was carried out in the metropolitan area of Barcelona and 160 people with dementia and their informal caregivers were selected, distributed in the control group, who received standard care, and in the intervention group, who received the INFOSA-DEM program.

The efficacy of the INFOSA-DEM intervention has been evaluated using valid and reliable instruments in the context of the study, aimed at informal caregivers and people with dementia. In the person with dementia, the degree of deterioration has been evaluated using the Mini-Mental Scale; quality of life using the Quality of Life in Alzheimer's Disease (QoL-AD) and the presence of comorbidities with the Charlson Comorbidity Index (CCI) and the Global Impairment Scale (GDS). In the IC, the degree of overload was evaluated using the Spanish version of the Zarit Burden Interview (ZBI); emotional well-being was assessed using the General Health Questionnaire (GHQ-12); the caregiver's reaction in relation to her role, with the Reaction Aspects Questionnaire (CRA); the quality of life of the caregiver, using the Quality of Life Scale (EQ-5D); formal and informal care in dementia, with the Dementia Resource Utilization Scale (RUD) and neuropsychiatric symptoms in people with dementia, with the Neuropsychiatric Symptom Inventory (NPI).

For the statistical analysis of the data, the paired $t$ test or independent samples $t$ test was used to compare the results between the initial visit and the follow-up at three months. The Jonckheere-Terpstra monotonic trend test, equivalent to the Kruskal-Wallis test, was used for the ordered categories, to verify the possible existence of a trend between successive visits (baseline, three months and follow-up at six months). The mean differences between the 
intervention group and the control group were analyzed and their $95 \%$ confidence intervals were calculated. All tests of significance were two-tailed and $p$ values $<0.05$ were considered significant.

\section{Results}

The previous review of the scientific literature suggests that interventions with a psychoeducational approach are practical interventions that can have protective effects on the caregiver by providing information about the disease and advice on how to respond to certain situations, which can improve self-efficacy and reduce anxiety and depression symptoms. Taking into account the above, the INFOSA-DEM program was designed, which consists of five informative-educational and emotional and social support sessions given consecutively during a week, with an approximate duration of 90 minutes / session / day, for groups reduced from 8 to 10 caregivers. The main topics were basic concepts of dementia, nutrition, rest, medication, physical and cognitive alterations and management of behavioral symptoms, as well as affective problems in the patient and in the informal caregiver, verbal and non-verbal communication techniques, self-care of the caregiver. and information on available community resources and services. In addition, four explanatory videos and a practical guide for caregivers were produced.

In the baseline interview, $68 \%$ of the informal caregivers stated that they had a good state of health and psychological well-being within normal values, and $32 \%$ had a low level of psychological well-being. $45 \%$ reported having a mild to moderate overload, and $49 \%$ a high level of overload. A positive effect of the intervention on overload and psychological state was observed, with non-significant improvements. A worsening of emotional burden and well-being was observed in informal caregivers in the control group. Taking into account the three visits, the improvement in burden and emotional well-being were maintained in the intervention group after six months, although the differences were not statistically significant. Likewise, a statistically significant worsening was observed over time in the control group $(p<0.017)$ with regard to self-esteem and interference in daily activities.

\section{Conclusions}

This study represents a new approach with an effective psychoeducational intervention for informal caregivers of people with dementia in the community setting that supports the importance of counseling as a measure of social support, in order to guide the coping style of the informal caregiver from of skill development and cognitive restructuring. In addition, it describes the importance of providing informal caregivers with training programs, information and emotional and social support in order to meet the needs expressed by caregivers to improve the quality of care provided to people with dementia in the home context and also improve their own well-being.

\section{Implication for Practice}

This intervention can be implemented in the daily practice of formal home care in Primary Care Centers, in order to help health professionals to improve the management of dementia care in the community and to improve the quality of the care and quality of life of people with dementia and their informal caregivers.

Key Words: Informal caregivers, dementia, home care, psychoeducational intervention, burden and psychological well-being, distress 


\section{Resum}

\section{Antecedents}

En el nostre entorn, com en altres països europeus, l'atenció a les persones amb demència segueix sent un repte molt gran, ja que constitueix una de les principals causes de discapacitat a causa de la pèrdua progressiva de l'autonomia, de manera que és necessari l'acompanyament d'un cuidador informal durant el curs de la malaltia.

A partir d'això, s'evidencia que les principals necessitats dels cuidadors són rebre informació pel que fa a l'evolució i el progrés de la malaltia, obtenir formació específica, amb l'objectiu d'adquirir habilitats i poder afrontar activitats quotidianes, i la necessitat de rebre suport social per poder minimitzar el risc que pugui suposar el paper de cuidador en la seva pròpia salut. D'aquesta manera, es podria fomentar l'autonomia de la persona amb demència i evitar la seva institucionalització, a el mateix temps que es reforça l'autocura dels cuidadors informals.

\section{Objectiu}

Per tal d'orientar el procés i encaminar l'afrontament i les habilitats dels cuidadors, aquest estudi presenta el desenvolupament, la implementació i l'avaluació de l'impacte d'un nou enfocament psicoeducatiu de el programa INFOSA-DEM (Informació, Formació i Suport Social) en cuidadors informals de persones amb demència en relació amb la sobrecàrrega i el benestar emocional.

\section{Mètode}

La investigació es va realitzar en tres etapes. A la primera etapa, l'estudi va recollir les dades mitjançant una revisió de la literatura i del balance of care, amb la participació de cuidador informal, en relació amb les millors pràctiques per a cada tipus de situació pacient-cuidador, els recursos comunitaris amb què es compte en l'actualitat i les necessitats principals del cuidador informal per a la construcció i el desenvolupament de el programa psicoeducatiu INFOSA-DEM, per mitjà de la feina multidisciplinar de professionals experts en l'atenció de persones amb deteriorament cognitiu. Les dades es van recopilar durant set mesos en l'any 2017.

En la segona etapa de construcció de el programa, per comprendre millor el context de la implementació de el programa INFOSA-DEM, es va realitzar una prova pilot per analitzar l'aplicabilitat i dur a terme les modificacions pertinents a partir de les conclusions del pilotatge de el programa. Així mateix, es va elaborar una anàlisi de la població per iniciar el reclutament, la implementació de el programa i el seguiment de la mostra. En la tercera etapa es va avaluar l'impacte de el programa INFOSA-DEM a partir de visites domiciliàries i de l'avaluació de les variables estudiades.

L'estudi va ser aprovat pel Comitè d'Ètica d'Investigació Clínica. Es tracta d'un estudi longitudinal multicèntric amb observacions (pre i post intervenció I al cap de tres mesos i post intervenció II als sis mesos) en el domicili dels participants, de disseny semi experimental, no aleatoritzat, amb grup intervenció i grup control. L'estudi s'ha desenvolupat a l'àrea metropolitana de Barcelona i es va seleccionar a 160 persones amb demència i els seus cuidadors informals, distribuïts en el grup control, que va rebre la cura estàndard, i en el grup intervenció, que va rebre el programa INFOSA-DEM.

L'eficàcia de la intervenció INFOSA-DEM s'ha avaluat mitjançant instruments vàlids i fiables en el context de l'estudi, dirigits a cuidadors informals i persones amb demència. En la persona amb demència s'ha avaluat el grau de deteriorament mitjançant l'Escala Mini-Mental; la qualitat de vida mitjançant la Quality of Life in Alzheimer 's Disease (QOL-AD) i la presència de comorbiditats amb l'Índex de Comorbiditat de Charlson (CCI) i l'Escala de Deteriorament Global (GDS). Al Cl es va avaluar el grau de sobrecàrrega utilitzant la versió espanyola de l'Entrevista de Zarit Burden (ZBI); el benestar emocional es va avaluar mitjançant el qüestionari de salut general (GHQ-12); la reacció del cuidador en relació amb el seu rol, amb el Qüestionari d'Aspectes de Reacció (CRA); la qualitat de vida del cuidador, mitjançant la Quality of Life Scale (EQ-5D); I'atenció formal i informal a la demència, amb l'Escala de la Utilització de Recursos en Demència (RUD) i els símptomes neuropsiquiàtrics en les persones amb demència, amb l'Inventari de símptomes neuropsiquiàtrics (NPI).

Per a l'anàlisi estadística de les dades es va utilitzar la prova t aparellada o prova t de mostres independents per 
comparar els resultats entre la visita inicial i el seguiment als tres mesos. Es va emprar La prova de tendència monòtona de Jonckheere-Terpstra, equivalent a la prova de Kruskal-Wallis, per a les categories ordenades, per verificar la possible existència de tendència entre visites successives (línia de base, tres mesos i seguiment als sis mesos) . Es van analitzar les diferències mitjanes entre el grup intervenció $i$ grup control $i$ es van calcular els seus intervals de confiança de l'95\%. Totes les proves de significació van ser de dues cues i els valors de $p<0,05$ es van considerar significatius.

\section{Resultats}

La revisió prèvia de la literatura científica suggereix que les intervencions amb un enfocament psicoeducatiu són intervencions pràctiques que poden tenir efectes protectors en el cuidador mitjançant el subministrament d'informació sobre la malaltia i els consells sobre com respondre a determinades situacions, que poden millorar l'autoeficàcia i reduir l'ansietat i els símptomes de depressió. Tenint en compte l'anterior, es va dissenyar el programa INFOSA-DEM, que consisteix en cinc sessions informatives-formatives i de suport emocional i social impartides de manera consecutiva durant una setmana, amb una durada aproximada de 90 minuts / sessió / dia, per a grups reduïts de 8 a 10 cuidadors. Els temes principals van ser conceptes bàsics de la demència, nutrició, descans, medicació, alteracions físiques i cognitives i maneig de símptomes conductuals, així com problemes afectius en el pacient i en el cuidador informal, tècniques de comunicació verbal i no verbal, autocura del cuidador i informació sobre recursos i serveis comunitaris disponibles. A més, es van elaborar quatre vídeos explicatius i una guia pràctica per a cuidadors.

El 68\% dels cuidadors informals van manifestar en l'entrevista basal tenir un bon estat de salut $i$ un benestar psicològic dins dels valors normals i el $32 \%$ presentaven un nivell baix de benestar psicològic. El $45 \%$ van manifestar tenir una sobrecàrrega de lleu a moderada, i el $49 \%$ un nivell elevat de sobrecàrrega. Es va observar un efecte positiu de la intervenció en la sobrecàrrega i en l'estat psicològic, amb millores no significatives. Es va observar un empitjorament de la sobrecàrrega i del benestar emocional en els cuidadors informals de el grup control. Tenint en compte les tres visites, la millora de la sobrecàrrega i de el benestar emocional es van mantenir en el grup intervenció després de sis mesos, tot i que les diferències no van ser estadísticament significatives. Així mateix, es va observar un empitjorament al llarg de el temps estadísticament significatiu en el grup control $(p<0,017)$ pel que fa a l'autoestima i en les interferències en les activitats diàries.

\section{Conclusions}

Aquest estudi representa un nou enfocament amb una intervenció psicoeducativa eficaç per a cuidadors informals de persones amb demència en l'àmbit comunitari que dóna suport a la importància de l'orientació com a mesura de suport social, per tal d'anar encaminant l'estil d'afrontament del cuidador informal a partir de el desenvolupament d'habilitats i de la reestructuració cognitiva. A més, es descriu la importància proporcionar als cuidadors informals programes de formació, informació i suport emocional i social per poder satisfer les necessitats expressades pels cuidadors per millorar la qualitat de la cura que es brinda a persones amb demència en el context domiciliari $i$ millorar també el seu propi benestar.

\section{Implicacions per a la pràctica}

Aquesta intervenció pot implementar-se en la pràctica diària de l'atenció domiciliària formal en els Centres d'Atenció Primària, per tal d'ajudar els professionals de la salut a millorar la gestió de l'atenció de la demència en la comunitat i per millorar la qualitat de l'atenció i la qualitat de vida de les persones amb demència i els seus cuidadors informals.

Paraules Claus: Cuidadors informals, demència, cures domiciliaries, intervenció psicoeducativa, sobrecàrrega, benestar emocional, distress. 


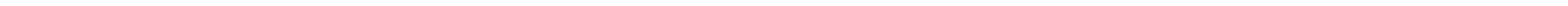


3. Introducción

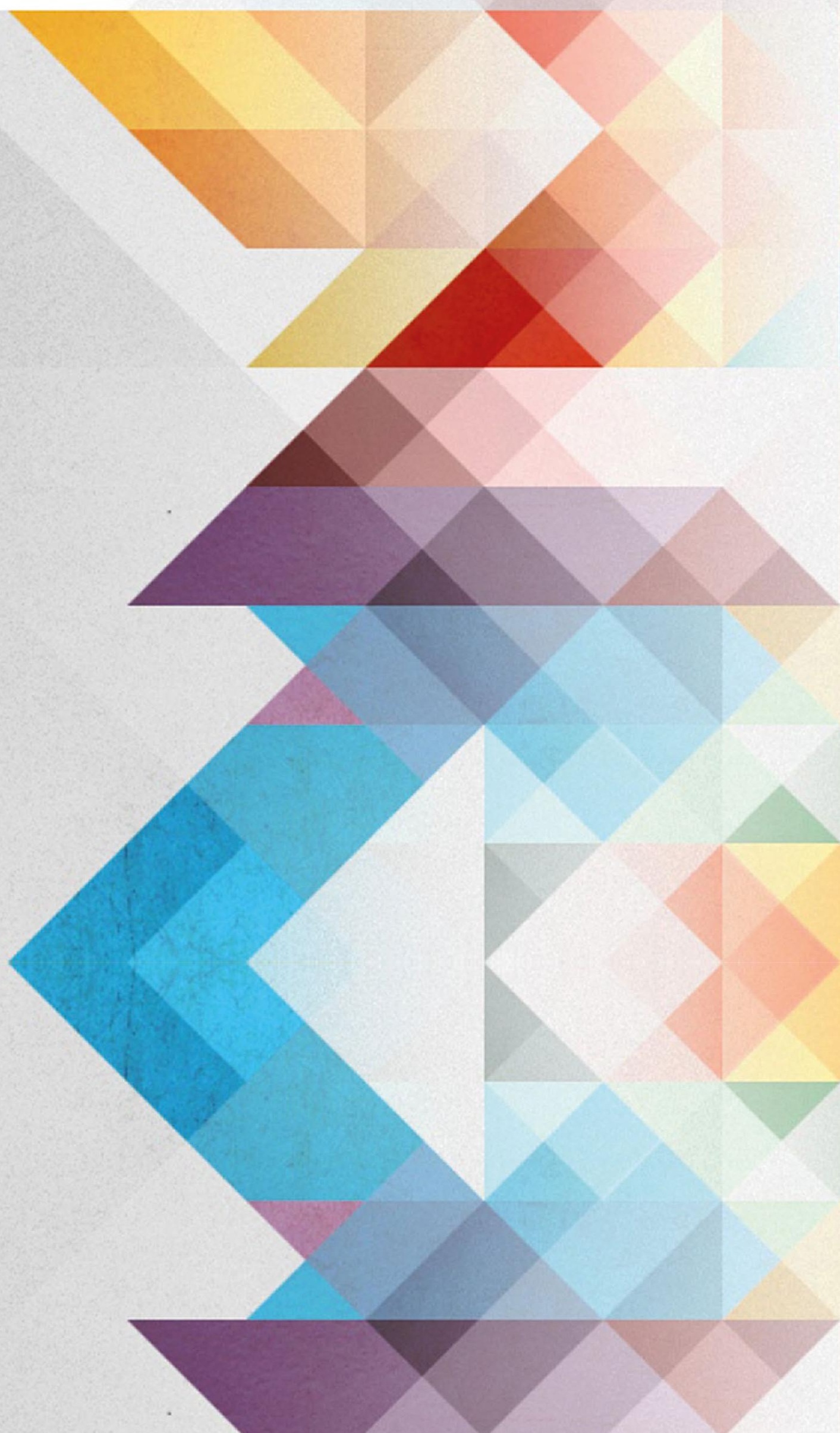




\subsection{El envejecimiento}

A partir de la transformación demográfica a nivel mundial, se estima que para el 2050, la población de más de 60 años aumente de 600 millones a casi 2000 millones, y además se prevé que se duplique el porcentaje de personas de 60 años o más, pasando de un $10 \%$ a un $21 \%$. Todo este incremento porcentual será posible por el descenso de la tasa de natalidad, de la tasa mortalidad infantil, del avance de la tecnología, de los factores ambientales, del proceso migratorio y del aumento de la calidad de vida de la población general ${ }^{(1)}$. De hecho, el incremento de adultos mayores será más rápido y notorio en los países en desarrollo, donde se prevé que la población anciana se multiplique por cuatro en los próximos 50 años. Por esta razón, el envejecimiento es visto como un fenómeno global, con consecuencias económicas, sociales y políticas ${ }^{(2)}$.

El envejecimiento como parte del proceso natural e irreversible de transformación del ser humano, se asocia a factores individuales y colectivos relacionados con la presencia de enfermedades crónicas, no transmisibles que reducen las capacidades físicas, mentales y sociales de la persona, vinculados a deterioro, minusvalía, discapacidad y vejez. De esta manera, el concepto de envejecimiento se analiza como el conjunto de cambios morfológicos, funcionales y psicológicos que conllevan a cambios en la estructura y función de los diferentes sistemas, aumentando la vulnerabilidad del individuo al estrés ambiental y a la aparición de enfermedades que cursan con deterioro cognitivo ${ }^{(2)}$.

\subsection{Concepto de demencia}

Dentro de todo el proceso de envejecimiento se manifiestan diferentes enfermedades crónicas, entre las que destacan aquellas derivadas del proceso de deterioro cognitivo. La demencia es un término que se utiliza para describir los síndromes clínicos asociados con el deterioro progresivo e irreversible de múltiples funciones corticales superiores, incluido el lenguaje, la memoria, el cálculo, la comprensión, el pensamiento, las habilidades de aprendizaje y el juicio adecuado, que interfieren en la capacidad funcional y la vida diaria de la persona que la padece ${ }^{(3)}$.

Según el CIE-10, el déficit de estas funciones superiores afecta el funcionamiento global de la persona impidiéndole mantener una vida normal a nivel laboral, social e incluso familiar. De acuerdo con esta clasificación, el déficit se acompaña de deterioro del control emocional, del comportamiento social o de la motivación, produciendo en la persona un deterioro intelectual apreciable que repercute en sus actividades básicas de la vida diaria (ABVD), lo que le puede imposibilitar asearse y/o vestirse de forma autónoma, comer o incluso ir al baño ${ }^{(4,5)}$.

Se señala que para el diagnóstico de la enfermedad, es necesario que los síntomas se acompañen de una duración del cuadro de deterioro cognitivo no inferior a seis meses. Así mismo, se deberán obtener datos significativos a partir de la exploración del paciente y de la información que se pueda recabar de la anamnesis a una tercera persona, que por lo general será alguien de la familia o que por lo menos conviva con el paciente ${ }^{(6,7)}$.

La demencia en sí, es un problema de salud complejo, ya que según la Organización Mundial de la Salud (OMS) se espera que se diagnostiquen 10 millones de personas cada año. Por ello, la demencia, se encuentra dentro de las prioridades de salud pública en todo el mundo debido a su prevalencia, coste y profundo impacto social. En este sentido, la enfermedad supone un reto para todo el conjunto de profesionales de salud, en quienes el objetivo principal está basado en brindar una atención adecuada para mantener la independencia y participación de la persona con demencia (PCD) en su proceso asistencial y evitar su ingreso en centros de larga estancia ${ }^{(7)}$.

La demencia suele estar asociada con el desarrollo de comorbilidad, por la aparición de otras enfermedades como hipertensión, accidente cerebrovascular, diabetes y cardiopatía coronaria, lo que aumenta las necesidades de atención médica y el uso de otros tratamientos farmacológicos. Igualmente, las complicaciones relacionadas con la demencia son causas comunes de atención por diferentes profesionales sanitarios, ya que las consecuencias adversas a la enfermedad incluyen caídas, fragilidad, desnutrición, aumento de la tasa de mortalidad y el ingreso a centros de larga estancia ${ }^{(3)}$

Por lo tanto, la atención y el tratamiento de las personas con demencia conlleva a desafíos sustanciales para todas 
las personas involucradas, no solo por el deterioro cognitivo de las personas afectadas, sino también por los síntomas no cognitivos o neuro-psiquiátricos que surgen durante el curso de la enfermedad ${ }^{(8)}$.

El aumento progresivo de personas con deterioro cognitivo hace que sea fundamental el reconocimiento de los primeros signos y síntomas de la enfermedad, solicitando las pruebas adecuadas, diagnosticando formalmente $y$, finalmente, tratando a los pacientes. Sin embargo, en la actualidad, el diagnóstico puede ser un desafío. En las primeras etapas, puede ser difícil distinguir el deterioro de las capacidades cognitivas debido al envejecimiento normal y al deterioro cognitivo leve (DCL) que a menudo precede a la demencia ${ }^{(9)}$.

La detección temprana de algunas causas de la demencia pueden llegar a ser reversibles. Sin embargo, las causas más comunes de demencia, como la EA, no lo son. Las demencias se clasifican en función de sus características clínicas en demencias corticales, subcorticales y mixtas o en función de su etiología en demencias degenerativas ${ }^{(9,10,11)}$. A continuación se describen éstas últimas.

\subsubsection{Demencias de tipo degenerativo}

El proceso de diagnóstico de la demencia debe seguir una serie de pasos ordenados que permitan categorizar a la PcD dentro del tipo en el que se encuentre y valorar el grado de repercusión funcional, familiar y social. La presencia de afectación de la memoria será un requisito necesario para su diagnóstico ${ }^{(12)}$. Entre las demencias de tipo degenerativo destacan las de tipo Alzheimer, vascular, de cuerpos de Lewy y fronto-temporal ${ }^{(12,13,14)}$.

\subsubsection{La enfermedad de Alzheimer}

La EA constituye la demencia más frecuente, se diagnostica entre el 60 y $80 \%$ de las PcD. Se caracteriza por la acumulación gradual de seniles placas y ovillos neuro fibrilares en el cerebro que ocurre años antes de que aparezcan los síntomas clínicos ${ }^{(15)}$.

Es una demencia degenerativa primaria de inicio insidioso y curso progresivo, por lo que es más probable que los síntomas se desarrollen durante un período de 7 a 15 años.

La EA se caracteriza clínicamente por la pérdida de memoria y de otras funciones cognoscitivas, con síntomas psiquiátricos, de tipo depresivo o psicótico, y síntomas neuropsiquiátricos, por lo que los pacientes suelen ser llevados al médico de cabecera por sus familiares debido a los olvidos o cambios del comportamiento. Al principio, el individuo olvida acontecimientos recientes y tiene dificultades para realizar algunas tareas.

Igualmente, se pueden presentar disminución del apetito e insomnio. Toda esta sintomatología sugiere que la causa del trastorno es multifactorial, por cambios químicos y anatómicos de la estructura cerebral.

\subsubsection{La demencia vascular}

La DV también llamada demencia por infarto múltiple, representa el 15\% de todas las demencias. Es de inicio repentino, siendo el riesgo vascular un factor de riesgo que predispone a su aparición. A menudo, las personas con demencia vascular experimentan déficits neurológicos focales, como dificultad para hablar o función sensorial y motora, ya que la etiología de la enfermedad se debe a lesión vascular cerebral, de tipo isquémico, hemorrágico o hipóxico.

Por ello, se señala que la mayoría de afecciones vasculares pueden contribuir a la aparición de demencia vascular, incluido el accidente cerebrovascular y la enfermedad cerebrovascular (con o sin antecedentes de accidente cerebrovascular).

En este tipo de demencia, los estadios iniciales y la pérdida de memoria es menor, siendo más acentuadas las alteraciones del estado de ánimo, como la labilidad afectiva y la sintomatología depresiva, sin cambios significativos de la conducta ${ }^{(13,16)}$. 


\subsubsection{La demencia de cuerpos de Lewy}

Representa hasta el $25 \%$ de todas las demencias. Sin embargo, es difícil cuantificar su prevalencia, ya que a menudo se superpone a otras causas de demencia.

Es uno de los tipos más progresivos e irreversibles y está causada por el deterioro o la muerte neuronal como consecuencia de la aparición de depósitos de proteínas en las neuronas, conocidos como cuerpos de Lewy o pequeños intracitoplasmas en las esferas intraneurales que aparecen en tinción patológica e interrumpen el proceso de la neurotransmisión cerebral.

Los síntomas incluyen el deterioro de las funciones ejecutivas, la pérdida de la fluencia verbal y la alteración visoespacial y visoconstructiva. En ocasiones la memoria no se ve tan alterada. Cabe resaltar que las fluctuaciones cognitivas pueden presentarse con cambios bruscos, con posibles variaciones en un mismo día o una misma hora. Las alteraciones del contenido del pensamiento son muy frecuentes y se caracterizan por ser de tipo alucinatorio visual ${ }^{(13,15,16)}$.

\subsubsection{La demencia frontotemporal}

Representa aproximadamente entre el $5 \%$ y el $10 \%$ de las demencias. De inicio insidioso, típicamente en la quinta década del paciente, parece tener un fuerte componente hereditario. Por este motivo, es de los casos menos frecuentes y en ocasiones se asocia a patología psiquiátrica, debido a la sintomatología que presenta la PcD.

Este tipo de demencia afecta a los lóbulos frontales, que se encargan del comportamiento y las emociones, y a los lóbulos temporales, responsables de las funciones de la percepción, la audición, la memoria, el lenguaje, la comprensión, la emocionalidad, la percepción visual y el reconocimiento facial. Se desconocen las causas de este tipo de demencia, pero se ha relacionado con la mutación genética de los lóbulos afectados, que produce una disminución de su tamaño.

Los síntomas suelen variar en cada persona, dependiendo del predominio de las áreas afectadas y de su desarrollo, que preceden o acompañan a los déficits de memoria. Sin embargo, son notorios los cambios conductuales y de la personalidad, por lo que los pacientes pueden mostrarse desinhibidos, apáticos y poco empáticos en algunas situaciones. Así mismo, pueden aparecer compulsiones o rituales y descuido de la higiene personal e incluso pueden destacar un deterioro de la higiene personal y cambios en la alimentación, entre otros aspectos.

Por otra parte, puede aparecer una dificultad progresiva en el lenguaje y la comprensión, anomia (dificultad para nombrar objetos) o pérdida de la capacidad para reconocer el significado de las palabras. Este tipo de demencia se caracteriza también por la aparición de alteraciones en el movimiento, temblores, contracciones musculares, alteración en la coordinación, rigidez, dificultad para tragar o debilidad muscular.

Otro tipo de demencia frontotemporal es la enfermedad de Pick, que es una dolencia clínicopatológica importante que tiene atrofia circunscrita en el lóbulo frontotemporal ${ }^{(17)}$. Las personas con enfermedad de Pick manifiestan deterioro del lenguaje y alteraciones del comportamiento, que tienden a presentarse al principio de la enfermedad ${ }^{(13)}$.

\subsubsection{Otras causas de demencia}

La demencia se puede desarrollar con menos frecuencia en algunas patologías que afectan al sistema nervioso. Por ejemplo, los pacientes con hidrocefalia normotensiva pueden presentar deterioros cognitivos con alteraciones en la marcha y desarrollar demencia.

Otras enfermedades degenerativas, como algunos tipos de parálisis, la enfermedad de Huntington y la enfermedad de Parkinson, también pueden causar demencia; de hecho, casi el 30\% de las personas con Parkinson presentan demencia. En la enfermedad de Creutzfeldt-Jakob, el deterioro progresivo de la funcionalidad mental por la presencia de formas anormales de proteína priónica puede producir pérdida neuronal, con aparición de demencia.

Igualmente, en ciertas enfermedades infecciosas se pueden presentar síntomas asociados a la demencia. Por ejemplo el virus de Inmunodeficiencia humana $(\mathrm{VIH})$ es una de las causas de deterioro cognitivo que llevan a la aparición de síntomas asociados a la demencia, por lo que hasta el 7\% de los pacientes con síndrome de inmunodeficiencia adquirida (sida) pueden presentar demencia dentro de los primeros doce meses después del diagnóstico ${ }^{(13)}$. 


\subsubsection{Diagnóstico de la demencia}

Para el diagnóstico de la enfermedad se requiere una elaboración exhaustiva de la historia clínica en la que se identifique el empeoramiento de las capacidades cognitivas en el tiempo y que este empeoramiento esté asociado a problemas funcionales como la realización de las tareas del día a día (ir de compras, pagar facturas, conducir). Un familiar o amigo cercano debe confirmar la presencia de deterioro cognitivo y problemas funcionales. Así mismo, se llevará a cabo una breve prueba cognitiva para evaluar la memoria y un examen físico para valorar la fuerza, los reflejos y otros signos neurológicos. Y, por lo general, también se realizan analíticas sanguíneas y una exploración cerebral por medio de tomografía axial computarizada o resonancia magnética cerebral ${ }^{(16)}$.

Según el National Institute on Aging y la Alzheimer's Association, el diagnóstico de deterioro cognitivo y demencia requiere un déficit en al menos dos funciones cognitivas o conductuales, incluidos el aprendizaje y el recuerdo de la información, el razonamiento o la realización de tareas, la competencia visoespacial, el habla, la lectura y la escritura, el comportamiento y la personalidad ${ }^{(17) .}$

Los instrumentos de cribado varían según los dominios cognitivos y conductuales que evalúen. La herramienta de prueba cognitiva más utilizada es el Mini-Mental State Examination (MMSE). La administración requiere de 6 a 10 minutos, aunque puede llevar más tiempo dependiendo del grado de deterioro. El MMSE evalúa una amplia gama de dominios, que incluyen atención, lenguaje, memoria, orientación y competencia visoespacial ${ }^{(18,19)}$.

\subsubsection{Síntomas psicológicos y conductuales de la demencia}

En el transcurso de la enfermedad se presentan diferentes manifestaciones clínicas, físicas y mentales, entre las que destacan los síntomas psicológicos y conductuales de la demencia (SPCD).

Entre los síntomas psicológicos obtenidos a través de la entrevista con la PcD y su familia, destacan los síntomas depresivos, ansiosos y psicóticos y otros comportamientos problemáticos como deambular, conductas sexualmente inapropiadas y rechazo a ser atendidos ${ }^{(20,21)}$. Los síntomas psicóticos que predominan son las ideas delirantes y las alucinaciones. Los delirios más comunes tienen una dimensión paranoica e incluyen celotipias, abandono, robo y/o autorreferencialidad ${ }^{(18)}$.

Las ideas delirantes menos habituales que se pueden manifestar en la PcD incluyen el síndrome de Capgras, en el que un individuo piensa que su cónyuge o pariente ha sido reemplazado por una impostura idéntica, o la paramnesia reduplicativa, en la cual la persona cree que vive en una réplica de su casa que no es su hogar original (18). Entre los síntomas o signos conductuales más básicos obtenidos mediante la observación directa de la PcD encontramos, por ejemplo, los que se relacionan con los cambios conductuales (agresividad, hiperactividad motora, desinhibición) ${ }^{(21)}$.

Los SPCD generan sufrimiento en la persona que los padece y en la familia, agravan el deterioro cognitivo y funcional y precipitan la institucionalización. Pueden aparecer en cualquier momento de la enfermedad, con un patrón variable, por la influencia de factores psicológicos y ambientales ${ }^{(19)}$.

Desde la perspectiva biológica, los SPCD se explican por una combinación de factores anatómicos, bioquímicos y genéticos. La disfunción frontal ha sido descrita como el principal determinante de las alteraciones conductuales, ya sea debido a una alteración en los impulsos, con manifestación de apatía, hiperactividad, desinhibición, y cambios en la alimentación, o a un deficiente juicio o contraste con la realidad ${ }^{(20,21,19)}$. 


\subsubsection{Tratamiento de la demencia}

Actualmente aún no se ha encontrado ningún tratamiento curativo para la demencia, por lo que es necesario un abordaje terapéutico multidimensional que incluya intervenciones o tratamientos farmacológicos y tratamientos no farmacológicos (TNF), dirigidos a optimizar la cognición, la conducta y la función de las PcD y que, además, atienda las necesidades de los cuidadores ${ }^{(18,19)}$.

La eficacia del tratamiento de la demencia dependerá de la instauración de un tratamiento farmacológico temprano para intentar reducir el riesgo vascular que supone la enfermedad. Así mismo, los beneficios clínicos de los fármacos utilizados en la demencia se relacionan con un retraso en la progresión de los síntomas durante varios meses, sin tener un efecto curativo total ${ }^{(22,23)}$.

De hecho, aún se siguen desarrollando nuevos fármacos para retrasar los síntomas característicos de la enfermedad. La utilización de medicamentos para el tratamiento de los SPCD debe estar enmarcada en una serie de principios fundamentales e intentar prevenir o aliviar por sí mismos los síntomas, individualizando el tratamiento para atender a las características concretas de cada paciente.

El manejo inicial de los SPCD ha de basarse en la comprensión del proceso biológico que produce la demencia, la asunción de la perspectiva personal de la PcD y la búsqueda y la modificación de posibles factores desencadenantes, como, por ejemplo, procesos médicos intercurrentes, necesidades no cubiertas, factores ambientales, etcétera $(21,23)$.

El primer paso del tratamiento sería realizar una evaluación completa de la PcD, a partir de la información de los antecedentes médicos y psiquiátricos, incluido el uso de sustancias. A continuación, se deberá especificar la presencia de SPCD y el contexto que rodea el comportamiento, definiendo detalles importantes que incluyan la descripción del comportamiento, el momento, el inicio, la gravedad, los aspectos precipitantes y las consecuencias de la conducta, y los antecedentes de comportamiento. Igualmente, se deben identificar los factores psicológicos o ambientales que contribuyen a la aparición de SPCD ${ }^{(24)}$.

\subsubsection{Tratamiento farmacológico}

En el tratamiento farmacológico de la demencia se utilizan los inhibidores de la acetilcolinesterasa (AChEI) en las fases leves a moderadas. Se han detectado cambios globales cognitivos, de comportamiento y funcionales tras su uso. No obstante, la enfermedad sigue progresando a pesar del tratamiento y la magnitud de la eficacia promedio es modesta. Se utilizan la tacrina, el donepezilo, la rivastigmina y la galantamina ${ }^{(25,26)}$.

La presencia de SPCD en la PCD obliga a valorar al paciente antes de prescribir un tratamiento farmacológico, pues muy frecuentemente los síntomas son secundarios a causas orgánicas, desde un dolor cuya cualidad y localización no nos sabe describir el enfermo hasta un simple estreñimiento. En estos casos, el tratamiento de la enfermedad causal resolvería también el trastorno psicológico o conductual. Por lo general, se utilizan antipsicóticos para tratar la agitación o la psicosis, siempre que las medidas ambientales y los TNF no sean suficientes $(25,26,27,28)$.

Los antipsicóticos atípicos (como la risperidona, la quetiapina o la olanzapina) pueden ser la mejor opción en comparación con los antipsicóticos típicos como el haloperidol, con los que existe un riesgo de aparición de signos extrapiramidales. En el tratamiento de los síntomas depresivos puede considerarse el uso de antidepresivos como los inhibidores de recaptación de la serotonina (fluoxetina, citalopram, paroxetina) y para los síntomas ansiosos se suelen añadir al tratamiento los ansiolíticos; son preferibles los de acción corta (alprazolam) a los de acción intermedia (bromazepam) o larga (diazepam) ${ }^{(26)}$. 
Tabla 1. Posibles fármacos para el tratamiento de los síntomas neuropsiquiátricos en la demencia

\begin{tabular}{|c|c|c|c|c|c|}
\hline Clase & Fármaco & $\begin{array}{l}\text { Nombre } \\
\text { comercial }\end{array}$ & $\begin{array}{c}\text { Dosis } \\
\text { (mg/día) }\end{array}$ & $\begin{array}{c}\text { N.o de } \\
\text { tomas/día }\end{array}$ & $\begin{array}{c}\text { Usos/ } \\
\text { comentarios }\end{array}$ \\
\hline & Fluoxetina & $\begin{array}{c}\text { Adofen }^{\circledR}, \text { Prozac }^{\circledast}, \\
\text { Luramon }^{\circledR}, \\
\text { Reneuron }^{\circledR}\end{array}$ & 20 & 1, por la mañana & Perfil estimulante \\
\hline & Fluvoxamina & Dumirox $^{\circledR}$ & $50-150$ & 2 & $\begin{array}{l}\text { Útil en conductas } \\
\text { reiterativas }\end{array}$ \\
\hline & Sertralina & $\begin{array}{c}\text { Altisbén }{ }^{\oplus}, \text { Aremis }^{\oplus}, \\
\text { Aserin }^{\circledast}\end{array}$ & $50-100$ & 1, por la mañana & $\begin{array}{c}\text { Útil en la depresión } \\
\text { asociada a } \\
\text { enfermedad } \\
\text { cerebrovascular }\end{array}$ \\
\hline & Paroxetina & $\begin{array}{l}\text { Arapaxel }^{\oplus}, \text { Casbol }^{\oplus}, \\
\text { Daparox }^{\oplus}, \text { Frosinor }^{\circledast}, \\
\text { Motivan } \\
\text {, Seroxat } \\
\text { y Xetin }\end{array}$ & 20 & 1, por la mañana & Perfil sedante \\
\hline & Citalopram & $\begin{array}{l}\text { Prisdal }^{\circledast} \text { y } \\
\text { Seropram }^{\circledast}\end{array}$ & $10-20$ & 1, por la mañana & $\begin{array}{c}\text { Útil en la depresión } \\
\text { asociada a } \\
\text { enfermedad } \\
\text { cerebrovascular }\end{array}$ \\
\hline \multirow[t]{6}{*}{ Antidepresivos } & Escitalopram & $\begin{array}{c}\text { Cipralex }^{\oplus}, \text { Esertia }^{\oplus} \mathrm{y} \\
\text { Heipram }^{\circledast}\end{array}$ & $5-10$ & 1, por la mañana & $\begin{array}{c}\text { Útil en la depresión } \\
\text { asociada a } \\
\text { enfermedad } \\
\text { cerebrovascular }\end{array}$ \\
\hline & Trazodona & Deprax $^{\circledast}$ & $50-300$ & $1-3$ & $\begin{array}{l}\text { Útil en la ansiedad } \\
\text { y el insomnio, aun } \\
\text { sin síntomas de } \\
\text { depresión }\end{array}$ \\
\hline & Venlafaxina & 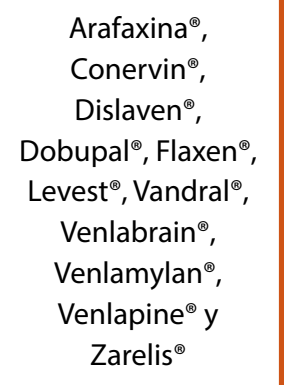 & $75-150$ & 1, por la mañana & $\begin{array}{c}\text { Útil en la depresión } \\
\text { geriátrica }\end{array}$ \\
\hline & Duloxetina & Cymbalta $^{\oplus}$, Xeristar $^{\oplus}$ & $60-90$ & $1-2$ & $\begin{array}{l}\text { Favorable en la } \\
\text { cognición }\end{array}$ \\
\hline & Mirtazapina & $\begin{array}{l}\text { Rexer }^{\circledR}, \text { Vastat }^{\oplus} \mathrm{y} \\
\text { Afloyan }\end{array}$ & $15-30$ & 1, por la mañana & $\begin{array}{c}\text { Útil para el aumento } \\
\text { del apetito }\end{array}$ \\
\hline & Bupropión & Elontril $^{\oplus}$, Zyntabac $^{\oplus}$ & $150-300$ & 1, por la mañana & Útil en la apatía \\
\hline \multirow[t]{2}{*}{ Benzodiacepinas } & Midazolam & $\begin{array}{l}\text { Buccolam }^{\circledast} \\
\text { Dormicum }^{\circledast}\end{array}$ & $3,7-15$ & $1-3$ & $\begin{array}{c}\text { Útil si es necesaria } \\
\text { una sedación rápida } \\
\text { y breve }\end{array}$ \\
\hline & Lorazepam & $\begin{array}{l}\text { Donix }^{\oplus}, \text { Idalprem }^{\circledast} \text {, } \\
\text { Orfidal }^{\oplus}, \text { Placinoral }^{\circledast}\end{array}$ & $0,5-2$ & $1-3$ & $\begin{array}{l}\text { Tomar entre } 1 \text { - } 2 \\
\text { semanas }\end{array}$ \\
\hline
\end{tabular}




\section{Introducción}

\begin{tabular}{|c|c|c|c|c|c|}
\hline & Lormetazepam & Noctamid $^{\circledR}$ & $0,5-2$ & $1-3$ & $\begin{array}{l}\text { Tomar entre } 1 \text { - } 2 \\
\text { semanas }\end{array}$ \\
\hline & Clonazepam & Rivotril $^{\circledR}$ & $0,5-2$ & 1, por la noche & $\begin{array}{c}\text { Útil en el } \\
\text { tratamiento de la } \\
\text { conducta del sueño } \\
\text { REM }\end{array}$ \\
\hline & Alprazolam & Trankimazin $^{\circledR}$ & $0,5-1,5$ & $1-2$ & Mejora el temblor \\
\hline & Clorazepato & Tranxilium $^{\circledR}$ & $5-10$ & 1 & $\begin{array}{c}\text { Solo en dosis únicas, } \\
\text { no continuadas }\end{array}$ \\
\hline & Diazepam & Valium $^{\circledast}$ & 5 & 1 & $\begin{array}{c}\text { Solo en dosis únicas, } \\
\text { no continuadas }\end{array}$ \\
\hline Neurolépticos & Haloperidol & $\mathrm{Haldol}^{\circledR}$ & $0,5-6$ & $1-3$ & $\begin{array}{c}\text { Eficaz en la } \\
\text { agresividad y en } \\
\text { situaciones agudas }\end{array}$ \\
\hline Típicos & Zuclopentixol & Clopixol Depot $^{\circledR}$ & $5-15$ & $\begin{array}{c}1-2, \text { inicio por la } \\
\text { noche }\end{array}$ & $\begin{array}{c}\text { Eficaz en la } \\
\text { agitación, la } \\
\text { agresividad y } \\
\text { las conductas } \\
\text { disruptivas }\end{array}$ \\
\hline \multirow[t]{4}{*}{ Atípicos } & Risperidona & $\begin{array}{c}\text { Risperdal }^{\circledR}, \\
\text { Risperdal flas }^{\circledR}\end{array}$ & $0,5-2$ & $1-3$ & $\begin{array}{c}\text { Eficaz en síntomas } \\
\text { psicóticos y en } \\
\text { SCPD }\end{array}$ \\
\hline & Olanzapina & $\begin{array}{l}\text { Zolafren }^{\circledR}, \\
\text { Zypadhera }^{\oplus}, \\
\text { Zyprexa }^{\circledR}\end{array}$ & $2,5-10$ & 1, por la noche & $\begin{array}{c}\text { Eficaz en síntomas } \\
\text { psicóticos y en } \\
\text { SCPD }\end{array}$ \\
\hline & Quetiapina & Seroquel ${ }^{\circledR}$ & $50-400$ & $\begin{array}{c}1 \text { - 3, inicio por la } \\
\text { noche }\end{array}$ & Perfil sedante \\
\hline & Aripiprazol & Abilify $^{\circledR}$ & $2,5-15$ & 1, por la mañana & $\begin{array}{l}\text { Eficaz en la } \\
\text { agresividad }\end{array}$ \\
\hline \multirow[t]{5}{*}{ Antiepilépticos } & Gabapentina & Neurontin $^{\circledR}$ & $300-900$ & $\begin{array}{c}1-3, \text { inicio por la } \\
\text { noche }\end{array}$ & $\begin{array}{l}\text { Eficaz en la } \\
\text { ansiedad y el } \\
\text { insomnio }\end{array}$ \\
\hline & Pregabalina & Lyrica ${ }^{\circledR}$ & $25-150$ & $\begin{array}{c}1-2, \text { inicio por la } \\
\text { noche }\end{array}$ & $\begin{array}{l}\text { Eficaz en la } \\
\text { ansiedad y el } \\
\text { insomnio }\end{array}$ \\
\hline & Carbamazepina & Tegretol $^{\circledR}$ & $200-400$ & $\begin{array}{c}2-3, \text { inicio por la } \\
\text { noche }\end{array}$ & $\begin{array}{c}\text { Eficaz en la } \\
\text { hostilidad y la } \\
\text { agresividad }\end{array}$ \\
\hline & Ácido valproico & 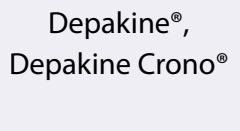 & $500-1000$ & $\begin{array}{c}1 \text { - 3, inicio por la } \\
\text { noche }\end{array}$ & $\begin{array}{l}\text { Eficaz en la } \\
\text { agitación y la } \\
\text { agresividad }\end{array}$ \\
\hline & Topiramato & Topamax $^{\circledR}$ & $50-150$ & 2 & $\begin{array}{c}\text { Eficaz en la } \\
\text { hipertimia y la } \\
\text { agresividad }\end{array}$ \\
\hline \multirow[t]{2}{*}{ Otros fármacos } & Clometiazol & Distraneurine $^{\circledR}$ & $192-384$ & 1 , por la noche & $\begin{array}{l}\text { Eficaz en el } \\
\text { insomnio }\end{array}$ \\
\hline & Metilfenidato & $\begin{array}{l}\text { Concerta }^{\circledR}, \\
\text { Medikinet }^{\circledast}, \\
\text { Rubifen }^{\circledR}\end{array}$ & $10-40$ & $\begin{array}{c}1 \text { - 2, inicio por la } \\
\text { mañana }\end{array}$ & Eficaz en la apatía \\
\hline
\end{tabular}




\subsubsection{Tratamiento no farmacológico}

En relación con el TNF, a lo largo de los años se ha ido profundizando en la implementación y la evaluación del impacto de este tratamiento en las PcD, que dependerá de las condiciones del paciente.

En la actualidad, las terapias no farmacológicas se definen como las intervenciones de naturaleza no química que pueden realizarse y replicarse en el paciente o en el cuidador para conseguir, potencialmente, un beneficio importante.

El TNF persigue múltiples y diferentes objetivos, entre los que cabe destacar, por ser uno de los más relevantes, estimular, mantener o mejorar la capacidad mental y el rendimiento cognitivo, la autonomía y el funcionamiento global del paciente; mantener o fortalecer la interacción con el entorno, evitar o minimizar el estrés y mejorar la CdV de la PcD y su familiar ${ }^{(29,30)}$.

Entre las diferentes intervenciones orientadas como TNF que se ofrecen a las PcD se encuentran aquellas orientadas a la mejora de los síntomas cognitivos, ya que estos implican una gran pérdida de la funcionalidad de la persona (31). En este sentido, se ofrecen programas de estimulación cognitiva, que consisten en ejercicios de estimulación de funciones preservadas y no alteradas, con el objetivo de enlentecer el proceso de pérdida de las funciones cognitivas.

La estimulación cognitiva implica una variedad de actividades placenteras, como juegos de palabras, rompecabezas, música, cocina, jardinería y debatir eventos pasados y presentes, y generalmente la lleva a cabo personal capacitado con pequeños grupos de cuatro a cinco personas. Cada sesión tiene una duración de 45 minutos, y deben realizarse como mínimo dos veces por semana. Se basan en la terapia de orientación a la realidad, que se desarrolló en la década de 1950 para contrarrestar la confusión y la desorientación de las personas mayores durante las hospitalizaciones ${ }^{(25)}$

Así mismo, se ofrece la reminiscencia como forma de mantener el pasado personal y perpetuar la identidad personal. Para ello, se emplean técnicas como la estimulación, la comunicación, la socialización y el entretenimiento, a partir de las cuales se generan memorias e interpretaciones presentes de experiencias pasadas.

La terapia de reminiscencia es una intervención no farmacológica que implica la discusión de experiencias, eventos y actividades pasadas con miembros de la familia u otros grupos de personas. La intervención utiliza materiales como fotografías, libros, periódicos antiguos y elementos familiares del pasado para inspirar reminiscencias y facilitar que las personas compartan y valoren sus experiencias. La reminiscencia ha demostrado eficacia en síntomas depresivos y de agitación, con la consiguiente mejora del estado de ánimo de los pacientes y disminución de la agitación ${ }^{(25,29)}$

Por otro lado, destacan las terapias orientas a la estimulación sensorial y el ejercicio.

La aromaterapia se propone como una intervención complementaria para tratar una amplia gama de problemas de salud, incluidos la falta de sueño y los síntomas conductuales de las PcD. Se basa en el uso de productos o aceites vegetales aromáticos y mezclas de compuestos aromáticos en forma de masaje o aplicación tópica, inhalación e inmersión en agua ${ }^{(25,29,30)}$.

El ejercicio físico ha demostrado beneficio en síntomas como la agitación, el sundowning, o síndrome del ocaso, o el vagabundeo. Parece que este beneficio está relacionado con la sincronización de los ritmos circadianos de la $\operatorname{PcD}{ }^{(31)}$.

Otro tipo de intervención es la musicoterapia, que se puede ofrecer de manera grupal o individual y es una buena opción como acompañamiento de otra TNF. Se ofrece este tipo de intervención porque la música relaja y evoca recuerdos placenteros, además de que se ha comprobado que la receptividad a la música puede perdurar hasta las fases tardías de la demencia, por lo que ofrece la posibilidad de que la PCD se comunique con el entorno (22, 23). Diferentes estudios apuntan que el tratamiento con musicoterapia es beneficioso para mejorar las alteraciones conductuales, la ansiedad y la agitación en PcD ${ }^{(32,33)}$.

A nivel internacional, las guías de práctica clínica para la demencia recomiendan que se utilicen enfoques no farmacológicos para el tratamiento de los SPCD como enfoque de primera línea y que los tratamientos farmacológicos se utilicen además de los enfoques no farmacológicos. Si bien la calidad de la base de evidencia para los enfoques no farmacológicos es generalmente menor que para los tratamientos farmacológicos, cabe destacar que las estimaciones del tamaño del efecto de estas intervenciones son similares a las de los tratamientos farmacológicos y que el TNF no está asociado a eventos adversos ${ }^{(29,30) .}$ 


\section{Introducción}

\subsection{La demencia y la familia}

La demencia, como primera causa de discapacidad y dependencia en las personas mayores, requiere un cuidado desde el inicio de la enfermedad que, en la mayoría de los casos, es proporcionado por la familia en el domicilio. Las PcD pueden convivir 8 o 10 años con el diagnóstico, tiempo en el que la persona se vuelve cada vez más dependiente de los demás para el desempeño de las actividades ${ }^{(34)}$.

Por lo tanto, la demencia representa no solamente un problema sanitario, sino también socioeconómico y familiar, puesto que son las familias las que asumen la mayor parte del gasto. Un $87 \%$ del total de la dedicación del cuidado de la PcD lo asume la familia, invirtiendo una media de 70 horas semanales para atender a su ser querido, lo que supone un total de 286 horas al mes.

Por este motivo, expertos en el área del cuidado familiar en la demencia sostienen que la enfermedad afecta a todo el sistema familiar, dado que compromete y modifica la dinámica y el funcionamiento normal de todo el grupo ${ }^{(34,35)}$.

El Sistema Nacional de Salud español estima que el gasto medio en la atención a la PcD se encuentra entre los 27.000 y los 37.000 euros anuales, de los que la mayoría del gasto asociado a la atención es el derivado del cuidado informal (77-81\%), y solo el 10-13\% corresponde al gasto sanitario, más el 6-12\% del cuidado profesional (36).

Teniendo en cuenta que la gran mayoría de los cuidados a las PCD los lleva a cabo el entorno familiar, es evidente que el cuidado tiene un importante impacto económico para las familias ${ }^{(36) .}$

A partir de esto, el cuidado puede conceptualizarse como un gran sistema en el que se da una íntima relación entre tres componentes principales: la persona que padece la enfermedad, la persona que «asume» los cuidados y la familia, como sistema compuesto por la PcD, el cuidador y el resto de la familia y las interrelaciones entre estos tres componentes.

El sistema familiar, a su vez, se enmarca en un macrosistema en el que tiene lugar el proceso de la demencia: el contexto asistencial (servicios sociales y de salud y sus profesionales), social, cultural, económico y político en el que viven las familias ${ }^{(35,37)}$.

\begin{tabular}{|c|}
\hline Impacto psicológico \\
CUIDADOR \\
\hline Vulnerabilidad previa (salud fisica, personalidad, fuentes de estrés, recursos) \\
Desconocimiento \\
\hline Percepción de obligación/autoexigencia \\
\hline FAMILIA \\
\hline Desconocimiento de la demencia \\
Disfunción familiar \\
Poco apoyo social \\
\hline Poca información de recursos \\
PERSONA CUIDADA \\
\hline Necesidades insatisfechas \\
Presencia de SPCD \\
\hline Alta emocionalidad expresada \\
\hline Comportamientos dependientes \\
\hline Restricción conductual/baja estimulación
\end{tabular}

Figura 1. Factores asociados al cuidado familiar de la demencia 


\subsubsection{El cuidador informal}

El cuidador principal o cuidador informal $(\mathrm{Cl})$ puede ser un hombre o una mujer. Es aquella persona que asume la tarea de ayudar a cubrir o asistir las necesidades básicas y psicosociales de la PcD y que supervisa las acciones cotidianas en el domicilio. Por lo general, tiene una relación personal significativa y proporciona una amplia gama de asistencia no remunerada a una persona mayor o a un adulto con una condición crónica o discapacitante fuera de un marco profesional o formal (38).

La contribución de estos cuidadores constituye un gran recurso para la sociedad y, en los países de la Organización para la Cooperación y el Desarrollo Económico (OCDE), este cuidado excede el gasto del cuidado formal. Hoy en día, la prestación informal de cuidados es más intensiva, compleja y duradera que en el pasado, y debido a la asignación del rol, ya sea por conveniencia o arbitraria, los cuidadores rara vez reciben la preparación adecuada para su función, por lo que se enfrentan a situaciones que muchas veces desconocen, y es posible que experimenten temor, ansiedad o estrés ${ }^{(35,38,39)}$.

El Cl suele tener diferentes responsabilidades: brinda asistencia no remunerada a una persona dependiente y realiza tareas de la vida diaria de forma concomitante con otras actividades vinculadas a la atención médica de la persona cuidada, generalmente relacionadas con la medicación, el tratamiento de heridas y la monitorización de equipos médicos, entre otras, y a la preparación de alimentos, el vestido y la higiene personal ${ }^{(39,40,41,42)}$.

No obstante, la prestación de cuidados de manera informal puede ser una experiencia positiva, particularmente en términos psicosociales relacionados con el bienestar personal y la satisfacción de cuidar a otra persona.

Cuidar puede representar un mayor nivel de satisfacción entre los cuidadores en la medida en que exista una mejor relación entre el cuidador y el receptor del cuidado. Aspectos relacionados con el parentesco, la elección voluntaria de asumir el rol, tener tiempo libre para uno mismo y el apoyo social y del resto de la familia también serán factores predisponentes para que se mantenga ese nivel de satisfacción a lo largo del tiempo ${ }^{(41,42,43)}$.

Sin embargo, se sabe muy poco sobre los determinantes de la satisfacción del cuidador o sobre cómo estos difieren entre hombres y mujeres. En los pocos estudios que han realizado análisis estratificados por género, los resultados han sido contradictorios, ya que algunos autores informan de que los hombres obtienen una mayor satisfacción que las mujeres al ofrecer cuidados ${ }^{(44)}$.

\subsubsection{Necesidades del cuidador informal}

De acuerdo con la teoría de Dorothea Orem, existen requisitos universales de autocuidado que deberían ser tenidos en cuenta dentro de las áreas importantes de evaluación en una persona dependiente: 1) el mantenimiento de una cantidad suficiente de aire; 2) una ingesta suficiente de agua; 3) una ingesta suficiente de alimentos; 4) tener cuidado con los procesos de eliminación; 5) el equilibrio entre actividad y descanso; 6) el equilibrio entre la soledad y la interacción social; 7) la prevención de peligros para la vida humana, el funcionamiento y el bienestar del ser humano; y 8) la promoción del funcionamiento y el desarrollo del ser humano dentro de los grupos sociales ${ }^{(42,43)}$.

Sin embargo, los $\mathrm{Cl}$ suelen verbalizar una preparación insuficiente para una continuidad adecuada del cuidado de la persona dependiente en casa y cuentan con poca información sobre el proceso asistencial, el tratamiento y los recursos ${ }^{(43)}$.

A partir de ello, se evidencia que la principal necesidad de los cuidadores es la de información con respecto a la evolución y el progreso de la enfermedad, ya que la poca información que reciben acerca del tratamiento imposibilita la confianza en los profesionales sanitarios encargados del seguimiento de la PcD, y revierte negativamente en su salud y en la persona cuidada. Es necesario saber el tipo de información que precisan los cuidadores para facilitar una atención más efectiva, teniendo en cuenta que las necesidades percibidas por los cuidadores pueden variar dependiendo de las diferentes circunstancias que rodean a la familia, la etapa de la enfermedad y el grado de dependencia de la PcD.

La necesidad de formación es otra de las peticiones de los cuidadores, con el objetivo de adquirir habilidades y poder afrontar actividades cotidianas como la higiene, la alimentación, el vestido, la deambulación, la incontinencia, la movilización o la desorientación, y que además los instruya sobre la disponibilidad de recursos comunitarios y sobre cómo acceder a los servicios que existen en la comunidad. 
Por otro lado, la necesidad de apoyo social en el $\mathrm{Cl}$ es evidente para poder minimizar el riesgo que pueda suponer el rol de cuidador para su propia salud. El apoyo social, definido como una práctica de cuidado que se genera con el intercambio de relaciones entre las personas, se caracteriza por las expresiones de afecto, afirmación o respaldo de los comportamientos de otra persona y puede llevarse a cabo desde el entorno familiar. La figura de un cuidador sustituto como medida de apoyo social permitirá que el cuidador habitual pueda salir de casa o tomarse un descanso ${ }^{(45)}$.

Cuando las necesidades del $\mathrm{Cl}$ no son satisfechas, el rol impacta de manera negativa en su salud física y mental. Muchos $\mathrm{Cl}$, incluidos aquellos que no consideran el cuidado como una carga, sufren una amplia gama de problemas, como trastornos del sueño, ansiedad, depresión y dificultades económicas por el abandono de sus funciones laborales remuneradas. Por ende, las necesidades insatisfechas de los cuidadores pueden aumentar el nivel de sobrecarga y reducir su propia $\mathrm{CdV}^{(46)}$.

\subsubsection{Impacto del rol de cuidador en la sobrecarga y en el bienestar emocional}

Estudios comparativos entre personas cuidadoras y no cuidadoras muestran que los cuidadores tienen niveles estadísticamente significativos más altos de estrés y depresión y más bajos de bienestar subjetivo, salud física y autoeficacia en comparación con los no cuidadores, y que un estado de tensión mental o emocional se asocia con un $63 \%$ más de riesgo de mortalidad en comparación con los no cuidadores. Estos datos evidencian la necesidad de atender los requerimientos de los cuidadores y garantizar el apoyo en el mantenimiento de su propia salud ${ }^{(47)}$. Se destaca que cuando los $\mathrm{CI}$ no reciben apoyo o tratamiento suficiente existe un alto riesgo de que la PcD tenga una institucionalización temprana ${ }^{(48)}$. Por ello, los gobiernos y las organizaciones mundiales coinciden en la necesidad de estrategias, políticas y marcos de acción dirigidos a mejorar el bienestar de las PcD y disminuir la carga de sus cuidadores ${ }^{(35)}$.

Dada la creciente prevalencia de la demencia, la ausencia de una cura inminente o una farmacoterapia eficaz y los profundos costos y consecuencias de los SPCD, es vital identificar intervenciones que ayuden a abordar el cuidado domiciliario y mejoren o mantengan la CdV de los cuidadores y del receptor de cuidado.

Estudios recientes han demostrado que enseñar a los cuidadores a administrar intervenciones no farmacológicas puede reducir significativamente la carga del cuidador y permitir que las PCD permanezcan más tiempo en la comunidad, sobre todo en su propio domicilio ${ }^{(49)}$.

\subsection{Intervenciones de enfermería basadas en la psicoeducación}

Se considera que la intervención enfermera puede centrarse en el desarrollo de técnicas de aprendizaje, en la relación enfermo-cuidador, en el manejo del estrés, en la transmisión de información y en aportar recursos que permitan un adecuado afrontamiento de la situación a partir de talleres pensados para que los cuidadores desarrollen habilidades relacionadas con la atención de la persona que cuidada.

Los talleres pueden estar basados en el entrenamiento de técnicas de movilización, posición, comunicación, estimulación, o en proporcionar apoyo emocional, estimulando un entorno que facilite compartir emociones, vivencias, angustias o sentimientos a través de la escucha activa. Estas intervenciones intentarán reducir la sobrecarga física y psicológica de familiares y cuidadores ${ }^{(49)}$.

La psicoeducación es una herramienta terapéutica o modelo de salud diseñada para mejorar la CdV, ya que incorpora estrategias psicológicas y educativas para la resolución de conflictos, estrategias de afrontamiento y estrategias educativas para el manejo de necesidades de cuidado en pacientes con enfermedades crónicas ${ }^{(50)}$.

A partir de esta herramienta se les proporciona a los familiares o cuidadores de PcD información y formación específica acerca de la enfermedad y de los recursos sanitarios y comunitarios para el abordaje multidisciplinar. Por tanto, se utiliza como un servicio informativo y de apoyo que se aplica globalmente, ya que está especialmente diseñado para aportar información objetiva sobre enfermedades a los pacientes y sus cuidadores ${ }^{(51,52)}$. 
Típicamente, los profesionales sanitarios que utilizan el modelo detallan y resumen información científica actual y relevante para responder a preguntas acerca del origen, la evolución y el abordaje de una enfermedad desde su entorno, proporcionan consejos y entrenan en técnicas de manejo en el ámbito domiciliario ${ }^{(53)}$.

El modelo de psicoeducación plantea una forma de dar solución a los sucesos estresantes contingentes que se presentan en la vida cotidiana y que son de difícil resolución para el individuo en su rol de cuidador. El modelo se enmarca en la creación de programas de salud específicos para promover el bienestar de cuidadores y pacientes (53). Los programas de psicoeducación son intervenciones que complementan el tratamiento farmacológico con el objetivo de reducir aún más la carga y la recurrencia de la enfermedad, y han demostrado tasas reducidas de recaídas, una mejor recuperación de los pacientes y un mayor bienestar familiar. Incluyen participación empática, educación, apoyo continuo, recursos clínicos durante períodos de crisis, mejora de la red social y aumento de las habilidades de comunicación y de resolución de problemas entre sus participantes, lo que implica un cambio de actitudes y comportamientos, a la vez que hace hincapié en la importancia del sueño, las rutinas y los hábitos saludables ${ }^{(52,53)}$.

La psicoeducación es una estrategia viable, económica y efectiva para abordar las necesidades de las personas desde la atención primaria de salud. Propone integrar un enfoque educativo-preventivo y psicológico, con el fin de fortalecer las capacidades para afrontar la enfermedad de un modo más adaptativo. La inclusión de la psicoeducación propiciaría la mejora de la CdV y ayudaría a disminuir la vulnerabilidad ante la enfermedad en la familia y el cuidador. De este modo, la persona que ostente el rol de cuidadora estará en mejores condiciones para comprender el estado de salud del paciente y responder con eficacia a los desafíos que impone su condición a partir de sus recursos personales ${ }^{(54)}$.

\subsubsection{Impacto de la psicoeducación en el cuidador informal}

Como se ha comentado anteriormente, habitualmente los cuidadores realizan su función sin una formación previa específica, lo que los condiciona y representa una gran vulnerabilidad y un riesgo potencial de incremento de carga, malestar y baja CdV. Por este motivo, una de las opciones para reducir el impacto de la prestación de cuidados puede ser el empoderamiento frente a la situación, fruto de la información y la formación para la toma de decisiones y el incremento de las habilidades comunicativas, teniendo en cuenta las posibles limitaciones físicas y psicológicas de la persona atendida y/o el trabajo de gestión de las emociones y las habilidades para la vida.

En este sentido, programas de apoyo a cuidadores pueden incluir este aspecto de incremento de la significación de la tarea asistencial como valor añadido a la comprensión y el manejo de la persona dependiente ${ }^{(55)}$.

Los programas dirigidos a cuidadores y basados en la psicoeducación han demostrado un impacto positivo en la mejora de los resultados primarios de CdV, bienestar emocional y funcional y angustia emocional, y también han sido efectivos en la mejora de la autoeficacia ${ }^{(56)}$.

$\mathrm{En} \mathrm{Cl}$ de $\mathrm{PcD}$, el objetivo de estas intervenciones es dotar a las familias de medios para adaptarse a los cambios y hacer frente a la demencia, así como retrasar la institucionalización. En este sentido, los programas de psicoeducación han mostrado ser un medio eficaz para ofrecer a los cuidadores el conocimiento que necesitan para el rol que desarrollan, ayudándolos a aliviar su angustia, para que puedan hacer frente a las demandas del día a día y ayudar a la dignidad y la autonomía de la PcD ${ }^{(57)}$.

No obstante, y a pesar de la heterogeneidad de la metodología y las características de los estudios publicados en la literatura científica, se pone de manifiesto que estas intervenciones, ya sean en formato grupal o individual, que, además, utilizan nuevas tecnologías de la información y la comunicación (TIC), pueden dar resultados positivos e incidir en la mejora del bienestar de los $\mathrm{Cl}$. Reducen la sobrecarga, la soledad y el aislamiento social, ya que el hecho de compartir sus experiencias permite la creación de nuevos lazos sociales, en sintonía con los efectos positivos típicos de los grupos de apoyo, al igual que permite la mejora en el bienestar emocional del cuidador, con una disminución de los síntomas de ansiedad y depresivos y del nivel de estrés subjetivo $(57,58)$.

Estudios de revisión muestran que los beneficios frente a la depresión y la sobrecarga son duraderos a medio y largo plazo, por lo que resulta interesante crear programas de enfermería basados en los elementos característicos de las intervenciones psicoeducativas, tales como el afrontamiento o la técnica de resolución de problemas ${ }^{(59)}$. 


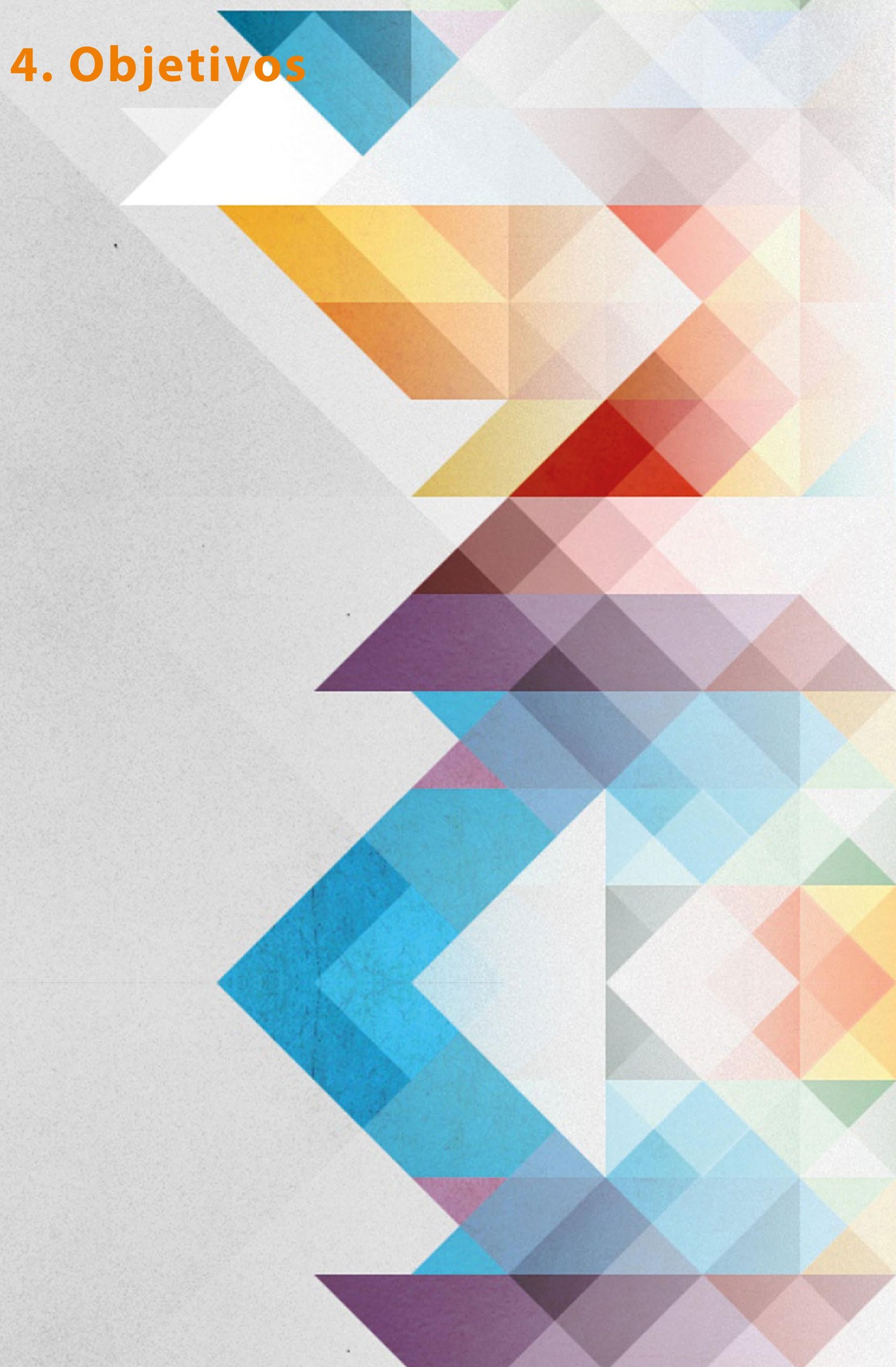




\section{Objetivos}

\subsection{Objetivo general}

Desarrollar, implementar y analizar el impacto de un nuevo enfoque psicoeducativo a partir del programa INFOSA-DEM (Información, Formación y Apoyo Social), en Cl de PcD en relación con la sobrecarga y el bienestar emocional

\subsection{Objetivos específicos}

- Evaluar el impacto de la intervención en la sobrecarga y en el bienestar emocional.

- Determinar el tiempo de permanencia del efecto de la intervención psicoeducativa en los $\mathrm{Cl}$.

- Analizar la CdV de los Cl de PcD que viven en su domicilio. 


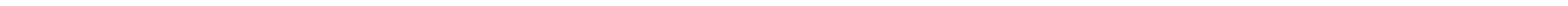




\section{Hipótesis}

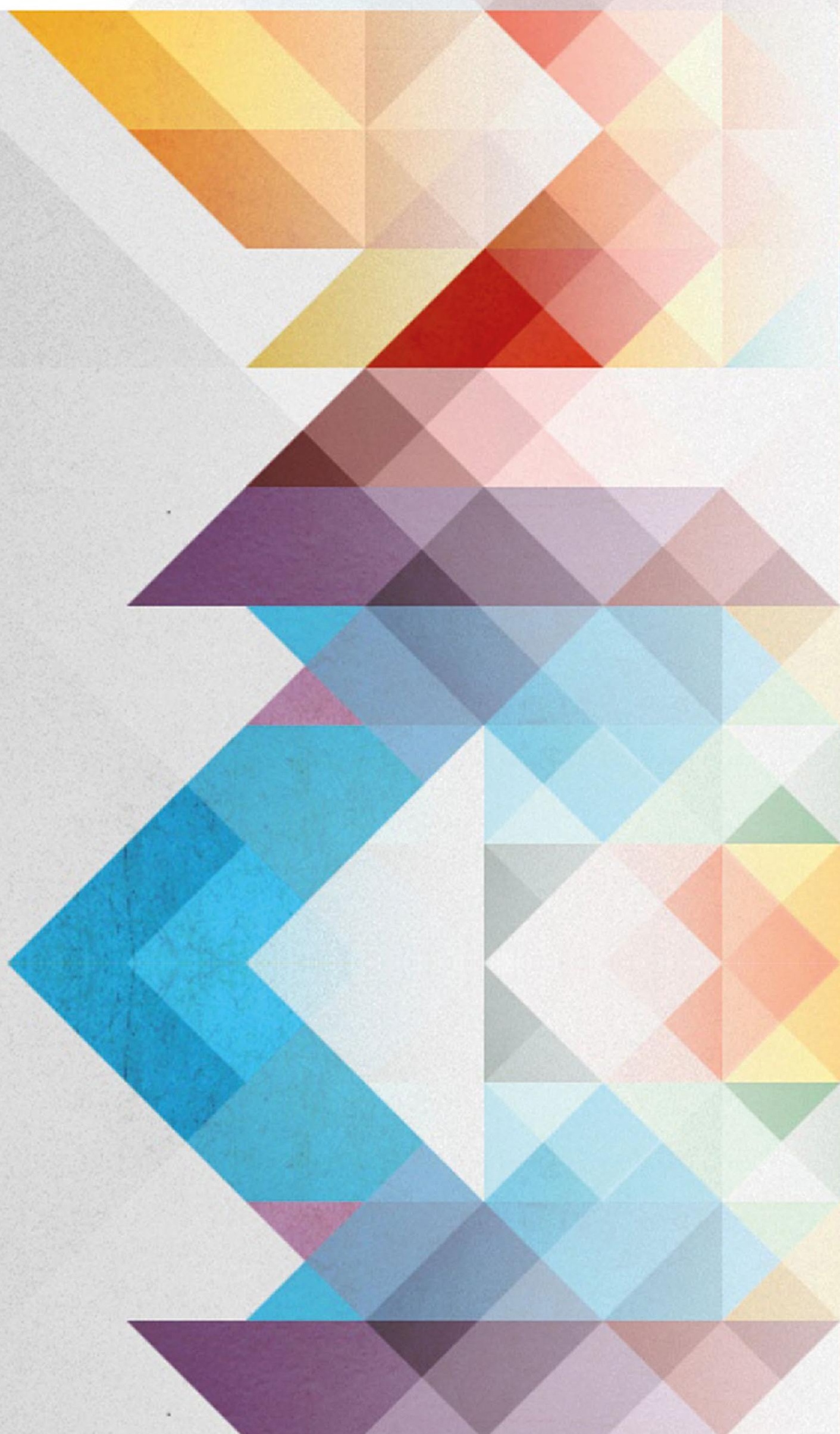




\section{Hipótesis}

- La intervención psicoeducativa INFOSA-DEM tendrá un impacto positivo directo en el $\mathrm{Cl}$ al disminuir la sobrecarga y mejorar su bienestar emocional.

- Los efectos positivos de la intervención se mantendrán tres meses después de su participación en el programa.

- Los participantes del grupo intervención (Gl) tendrán un grado de satisfacción más elevado respecto al grupo control (GC) debido al incremento de las habilidades y al uso de los conocimientos y los recursos adquiridos. 


\section{Publicac
Científicas}

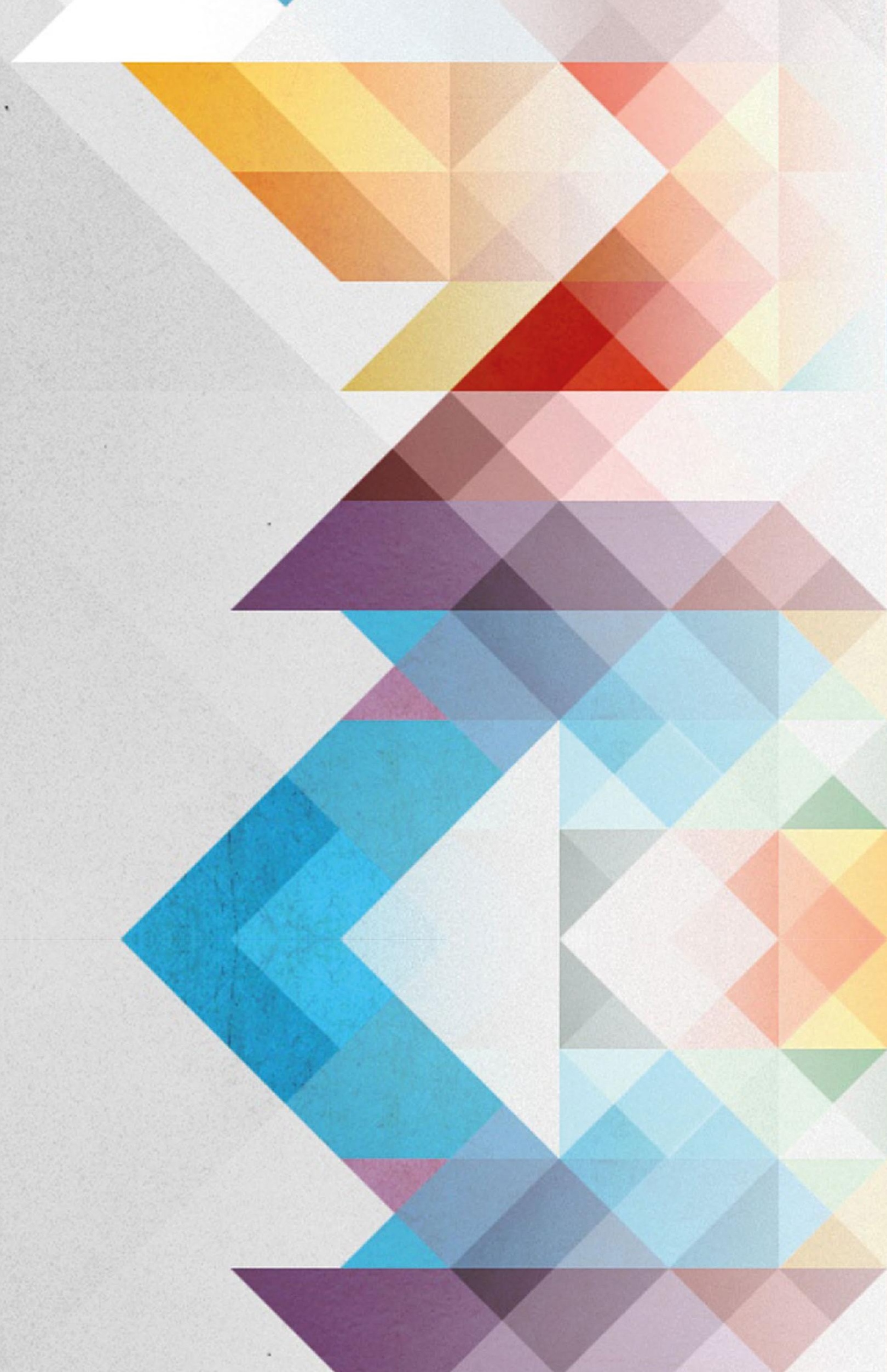




\section{Publicaciones Científicas}

\subsection{Artículo 1}

Effectiveness of a psychoeducational intervention for caregivers of People With Dementia with regard to burden, anxiety and depression: A systematic review.

Cindy E. Frías, Marta García-Pascual, Mercedes Montoro, Nuria Ribas, Ester Risco, Adelaida Zabalegui

J Adv Nurs. 2020; 76(3): 787-802. https://doi.org/10.111/jan.14286.

IF: 2.561.Q1 


\title{
Effectiveness of a psychoeducational intervention for caregivers of People With Dementia with regard to burden, anxiety and depression: A systematic review
}

\author{
Cindy E. Frias RN, MSC, Mental Health Nurse (D) | Marta Garcia-Pascual RN, MSC, Nurse (D) \\ Mercedes Montoro RN, MSC, Nurse | Nuria Ribas RN, Nurse | Ester Risco PhD, RN, Nurse \\ Consultant of Research (D) | Adelaida Zabalegui PhD, RN, FEANS, Deputy Director of Research
}

Hospital Clinic of Barcelona, Barcelona, Spain

Correspondence

Cindy E. Frias, Hospital Clinic of Barcelona, Barcelona, Spain.

Email: cfrias@clinic.cat

\begin{abstract}
Aim: To assess the effectiveness of psychoeducational interventions with respect to burden, anxiety and depression in family caregivers of People With Dementia living at home.

Background: In dementia, the family assumes the role of main caregiver, maintaining the patient in a good state of health. Nevertheless, burden, anxiety and depression may have negative repercussions in caregivers. Therefore, professional supports through psychoeducational programmes are recommended as interventions for improving caregivers' health. Design: A quantitative systematic review.

Data Sources: Electronic searches were performed in CINAHL/AMED/CENTRAL/ Web of Science/LILACS/PUBMED from January 2005-August 2018.

Review Methods: The review was conducted using the JADAD scale to assess bias risk and the quality of the randomized controlled trials (RCTs) and the CONSORT instrument to assess study quality report. The extracted data were reviewed by independent reviewer pairs. The review was reported using PRISMA.

Results: A total of 18 RCTs met inclusion criteria. Seven were classified as Technologybased Interventions and 11 as Group-based Interventions.

Conclusion: Psychoeducational interventions for caregivers allow them to increase their knowledge of the illness, develop problem-solving skills and facilitate social support. Technology-based Interventions significantly affect burden while Groupbased Interventions affect anxiety, depression, insomnia and burden and quality of life and self-efficacy.

Impact: Research findings can be used to classify caregivers in future interventions according to illness stage to obtain more precise results.
\end{abstract}

\section{KEYWORDS}

anxiety, burden, carers, depression, home care, informal caregiver, nurse, psychoeducational intervention, randomized controlled trial, systematic review

The peer review history for this article is available at https://publons.com/publo $\mathrm{n} / 10.1111 /$ jan.14286 


\section{I INTRODUCTION}

Care of People With Dementia must go beyond treatment of symptomatology and maintenance of cognitive functions in the person with the illness. Dementia is a complex illness that causes changes in the family dynamic and involves an increase in expenditure (Buckley \& Salpeter, 2015). The People With Dementia (PwD) prefers to remain in the family environment rather than be admitted to a long-term care institution. In most cases and the duration of in-home caregiving can be as long as a median of 6.5 years (Bökberg et al., 2015; Giebel et al., 2015; Wübker et al., 2014). PWD is affected by cognition deficits, emotional disorders and even behaviour disturbances, all of which eventually lead to inability to function independently. However, home care is a challenge for the family as the illness entails progressive cognitive impairment and behavioural changes that cause stress and generate burden in family members and can lead to medical illnesses and changes in the mental health of the caregiver, who could even be obliged to give up work and change relationships or social activities (Goren, Montgomery, Kahle-Wrobleski, Nakamura, \& Ueda, 2016).

It is important to address biopsychosocial aspects where care of the family is included as a determining factor in maintenance of the person's health. As such, multidisciplinary professional support for family caregivers through psychoeducational programmes is recommended as interventions for improvement of both care and one's own health (Barr, Riolacci-Dhoyen, Galbraith, \& Leperre-Desplanques, 2012; Zabalegui, Bover, et al., 2008; Zabalegui et al., 2014; Zabalegui, Navarro, et al., 2008).

\section{1 | Background}

In dementia, the family, or on occasion friends or neighbours, assumes the role of main caregiver, taking responsibility for daily care of the PWD, meeting basic and instrumental daily life needs (Chiao, Wu, \& Hsiao, 2015) and maintaining the patient in a good state of health. In Spain, the caregiver role is usually taken on by a family member (Alvira et al., 2014; Wimo et al., 2010). It is highly demanding care and provokes burden, particularly due to a lack of specific training and scant support from other family members (Bleijlevens et al., 2014; Chiao et al., 2015; Zabalegui, Navarro, et al., 2008). Caregiving generates positive aspects with respect to caregiver self-esteem, a feeling of satisfaction with the work carried out and the ability to overcome certain difficulties and the strengthening of the bond with the person receiving care (Chiao et al., 2015). Nevertheless, the appearance of symptoms such as burden, anxiety, depression and a low perception of well-being may have negative repercussions for the health of both caregiver and PwD (Zabalegui, Bover, et al., 2008; Zabalegui, Navarro, et al., 2008). Beinard, Weinman, Wade, and Brady (2012), in their systematic review, found that demographic and psychosocial attributes of the caregiver that predict greater burden include older age, lower socioeconomic status, family relationship, type of coping strategy and poor access to/low acceptance of social support and female caregivers have been found to be at higher risk of psychological symptoms. Separately, home care involves extra expenses and alters the family economy. Increasing illness severity of the illness is associated with an increase in economic costs, so that a search for social assistance becomes necessary (Darbà, Kaskens, \& Lacey, 2014).

In Spain, the family caregiver assumes $87 \%$ of indirect costs and solely the remaining $13 \%$ comes from public funding. For this reason, Spain, in common with Estonia, is one of the European countries that allocates least funding to aiding families of PWD (McFarlane, Dixon, \& Lucksted, 2003), while in countries such as France and Germany, there is more social economic assistance (Wübker et al., 2014). These differences encourage the establishment of treatment alternatives that can be shown to be of use in reducing stress and economic costs through interventions or educational programmes (Darbà et al., 2014).

Previous reviews did provide preliminary evidence and highlight the mental health benefits for caregivers through face-to-face interventions and support groups through group discussions and written materials to prevent anxiety, depression and burden. Due to accessibility and cost-effective implementation, future research should emphasize the use of new technologies, given the rapidly changing technology field and the needs expressed by caregivers to receive support and considering the variation in complexity and severity of needs in the PwD. Likewise, psychoeducational programs offered over the internet and computer or telephone delivered interventions has received considerable attentions from researchers and caregivers due to this probably facilitate access and participation without having to leave loved ones alone at home and this type of format also allows information to reach people in remote areas and those who have difficulty accessing traditional services and could be an efficacious alternative, ensuring that education and support can continue to be provided to families at low cost (Boots, Vugt, Knippenberg, Kempen, \& Verhey, 2013).

We concluded that there was a need for an updated general systematic review due to the rise in the prevalence of the illness has led to concern and question marks regarding future demands. Therefore, we would like to know what kind of intervention is highly effective and readily available for different types of dementia caregivers and could serve as a form of training in the development of skills and the results can identify gaps that can be targeted by further research to guide practice and policy. In addition, it is important to know if attending a group intervention or only receiving individual theoretical training of interventions via the Internet or via telephone at home could have a different impact on the variables analysed in the different RCTs. (Farre et al., 2016; Goren et al., 2016; Wübker et al., 2014; Zabalegui et al., 2014). 


\section{THE REVIEW}

\section{1 | Aim}

The aim of this systematic review was to assess the effectiveness of psychoeducational interventions with respect to burden, anxiety and depression in family caregivers of People With Dementia living at home.

\section{2 | Design}

A quantitative systematic review was carried out and was reported following PRISMA method guidelines (Moher, Liberati, Tetzlaff, \& Altman, 2009). The purpose of the guidelines is to ensure that the articles included are reviewed in their totality in a clear and transparent way. The systematic review focused on the search for articles that analysed the effectiveness of psychoeducational interventions addressed to main family caregivers with respect to burden, anxiety and depression. Duplicates were eliminated and, subsequently, a three-step inclusion process was carried out: (a) Screening based on title and abstract, (b) Article selection based on a reading of the complete text, (c) Review and selection of texts by independent pairs.

\subsection{Search methods}

The review examined articles in English and Spanish published between January 2005-August 2018 which included psychoeducational interventions designed to improve burden, anxiety and depression in family caregivers of People With Dementia. The search was conducted in 2017 and 2018 in the following databases: CINAHL, AMED, CENTRAL, ISI Web of Science, LILACS, MEDLINE (PUBMED) and Psicodoc. The search strategy was: psychoeducational intervention AND (dementia OR Alzheimer's disease) AND informal caregiver AND home care.

\subsection{Search outcomes}

We included original studies with the following inclusion criteria: (a) Randomized controlled trials (RCTs); (b) Published in English or Spanish; (c) Published between January 2005-August 2018; (d) Studies of psychoeducational interventions addressed to family caregivers of people with a diagnosis of dementia or Alzheimer's living at home; (e) Studies that include a detailed description of the educational programme used (content of sessions, numbers of meetings, duration, format and electronic devices used, etc) and ( $f$ ) The use of validated, reliable scales to analyse the intervention on the dependent variables, comparing the intervention with usual care and with other standard procedures.

We excluded: (a) Studies which assessed pharmacological treatment or had been carried out in caregivers of patients admitted to centres or long-term care institutions; (b) Studies which did not measure depression, anxiety and/or burden variables; (c) Studies which did not describe what the intervention consisted of in detail and (d) Studies where the psychosocial intervention was not implemented by nurses, social workers, doctors or psychologists with expertize in caring for People With Dementia.

PRISMA recommendations were followed to report the search process (Moher et al., 2009). After removing those manuscripts that were duplicated (38 entries), we reviewed the remaining 79 articles, noting whether the title and abstract met the inclusion/exclusion criteria. Reviewers reached a consensus considering 34 entries as acceptable. After reading the full text of these articles, we removed 14 articles for the following reasons: Two interventions included PwD living in long-term institutional care; two interventions that use pharmacological treatment to improve emotional symptoms of the caregiver; three interventions has not been compared with standard care; in four interventions there is no specific description of the intervention and in three interventions depression, anxiety and burden are not evaluated (Figure 1).

\section{5 | Quality appraisal}

All RCTs were fur ther evaluated and graded by two reviewers. Where there was disagreement, consensus was arbitrated by the principal investigating author. Assessing the risk of bias is a part of the conduct and reporting of any systematic review. In this regard, to assess the risk of bias and the quality of the studies of RCTs, the JADAD scale was used in each study. This is a scale containing three items describing randomization, blinding and accountability (dropout and withdrawals). We assigned 1 point if randomization was mentioned and 1 additional point if the method of randomization was appropriate; also, we deducted 1 point if the method of randomization was inappropriate. Regarding blinding, we assigned 1 point if blinding was mentioned and 1 additional point if the method of blinding was appropriate and again we deducted 1 point if the method of blinding was inappropriate. Finally, we assigned 1 point if the accountability was known; if there were no data, the reason should have been stated. The Jadad scale ranges from $0-5$. If the Jadad score was $\geq 3$ points, the trial was considered high-quality research, whereas if the Jadad score was $\leq 2$ points, the study was considered a low-quality trial (Espi-López, Arnal-Gómez, Balasch-Bernat, \& Inglés, 2017; Jadad et al., 1996; Seminario-Amez, López-López, Estrugo-Devesa, Ayuso-Montero, \& Jané-Salas, 2017; Zhang, Lan, Pen, \& Li, 2019).

Likewise, to assess the study quality report, the CONSORT checklist was used. This quality appraisal included the identification as a randomized trial in the title and structured summary, scientific background and explanation of rationale and objectives or hypothesis, description of the trial design and important changes, eligibility criteria for participants and study setting, interventions for each group with details for replication, outcomes and changes to outcomes, sample size and interim analyses and stopping guidelines, explanation of randomization, blinding and similarity of interventions, statistical methods and additional analyses, participants 


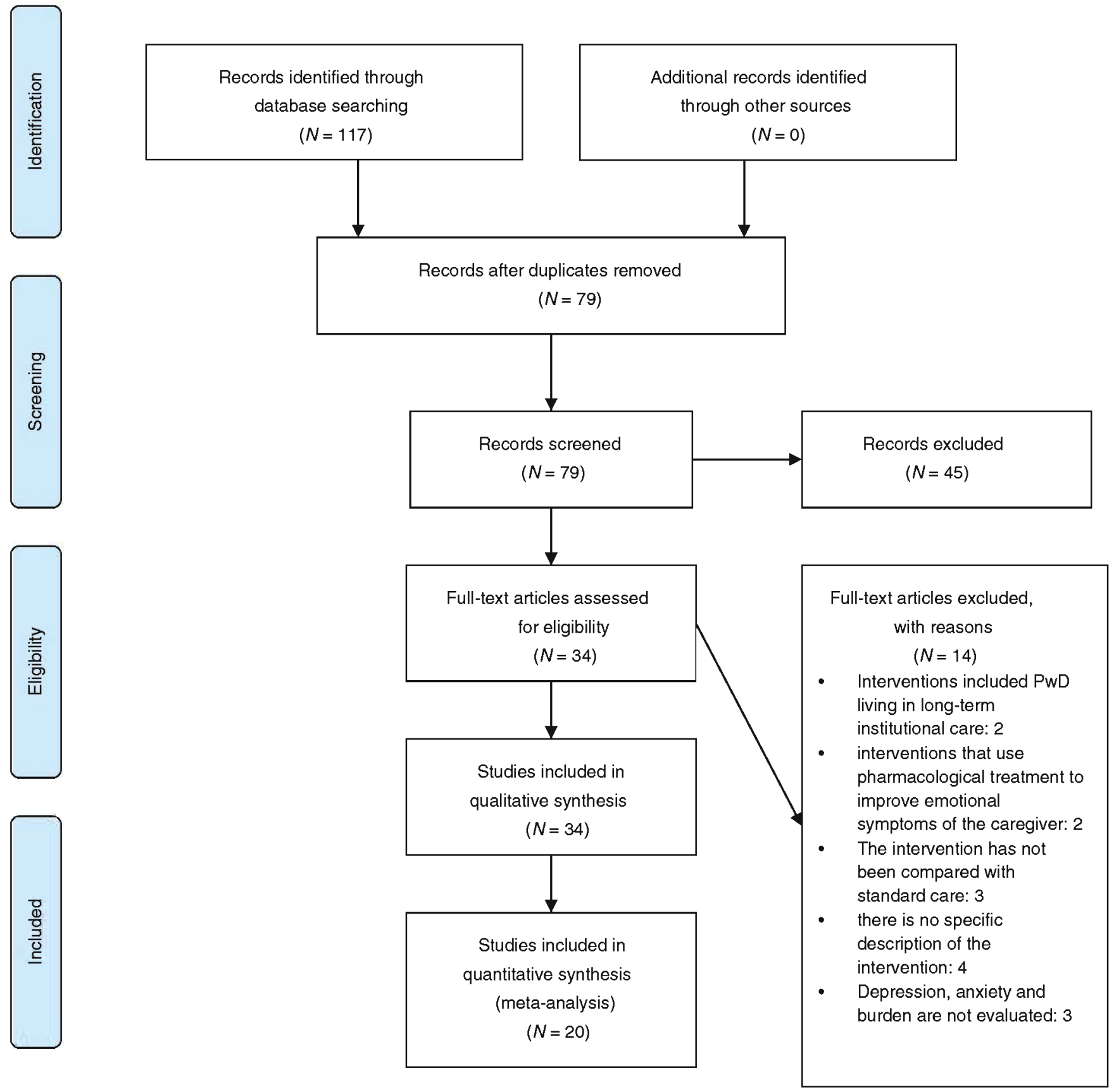

FIGURE 1 Flowchart of the inclusion procedure according to PRISMA [Colour figure can be viewed at wileyonlinelibrary.com]

flow, losses and exclusions, recruitment and reasons for stopped trial, baseline data, numbers analysed, outcomes and estimation and binary outcomes, ancillary analyses, harms, limitations, generalizability and interpretation. Studies that did not fulfil at least $70 \%$ of the included elements for the CONSORT statements were considered to contain substantial methodological flaws.

\subsection{Data extraction}

Two of the authors independently conducted data extraction from each included studies; conflicts were resolved by discussion with a third member of the team. A data-extraction document was prepared for the analysed studies where the following information was recorded: authors/year of publication, sample size, intervention details and number of sessions, measurement instruments and results.

\subsection{Data synthesis}

To describe the results of the review, we used a narrative technique rather than a quantitative meta-analysis as the dynamic of the interventions, their duration and patient follow-up varied among the 
different studies. Similarly, the number of studies with consistent results found and included limited the meta-analysis. Furthermore, reviewers reached a consensus regarding from the delivery format of the educational programme sessions and the use of electronic devices. Therefore, the interventions included in the review were classified into two groups: Technology-based interventions and Group-based Interventions. Technology-based Interventions: In this category, caregivers could access to the programme from their own homes individually through web portals, electronic devices and or telephone sessions with a health professional that was part of the educational program. Group-based Interventions: This technique involved forming small groups of family caregivers and conducting the sessions in a specially adapted room. In some cases, caregivers may make a telephone call for personal counselling. A narrative synthesis was carried out for both groups.

\section{3 | RESULTS}

Following the exclusion of duplicates, 79 references were obtained from the interventions or psychoeducational programs. Finally, after a study-relevance analysis was conducted, a total of $18 \mathrm{RCTs}$ were obtained that satisfied the inclusion and exclusion criteria for this review
(Figure 1.). The 18 studies obtained an acceptable methodological quality (JADAD scale). The quality of each study design was assessed on the basis of parameters such as randomization and study method, type of blinding and its procedure and tracking of the dropouts (Table 1).

We decided to use a narrative analysis to describe the results of the systematic review based on the highest level of evidence, including only RCTs. These RCTs used different instruments to measure same outcomes inevitably subjective such as burden, depression and anxiety. Moreover, according to the literature review, several disadvantages have been associated with the most widely used scales to measure burden (Zarit Burden Interview) and depression (Center for Epidemiological Studies Depression). It cannot be ruled out that possible reporting biases also exist. On the other hand, the professionals who carried out the interventions do not belong to the same discipline and, therefore, the approach could be different. Due to all these reasons, finally we did not perform a meta-analysis.

\section{1 | Description of the included studies}

Eighteen studies were performed in Europe, Asia and North America: Germany $(N=1)$, Spain $(N=2)$, France $(N=1)$, Netherlands

TA BLE 1 Quality analysis of the included studies by the Jadad quality scale

\begin{tabular}{|c|c|c|c|c|c|c|}
\hline Authors & $\begin{array}{l}\text { Was the } \\
\text { study } \\
\text { randomized? }\end{array}$ & $\begin{array}{l}\text { Was the method } \\
\text { of randomization } \\
\text { described and } \\
\text { appropriate? }\end{array}$ & $\begin{array}{l}\text { Was the } \\
\text { study } \\
\text { double-blind? }\end{array}$ & $\begin{array}{l}\text { Was the blinding } \\
\text { method described, } \\
\text { and appropriate? }\end{array}$ & $\begin{array}{l}\text { Was there a } \\
\text { description of } \\
\text { withdrawals } \\
\text { and } \\
\text { dropouts? }\end{array}$ & $\begin{array}{l}\text { Total quality } \\
\text { score ( } \geq 3 \text { points } \\
\text { high range of } \\
\text { quality) }\end{array}$ \\
\hline Söylemez et al. (2016) & 1 & 1 & 0 & 1 & 1 & 4 \\
\hline Gonyea et al. (2014) & 1 & 1 & 0 & 1 & 1 & 4 \\
\hline $\begin{array}{l}\text { Martín-Carrasco et al. } \\
\text { (2014) }\end{array}$ & 1 & 1 & 0 & 0 & 1 & 3 \\
\hline Rotrou et al. (2010) & 1 & 1 & 0 & 0 & 1 & 3 \\
\hline Ducharme et al. (2011) & 1 & 1 & 0 & 0 & 1 & 3 \\
\hline $\begin{array}{l}\text { Losada, Márquez-González, } \\
\text { and Romero-Moreno } \\
\text { (2011) }\end{array}$ & 1 & 1 & 0 & 0 & 1 & 3 \\
\hline Kurz et al. (2009) & 1 & 1 & 0 & 0 & 1 & 3 \\
\hline Chien and Lee (2008) & 1 & 0 & 1 & 1 & 1 & 4 \\
\hline Gonyea et al. (2006) & 1 & 1 & 0 & 1 & 1 & 4 \\
\hline Rabinowitz et al. (2006) & 1 & 0 & 0 & 1 & 1 & 3 \\
\hline Kuo et al. (2016) & 1 & 1 & 0 & 1 & 1 & 4 \\
\hline Hattink et al. (2015) & 1 & 1 & 0 & 0 & 1 & 3 \\
\hline Hatch et al. (2013) & 1 & 1 & 0 & 1 & 1 & 4 \\
\hline Kajiyama et al. (2013) & 1 & 0 & 0 & 1 & 1 & 3 \\
\hline Kwok et al. (2013) & 1 & 1 & 0 & 1 & 1 & 4 \\
\hline Gitlin et al. (2010) & 1 & 1 & 0 & 0 & 1 & 3 \\
\hline Tremont et al. (2008) & 1 & 1 & 0 & 0 & 1 & 3 \\
\hline Beauchamp et al. (2005) & 1 & 0 & 0 & 1 & 1 & 3 \\
\hline
\end{tabular}


$(N=1)$, Turkey $(N=1)$, China $(N=3)$, United States of America $(N=8)$ and Canada $(N=1)$. The common aim was the assessment of the impact of the intervention on the main family caregiver (Table 2 ).

\subsection{Intervention characteristics}

In general, interventions consisted of several components, such as education, social support, counselling, problem-solving techniques, coping strategies (Chien \& Lee, 2008; Hatch, Dehart, \& Norton, 2013; Kwok et al., 2013; Losada et al., 2011; Rotrou et al., 2010; Söylemez, Küçükgüçlü, \& Buckwalter, 2016), future activity planning, self-care (Chien \& Lee, 2008; Martin-Carrasco, DominguezPanchón, González-Fraile, Muñoz-Hermoso, \& Ballesteros, 2014; Schulz, Gallagher-Thompson, Haley, \& Czaja, 2000) and leisure activities (Gitlin, Winter, Dennis, Hodgson, \& Hauck, 2010).

Some of the interventions were designed and delivered in group sessions (weekly, fortnightly or monthly) in memory clinics or non-hospital settings where a PwD follow-up was conducted (N: 11). In cases where the caregiver was unable to travel to the centre, where the intervention would be delivered, special programmes were designed that were provided individually at home through information technology (computer networks and specialized telephones), that could include follow-up telephone calls or explanations on various subjects (e.g., emotional support, directing the caregiver towards specific social resources, encouraging the caregiver to attend to his/her own health, education in coping strategies for particular problems at home), as complementary strategies to the programme ( $N:$ 7) (Gonyea, Oconnor, \& Boyle, 2006). By reviewers' consensus regarding from the design and delivery format of the educational programme sessions and the use of electronic devices, the interventions were classified in: Technology-based Interventions and Group-based Interventions (Table 3).

\section{3 | Technology-based Interventions}

In the studies analysed and classified into this category, $(N=7)$, three divided the sessions into home sessions, where the caregivers could access a programme from their own homes though a web portal and telephone sessions with a health professional who was part of the educational programme (Beauchamp, Irvine, Seeley, \& Johnson, 2005; Hattink et al., 2015; Kajiyama et al., 2013). Four studies, delivered the programme through telephone networks, that is, a health professional explained the sessions to the caregiver by phone, so that queries were dealt with immediately (Gitlin et al., 2010; Hatch et al., 2013; Kuo et al., 2016; Kwok et al., 2013; Tremont, Davis, Bishop, \& Fortinsky, 2008). In the three remaining studies, the programme included a web page, divided into specific sessions for the home care of the PwD. In this way, caregivers could participate in the programme from home. Each caregiver was given a password and the number of visits made on each issue was recorded with the aim of discovering which subject roused the greatest interest (Beauchamp et al., 2005; Hattink et al., 2015; Kajiyama et al., 2013). The interventions lasted between 6-12 months and theoretical and support content was provided through internet portals, home sessions and weekly telephone calls. The interventions were divided into active and maintenance sessions, depending on whether they were home sessions (active phase, with a duration of 30-90 $\mathrm{min}$ ) and telephone calls (maintenance phase, with a duration of 15-30 min) (Gitlin et al., 2010; Hatch et al., 2013; Kuo et al., 2016), or active phase only, if delivered entirely by telephone (Kwok et al., 2013; Tremont et al., 2008). The interventions had a baseline assessment and follow-up assessments on completion of the intervention and at 3 and 6 months postintervention. The aim of the programme was to decrease burden and promote self-efficacy (Gitlin et al., 2010; Hatch et al., 2013; Kwok et al., 2013; Tremont et al., 2008), reduce levels of depression and anxiety (Beauchamp et al., 2005; Gitlin et al., 2010; Hatch et al., 2013; Kajiyama et al., 2013; Tremont et al., 2008) and stress (Hattink et al., 2015; Kajiyama et al., 2013) and improve quality of life (Ducharme et al., 2011).

\section{4 | Group-based interventions}

Of the studies analysed, 11 used a group technique to carry out the psychoeducational program. This technique involved forming small groups (5-10 people) of family caregivers and carrying out the sessions in a specially adapted room (Chien \& Lee, 2008; Ducharme et al., 2011; Gonyea, López, \& Velásquez, 2014; Kurz et al., 2009; Losada et al., 2011; Martin-Carrasco et al., 2014; Rabinowitz et al., 2006; Rotrou et al., 2010; Söylemez et al., 2016). Some programmes organized prior training for the health professional in charge of the intervention (Chien \& Lee, 2008; Ducharme et al., 2011; Gonyea et al., 2014; Rotrou et al., 2010). The total number of sessions varied, delivered in seven (Söylemez et al., 2016) (21), 5 (Ducharme et al., 2011; Rabinowitz et al., 2006), seven (Gonyea et al., 2006; Kurz et al., 2009) and 12 sessions (Chien \& Lee, 2008; Losada et al., 2011; Rotrou et al., 2010), with each session lasting 90-120 min (Gonyea et al., 2014; Rabinowitz et al., 2006; Söylemez et al., 2016) or, in others, up to $2 \mathrm{hr}$ per session (Chien \& Lee, 2008; Losada et al., 2011; Rotrou et al., 2010). The number of participants varied from group to group, with a minimum of five (Robinson, Crawford, Buckwalter, $\&$ Casey, 2018), 5 (Ducharme et al., 2011) and a maximum of eight (Losada et al., 2011) or 10 caregivers in each group (Rotrou et al., 2010). The sessions focused primarily on dementia, specific home care, well-being, pleasurable activities and support resources, strategies for the management of behavioural problems and redirection of negative thoughts. Caregiver burden was assessed (Chien \& Lee, 2008; Ducharme et al., 2011; Gonyea et al., 2006; Rabinowitz et al., 2006; Rotrou et al., 2010), along with the levels of anxiety (Rabinowitz et al., 2006), depression (Gonyea et al., 2006; Losada et al., 2011 ; Rotrou et al., 2010), care self-efficacy (Kurz et al.,2009; Rabinowitz et al., 2006) and stress (Rabinowitz et al., 2006). All these 

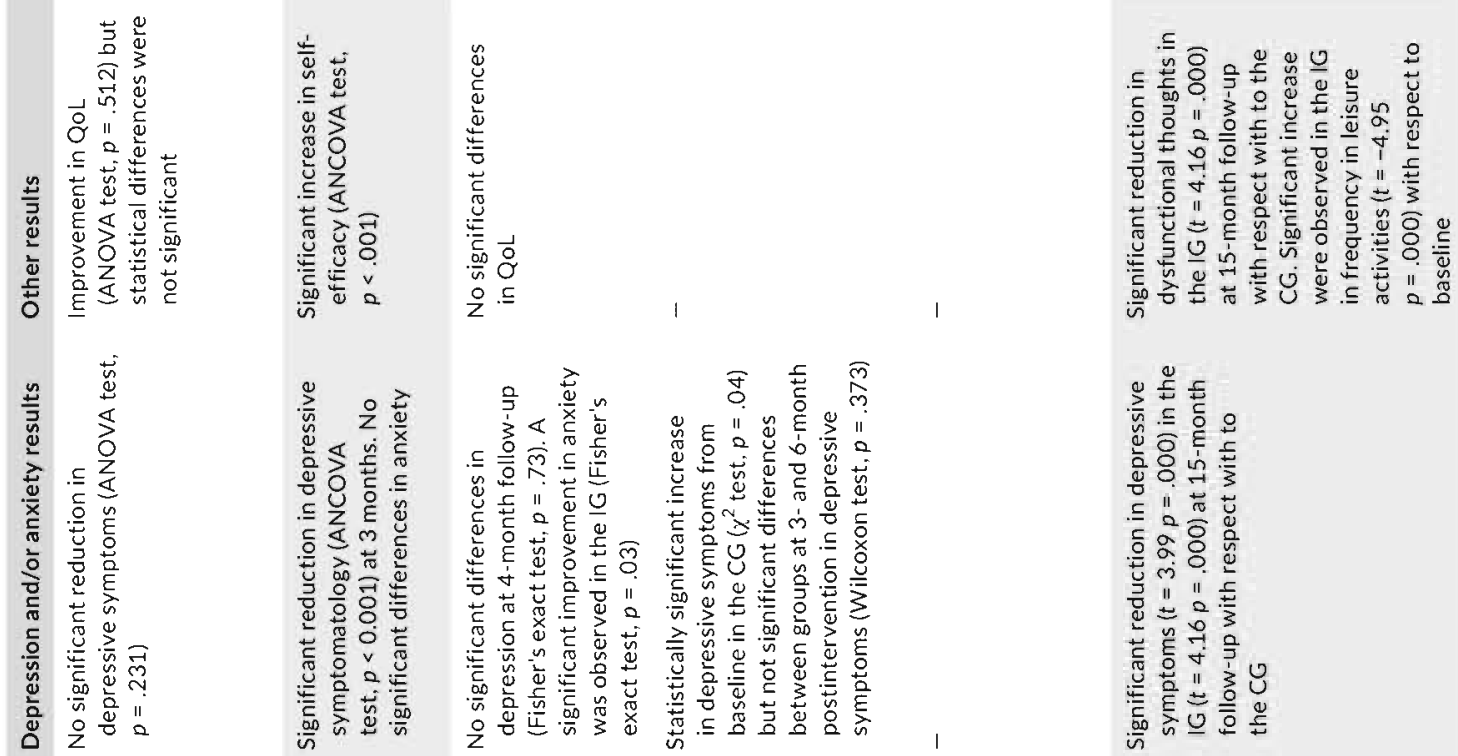

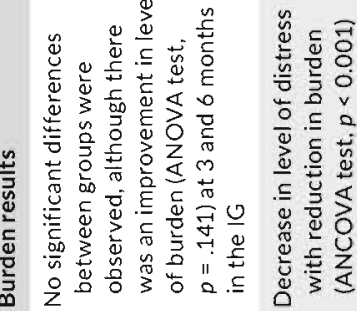

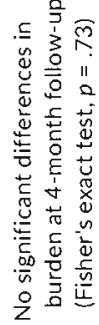
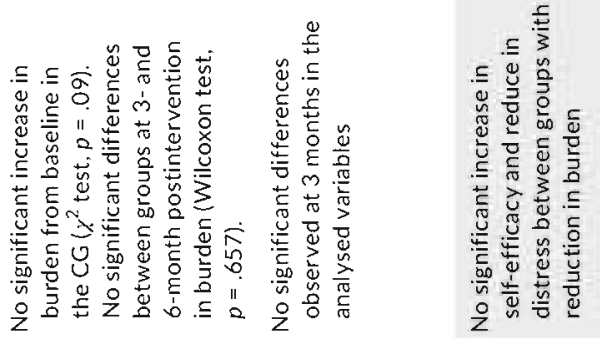

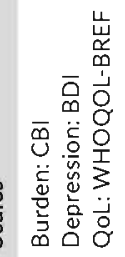

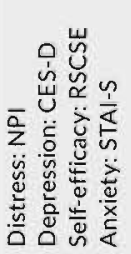

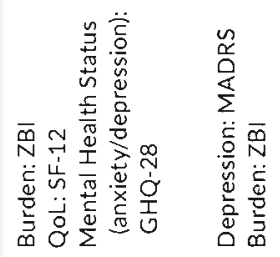

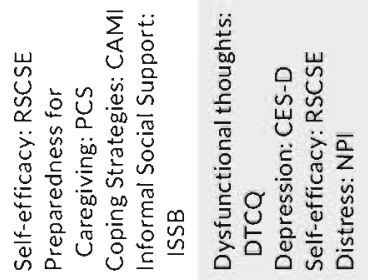

产

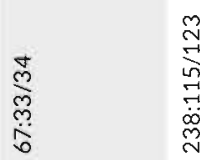

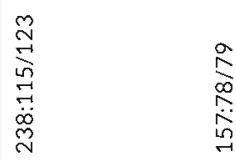

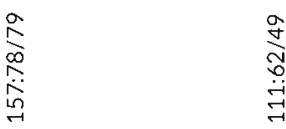

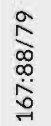

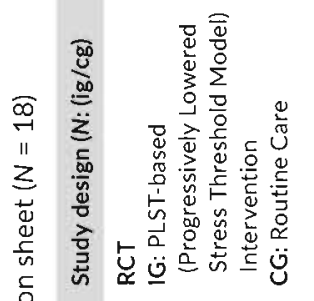
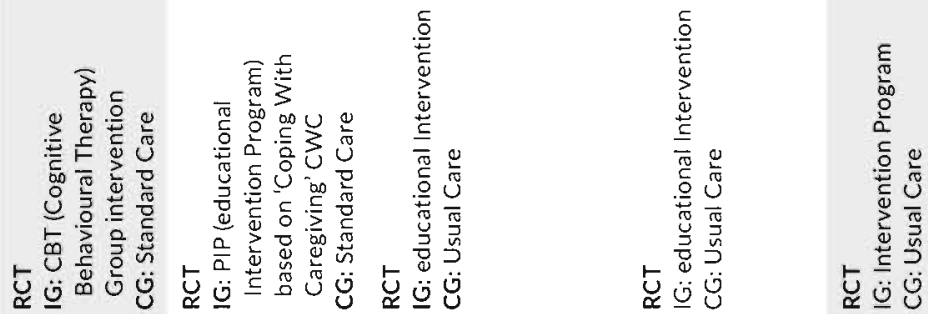

竞

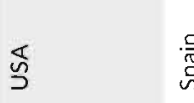

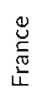

荧

등

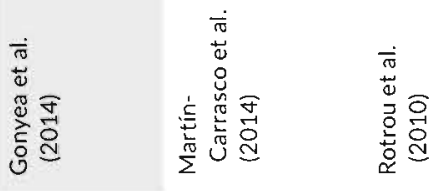

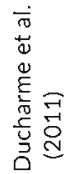

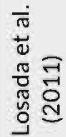



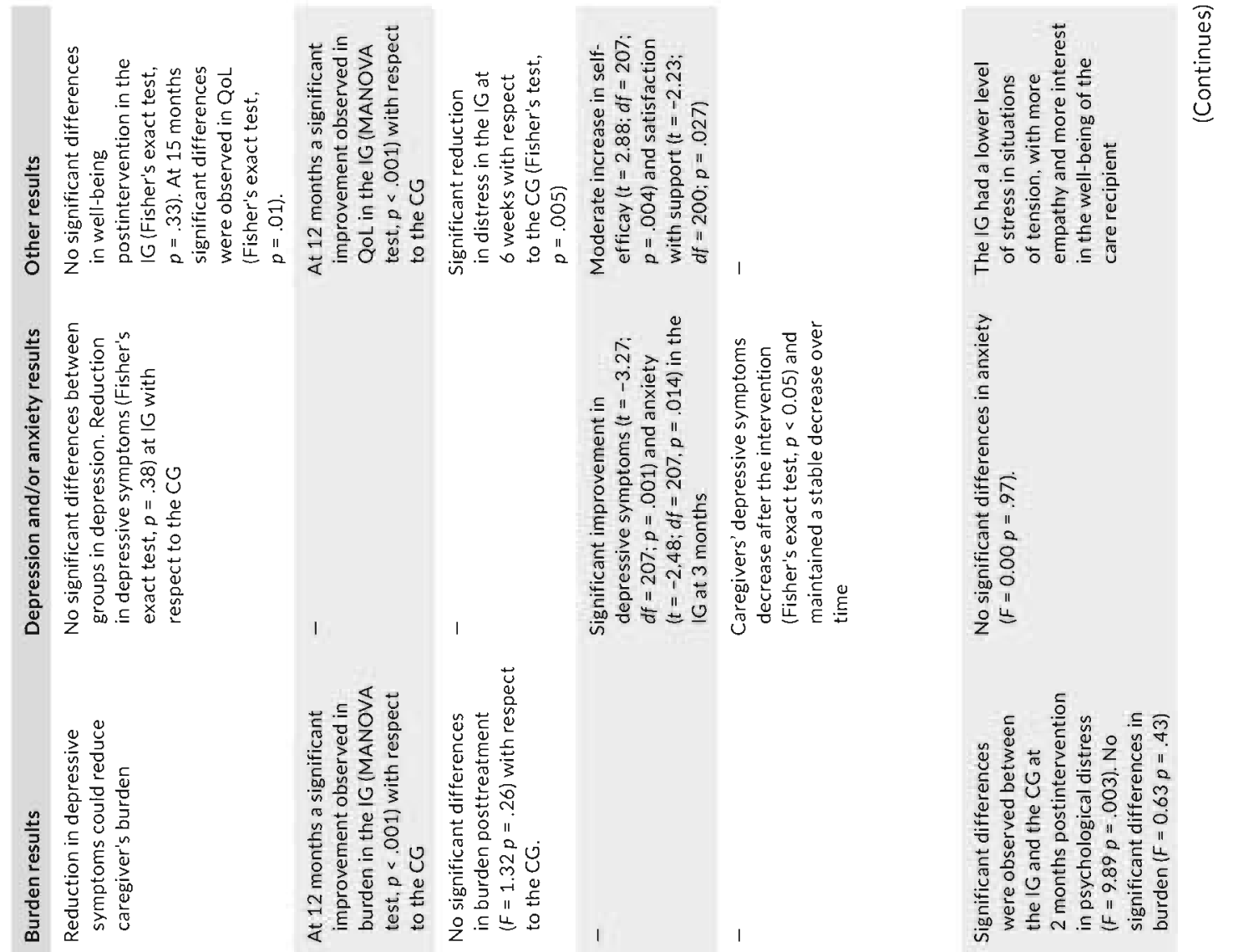

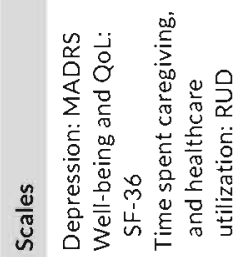
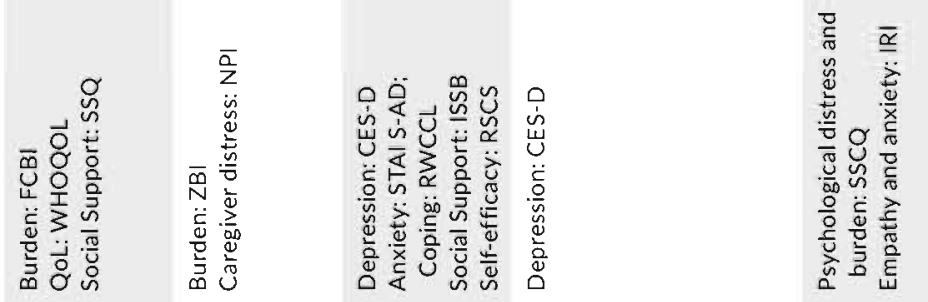

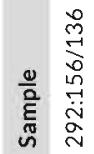
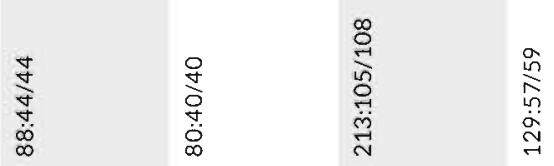

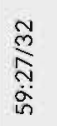
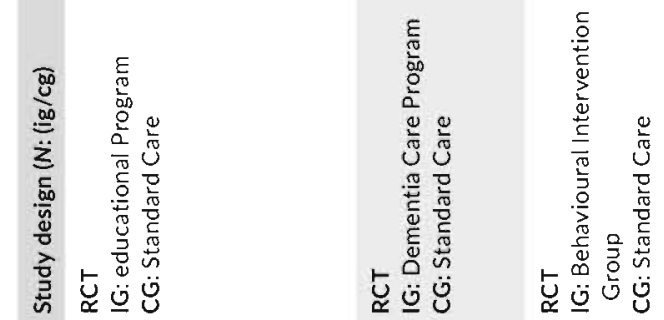

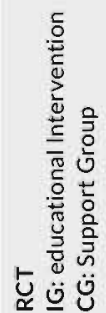
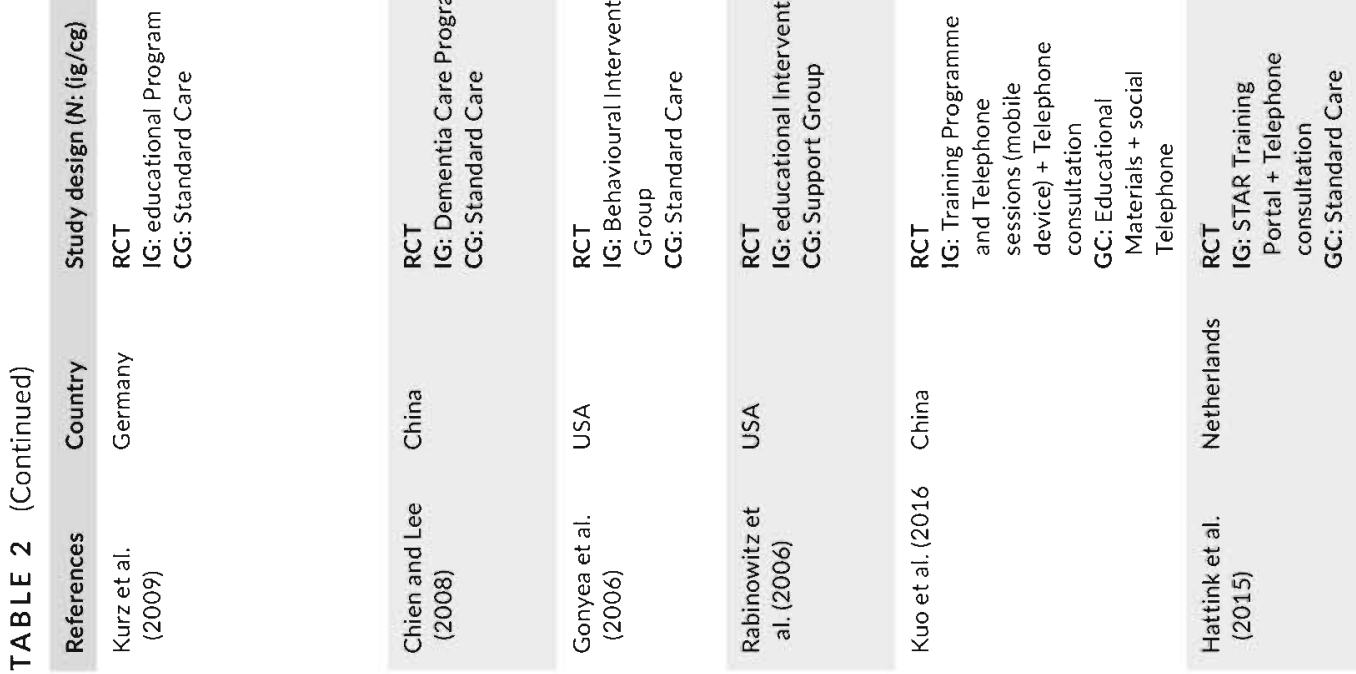

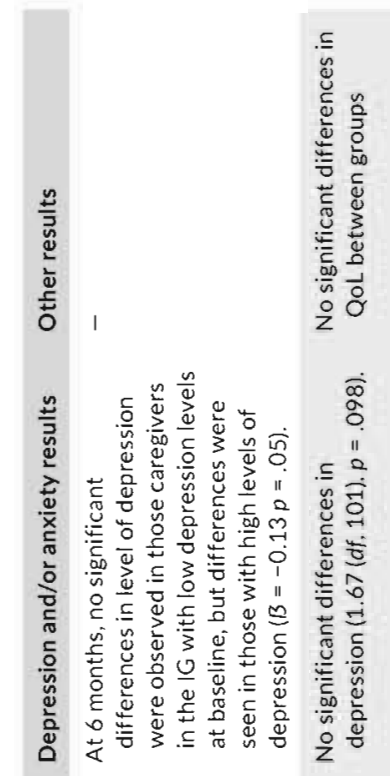

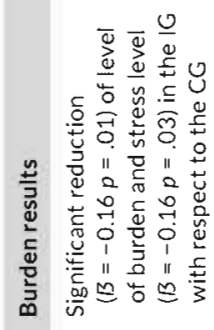
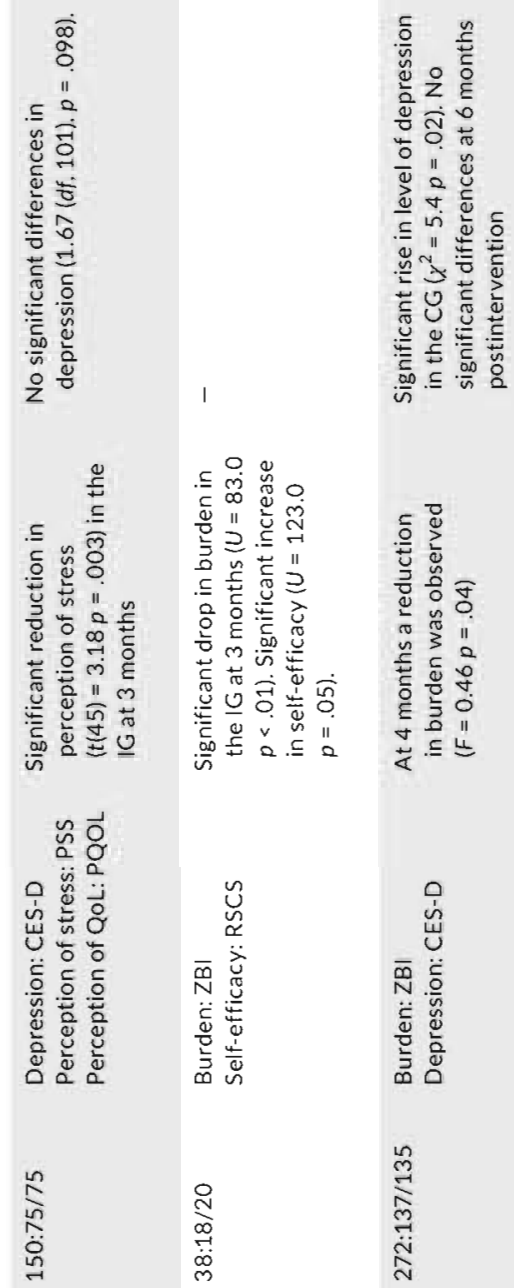
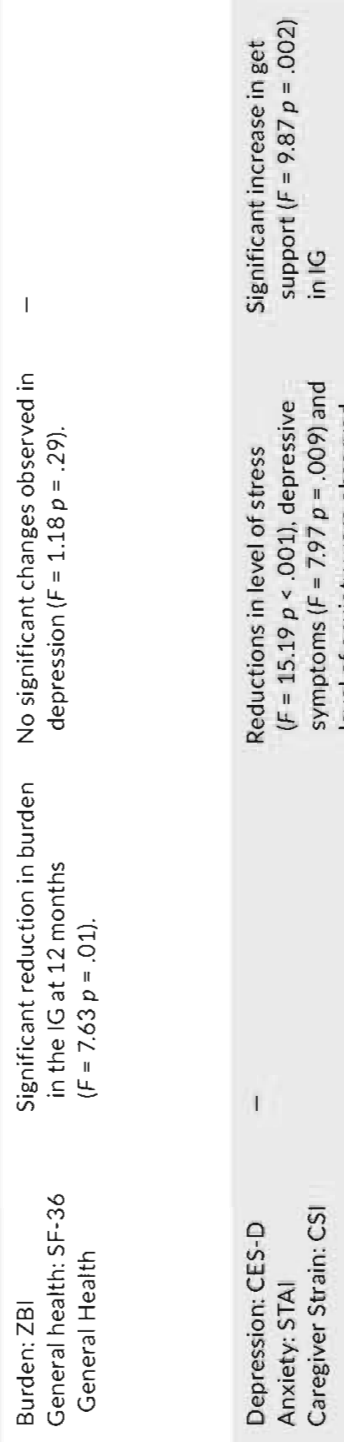

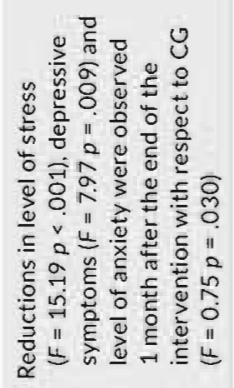

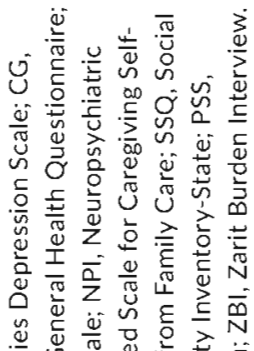

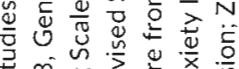

专等

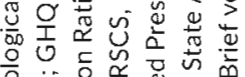

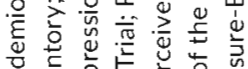

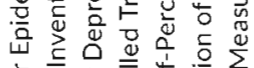

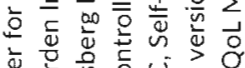

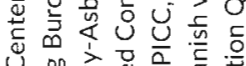

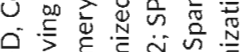

i 列 记

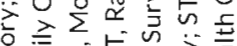

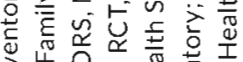

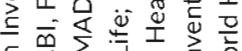

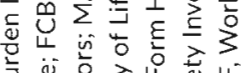

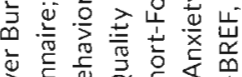

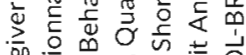

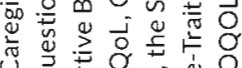
Ư

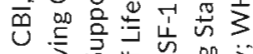

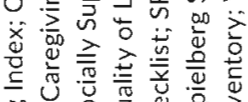

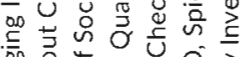

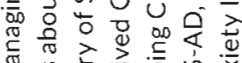

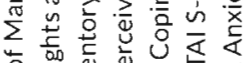

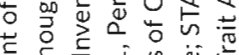

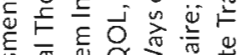

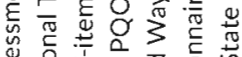

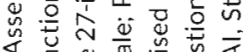

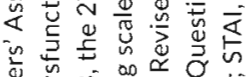

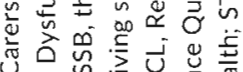

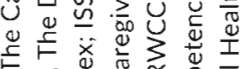

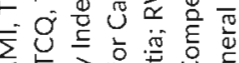

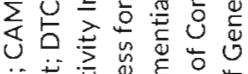
它完

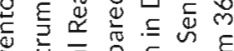

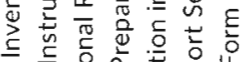

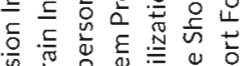

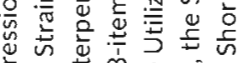

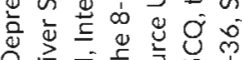

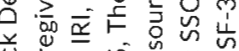

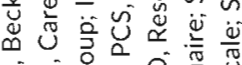

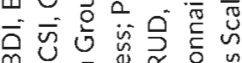
O.

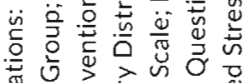

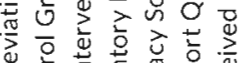

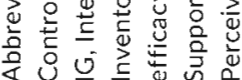



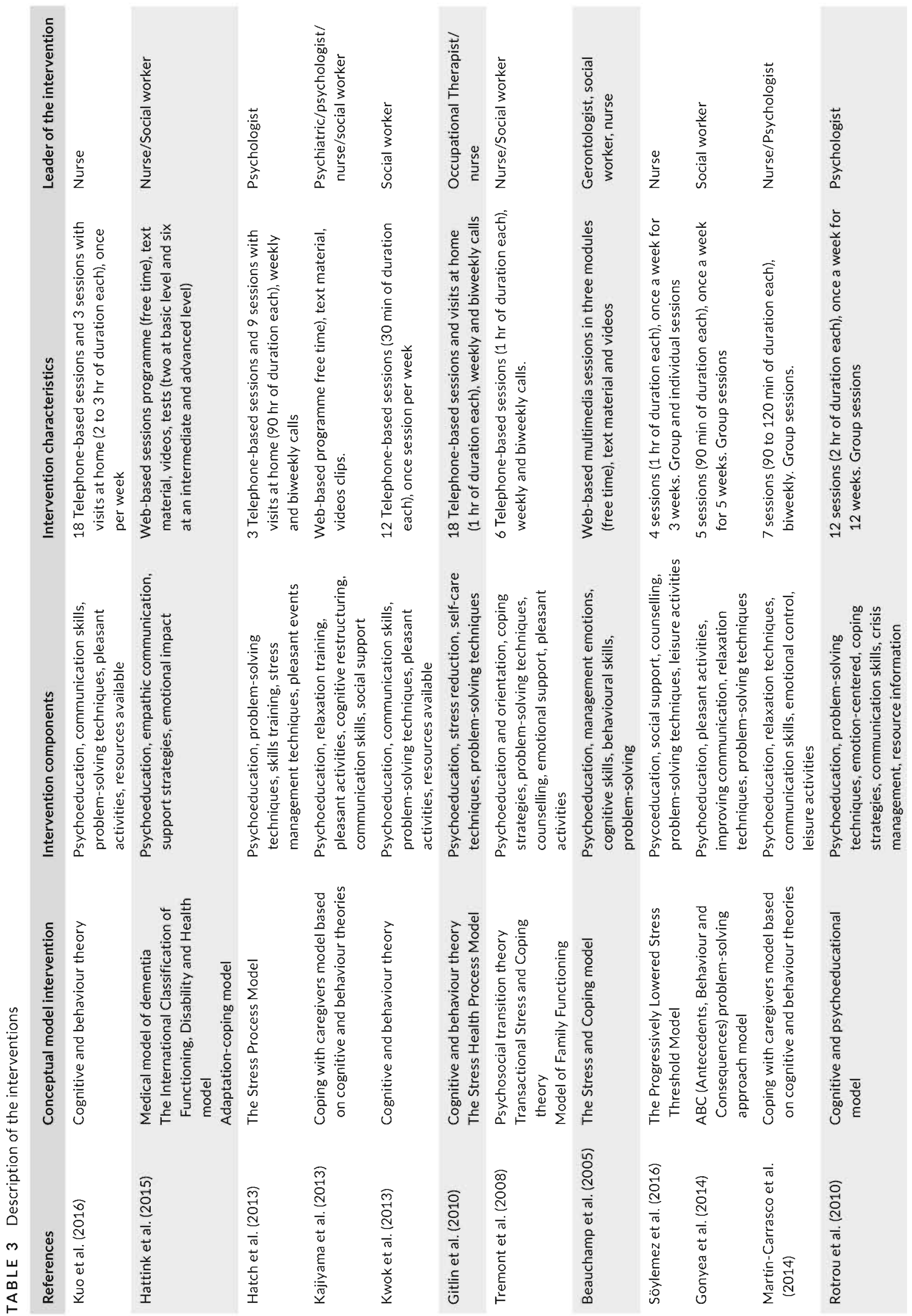
variables were evaluated pre- and postintervention and at follow-up using validated scales.

\section{5 | Effectiveness of intervention in family caregivers}

\subsection{1 | Technology-based intervention effects}

Compared with their respective control groups (CGs), the interventions achieved a significant reduction in burden (Gitlin et al., 2010; Hatch et al., 2013; Kajiyama et al., 2013; Kwok et al., 2013), levels of depression (Beauchamp et al., 2005; Gitlin et al., 2010; Hattink et al., 2015; Kajiyama et al., 2013; Kuo et al., 2016) and anxiety (Beauchamp et al., 2005), improved communication with the care recipient (Gitlin et al., 2010) (caregiver self-efficacy and well-being, and improvements in strategies for seeking help from other people (Kwok et al., 2013). It should be noted that the reductions in depression and anxiety were most significant in those caregivers who presented higher level prior to the intervention (Hatch et al., 2013). An increase in depressive symptomatology was observed in the CG postintervention (Gitlin et al., 2010; Kuo et al., 2016) and caregiver burden was associated with provision of constant care due to deterioration in the functional capacities of the $\mathrm{PwD}$, resulting in dedication of more time to caregiving activities (Kuo et al., 2016; Kwok et al., 2013). Similarly, it was observed that the level of burden depended on the presence or otherwise of externally recruited caregivers (Hatch et al., 2013). The mean duration of interventions that demonstrated a significant postintervention effect was 4.5 months, showing that an intervention with 12 sessions can help to reduce caregiver burden and increase self-efficacy (Kwok et al., 2013).

As caregivers learned from the information received in the interventions, which contributed to increased self-efficacy and skills development, the caregivers stated that better understanding of the illness enhanced their ability to care (Gitlin et al., 2010; Kwok et al., 2013) and that constant professional support also facilitated care of the PwD. The interventions that combine psychoeducation and emotional support by telephone are helpful to the caregiver as they allow patient follow-up based on what has been learned and a response to questions (Kuo et al., 2016; Kwok et al., 2013). On the other hand, it can be seen that interventions over the internet are potentially of help and may be more effective, for those caregivers that cannot access face-to-face programmes (Kajiyama et al., 2013).

\subsection{2 | Group-based intervention effects}

After the initial comparative analysis and follow-up of the results (IG \& CG) of the face-to-face psychoeducational interventions conducted in a group format, six of the 12 interventions (50\%) were observed to have had a positive effect in terms of reducing negative mood changes, specifically in caregiver depression and anxiety (Gonyea et al., 2006; Losada et al., 2011). Similarly, a decrease in 
burden (Chien \& Lee, 2008; Rabinowitz et al., 2006) and an improvement in caregivers' quality of life were observed (Gonyea et al., 2006). This significantly lowered the level of psychological distress produced by the neuropsychiatric symptomatology in the PwD and reduced dysfunctional thoughts which negatively affected the caregiver (Losada et al., 2011). The drop in levels in these variables represents an improvement in caregiver self-efficacy (Rabinowitz et al., 2006), allowing them to feel more prepared, with better tools for future activity planning (Gonyea et al., 2014) and to increase the number of pleasurable activities in their daily lives (Losada et al., 2011). Nevertheless, some findings do not support the results obtained in the IG, showing that the programme itself is only better than usual care in reducing the levels of caregiver burden and distress, as no significant differences were found between the intervention and CGs. This is, according to the authors, possibly due to methodological aspects such as the intervention format (individual or group, number and content of sessions), the measurement scale (perhaps the ZARIT is not sufficiently sensitive to change) or the clinical setting, among other aspects. It should be pointed out that, in general, participants expressed a significantly heightened degree of satisfaction with the immediate tangible benefits from the pro gramme in their role as caregivers (Martín-Carrasco et al., 2014).

The duration of the interventions is a variable to bear in mind when assessing their effectiveness. Results indicate significant variations during follow-up of patients in the intervention group, for instance in relation to burden and psychological distress (Ducharme et al., 2011; Gonyea et al., 2006), until at least 3 or even 6 months (Gonyea et al., 2006) after the intervention, while in the CG, an increase in these variables can be observed during follow-up (Rotrou et al., 2010). Thus, the duration of the interventions and the assessment of their postintervention effects allow determination of the efficacy of the psychoeducation, as dementia is a chronic illness and patients and need care over many years. Participants rated the number of sessions positively and, in the main, completed them. In the studies analysed, differences in the number of sessions can be seen, ranging from brief, basic interventions of four or five sessions up to those that use 10 or 12 sessions to carry out their educational program. Therefore, we do not speculate on which is the best proposal for the duration of an intervention, but rather recommend that the situation of the PwD and their family caregivers be taken into account. However, Mattila et al, stated in their review that the only effective way to approach the diverse problems that threaten the health of the family is through longer interventions while short, simple interventions can help to maintain family health and prevent the appearance of factors that can have adverse effects on health (Mattila, Leino, Paavilainen, \& Astedt-Kurki, 2009).

\section{4 | DISCUSSION}

The objective of this review is to provide an analysis of training programmes specifically designed for family caregivers of PwD, with the aim of assessing the impact of the intervention on burden, anxiety and depression in caregivers. Twenty RCTs were identified which evaluated the efficacy of the various interventions for the care of PwD through face-to-face or technology-based training programs. Despite some limitations and the heterogeneity of study design, interventions and measurements, the interventions share the goal of developing caregivers' skills and improving their mental and physical health (Gilhooly et al., 2016; Zabalegui, Bover, et al., 2008; Zabalegui, Navarro, et al., 2008). Consequently, this type of educational intervention has also been used with caregivers of patients with other pathologies, analysing the impact of psychoeducation on burden and the quality of life of both patient and caregiver. In addition, beneficial effects were observed with regard to caregiver health (Hasan, 2015).

Structured psychoeducational programmes addressed to family caregivers of $\mathrm{PwD}$ are viable professional support for improvements in quality of life and care provided (Darbà et al., 2014), the results of face-to-face programmes or those that employ technology demonstrate that the positive effect generated in the caregiver improves not only their well-being but also that of the patient, especially in depression and anxiety. This is due to the issues that are dealt with in the programs, the support from professionals and contact with other caregivers in the same situation (Gonyea et al., 2014; Lewis, Hobday, \& Hepburn, 2010). However, it could be said that, in some cases, the effects of these interventions are only stable up to 3 months, possibly as associated factors (financial, employment or family difficulties) could diminish the effect. Dementia is a complex illness which has a different course in each individual and, therefore, the burden perceived by each caregiver will vary and the benefit of interventions will differ from person to person, bearing in mind that the concept of burden is difficult to define and changes are difficult to perceive and/or measure (Darbà et al., 2014; Jensen, Agbata, Canavan, \& Mccarthy, 2014). Thus, Zabalegui, Bover, et al. (2008), Zabalegui, Navarro, et al. (2008), in their review state that the efficacy of interventions with regard to anxiety and depression variables reduces negative symptomatology in the short term and that the positive effects diminish over time. This is in line with studies that indicate that follow-up at 9 months postintervention reveals no statistically significant differences in anxiety and depression (Boots, Vugt, Withagen, Kempen, \& Verhey, 2016; Gonyea et al., 2006). Two possible explanations for the decrease in the positive effect over time could be: (a) the lack of home reinforcement for caregivers and (b) the lack of time available for caregivers to travel to support groups outside the home (Hatch et al., 2013).

One of the needs verbalized by the caregivers highlights the importance of professional guidelines, which would increase commitment to the intervention and their confidence when implementing the strategies learned (Chiu, Pauley, Wesson, Pushpakumar, \& Sadavoy, 2015; Nelis, Quinn, \& Clare, 2007), some interventions combine group sessions with follow-up home visits and/or telephone calls to determine whether the learned strategies have been put into practice (Hatch et al., 2013). Similarly, programmes delivered through the internet are gaining ground and providing knowledge to the caregiver 
on specific issues such as stress management and certain PWD behaviour (Chiu et al., 2015; Nelis et al., 2007). As one of the main advantages is fast, easy access to information, whenever necessary and at low cost (Chiu et al., 2015). In addition, the use of telephone technology as a means of offering advice and professional support is helpful in reducing anxiety and depressive symptoms as the professional can redirect certain situations which cause stress and anxiety in the caregiver and/or immediately make recommendations. However, it is still not clear whether telephone advice reduces burden, or improves the caregiver's quality of life or self-efficacy (Nelis et al., 2007).

The Technology-based Interventions that only use internet platforms may, on the other hand, fail to respond to the caregiver's queries immediately and some authors maintain that it is difficult to measure the intensity, duration, number and frequency of sessions or evaluate whether the programme has been completed (Cristancho-Lacroix et al., 2015; Dickinson et al., 2016; Nelis et al., 2007). Consequently, it has been proposed that online programmes include real-time chats (Chiu et al., 2015; Hasan, 2015). It should be noted that the evidence suggests that they would be more beneficial and the positive effects would be longer lasting if they also use multiple components such as advice, information and social support, although results must be interpreted with caution as, on occasion, it is not easy to measure these variables effectively. Group-based interventions generally try to increase the knowledge of dementia and develop the skills required for the emotional and behavioural management of the patient, along with other situations that arise as a consequence of the illness, which can significantly lower levels of burden, anxiety and depression in the caregiver. Their effectiveness is due to the group format, which allows reciprocal support between caregivers, so strengthening their beneficial effects if other follow-up methods are included (online or by telephone). It would also be important to assess the dose of the intervention to determine the utility of developing programmes with a specific number of sessions, to avoid saturating the caregiver, bearing in mind that travelling to the centre involves activating certain resources that, on occasion, determine whether the programme is completed in its entirety (MartinCarrasco et al., 2014). It would also be useful to increase the size of the sample (Hasan, 2015) and/or classify the caregivers according to the stage of the illness of the PwD with the aim of obtaining more significant results as the needs and strategies that caregivers require are different (Hatch et al., 2013) and analysing variables such as caregiver competencies, learning assessment and application of techniques that have been taught in the educational programme (Chien \& Lee, 2008). Furthermore, it has been suggested that the age of the caregiver is an important variable to take into account when evaluating competence, learning and capacity to take advantage of group-based or technology-based Interventions (Bank, Argüelles, Rubert, Eisdorfer, \& Czaja, 2006; Cristancho-Lacroix et al., 2015).

Currently, health policies are committed to reducing hospitalizations of PwD in long-term care institutions, since these health institutions should be more oriented towards caring for people with high levels of dependence and for their illness process and surely they would not receive adequate treatment at home. Several European studies have been carried out to compare and evaluate among countries the services available and aimed at informal caregivers of People With Dementia, the access and the responsiveness to improve the quality of care provided by caregivers, their quality of life and also the quality of life of PwD. The results of these studies have shown that innovative and creative services should be developed, based on the collaborative relationship between caregivers and professionals. However, despite the scientific evidence of experimental studies and systematic reviews, a comprehensive response to the needs expressed by caregivers has not yet been achieved. In Spain, not all specialized care settings for PwD offer educational programmes to caregivers to improve their daily care, attention to caregiver and the PWD immediate needs is a priority although the nature of the illness process and the strengthening of resources is not taken into account. Today, the lack of interventions that prepare the family to provide care over time is evident and although some centres offer support programmes for caregivers, these programmes have been temporarily designed and do not have specific follow-up to the caregivers. Likewise, the support offered by professionals to caregivers and patients is conditioned by a biomedical vision, where the health problems of PwD are more important than the social and well-being caregiver problems (Esandi \& Canga, 2016; Risco et al., 2017).

\section{1 | Limitations}

Although an exhaustive electronic search was conducted, this study has several limitations. First, the possibility of that the number of selected studies was limited by the reviewers decision not to include grey literature. Evenly, the search strategy might not be fully comprehensive. Second, studies in this analysis are limited to those published in English and Spanish journals, most of included studies were conducted in USA and China and this may potentially limit the generalizability to other countries and settings.

Third, the review has included only RCT studies and this can also be a limitation. For this, we use a quality assessment tool, the JADAD scale, to determine the methodological quality of the included studies. It should be noted that, although the JADAD scale is currently widely used and even used as a gold standard, it was fundamentally criticized.

\section{5 | CONCLUSION}

This article contributes information on the types of non-pharmaceutical interventions for caregivers of PwD, suggesting that psychoeducational interventions are practical interventions that can have protective effects on the caregiver through provision of information on the illness and advice on how to respond to certain situations, which can improve self-efficacy, reduce anxiety and have an impact on level of depression. They are also cost-effective if technological methods are used for the follow-up of caregivers, so that travel can be avoided. Nevertheless, it is vital that studies are more methodologically rigorous, especially those that depend on technology for their implementation. 


\section{ACKNOWLEDGEMENTS}

The authors thank Dr Zabalegui and Dr Risco for their guidance on the development of this manuscript.

\section{CONFLICT OF INTEREST}

The authors state no conflict of any interest.

\section{AUTHOR CONTRIBUTIONS}

All authors have agreed and approved the final version of the manuscript and confirm that it has not been previously published. Substantial contributions to conception and design, acquisition of data or analysis and interpretation of data; Drafting the article or revising it critically for important intellectual content. Frias CE: made substantial contributions to conception and design, or acquisition of data, or analysis and interpretation of data. Frias CE; Montoro $\mathrm{M}$; Garcia-Pascual M; Ribas N: involved in drafting the manuscript or revising it critically for important intellectual content. Frias $C E$; Montoro M; Garcia-Pascual M; Ribas N; Risco E; Zabalegui A: given final approval of the version to be published. Each author should have participated sufficiently in the work to take public responsibility for appropriate portions of the content. Frias CE; Risco E; Zabalegui A: agreed to be accountable for all aspects of the work in ensuring that questions related to the accuracy or integrity of any part of the work are appropriately investigated and resolved.

\section{ORCID}

Cindy E. Frias (D) https://orcid.org/0000-0001-6927-573X

Marta Garcia-Pascual (D) https://orcid.org/0000-0003-2744-5539 Ester Risco (iD) https://orcid.org/0000-0002-8174-8592. Adelaida Zabalegui (D) https://orcid.org/0000-0003-1205-3997

\section{REFERENCES}

Alvira, M. C., Risco, E., Cabrera, E., Farré, M., Rahm Hallberg, I. Bleijlevens, M. H. C., ... Zabalegui, A. (2014). The association between positive-negative reactions of informal caregivers of people with dementia and health outcomes in eight European countries: A cross-sectional study. Journal of Advanced Nursing, 71(6), 1417-1434. https://doi.org/10.1111/jan.12528

Bank, A. L., Argüelles, S., Rubert, M., Eisdorfer, C., \& Czaja, S. J. (2006) The value of telephone support groups among ethnically diverse caregivers of persons with dementia. The Gerontologist, 46(1), 134138. https://doi.org/10.1093/geront/46.1.134

Barr, C., Riolacci-Dhoyen, N., Galbraith, M., \& Leperre-Desplanques, A. (2012). Sharing knowledge to advance healthcare policies in Europe for people living with dementia and their carers: The ALCOVE project. Archives of Public Health, 70(1), 21, https://doi. org/10.1186/0778-7367-70-21

Beauchamp, N., Irvine, A. B., Seeley, J., \& Johnson, 8. (2005). Worksitebased internet multimedia program for family caregivers of persons with dementia. The Gerontologist, 45(6), 793-801. https:/doi org/10.1093/geront/45.6.793

Beinard, N., Weinman, J., Wade, D., \& Brady, R. (2012). Caregiver burden and psychoeducational interventions in Alzheimer's disease: A review. Dementia and Geriatric Cognitive Disorders Extra, 2(1), 638-648. https://doi.org/10.1159/000345777

Bleijlevens, M. H. C., Stolt, M., Stephan, A., Zabalegui, A., Saks, K., Sutcliffe, C., ... Zwakhalen, S. M. G. (2014). Changes in caregiver burden and health-related quality of life of informal caregivers of older people with dementia: Evidence from the European RightTimePlaceCare prospective cohort study. Journal of Advanced Nursing, 71(6), 13781391. https://doi.org/10.1111/jan.12561

Bökberg, C., Ahlström, G., Leino-Kilpi, H., Soto-Martin, M. E., Cabrera, E., Verbeek, H., ... Karlsson, S. (2015). Care and service at home for persons with dementia in Europe. Journal of Nursing Scholarship, 47(5), 407-416. https://doi.org/10.1111/jnu.12158

Boots, L. M., Vugt, M. E., Knippenberg, R. J., Kempen, G. I., \& Verhey, F. R. (2013). A systematic review of Internet-based supportive interventions for caregivers of patients with dementia. International Journal of Geriatric Psychiatry, 29(4), 331-344. https://doi.org/10.1002/ gps. 4016

Boots, L. M., Vugt, M. E., Withagen, H. E., Kempen, G. I., \& Verhey, F. R. (2016). Development and initial evaluation of the web-based self-management program "partner in balance" for family caregivers of people with early stage dementia: An exploratory mixed-methods study. JMIR Research Protocols, 5(1), e33. https://doi.org/10.2196/ resprot. 5142

Buckley, J. S., \& Salpeter, S. R. (2015). A risk-benefit assessment of dementia medications: Systematic review of the evidence. Drugs \& Aging, 32(6), 453-467. https://doi.org/10.1007/ s40266-015-0266-9

Chiao, C., Wu, H., \& Hsiao, C. (2015). Caregiver burden for informal caregivers of patients with dementia: A systematic review. International Nursing Review, 62(3), 340-350. https://doi.org/10.1111/inr.12194

Chien, W. T., \& Lee, Y. M. (2008). A disease management program for families of persons in Hong Kong with dementia. Psychiatric Services, 59(4), 433-436. https://doi.org/10.1176/appi.ps.59.4.433

Chiu, M., Pauley, T., Wesson, V., Pushpakumar, D., \& Sadavoy, J. (2015). Evaluation of a problem-solving (PS) techniques-based intervention for informal carers of patients with dementia receiving in-home care. International Psychogeriatrics, 27(06), 937-948. https://doi. org/10.1017/S1041610214002798

Cristancho-Lacroix, V., Wrobel, J., Cantegreil-Kallen, I., Dub, T., Rouquette, A., \& Rigaud, A. (2015). A web-based psychoeducational program for informal caregivers of patients with Alzheimer's disease: A pilot randomized controlled trial. Journal of Medical internet Research, 17(5), e117. https://doi.org/10.2196/jmir.3717

Darbà, J., Kaskens, L., \& Lacey, L. (2014). Relationship between global severity of patients with Alzheimer's disease and costs of care in Spain; results from the co-dependence study in Spain. The European Journal of Health Economics, 16(8), 895-905. https://doi.org/10.1007/ s10198-014-0642-0

Dickinson, C., Dow, J., Gibson, G., Hayes, L., Robalino, S., \& Robinson, L. (2016). Psychosocial intervention for carers of people with dementia: What components are most effective and when? A systematic review of systematic reviews. International Psychogeriatrics, 29(1), 31-43. https://doi.org/10.1017/S1041610216001447

Ducharme, F. C., Levesque, L. L., Lachance, L. M., Kergoat, M., Legault, A. J., Beaudet, L. M., \& Zarit, S. H. (2011). "Learning to become a family caregiver" efficacy of an intervention program for caregivers following diagnosis of dementia in a relative. The Gerontologist, 51(4), 484-494. https://doi.org/10.1093/geront/gnr014

Esandi, N., \& Canga, A. (2016). Atención centrada en la familia: Un modelo para abordar los cuidados de la demencia en la comunidad. Atención Primaria, 48(4), 265-269. https://doi.org/10.1016/j. aprim.2015.11.006

Espi-López, G. V., Arnal-Gómez, A., Balasch-Bernat, M., \& Inglés, M. (2017). Effectiveness of manual therapy combined with physical therapy in treatment of patellofemoral pain. Syndrome: Systematic review. Journal of Chiropractic Medicine, 16(2), 139-146. https://doi. org/10.1016/j.jcm.2016.10.003

Farré, M., Haro, J. M., Kostov, B., Alvira, C., Risco, E., Miguel, S., ... Zabalegui, A. (2016). Direct and indirect costs and resource use in 
dementia care: A cross-sectional study in patients living at home. International Journal of Nursing Studies, 55, 39-49. https://doi. org/10.1016/j.ijnurstu.2015.10.012

Giebel, C., Sutcliffe, C., Verbeek, H., Zabalegui, A., Soto, M., Hallberg, I. R., ... Challis, D. (2015). Depressive symptomatology and associated factors in dementia in Europe: Home care versus long-term care. International Psychogeriatrics, 28(04), 621-630. https://doi. org/10.1017/S1041610215002100

Gilhooly, K. J., Gilhooly, M. L., Sullivan, M. P., Mclntyre, A., Wilson, L., Harding, E., ... Crutch, S. (2016). A meta-review of stress, coping and interventions in dementia and dementia caregiving. BMC Geriatrics, 16(1), 106. https://doi.org/10.1186/s12877-016-0280-8

Gitlin, L. N., Winter, L., Dennis, M. P., Hodgson, N., \& Hauck, W. W. (2010). Targeting and managing behavioral symptoms in individuals with dementia: A randomized trial of a nonpharmacological intervention. Journal of the American Geriatrics Society, 58(8), 1465-1474. https://doi.org/10.1111/j.1532-5415.2010.02971.x

Gonyea, J. G., López, L. M., \& Velásquez, E. H. (2014). The effectiveness of a culturally sensitive cognitive behavioral group intervention for latino Alzheimer's caregivers. The Gerontologist, 56(2), 292-302. https://doi.org/10.1093/geront/gnu045

Gonyea, J. G., Oconnor, M. K., \& Boyle, P. A. (2006). Project CARE: A randomized controlled trial of a behavioral intervention group for Alzheimers disease caregivers. The Gerontologist, 46(6), 827-832. https://doi.org/10.1093/geront/46.6.827

Goren, A., Montgomery, W., Kahle-Wrobleski, K., Nakamura, T., \& Ueda, K. (2016). Impact of caring for persons with Alzheimer's disease or dementia on caregivers' health outcomes: Findings from a community based survey in Japan. BMC Geriatrics, 16(1), 122. https://doi. org/10.1186/s12877-016-0298-y

Hasan, A. (2015). Evaluation of the impact of a psycho-educational intervention on knowledge levels and psychological outcomes for people diagnosed with schizophrenia and their caregivers in Jordan. European Psychiatry, 30, 1672, https://doi.org/10.1016/ S0924-9338(15)31283-9

Hatch, D. J., Dehart, W. B., \& Norton, M. C. (2013). Subjective stressors moderate effectiveness of a multi-component, multi-site intervention on caregiver depression and burden. International Journal of Geriatric Psychiatry, 29(4), 406-413. https://doi.org/10.1002/ gps.4019

Hattink, B., Meiland, F., van der Roest, H., Kevern, P., Abiuso, F., Bengtsson, J., ... Dröes, R.-M. (2015). Web-based STAR E-learning course increases empathy and understanding in dementia caregivers: Results from a randomized controlled trial in the Netherlands and the United Kingdom. Journal of Medical internet Research, 17(10), e241. https://doi.org/10.2196/jmir.4025

Jadad, A. R., Moore, R. A., Carroll, D., Jenkinson, C., Reynolds, D. J. M., Gavaghan, D.J., \&McQuay, H. J.(1996). Assessing the quality of reports of randomized clinical trials: Is blinding necessary? Control Clinical Trials, 17(1), 1-12. https://doi.org/10.1016/0197-2456(95)00134-4

Jensen, M., Agbata, I. N., Canavan, M., \& Mccarthy, G. (2014). Effectiveness of educational interventions for informal caregivers of individuals with dementia residing in the community: Systematic review and meta-analysis of randomised controlled trials. International Journal of Geriatric Psychiatry, 30(2), 130-143. https:// doi.org/10.1002/gps.4208

Kajiyama, B., Thompson, L. W., Eto-Iwase, T., Yamashita, M., Mario, J. D., Tzuang, Y. M., \& Gallagher-Thompson, D. (2013). Exploring the effectiveness of an Internet-based program for reducing caregiver distress using the iCare Stress Management e-Training Program. Aging \& Mental Health, 17(5), 544-554. https://doi.org/10.1080/13607 863.2013.775641

Kuo, L., Huang, H., Liang, J., Kwok, Y., Hsu, W., Su, P., \& Shyu, Y. L. (2016). A randomized controlled trial of a home-based training programme to decrease depression in family caregivers of persons with dementia. Journal of Advanced Nursing, 73(3), 585-598. https://doi org/10.1111/jan.13157

Kurz, A., Wagenpfeil, S., Hallauer, J., Schneider-Schelte, H., \& Jansen, S. (2009). Evaluation of a brief educational program for dementia carers: The AENEAS study. International Journal of Geriatric Psychiatry, 25(8), 861-869. https://doi.org/10.1002/gps.2428

Kwok, T., Wong, B., Ip, I., Chui, K., Young, D., \& Ho, F. (2013). Telephonedelivered psychoeducational intervention for Hong Kong Chinese dementia caregivers: A single-blinded randomized controlled trial. Clinical interventions in Aging, 8, 1191-1197. https://doi.org/10.2147/ CIA.S48264

Lewis, M., Hobday, J., \& Hepburn, K. (2010). Internet-based program for dementia caregivers. American Journal of Alzheimer's Disease and Other Dementias, 25(8), 674-679. https://doi.org/10.1177/15333 17510385812

Losada, A., Márquez-González, M., \& Romero-Moreno, R. (2011). Mechanisms of action of a psychological intervention for dementia caregivers: Effects of behavioral activation and modification of dysfunctional thoughts. International Journal of Geriatric Psychiatry, 26(11), 1119-1127. https://doi,org/10.1002/gps.2648

Martín-Carrasco, M., Domínguez-Panchón, A. I., González-Fraile, E., Muñoz-Hermoso, P., \& Ballesteros, J. (2014). Effectiveness of a psychoeducational intervention group program in the reduction of the burden experienced by caregivers of patients with dementia. Alzheimer Disease \& Associated Disorders, 28(1), 79-87. https://doi. org/10.1097/WAD.0000000000000003

Mattila, E., Leino, K., Paavilainen, E., \& Astedt-Kurki, P. (2009), Nursing intervention studies on patients and family members: A systematic literature review. Scandinavian Journal of Caring Sciences, 23(3), 611622. https://doi.org/10.1111/j.1471-6712.2008.00652.x

McFarlane, W., Dixon, L., \& Lucksted, A. (2003). Family psychoeducation and schizophrenia: A review of the literature Journal of Marital and Family Therapy, 29(2), 223. https://doi. org/10.1111/j.1752-0606.2003.tb01202.x

Moher, D., Liberati, A., Tetzlaff, J., \& Altman, D. G.; The PRISMA Group. (2009). Preferred reporting items for systematic reviews and meta-analyses: The PRISMA Statement. PLoS Med, 6(7), e1000097. https://doi.org/10.1371/journal.pmed.1000097

Nelis, S., Quinn, C., \& Clare, L. (2007). Information and support interventions for informal caregivers of people with dementia. Cochrane Database of Systematic Reviews, 2, 6. https://doi.org/10.1002/14651 858.cd006440

Rabinowitz, Y. G., Mausbach, B. T., Coon, D. W., Depp, C., Thompson, L. W., \& Gallagher-Thompson, D. (2006). The moderating effect of self-efficacy on intervention response in women family caregivers of older adults with dementia. The American Journal of Geriatric Psychiatry, 14(8), 642-649. https://doi.org/10.1097/01.JGP.00001 92496.73673.e5

Risco, E., Zabalegui, A., Miguel, S., Farré, M., Alvira, C., \& Cabrera, E. (2017). Application of the Balance of Care model in decisión-making regarding the best care for patients with dementia. Gaceta Sanitaria 31(6), 518-523. https://doi.org/10.1016/j.gaceta.2016.07.006

Robinson, K. M., Crawford, T. N., Buckwalter, K. C., \& Casey, D. A. (2018), Outcomes of a two-component intervention on behavioral symptoms in persons With Dementia and symptom response in their caregivers. Journal of Applied Gerontology, 37(5), 570-594. https://doi org/10.1177/0733464816677549

Rotrou, J. D., Cantegreil, I., Faucounau, V., Wenisch, E., Chausson, C., Jegou, D.,... Rigaud, A. (2010). Do patients diagnosed with Alzheimers disease benefit from a psycho-educational programme for family caregivers? A randomised controlled study. International Journal of Geriatric Psychiatry, 26(8), 833-842. https://doi.org/10.1002/ gps.2611

Schulz, R., Gallagher-Thompson, D., Haley, W., \& Czaja, S. (2000) Understanding the interventions process: A theoretical/conceptual 
framework for intervention approaches to caregiving. In R. Schulz (Ed.), Handbook on dementia caregiving: Evidence-based interventions for family caregivers ( $p$ p. 33-60). New York, NY, US: Springer Publishing $\mathrm{Co}$

Seminario-Amez, M., López-López, J., Estrugo-Devesa, A., AyusoMontero, R., \& Jané-Salas, E. (2017). Probiotics and oral health: A systematic review. Medicina Oral Patología Oral Y Cirugia Bucal, 22(3), e282-e288.

Söylemez, B. A., Küçükgüçlü, Ö., \& Buckwalter, K. C. (2016). Application of the progressively lowered stress threshold model with community-based caregivers: A randomized controlled trial. Journal of Gerontological Nursing, 42(7), 44-54. https://doi.org/10.3928/00989 134-20160406-01

Tremont, G., Davis, J. D., Bishop, D. S., \& Fortinsky, R. H. (2008). Telephone-delivered psychosocial intervention reduces burden in dementia caregivers. Dementia, 7(4), 503-520. https://doi. org/10.1177/1471301208096632

Wimo, A., Jönsson, L., Gustavsson, A., McDaid, D., Ersek, K., Georges, J., ... Valtonen, H. (2010). The economic impact of dementia in Europe in 2008-cost estimates from the Eurocode project. International Journal of Geriatric Psychiatry, 26(8), 825-832. https://doi.org/10.1002/ gps. 2610

Wübker, A., Zwakhalen, S. M. G., Challis, D., Suhonen, R., Karlsson, S., Zabalegui, A., ... Sauerland, D. (2014). Costs of care for people with dementia just before and after nursing home placement: Primary data from eight European countries. The European Journal of Health Economics, 16(7), 689-707. https://doi.org/10.1007/ s10198-014-0620-6

Zabalegui, A., Bover, A., Rodriquez, E., Cabrera, E., Diaz, M., Gallart, A., ... Ramírez, A. (2008). Informal caregiving: Perceived needs. Nursing
Science Quarterly, 21(2), 166-172. https://doi.org/10.1177/08943 18408314978

Zabalegui, A., Hamers, J. P. H., Karlsson, S., Leino-Kilpi, H., RenomGuiteras, A., Saks, K., ... Cabrera, E. (2014). Best practices interventions to improve quality of care of people with dementia living at home. Patient Education and Counseling, 95(2), 175-184. https://doi. org/10.1016/j.pec.2014.01.009

Zabalegui, A., Navarro, M., Cabrera, E., Gallart, A., Bardallo, D., Rodriguez, E., ... Argemí, J. (2008). Efficacy of interventions aimed at the main carers of dependent individuals aged more than 65 years old. A systematic review. Revista Española De Geriatría Y, Gerontología, 43(3), 157-166.

Zhang, H., Lan, X., Pen, G. B., \& Li, B. (2019). Is total laparoscopic pancreaticoduodenectomy superior to open procedure? A meta-analysis. World Journal of Gastroenterology, 25(37), 5711-5731. https://doi. org/10.3748/wjg.v25.i37.5711

How to cite this article: Frias CE, Garcia-Pascual M, Montoro M, Ribas N, Risco E, Zabalegui A. Effectiveness of a psychoeducational intervention for caregivers of People With Dementia with regard to burden, anxiety and depression: A systematic review. J Adv Nurs. 2020;76:787802. https://doi.org/10.1111/jan.14286

The Journal of Advanced Nursing (JAN) is an international, peer-reviewed, scientific journal. JAN contributes to the advancement of evidence-based nursing, midwifery and health care by disseminating high quality research and scholarship of contemporary relevance and with potential to advance knowledge for practice, education, management or policy. JAN publishes research reviews, original research reports and methodological and theoretical papers.

For further information, please visit JAN on the Wiley Online Library website: www.wileyonlinelibrary.com/journal/jan

Reasons to publish your work in JAN:

- High-impact forum: the world's most cited nursing journal, with an Impact Factor of 1.998 - ranked 12/114 in the 2016 ISI Journal Citation Reports (C) (Nursing (Social Science)).

- Most read nursing journal in the world: over 3 million articles downloaded online per year and accessible in over 10,000 libraries worldwide (including over 3,500 in developing countries with free or low cost access).

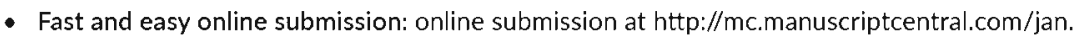

- Positive publishing experience: rapid double-blind peer review with constructive feedback.

- Rapid online publication in five weeks: average time from final manuscript arriving in production to online publication.

- Online Open: the option to pay to make your article freely and openly accessible to non-subscribers upon publication on Wiley Online Library, as well as the option to deposit the article in your own or your funding agency's preferred archive (e.g. PubMed). 


\title{
6. Publicaciones Científicas
}

\author{
6.2 Artículo 2
}

Psychoeducational intervention on burden and emotional well-being addressed to informal caregivers of people with dementia.

Cindy E. Frías, Ester Risco, Adelaida Zabalegui

Psychogeriatrics. 2020; 20(6): 900-909. https://doi.org/10.1111/psyg.12616.

IF: 1.75. Q2 


\title{
Psychoeducational intervention on burden and emotional well-being addressed to informal caregivers of people with dementia
}

\author{
Cindy E. FRIAS $\bullet{ }^{1}$ Ester RISCO $^{2}$ and Adelaida ZABALEGUI ${ }^{1}$
}

\author{
${ }^{1}$ Department of Nursing, Hospital Clinic of Barce- \\ lona and ${ }^{2}$ Hospital Pere [ Virgili of Barcelona, Bar- \\ celona, Spain \\ Correspondence: Ms Adelaida Zabalegui, Hospital \\ Clinic of Barcelona, Villarroel Street, 170, Barcelona \\ 08036, Spain. Email: azabaleg@clinic.cat \\ Disclosure: The authors report no conflict of \\ interest. The corresponding author has had full \\ access to all study data and was ultimately \\ responsible for the decision of submit for \\ publication. \\ marato Tv3 Foundation 20144410 \\ Received 9 June 2020; revision received 24 August 2020; \\ accepted 2 September 2020.
}

Key words: burden, dementia, emotional well-being, informal caregivers, mental health nurse.

\begin{abstract}
Background: In dementia it is necessary that a family member become an informal caregiver. This labour has social, physical and emotional repercussions on the caregiver's health. The objective was to assesses the impact of the INFOSA-DEM intervention on burden and emotional well-being among caregivers of people with dementia, evaluating the effects at 3 and 6 months.

Method: We adopted an experimental, non-randomised design with an intervention group and a control group. The intervention group received the intervention and the control group received usual care. The study was carried out in the catchment areas of three centres specialising in the care of people with cognitive impairment in the province of Barcelona.

Results: At 3 months, there was an improvement with respect to burden in the intervention group with a significant worsening $(P<0.012)$ in the control group. Similarly, a positive effect on emotional well-being was observed in the intervention group compared with a small negative effect among controls. Conclusions: Programs addressed to informal caregivers based on psychoeducational and cognitive-behavioural therapies are effective in improving quality of life and emotional well-being, and in reducing burden, with a positive effect on the quality of care provided at home.
\end{abstract}

\section{INTRODUC'TION}

Ageing is associated with a rise in chronic, noncommunicable diseases, such as dementia, which reduce a person's cognitive, physical and social capacities and lead to dependence. ${ }^{1,2}$ Dementia affects around 47 million people worldwide and, according to World Health Organization (WHO) data, there are almost 10 million new cases each year. This is expected to rise to 75 million by 2030 and to triple by $2050 .{ }^{3}$ Of these new cases, 19 million correspond to people diagnosed in Europe. Currently, there are 800000 people diagnosed with Alzheimer's in Spain and more than 86000 in Catalonia. ${ }^{4}$ As such, and due to its medical and direct social economic costs, along with the costs of informal care, it has become a public health priority among European member states. ${ }^{5,6}$
In dementia, progressive loss of autonomy in activities as basic as showering, dressing or eating results in a constant search for help among friends and family. There is a change in roles in the nucleus of the family and, in general, one of the family members becomes the main or informal caregiver $(\mathrm{IC})^{2}$, 7-9 There is a lack of awareness and understanding of dementia in most countries, which leads to an increase in stigmatisation and barriers to diagnosis and care that affect caregivers and the entire family. In Latin American and some European countries, care is provided by the family itself, which can raise familial expenses as the services and resources supplied by some public institutions do not always totally cover the needs of people with dementia (PwD). ${ }^{1,} 11$ Being an IC of PWD has social and emotional 
consequences, which together with burden, affect caregivers' physical health to the extent that they may abandon their own social or even work activities and take little time to rest. ${ }^{5}$ Findings from studies carried out by the Dementia Research Group 10/66 (10/66 DRG) showed that comparison of the physical and emotional health of caregivers of PwD from 24 centres in South and Southeast Asia, Africa and Latin America revealed levels of psychological stress and morbidity that were comparable with those seen in developed countries, and that in countries such as Cuba and the Dominican Republic, dementia was highly associated with dependence. Similarly, the ICs had depressive symptoms and/or high physical morbidity, giving up their work to take care of their relatives. ${ }^{11}$

In Spain, most dependent individuals are cared for in their own home voluntarily and informally by a family member. This can have negative consequences in the medium term on the caregivers' physical and emotional health, finances and social relationships. ${ }^{12}$ Over time, this translates into burden as the IC gives up employment or reduces her/his work schedule to spend more time caring for the PwD. ${ }^{7,} 13$ If carers of PwD are compared with other types of caregivers, even immune system deficiencies can be observed. ${ }^{8}$ These can lead to greater risk of alterations to emotional well-being, especially if there is less social and family support, resulting in negative effects on the quality of life of the PwD and the quality of care provided by the $\mid \mathrm{C} .^{1,14}$ Under these circumstances, there is a need to guide home care through an INFOSA-DEM training, information and social support program addressed to ICs to improve their quality of life and quality of home care provision. The complexity of dementia, the heterogeneity of families and their financial resources, available social and health services, and the country in question should all be taken into account with the aim of establishing best practices for the improvement of care in the home environment. The program includes emotional and social support based on psychoeducational theories developed by Lukens and McFarlane, cognitivebehavioural theories and the Antecedent-BehaviourConsequence (ABC) Model ${ }^{15},{ }^{16}$ which promote problem-management and cognitive restructuring, stress and burden management to reduce their consequences. Emphasis is placed on engagement in pleasurable activities, based on the hypothesis that these activities increase emotional well-being, reduce anxiety, improve the quality of life of both the PwD and caregiver, and improve the quality of care provided at home as satisfaction and relaxation are protective factors against the negative effects of care demands. ${ }^{1}, 13,17,18$ The aim of this study was to assess the impact of the INFOSA-DEM psychoeducational intervention: training, information and social support, on burden and emotional well-being in $I C s$ of PwD living at home, evaluating the durability of the effects at 3 and 6 months post-intervention.

\section{MATERIALS AND METHODS}

This was a multicentre, longitudinal study with repeated observations (Pre and Post-test I at 3 months and Post-test II at 6 months)with an experimental, non-randomised design with an intervention group $(I G)$ and a control group (CG).

\section{Setting and participants}

The study was carried out in the catchment areas of three centres specialising in the care of people with cognitive impairment in the province of Barcelona. The project was approved by the ethics committee and follows the recommendations of the Declaration of Helsinki. The population of interest consisted of family or informal caregivers of people with a diagnosis of dementia living at home with an identified caregiver, treated at the three centres. Inclusion criteria were: informal/family caregivers (over 18 years old) of people aged 65 years or older with a diagnosis of dementia and a Mini-Mental State Examination (MMSE) test score $<24$, living with the person with dementia or visiting him/her at least twice a week. People with other psychiatric illnesses or Korsakov's syndrome were excluded. The IC was excluded if she/he had participated in any training or structured activity related to the subject of study in the previous year.

Participants were included from primary care settings or community services through convenience sampling, recruiting cases as they confirmed they were interested in participating. After agreeing to take part, caregivers provided signed informed consent. Baseline data were collected on participants and they were subsequently assigned to the $I G$ or the $\mathrm{CG}$. ICs in the IG received the INFOSA-DEM 
psychoeducational intervention, together with usual care offered by the participating centres.

The intervention consisted in a program of five training/information sessions imparted consecutively over 1 week with an approximate duration of $90 \mathrm{~min}$ per session per day. Content included information on dementia and its care, communication strategies, approaches to emotional and behavioural symptoms in PWD, and the importance of self-care and engaging in pleasurable activities. Sessions were conducted using audiovisual support to facilitate understanding and encourage the active participation of caregivers in sharing their experiences. Four explanatory films, created specifically for this program, were shown under the heading of 'living with dementia'. In addition, a guidebook was provided to caregivers with details on the contents of the program. Each session was performed in a location with sufficient physical space and ample time for dialogue and mutual support to be established between caregivers (Table SS1).

Caregivers in the $C G$ only received usual care in the centres where the PwD was monitored. Monitoring consisted of annual or quarterly visits with the referring doctor (family physician, geriatrician or neurologist), nursing staff or social worker, depending on the care centre and the needs of the PwD.

\section{Ethical considerations}

All patients and informal caregivers were asked to provide written informed consent prior to participation in the study, although in cases of severe cognitive impairment of the person with dementia, consent was requested only from the IC. Ethics Committee approval was obtained (Reg. HCB/2018/0737).

\section{Data collection}

Data were collected during face-to-face interviews with dementia patients and caregivers by trained interviewers following instructions in a written manual. Patients and caregivers were the informants in the home care setting. Interviews were carried out at baseline and at 3-month and 6-month follow-up between January, 2018 and September, 2019. Interviewers were nurses with clinical experience and at least a master's degree. Furthermore, they received additional training on data collection including all procedures, content of the assessments and completion of questionnaires. In the PwD variables analysed were assessed on one occasion and in $\mathrm{IC}$ were assessed at three time-points (Pre-test, Post-test I and Post-test II).

\section{Demographic characteristics}

Socio-demographic data were evaluated through a specifically designed questionnaire from the caregivers and PwD (age, gender, relationship with PwD, marital status, type of dementia, and time since diagnosis).

\section{Measures for PwD}

These included quality of life, using the Quality of Life in Alzheimer's Disease (QoL-AD). Presence of comorbidities, through the Charlson Comorbidity Index (CCl). Degree of cognitive impairment was also evaluated using $\mathrm{MMSE}^{19}$ and Global Deterioration Scale $(\mathrm{GDS}){ }^{20}$

\section{Measures for IC}

Degree of burden was assessed using the Spanish version of the Zarit Burden Interview (ZB|). This evaluated subjective perception of care, emotional and physical burden, financial difficulties and limitations to social activities associated with care provision. It consists of 22 items on a five-point Likert-type scale ranging from $0=$ 'never' to $4=$ 'almost always', with higher scores indicating a high degree of burden. Cronbach's alpha was $0.92 .^{21}$

Emotional well-being, was assessed using the General Health Questionnaire (GHQ-12), as a unidimensional measure seems to be a useful screening tool for the assessment of mental distress or a minor psychiatric morbidity in contexts such as primary care or in the general population. It has 12 items, six positively worded and six negatively worded. It has a four-point Likert-type scale (0-1-2-3) which can be transformed into a dichotomous score $(0-0-1-1)$, called the GHQ score. The GHQ-12 demonstrates good reliability in studies carried out with a Cronbach's alpha between 0.82 and $0.86{ }^{22,} 23$

Caregiver reactions, was assessed using Caregiver Reaction Aspects (CRA), an instrument designed to assess specific facets of caregiving, including both negative and positive dimensions of caregiving reactions. It consists of 24 items in five subscales: self-esteem (score range 7-35), lack of family support (range 5-25), financial problems (range 3-15), disrupted schedule (range 5-25) and health 
problems (range 4-20). Responses are represented on a Likert-type scale of 1 = strongly disagree to $5=$ strongly agree. A higher score on the caregiver's self-esteem subscale indicates a more positive reaction to caregiving, while higher scores on the other four subscales indicate greater negative reactions. Reliability analyses showed that standardised Cronbach's alphas varied between 0.62 and 0.83 for the separate subscales, indicating sufficient internal consistencies. Construct validity was supported. The CRA proves to be a feasible, reliable, valid instrument for assessing both negative and positive reactions to caregiving. $^{7}$, 24-26 Perceived social support, was assessed through the Perceived Social Support Questionnaire (Duke-UNC), an 11-item, selfadministered instrument that uses a Likert-type response scale ranging from 1 ('Much less than I would like') to 5 ('As much as I would like'). The questionnaire quantitatively evaluates perceived social support and includes two dimensions: confidential social support (advice or guidance, or reliance on people with whom one can share concerns or problems); and affective social support (expressions of love, appreciation, sympathy or belonging to a group), Cronbach's alpha was 0.90 for the total scale and 0.88 for the confidential support scale. ${ }^{27-29}$

QoL was assessed with the Quality of Life Scale (EQ-5D), a measure of self-reported QoL that covers a wide range of health conditions and treatments. It consists of two parts: a descriptive system (Part l) and a visual analogue scale (VAS) (Part II). Part I has five single-item dimensions: mobility, self-care, usual activities, pain/discomfort and anxiety/depression. Each dimension has a three-point response scale. Part II measures health status, ranging from worst imaginable health status to best. ${ }^{30}$

The formal and informal care in dementia was assessed using items from the Resource Utilisation in Dementia (RUD) questionnaire related to caregiving hours. These items record the time spent by the IC on care in three categories: activities of daily living (ADL), instrumental activities of daily living (IADL) and supervision of the PwD. For each of the three categories, ICs are asked to specify on how many days they provided care in the past 30 . If care is provided by the $I C$ in a particular category, an additional question is asked to ascertain how many minutes are spent on average per care-day, to provide estimates of time spent per month on $A D L$ care, $I A D L$ care and supervision. Additionally, socio-demographic data (including age, gender and marital status) were collected about both the person with dementia and the informal caregiver. This has previously been used by Farré et al., in a Spanish population., 31

Neuropsychiatric symptoms in the PwD were measured using the Neuropsychiatric Inventory (NPI), which includes 10 behavioural domains (delusions, hallucinations, dysphoria, anxiety, agitation/aggression, euphoria, disinhibition, irritability, apathy and aberrant motor activity) with 7-8 sub-questions and measures severity (three-point scale) and frequency (four-point scale). The total NPI score is the sum of the subscale scores. Higher scores indicate more behavioural disturbance. Analyses showed that standardised Cronbach's alpha's is $0.783{ }^{32}$ Measurement instruments were selected based on their psychometric properties (validity, reliability), clinical utility and suitability for the target settings and population. At the 3-month and 6-month follow-up interviews, these measures were repeated at home.

\section{Data analysis}

Descriptive data are presented as means and standard deviation (SD) for continuous variables and numbers and percentages (\%) for categorical variables. Paired $t$-test or the independent samples $t$-test were used to compare the continuous outcomes between baseline visit and 3-month follow-up. Jonckheere-Terpstrata monotonic trend test, equivalent to Kruskal-Wallis test, but for the ordered categories, was used to verify the possible existence of a trend between successive visits (baseline, 3-month and 6-month follow-up). The mean differences between the control and intervention groups and their $95 \%$ confidence intervals were calculated. Data visualisation techniques were used to summarise information such as bar charts, jitter plots and error bars. All significance tests were two-tailed and values of $P<0.05$ were considered significant. All analyses were conducted using $R$ version 3.4.1 for Windows statistical software package.

\section{RESULTS}

\section{Overall characteristics of the IC and PwD}

A total of $160 \mathrm{lCs}$ who completed baseline assessments took part and were assigned to the $C G$ or the IG; 74 and 86 caregivers, respectively. At 6 months, 
112 participants completed evaluations. Seventeen of 86 participants in the IG dropped out of the study or declined to continue with follow-up assessments (19\%) due to a lack of time. Twenty-eight of 74 participants in the CG were not available for subsequent evaluations or dropped out due to death or admission of the PwD to a residential facility. The average age of the ICs was 63.7 years (SD 12.8). Some $76.2 \%$ of the caregivers were women and more than $50 \%$ were spouses of the PwD while $38 \%$ were offspring. Almost $80 \%$ of caregivers lived with the PwD. Regarding the $\mathrm{PwD}$, the average age was 79 years (SD 8.2). More than $50 \%$ were women and $70 \%$ had been diagnosed with dementia at least 5 years previously (SD 3.2) (Table 1). Seven groups of 10 caregivers and two groups of eight caregivers received the psychoeducational intervention and following completion of assessments at 6-month follow-up; three more groups of 10 caregivers from the $C G$ also received the INFOSA-DEM psychoeducational program.

\section{Cognitive status assessed and physical dependency of PwD}

A total of $39 \%$ of $\mathrm{PwD}$ had moderate cognitive impairment, and $43 \%$ presented moderate cognitive impairment when evaluated with the GDS. Some $49 \%$ had an illness in addition to their diagnosis of dementia. More than $38 \%$ of PwD had partial dependence in ADL and an average of 6.7 (SD 5.4) presented severe neuropsychiatric symptoms that disturbed their behaviour and produced stress in their IC (Table 2).

\section{Levels of burden and reactions to caregiving}

A total of $25 \%$ of ICs were in paid employment but reported losing an average of $11.2 \mathrm{~h}$ per week (SD 7.6) in order to take care of their family member. Prior to receiving the INFOSA-DEM psychoeducational intervention, $39 \%$ of caregivers in the IG showed mild to moderate burden and more than $37 \%$ reported a high level of burden. Regarding those in the CG, $52 \%$ presented mild to moderate burden while almost $22 \%$ reported high burden. A slightly higher burden was observed in caregivers not living with PwD (mean 35.7 in caregivers not living with $P w D$ vs 32.6 caregivers living with $P w D$ ) at baseline but this small difference was not statistically significant $(P=0.317)$. Three months after receiving the psychoeducational program, $9 \%$ of caregivers in the IG went from having a high level of burden to a mild or moderate level, while in the CG, the percentage of caregivers with a mild to moderate burden rose by almost $8 \%$ and the percentage with a high level of burden remained the same. Few changes were observed in the positive and negative effects of caregiving in either group at 3 months follow-up, although a statistically significant $(P<0.012)$ worsening in the CG was observed in the interference in daily activities dimension. This suggested a slight increase in burden and a greater impact of care on health problems in this group compared with those in the IG, with the differences at the limit of statistical significance (Table 3). It is noteworthy that analysis of trends over the three time-points showed improvements in the health dimension and burden in caregivers in the IG was maintained even at 6 months, although the differences were not statistically significant (Table 4).

\section{Psychological well-being of the IC and perceived social support}

With regard to emotional well-being, $68 \%$ of caregivers in the IG reported normal psychological wellbeing at the baseline interview although $32 \%$ had a low level (Table 3). Following the intervention, a positive effect on emotional well-being was observed in caregivers in the IG (3.77 baseline vs 3.16 at 3 months follow-up, $P=0.176$ ), representing non-significant improvements. Similarly, a slight improvement was seen in the $I G$ in emotional well-being compared with a slight worsening in the CG. Considering the three time-points, the improvement in emotional well-being was maintained in the IG at 6 months, although the differences were not statistically significant (Table 4). Despite the intervention, there was a slight worsening in self-perceived quality of life $(72.12$ baseline vs 68.06 at 3 months follow-up, $P=0.080$ ) among caregivers in the IG. The trends for indicators for quality of life and emotional well-being were negative in the $\mathrm{CG}$, indicating a slight worsening in the emotional health of these caregivers. Self-esteem and impact on schedule dimensions worsened slightly in both groups but only showed statistical significance in the CG $(P<0.017)$ (Table SS2). Some $79 \%$ of caregivers reported having a good social support network. 
Table 1 Socio-demographic characteristics of people with dementia and informal caregivers at baseline

\begin{tabular}{|c|c|c|c|}
\hline Variable & Total $(N=160)$ & Control $(n=74)$ & Intervention $(\mathrm{n}=86)$ \\
\hline \multicolumn{4}{|l|}{ Age, years } \\
\hline Informal caregivers & $63.7 \pm 12.8$ & $62.4 \pm 14.3$ & $64.7 \pm 11.5$ \\
\hline Patients with dementia & $79.1 \pm 8.2$ & $80.1 \pm 8.5$ & $78.3 \pm 7.9$ \\
\hline \multicolumn{4}{|l|}{ Gender, female } \\
\hline Informal caregivers & $122(76.2)$ & $54(73)$ & $68(79.1)$ \\
\hline Patients with dementia & $87(54.4)$ & $42(56.8)$ & $45(52.3)$ \\
\hline \multicolumn{4}{|l|}{ Relationship with person with dementia } \\
\hline Spouses & $82(51.2)$ & $30(40.5)$ & $52(60.5)$ \\
\hline Child & $61(38.1)$ & $31(41.9)$ & $30(34.9)$ \\
\hline Others & $17(10.7)$ & $13(17.6)$ & $4(4.6)$ \\
\hline \multicolumn{4}{|l|}{ Marital status caregiver } \\
\hline Married/cohabitant & $127(79.4)$ & $56(75.7)$ & $71(82.6)$ \\
\hline Never married & $13(8.1)$ & $5(6.8)$ & $8(9.3)$ \\
\hline Divorced & $10(6.2)$ & $4(5.4)$ & $6(7)$ \\
\hline Widowed & $4(2.5)$ & $3(4.1)$ & $1(1.2)$ \\
\hline Did not answer & $6(3.8)$ & $6(8.1)$ & $0(0)$ \\
\hline Caregiver lives with patient & $121(75.6)$ & $53(71.6)$ & $68(79.1)$ \\
\hline \multicolumn{4}{|l|}{ Type of dementia } \\
\hline Alzheimer & $112(70)$ & $53(71.6)$ & $59(68.6)$ \\
\hline Unknown & $21(13.1)$ & $11(14.9)$ & $10(11.6)$ \\
\hline Vascular dementia & $11(6.9)$ & $3(4.1)$ & $8(9.3)$ \\
\hline Others & $9(5.6)$ & $5(6.8)$ & $4(4.7)$ \\
\hline Dementia with Lewy bodies & $6(3.8)$ & $2(2.7)$ & $4(4.7)$ \\
\hline Alzheimer with cerebrovascular disease & $1(0.6)$ & $0(0)$ & $1(1.2)$ \\
\hline Time since diagnosis, years & $5.4 \pm 3.2$ & $5.2 \pm 3.5$ & $5.5 \pm 2.9$ \\
\hline Caregivers burden $(\mathrm{ZBI})^{\dagger}$ & $33.3 \pm 15.3$ & $32.1 \pm 14.4$ & $34.4 \pm 15.9$ \\
\hline Little to mild burden $(0-20)$ & $36(23.2)$ & $16(23.2)$ & $20(23.3)$ \\
\hline Mild to moderate burden $(21-40)$ & $70(45.2)$ & $36(52.2)$ & $34(39.5)$ \\
\hline High burden $(>40)$ & $49(31.6)$ & $17(24.6)$ & $32(37.2)$ \\
\hline Psychological well-being (GHQ-12) ${ }^{\dagger}$ & $3.6 \pm 3.3$ & $3.3 \pm 3.3$ & $3.8 \pm 3.4$ \\
\hline Normal $(0-4)$ & $105(67.7)$ & $49(71)$ & $56(65.1)$ \\
\hline Poor (5-12) & $50(32.3)$ & $20(29)$ & $30(34.9)$ \\
\hline \multicolumn{4}{|c|}{ Positive and negative aspects of caregiving (CRA $)^{\ddagger}$} \\
\hline Caregiver self-esteem & $27.6 \pm 4.2$ & $27.8 \pm 4.6$ & $27.4 \pm 3.9$ \\
\hline Lack of family support & $12.7 \pm 4.3$ & $13.2 \pm 4.6$ & $12.4 \pm 4.1$ \\
\hline Impact on finances & $8 \pm 2.3$ & $8.2 \pm 2.6$ & $7.9 \pm 2.1$ \\
\hline Impact on schedule & $16.5 \pm 4.9$ & $16.2 \pm 5.4$ & $16.8 \pm 4.5$ \\
\hline Impact on health & $10.7 \pm 4.4$ & $10.1 \pm 4.6$ & $11.2 \pm 4.2$ \\
\hline
\end{tabular}

Data are presented as number (percentage) or means \pm standard deviation. ${ }^{\dagger}$ Missing data from five patients. ${ }^{\ddagger}$ Missing data from 13 patients. CRA, Caregiver Reaction Assessment; GHQ-12, General Health Questionnaire 12 item version; ZBI, Zarit Burden Interviews.

Despite the intervention, there was a slight worsening in the perception of social support (41.1 baseline vs 39.8 at 3 months follow-up, $P=0.154$ ) among caregivers in the $I G$. The trend in this variable was negative in the $C G$, indicating a slight worsening among these caregivers.

\section{DISCUSSION}

The study aim was to assess the impact of the INFOSA-DEM psychoeducational intervention: training, information and social support, in ICs of PwD with respect to reduction of burden and improvement in emotional well-being, evaluating the durability of effects at 3 and 6 months follow-up. The intervention consists of psychoeducation, training in communication strategies and emphasis on the importance of planning self-care activities. The IG and the CG were similar at the beginning of the study and the explanations for dropping out were reasonable and acceptable bearing in mind the vulnerable circumstances of the PwD. ${ }^{33}$

Results confirmed the initial hypothesis that taking part in interventions of this type has beneficial effects on caregivers' physical and emotional health. Caregivers highlighted a need for general information on 
Table 2 People with dementia outcomes at baseline

\begin{tabular}{|c|c|c|c|}
\hline Variable & Total $(N=160)$ & Control $(n=74)$ & Intervention $(n=86)$ \\
\hline \multicolumn{4}{|l|}{ People with dementia outcomes } \\
\hline Disease severity (MMSE) & $17.3 \pm 6.6$ & $16.6 \pm 7$ & $18.1 \pm 6.1$ \\
\hline Mild (21-28) & $52(38)$ & $24(35.3)$ & $28(40.6)$ \\
\hline Moderate $(15-20)$ & $53(38.7)$ & $26(38.2)$ & $27(39.1)$ \\
\hline Moderately severe/severe $(<15)$ & $32(23.4)$ & $18(26.5)$ & $14(20.3)$ \\
\hline Dependency in ADL (Katz Index) & $3.9 \pm 2.1$ & $3.5 \pm 2.1$ & $4.1 \pm 2$ \\
\hline Disability $(0-2)$ & $45(29.8)$ & $26(38.2)$ & $19(22.9)$ \\
\hline Partial disability (3-5) & $58(38.4)$ & $23(33.8)$ & $35(42.2)$ \\
\hline Function independence (6) & $48(31.8)$ & $19(27.9)$ & $29(34.9)$ \\
\hline Comorbidity (Charlson Index) & $1.5 \pm 1.2$ & $1.5 \pm 1.4$ & $1.4 \pm 1.1$ \\
\hline 0 & $28(17.5)$ & $18(24.3)$ & $10(11.6)$ \\
\hline 1 & $79(49.4)$ & $27(36.5)$ & $52(60.5)$ \\
\hline 2 & $23(14.4)$ & $14(18.9)$ & $9(10.5)$ \\
\hline More than 2 & $30(18.8)$ & $15(20.3)$ & $15(17.4)$ \\
\hline \multicolumn{4}{|l|}{ Behavioural disturbance (NPI) } \\
\hline Severity & $6.7 \pm 5.4$ & $7.3 \pm 5.9$ & $6.2 \pm 4.9$ \\
\hline Distress & $4 \pm 6.1$ & $4.8 \pm 6.8$ & $3.4 \pm 5.3$ \\
\hline \multicolumn{4}{|l|}{ Quality of life } \\
\hline$E Q-5 D$ & $0.6 \pm 0.3$ & $0.5 \pm 0.3$ & $0.6 \pm 0.3$ \\
\hline Self-reported (NAS) & $67.3 \pm 20.1$ & $61 \pm 21.7$ & $72.6 \pm 17.1$ \\
\hline QOL-AD & $29.3 \pm 5.1$ & $28.4 \pm 5$ & $30 \pm 5.1$ \\
\hline \multicolumn{4}{|l|}{ Cognitive function (GDS) } \\
\hline Very mild cognitive decline & $2(1.2)$ & $0(0)$ & $2(2.3)$ \\
\hline Mild cognitive decline & $34(21.2)$ & $13(17.6)$ & $21(24.4)$ \\
\hline Moderate cognitive decline & $69(43.1)$ & $31(41.9)$ & $38(44.2)$ \\
\hline Moderately severe cognitive decline & $31(19.4)$ & $14(18.9)$ & $17(19.8)$ \\
\hline Severe cognitive decline & $16(10)$ & $10(13.5)$ & $6(7)$ \\
\hline Very severe cognitive decline & $8(5)$ & $6(8.1)$ & $2(2.3)$ \\
\hline
\end{tabular}

Data are presented as number (percentage) or means \pm standard deviation. ADL, activities of daily living; EQ-5D, EuroQuol 5 Dimension; GDS, Global Deterioration Scale; MMSE, Mini-Mental Stage Examination; NPI, Neuropsychiatric Inventory; QoL-AD, Quality of Life in Alzheimer's Disease; VAS, visual analogue scale.

dementia and available community resources, especially at the onset of the illness, and being able to avail themselves of the services of health professionals who monitor the PwD. ${ }^{34}$ Caregiver characteristics were similar to those observed in other studies; typically the middle-aged, female spouses of the PwD. Most caregivers lived with the PwD and the duration in years of care provided was similar. ${ }^{16}$, 35,36 The ZBI revealed a mild to moderate degree of burden in the caregivers, possibly associated with the number of hours spent in the daily care of the family member, as the majority lived with the PwD which would indicate provision of 24-h care. ${ }^{34}$ However, the positive effect of participating in the program on burden was barely significant even at 3 months, possibly due to the presence of stressor factors arising from the care context, such as the degree of cognitive impairment and/or comorbidity in the PwD, family financial problems or even social aspects. ${ }^{36,} 37$ In fact, Gonyea et al., stated that this finding could be related to 'internal caregiver attributes not easy to change', based on the theory of biological adjustment. ${ }^{16}$ Although the direct, positive effects of the intervention on caregivers cannot be represented with statistically significant results, some authors suggest that a reduction in burden possibly improves emotional well-being, ${ }^{38}$ especially when the burden is due to the presence of neuropsychiatric symptoms in the PwD. ${ }^{16},{ }^{37}$ Similarly, previous research emphasises that interventions focused on the promotion of coping strategies and problemsolving for the IC by improving self-esteem, which can lead to a beneficial effect on emotional wellbeing. $^{7}$

Caregivers value outside help in care tasks and household chores, access to public services and the provision of professional assistance. ${ }^{34}$ This support is crucial in reducing perceived stress and in achieving improvements in emotional well-being. Low perceived social support can have negative consequences on the caregiver ${ }^{39}$ and can even lead to the admission of the PwD to a long-term care 


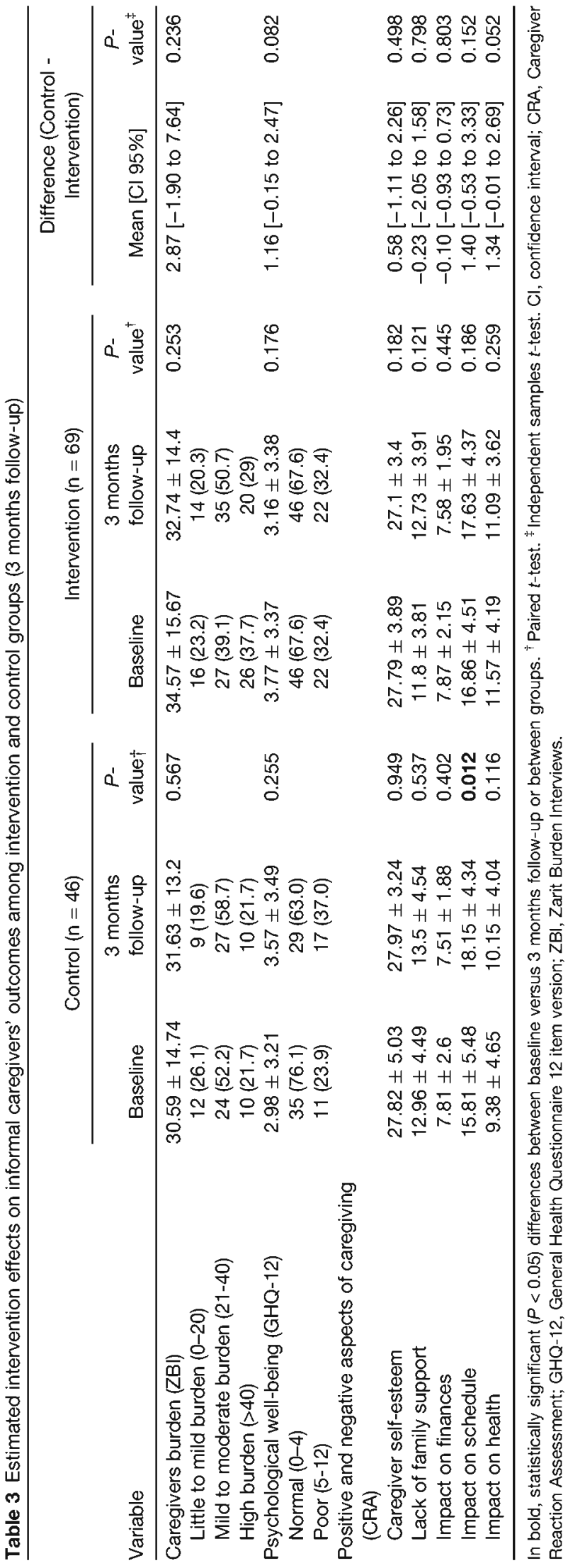

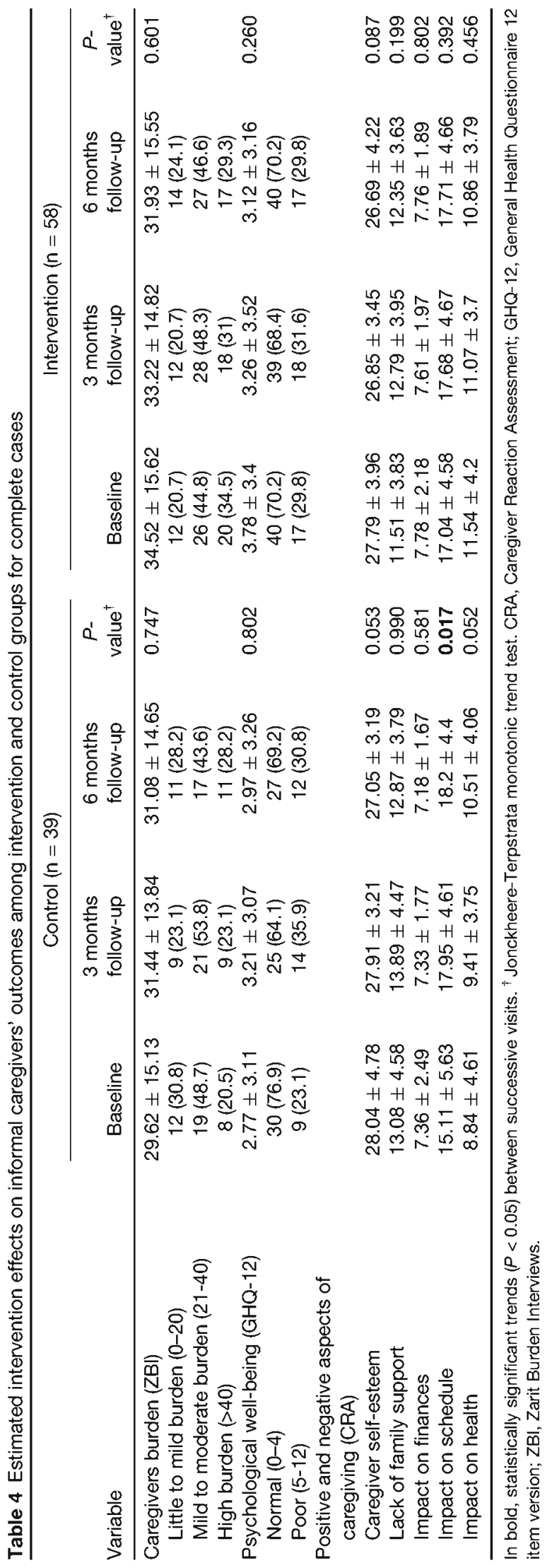

(C) 2020 Japanese Psychogeriatric Society 
centre. ${ }^{7}$ Following the intervention, there was a decrease in perceived social support among ICs, which had a negative impact on their emotional wellbeing. This is in line with the findings of Del PinoCasado et al., who demonstrated that caregivers with lower perceived social support show an increase in degree of burden and that greater social support can be a protective factor against burden, along with producing improvements in emotional well-being. ${ }^{40,41}$

This study has some limitations. First, participants in this study were only enrolled from three centres in the province of Barcelona. Second, the sample could not be randomised due to the difficulty of recruiting ICs as there was no specific list of informal caregivers of PwD. This non-randomised design is likely to give rise to imbalances in prognostic factors between the groups that can bias estimates of treatment effects. Thus, the results should be interpreted with caution. Third, PwD were not categorised by stage of the illness, nor by availability of external assistance (family or paid care) as, possibly, severity of cognitive impairment and duration of care required are variables that can modify the effect of the intervention on the caregiver. Fourth, having to travel to another location each day can be an inconvenience for caregivers who do not have additional help at home as the severity of the illness, comorbidity and degree of dependence of the PwD precludes them being left at home alone for more than an hour each day for a week.

\section{ACKNOWLEDGMENTS}

The authors would like to thank the Marató TV3 Foundation for financial support and we thank Stephen Kelly for participated in writing of the manuscript and all the caregivers who participated in the study.

\section{AUTHORSHIP STATEMENT}

All authors meet the authorship criteria and are in agreement with the final version and submission of this manuscript and confirm that it has not been previously published.

\section{FUNDING}

The INFOSA-DEM study was supported by the Marató TV3 Foundation under Grant (20144410).

\section{REFERENCES}

1 González-de Paz L, Real J, Borrás-Santos A, MartínezSanchez JM, Rodrigo-Baños V, Navarro-Rubio MD. Associations between informal care, disease and risk factors: a Spanish country-wide population-based study. I Public Health Policy 2016; 37: 173-189.

2 Frías CE, García-Pascual M, Montoro M, Ribas N, Risco E, Zabalegui $A$. Effectiveness of psychoeducational intervention for caregivers of people with dementia with regard to burden, anxiety and depression: a systematic review. J Adv Nurs 2020; 76: 787-802.

3 World Health Organisation. Global action plan on the public health response to dementia 2017-2025. [Cited 02 Jun 2019.] Available from URL: https://www.who.int/mental_health/ neurology/dementia/action_plan_2017_2025/en/

4 Alzheimer Cataluña Fundació. Lo que no sabéis sobre las demencias y el Alzheimer. [Cited 02 Jun 2019.] Available from URL: https://alzheimercatalunya.org/es/demencias-y-alzheimer/

5 Farré M, Kostov B, Haro JM et al. Costs and burden associated with loss of labor productivity in informal caregivers of people with dementia. J Occup Environ Med 2018; 60: 449-456.

6 Chiao CY, Wu HS, Hsiao CY. Caregiver burden for informal caregivers of patients with dementia: a systematic review. Int Nurs Rev 2015; 62: 340-350.

7 Alvira MC, Risco E, Cabrera FM, Rahm I, Bleijlevens M et al. The association between positive-negative reactions of informal caregivers of people with dementia and health outcomes in eight European countries: a cross-sectional study. J Adv Nurs 2015; 71: 1417-1434.

8 Bremer $\mathrm{P}$, Cabrera $\mathrm{E}$, Leino-Kilpi $\mathrm{H}$ et al. Informal dementia care: consequences for caregivers' health and health care use in 8 European countries. Health Policy 2015; 119: 1459-1471.

9 Dodel R, Belger M, Reed C et al. Determinants of societal costs Alzheimer's disease: GERAS study baseline results. Alzheimers Dement 2015; 11: 933-945.

10 Guerra M, Ferri CP, Fonseca M, Banerjee S, Prince M. Helping carers to care: the 10/66 dementia research Group's randomized control trial of a caregiver intervention in Peru. Braz J Psychiatry 2011; 33: 47-54.

11 Zabalegui A, Hamers JP, Karlsson S et al. Best practices interventions to improve quality of care of people with dementia living at home. Patient Educ Couns 2014; 95: 175-184.

12 Alves LCS, Monteiro DQ, Bento SR, Hayashi VD, Pelegrini LNC, Vale FAC. Burnout syndrome in informal caregivers of older adults with dementia: a systematic review. Dement Neuropsychol 2019; 13: 415-421.

13 Miguel S, Alvira MC, Farré M, Risco E, Cabrera E, Zabalegui A. Quality of life and associated factors in older people with dementia living in long-term institutional care and home care. Eur Geriaticr Med 2016; 7: 346-351.

14 Cheng HY, Chair SY, Chau JPC. Effectiveness of a strengthoriented psychoeducation on caregiving competence, problemsolving abilities, psychosocial outcomes and physical health among family caregiver of stroke survivors: a randomised controlled trial. Int J Nurs Stud 2018; 87: 84-93.

15 Gonyea JG, López LM, Velásquez EH. The effectiveness of a culturally sensitive cognitive behavioral group intervention for Latino Alzheimer's caregivers. Gerontologist 2014; 56: 292-302.

16 Au A, Gallagher-Thompson D, Wong MK et al. Behavioral activation for dementia caregivers; scheduling pleasant events and enhancing communications. Clin Interv Aging 2015; 10: 611-619. 
17 Afram B, Verbeek H, Bleijlevens MH, Hamers JP. Needs of informal caregivers during transition from home towards institutional care in dementia: a systematic review of qualitative studies. Int Psychogeriatr 2015; 27: 891-902.

18 Folstein M, Folstein S, McHugh P. "mini-mental state". A practical method for grading the cognitive state of patients for the clinician. J Psychiatr Res 1975; 12: 189-198.

19 Reisberg B, Ferris S, De Leon M, Crook T. The global deterioration scale for assessment of primary degenerative dementia. Am J Psychiatry 1982; 139: 1136-1139.

20 Martín-Carrasco M, Salvadó I, Nadal S et al. Adaptación para nuestro medio de la Escala de Sobrecarga del Cuidador (Caregiver Burden Interview) de Zarit. Revista Gerontol 1996; 6: 338-345

21 Romppel M, Braehler E, Roth M, Glaesmer H. What is the general health Questionnaire-12 assessing? Dimensionality and psychometric properties of the general health Questionnaire-12 in a large scale German population sample. Compr Psychiatry 2013; 54: 406-413.

22 Rocha KB, Pérez K, Rodríguez-Sanz M, Borrel C, Obiols JE. Propiedades psicométricas y valores normativos del General Health Questionnaire (GHQ-12) en población general española. Int J Clin Health Psychol 2011; 11: 125-139.

23 Chang $S$, Zhang $Y$, Jeyagurunathan $A$ et al. Providing care to relatives with mental illness: reactions and distress among primary informal caregivers. BMC Psychiatry 2016; 16: 80.

24 Barr C, Riolacci-Dhoyen N, Galbraith M, LeperreDesplanques A, COVE GROUP. Sharing knowledge to advance healthcare policies in Europe for people living with dementia and their carers: the ALCOVE project. Arch Public Health 2012; 70: 21.

25 Verbeek $\mathrm{H}$, Meyer $\mathrm{G}$, Leino-Kilpi $\mathrm{H}$ et al. A European study investigating patterns of transition from home care towards institutional dementia care: the protocol of a RightTimePlaceCare study. BMC Public Health 2012; 12.

26 Given CW, Given B, Stommel M, Collins C, King S, Franklin S. The caregiver reaction assessment (CRA) for caregivers to persons with chronic physical and mental impairments. Res Nurs Health 1992; 15: 271-283.

27 Broadhead WE, Gehlbach SH, De Gruy FV, Kaplan BH. The Duke-UNC functional social support questionnaire. Measurement of social support in family medicine patients. Med Care 1988; 26: 709-723.

28 Cuéllar-Flóres I, Dresch V. Validación del cuestionario de Apoyo Social Funcional Duke-UNK-11 en personas cuidadoras. RIDEP 2012; 34: 89-101.

29 The EuroQol Group. EuroQol - a new facility for the measurement of health-related quality of life. Health Policy 1990; 16: 199-208.

30 Wimo A, Gustavsson A, Jönsson L, Winblad B, Hsu M, Gannon B. Application of resource utilization in dementia (RUD) instrument in a global setting. Alzheimers Dement 2013; 9: 429-435.e17.

31 Vilalta-Franch J, Lozano-Gallego $M$, Hernández-Ferrándiz $M$, Llinàs-Reglà J, López-Pousa S, López $\mathrm{O}$. The neuropsychiatric inventory. Psychometric properties of its adaptation into Spanish. Rev Neurol 1999; 29: 15-19.

32 Prick AE, de Lange J, Twisk J, Pot AM. The effects of a multicomponent dyadic intervention on the psychological distress of family caregivers providing care to people with dementia: a randomized controlled trial. Int Psychogeriatr 2015; 27: 2031-2044.

33 Moreno-Cámara S, Palomino-Moral PÁ, Moral-Fernández L, Frías-Osuna A, Parra-Anguita L, Del-Pino-Casado R. Perceived needs of the family caregivers of people with dementia in a Mediterranean setting: a qualitative study. Int $J$ Environ Res Public Health 2019; 16: 993-1005.

34 Tang SH, Chio Ol, Chang LH et al. Caregiver active participation in psychoeducational intervention improved caregiving skills and competency. Geriatr Gerontol Int 2018; 18: 750-757.

35 Martín-Carrasco M, Domínguez-Panchón Al, González-Fraile E, Muñoz-Hermoso P, Ballesteros J. Effectiveness of a Psychoeducational intervention group program in the reduction of the burden experienced by caregivers of patients with dementia. Alzheimer Dis Assoc Disord 2014; 28: 79-87.

36 Hatch DJ, DeHart WB, Norton MC. Subjective stressors moderate effectiveness of a multi-component, multi-site intervention on caregiver depression and burden. Int $J$ Geriatr Psychiatry 2014; 29: 406-413.

37 Llanque $\mathrm{SM}$, Enrique $\mathrm{M}$, Cheng $\mathrm{AL}$ et al. The family series workshop: a community-based psychoeducational intervention. Am J Alzheimers Dis Other Demen 2015; 30: 573-583.

38 Wimo A, Sjölund BM, Sköldunger A, Johansson L, Nordberg G, Von Strauss E. Incremental patterns in the amount of informal and formal care among non-demented and demented elderly persons: results from a 3-year follow-up population-based study. Int J Geriatr Psychiatry 2011; 26: 56-64.

39 Del Pino Casado R, Millán-Cobo MD, Palomino-Moral PA, Frías-Osuna A. Cultural correlates of burden in primary caregivers of older relatives: a cross-sectional study. J Nurs Scholarsh 2014; 46: 176-186.

40 De la Revilla L, Bailón E, De Dios J, Delgado A, Prados M, Fleitas L. Validación de una escala de apoyo social funcional para su uso en la consulta del médico familia. Aten Primaria $1991 ; 8: 688-692$.

\section{SUPPORTING INFORMATION}

Additional supporting information may be found in the online version of this article at the publisher's website: http://onlinelibrary.wiley.com/doi//suppinfo.

TABLE S1. INFOSA-DEM Program.

TABLE S2. Estimated intervention effects on people with dementia and informal caregivers' outcomes among intervention and control groups (complete cases). 


\section{Publicaciones Científicas}

\subsection{Artículo 3}

Informal Caregivers' Roles in Dementia. The Impact on Their Quality of Life.

Cindy E. Frías, Ester Cabrera, Adelaida Zabalegui

Life (Basel). 2020; 10(11): 251. https://doi.org/10.3390/life10110251.

IF: 2.991. Q1 


\title{
Informal Caregivers' Roles in Dementia: The Impact on Their Quality of Life
}

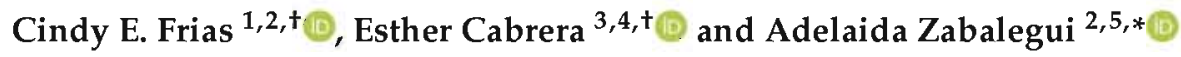 \\ 1 Mental Health Nurse, Hospital Clinic, 08036 Barcelona, Spain; cfrias@clinic.cat \\ 2 School of Health Sciences, University of Barcelona, 08036 Barcelona, Spain \\ 3 School of Health Sciences, TecnoCampus Universitat, Pompeu Fabra, 08301 Mataró, Spain; \\ ecabrera@tecnocampus.cat \\ 4 Department of Care Management and Social Work, Sechenov University, Moscow 101000, Russia \\ 5 Department of Nursing, Hospital Clínic de Barcelona, 08001 Barcelona, Spain \\ * Correspondence: azabaleg@clinic.cat \\ + These authors contributed equally to this work.
}

Received: 8 October 2020; Accepted: 21 October 2020; Published: 23 October 2020

\begin{abstract}
The constantly changing process of caring for a person with dementia affects the informal caregivers' role due to its psychosocial impact. This cross-sectional study aimed to analyze the impact of the Person with Dementia informal caregiver's role caregiver to a person with dementia on the self-perceived quality of life (QoL) of the caregiver. In total, 160 informal caregivers were recruited between January and December 2019. Informal caregivers' quality of life was assessed using the European Quality of Life 5-Dimension scale, burden with the Zarit Burden Scale, emotional wellbeing using the General Health Questionnaire, and caregiver reactions using Caregiver Reaction Aspects. Patients' cognitive impairment was assessed with the Mini-Mental State Examination, their quality of life using Quality of Life in Alzheimer's Disease, and neuropsychiatric symptoms using the Neuropsychiatric Inventory. Outcomes were studied using the Pearson correlation coefficient and ANOVA test. Most informal caregivers' outcomes were significantly associated with their quality of life. Male informal caregivers have a slightly better quality of life than female caregivers $(p<0.001)$. Caregiver burden $(p<0.001)$, psychological wellbeing $(p<0.001)$ and negative aspects of caregiving on health $(p<0.001)$ correlated moderately with informal caregivers' quality of life. Factors associated with dementia, including the course of the illness and its severity with the presence of neuropsychiatric symptoms can negatively affect the informal caregiver's role and produce a low self-perception of quality of life; thus, social and professional support for informal caregivers is essential.
\end{abstract}

Keywords: dementia; informal caregivers; quality of life; emotional wellbeing; nurse

\section{Introduction}

The progressive decrease in the cognitive and functional abilities of a person with dementia (PwD) and the presence of neuropsychiatric symptoms (NS) lead to behavioral changes which interfere with the patient's autonomy and daily functioning [1]. Dementia is known to affect around 10 million people in Europe, of which 800,000 cases are people diagnosed in Spain, with more than 86,000 of these in Catalonia [2,3]. The adjustments for daily activities generate a change in the roles in a family, so that a member becomes an informal caregiver (IC), usually the spouse or one of the offspring [4]. It is estimated that about $84 \%$ of PwD live in their own home and it is the caregiver who is responsible for keeping them in optimal health; this role can extend up to an average of 6.5 years [4-6].

As the illness is progressive, the process of caring for a PwD changes constantly and has a significant psychosocial impact on the family and the PwD. Due to the considerable stress involved, 
it is essential to prevent the physical and mental effects on the IC, which include cardiovascular disease, stress-related disorders, burden, sleep problems, anxiety, and even depression, all of which affect the informal caregivers' role [6]. In fact, there is strong evidence that the feeling of burden among IC of $\mathrm{PwD}$ is greater than in other types of care and that this frequently leads to them working fewer hours or losing their job, with a resulting decrease in their own quality of life (QoL) [4-6]. Some studies show that the emotional effects of burden can also have a negative impact on the PwD's life, which can be even greater than the degree of severity of the disease itself $[7,8]$. QoL is a multidimensional concept, which varies between individuals and depends directly on the life stage of the person, and on positive and negative factors related to the changes that occur at each stage $[6,8]$. De Miguel et al. point out that QoL is a concept that is difficult to define and that this has a special connotation when associated with dementia care. The same authors report that a caregiver having a better or worse QoL is directly related to the presence of neuropsychiatric symptoms in the PwD. They conclude that intervening to decrease or control NS and depressive symptoms in the PwD will improve or maintain informal caregivers' QoL [9]. Nevertheless, caring generates positive aspects with respect to ICs' satisfaction with the work carried out, the ability to overcome certain difficulties and the strengthening of the bond with the person receiving care [5]. Under these circumstances, home care needs to be oriented towards improving ICs' roles and to improving the self-perceived caregiver's QoL, reducing burden, and promoting home management strategies [5,7]. In this sense, professional support and counselling allow for the early detection and prevention of alterations in the IC's physical and mental health [5]. The aim of this study was to analyze the impact of the role of an informal caregiver to a PwD on the self-perceived QoL of the caregiver.

\section{Materials and Methods}

\subsection{Study Design}

This was a cross-sectional study based on data from a larger investigation.

\subsection{Study Settings and Participants}

The study was conducted with informal caregivers (IC) of a person with dementia (PwD). Participants were recruited in 3 primary care centers in Barcelona. During the PwD's regular follow-up visits with the family physician (FP) or nurse, ICs were invited to participate in the study. Those who accepted were contacted by telephone by a person from the research team.

During primary care visits, the family physician (FP) or nurse provided additional information about the study verbally or through pamphlets. Those participants who met inclusion criteria received a second call to make an appointment at home for the collection of initial data. The interviews were conducted between January and December 2019. All participating ICs and PwDs provided signed informed consent.

The inclusion criteria for the informal/family caregivers, defined as people who provided informal care on regular basis, were as follows: (1) $>18$ years old; (2) living with the person with dementia or visiting him/her at least twice a week; (3) not being paid for caregiving. The inclusion criteria for the people with dementia were as follows: (1) having a Mini-Mental State Examination (MMSE) test score $<24 ;(2)$ living at home. The exclusion criteria for the PwD were as follows: (1) having another psychiatric illnesses or Korsakov's syndrome. PwD were informed about the study and they provided signed informed consent at home. In the case of the severe cognitive impairment of the PwD, consent was only signed by the IC.

The complete study was revised and approved prior to study initiation by the Ethical Committee at the Clinic Hospital (Reg. HCB/2018/0737) and followed the recommendations of the Declaration of Helsinki. 


\subsection{Data Collection}

Data were collected during face-to-face interviews with by trained interviewers following instructions in a written manual. IC and PwD were the informants in the home care setting. Interviews were carried out between January and December 2019. Interviewers were nurses with clinical experience and at least a master's degree. Furthermore, they received additional training on data collection, including all procedures, the content of the assessments and the completion of questionnaires.

\subsection{Measures and Instruments}

Socio-demographic and other potential variables related to QoL in IC and PwD were collected.

\subsubsection{Informal Caregiver Assessments}

Caregivers' QoL was assessed using the European Quality of Life 5-Dimension (EQ-5D) scale, a measure of self-reported quality of life that is applicable to a wide range of health conditions and treatments. EQ-5D has two components: a health state description and self-reported evaluation. The first component consists of 5 single-item dimensions, including mobility, self-care, usual activities, pain/discomfort, and anxiety/depression. Each dimension has a 3-point response scale designed to indicate the degree of the problem. The index of health states generated by the EQ-5D is obtained using a composite time trade-off (cTTO) valuation technique proposed for the study in the Spanish general population. The index ranges from 1 (the best health status) to 0 (death). A visual analogue scale is the second component of the questionnaire, asking respondents to mark their health status on the day of the interview on a $20-\mathrm{cm}$ vertical scale with end points of 0 and 100 . This scale includes notes at the ends of the scale, explaining that the bottom rate (0) corresponds to "the worst health you can imagine", and the highest rate (100) corresponds to "the best health you can imagine" [10].

Burden was assessed using the Spanish version of the Zarit Burden Scale (V1, Navarra, Spain). This evaluated subjective perception of care, emotional and physical burden, financial difficulties and limitations to social activities associated with care provision. It consists of 22 items on a 5-point Likert-type scale ranging from $0=$ "never" to $4=$ "almost always", with higher scores indicating a high degree of burden. The scale has excellent internal consistency with a Cronbach's alpha of 0.92 [11]. Emotional wellbeing was assessed using the General Health Questionnaire (GHQ-12). As a unidimensional measure, it seems to be a useful screening tool for the assessment of mental distress or a minor psychiatric morbidity in contexts such as primary care or in the general population. It has 12 items -6 positively worded and 6 negatively worded. It is a 4-point Likert-type scale (0-1-2-3) that can be transformed into a dichotomous score (0-1) called the GHQ score. The GHQ-12 demonstrates good reliability in studies carried out with a Cronbach's alpha between 0.82 and 0.86 [12,13].

Caregiver reactions were evaluated using Caregiver Reaction Aspects (CRA). This is an instrument designed to assess specific facets of caregiving, including both negative and positive dimensions of caregiving reactions. It consists of 24 items in five subscales: self-esteem (score range 7-35), lack of family support (range 5-25), financial problems (range 3-15), disrupted schedule (range 5-25) and health problems (range 4-20). Responses are represented on a Likert-type scale from $1=$ strongly disagree to $5=$ strongly agree. A higher score on the caregiver's self-esteem subscale indicates a more positive reaction to caregiving, while higher scores on the other four subscales indicate greater negative reactions. Reliability analyses showed that standardized Cronbach's alphas varied between 0.62 and 0.83 for the separate subscales, indicating sufficient internal consistencies. Construct validity was supported. The CRA proves to be a feasible, reliable, valid instrument for assessing both negative and positive reactions to caregiving $[14,15]$.

\subsubsection{PwD Assessments}

The degree of cognitive impairment was assessed with the Mini-Mental State Examination (MMSE) and the Global Deterioration Scale (GDS), where higher scores indicate less cognitive impairment $[16,17]$. 
QoL in PwD was also evaluated using the Quality of Life in Alzheimer's Disease (QoL-AD) instrument. The QoL-AD consists of 13 items relating to QoL, each measured on a four-point scale (ranging from 1 = poor to $4=$ excellent). Possible scores on the QoL-AD range from 13 to 52 . Higher scores indicate better QoL [18]. Neuropsychiatric symptoms in the PwD were measured using the Neuropsychiatric Inventory (NPI), which includes 10 behavioral domains (delusions, hallucinations, dysphoria, anxiety, agitation/aggression, euphoria, disinhibition, irritability, apathy and aberrant motor activity) with 7-8 sub-questions and measures severity (3-point scale) and frequency (4-point scale). The total NPI score is the sum of the subscale scores. Higher scores indicate more behavioral disturbance. Analyses showed that the standardized Cronbach's alpha is 0.783 [19].

Measurement instruments were selected based on their psychometric properties (validity, reliability), clinical utility and suitability for the target settings and population.

\subsection{Statistical Analyses}

Descriptive data are presented as the mean and standard deviation (SD) for continuous outcomes and number and the percentage (\%) for categorical outcomes. The association between the informal caregivers' quality of life (EQ-5D and VAS), PwD outcomes (age, gender, type of dementia, time since diagnosis, illness severity, ability to perform activities of daily living, comorbidity, behavioral disturbance, quality of life, cognitive function) and IC outcomes (age, gender, marital status, relationship with patient, living with patient, caregiver burden, psychological wellbeing, social support, preparedness for caregiving, care needs of families, caregiving competence, positive and negative aspects of caregiving) was studied using the Pearson correlation coefficient for continuous outcomes and the ANOVA test for categorical outcomes. Outcomes with a $p$-value $<0.05$ were included in a multiple linear regression model to determine outcomes independently associated with the informal caregivers quality of life. The stepwise Akaike Information Criterion (AIC) method was used for variable selection [19]. Variance inflation factor (VIF) was used to quantify the severity of the multicollinearity effect. VIF values higher than 5 are considered to have high multicollinearity [20]. All significance tests were 2-tailed, and values of $p<0.05$ were considered significant. Statistical analyses were conducted using the R 3.6.1 (Vienna, Austria) for Windows statistical software package for Windows [21,22].

\section{Results}

\subsection{Sociodemographic Characteristics and Outcomes}

A total of 160 informal caregivers of PwD were included in the study. The sociodemographic characteristics and outcomes of informal caregivers and persons with dementia are detailed in Tables 1 and 2. The mean age was 63.7 (SD 12.8) years for IC and 79.1 (SD 8.2) years for PwD. In total, $76.2 \%$ of IC and $54.4 \%$ of PwD were female. Almost half of IC $(51.2 \%)$ were spouses and $75.6 \%$ of IC were living with the PwD. Regarding informal caregivers, $119(76.8 \%)$ were considered to have a moderate to high burden due to caregiving. Overall, $50(32.3 \%)$ caregivers indicated poor psychological wellbeing and $33(21.3 \%)$ low social support (Table 1). The main type of dementia was Alzheimer's (70\%). Eighty-five (62.1\%) PwD had moderate or severe disease severity. In total, $103(68.2 \%)$ had some degree of disability (Table 2$)$. 
Table 1. Informal caregivers' characteristics and outcomes.

\begin{tabular}{|c|c|}
\hline Variable & Total $(n=160)$ \\
\hline Age, years & $63.7 \pm 12.8$ \\
\hline Gender, female & $122(76.2)$ \\
\hline \multicolumn{2}{|l|}{ Marital status caregiver } \\
\hline Married/cohabitant & $127(79.4)$ \\
\hline Never married & $13(8.1)$ \\
\hline Divorced & $10(6.2)$ \\
\hline Widowed & $4(2.5)$ \\
\hline No response & $6(3.8)$ \\
\hline \multicolumn{2}{|l|}{ Relationship with person with dementia } \\
\hline Spouses & $82(51.2)$ \\
\hline Offspring & $61(38.1)$ \\
\hline Others & $17(10.7)$ \\
\hline Caregiver lives with patient & $121(75.6)$ \\
\hline Caregiver burden (ZBI) & $33.3 \pm 15.3$ \\
\hline Little to mild burden $(0-20)$ & $36(23.2)$ \\
\hline Mild to moderate burden $(21-40)$ & $70(45.2)$ \\
\hline High burden $(>40)$ & $49(31.6)$ \\
\hline Quality of Life (EQ-5D) & $0.7 \pm 0.2$ \\
\hline Self-reported quality of life (VAS) & $71.2 \pm 17.2$ \\
\hline Psychological well-being (GHQ-12) & $3.6 \pm 3.3$ \\
\hline Normal (0-4) & $105(67.7)$ \\
\hline Poor (5-12) & $50(32.3)$ \\
\hline Social support (Duke) & $40.8 \pm 9.6$ \\
\hline Low $(<33)$ & $33(21.3)$ \\
\hline Normal (33-55) & $122(78.7)$ \\
\hline \multicolumn{2}{|l|}{ Care needs of families (FIN) } \\
\hline Importance & $35.9 \pm 5.4$ \\
\hline Needs are important (36-44) & $67(43.5)$ \\
\hline Needs are not important $(<36)$ & $87(56.5)$ \\
\hline Fulfillment & $24.0 \pm 10.2$ \\
\hline Needs are fulfilled (26-44) & $71(46.1)$ \\
\hline Needs are not fulfilled $(<26)$ & $83(53.9)$ \\
\hline Total & $59.9 \pm 12.1$ \\
\hline Needs are identified (65-88) & $63(40.9)$ \\
\hline Needs are not identified $(<65)$ & $91(59.1)$ \\
\hline \multicolumn{2}{|c|}{ Positive and negative aspects of caregiving (CRA) } \\
\hline Caregiver self-esteem & $27.6 \pm 4.2$ \\
\hline Lack of family support & $12.7 \pm 4.3$ \\
\hline Impact on finances & $8.0 \pm 2.3$ \\
\hline Impact on schedule & $16.5 \pm 4.9$ \\
\hline Impact on health & $10.7 \pm 4.4$ \\
\hline
\end{tabular}

Data are presented as number (percentage) or means \pm standard deviation. ZBI: Zarit Burden Interviews, EQ-5D: EuroQol 5 Dimension, VAS: Visual Analogue Scale, GHQ-12: General Health Questionire 12 item version, FCI: Family Caregiving Inventory, FIN: Family Inventory of Needs, PCSS: Pearlin Caregivers' Stress Scale, KESO: Knowledge Expectations of significant other-scale, RKSO: Received Knowledge of significant other-scale, CRA: Caregiver Reaction Assessment. 
Table 2. People with dementia characteristics and outcomes.

\begin{tabular}{|c|c|}
\hline Variable & Total $(n=160)$ \\
\hline Age, years & $79.1 \pm 8.2$ \\
\hline Gender, female & $87(54.4)$ \\
\hline \multicolumn{2}{|l|}{ Type of dementia } \\
\hline Alzheimer & $112(70.0)$ \\
\hline Unknown & $21(13.1)$ \\
\hline Vascular dementia & $11(6.9)$ \\
\hline Others & $9(5.6)$ \\
\hline Dementia with Lewy bodies & $6(3.8)$ \\
\hline Alzheimer's with cerebrovascular disease & $1(0.6)$ \\
\hline Time since diagnosis, years & $5.4 \pm 3.2$ \\
\hline Disease severity (MMSE) & $17.3 \pm 6.6$ \\
\hline Mild $(21-28)$ & $52(38.0)$ \\
\hline Moderate (15-20) & $53(38.7)$ \\
\hline Moderately severe/severe $(<15)$ & $32(23.4)$ \\
\hline Dependency in ADL (Katz Index) & $3.9 \pm 2.1$ \\
\hline Disability $(0-2)$ & $45(29.8)$ \\
\hline Partial disability (3-5) & $58(38.4)$ \\
\hline Functional independence (6) & $48(31.8)$ \\
\hline Comorbidity (Charlson Index) & $1.5 \pm 1.2$ \\
\hline 0 & $28(17.5)$ \\
\hline 1 & $79(49.4)$ \\
\hline 2 & $23(14.4)$ \\
\hline More than 2 & $30(18.8)$ \\
\hline \multicolumn{2}{|l|}{ Behavioral disturbance (NPI) } \\
\hline Severity & $6.7 \pm 5.4$ \\
\hline Distress & $4.0 \pm 6.1$ \\
\hline \multicolumn{2}{|l|}{ Quality of Life } \\
\hline EQ-5D & $0.6 \pm 0.3$ \\
\hline Self reported (VAS) & $67.3 \pm 20.1$ \\
\hline QoL-AD & $29.3 \pm 5.1$ \\
\hline \multicolumn{2}{|l|}{ Cognitive function (GDS) } \\
\hline Very mild cognitive decline & $2(1.2)$ \\
\hline Mild cognitive decline & $34(21.2)$ \\
\hline Moderate cognitive decline & $69(43.1)$ \\
\hline Moderately severe cognitive decline & $31(19.4)$ \\
\hline Severe cognitive decline & $16(10.0)$ \\
\hline Very severe cognitive decline & $8(5.0)$ \\
\hline
\end{tabular}

Data are presented as number (percentage) or means \pm standard deviation. MMSE: Mini-Mental Stage Examination, ADL: activities of daily living, NPI: Neuropsychiatric Inventory, EQ-5D: EuroQol 5 Dimension, VAS: Visual Analogue Scale, QoL-AD: Quality of Life in Alzheimer's Disease, GDS: Global Deterioration Scale.

\subsection{Informal Caregivers' QoL}

The QoL of informal caregivers of female persons with dementia was slightly better than the QoL of caregivers of male persons with dementia ( 0.72 female patient versus 0.65 male patient, $p=0.002$ ) (Table 3). The severity of PwDs' behavioral disturbance was another outcome associated with informal caregivers' QoL even though the correlation is low $(r=-0.178, p=0.028)$. Self-perceived QoL was associated with time since diagnosis and PwD QoL measured by QoL-AD. Less time since diagnosis $(\mathrm{r}=-0.230, p=0.009)$ and better PwD QoL $(r=0.165, p=0.042)$ indicate better informal caregiver QoL. Despite the tendencies previously mentioned, the strength of the relationships between the informal caregivers' QoL and PwD outcomes was low. Most of the caregivers' outcomes were significantly associated with their QoL (Table 4). Male caregivers have a slightly better QoL than female caregivers (0.77 male caregiver versus 0.67 female caregiver, $p<0.001)$. Caregiver burden $(r=-0.437, p<0.001)$, psychological wellbeing $(\mathrm{r}=-0.474, p<0.001)$ and impact of negative aspects of caregiving on health $(\mathrm{r}=-0.465, p<0.001)$ were moderately correlated with informal caregivers' QoL. In the case of 
self-perceived quality of life, impact of negative aspects of caregiving on health $(\mathrm{r}=-0.439, p<0.001)$, psychological wellbeing $(r=-0.370, p<0.001)$ and caregiver self-esteem $(r=0.317, p<0.001)$ were the three outcomes with the highest correlation with self-perceived QoL. Moreover, the results show that caregivers with low social support ( $<33$ on the DUKE scale) have significantly lower QoL compared to those with normal social support ( $\geq 33$ on the DUKE scale) (63.79 low social support versus 73.18 normal social support, $p=0.003$ ).

Table 3. Association between people with dementia outcomes and informal caregivers' quality of life.

\begin{tabular}{|c|c|c|c|c|}
\hline Variable & $\begin{array}{c}\text { Quality of } \\
\text { Life (EQ-5D) }\end{array}$ & $p$-Value ${ }^{+}$ & $\begin{array}{c}\text { Self-Reported Quality } \\
\text { of Life (VAS) }\end{array}$ & $p$-Value $\ddagger$ \\
\hline Age, years & -0.109 & 0.197 & -0.054 & 0.522 \\
\hline Gender & & 0.002 & & 0.933 \\
\hline Male & $0.65(0.15)$ & & $71.03(18.50)$ & \\
\hline Female & $0.72(0.15)$ & & $71.27(16.08)$ & \\
\hline Type of dementia & & 0.181 & & 0.429 \\
\hline Alzheimer's & $0.70(0.15)$ & & $70.57(17.93)$ & \\
\hline Unknown & $0.65(0.15)$ & & $75.00(15.34)$ & \\
\hline Vascular dementia & $0.62(0.14)$ & & $73.18(12.10)$ & \\
\hline Others & $0.73(0.05)$ & & $68.89(18.50)$ & \\
\hline Dementia with Lewy bodies & $0.65(0.24)$ & & $75.00(12.25)$ & \\
\hline Time since diagnosis, years & -0.050 & 0.573 & -0.230 & 0.009 \\
\hline Disease severity (MMSE) & -0.120 & 0.166 & 0.090 & 0.299 \\
\hline Mild $(21-28)$ & $0.67(0.15)$ & & $71.86(18.05)$ & \\
\hline Moderate (15-20) & $0.72(0.14)$ & & $72.96(14.26)$ & \\
\hline Moderately severe/severe $(<15)$ & $0.70(0.15)$ & & $67.42(18.48)$ & \\
\hline Dependency in ADL (Katz Index) & -0.023 & 0.781 & 0.028 & 0.731 \\
\hline Disability $(0-2)$ & $0.71(0.18)$ & & $71.16(18.19)$ & \\
\hline Partial disability (3-5) & $0.66(0.15)$ & & $71.46(16.08)$ & \\
\hline Functional independence (6) & $0.71(0.13)$ & & $70.68(17.62)$ & \\
\hline Comorbidity (Charlson Index) & -0.096 & 0.237 & 0.045 & 0.585 \\
\hline 0 & $0.72(0.14)$ & & $70.04(20.05)$ & \\
\hline 1 & $0.68(0.15)$ & & $71.81(16.34)$ & \\
\hline 2 & $0.70(0.19)$ & & $67.70(22.78)$ & \\
\hline More than 2 & $0.67(0.14)$ & & $73.10(11.05)$ & \\
\hline \multicolumn{5}{|l|}{ Behavioral disturbance (NPI) } \\
\hline Severity & -0.178 & 0.028 & -0.029 & 0.723 \\
\hline Distress & -0.053 & 0.517 & -0.100 & 0.218 \\
\hline \multicolumn{5}{|l|}{ Quality of Life } \\
\hline EQ-5D & 0.031 & 0.753 & 0.105 & 0.286 \\
\hline Self-reported (VAS) & 0.049 & 0.638 & 0.193 & 0.060 \\
\hline QoL-AD & 0.116 & 0.153 & 0.165 & 0.042 \\
\hline Cognitive function (GDS) & & 0.236 & & 0.537 \\
\hline Very mild cognitive decline & $0.66(0.10)$ & & $74.50(34.65)$ & \\
\hline Mild cognitive decline & $0.63(0.16)$ & & $72.12(18.53)$ & \\
\hline Moderate cognitive decline & $0.71(0.14)$ & & $70.28(16.24)$ & \\
\hline Moderately severe cognitive decline & $0.71(0.16)$ & & $75.39(15.15)$ & \\
\hline Severe cognitive decline & $0.67(0.20)$ & & $65.67(23.06)$ & \\
\hline Very severe cognitive decline & $0.74(0.12)$ & & $67.50(8.86)$ & \\
\hline
\end{tabular}

Data are presented as means (standard deviation) or Pearson correlation coefficient. In bold, people with dementia outcomes significantly $(p<0.05)$ associated with informal caregivers' quality of life. ${ }^{+}$Association between people with dementia outcomes and EQ-5D. ANOVA test was used for categorical outcomes and correlation test for continuous outcomes. ${ }^{\ddagger}$ Association between people with dementia outcomes and VAS. ANOVA test was used for categorical outcomes and correlation test for continuous outcomes. MMSE: Mini-Mental State Examination, ADL: activities of daily living, NPI: Neuropsychiatric Inventory, EQ-5D: European Quality of Life 5-Dimension scale, VAS: Visual Analogue Scale, QoL-AD: Quality of Life in Alzheimer's Disease, GDS: Global Deterioration Scale. 
Table 4. Informal caregivers' outcomes associated with informal caregivers' quality of life.

\begin{tabular}{|c|c|c|c|c|}
\hline Variable & $\begin{array}{c}\text { Quality of } \\
\text { Life (EQ-5D) }\end{array}$ & $p$-Value ${ }^{+}$ & $\begin{array}{l}\text { Self-Reported Quality } \\
\text { of Life (VAS) }\end{array}$ & $p$-Value $\ddagger$ \\
\hline Age, years & -0.042 & 0.603 & -0.051 & 0.531 \\
\hline Gender & & $<0.001$ & & 0.204 \\
\hline Male & $0.77(0.09)$ & & $74.55(12.95)$ & \\
\hline Female & $0.67(0.16)$ & & $70.23(18.17)$ & \\
\hline Marital status caregiver & & 0.936 & & 0.479 \\
\hline Married/cohabitant & $0.69(0.15)$ & & $71.19(17.81)$ & \\
\hline Never married & $0.69(0.16)$ & & $72.31(17.98)$ & \\
\hline Divorced & $0.65(0.20)$ & & $72.50(5.89)$ & \\
\hline Widowed & $0.71(0.03)$ & & $57.50(9.57)$ & \\
\hline No response & $0.74(0.08)$ & & $82.50(17.68)$ & \\
\hline Relationship with person with dementia & & 0.790 & & 0.829 \\
\hline Spouses & $0.68(0.15)$ & & $71.94(17.90)$ & \\
\hline Offspring & $0.70(0.16)$ & & $70.43(15.62)$ & \\
\hline Others & $0.69(0.18)$ & & $69.64(19.95)$ & \\
\hline Caregiver lives with patient & & 0.249 & & 0.971 \\
\hline No & $0.72(0.15)$ & & $71.06(14.88)$ & \\
\hline Yes & $0.68(0.15)$ & & $71.18(17.81)$ & \\
\hline Caregiver burden (ZBI) & -0.437 & $<0.001$ & -0.204 & 0.011 \\
\hline Little to mild burden $(0-20)$ & $0.75(0.09)$ & & $74.64(17.11)$ & \\
\hline Mild to moderate burden $(21-40)$ & $0.71(0.12)$ & & $73.28(14.98)$ & \\
\hline High burden $(>40)$ & $0.61(0.20)$ & & $65.65(18.99)$ & \\
\hline Psychological wellbeing (GHQ-12) & -0.474 & $<0.001$ & -0.370 & $<0.001$ \\
\hline Normal $(0-4)$ & $0.73(0.12)$ & & $74.66(15.15)$ & \\
\hline Poor $(5-12)$ & $0.62(0.18)$ & & $63.71(18.92)$ & \\
\hline Social support (Duke) & 0.148 & 0.067 & 0.240 & 0.003 \\
\hline Low $(<33)$ & $0.66(0.20)$ & & $63.79(19.80)$ & \\
\hline Normal (33-55) & $0.70(0.14)$ & & $73.18(15.87)$ & \\
\hline \multicolumn{5}{|l|}{ Care needs of families (FIN) } \\
\hline Importance & 0.003 & 0.970 & -0.062 & 0.446 \\
\hline Needs are important $(36-44)$ & $0.69(0.16)$ & & $69.23(18.82)$ & \\
\hline Needs are not important $(<36)$ & $0.69(0.15)$ & & $72.23(15.78)$ & \\
\hline Fulfillment & 0.191 & 0.019 & 0.182 & 0.026 \\
\hline Needs are fulfilled (26-44) & $0.73(0.13)$ & & $73.22(15.55)$ & \\
\hline Needs are not fulfilled $(<26)$ & $0.65(0.16)$ & & $69.02(18.28)$ & \\
\hline Total & 0.162 & 0.048 & 0.124 & 0.129 \\
\hline Needs are identified (65-88) & $0.70(0.14)$ & & $71.59(16.22)$ & \\
\hline Needs are not identified $(<65)$ & $0.68(0.16)$ & & $70.50(17.84)$ & \\
\hline \multicolumn{5}{|l|}{ Positive and negative aspects of caregiving (CRA) } \\
\hline Caregiver self-esteem & 0.254 & 0.002 & 0.317 & $<0.001$ \\
\hline Lack of family support & -0.098 & 0.239 & -0.092 & 0.267 \\
\hline Impact on finances & -0.233 & 0.004 & -0.255 & 0.002 \\
\hline Impact on schedule & -0.262 & 0.001 & -0.224 & 0.007 \\
\hline Impact on health & -0.465 & $<0.001$ & -0.439 & $<0.001$ \\
\hline
\end{tabular}

Data are presented as means (standard deviation) or Pearson correlation coefficient. In bold, informal caregiver outcomes significantly $(p<0.05)$ associated with informal caregivers' quality of life. ${ }^{\dagger}$ Association between informal caregiver outcomes and EQ-5D. ANOVA test was used for categorical outcomes and correlation test for continuous outcomes. ${ }^{\ddagger}$ Association between informal caregiver outcomes and VAS. ANOVA test was used for categorical outcomes and correlation test for continuous outcomes. EQ-5D: European Quality of Life 5-Dimension scale, VAS: Visual Analogue Scale, ZBI: Zarit Burden Interviews, GHQ-12: General Health Questionnaire (12-item version), FCI: Family Caregiving Inventory, FIN: Family Inventory of Needs, PCSS: Pearlin Caregivers' Stress Scale, KESO: Knowledge Expectations of Significant Other scale, RKSO: Received Knowledge of Significant Other scale, CRA: Caregiver Reaction Assessment.

\subsection{Outcomes Independently Associated with the Informal Caregivers' QoL}

The results of the multiple linear regression models are detailed in Table 5 . There is no multicollinearity (the VIF are lower than 5). After including PwDs' and informal caregivers' outcomes significantly associated with QoL in the model, patient gender, caregiver burden and the impact of negative aspects of caregiving on health appeared as the only factors independently associated with QoL. On the other hand, time since diagnosis, informal caregiver's psychological wellbeing and impact of negative aspects of caregiving on health were the factors independently associated with self-perceived quality of life. Both models were able to explain around $30 \%$ of the total variability for quality of life, indicating that other important variables associated with QoL exist that are not related to informal caregivers' or PwDs' outcomes. 
Table 5. Multiple lineal regression model for informal caregivers' quality of life.

\begin{tabular}{cccccc}
\hline Parameter & $\beta$ Coefficient & Std. Error & t Value & Sig. & VIF \\
\hline Quality of Life (EQ-5D) & & & & & \\
Intercept & 0.847 & 0.033 & 25.340 & $<0.001$ & 1.02 \\
PwD gender, female & 0.078 & 0.022 & 3.486 & 0.001 & 1.58 \\
Caregiver burden (ZBI) & -0.003 & 0.001 & -3.225 & 0.002 & 1.59 \\
Impact on health (CRA) & -0.010 & 0.003 & -3.042 & 0.003 & \\
$\quad$ Adjusted R2 = 0.318 & & & & & \\
Self-reported quality of life (VAS) & & & & & \\
$\quad$ Intercept & 95.365 & 4.029 & 23.669 & $<0.001$ & \\
Time since diagnosis, years & -1.049 & 0.423 & -2.480 & 0.015 & 2.03 \\
Psychological wellbeing (GHQ-12) & -0.869 & 0.547 & -1.589 & 0.115 & 2.07 \\
Impact on health (CRA) & -1.337 & 0.421 & -3.178 & 0.002 & \\
Adjusted R2 = 0.302 & & & & & \\
\hline
\end{tabular}

EQ-5D: European Quality of Life 5-Dimension scale, VAS: Visual Analogue Scale, ZBI: Zarit Burden Interviews, GHQ-12: General Health Questionnaire (12-item version), CRA: Caregiver Reaction Assessment., Std.: Standard, Sig.: Significance, VIF: Variance Inflation Factor.

\section{Discussion}

Dementia has important consequences for the quality of life of informal caregivers. The current study analyzes the impact of the role of informal caregivers to PwD on the self-perceived QoL of caregivers. Findings confirm that the progressive nature of dementia, burden, and aspects related to informal caregivers' physical and mental health increase the vulnerability of informal caregivers. This has direct repercussions on care provision in the home, which are associated with self-perceived QoL.

IC and PwDs' sociodemographic characteristics are similar to those of other studies. The IC is, in general, a person over 60 years old, who is female, and who lives with and shares a bond with the PwD-in most cases, the spouse of the PwD [23,24]. For their part, the PwD are frequently female with an average age of over 70 years. As such, our findings indicate that gender is one of the variables influencing perception of QoL in both IC and PwD. Alzheimer's is the most frequent type of dementia with a manifestation of neuropsychiatric symptoms, which, with the passing of time, entail a need for continuous care. This can lead to a certain degree of burden and to the appearance of alterations in the emotional wellbeing of the IC of a depressive or anxious type, and/or psychological distress. However, our results show that time since diagnosis is also one of the associated factors that influences self-perceived QoL, so that-in the initial or intermediate phases of dementia, when the PwD demand greater attention due to the progress of the illness-there is a need for new interventions that can slow down or arrest this progression and maintain or improve PwDs' results $[2,25]$.

\subsection{Informal Caregivers' Quality of Life}

Different perspectives have been unified over the years to help to define and analyze the concept of QoL and its relationship with care. Nevertheless, its multidimensional, nebulous nature defies a precise description of its defining variables. Thus, assessments of physical and emotional wellbeing are important in the perception of better or worse QoL in the informal caregiver $[3,25,26]$.

Regarding the relationship between QoL and the role of the informal caregiver, it would appear that different aspects of dementia positively or negatively influence the perception of better or worse QoL. One of the main aspects that affects the informal caregiver's role is illness severity, one of the principal reasons for role reorganization, as PwD care-related activities change over the years with a possible need to increase the number of hours of daily care [25]. Kaizik et al. stated that the severity of dementia is a factor which influences the appearance of caregiver burden as those IC who dedicate more time to general supervision and provide more assistance to PwD in daily activities experience a high level of tension. Study findings demonstrate that more than $70 \%$ of ICs have a high degree of burden, with low levels of emotional wellbeing as a result of their informal caregiving role and a greater number of hours dedicated to care provision. Comparative studies between different types of 
caregivers show that the IC of PwD report a significantly higher degree of burden than other types of caregivers due to the greater number of hours per day devoted to patient care and that, in addition, there is a strong association between high levels of depression and advanced states of dementia [26]. Therefore, identification of those more specific needs is useful for the intervention of professionals who guide home care $[25,27,28]$.

Another aspect of dementia associated with informal caregiver QoL is the presence of neuropsychiatric symptoms (NS). In fact, the appearance of these symptoms in PwD in the sample negatively influenced the QoL of the IC. In accordance with Karg et al., the presence and severity of NS, together with the age at onset and the number of years of providing care, affect the personal life and role of the IC as they increase the PwD and ICs' needs and this increase is possibly perceived as a reduction in QoL itself $[25,26,29,30]$. This has led to an analysis of the impact of the informal caregiver's role on their own lives in order to be able to intervene early in aspects that can be modified to delay or avoid the emergence of alterations in their physical or emotional wellbeing. Some reviews suggest that the positive and negative dimensions of care are different concepts, although there are an increasing number of studies that show the association between these dimensions and the appearance of burden and these alterations in the IC [31]. Indeed, in the present study, the impact of the negative aspects of care on health is one of the variables with the greatest correlation with the self-perception of QoL. Acosta et al. reported that the informal caregiver role can, over time, negatively affect both the personal and working life, as daily care provided over many years means less time for leisure activities and self-care and can even lead to conflict within the family $[5,28]$.

Finally, our findings highlight the significant association between low social support, whether from family and/or friends, and self-perceived QoL as it appears that those ICs with low social support have a significantly lower QoL than those with good social support. This is consistent with other studies which indicate that IC with good social support experience fewer alterations in their emotional wellbeing and less stress as they have more time to enjoy pleasant activities. This would represent an effective strategy for the prevention of alterations in the mental health of IC and an improvement in self-perceived QoL since, according to the authors, it would be based on the fact that "social support does not only directly affect depression but also exercises an indirect influence on depression through the informal caregiver role". These findings also emphasize the need for comprehensive support services for both PwD and IC [32,33].

\subsection{Limitations}

Despite the relevant aspects of our study and the correlation of variables associated with the QoL of PwD and IC, some limitations should be recognized. First, convenience sampling was performed, which could limit the generalization of the results. However, variables related to the PwD and IC were identified and considered in the analysis of causal relationships. Second, socioeconomic differences between participants were not taken into account and it would have been useful to analyze economic impact on caregivers' QoL.

\section{Conclusions}

The present study offers a description of the relationship between the informal caregiver role and the QoL of informal caregivers of people with dementia. It can be observed that factors associated with dementia such as its progressive nature and severity with the presence of neuropsychiatric symptoms can have a negative influence on the role of the informal caregiver, leading to the emergence of burden and a consequent self-perception of low QoL. For this reason, social and professional support is essential for IC to facilitate care provision and improve the quality of life of IC and PwD. Similarly, follow-up and accompaniment of informal caregivers and persons with dementia by health professionals can promote timely detection of the appearance of alterations in physical health and emotional wellbeing, allowing for early intervention and referrals to specific centers. 
Author Contributions: Conceptualization, C.E.F., A.Z. and E.C.; methodology, C.E.F. and A.Z.; investigation, C.E.F.; resources, C.E.F.; writing-original draft preparation, C.E.F.; writing-review and editing, C.E.F., A.Z. and E.C.; supervision, A.Z. and E.C.; project administration, A.Z.; funding acquisition, A.Z. All authors have read and agreed to the published version of the manuscript.

Funding: This research was funded by the Marató TV3 Foundation under grant 20144410.

Acknowledgments: The authors would like to thank the Marató TV3 Foundation for the financial support and we thank all the caregivers who participated in this study.

Conflicts of Interest: The authors declare no conflict of interest. The funders had no role in the design of the study; in the collection, analyses, or interpretation of data; in the writing of the manuscript, or in the decision to publish the results.

\section{References}

1. Gale, S.A.; Acar, A.; Daffner, K.R. Dementia. Am. J. Med. 2018, 131, 1161-1169. [CrossRef]

2. Ponjoan, A.; Garre-Olmo, J.; Blanch, J.; Fages, E.; Alves-Cabratosa, L.; Martí-Lluch, R.; Comas-Cufí, M.; Parramon, D.; Garcia-Gil, M.; Ramos, R. Epidemiology of dementia: Prevalence and incidence estimates using validated electronic health records from primary care. Clin. Epidemiol. 2019, 11, 217-228. [CrossRef]

3. Alzheimer Cataluña Fundació. Lo Que no Sabéis sobre las Demencias y el Alzheimer. Available online: https://alzheimercatalunya.org/es/demencias-y-alzheimer/ (accessed on 2 June 2019).

4. Rose, K.M.; Williams, I.C.; Anderson, J.G.; Geldmacher, D.S. Development and Validation of the Family Quality of Life in Dementia Scale. Gerontology 2020, 1-9. [CrossRef]

5. Frias, C.E.; Garcia-Pascual, M.; Montoro, M.; Ribas, N.; Risco, E.; Zabalegui, A. Effectiveness of a Psychoeducational Intervention for Caregivers of People with Dementia with Regard to Burden, Anxiety and Depression: A Systematic Review. J. Adv. Nurs. 2020, 76, 787-802. [CrossRef]

6. Liu, Z.; Sun, Y.Y.; Zhong, B.L. Mindfulness-based stress reduction for family carers of people with dementia. Cochrane Database Syst. Rev. 2018, 8. [CrossRef]

7. Seitz, D.; Chan, C.C.; Newton, H.T.; Gill, S.S.; Herrmann, N.; Smailagic, N.; Nikolaou, V.; Fage, B.A. Mini-Cog for the diagnosis of Alzheimer's disease dementia and other dementias within a primary care setting. Cochrane Database Syst. Rev. 2018, 2, CD011415. [CrossRef]

8. Balash, Y.; Korczyn, A.D.; Knaani, J.; Migirov, A.A.; Gurevich, T. Quality-of-life perception by Parkinson's disease patients and caregivers. Acta Neurol. Scand. 2017, 136, 151-154. [CrossRef] [PubMed]

9. Miguel, S.; Alvira, M.; Farré, M.; Risco, E.; Cabrera, E.; Zabalegui, A. Quality of life and associated factors in older people with dementia living in long-term institutional care and home care. Eur. Geriatr. Med. 2016, 7, 346-351. [CrossRef]

10. The EuroQol Group. EuroQol-A new facility for the measurement of health-related quality of life. Health Policy 1990, 16, 199-208. [CrossRef]

11. Martín-Carrasco, M.; Salvadó, I.; Nadal, S.; Miji, L.C.; Rico, J.M.; Lanz, P.; Taussig, M.I. Adaptación para nuestro medio de la Escala de Sobrecarga del Cuidador (Caregiver Burden Interview) de Zarit. Rev. Gerontol. $1996,6,338-346$.

12. Romppel, M.; Braehler, E.; Roth, M.; Glaesmer, H. What is the General Health Questionnaire-12 assessing? Dimensionality and psychometric properties of the General Health Questionnaire-12 in a large scale German population sample. Compr. Psychiatry 2013, 54, 406-413. [CrossRef]

13. Rocha, K.B.; Pérez, K.; Rodríguez-Sanz, M.; Borrel, C.; Obiols, J.E. Propiedades psicométricas y valores normativos del General Health Questionnaire (GHQ-12) en población general española. Int. J. Clin. Health Psychol. 2011, 11, 125-139.

14. Alvira, M.C.; Risco, E.; Cabrera, E.; Farré, M.; Hallberg, I.R.; Bleijlevens, M.H.C.; Meyer, G.; Koskenniemi, J.; López, M.E.S.; Zabalegui, A.; et al. The association between positive-negative reactions of informal caregivers of people with dementia and health outcomes in eight European countries: A cross-sectional study. J. Adv. Nurs. 2015, 71, 1417-1434. [CrossRef]

15. Alvira, C.; Cabrera, E.; Kostov, B.; Risco, E.; Farré, M.; Miguel, S.; Zabalegui, A. Validity and reliability of the Spanish caregiver reaction assessment scale for caregivers of people with dementia. Int. J. Nurs. Pr. 2020, e12848. [CrossRef]

16. Folstein, M.; Folstein, S.; McHugh, P. "Mini-mental state". A practical method for grading the cognitive state of patients for the clinician. J. Psychiatry Res. 1975, 12, 189-198. [CrossRef] 
17. Reisberg, B.; Ferris, S.H.; De Leon, M.J.; Crook, T. The Global Deterioration Scale for assessment of primary degenerative dementia. Am. J. Psychiatry 1982, 139, 1136-1139. [CrossRef]

18. Gómez-Gallego, M.; Gómez-Amor, J.; Gómez-García, J. Validation of the Spanish version of the QoL-AD scale in Alzheimer disease patients, their carers, and health professionals. Neurología 2012, 27, 4-10. [CrossRef]

19. Vilalta-Franch, J.; Lozano-Gallego, M.; Hernández-Ferrándiz,M.; Llinàs-Reglà, J.; López-Pousa, S.; López, O.L. The Neuropsychiatric Inventory. Psychometric properties of its adaptation into Spanish. Rev. Neurol. 1999, 29, 15-19.

20. Yamashita, T.; Yamashita, K.; Kamimura, R. A Stepwise AIC Method for Variable Selection in Linear Regression. Commun. Stat. Theory Methods 2007, 36, 2395-2403. [CrossRef]

21. Sheather, S. A Modern Approach to Regression with R; Springer: New York, NY, USA, 2009; ISBN 978-0-387-09607-0.

22. R Core Team. R: A Language and Environment for Statistical Computing; R Foundation for Statistical Computing: Vienna, Austria, 2018; Available online: https://www:R-project.org/ (accessed on 4 June 2020).

23. Gonyea, J.G.; López, L.M.; Velásquez, E.H. The effectiveness of a culturally sensitive cognitive behavioural group intervention for Latino Alzheimer's Caregivers. Gerontologist 2014, 56, 292-302. [CrossRef]

24. Tang, S.-H.; Chio, O.-I.; Chang, L.-H.; Mao, H.-F.; Chen, L.-H.; Yip, P.-K.; Hwang, J.-P. Caregiver active participation in psychoeducational intervention improved caregiving skills and competency. Geriatr. Gerontol. Int. 2018, 18,750-757. [CrossRef] [PubMed]

25. Kerpershoek, L.; De Vugt, M.; Wolfs, C.; Woods, B.; Jelley, H.; Orrell, M.; Stephan, A.; Bieber, A.; Meyer, G.; Selbaek, G.; et al. Needs and quality of life of people with middle-stage dementia and their family carers from the European Actifcare study. When informal care alone may not suffice. Aging Ment. Heal. 2018, 22, 897-902. [CrossRef] [PubMed]

26. Karg, N.; Graessel, E.; Randzio, O.; Pendergrass, A. Dementia as a predictor of care-related quality of life in informal caregivers: A cross-sectional study to investigate differences in health-related outcomes between dementia and non-dementia caregivers. BMC Geriatr. 2018, 18,1-9. [CrossRef]

27. Lee, M.; Ryoo, J.H.; Crowder, J.; Byon, H.D.; Wiiliams, I.C. A systematic review and meta-analysis on effective interventions for health-related quality of life among caregivers of people with dementia. J. Adv. Nurs. 2020, 76, 475-489. [CrossRef]

28. Kaizik, C.; Caga, J.; Camino, J.; O'Connor, C.M.C.; McKinnon, C.; Oyebode, J.R.; Piguet, O.; Hodges, J.R.; Mioshi, E. Factors Underpinning Caregiver Burden in Frontotemporal Dementia Differ in Spouses and their Children. J. Alzheimer Dis. 2017, 56, 1109-1117. [CrossRef]

29. Acosta, D.; Rottbeck, R.; Rodríguez, G.; Ferri, C.; Prince, M.J. The epidemiology of dependency among urban-dwelling older people in the Dominican Republic; a cross-sectional survey. BMC Public Heal. 2008, 8, 285. [CrossRef]

30. Farina, N.; Page, T.E.; Daley, S.; Brown, A.; Bowling, A.; Basset, T.; Livingston, G.; Knapp, M.; Murray, J.; Banerjee, S. Factors associated with the quality of life of family carers of people with dementia: A systematic review. Alzheimer Dement. 2017, 13, 572-581. [CrossRef]

31. Cruz, M.R.S.; Hidalgo, P.C.; Lee, M.S.; Thomas, C.W.; Holroyd, S. Buspirone for the treatment of dementia with behavioral disturbance. Int. Psychogeriatrics 2017, 29, 859-862. [CrossRef]

32. Quinn, C.; Nelis, S.M.; Martyr, A.; Victor, C.; Morris, R.G.; Clare, L.; IDEAL Study Team. Influence of positive and negative dimensions of dementia caregiving on caregiver well-being and satisfaction with life: Findings from the IDEAL study. Am. J. Geriatr. Psychiatry 2019, 27, 838-848. [CrossRef]

33. Sun, X.; Ge, J.; Meng, H.; Chen, Z.; Liu, D. The Influence of Social Support and Care Burden on Depression among Caregivers of Patients with Severe Mental Illness in Rural Areas of Sichuan, China. Int. J. Environ. Res. Public Health 2019, 16, 1961. [CrossRef]

Publisher's Note: MDPI stays neutral with regard to jurisdictional claims in published maps and institutional affiliations.

(C) 2020 by the authors. Licensee MDPI, Basel, Switzerland. This article is an open access article distributed under the terms and conditions of the Creative Commons Attribution (CC BY) license (http://creativecommons.org/licenses/by/4.0/). 


\section{Publicaciones Científicas}

\subsection{Artículo 4}

\section{INFOSA-DEM: programa dirigido a figuras cuidadoras de personas con demencia.}

Cindy E. Frías, Marta García-Pascual, Estela Solbes, Teresa Jordi, Irene Torrero, Rodríguez Ana María, Elisabeth Calvo,

Ester Risco, Adelaida Zabalegui

Metas Enferm. 2020; 23(4): 16-24. https://doi.org/10.35667/

MetasEnf.2019.23.1003081581. 


\title{
INFOSA-DEM: programa dirigido a figuras cuidadoras de personas con demencia
}

\author{
Cindy E Frías-Torres', Marta García-Pascual², Estela Solbes-Pina³, Teresa Jordi-Ferran4, Irene Torrero-Capilla', \\ Ester Risco-Vilarasau', Ana Ma Rodríguez-Lavandeira”, Elisabeth Calvo-Fernández ${ }^{8}$, Adelaida Zabalegui ${ }^{9}$
}

'Especiolista en Solud Mental. Máster en Investigación en Salud Mental. PhD (c) en Ciencias de la Enfermería. Hospital Clínic de Barcelona zMáster en Ciencias de la Enfermería. Hospital Clinic de Barcelono

3Máster de SIDA. Hospital Clínic de Barcelono

4Máster en Psicogeriatría. Hospital Clínic de Barcelono

5Máster en Cuidados en la Atención Primaria Postgrado en Paciente Crónico. Hospital Cínic de Barcelona

${ }^{5}$ Doctora en Enfermería. Parc Sanitari Pere i Virgili Barcelona

- Máster en Enfermería Gerontológica. Postgrado en psicogeriatría. Sociosanitario de Mollet. Barcelono

sMóster en Enfermería Gerontológica y Geriátrica. Postgrado en Atención Enfermera en Cuidados Paliativos. Postgrado en psicogeriatría

Porc Sonitori Pere i Virgili. Borcelono

${ }^{9}$ Doctora en Enfermería. Subdirectora de Investigación en Enfermería. Hospital Clinic de Barcelona

Fecha de recepción: 9 de diciembre de 2019. Aceptada su publicación: 13 de abril de 2020

\section{Resumen}

Objetivo: evaluar el impacto del Programa Informativo, Formativo y de Apoyo Social para figuras cuidadoras de personas con demencia (INFOSA-DEM), en relación al bienestar emocional, evaluando el tiempo de permanencia del efecto del programa a los tres y seis meses post-intervención.

Método: se llevó a cabo un diseño cuasi-experimental, multicéntrico, no aleatorizado con grupo intervención (GI) y grupo control (GC). La asignación al Gl y GC se realizó a través de muestreo no probabilístico, de asignación intencional, teniendo en cuenta la disponibilicad de las figuras cuidadoras para asistir a las sesiones del proprama diseñado. La recogida de datos fue efectuada por medio de entrevistas personales con la cuidadora o cuidador en el domicilio de la persona con demencia, antes de la intervención y a los tres y seis meses de seguimiento. Se recogieron variables de bienestar emocional y calidad de vida, entre otras. Se llevó a cabo análisis descriptivo y comparativo en los tres momentos de medida

Resultados: participaron 760 figuras cuidadoras, 74 en GC y 86 en Gl. A los tres meses se observó un efecto positivo en el bienestar emocional en el Gl en comparación con un pecueño efecto negativo entre los controles. Teniendo en cuenta las tres visitas se comprobó que la mejora en dimensión salud relacionada con el bienestar emocional de los cuidadores del Gl se mantuvo incluso después de seis meses, aunque las ciferencias no fueron estadísticamente significativas.

Conclusión: los programas educativos dirigidos a cuidadores informales basacos en terapias psicoeducativas y teorías cognitivo-conductuales parecen tener efectos positivos en la mejora del bienestar emocional de los cuidadores, y mejora la calidad del rol de la figura cuidadora.

\section{Palabras clave}

Cuidadores; demencia; bienestar emocional; Enfermería

\section{Abstract \\ INFOSA-DEM: a programme targeted to caregivers of persons with dementia}

Objective: to evaluate the impact of the Information, Training and Social Support programme for caregivers of persons with dementia (INFOSA-DEM) in terms of emotional wellbeing, evaluating the duration of the effect of the program at three and sixmonths after the intervention.

Method: a multicenter and non-randomized study was conducted, with quasi-experimental design, and with an Intervention Arm (IA) and o Control Arm (CA). Porticipants were allocated to IA or CA though non-probabilistic sample, with intentional allocation, taking into occount the availability of the caregivers to attend the sessions of the programme designed. Data were collected through personal interviews with the caregiver at the home of the person with dementia, before the intervention and at three and six months of follow-up. Emotional wellbeing and quality of life variables were collected, among others. Descriptive and comparative analysis was conducted at the three points of measurement

Results: the study included 160 caregivers, 74 in the CA and 86 in the IA. At three months, a positive effect was observed in the emotional wellbeing of the intervention Arm, vs. a slight negative effect among Control participants. Taking into account all three visits, it was confirmed that the improvement in the dimension health associated with the emotional wellbeing of caregivers in the intervention Arm was sustained even after six months, however, differences were not statis ticolly sionificant. Conclusion: educational progroms torgeted to informal caregivers and based on psychoeducational therapies and cognitive-behovioural theories seem to hove positive effects in terms of an improvement in the emotional wellbeing of coregivers, ond there is on improvement in the quality of the coregiver role.

\section{Key words}

Caregivers; dementia; emotional wellbeing; Nursing

\section{Dirección de contacto:}

Adelaida Zabalegui. Hospital Clínic de Barcelona. C/ Villarroel, 170.08036 Barcelona. Email: azabaleg@clinic.cat

\section{Cómo citar este artículo:}

Frías-Torres CE, García-Pascual M, So bes-Pina E; Jordi-Ferran T, Torrero-Capilla I, Risco-Vilarasau E, et al. INFOSA-DEM: programa dirigido a figuras cuidadoras de personas con demencia. Metas Enferm may 2020; 23(4):16-24. Doi: https://doi.org/70.35667/ MetasEnf.2019.23.1003081581 


\section{Introducción}

La demencia reduce las capacidades cognitivas, físicas y sociales, limitando la autonomía del paciente para ciertas actividades de la vida diaria. Afecta a alrededor de 47 millones de personas en el mundo y según datos de la Organización Mundial de la Salud (OMS) anualmente se pueden presentar alrededor de 10 millones de casos nuevos, con una es timación aproximada de 75 millones de nuevos casos para el 2030, de los cuales 19 millones corresponderán a personas diagnosticadas en Europa. Actualmente en España hay más de 800.000 personas diagnosticadas de alzhéimer y en Cataluña más de 86.000 sujetos tienen un diagnóstico de demencia (1-3). Por ello, la demencia es una prioridad para los Estados miembros de la Unión Europea debido a los costes médicos, sociales y familiares que genera $(4,5)$

La dependencia que se crea en la persona con demencia (PCD) para realizar ciertas actividades de la vida diaria (AVD) hace que un miembro de la familia se convierte en el cuidador principal o figura cuidadora, por lo que es importante mantener la calidad de vida del paciente y del cuidado que recibe (6-9). Cabe resaltar que, en comparación con otro tipo cuidados, cuidar a una persona con demencia es extremadamente exigente, que genera consecuencias sociales y emocionales, afectando la salud física y mental de la figura cuidadora, quien puede llegar a abandonar sus propias actividades, empleando poco tiempo para descansar $(1,4,10)$.

Ante esta situación se planteó la necesidad de guiar el cuidado domiciliario a partir de un programa informativo, formativo y de apoyo social Ilamado INFOSA-DEM, dirigido a figuras cuidadoras, para mejorar su calidad de vida y establecer prácticas para que la atención domiciliaria sea más efectiva. El programa incluyó el apoyo emocional y social, teorías cognitivo-conductuales y la teoría de la vulnerabilidad, a partir del enfoque educativo (1 1-14), para promover la gestión de problemas y la reestructuración cognitiva, el manejo del estrés para reducir sus consecuencias, enfatizando en la realización de actividades placenteras basándose en la hipótesis de que estas actividades aumentan el bienestar emocional, reducen la ansiedad, mejoran la calidad de vida del cuidador y de la persona con demencia, ya que al parecer, la satisfacción y el descanso son factores protectores frente al cuidado $(1,7,1,15)$.

Por todo ello, el objetivo de este estudio fue evaluar el impacto del programa INFOSA-DEM en figuras cuidado- ras de personas con demencia que viven en su domicilio en relación al bienestar emocional, evaluando el tiempo de permanencia del efecto del programa a los tres y seis meses post-intervención.

\section{Método}

Se llevó a cabo un diseño cuasi-experimental, no aleatorizado con grupo intervención (Gl) y grupo control (GC). Se trató de un estudio multicéntrico, con observaciones repetidas, pre y post-test a los tres meses y a los seis meses. El reclutamiento tuvo lugar entre 2018 y 2019. La asignación al Gl y GC se realizó a través de muestreo no probabilístico, de asignación intencional o de conveniencia, teniendo en cuenta la disponibilidad de las cuidadoras y los cuidadores para asistir a las sesiones del programa diseñado.

El estudio se efectuó en el área de influencia de tres centros especializados en el cuidado de personas con deterioro cognitivo de la provincia de Barcelona: Hospital Clínic de Barcelona, Fundació Sanitària Mollet y Hospital Pere i Virgili de Barcelona. Para la captación de los participantes se seleccionó un listado de pacientes con demencia atendidos en cada centro. El médico responsable (médico de familia, geriatra y/o neurólogo) y la gestora de pacientes actuaron de intermediaros durante la consulta o por contacto telefónico, para proponer a las figuras cuidadoras su participación en el estudio. Para llegar a la mayor cantidad de personas posibles en la población se diseñaron carteles, diapositivas y hojas informativas con información del programa y datos de contacto en cada uno de los centros participantes. Además, la emisora pública estatal, TVE2, Gifundió y promocionó el proyecto en una sola transmisión (http:// www.rtve.es/alacarta/videos/tips/tips-vida-sana-acordarse-memoria/3863705/)

Una vez que se identificaron los posibles candidatos, el equipo de inves tigación llevó a cabo entrevistas telefónicas para recopilar más información y seleccionar a las cuidadoras y cuidadores que cumplían con los criterios de inclusión. Posteriormente se organizó una visita domiciliaria para la firma del consentimiento informado y para efectuar la evaluación inicial. El primer paciente fue seleccionado en enero de 2018 y el reclutamiento concluyó en septiembre de 2019. Por lo tanto, la recopilación de datos del seguimiento se completó en noviembre de 2019 .

Los criterios de inclusión fueron: figuras cuidadoras mayores de 18 años de personas con edad igual o 
superior a 65 años, con diagnóstico de demencia y con un test Mini-Mental State Examination (MMSE) inferior a 24, que vivían en su domicilio y cuyo cuidador/a principal vivía con él/ella o le visitaba por lo menos dos veces a la semana. Se excluyeron (a) personas con alguna enfermedad psiquiátrica invalidante o síndrome de Korsakov, (b) cuidadores que hubiesen participado en un taller o programa formativo durante el último año relacionado con el cuidado de personas con demencia.

Una vez aceptada la participación en el estudio, mediante firma de consentimiento informado, se recogieron los datos basales de los sujetos de estudio y, posteriormente, se asignó a las cuidadoras y cuidadores al Gl o GC. Las figuras cuidadoras del Gl recibieron el programa INFOSA-DEM (Cuadro 1), junto con el cuidado habitual proporcionado por los centros participantes. El programa INFOSA-DEM constaba de cinco sesiones informativas y formativas de 90 minutos, impartidas consecutivamente durante una semana. Se ofrecieron grupos por la mañana y por la tarde, según la disponibilidad del cuidador/a. El contenido del programa fue desarrollado en pequeños grupos de seis a ocho personas. Los temas en las sesiones incluyeron conceptos básicos en demencia y temas específicos, como nutrición, descanso, medicación, cambios físicos y cognitivos, manejo de síntomas conductuales, problemas afectivos en la persona con demencia y la figura cuidadora, técnicas de comunicación verbal y no verbal, cuidado personal y atención, además de información sobre recursos disponibles y servicios comunitarios.

Las figuras cuidadoras del GC únicamente recibieron el seguimiento habitual o cuidado estándar de los centros donde se realizaba el seguimiento de la persona con demencia, que consistió en visitas anuales o trimestrales por el médico de referencia (médico de familia, geria- tra o neurólogo), el profesional enfermero y trabajador social, dependiendo del centro asistencial. Al acabar e seguimiento de todos los cuidadores se ofreció el programa a las figuras cuidadoras del GC.

La recogida de datos fue efectuada por medio de entrevistas personales con la cuidadora o cuidador en el domicilio de la persona con demencia, antes de la intervención y a los tres y seis meses de seguimiento. Se recopilaron datos sociodemográficos (incluyendo edad, sexo y estado civil) de la persona con demencia y su respectivo cuidador/a.

En la persona con demencia se llevó a cabo una única valoración, en la que se recopiló información sobre presencia de comorbilidades, a través del Charlson Comorbidity Index (CCI) (16); el grado de afectación cognitiva mediante el MMSE (17) y Global Deterioration Scale (GDS) (18); y la calidad de vida mediante Quality of Life in Alzheimer's Disease (QoL-AD) (19).

En el caso de las figuras cuidadoras se midió el bienestar emocional utilizando el General Health Questionnarie (GHQ-12), que detecta y evalúa la angustia mental o la morbilidad psiquiátrica menor en contextos como la Atención Primaria y en población general. Consta de 12 ítems, seis que evalúan aspectos positivos y seis aspectos negativos relacionados con el bienestar emocional del entrevistado. Es una escala tipo Likert de 4 puntos (0-1-2-3) que se puede transformar en una puntuación dicotómica (0-0-1-1), llamada puntuación GHQ. E GHQ-12 demuestra buena confiabilidad en estudios realizados, con un alfa de Cronbach entre 0,82 y 0,86 $(20,21)$.

Así mismo se evaluó la calidad de vida a través del Quality of Life Scale (EQ-5D), escala que mide la autopercep-

\begin{tabular}{|c|c|c|c|c|}
\hline Sesión & Objetivo de la sesión & Contenido & $\begin{array}{l}\text { Vídeo } \\
\text { proyectado }\end{array}$ & $\begin{array}{l}\text { Profesional } \\
\text { encargado }\end{array}$ \\
\hline 1 & $\begin{array}{l}\text { Introducción al programa. } \\
\text { Conocimientos sobre la enfermedad }\end{array}$ & $\begin{array}{l}\text { Información sobre la demencia. Soporte y } \\
\text { experiencia en el cuidado }\end{array}$ & La deambulación & Enfermera \\
\hline 2 & Estrategias de comunicación & $\begin{array}{l}\text { Comunicación verbal y no verbal. Vivencias de } \\
\text { momentos agradables con la persona con } \\
\text { demencia }\end{array}$ & La comunicación & Enfermera \\
\hline 3 & $\begin{array}{l}\text { Estrategias de manejo de síntomas } \\
\text { neuropsiquiátricos }\end{array}$ & $\begin{array}{l}\text { Manejo de los síntomas conductuales en la } \\
\text { persona con demencia }\end{array}$ & La desorientación & Enfermera \\
\hline 4 & Información y búsqueda de recursos & $\begin{array}{l}\text { Recursos y servicios sociales comunitarios. } \\
\text { Uso y planificación para el futuro }\end{array}$ & No aplica & $\begin{array}{l}\text { Trabajadora } \\
\text { social }\end{array}$ \\
\hline 5 & $\begin{array}{l}\text { Estrategias de manejo de síntomas } \\
\text { afectivos. } \\
\text { Identificación y prevención de la } \\
\text { sobrecarga }\end{array}$ & $\begin{array}{l}\text { Problemas y manejo de síntomas afectivos en } \\
\text { la persona con demencia y en la figura } \\
\text { cuidadora }\end{array}$ & Cuidarse & Enfermera \\
\hline
\end{tabular}


ción de calidad de vida y evalúa una amplia gama de afec ciones y tratamientos de salud. Consta de dos partes: un sistema descriptivo (parte l) y una escala analógica visual (VAS) (parte II). La parte I tiene cinco dimensiones individuales: movilidad, autocuidado, actividades habituales, dolor/incomodidad y ansiedad/depresión. Cada dimensión tiene una escala de respuesta de tres puntos. La parte ll mide el estado de salud, desde el peor estado de salud imaginable hasta el mejor (22). Todos los cuestionarios utilizados fueron escalas válidas y fiables.

Se llevaron a cabo análisis descriptivos univariantes con medias y desviaciones estándar (DE). Para comparar los resultados continuos entre la visita inicial y el seguimiento de tres meses se utilizó la prueba t-test pareada o la prueba t de muestras independientes; y para verificar la tendencia entre visitas sucesivas se usó la prueba de tendencia monotónica de Jonckheere-Terpstrata, equivalente a la prueba de Kruskal-WaIlis. Se calcularon las medias entre los GI y GC y un intervalo de confianza del 95\%. Todas las pruebas de significación fueron de dos colas y los valores de $\mathrm{p}<0,05$ se consideraron significativos. Todos los análisis se realizaron utilizando el paquete de software estadístico $R$ versión 3.4.1 para Windows.

A todos los pacientes y figuras cuidadoras se les pidió su consentimiento informado por escrito para participar en el estudio, aunque en casos de deterioro cognitivo severo de la persona con demencia solo se solicitó el consentimiento de la cuidadora o cuidador. Se obtuvo la aprobación del Comité de Ética de Investigación Clínica (Reg. HCB / 2018/0737).

\section{Resultados}

Participaron un total de 160 figuras cuidadoras, que realizaron evaluaciones basales, y fueron asignadas 74 en el Gc y 86 en el Gl (Figura 1).

A los seis meses, 112 participantes completaron las evaluaciones. 17 de los 86 participantes (19,8\%) en el Gl abandonaron el estudio debido a la falta de tiempo. 28 de 74 participantes (37,8\%) en el GC no estuvieron disponibles para evaluaciones posteriores. Las pérdidas fueron por cansancio, fallecimiento o ingreso de la persona con demencia en un centro de larga estancia.

La edad media (DE) de las figuras cuidadoras fue de 63,7 (12,8). El 76,2\% de los cuidadores era mujer y más del $50 \%$ eran las esposas de la persona con demencia. Un 38\% de las figuras cuidadoras era hijo/a de la persona con demencia. Casi el $80 \%$ de las cuidadoras convivía con la persona con demencia (Tabla 1).

En cuanto a la persona con demencia, la edad media (DE) fue de $79(8,2)$ años. Más del 50\% era mujer, un

Figura 1. Flujo de los participantes del estudio

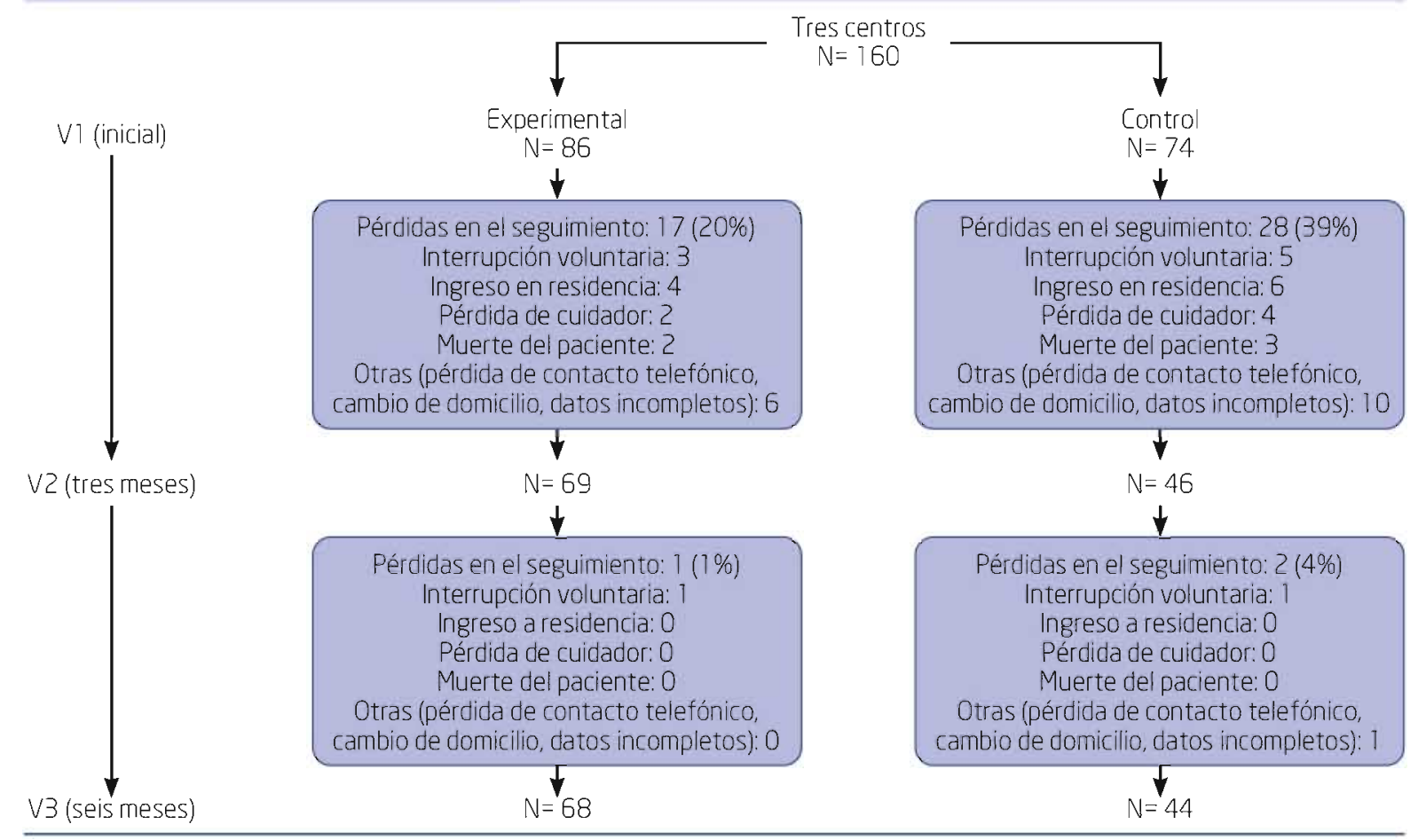




\begin{tabular}{|c|c|c|c|}
\hline Variable & $\begin{array}{c}\text { Total }(n=160) \\
n(\%)\end{array}$ & $\begin{array}{c}\text { Control }(n=74) \\
n(\%)\end{array}$ & $\begin{array}{c}\text { Intervención }(n=86) \\
n(\%)\end{array}$ \\
\hline \multicolumn{4}{|l|}{ Edad, años media (DE) } \\
\hline Figura cuidadora & $63,7(12,8)$ & $62,4(14,3)$ & $64,7(11,5)$ \\
\hline Pacientes con demencia & $79,1(8,2)$ & $80,1(8,5)$ & $78,3(7,9)$ \\
\hline \multicolumn{4}{|l|}{ Género, femenino } \\
\hline Figura cuidadora & $122(76,2)$ & $54(73)$ & $68(79,1)$ \\
\hline Pacientes con demencia & $87(54,4)$ & $42(56,8)$ & $45(52,3)$ \\
\hline \multicolumn{4}{|l|}{ Relación con la persona con demencia } \\
\hline Esposa & $82(51,2)$ & $30(40,5)$ & $52(60,5)$ \\
\hline Hijo & $61(38,1)$ & $31(41,9)$ & $30(34,9)$ \\
\hline Otros (amistad) & $17(10,7)$ & $13(17,6)$ & $4(4,6)$ \\
\hline Cuidadores viviendo con el paciente & $121(75,6)$ & $53(71,6)$ & $68(79,1)$ \\
\hline \multicolumn{4}{|l|}{ Tipo de demencia } \\
\hline Alzhéimer & $112(70)$ & $53(71,6)$ & $59(68,6)$ \\
\hline Desconocido & $21(13,1)$ & $11(14,9)$ & $10(11,6)$ \\
\hline Demencia vascular & $11(6,9)$ & $3(4,1)$ & $8(9,3)$ \\
\hline Otros & $9(5,6)$ & $5(6,8)$ & $4(4,7)$ \\
\hline Demencia con cuerpos de Levy & $6(3,8)$ & $2(2,7)$ & $4(4,7)$ \\
\hline Alzhéimer con enfermedad vascular & $1(0,6)$ & $0(0)$ & $1(1,2)$ \\
\hline Tiempo en años desde el diagnóstico media (DE) & $5,4(3,2)$ & $5,2(3,5)$ & $5,5(2,9)$ \\
\hline
\end{tabular}

DE: desviación estándar

70\% tenía un diagnóstico de demencia, habiéndose diagnosticado desde hacía una media (DE) de $5(3,2)$ años, y el 39\% presentaba una dependencia parcial para las AVD (Tabla 1 y 2). Un 39\% de las personas con demencia tenía un deterioro cognitivo moderado, y el 23\% presentaba un deterioro cognitivo severo. Alrededor del $49 \%$ tenía alguna enfermedad, además de su diagnós tico de demencia. Más del $38 \%$ de los pacientes tenía dependencia parcial en las AVD (Tabla 2).

Con respecto al bienestar emocional, el 68\% de los cuidadores en el IG informó bienestar psicológico normal en la entrevista inicial, aunque el $32 \%$ tenía un nivel bajo (Tabla 3).

Después de la intervención se observó un efecto positivo sobre el bienestar emocional en las cuidadoras y cuidadores en el Gl (3,77 basal frente a 3,76 a los tres meses de seguimiento, $p=0,176$ ). Del mismo modo se observó una ligera mejora en el Gl en esta variable, en comparación con un ligero empeoramiento en el GC. Teniendo en cuenta los tres puntos temporales, la mejora en el bienestar emocional se mantuvo en el Gl incluso a los seis meses, aunque las diferencias no fueron estadísticamente significativas. Igualmente se observó que, a pesar de la intervención, hubo un ligero empeoramiento en la calidad de vida autopercibida (72,12 basal frente a 68,06 a los tres meses de seguimiento, $p=0,080$ ) entre los cuidadores en el Gl. Las tendencias de los indicadores de calidad de vida y bienestar emocional fueron negativas en el GC, lo que indica un ligero empeoramiento de la salud emocional de es tos cuidadores (Tabla 4).

En total se organizaron siete grupos de 10 figuras cuidadoras y dos grupos de ocho, quienes recibieron el programa INFOSA-DEM. EI $97 \%$ de las cuidadoras y cuidadores estuvo totalmente de acuerdo en que la información recibida fue de ayuda y más del $93 \%$ respondió que la duración de las sesiones fue adecuada. Tras completar las evaluaciones a los seis meses de seguimiento se organizaron tres grupos de más de 10 cuidadores/as que formaban parte del GC y se les impartió el programa.

\section{Discusión y conclusiones}

El objetivo del estudio fue evaluar el impacto del programa INFOSA-DEM en figuras cuidadoras de personas con demencia que viven en su domicilio en relación con el bienestar emocional, evaluando el tiempo de permanencia del efecto del programa a los tres y seis meses post-intervención. Dicho programa se planteó a partir de la psicoeducación, el entrenamiento de estrategias de comunicación e importancia y planificación de actividades para el autocuidado.

Ambos grupos fueron similares al inicio del estudio y las razones de abandono fueron parecidas a las registra- 
Tabla 2. Datos basales de la persona con demencia

\begin{tabular}{|c|c|c|c|}
\hline Variable & $\begin{array}{c}\text { Total }(n=160) \\
n(\%)\end{array}$ & $\begin{array}{c}\text { Control }(n=74) \\
n(\%)\end{array}$ & $\begin{array}{c}\text { Intervención }(n=86) \\
n(\%)\end{array}$ \\
\hline Gravedad de la enfermedad (MMSE) media (DE) & $17,3(6,6)$ & $16,6(7)$ & $18,1(6,1)$ \\
\hline Leve (27-28) & $52(38)$ & $24(35,3)$ & $28(40,6)$ \\
\hline Moderado (15-20) & $53(38,7)$ & $26(38,2)$ & $27(39,1)$ \\
\hline Moderadamente severo/severo (< 15) & $32(23,4)$ & $18(26,5)$ & $14(20,3)$ \\
\hline Dependencia para ADL (Katz Index) media (DE) & $3,9(2,1)$ & $3,5(2,1)$ & $4,1(2)$ \\
\hline Incapaz (0-2) & $45(29,8)$ & $26(38,2)$ & $19(22,9)$ \\
\hline Incapacidad parcial (3-5) & $58(38,4)$ & $23(33,8)$ & $35(42,2)$ \\
\hline Funcionalidad independiente (6) & $48(31,8)$ & $19(27,9)$ & $29(34,9)$ \\
\hline Comorbilidad (Charlson Index) media (DE) & $1,5(1,2)$ & $1,5(1,4)$ & $1,4(1,1)$ \\
\hline 0 & $28(17,5)$ & $18(24,3)$ & $10(11,6)$ \\
\hline 1 & $79(49,4)$ & $27(36,5)$ & $52(60,5)$ \\
\hline 2 & $23(14,4)$ & $14(18,9)$ & $9(10,5)$ \\
\hline Más de 2 & $30(18,8)$ & $15(20,3)$ & $15(17,4)$ \\
\hline Función cognitiva (GDS) & $2(1,2)$ & $0(0)$ & $2(2,3)$ \\
\hline Deterioro cognitivo muy leve & $34(21,2)$ & $13(17.6)$ & $21(24,4)$ \\
\hline Deterioro cognitivo leve & $69(43,1)$ & $31(41,9)$ & $38(44,2)$ \\
\hline Deterioro cognitivo moderado & $31(19,4)$ & $14(18,9)$ & $17(19,8)$ \\
\hline Deterioro cognitivo moderadamente severo & $16(10)$ & $10(13,5)$ & $6(7)$ \\
\hline Deterioro cognitivo severo & $8(5)$ & $6(8,1)$ & $2(2, \overline{3})$ \\
\hline Deterioro cognitivo muy severo & $2(1,2)$ & $0(0)$ & $2(2,3)$ \\
\hline \multicolumn{4}{|l|}{ Calidad de vida } \\
\hline EQ-5D media (DE) & $0,6(0,3)$ & $0,5(0,3)$ & $0,6(0,3)$ \\
\hline Auto-reporte (VAS) media (DE) & $67,3(20,1)$ & $61(21.7)$ & $72.6(17.1)$ \\
\hline QoL-AD media (DE) & $29,3(5,1)$ & $28,4(5)$ & $30(5,1)$ \\
\hline
\end{tabular}

DE: desviación estándar. MMSE: Test Mini-Mental. ADL: actividades de la vida diaria. GDS: escala de valoración del deterioro global. EQ-5D: escala de calidad de vida, versión de 5 ítems. VAS: escala visual analógica. QoL-AD: escala de valoración de calidad de vida en alzhéimer

Tabla 3. Datos basales de las figuras cuidadoras

\begin{tabular}{lccc} 
Variable & $\begin{array}{c}\text { Total } \mathbf{( n = 1 6 0 )} \\
\mathbf{n}(\%)\end{array}$ & $\begin{array}{c}\text { Control }(\mathbf{n = 7 4 )} \\
\mathbf{n}(\%)\end{array}$ & $\begin{array}{c}\text { Intervención }(\mathbf{n}=\mathbf{8 6}) \\
\mathbf{n}(\%)\end{array}$ \\
\hline Calidad de vida (EQ-5D) media (DE) & $0,7(0,2)$ & $0,7(0,1)$ & $0,7(0,2)$ \\
\hline Auto-reporte de la calidad de vida (VAS) media (DE) & $71,2(17,2)$ & $69,9(18,6)$ & $72,2(16)$ \\
\hline Bienestar emocional (GHQ-12) media (DE) & $3,6(3,3)$ & $3,3(3,3)$ & $3,8(3,4)$ \\
\hline Normal (0-4) & $105(67,7)$ & $49(71)$ & $56(65,1)$ \\
\hline Malo (5-12) & $50(32,3)$ & $20(29)$ & $30(34,9)$ \\
\hline
\end{tabular}

DE: desviación estándar. EQ-5D: escala de calidad de vida, versión de 5 ítems. VAS: escala visual analógica. GHQ-12: cuestionario general de salud versión de 12 ítems

Tabla 4. Estimación de los efectos del Programa INFOSA-DEM en las figuras cuidadoras a los tres y seis meses de seguimiento

\begin{tabular}{|c|c|c|c|c|c|c|c|c|}
\hline \multirow{2}{*}{ Variables } & \multicolumn{4}{|c|}{ Control (Atención habitual) } & \multicolumn{4}{|c|}{$\begin{array}{l}\text { Intervención (atención habitual + } \\
\text { Programa INFOSA-DEM) }\end{array}$} \\
\hline & $\begin{array}{c}\text { Inicial } \\
\text { media (DE) }\end{array}$ & $\begin{array}{c}3 \text { meses } \\
\text { media (DE) }\end{array}$ & $\begin{array}{l}6 \text { meses } \\
\text { media (DE) }\end{array}$ & $\begin{array}{l}\text { Valor } \\
\text { de } p^{\star}\end{array}$ & $\begin{array}{c}\text { Inicial } \\
\text { media (DE) }\end{array}$ & $\begin{array}{l}3 \text { meses } \\
\text { media (DE) }\end{array}$ & $\begin{array}{c}6 \text { meses } \\
\text { media (DE) }\end{array}$ & $\begin{array}{l}\text { Valor } \\
\text { de } p^{\star}\end{array}$ \\
\hline Bienestar emocional (GHQ-12) & $2.77(3,11)$ & $3,21(3,07)$ & $2,97(3,26)$ & 0,802 & $3,77(3,37)$ & $3,16(3,38)$ & $3,12(3,16)$ & 0,176 \\
\hline Normal $(0-4)^{* *}$ & $30(76,9)$ & $25(64,1)$ & $27(69,2)$ & & $40(70,2)$ & $39(68,4)$ & $40(70,2)$ & \\
\hline $\operatorname{Bajo}(5-12)^{* *}$ & $9(23,1)$ & $14(35,9)$ & $12(30,8)$ & & $17(29,8)$ & $18(31,6)$ & $17(29,8)$ & \\
\hline Calidad de vida (EQ-5D) & $0,74(0,13)$ & $0.73(0,1)$ & $0.71(0,14)$ & 0,333 & $0,66(0,16)$ & $0,68(0,13)$ & $0,69(0,12)$ & 0,347 \\
\hline Auto-reporte de calidad de vida (VAS) & $71,85(19,28)$ & $71,31(1,5,6) 1$ & $68,21(16,44)$ & 0,183 & $72,12(16,18)$ & $68,06(17,94)$ & $69,71(17,24)$ & 0,080 \\
\hline
\end{tabular}

DE: desviación estándar. GHQ-12: cuestionario general de salud versión de 12 items. *onckheere-Terpstrata prueba de tendencia monotónica. ${ }^{* *}$ frecuencia absoluta (n) y relativa (\%) 
das en intervenciones dirigidas a cuidadores, ya que en ocasiones la situación de vulnerabilidad de la persona con demencia, y el tener que desplazarse al centro donde se impartía el programa, dificultaba la continuidad y la asistencia completa a las sesiones (23-25). Las características observadas de las figuras cuidadoras fueron similares a las encontradas en otros estudios, en los que prevalece la figura de la mujer de mediana edad, esposa de la persona con demencia. La mayoría de las figuras cuidadoras convive con la persona con demencia, y el periodo en años de cuidado desde el diagnóstico de la enfermedad es similar (26,27).

En los resultados se puede observar que apenas se detectan cambios en el seguimiento a los tres y seis meses respecto a la medición basal de las figuras cuidadoras, en relación a la salud emocional y en la calidad de vida. No obstante, se considera beneficiosa la participación de las figuras cuidadoras en un programa psicoeducativo, sobre todo porque podría ayudar a desarrollar en el cuidador o la cuidadora ciertas habilidades para el manejo emocional y conductual de la persona con demencia, y de otras situaciones que puedan surgir en el domicilio como consecuencia de la enfermedad, reduciendo significativamente los niveles de sobrecarga, ansiedad y depresión en el cuidador (25). Algunos autores resaltan en que solo el $24 \%$ de los estudios evalúa la efectividad de las intervenciones educativas en los cuidadores en periodos no mayores de seis meses y quienes lo han evaluado han observado que los efectos durante ese periodo de seguimiento son poco significativos (23).

Las alteraciones en el bienestar emocional encontradas a nivel basal en ambos grupos posiblemente se relacionen con el número elevado de horas diarias dedicadas al cuidado de su familiar, ya que la mayoría cohabita con la persona con demencia, lo que supone un cuidado diario de 24 horas al día (26). No obstante, el efecto positivo en el bienestar emocional tras participar en un programa es poco significativo incluso a los tres meses, probablemente debido a factores externos a la figura cuidadora (problemas económicos familiares, estresores sociales) y los propios de la persona con demencia (grado de deterioro cognitivo, comorbilidades, etc.) $(25,28)$. Aunque no se pueda demostrar estadísticamente el efecto positivo en el bienestar emocional, algunos autores sugieren que si se aumenta la ayuda externa y la colaboración de otras personas para el cuidado del sujeto con demencia, la puesta en marcha de intervenciones, el acceso a servicios públicos y la pres- tación de asistencia técnica (23), lo más posible es que esos factores puedan influir en la mejora del bienestar emocional de los cuidadores y que este efecto positivo se podría mantener en el tiempo (6, 28-30).

Teniendo en cuenta los hallazgos resultaría interesante evaluar en las figuras cuidadoras el impacto de las intervenciones centradas en la psicoeducación, más allá de los seis meses, y también los posibles efectos indirectos en el receptor de cuidados. Por esta razón, el soporte profesional es fundamental, ya que las cuidadoras y cuidadores desempeñan un papel cada vez más importante en el proceso de atención, dada la tendencia actual hacia la atención de salud comunitaria y el mantenimiento de la persona con demencia en el domicilio (28).

Este estudio presenta algunas limitaciones. La más importante se debe a que no fue posible la aleatorización de la muestra, pues to que durante las visitas con su médico responsable una las principales peticiones de las figuras cuidadoras era la necesidad inmediata de recibir información y en las visitas iniciales en el domicilio se observó la necesidad de soporte profesional para mejorar el cuidado diario de la persona con demencia, por lo que fue necesario ir incluyendo a estos cuidadores en el Gl, para responder a sus demandas a través del Programa INFOSA-DEM. Por otra parte, no se realizó una clasificación de las personas con demencia por fase de la enfermedad y/o severidad del deterioro cognitivo, por lo que realmente se desconoce la influencia que pueda tener la gravedad de la demencia en la efectividad de la intervención y es una posibilidad que sean variables que modifiquen el efecto y su durabilidad en el tiempo. Así mismo, la edad y el nivel cultural del cuidador o de la cuidadora deberían tenerse en cuenta para evaluar la competencia, el aprendizaje y la capacidad de aprovechar la información recibida. Además, la falta de asistencia a algunas sesiones pudo haber sido un inconveniente para aquellos cuidadores que no contaban con ayuda extra en el domicilio (familiar o de pago), ya que en algunos casos el nivel de dependencia no permitió que la persona con demencia se quedara sola en el domicilio, aumentando el porcentaje de pérdidas durante el seguimiento.

En este tipo de intervenciones queda manifiesta la labor de los profesionales enfermeros a partir de su rol educativo, para aumentar la competencia de la figura cuidadora y dotarles de herramientas para el desarrollo de habilidades de afrontamiento en el cuidado domici- 
liario en las diferentes etapas del proceso de la enfermedad; y abre líneas de investigación orientadas hacia la detección temprana de alteraciones en el bienestar emocional y el mantenimiento y mejora de la salud mental de las cuidadoras y cuidadores de personas con demencia

En conclusión, este estudio aporta información que se suma a los resultados encontrados en intervenciones similares, que sugieren que programas dirigidos a figuras cuidadoras basados en terapias cognitivo-conductuales y en la psicoeducación podrían tener efectos protectores, ya que el desarrollo de ciertas habilidades y la utilización de estrategias de afrontamientos aprendidas a partir del soporte profesional, pueden mejorar la autoeficacia y el bienestar emocional, teniendo a su vez un efecto positivo en la calidad de vida del cuidador o cuidadora.

\section{Financiación}

Ninguna.

\section{Conflicto de intereses}

Ninguno

\section{Bibliografía}

1. González-de Paz L, Real J, Borrás-Santos A, Martínez-Sánchez JM, Rodrigo-Baños V. Navarro-Rubio MD. Associations between informal care, disease and risk factors: A Spanish country-wide population-based study. J Public Health Policy 2016;37(2):173-89. Doi: http://doi.org/10.1057/jphp.2016.3

2. World Health Organization. Global action plan on the public health response to dementia 2017-2025 [internet]. Geneva: WHO; 2019 may 14. [citado 8 abr 2020]. Disponible en: https://www.who.int/mental_ health/neurology/dementia/action_plan_2017_20 25/en/

3. Alzheimer Cataluña Fundació. Lo que no sabéis sobre las demencias y el alzhéimer. Alzheimercatalunya.org [internet] 2019 Jul 15. [citado 8 abr 2020]. Disponible en: https://alzheimercatalunya.org/es/demencias -y-alzheimer/

4. Farré M, Kostov B, Haro JM, Cabrera E, Risco E, Alvira $M$, et al. Costs and Burden Associated With Loss of Labor Productivity in Informal Caregivers of People with Dementia. J Occup Environ Med 2018; 60(5): 449-56. Doi: http://doi.org/10.1097/J0M.00000000 00001229

5. Chiao CY, Wu HS, Hsiao CY. Caregiver burden for informal caregivers of patients with dementia: A systematic review. Int Nurs Rev. 2015; 62(3):340-50. Doi: http://doi.org/10.1111/inr.12194

6. Alvira MC, Risco E, Cabrera E, Farré M, Ranm-Hallberg I, Bleijlevens MH, et al. RightTimePlaceCare Consor- tium. The association between positive-negative reactions of informal caregivers of people with dementia and health outcomes in eight European countries: a cross-sectional study. I Adv Nurs. 2015; 71(6):141734. Dol: htto://doi.org/10.1111/jan.12528

7. Barr C, Riolacci-Dhoyen N, Gabraith M, Leperre-Desplanques $A$, COVE GROUP. Sharing knowledge to advance healthcare policies in Europe for people living with dementia and their carers: the ALCOVE project. Arch Public Health, 2012; 70(1):21. Doi: http://doi.org/10.1 186/0778-7367-70-21

8. Bremer P, Cabrera E, Leino-Kilpi H, Lethin C, Saks K, Sutcliffe C, et al. RightTimePlaceCare Consortium. Informal dementia care: Consequences for caregivers health and health care use in 8 European countries Health Policy $2015119(11): 1459-71$. Doi: http://doi. org/10.1016/j.healthpol.2015.09.014

9. Dodel R, Belger M, Reed C, Wimo A, Jones RW, Happich $M$, et al. Determinants of societal costs Alzheimer's disease: CERAS study baseline results. Alzheimers Dement, 2015; 11 (8):933-45. Doi: http://doi.org/10 1016/j.jalz.2015.02.005

10. Farré M, Haro JM, Kostov B, Alvira C, Risco E, Miguel $S$, et al. Direct and indirect costs and resource use in dementia care: A cross-sectional study in patients living at home. Int I Nurs Stud 2016; 55:39-49. Doi: http://doi.org/10.1016/j.jinurstu.2015.10.012

11. Au A, Gallagher-Thompson D, Wong MK, Leung Chan WCh, Chan C, Lu HI, et al. Behavioral activation for dementia caregivers; scheduling pleasant events and enhancing comunications. Clin Interv Aging 2015; 10:61 1 -9. Doi: http://doi.org/10.2147/CIA.572348

12. Llanque SM, Enríquez M, Cheng AL, Doty L, Brotto MA, Kelly PJ, et al, The family series workshop: a community-based psychoeducational intervention. Am J Alzheimers Dis Other Demen 2015; 30(6):573-83. Doi: http://doi.org/10.1 177/1533317514568003

13. Conyea JG, López LM, Velásquez EH. The effectiveness of a culturally sensitive cognitive behavioral group intervention for Latino Alzheimer's Caregivers Gerontologist 2014; 56(2):292-302. Doi: http://doi. org/10.1093/geront/gnu045

14. Zubin J, Spring B. Vulnerability: a new view of schizophrenia. Abnorm Psychol. 1977; 86:103-26.

15. Afram B, Verbeek $H$, Bleijlevens MH, Hamers JP Needs of informal caregivers during transition from home towards institutional care in dementia: a systematic review of qualitative studies. Int Psychogeriatt 2015;27(6):891-902. Doi:http://doi.org/10.101 7/S1041610214002154

16. Frenkel WJ, Jongerius E], Uitert MJ, Munster BC, Rooij SE. Validation of the Charlson Comorbidity Index in Acutely Hospitalized Elderly Adults: A Prospective Cohort Study. I Am Geriatr Soc, 2014; 62(2):342-6. Doi: http://doi.org/10.1111/jgs.12635

17. Folstein M, Folstein S, McHughm P. "Mini-mental state". A practical method for grading the cognitive state of patients for the clinician. Journal of Psychiatric Research 1975; 12(3):189-98.

18. Reisberg B, Ferris S, de León M, Crook T. The Global Deterioration Scale for assessment of primary degenerative dementia. Am. J. Psychiatry 1982; $139(9)$ $1136-9$ 
19. Gómez-Gallego M, Gómez-Amor J, Gómez-García J. Validation of the Spanish version of the QoL-AD scale in Alzheimer's disease patients, their carers, and health professionals. Neurología 2012; 27(1):410. Doi: http://doi.org/10.1016/j.nrl.2017.03.006.

20. Romppel M, Braehler $E$, Roth M, Glaesmer $H$. What is the General Health Questionnaire-12 assessing? Dimensionality and psychometric properties of the General Health Questionnaire-12 in a large scale German population sample. Compr Psychiatry 2013 ; 54(4):406-13. Doi: http://doi.org/10.1016/j.comp psych.2012.10.010

21. Rocha KB, Pérez K, Rodríguez-Sanz M, Borrel C, Obiols JE. Propiedades psicométricas y valores normativos del General Health Questionnaire (GHQ-12) en población general española. Int J Clin Health Psychol 201 1: 1 1 (1):125-39.

22. EuroQol Group. EuroQol-a new facility for the measurement of health-related quality of life. Health Policy 1990; 16(3): 199-208.

23. Chang S, Zhang Y, Jeyagurunathan A, Lau YW, Sagayadevan $V$, Chong SA, et al. Providing care to relatives with mental illness: reactions and distress among primary informal caregivers. BMC Psychiatry 2016; 16,80. Doi: http://doi.org/10.1 186/s12888-016-07 $86-9$

24. Prick AE, de Lange J, Twisk J, Pot AM. The effects of a multi-component dyadic intervention on the psychological distress of family caregivers providing care to people with dementia: a randomized controlled trial. Int Psychogeriatr 2015:27(12):2031 -44. Doi: http:// doi.org/10.1017/5104161021500071X

25. Moreno-Cámara S, Palomino-Moral PA, Moral-Fernández L, Frías-Osuna A, Parra-Anguita L, Del-Pino-Casado R. Perceived Needs of The Family Caregivers of People with Dementia in a Mediterranean Setting: A Qualitative Study. Int I Environ Res Public Health
2019; 16(6). Doi: http://doi.org/10.3390/ijerph1606 0993

26. Tang SH, Chio Ol, Chang LH, Mao HF, Chen LH, Yip PK, et al. Caregiver active participation in psychoeducational intervention improved caregiving skills and competency. Geriatr Gerontol Int 2018; 18(5):750-7. Doi: http://doi.org/10.1111/ggi.13246

27. Gonyea JG, O'Connor MK, Boyle PA. Project CARE: A Randomized Controlled Trial of a Behavioral Intervention Group for Alzheimers Disease Caregivers. The Gerontologist 2006; 46(6):827-32. Doi http://doi.org/10.1093/geront/46.6.827

28. Frías CE, García-Pascual M, Montoro M, Ribas N, Risco E, Zabalegui A. Effectiveness of a psychoeducational intervention for caregivers of People with Dementia with regard to burden, anxiety and depression A systematic review. Adv Nurs 2020; 76(3):787-802

29. Hatch DJ, DeHart WB, Norton MC. Subjective stressors moderate effectiveness of a multi-component multi-site intervention on caregiver depression and burden. Int. J. Geriatr. Psychiatr 2014; 29:406-13 Dol: http://doi.org/10.1002/gps.4019

30. Del Pino-Casado R, Millán-Cobo MD, Palomino-Moral PA, Frías-Osuna A. Cultural Correlates of Burden in Primary Caregivers of Older Relatives: A Cross-sectional Study. J Nurs Scholarsh 2014; 46(3):176-86 Doi: http://doi.org/10.1111/jnu.12070

\begin{tabular}{l}
\hline Si quieres ampliar más información sobre este ar tículo, consulta: \\
$\begin{array}{l}\text { Introduce estos } \\
\text { términos: }\end{array} \quad$ Cuidadores; demencia; bienestar emocio- \\
encuentr@ nal; Enfermería. \\
\hline
\end{tabular}

\section{Contacta con los autores en:} azabaleg@clinic.cat 



\section{Publicaciones Científicas}

\subsection{Artículo 5}

The INFOSA-DEM programme.

An intervention for caregivers.

Cindy E. Frías, Ester Risco, Adelaida Zabalegui

Enviado a Psychogeriatrics

IF: 1.75. Q2 



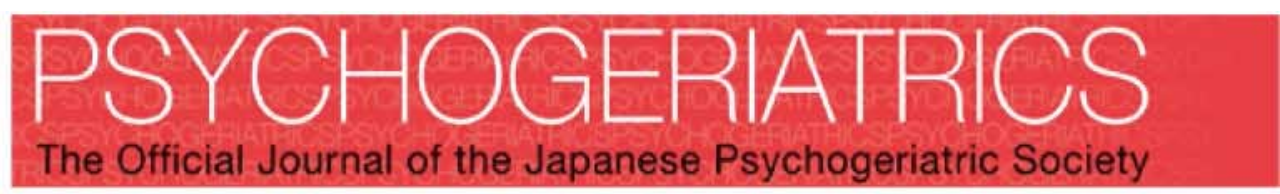

\section{The INFOSA-DEM programme. An intervention for caregivers}

\begin{tabular}{|c|c|}
\hline Journal: & Psychogeriatrics \\
\hline Manuscript ID & Draft \\
\hline Wiley - Manuscript type: & Original Article \\
\hline $\begin{array}{r}\text { Date Submitted by the } \\
\text { Author: }\end{array}$ & n/a \\
\hline Complete List of Authors: & $\begin{array}{l}\text { Frias, Cindy E.; Hospital Clinic de Barcelona, } \\
\text { Risco, Ester; Hospital Clinic de Barcelona } \\
\text { Zabalegui, Adelaida; Hospital Clinic de Barcelona }\end{array}$ \\
\hline Keywords: & Dementia, caregivers, home care, intervention, social support, nurse \\
\hline Abstract: & $\begin{array}{l}\text { Background: Dementia is a factor in institutionalisation in itself. Policy in } \\
\text { Europe prioritises investment in resources that ensure that the person } \\
\text { with dementia is maintained, at home, thus delaying or avoiding } \\
\text { institutionalisation of the person. This implies that Home Care is } \\
\text { provided, informally, and voluntarily, over months or years by a family } \\
\text { member. The objective was to describe the development and } \\
\text { implementation of a structured, intervention addressed to caregivers of } \\
\text { people with dementia cared for at home. } \\
\text { Methods: A multicenter, descriptive study of the development and } \\
\text { implementation of an intervention in caregivers of people with dementia } \\
\text { living at home. The presentation followed the Consolidated Standards of } \\
\text { Reporting Trials (CONSORT) statement guidelines. } \\
\text { Results: A psychoeducational intervention was structured, developed, } \\
\text { and implemented following clinical guidelines, caregiver needs, and } \\
\text { psychoeducational theories, which consist of a multicomponent training, } \\
\text { information, and emotional support programme of five, } 90 \text {-minute } \\
\text { sessions over one week. } \\
\text { Conclusions: The development of this intervention support other studies } \\
\text { and contribute scientific evidence on the importance of promoting non- } \\
\text { pharmacologic-interventions in caregivers, and they can be used as the } \\
\text { basis for the implementation of interventions in-home care and in long } \\
\text { term care institutions; responding to training and information needs, and } \\
\text { providing the social-support that the caregivers themselves demand. }\end{array}$ \\
\hline
\end{tabular}




\section{TITLE PAGE}

Title: The INFOSA-DEM programme. An intervention for caregivers

Short running title: Psychoeducational Intervention

\section{Author descriptions:}

Cindy E. Frias ${ }^{\text {a }}$, Ester Risco ${ }^{b}$, Adelaida Zabalegui ${ }^{{ }^{*}}$.

\section{Affiliations:}

a. Cindy E. Frias. RN, MsC. Mental Health Nurse.

Hospital Clinic of Barcelona. Villarroel Street, 170. 08036. cfrias@clinic.cat. https://orcid.org/0000-0001-6927-573X. Telephone Number: (+34) 93. 227.5400, ext: 380827.Twitter:@cindyft1. Linkedin: https://www.linkedin.com/in/cindyfriastorres/.

b. Ester Risco. RN, PhD. Nurse Consultant Research of the Nursing Director.

Hospital Pere and Virgili of Barcelona. Esteve Terrades Street, 30. 08023. erisco@clinic.cat . https://orcid.org/0000-0002-8174-8592. Telephone Number: (+34) 9325940 00. Twitter:@ester_risco

c. Adelaida Zabalegui. RN, PhD, FEANS. Deputy Director of Research

Hospital Clinic of Barcelona. Villarroel Street, 170. 08036. azabaleg(a)clinic.cat. https://orcid.org/0000-0003-1205-3997. Telephone Number: (+34) 93. 227.5400. Twitter: @AdelaidaZabale1

\section{Corresponding author:}

Adelaida Zabalegui. Hospital Clinic of Barcelona. Villarroel Street, 170. 08036. $(+34)$ 93.227.5400. azabaleg@clinic.cat 
The corresponding author has had full access to all study data and was ultimately responsible for the decision of submit for publication.

\begin{abstract}
Background: Dementia is a factor in institutionalisation in itself. Policy in Europe prioritises investment in resources that ensure that the person with dementia is maintained, at home, thus delaying or avoiding institutionalisation of the person. This implies that Home Care is provided, informally and voluntarily, over months or years by a family member. The objective was to describe the development and implementation of a structured, intervention addressed to caregivers of people with dementia cared for at home.
\end{abstract}

Methods: A multicenter, descriptive study of the development and implementation of a intervention in caregivers of people with dementia living at home. The presentation followed the Consolidated Standards of Reporting Trials (CONSORT) statement guidelines.

Results: A psychoeducational intervention was structured, developed and implemented following clinical guidelines, caregiver needs and psychoeducational theories, which consists of a multicomponent training, information and emotional support programme of five, 90 minute sessions over one week.

Conclusions: The development of this intervention support other studies and contribute scientific evidence on the importance of promoting non-pharmacologic-interventions in caregivers, and they can be used as the basis for the implementation of interventions in home care and in long term care institutions; responding to training and information needs, and providing the social-support that the caregivers themselves demand.

Key words: Dementia, caregivers, home care, intervention, social support, nurse 


\section{INTRODUCTION}

Dementia is characterised by progressive loss of a person's cognitive and functional capacities. It mostly affects people of advanced age, leading to physical illnesses which, together with the symptomology of dementia, generate disability and dependency. ${ }^{1}$ Dementia is a factor in institutionalisation in itself. As such, policy in Europe prioritises investment in resources that ensure that the person with dementia is maintained, as far as possible, at home, thus delaying or avoiding institutionalisation of the person. ${ }^{2}$ This implies that Home Care (HC) is provided, informally and voluntarily, over months or years by a family member, which leads to alterations in familial and social arrangements as well as changes in the physical and mental health of the caregiver. ${ }^{1,3}$ For this reason, recent studies indicate that informal caregivers (IC) of people with dementia (PwD) have a higher risk of suffering stress, burden, sleep problems, depression, anxiety, reduction in quality of life $(\mathrm{QoL})$ and other complications with respect to the rest of the population as time dedicated and care burden are greater in $\mathrm{HC}_{,}^{4,5,6}$ especially when dealing with a PwD with behavioural and neuropsychiatric symptoms. ${ }^{5}$

In Spain, families invest an average of 60 to 75 hours per week in caregiving and assume $88 \%$ of the total care costs (approximately 1,244 euros/month) ${ }^{6}$ as there are fewer socio-economic resources for this type of care. $\mathrm{HC}$ is performed without an adequate family-support network which leads to increased caregiver burden, isolation and poorer QoL. 6, 7, 8, 9 According to data from the European RightTimePlaceCare (RTPC) study, ${ }^{10}$ Spain is one of the countries in the European Union with high levels of negative effects, not only on the health of the caregiver but also in terms of financial hardship, employment difficulties and even loss of social relationships. ${ }^{3}$

Most caregivers express a need to receive some type of help or specific training that assist them in $\mathrm{HC}^{8}$ Therefore, development of resources that support the caregiver are 
essential. With the aim of meeting this need, interventions have been designed to improve the health of caregivers and help them to enhance their QoL and the care they provide. As such, the effectiveness of these interventions and their impact on the caregivers' health needs to be explored in greater depth. ${ }^{4}$ Some authors underline and support the effectiveness of educational interventions in IC of $\mathrm{PwD}$ with respect to variables including depression and QoL. Zabalegui et al., in their review, state that the development of this type of educational intervention has a positive effect on the IC regarding burden, depression, feelings of loneliness and management of PwD symptomatology. ${ }^{10}$ In addition, similar studies suggest that there is a probability of a significant decrease in depressive symptomatology in IC after receiving a six-month educational programme ${ }^{5}$ and they identify the most commonly-used resources as counselling, education and psychoeducation or respite centres and psychotherapeutic support. ${ }^{11,12}$ For this reason, they highlight programmes whose results have shown them to be effective in other study populations with common characteristics, such as the INFOSA psychoeducational intervention addressed to caregivers of dependent people which has demonstrated a positive, durable impact on health, anxiety, depression, and QoL in those caregivers who participated in the programme. ${ }^{13}$ It should be noted that this intervention, has not been performed in ICs of PwD and it is vital to create, structured, validated, innovative programmes that can meet the specific, current needs of IC of PwD cared for at home. ${ }^{11,15}$ This study was thus conceived to respond to these needs and provide IC with the appropriate skills to carry out $\mathrm{HC}$ of PwD with the objective of describe the development and implementation of a structured, psychoeducational intervention addressed to informal caregivers of people with dementia cared for at home called INFOSA-DEM. The programme combines face-toface training with audio-visual material as a useful active-learning method. 


\section{MATERIAL AND METHODS}

\section{Study Design}

A multicenter, descriptive study of the development and implementation of a psychoeducational intervention in caregivers of people with dementia living at home. The presentation followed the Consolidated Standards of Reporting Trials (CONSORT) statement guidelines.

\section{Setting and Participants}

This study was conducted in a metropolitan area of Barcelona - Spain. Health professionals participated for the development of the intervention from three primary care centres that compose the Barcelona Primary Health Care Consortium and three Day Hospitals specialising in the care of people with cognitive impairment; the Reina Amalia Day Hospital for Neurodegenerative Diseases, the Mollet Day Hospital for Psychogeriatrics and the Benito Menni Hospital in Sant Boi de Llobregat. Some caregivers from the three day hospitals participated in the feasibility pilot study

\section{Ethical considerations}

All caregivers who participated for pilot study signed the voluntary informed consent form, and the Ethics Committee approval of institutions participants was obtained (HCB/2014/0317). This study complies with the Declaration of Helsinki. The aim of the study was explained to the participants verbally and in writing. To minimise the risk of stress, it was made clear to participants that their participation, or otherwise, would not affect the care provided by professionals in the various health care centres and that they can drop out of the study at any time if they so decide. 


\section{RESULTS}

\section{Intervention development}

The INFOSA-DEM intervention was developed taking the information needs of IC of PwD in our context into account along with the impact that $\mathrm{HC}$ has on the caregiver. This was based on evidence from results obtained in IC of PwD cared for at home in the European study funded by the European Commission for Research (2421153) RightTimePlaceCare-(RTPC), ${ }^{10}$ using information collected from the IC of PwD focus groups in field work ${ }^{15}$ and from the Balance of Care model. ${ }^{16}$ The intervention is also based on methodology used in the development of the INFOSA psychoeducational programme financed by the Carlos III Health Institute of Spain (PI09/00111), addressed to caregivers of dependent people due to its positive effects in terms of burden, emotional support and health status. ${ }^{13}$ The programme was developed by nurses with expertise in the subject following recommendations described in the literature and the experiences of caregivers. Prior to the design phase, a list of available public and private community resources was prepared for IC. Subsequently, validation of design, content and reliability of the intervention and the informational material to be presented in the sessions (practical guide and four videos for caregivers of PwD) was conducted by a multidisciplinary group of experts composed of nurses, geriatricians, neurologists, social workers and IC, through consensus reached in work meetings. The INFLESZ instrument was also used to assess semantic clarity of the guide from the users' perspective. ${ }^{17}$ This intervention was designed to be performed by nurses with expertise in the care of older patients with cognitive disorders or dementias and by social workers and is addressed especially to IC of PwD who carry out their role in the home setting role. It is expected that the use of INFOSA-DEM will offer more effective treatment to this population, providing information, education and caregivers support based on 
scientific evidence, the values and preferences of the PwD and IC, and professional competencies. The intervention includes group work to encourage support among caregivers and is tailored to the specific needs of each PwD and his or her caregiver.

The INFOSA-DEM programme was created to be offered in five, 90-minute informational/training sessions delivered consecutively over one week. Programme content was developed for use in small groups of 6-8 caregivers. Topics covered in the sessions include basic concepts in dementia and specific issues such as nutrition, rest, medication, physical and cognitive changes, management of behavioural symptoms, affective problems in the patient and IC, verbal and non-verbal communication techniques, caregiver self-care and information on available resources and community services (Table 1).

The sessions were conducted using audio-visual material to facilitate understanding of the content and to encourage active participation among caregivers when talking about their experiences. This consists of four explanatory videos https://www.youtube.com/watch?v=KNDo6l-LOtw\&t=13s created for this programme under the slogan "Living with dementia" that deal with issues such as communication, disorientation, wandering, and the importance of self-care, accompanied by a guide to programme content. Caregiver training was led by a nurse together with a social worker involved in the development of the session on available resources and community services. With the aim of standardising the educational process, the professionals responsible for training was always the same and they were clinical experience in the care of PwD and advanced training in mental health or a master's degree. 


\section{Feasibility pilot study}

A pilot study was conducted in six informal caregivers of PwD. This test allowed validation on the part of the IC and an opportunity for training for the social worker and the two expert nurses qualified in treatment approaches to patients with cognitive impairment who was responsible for implementing the training sessions. For the final evaluation of the pilot study, a survey was created containing 18 questions on programme content, session dynamics and amount of information provided. Feedback from the participants was positive with respect to content and structure. Based on the pilot study, the number of sessions was reduced from eight to five. This change resulted from IC citing a lack of time to carry out the activity due to the high demands of caring for the PwD. Similarly, other changes were made, including lengthening the sessions with the aim of increasing caregiver participation time and adding a synthesis of concepts.

\section{Implementation of the intervention}

Prior to implementation of the programme, existing $\mathrm{HC}$ situations specifically associated with PwD and their IC were identified based on the results of the RTPC and the Balance of Care Model. ${ }^{16}$ Separately, geographical areas of interest were identified and the research team organised information/training sessions for health personnel in each of the centres that agreed to take part in the project, with information provided on the structure of the study, inclusion criteria, recruitment guidelines and research-team contact details. Depending on the centre involved, selection of potential candidates was carried out by the geriatricians, neurologist and/or nursing coordinator while dissemination of the programme was performed by health professionals though individual interviews during the consultation and/or telephone contact. 
To reach as many people as possible in the population, posters, slides and factsheets were designed containing programme information and contact details for participating centres. In addition, the public state and local broadcaster, promoted the project in a single transmission http://www.rtve.es/alacarta/videos/tips/tips-vida-sana-acordarse$\underline{\text { memoria/3863705/ }}$ and https://www.youtube.com/watch? $v=$ eZPiuNAFdU. Once potential candidates were identified, the research team carried out telephone interviews to gather more information for the study and select those caregivers that met inclusion criteria. Subsequently, a home visit was arranged to sign the informed consent form and carry out the initial assessment. The first patient was selected in January 2018 and recruitment concluded in September 2019.

\section{Measures}

Efficacy of the INFOSA-DEM intervention could be evaluated through valid, reliable instruments in the study context, addressed to IC and PwD (Table 2.)

\subsection{Measures for Caregivers}

Preparation for care through the Preparedness for Caregiving Scale (PCS) $)^{18,19}$ and The Perceived Competence Scale for Care ${ }^{19}, 20$ level of burden using the Zarit Burden Scale, ${ }^{21}$ degree of independence in activities of daily living through the Katz Index of Independence in Activities of Daily Living, ${ }^{22,}{ }^{24}$ positive and negative aspects of care with the Caregiver Reaction Assessment (CRA); ${ }^{25}$ perceived social support using the Perceived Social Support Questionnaire (Duke-UNK ), ${ }^{26,27}$ QoL through the Quality of Life Scale (EQ-5D);28 general health with the General Health Questionnaire (GHQ-

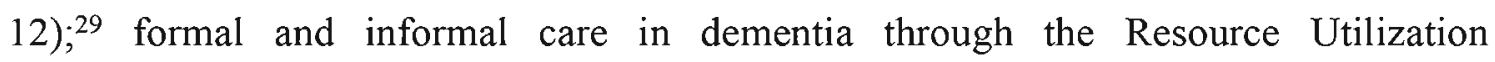
Questionnaire for dementia (RUD); ${ }^{30}$ and presence of behavioural changes using the Neuropsychiatric Inventory (NPI). ${ }^{31}$ 


\section{Measures for PwD}

Assessment of PwD was carried out through Quality of Life in Alzheimer's Disease (QoL-AD), ${ }^{32}$ sociodemographic data using a self-report questionnaire; presence of comorbidities with the Charlson Comorbidity Index $(\mathrm{CCI})^{33}$ and degree of cognitive impairment using the Mini-Mental State Examination (MMSE) (M) $^{34}$ and the Global Deterioration Scale (GDS). ${ }^{35}$

\section{Data collection time-point}

Data collection took place in the initial assessment (before the intervention) and at three and six months following the intervention. Furthermore, during the follow-up period, at least two phone calls was made to answer possible caregivers' questions.

\section{Cost-benefit}

This intends to be the basis of a cost-effective non-pharmacological multidisciplinary intervention. New trends need to be implemented and new technologies and activities need to be established in our daily health care practice. Moreover, better support for IC will enhance PwD and IC QoL and quality of care. Resource efficiency is also expected, especially in countries where health care resources are restricted. ${ }^{36} \mathrm{~A}$ decrease in use of emergency services and unnecessary medical visits can even be observed, postponing or reducing PwD institutionalisation. Thus, the cost of healthcare is reduced.

\section{DISCUSSION}

The INFOSA-DEM programme aims to inform, educate and provide social support to IC of PwD to improve the quality of $\mathrm{HC}$ and their QoL. The programme's educational aspect is a key element in empowerment of caregivers as it increases knowledge of the illness and the available resources, along with offering solutions to the problems associated with providing care to PwD. ${ }^{37}$ Similarly, the programme allows caregivers to 
talk about their experiences and meet other people in the same situation so that they can express their feelings and empathise with other group members through reciprocal support. As the caregivers group members have common needs, it is anticipated that they will develop informal mutual support networks. ${ }^{38}$

Care of PwD and their IC should be based on a holistic care model which permits multidisciplinary cooperation among professionals to ensure early detection or prevention of changes in the health of the caregivers ${ }^{39}$ as $\mathrm{HC}$ may lead to the appearance of adverse effects on the IC's mental and physical health. ${ }^{1} 4$ The development and implementation of non-pharmacologic interventions that provide support for caregivers and health professionals alike are of paramount importance. ${ }^{40}$ Some authors conclude that the impact of educational interventions on variables including burden or depression are insignificant, although this may be due to other IC stress factors such as their financial situation, health status and social and work relationships. ${ }^{11}$ Nevertheless, reviews of the literature describe positive results with respect to reduction in anxiety, depression and burden immediately after and up to 6 months post-intervention. ${ }^{6,40,41}$ The active participation of caregivers, provision of skills training during the programme and repeated reinforcement at home are essential for the efficacy of these multicomponent interventions. ${ }^{42}$

Therefore, it can be concluded that it is important to develop and implement interventions addressed to IC of PwD in primary care centres, day centres or day hospitals where PwD are treated. Assessment of the impact of the intervention through instruments or valid, reliable scales is fundamental in determining real efficacy and which factors influence the durability of the effects over time. ${ }^{43}$ The intervention developed support other studies and contribute scientific evidence on the importance of promoting non-pharmacological interventions for caregivers to prevent burden and 
emotional alterations of the IC. $6,11,44$ This often improves the QoL and quality of care provided. The programme can also serve as the basis for psychoeducational interventions in the home setting by centres responsible for monitoring PwD by responding to the need for training, information and the social support that the caregivers themselves demand. This will empower the caregiver at home to apply the recommendations according to identified needs.

\section{ACKNOWLEDGMENTS}

The authors would like to thank the Marató TV3 Foundation for financial support and we thank Stephen Kelly for participated in writing of the manuscript and all the caregivers who participated in the study. We would to give special thanks to all the health professionals who participated in the development and implementation of the intervention

\section{AUTHORSHIP STATMENT}

All authors meet the authorship criteria and are in agreement with the final version and submission of this manuscript and confirm that it has not been previously published.

\section{Disclosure Statement}

The authors declare they have no conflict of interest. 


\section{REFERENCES}

1. Boyacioğlu N, Kutlu Y. 2017. The Effectiveness of Psychoeducational Interventions in Reducing the Care Burden of Family Members Caring for the Elderly in Turkey: A Randomized Controlled Study: Arch Psychiatr Nurs, 31:183-189.

2. Saks K, Tiit E, Verbeek H, et al. 2015. Most appropriate placement for people with dementia: individual experts' vs. expert groups' decisions in eight European countries: J Adv Nurs, 71:1363-1377.

3. Müller C, Lautenschläger S, Meyer G, Stephan A. 2017. Interventions to support people with dementia and their caregivers during the transition from home care to nursing home care: A systematic review: Int J Nurs Stud, 71:139-152.

4. Koyama A, Matsushita M, Hashimoto M, et al. 2016. Mental health among younger and older caregivers of dementia patients: Psychogeriatrics, 17:108-114.

5. Kuo L, Huang H, Liang J, Kwok Y, Hsu W, Su P, Shyu Y. 2017. A randomized controlled trial of a home-based training programme to decrease depression in family caregivers of persons with dementia: J Adv Nurs, 73:585-598.

6. Frias CE, Risco E, Zabalegui A. 2020. Psychoeducational intervention on burden and emotional well-being addressed to informal caregivers of people with dementia: Psychogeriatrics.

7. Chiao CY, Wu HS, Hsiao CY. 2015. Caregiver burden for informal caregivers of patients with dementia: A systematic review: Int Nurs Rev, 62: 340-50.

8. Afram B, Stephan A, Verbeek H, et al. 2014. Reasons for Institutionalization of People With Dementia: Informal Caregiver Reports From 8 European Countries: J Am Med Dir Assoc, 15:108-16.

9. Risco E, Cabrera E, Jolley D, et al. 2015. The association between physical dependency and the presence of neuropsychiatric symptoms, with the admission of 
people with dementia to a long-term care institution: A prospective observational cohort study: Int J Nurs Stud, 52:980-7.

10. Verbeek H, Meyer G, Leino-Kilpi H, et al. 2012. A European study investigating patterns of transition from home care towards institutional dementia care: the protocol of a RightTimePlaceCare study: BMC Public Health, 12:68.

11. Zabalegui A, Hamers J, Karlsson S, et al. 2014. Best practices interventions to improve quality of care of people with dementia living at home. Patient Educ Couns, 95:175-84.

12. Frías CE, García-Pascual M, Montoro M, Ribas N, Risco E, Zabalegui A. 2020. Effectiveness of psychoeducational intervention for caregivers of people with dementia with regard to burden, anxiety and depression: a systematic review: J Adv Nurs, 76: 787-802.

13. Zabalegui A, Galisteo M, Navarro M, Cabrera E. 2016. INFOSA intervention for caregivers of the elderly, an experimental study: Geriatr Nurs, 37:426-433.

14. Stephan A, Afram B, Koskenniemi J, et al. 2015. Older persons with dementia at risk for institutionalization in eight European countries: a cross-sectional study on the perceptions of informal caregivers and healthcare professionals: J Adv Nurs, 71:1392-404.

15. Risco E, Cabrera E, Farré M, Alvira C, Miguel S, Zabalegui A. 2016. Perspectives About Health Care Provision in Dementia Care in Spain: Am J Alzheimers Dis Other Demen, 31:223-30.

16. Risco E, Zabalegui A, Miguel S, Farré M, Alvira C, Cabrera E. 2017. [Application of the Balance of Care model in decision-making regarding the best care for patients with dementia]: Gac Sanit, 31:518-523.

17. Barrio-Cantalejo IM, Simón-Lorda $P$, Melguizo $M$, Escalona I, Marijuán $M$, 
Hernando P. 2008 . [Validation of the INFLESZ scale to evaluate readability of texts aimed at the patient]: An Sist Sanit Navar, 31:135-52.

18. Archbold P, Stewart B, Greenlick M, Harvath T. 1990. Mutuality and preparedness as predictors of caregiver role strain: Res Nurs Health, 3:375-384.

19. Márquez IF, Grau J, Infante OE, Lacaba Y, Oliva I. 2015. Primary Validation Scales for the Training of Care Givers of Oncological-Geriatric Patients of Boyeros Municipality: Revista del Hospital Psiquiátrico de La Habana, 12.

20. Pearlin L, Mullan J, Semple S, Skaff M. 1990. Caregiving and the stress process: An overview of concepts and their measures: Gerontologist, 30:583-94.

21. Martín-Carrasco M, Salvadó I, Nadal S, Miji L, Rico J, Lanz P, Taussig M. 1996. Adaptación para nuestro medio de la Escala de Sobrecarga del Cuidador (Caregiver Burden Interview) de Zarit: Rev Gerontol, 6:338-346.

22. Alvarez M, de Alaiz AT, Brun E, et al. 1992. [Functional capacity of patients over 65 according to the Katz index. Reliability of the method]: Aten Primaria, 10:812-6.

23. Katz S, Downs TD, Cash HR, Grotz RC. 1970. Progress in Development of the Index of ADL: Gerontologist, 10:20-30.

24. Katz S, Forb A, Moskowitz R, Jaffe M. 1963. Studies of illness in the aged. The index of adl: a standardized measure of biological and psychosocial function: JAMA, 185:914-9.

25. Given CW, Given B, Stommel M, Collins C, King S, Franklin S. 1992. The caregiver reaction assessment (CRA) for caregivers to persons with chronic physical and mental impairments: Res Nurs Health, 15:271-83.

26. Broadhead WE, Gehlbach SH, De Gruy FV, Kaplan BH. 1988. The Duke-UNC Functional Social Support Questionnaire. Measurement of social support in family medicine patients: Med Care, 26:709-23. 
27. de la Revilla Ahumada L, Bailón E, de Dios Luna J, Delgado A, Prados MA, Fleitas L. 1991 . [Validation of a functional social support scale for use in the family doctor's office]: Aten Primaria, 8:688-92.

28. The EuroQol Group. 1990. EuroQol - a new facility for the measurement of healthrelated quality of life: Health Policy, 16:199-208.

29. Goldberg DP, Williams Paul. A user's guide to the General Health Questionnaire. NFER-Nelson, Windsor, Berks, 1988

30. Wimo A, Gustavsson A, Jönsson L, Winblad B, Hsu M, Gannon B. 2013. Application of Resource Utilization in Dementia (RUD) instrument in a global setting: Alzheimers Dement, 9:429-435.e17.

31. Vilalta-Franch $\mathrm{J}$, Lozano-Gallego $\mathrm{M}$, Hernández-Ferrándiz $\mathrm{M}$, Llinàs-Reglà $\mathrm{J}$, López-Pousa S, López O. 1999. [The Neuropsychiatric Inventory. Psychometric properties of its adaptation into Spanish]: Rev Neurol, 29:15-9.

32. Gómez-Gallego M, Gómez-Amor J, Gómez-García J. 2012.Validation of the Spanish version of the QoL-AD scale in Alzheimer's disease patients, their carers, and health professionals: Neurologia, 27:4-10.

33. Frenkel WJ, Jongerius EJ, Uitert MJ, Munster BC, Rooij SE. 2014. Validation of the Charlson Comorbidity Index in Acutely Hospitalized Elderly Adults: A Prospective Cohort Study: J Am Geriatr Soc, 62:342-6.

34. Folstein M, Folstein S, McHugh P. 1975. "Mini-mental state". A practical method for grading the cognitive state of patients for the clinician: J Psychiatr Res, 12:18998.

35. Reisberg B, Ferris S, De Leon M, Crook T. 1982. The Global Deterioration Scale for assessment of primary degenerative dementia: Am J Psychiatry, 139:1136-9.

36. Zabalegui A, Cabrera E. 2010. Economic crisis and nursing in Spain: J Nurs Manag, 
18:505-508.

37. Martín-Carrasco M, Domínguez-Panchón AI, González-Fraile E, Muñoz-Hermoso P, Ballesteros J. 2014. Effectiveness of a Psychoeducational Intervention Group Program in the Reduction of the Burden Experienced by Caregivers of Patients With Dementia: Alzheimer Dis Assoc Disord, 28:79-87.

38. Lavoie J, Ducharme F, Lévesque L, et al. 2005. Understanding the outcomes of a psycho-educational group intervention for caregivers of persons with dementia living at home: A process evaluation: Aging Ment Health, 9:25-34.

39. Bunn F, Burn A, Robinson L, et al. 2017. Healthcare organisation and delivery for people with dementia and comorbidity: a qualitative study exploring the views of patients, carers and professionals: BMJ Open, 7:e013067.

40. Rigaud A, Pino M, Wu Y, et al. 2011. [Support for patients with Alzheimer's disease and their caregivers by gerontechnology]: Geriatr Psychol Neuropsychiatr Vieil, 9:91-100.

41. Gonyea JG, Oconnor MK, Boyle PA. 2006. Project CARE: A Randomized Controlled Trial of a Behavioral Intervention Group for Alzheimers Disease Caregivers: Gerontologist, 46(6):827-32.

42. Selwood A, Johnston K, Katona C, Lyketsos C, Livingston G. 2007. Systematic review of the effect of psychological interventions on family caregivers of people with dementia: J Affect Disord, 101:75-89.

43. Farré M, Haro JM, Kostov B, et al. 2016. Direct and indirect costs and resource use in dementia care: A cross-sectional study in patients living at home: Int J Nurs Stud, 55:39-49. 


\section{TABLES}

Table 1. INFOSA-DEM Programme. Catalonia, Spain

\begin{tabular}{|c|c|c|c|c|}
\hline Session & Session Goal & Content & Video title & Professional \\
\hline 1 & $\begin{array}{l}\text { Introduction to the } \\
\text { program. Knowledge } \\
\text { about the disease }\end{array}$ & $\begin{array}{c}\text { Information on dementia. Support and care } \\
\text { experience }\end{array}$ & Ambulation & Nurse \\
\hline 2 & $\begin{array}{l}\text { Communication } \\
\text { strategies }\end{array}$ & $\begin{array}{l}\text { Verbal and non-verbal communication. } \\
\text { Experiences of pleasant moments with the } \\
\qquad \text { PwD }^{*}\end{array}$ & Communication. & Nurse \\
\hline 3 & $\begin{array}{l}\text { Neuropsychiatric } \\
\text { symptom and } \\
\text { management } \\
\text { strategies }\end{array}$ & Management of behavioral symptoms in PwD & Disorientation & Nurse \\
\hline 4 & $\begin{array}{l}\text { Information and } \\
\text { resource search }\end{array}$ & $\begin{array}{c}\text { Community social resources and services. } \\
\text { Use and planning for the future }\end{array}$ & Does not apply & $\begin{array}{l}\text { Social } \\
\text { Worker }\end{array}$ \\
\hline 5 & $\begin{array}{c}\text { Management } \\
\text { strategies of affective } \\
\text { symptoms. } \\
\text { Identification and } \\
\text { prevention of burden }\end{array}$ & $\begin{array}{l}\text { Problems and management of affective } \\
\text { symptoms in PwD and } \mathrm{IC}\end{array}$ & Cuidarse & Nurse \\
\hline
\end{tabular}

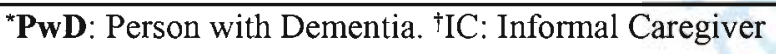


Table 2. Measurement Instrument. Catalonia, Spain

\begin{tabular}{|c|c|c|c|}
\hline Variable & Measure & $\mathrm{N}^{\circ}$ of items & $\begin{array}{c}\text { Data collection } \\
\text { time-point }\end{array}$ \\
\hline \multicolumn{4}{|l|}{ People with Dementia } \\
\hline Socio-demographics & Datasheet & $\mathrm{n} / \mathrm{a}$ & V1 \\
\hline Comorbidity & $\mathrm{CCI}^{*}$ & $\mathrm{n} / \mathrm{a}$ & V1 \\
\hline Cognition & $\mathrm{MMSE}^{\dagger}$ & $11(0-30)$ & V1 \\
\hline Behavior & NPI-Q $\ddagger$ & $13(0-36)$ & $\mathrm{V} 1, \mathrm{~V} 2, \mathrm{~V} 3$ \\
\hline Cognitive Function & GDS $^{\S}$ & 7 stages & Vi \\
\hline Quality of Life & QoL-AD' & $13(13-52)$ & $\mathrm{V} 1, \mathrm{~V} 2, \mathrm{~V} 3$ \\
\hline \multicolumn{4}{|l|}{ Informal Caregivers } \\
\hline Preparedness for caregiving & PCS $\pi$ & $8(0-4)$ & $\mathrm{V} 1, \mathrm{~V} 2, \mathrm{~V} 3$ \\
\hline Caregiver Burden & $\mathrm{ZBI}^{* *}$ & $22(0-88)$ & $\mathrm{V} 1, \mathrm{~V} 2, \mathrm{~V} 3$ \\
\hline $\mathrm{ADL}^{\dagger \dagger}$ of $\mathrm{PwD} \ddagger \ddagger$ & KATZ $\S$ & $6(0-6)$ & $\mathrm{V} 1, \mathrm{~V} 2, \mathrm{~V} 3$ \\
\hline Positive and Negative aspects of caregiving & CRA" & $\begin{array}{c}24(5 \\
\text { dimensions })\end{array}$ & $\mathrm{V} 1, \mathrm{~V} 2, \mathrm{~V} 3$ \\
\hline Social Support & Duke-UNK ศ & $8(0-40)$ & $\mathrm{V} 1, \mathrm{~V} 2, \mathrm{~V} 3$ \\
\hline Informal Caregivers Quality of Life & EQ-5D & $5(\mathrm{n} / \mathrm{a})$ & $\mathrm{V} 1, \mathrm{~V} 2, \mathrm{~V} 3$ \\
\hline Psychological well-being & GHQ-12*** & $12(0-36)$ & $\mathrm{V} 1, \mathrm{~V} 2, \mathrm{~V} 3$ \\
\hline Availability of Resources & $\mathrm{RUD}^{\dagger \dagger \dagger}$ & $\mathrm{n} / \mathrm{a}$ & $\mathrm{V} 1, \mathrm{~V} 2, \mathrm{~V} 3$ \\
\hline $\begin{array}{l}\text { Physical restraints, nutritional status, pain, } \\
\text { pressure ulcer, falls }\end{array}$ & $\begin{array}{l}\text { QoC } \ddagger \ddagger \ddagger \\
\text { questions }\end{array}$ & $\mathrm{n} / \mathrm{a}$ & $\mathrm{V} 1, \mathrm{~V} 2, \mathrm{~V} 3$ \\
\hline
\end{tabular}

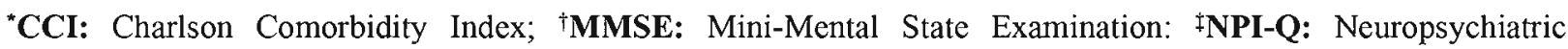
Inventory; SGDS: Global Deterioration Scale; 'QoL-AD: Quality of Life in Alzheimer's disease; 'PCS: Preparedness for Caregiving Scale; " ZBI: Zarit Burden Index; ${ }^{\dagger \dagger}$ ADL: Activities of Daily Life; ${ }^{\ddagger \neq}$ PwD: Person

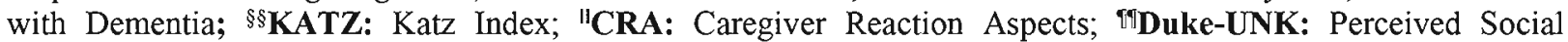
Support Questionnaire; ${ }^{* * *}$ GHQ-12: General Health Questionnaire; ${ }^{\dagger \dagger}$ RUD: Resource Utilization Questionnaire for Dementia; 



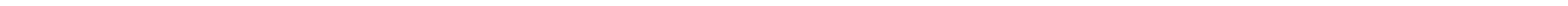


7. Discusión

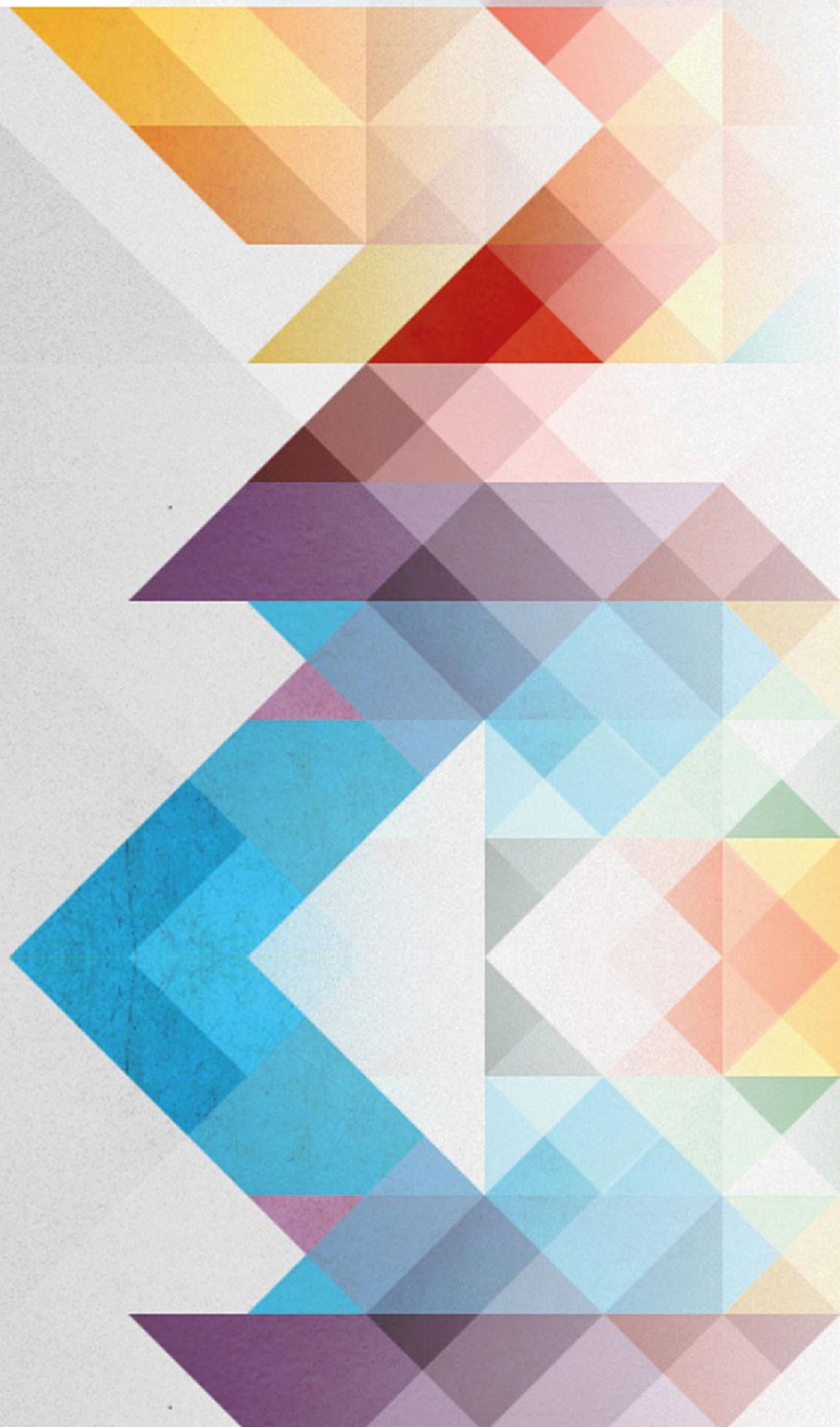


Los estudios que forman parte de la presente tesis doctoral han generado conocimiento práctico y respaldan el conocimiento teórico publicado en la literatura científica en relación con la importancia del diseño de intervenciones educativas basadas en modelos y teorías psicoeducativas dirigidas a las familias y al cuidado de PcD, debido al incremento de la dependencia tras el curso neurodegenerativo de la enfermedad $y$, en algunos casos, a la presencia de comorbilidades.

El conjunto de artículos presentados apoya la importancia del soporte profesional a los $\mathrm{Cl}$ de PcD, con el objetivo de potenciar el uso de estrategias y habilidades de afrontamiento a través de la reestructuración cognitiva. Esta intervención ayuda a prevenir la sobrecarga y a mejorar su bienestar emocional, debido a la disminución de los niveles de depresión y de estrés, y aumenta a su vez los conocimientos sobre la demencia, los cuidados específicos en el domicilio y los recursos comunitarios disponibles como método de apoyo social a pacientes y familias. Es importante tener en cuenta que uno de los objetivos de las políticas europeas es que la PcD permanezca el mayor tiempo posible viviendo en su domicilio ${ }^{(60)}$.

El soporte profesional a $\mathrm{Cl}$ y $\mathrm{PCD}$ incluye el diseño de protocolos de atención estructurados y la implementación de programas o intervenciones no farmacológicas adaptadas a sus necesidades para plantear una atención de salud centrada en la persona y en el cuidador, para que este último se sienta técnicamente competente y pueda realizar aquellas actividades relacionadas con su nuevo rol de forma satisfactoria $(60,61)$.

Así mismo, este trabajo científico analiza la CdV de los cuidadores y aporta conocimiento sobre cómo mejorar o mantener una buena $\mathrm{CdV}$ en los $\mathrm{Cl}$ de PcD en el ámbito domiciliario. Determina el impacto del rol de $\mathrm{Cl}$ en la sobrecarga y el bienestar emocional, ya que las rutinas de cuidado diario pueden desencadenar en este colectivo una variedad de sentimientos y experiencias negativas que incluyen malestar, miedo, incertidumbre, ansiedad y depresión, y que precipitan la aparición de síntomas físicos que se asocian a la sobrecarga, y que, junto con las alteraciones en su bienestar emocional, podrían llevar a la claudicación del cuidador ${ }^{(62)}$.

Los cuidadores incluidos en nuestro estudio son las personas que, durante el curso de la enfermedad y el tratamiento, han estado más involucradas en el cuidado de los pacientes y los han ayudado a adaptarse y a manejar su enfermedad crónica. Los $\mathrm{Cl}$ suelen ser familiares o amigos de las personas a las que cuidan, les dan una atención diaria, en el domicilio del paciente en la mayoría de los casos, y los apoyan física, mental y socialmente. No obstante, estos cuidadores no reciben ninguna retribución económica por la atención que brindan, por lo que deben adaptarse en poco tiempo a su nuevo rol de cuidador ${ }^{(63)}$.

Cuidar significa ayudar y asistir a la persona que lo necesita, por lo que requiere hacer frente a situaciones nuevas. Por consiguiente, el mecanismo o estilo de afrontamiento es fundamental en todas las personas, ya que les permitirá adaptarse a los cambios y a las nuevas situaciones.

Este estilo permitirá a los cuidadores hacer frente a los desafíos emergentes y a las amenazas propias de su rol. Por este motivo, es importante analizar la capacidad de afrontamiento de los $\mathrm{Cl}$, ya que, además de asistir a la PCD en todo tipo de actividades instrumentales, deberán proporcionar también un soporte emocional a la persona cuidada, que a su vez estará fuertemente relacionado con su propia salud mental. De este modo, cuidar también está vinculado a cuidar de uno mismo ${ }^{(62)}$.

Atendiendo a los objetivos de esta tesis doctoral, la evaluación del impacto de la intervención INFOSA-DEM en la sobrecarga y el bienestar emocional ha demostrado a partir de nuestros resultados que la intervención tuvo un efecto positivo en estas dos variables, sobre todo en la mejora del nivel de sobrecarga, en los cuidadores que recibieron el programa en comparación con los que no lo recibieron.

Por lo tanto, el planteamiento de intervenciones psicoeducativas evidencia su utilidad en la promoción del cambio conductual, con efectos positivos y protectores en el cuidador, lo cual invita a que se investi- 
gue más detalladamente la relación entre apoyo profesional, social y respuesta adaptativa del cuidador a la nueva situación de cuidado ${ }^{(64,65)}$.

Así mismo, se ha podido observar que el aumento de conocimientos a partir de la información obtenida en las sesiones educativas del programa INFOSA-DEM aumentó la autoeficacia en los cuidadores para llevar a cabo las tareas de cuidado, lo que mejora principalmente la capacidad de afrontamiento, sobre todo en aquellas situaciones difíciles que se presentan en el domicilio. En este sentido, el aumento de la capacidad de afrontamiento lleva a la resolución del problema y al abordaje efectivo de los síntomas de la demencia ${ }^{(66)}$.

De acuerdo con los resultados de Rodríguez et al., la intervención en cuidadores también tuvo un efecto positivo en la disminución del impacto psicológico del rol de cuidador, de la pérdida de autonomía de la PcD y del factor socioeconómico de la demencia, por lo que el apoyo emocional y la información acerca de la enfermedad que se ofrecieron a estos cuidadores permitieron modular sus estrategias de afrontamiento y disminuir la incidencia de sobrecarga ${ }^{(67)}$.

Por consiguiente, las intervenciones basadas en la psicoeducación tienen en cuenta que los estilos de afrontamiento son una reacción emocional, conductual y cognitiva y que deberían estar orientados a los problemas, a las emociones y a los estilos de afrontamiento disfuncionales, para guiar a los cuidadores en la mejora de sus mecanismos de afrontamiento. Para ello hay que destacar que mecanismos como la negación de las circunstancias, la evitación o desconectarse de la situación y recurrir al uso de sustancias psicoactivas o a la expresión de emociones negativas son herramientas inútiles que llevan a alteraciones del bienestar emocional y a la aparición de sobrecarga ${ }^{(67,68)}$.

Tras el planteamiento del segundo objetivo, el de determinar el tiempo de permanencia del efecto de la intervención en los cuidadores, los resultados han evidenciado que los efectos positivos de la intervención en la disminución de los niveles de sobrecarga se mantuvieron estables incluso seis meses después de recibida la intervención en los cuidadores del Gl, en comparación con los del GC, con un buen nivel de satisfacción y de acogida por parte de los cuidadores.

De hecho, estudios similares han demostrado la efectividad de las intervenciones presenciales en la disminución de los síntomas depresivos y en la sobrecarga de los cuidadores de patologías crónicas diferentes a la demencia, tras más de seis meses postintervención. En estos casos, la psicoeducación como método de entrenamiento ha sido igualmente útil para regenerar la salud mental, con la consiguiente mejora del bienestar emocional del cuidador ${ }^{(68,69)}$.

De acuerdo con Folkman (1997), aunque el estrés y la ansiedad formen parte del proceso de afrontamiento, la detección precoz de la angustia psicológica intensa como respuesta al cuidado y, por consiguiente, la intervención temprana, son fundamentales en aquellos familiares que dedican parte de su tiempo a cuidar a una persona dependiente, y en los que los efectos psicológicos negativos asociados a su rol de cuidador a menudo pueden durar meses o incluso años ${ }^{(70)}$.

Por este motivo, en casos de demencia, el apoyo social de amigos, familiares y profesionales permitirá orientar el proceso y los mecanismos de afrontamiento de los cuidadores, con el fin de superar los desafíos y las adversidades que surjan mientras desempeñan su papel. Este trabajo científico pone de manifiesto la importancia de la orientación como medida de apoyo social, con el fin de ir encaminando el estilo de afrontamiento del $\mathrm{Cl}$ a partir del desarrollo de habilidades y la reestructuración cognitiva ${ }^{(62)}$.

Si bien la intervención en formato grupal planteada en este trabajo científico y las encontradas en la literatura científica nos muestran que desde un principio las intervenciones dirigidas a cuidadores se han ofrecido de manera presencial y en formato grupal, en algunos casos se añaden sesiones individuales extra, asumiendo que el entorno grupal o individual juega un papel en la efectividad de la intervención. Por este motivo, se ha intentado comparar los formatos de presentación de las intervenciones dirigidas a los cuidadores ${ }^{(71,72) \text {. }}$ 
A través de las sesiones psicoeducativas del programa INFOSA-DEM se abordaron algunas situaciones con las que los cuidadores tenían que lidiar diariamente en el domicilio, por lo que resultaba fundamental orientar al cuidador y enseñarle técnicas para el manejo del estrés y la autoeficacia. Nuestro formato grupal y presencial permitió crear vínculos de apoyo mutuo, al poder compartir sus propias experiencias y transmitir consejos prácticos.

En relación con estos beneficios, Hopkinson et al. (2019) señalan que los efectos positivos de las intervenciones educativas sobre el estrés y la depresión solo se observan en programas grupales. No obstante, autores como Cheng et al. (2020) señalan que algunas técnicas de manejo del estrés son también efectivas cuando las sesiones se realizan individualmente ${ }^{(71,72) \text {. }}$

Por lo tanto, sería interesante adaptar los programas individuales y grupales a las necesidades específicas del cuidador, teniendo en cuenta que los programas grupales pueden ofrecer beneficios que no están disponibles en los programas individuales: por ejemplo, la creación de un vínculo o red de apoyo entre cuidadores a partir de la explicación de situaciones particulares, para las que se hace un reforzamiento positivo dentro del grupo y se comparten consejos ${ }^{(71,72)}$.

El programa INFOSA-DEM incluyó en su formato el uso de las TIC en el diseño de intervención, a partir de la creación de una página web para cuidadores que contenía vídeos explicativos, guías prácticas de cuidado, consultas de enfermería y llamadas de seguimiento. Esto fue beneficioso para los cuidadores participantes, puesto que podían utilizarla en su domicilio y consultar en el portal de salud el abordaje de situaciones difíciles derivadas de los síntomas de la demencia, lo que aumentó su autoeficacia y su satisfacción.

De hecho, algunos autores, como Mehta et al. (2018), Egan et al. (2018) y Teles et al. (2020), siguiendo las directrices y recomendaciones basadas en la evidencia del Programa de Acción para Superar las Brechas en Salud Mental (mhGAP, por sus siglas en inglés) de la OMS, también han innovado en la metodología educativa y en el diseño de intervenciones dirigidas a cuidadores de PcD a través de portales de internet para mejorar la salud mental. Con ello se superan las barreras de la falta de accesibilidad y del desplazamiento y se mantienen la privacidad del cuidador y la presunta costo-efectividad, por lo que se convierten en una herramienta atractiva para los cuidadores, con los mismos resultados positivos en las habilidades de conocimiento, la CdV, el afrontamiento y la autoeficacia $(73,74,75,76)$.

Se resalta que las intervenciones que se llevan a cabo por medio de, por ejemplo, seguimientos telefónicos, aplicaciones de teléfonos inteligentes, videoconferencias e internet pueden reducir la depresión y la carga de los cuidadores de manera similar a las intervenciones realizadas tradicionalmente de forma presencial ${ }^{(77)}$.

Teniendo en cuenta lo anterior, y dando respuesta al tercer objetivo de esta tesis, el de analizar la CdV del Cl de PcD, los resultados nos muestran que la $\mathrm{CdV}$ del $\mathrm{Cl}$ dependerá de diferentes factores, que en su mayoría estarán directamente relacionados con la persona cuidada.

Factores como la presencia de síntomas neuropsiquiátricos en la PcD, las horas de cuidado y el tiempo desde el diagnóstico al parecer son variables que impactan en el cuidador de una forma $u$ otra. En sintonía con nuestros resultados, el poco apoyo social y no contar con cuidadores sustitutos tuvo un efecto negativo en la autopercepción de la CdV de los cuidadores de la muestra. Por lo tanto, es de gran importancia ayudar a disminuir el efecto negativo que podría causar el rol de cuidador en el familiar que ha decidido cuidar, y es fundamental que las intervenciones se centren en las necesidades cambiantes del cuidador y en la presencia de síntomas de la enfermedad en la PcD que en ocasiones ponen a prueba la capacidad del cuidador ${ }^{(76) .}$

De esta manera, y de acuerdo con Roque et al., se plantea que participar en intervenciones dirigidas a la mejora de las habilidades comunicativas que tengan como base teórica la psicoeducación puede tener en 
los cuidadores un impacto positivo a la hora de llevar a cabo su rol: los dota de herramientas para mejorar la forma de comunicación y, de este modo, llegar a ser más empáticos y asertivos, con lo que también mejora, por consiguiente, la relación con la persona cuidada y aumentan las habilidades para el desempeño de las actividades diarias. Igualmente, participar en estas intervenciones les permitirá tener un acceso más próximo a los profesionales, incluso después de la intervención, que pueden despejarles dudas en el futuro ${ }^{(77)}$.

Con estos datos, los estudios de esta tesis pretenden dar a conocer la situación del grupo de $\mathrm{Cl}$ estudiado para poder dinamizar cuidados holísticos centrados en el cuidador y en la PCD. Asimismo, tratan de demostrar que la atención en salud se debe amoldar a las necesidades y debe complementar el seguimiento de la PcD para poder adaptar los servicios que se ofrecen o hacer derivaciones a centros más adecuados, teniendo en cuenta la fase de la enfermedad y los problemas que vayan surgiendo en el domicilio.

En particular, los estilos de afrontamiento disfuncionales incorporan una amplia gama de mecanismos de afrontamiento inútiles, incluida la negación de la situación, evitar la realidad o desconectarse de ella, recurrir al uso de sustancias psicoactivas y la expresión de emociones negativas ${ }^{(69)}$.

Por lo que, se ha destacado la importancia de la detección temprana de la angustia psicológica intensa como respuesta al cuidado en aquellos familiares que dedican parte de su tiempo a cuidar a una persona dependiente, y en los que efectos psicológicos negativos asociados a su rol de cuidador a menudo pueden durar meses e incluso años ${ }^{(70)}$, siendo necesaria la orientación por parte de los profesionales con el fin de ir encaminando el estilo de afrontamiento del $\mathrm{Cl}$ a partir del desarrollo de habilidades y la reestructuración cognitiva ${ }^{(62)}$.

Por otra parte, se ha destacado que existen algunos factores que determinan el proceso de afrontamiento de los cuidadores. Perpiñá-Galvañ et al. (2019) afirman que las necesidades de los cuidadores, el acceso a los recursos y algunas características sociodemográficas del cuidador (por ejemplo, la edad, el género o el tiempo de cuidado) pueden ser factores predictores de aislamiento social, dificultad para concentrarse o ansiedad que llevarán a la aparición de sobrecarga, con la consecuente afectación del bienestar emocional. Estos datos coinciden con nuestros resultados, ya que se ha demostrado que variables como el género femenino y el tiempo de cuidado tienen un efecto negativo en el bienestar emocional de los cuidadores estudiados $y$, por ende, en el proceso de afrontamiento y en la presentación de ciertas alteraciones ${ }^{(78)}$.

La sobrecarga es el estado psicológico que surge de la combinación del trabajo físico y emocional y de las restricciones sociales, de la percepción y la evaluación del propio cuidador acerca de las labores que realiza y de la posible influencia que tienen estas en su bienestar personal. La sobrecarga dependerá también de la implicación que requiera llevar a cabo la tarea de cuidado y de la evolución de la enfermedad de la persona que se tiene a cargo. Por este motivo, el cuidador tendrá cargas de trabajo tanto objetivas como subjetivas: las objetivas serían las horas dedicadas al cuidado de la PcD, y las subjetivas, los sentimientos y las percepciones negativas que el cuidador tiene de su propio rol ${ }^{(79)}$.

La percepción de un aumento de cargas objetivas se vincula con cambios significativos en el estilo de vida de las personas dependientes, de manera que la salud mental del $\mathrm{Cl}$ también se ve influenciada en diversos grados. De hecho, la cantidad de estrés que experimentan los cuidadores de un paciente con una enfermedad crónica como la demencia es elevada (69) y supone un riesgo sustancial para la aparición de síntomas depresivos y de ansiedad. Así mismo, la manifestación de síntomas neuropsiquiátricos y el deterioro cognitivo en la demencia predisponen a la aparición de sobrecarga y alteraciones en el bienestar emocional del cuidador. De hecho, nuestros resultados muestran que más del 39\% de los cuidadores presentan niveles moderados de sobrecarga, y más de $37 \%$ reportan niveles elevados, asociados al hecho de que más del $43 \%$ de las PCD tienen un grado de deterioro cognitivo moderado, por lo que necesitan 
mayor asistencia para las ABVD ${ }^{(80) .}$

Cuando hablamos de bienestar emocional nos referimos a un constructo multidimensional que se relaciona con la satisfacción positiva con la vida; tener un alto afecto positivo y un afecto negativo bajo ante las circunstancias diarias.

El afecto positivo puede implicar felicidad, satisfacción y energía, mientras que el afecto negativo a menudo supone sentirse triste, preocupado o deprimido. Existe una fuerte evidencia de un patrón normativo de mayor afecto positivo y menor afecto negativo a medida que la persona va madurando y experimentando ciertas situaciones que, asociadas al estilo de afrontamiento, le permitirán mantener un bienestar emocional positivo. Sin embargo, algunas personas pueden experimentar afectos negativos inmediatos a partir de la vivencia de una crisis y la gestión inefectiva de situaciones particulares, como, por ejemplo, un aumento de las responsabilidades relacionadas con el cuidado de una persona dependiente; en nuestro caso, el cuidado de PcD ${ }^{(81,82)}$.

Cuidar a una PcD en su domicilio implica gestionar diferentes actividades que se incrementarán a medida que vaya evolucionando la enfermedad. Como se ha señalado anteriormente, los cuidadores juegan un papel fundamental en tareas como la administración de medicamentos, la preparación de una dieta que se adapte a las necesidades del paciente, el transporte a los diferentes centros sociosanitarios, la orientación de la persona y el cuidado personal, lo que muchas veces supone estar con la persona más de doce horas al día. Como consecuencia de ello, el cuidador se ve obligado a renunciar a su propia vida e incluso puede llegar a descuidar su propia salud ${ }^{(81)}$.

Esta situación provoca con frecuencia un deterioro de las relaciones familiares, estrés y aislamiento social en los cuidadores. De hecho, más de un 35\% de los cuidadores incluidos en este trabajo de investigación tuvieron que reducir horas de su jornada laboral o incluso renunciar a su trabajo para cuidar de un familiar, lo que implicó que en este grupo de cuidadores existieran interferencias para realizar actividades placen- teras y que se observase la aparición de reacciones negativas asociadas a su papel como cuidadores ${ }^{(83)}$.

Esta tesis doctoral, a partir del material publicado y por medio del análisis de variables específicas, pone de manifiesto que existe la necesidad de facilitar un apoyo profesional que guíe el cuidado informal y permita ofrecer un acompañamiento durante todo el proceso de la enfermedad. El objetivo es mantener la CdV de la PcD para que reciba un cuidado de calidad en su propio domicilio y, de este modo, se retrase su ingreso en centros de larga estancia $(70,75)$.

De igual manera, se respalda la necesidad de incluir a la familia y a la PcD en la toma de decisiones, como actores principales dentro del proceso de una atención de salud efectiva. De este modo se refuerza la relación de colaboración y de ayuda mutua entre profesionales y familia, que lleve a la toma de decisiones centradas en la mejora de la salud ${ }^{\left({ }^{(2)} \text {. }\right.}$

El soporte profesional a los $\mathrm{Cl}$ hace referencia al apoyo social recibido a partir de las relaciones formales que tiene el cuidador, que proceden directamente del equipo multidisciplinar de atención (por ejemplo, médicos, enfermeras y trabajadores sociales) y que se convertirá en un predictor del bienestar individual, junto con los rasgos de personalidad de cada cuidador, como el optimismo y la autoestima. Algunos servicios sociosanitarios que atienden a PcD ya cuentan con programas que orientan de una manera más reglada al $\mathrm{Cl}^{(84,85)}$.

Por esta razón, planteamos que el desarrollo de las mejores prácticas de atención a la PcD tiene que conducir a la elaboración de intervenciones multicomponente y psicoeducativas que recalquen en el cuidador la importancia de tomarse un descanso, unirse a un grupo de apoyo, perseguir sus propios intereses y cuidar su propia salud.

Se debe ofrecer a los cuidadores capacitación en tareas médicas y necesidades de atención específicas con la ayuda de terapeutas y enfermeras, haciendo referencia a los recursos comunitarios apropiados. De hecho, la evidencia científica sugiere que cuando los 
receptores de cuidados y los cuidadores son tratados como una díada, los resultados mejoran para ambos. A su vez, los cuidadores pueden llegar a ser aliados vitales en el plan de gestión de cuidados, ya que su participación en el plan de cuidados aumenta el cumplimiento de las recomendaciones terapéuticas ${ }^{(86)}$. 


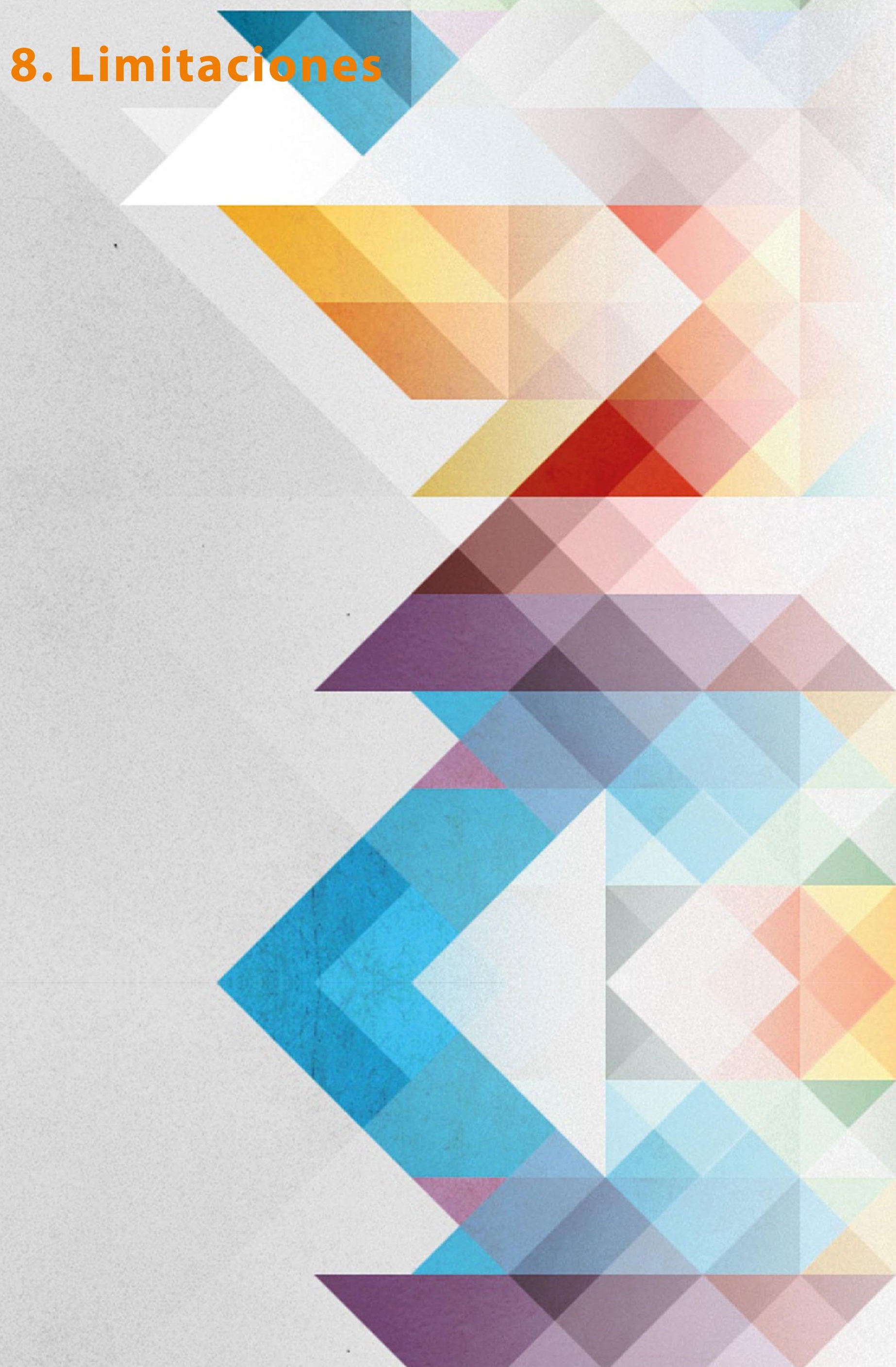




\section{Limitaciones}

El estudio INFOSA-DEM es una intervención pionera que podría aplicarse a sujetos en las mismas condiciones en otros contextos, ya que los resultados señalan que es una intervención que aporta efectos beneficiosos en el cuidador informal. Sin embargo, a pesar de los aspectos relevantes de nuestro estudio y de la identificación de correlaciones derivadas de las variables asociadas a los cuidadores informales y a la persona con demencia, se han encontrado algunas limitaciones.

En primer lugar, el estudio inicialmente se planteó como un diseño experimental con muestreo aleatorio de asignación en el grupo control y el grupo intervención, pero debido a la dificultad para el reclutamiento de participantes (poca disponibilidad horaria para asistir a las sesiones, enfermedad del familiar, inconvenientes para el desplazamiento al sitio de impartición) y a las necesidades de los cuidadores informales de información y de formación, siguiendo principios éticos se realizó un muestreo por asignación intencionada, sin aleatorización de la muestra, manteniendo la inclusión y la distribución de los cuidadores en ambos grupos. Cabe resaltar que la recogida de datos iniciales y de seguimiento se hizo de manera estructurada y separada para evitar la contaminación de la muestra, ya que los cuidadores y las personas con demencia compartían espacios (visitas en consultas externas, hospital de día, etcétera), lo que podría limitar la generalización de los resultados. Sin embargo, las variables analizadas permitieron identificar relaciones y responder a los objetivos de la investigación.

En segundo lugar, no se tuvieron en cuenta algunas variables, como las diferencias socioeconómicas, la etapa de la enfermedad o la disponibilidad de ayuda externa (por ejemplo, centro u hospitales de día, o centros de respiro), lo que, posiblemente, podría haber modificado el efecto de la intervención sobre el cuidador.

En tercer lugar, el formato presencial durante una semana pudo ser un inconveniente para aquellos cuidadores que no pudieron asistir a todas las sesiones por no contar con ayuda adicional en casa.

En cuarto lugar, los participantes que formaron parte del estudio pertenecían solamente al área metropolitana de Barcelona, por lo que en otros contextos metropolitanos, socioculturales o rurales los resultados podrían ser diferentes y podrían necesitar la adaptación de la intervención. Por último, es necesario destacar que las alteraciones del bienestar emocional y la sobrecarga son constructos complejos y multidimensionales asociados a su vez a otros factores vinculados al cuidador informal (por ejemplo, la percepción su propia salud, la edad avanzada o el desempleo) y al medio ambiente (por ejemplo, los recursos financieros y los recursos de atención formal) que no han sido tenidos en cuenta en el análisis del impacto de la intervención. 


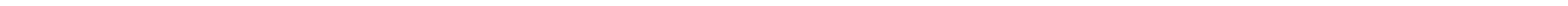


9. Conclusiones

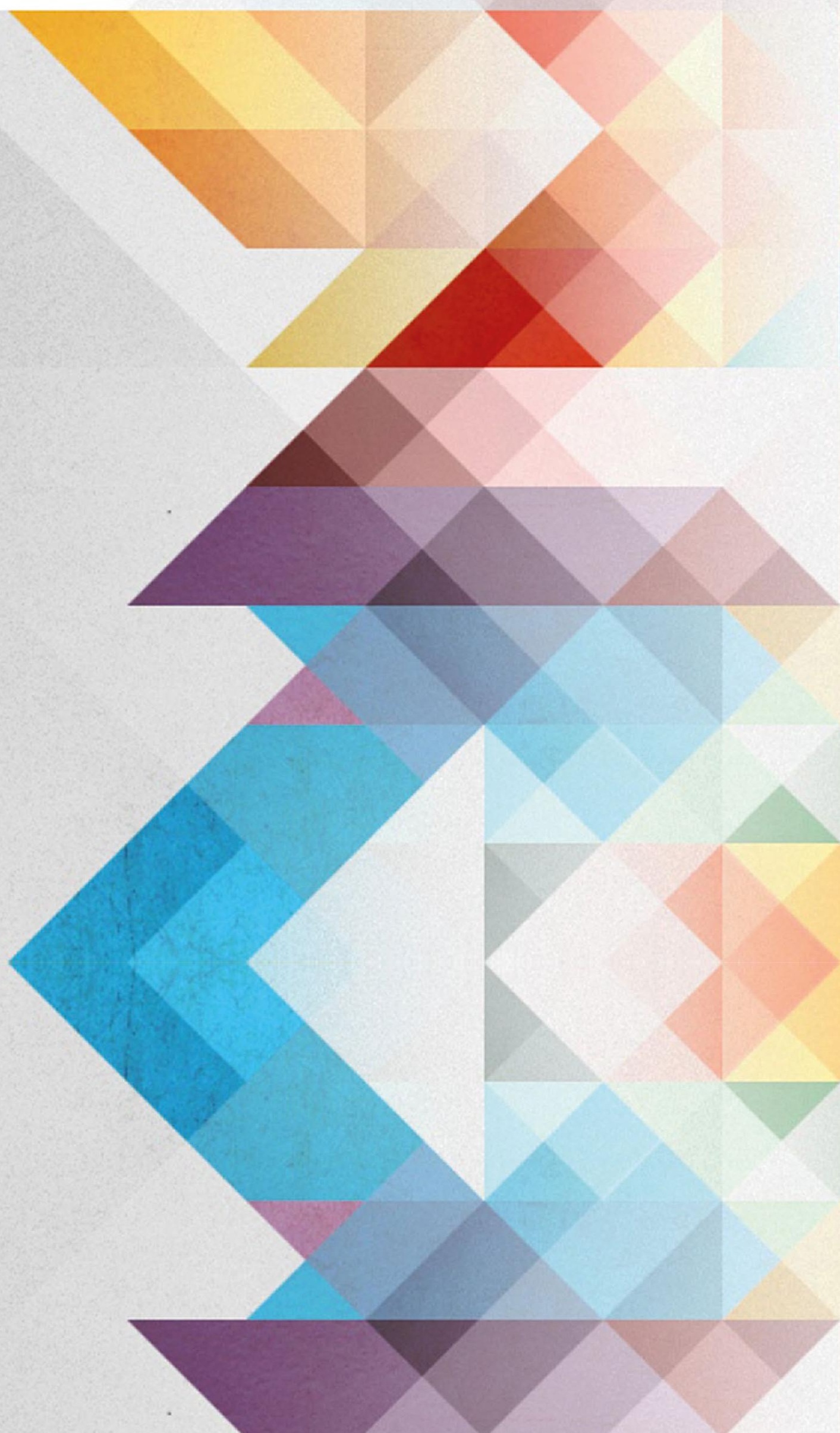




\section{Conclusiones}

El objetivo general de esta tesis doctoral ha sido desarrollar, implementar, analizar y el impacto del enfoque psicoeducativo del programa INFOSA-DEM (Información, Formación y Apoyo Social) en $\mathrm{Cl}$ de PCD en relación con la sobrecarga y el bienestar emocional.

Objetivo específico 1. Evaluar el impacto de la intervención en la sobrecarga y en el bienestar emocional.

Objetivo específico 2. Determinar el tiempo de permanencia del efecto de la intervención psicoeducativa en los $\mathrm{Cl}$.

Objetivo específico 3. Analizar la CdV de los Cl de PcD que viven en su domicilio.

A partir de los resultados de esta tesis doctoral y de la revisión de la literatura científica se concluye:

- Las intervenciones psicoeducativas son intervenciones prácticas que pueden tener efectos protectores en el cuidador por medio del suministro de información sobre la enfermedad y de consejos sobre cómo responder a determinadas situaciones relacionadas con el cuidado que proporcionan a pacientes con deterioro cognitivo y demencia, que pueden mejorar su autoeficacia y reducir el impacto negativo del cuidado en su propia salud.

Así mismo, las intervenciones psicoeducativas son provechosas en lo que se refiere al coste-beneficio cuando incluyen nuevas TIC, ya que, evita desplazamientos en el cuidador, por lo que los cuidadores que no pueden acceder a programas presenciales pueden beneficiarse al disminuir niveles de ansiedad y depresión. No obstante, para evaluar su beneficio y facilitar la interpretación de los resultados es necesario utilizar métodos rigurosos que incluyan en el análisis el perfil de los $\mathrm{Cl}$, su situación de salud y el grado de dependencia de los familiares a su cargo.

- El desarrollo del programa educativo INFOSA-DEM, basado en las mejores prácticas de cuidado de la revisión de la literatura y de la experiencia de los profesionales expertos, responde a las necesidades expresadas por los cuidadores de recibir orientación profesional en temas específicos desu rol de cuidador, con el fin de desarrollar habilidades de cuidado y de autocuidado y desarrollar de manera efectiva estrategias para la resolución de los problemas de cuidado a PcD en el domicilio.

- El programa INFOSA-DEM ha sido una intervención terapéutica validada por un equipo multidisciplinar constituido por profesionales expertos en la atención de PCD y probada en un grupo piloto de $\mathrm{Cl}$, quienes a su vez aprobaron el contenido, el formato metodológico y el número total de sesiones.

- Existe una heterogeneidad en cuanto a la duración de las intervenciones, no considerándose definitivo un período mínimo de duración de los mismas. Sin embargo, se observa que aquellas 
que incluyen seguimiento domiciliario como parte de la continuidad de las intervención, representan un factor fundamental como soporte a los cuidadores informales.

Consiste en cinco sesiones informativas-formativas impartidas de manera consecutiva durante una semana, con una duración aproximada de 90 minutos/sesión/día. Los temas tratados durante las sesiones incluyeron: conceptos básicos de la demencia y los cuidados en temas específicos como nutrición, descanso, medicación, alteraciones físicas y cognitivas, manejo de síntomas conductuales, problemas afectivos en el paciente y en el $\mathrm{Cl}$, técnicas de comunicación verbal y no verbal, autocuidado del cuidador e información sobre los recursos y servicios comunitarios disponibles.

- El programa INFOSA-DEM permitió aumentar los conocimientos del $\mathrm{Cl}$ y por consiguiente pudo mejorar su rol de cuidador.

- A partir de los resultados del estudio se pudo observar un efecto beneficioso en la salud física y emocional de los cuidadores y en la sobrecarga, aunque este no fue significativo, posiblemente debido a la presencia de otros factores generadores de estrés en el cuidador derivados del contexto de recursos asistenciales, familiares y de la situación clínica de la PcD.

- El estudio sirve de referencia y de soporte bibliográfico para la realización de intervenciones no farmacológicas de tipo educativo dirigidas a un grupo poblacional específico con necesidades particulares. También es útil para poder analizar si la información proporcionada, el tiempo y el número de sesiones de la intervención responde a las necesidades de los cuidadores.

- Este estudio permite implementar la intervención INFOSA-DEM en centros de atención primaria en el contexto catalán y estatal, ya que el programa hace que el cuidador conozca y entienda la demencia y los cambios que se producen en la persona que la padece. Además analiza si la información proporcionada, el tiempo y número de las sesiones utilizadas en la intervención responde a las necesidades y bienestar de los cuidadores 


\section{Implica thes para la Prácu}

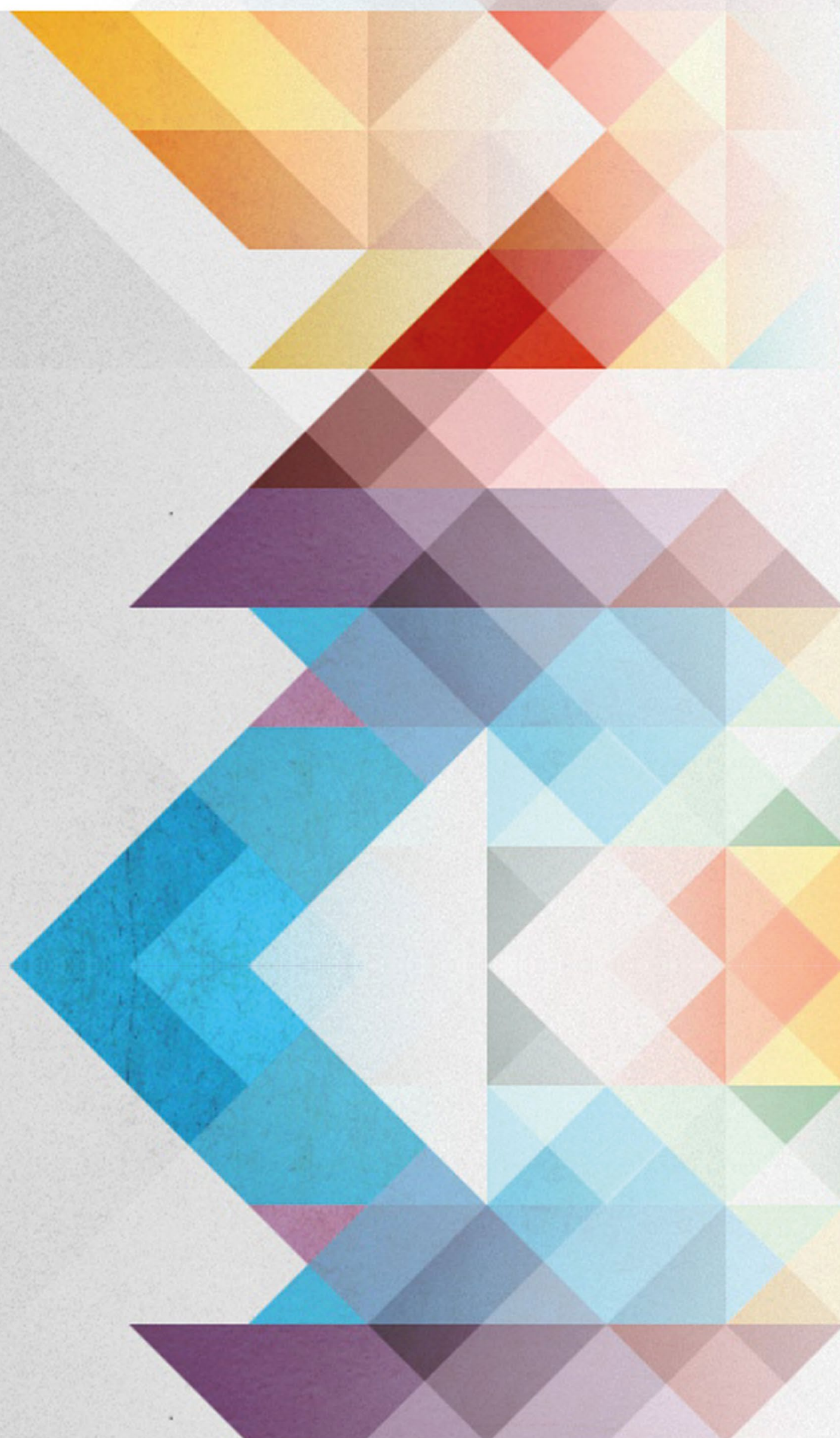




\section{Implicaciones para la Práctica}

El propósito de este trabajo ha sido diseñar, implementar y analizar un enfoque psicoeducativo liderado por enfermeras especializadas en salud mental en el cuidado informal de personas con deterioro cognitivo, para mejorar las estrategias de afrontamiento y las habilidades de los cuidadores informales a partir de la restructuración cognitiva.

Este proyecto sirve de base teórica para incluir programas educativos en centros de atención de personas con demencia para orientar a los familiares en el cuidado domiciliario, con el fin de mantener al paciente en su domicilio, en la medida de lo posible, en el entorno familiar, retrasando de este modo su ingreso en centros de larga estancia y evitando la claudicación del cuidador informal.

Así mismo, sirve de base para orientar prácticas basadas en la evidencia y líneas estratégicas de actuación en busca de las mejores prácticas enfermeras. Por tanto, es necesario desarrollar e implementar programas psicoeducativos en el marco de la atención primaria de salud, como garante de la atención holística del paciente con demencia y de su familia.

La intervención INFOSA-DEM permite, con su enfoque, la mejora de las capacidades del cuidador familiar al aumentar su conocimiento sobre la demencia, la preparación ante los cambios, la identificación de necesidades, aprendiendo a priorizarlas de acuerdo con la situación específica de cada PcD. Así mismo, aumentará la capacidad de los cuidadores para afrontar y resolver problemas, y percibirán una mejor preparación para desempeñar su rol de cuidador, teniendo en cuenta que el autocuidado es clave para poder cuidar a otros de manera efectiva. 


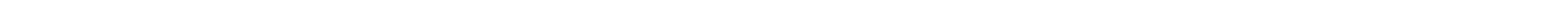


11. Futuras

investigaciones

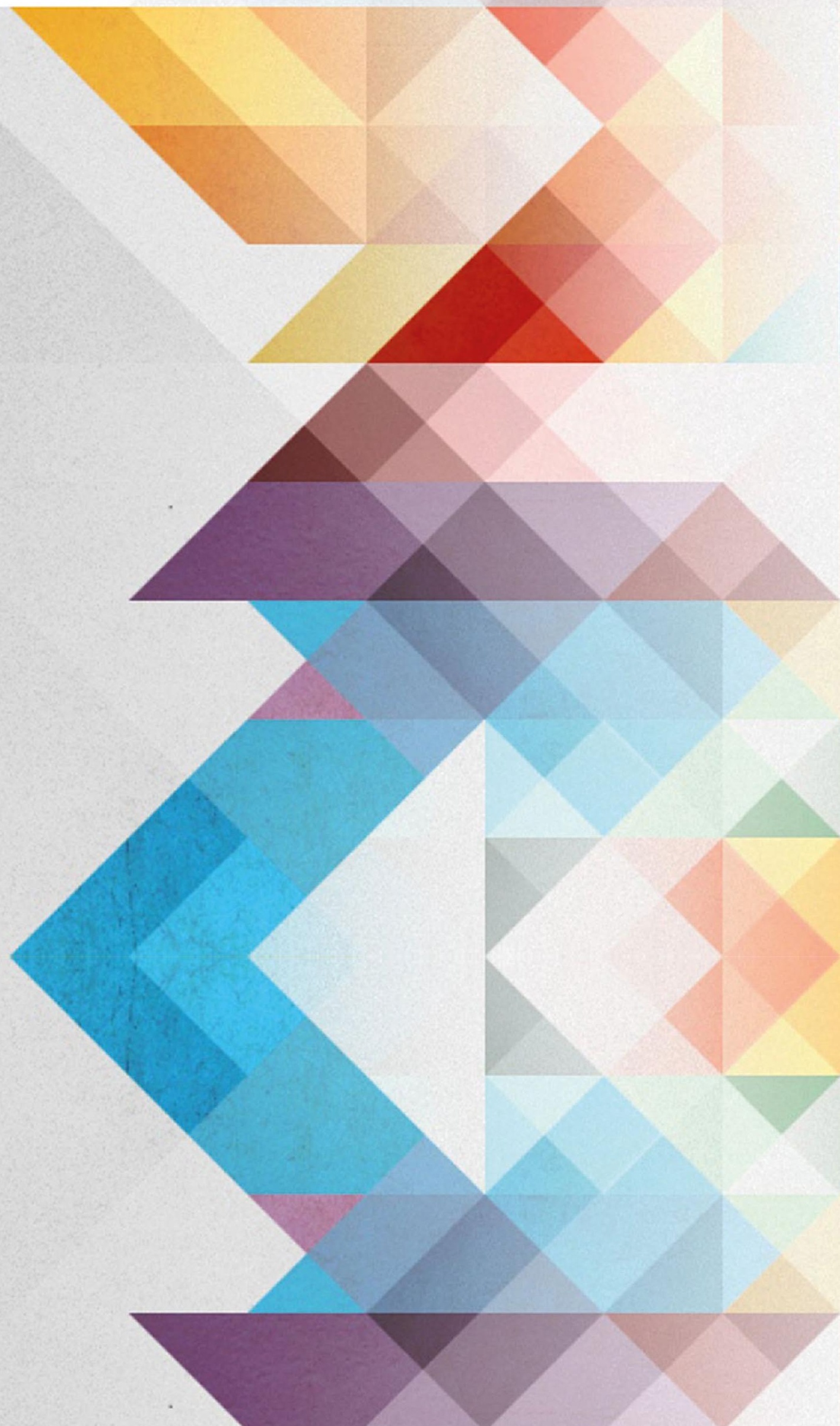




\section{Futuras investigaciones}

A partir de los resultados obtenidos en nuestro estudio se pueden plantear líneas de investigación en el campo de la salud que permitan el abordaje de los $\mathrm{Cl}$ y de las PcD:

- Diseñar, desarrollar e implementar ensayos clínicos controlados y aleatorizados de programas similares a INFOSA-DEM que ayuden a determinar la efectividad de estos y que contribuyan a la disminución de la sobrecarga y el estrés que generan los cuidados de larga duración, que comprometen todas las dimensiones del ser humano, su CdV y su salud. De igual manera, se recomienda que tras la participación de los cuidadores en el programa INFOSA-DEM se continúe con grupos de apoyo y visitas de seguimiento para abordar los problemas particulares de cada cuidador.

- Diseñar intervenciones psicoeducativas que utilicen las nuevas tecnologías a partir de la digitalización de la información, junto con la creación de aplicaciones interactivas que permitan que los cuidadores puedan acceder a ellas fácilmente desde la comodidad de su domicilio.

- Analizar el efecto del programa INFOSA-DEM en el ámbito rural.

- Implementar el programa INFOSA-DEM en grupos de cuidadores clasificados en función de sus características (estadio demencial y nivel de dependencia de la persona a la que cuidan, apoyo, recursos disponibles...), con el fin de personalizar la intervención, tal y como se sugiere en la literatura publicada recientemente, teniendo en cuenta las necesidades, valores y preferencias de la PcD y del Cl.

- Incluir en el diseño del programa INFOSA-DEM intervenciones de cuidados orientadas a etapas más avanzadas de la enfermedad como es el cuidado paliativo domiciliario incluyendo, la prevención de úlceras por presión, caídas o complicaciones respiratorias asociadas a la disfagia y el tratamiento del dolor en PcD.

- Identificar las variables sociodemográficas y clínicas del Cl y PCD que puedan estar significativamente relacionadas con a la $\mathrm{CdV}$ de los $\mathrm{Cl}$ y de las PcD. 
12. Refere Bibliográfica.

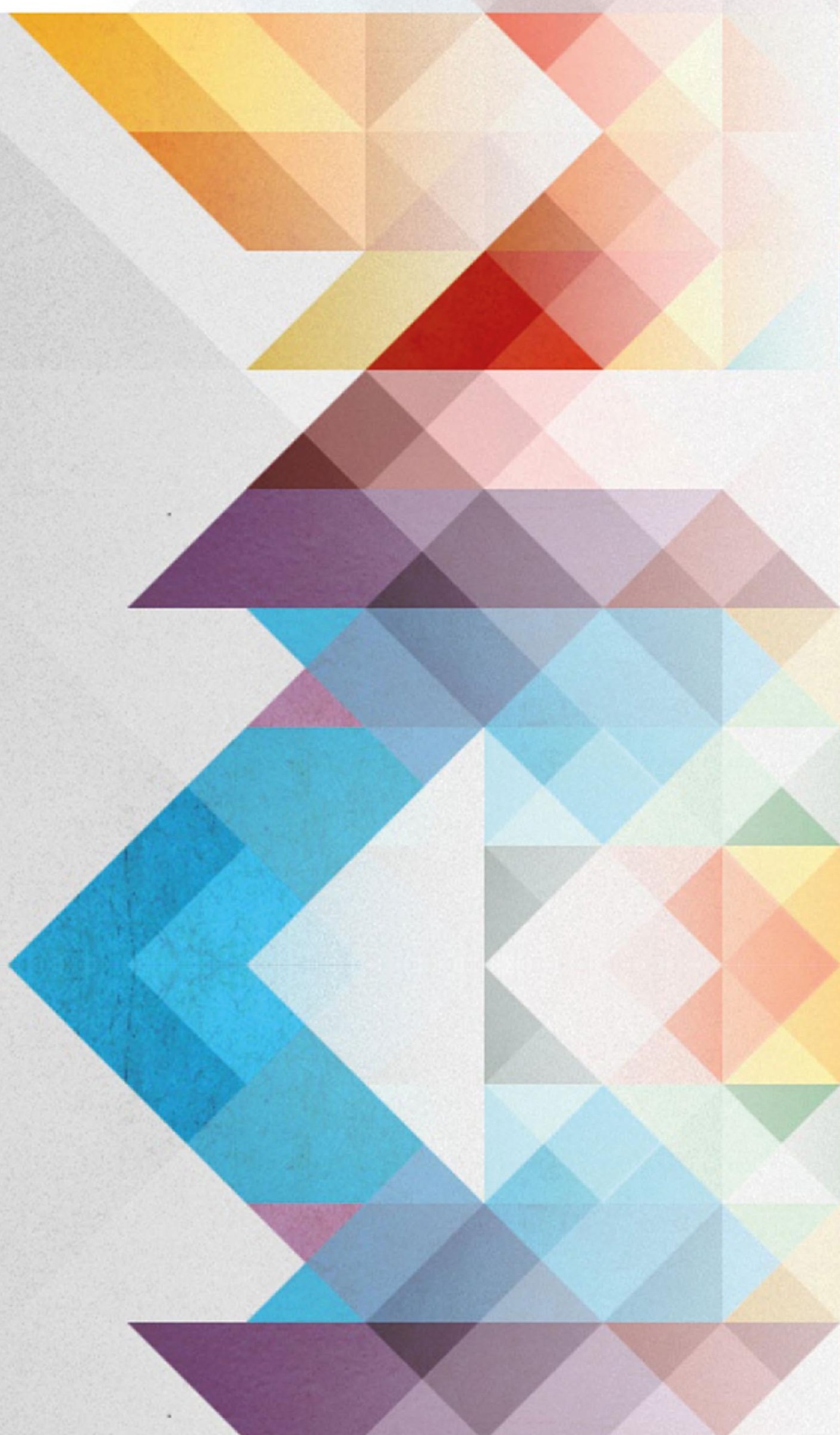




\section{Referencias Bibliográficas}

1. Vogelsang EM, Raymo JM, Liang J, Kobayashi E, Fukaya T. Population Aging and Health Trajectories at Older Ages. J Gerontol B Psychol Sci Soc Sci. 2019; 74(7): 12451255. https://doi.org/10.1093/geronb/gbx071.

2. Costantino S, Paneni F, Cosentino F. Ageing, metabolism and cardiovascular disease. J Physiol. 2016; 594(8): 2061-2073. https://doi.org/10.1113/JP270538.

3. Ruangritchankul S, Peel NM, Hanjani LS, Gray LC. Drug related problems in older adults living with dementia. PloS One. 2020; 15(7): e0236830. https://doi. org/10.1371/journal.pone.0236830.

5. Sathyanarayana Rao TS, Jacob KS, Shaji KS, Raju MSVK, Bhide AV, Prasad Rao G, et al. Dementia and the International Classification of Diseases-11 (Beta Version). Indian J Psychiatry. 2017; 59(1): 1-2. https://doi.org/10.4103/psychiatry.IndianJPsychiatry_66_17.

6. Garre-Olmo J. Epidemiologia de la enfermedad de Alzheimer y otras demencias. Rev Neurol. 2018; 66(11): 377-386. HYPERLINK “https://doi.org/10.33588/ rn.6611.2017519"\t“_blank" https://doi.org/10.33588/rn.6611.2017519.

7. Ljubenkov PA, Geschwind MD. Dementia. Semin Neurol. 2016; 36(4): 397-404. https://doi.org/10.1055/s-0036-1585096.

8. Geschwind MD. Rapidly Progressive Dementia. Continuum (Minneap Minn). 2016; 22(2 Dementia): 510-537. https://doi.org/10.1212/CON.0000000000000319.

9. Balzer K, Schröder R, Junghans A, Stahl U, Träder JM, Köpke S. Improving competencies in evidence-based dementia care: Results from a pilot study on a novel inter-professional training course (the KOMPIDEM project). GMS J Med Educ. 2016; 33(2): Doc35. https://doi.org/10.3205/zma001034.

10. Galvin JE, Sadowsky CH, NINCDS-ADRDA. Practical guidelines for the recognition and diagnosis of dementia. J Am Board Fam Med. 2012; 25(3): 367-382. https://doi. org/10.3122/jabfm.2012.03.100181.

11. Sabdilyan MB, Dening T. Diagnosis of dementia. Nurs Stand. 2015: 29(43): 36-41. doi: 10.7748/ns.29.43.36.e9441.

12. Arvanitakis $Z$, Shah RC, Bennett DA. (Diagnosis and Management of Dementia: Review. JAMA. 2019; 322(16): 1589-1599. https://doi.org/10.1001/jama.2019.4782.

13. Yang T, Sun Y, Lu Z, Leak RK, Zhang F. The impact of cerebrovascular aging on vascular cognitive impairment and dementia. Ageing Res Rev. 2017; 34: 15-29. https://doi. org/10.1016/j.arr.2016.09.007. 
14. Odle TG. Alzheimer disease and other dementias. Radiol Technol. 2003; 75(2): 111139.

15. Durongbhan P, Zhao Y, Chen L, Zis P, De Marco M, Unwin ZC, et al. A Dementia Classification Framework Using Frequency and Time-Frequency Features Based on EEG Signals. IEEE Trans Neural Syst Rehabil Eng. 2019; 27(5): 826-835. https://doi. org/10.1109/TNSRE.2019.2909100.

16. Bondi MW, Edmonds EC, Salmon DP. (Alzheimer's Disease: Past, Present, and Future. J Int Neuropsychol Soc. 2017; 23(9-10): 818-831. https://doi.org/10.1017/ S135561771700100X.

17. Arvanitakis Z, Bennett DA. What Is Dementia? JAMA. 2019; 322(17): 1728. https:// doi.org/10.1001/jama.2019.11653.

18. Takeda N, Kishimoto Y, Yokota O. Pick's disease. En: Ahmad SI (ed.). Neurodegenerative Diseases. Advances in Experimental Medicine and Biology. 2012; 724: 300-316. https://doi.org/10.1007/978-1-4614-0653-2_23.

19. Tisher A, Salardini A. A Comprehensive Update on Treatment of Dementia. Semin Neurol. 2019; 39(2): 167-178. https://doi.org/10.1055/s-0039-1683408.

20. Khan F, Curtice M. Non-pharmacological management of behavioural symptoms of dementia. Br J Community Nurs. 2011; 16(9): 441-449. https://doi.org/10.12968/ bjcn.2011.16.9.441.

21. Norris D, Clark MS, Shipley S. The Mental Status Examination. Am Fam Physician. 2016; 94(8), 635-641.

22. Olazarán-Rodríguez J, Agüera-Ortiz LF, Muñiz-Schwochert R. Síntomas psicológicos y conductuales de la demencia: prevención, diagnóstico y tratamiento. Rev Neurol. 2012; 55: 598-608. HYPERLINK" https://doi.org/10.33588/rn.5510.2012370" https:// doi.org/10.33588/rn.5510.2012370.

23. Perneczky R. Dementia treatment versus prevention. Dialogues Clin Neurosci. 2019; 21(1): 43-51. https://doi.org/10.31887/DCNS.2019.21.1/rperneczky.

24. Rodríguez D, Formiga F, Fort I, Robles MJ, Barranco E, Cubí D, Grupo de Trabajo de Demencias de la Sociedad Catalana de Geriatría y Gerontología. Tratamiento farmacológico de la demencia: cuándo, cómo y hasta cuándo. Recomendaciones del Grupo de Trabajo de Demencias de la Sociedad Catalana de Geriatría y Gerontología [Pharmacological treatment of dementia: when, how and for how long. Recommendations of the Working Group on Dementia of the Catalan Society of Geriatrics and Gerontology]. Rev Esp Geriatr Gerontol. 47(5): 228-233. https://doi.org/10.1016/j. regg.2012.02.008. 


\section{Referencias Bibliográficas}

25. Bessey LJ, Walaszek A. Management of Behavioral and Psychological Symptoms of Dementia. Curr Psychiatry Rep. 2019; 21(8): 66. https://doi.org/10.1007/s11920-0191049-5.

26. Ramos Cordero P, Yubero R. Tratamiento no farmacológico del deterioro cognitivo [Non pharmacological treatment of cognitive impairment]. Rev Esp Geriatr Gerontol. 2016; 51 (Suppl 1): 12-21. https://doi.org/10.1016/S0211-139X(16)30138-X.

27. Schwarz S, Froelich L, Burns A. Pharmacological treatment of dementia. Curr Opin Psychiatry. 2012; 25(6): 542-550. https://doi.org/10.1097/YCO.0b013e328358e4f2. Baruch N, Burgess J, Pillai M, Allan CL. Treatment for depression comorbid with dementia. Evid Based Ment Health. 2019; 22(4): 167-171. https://doi.org/10.1136/ebmental-2019-300113.

28. Dyer SM, Harrison SL, Laver K, Whitehead C, Crotty M. An overview of systematic reviews of pharmacological and non-pharmacological interventions for the treatment of behavioral and psychological symptoms of dementia. Int Psychogeriatr. 2018; 30(3): 295-309. https://doi.org/10.1017/S1041610217002344.

29. Abraha I, Rimland JM, Trotta FM, Dell'Aquila G, Cruz-Jentoft A, Petrovic M, et al. Systematic review of systematic reviews of non-pharmacological interventions to treat behavioural disturbances in older patients with dementia. The SENATOR-OnTop series. BMJ Open. 2017; 7(3):e012759. https://doi.org/10.1136/bmjopen-2016-012759.

30. Cai Y, Li L, Xu C, Wang Z. The Effectiveness of Non-Pharmacological Interventions on Apathy in Patients With Dementia: A Systematic Review of Systematic Reviews. Worldviews Evid Based Nurs. 2020; 17(4): 311-318. https://doi.org/10.1111/ wvn.12459.

31. Lo D, Grossberg GT. Use of memantine for the treatment of dementia. Expert Rev Neurother. 2011; 11(10): 1359-1370. https://doi.org/10.1586/ern.11.132.

32. Jiménez-Palomares $M$, Rodríguez-Mansilla J, González-López-Arza MV, Rodríguez-Domínguez MT, Prieto-Tato M. Beneficios de la musicoterapia como tratamiento no farmacológico y de rehabilitación en la demencia moderada [Benefits of music therapy as therapy no pharmacology and rehabilitation moderate dementia]. Rev Esp Geriatr Gerontol. 2013; 48(5): 238-242. https://doi.org/10.1016/j. regg.2013.01.008.

33. Gómez-Romero $M$, Jiménez-Palomares $M$, Rodríguez-Mansilla J, Flores-Nieto A, Garrido-Ardila EM, González López-Arza MV. Benefits of music therapy on behaviour disorders in subjects diagnosed with dementia: a systematic review. Beneficios de la musicoterapia en las alteraciones conductuales de la demencia. Revisión sistemática. Neurologia. 2017; 32(4): 253-263. https://doi.org/10.1016/j.nrl.2014.11.001. 
34. Martos Martínez Á, Cardila Fernández F, Barragán Martín AB, Pérez-Fuentes MDC, Molero Jurado MDM, Gázquez Linares JJ. Instrumentos para la evaluación de la sobrecarga del cuidador familiar de personas con demencia. EJIHPE. 2015; 5(2): 281. https://doi.org/10.30552/ejihpe.v5i2.119.

35. Esandi N, Canga A. Atención centrada en la familia: un modelo para abordar los cuidados de la demencia en la comunidad [Family-centered care: A model for approaching dementia care in the community]. Aten Primaria. 2016; 48(4): 265-269. https:// doi.org/10.1016/j.aprim.2015.11.006.

36. Farré $\mathrm{M}$, Kostov B, Haro JM, Cabrera E, Risco E, Alvira MC, et al. Costs and burden associated with loss of labor productivity in informal caregivers of people with dementia. J Occup Environ Med. 2018; 60: 449-456. doi: 10.1097/JOM.0000000000001229.

37. Casafont C, Risco E, Piazuelo M, Ancín-Pagoto M, Cobo-Sánchez JL, Solís-Muñoz M, et al. Care of older people with Cognitive Impairment or Dementia Hospitalized in Traumatology Units (CARExDEM): a quasi-experiment. BMC Geriatr. 2020; 20(1): 246. https://doi.org/10.1186/s12877-020-01633-5.

38. Lilleheie I, Debesay J, Bye A, Bergland A. Informal caregivers' views on the quality of health care services provided to older patients aged 80 or more in the hospital and 30 days after discharge. BMC Geriatr. 2020; 20(1): 97. https://doi.org/10.1186/ s12877-020-1488-1.

39. De Valle-Alonso MJ, Hernández-López IE, Zúñiga-Vargas ML, Martínez-Aguilera P. Sobrecarga y Burnout en cuidadores informales del adulto mayor. Enferm Universitaria. 2015; 12(1): 19-27. https://doi.org/10.1016/j.reu.2015.05.004.

40. Alvira MC, Cabrera E, Kostov B, Risco E, Farré M, Miguel S, et al. Validity and reliability of the Spanish caregiver reaction assessment scale for caregivers of people with dementia. Int J Nurs Pract. 2020: e12848. https://doi.org/10.1111/ijn.12848.

41. Alvira MC, Risco E, Cabrera FM, Rahm I, Bleijlevens M, Meyer G, et al. The association between positive-negative reactions of informal caregivers of people with dementia and health outcomes in eight European countries: a cross-sectional study. J Adv Nurs. 2015; 71: 1417-1434. doi: 10.0000/jan.12528.

42. Miguel S, Alvira MC, Farré M, Risco E, Cabrera E, Zabalegui A. Quality of life and associated factors in older people with dementia living in long-term institutional care and home care. Eur Geriatr Med. 2016; 7(4): 346-351. https://doi.org/10.1016/j.eurger.2016.01.012. 


\section{Referencias Bibliográficas}

43. Dixe $M$, da Conceição Teixeira LF, Areosa T, Frontini RC, de Jesus Almeida Peralta T, Querido A. Needs and skills of informal caregivers to care for a dependent person: a cross-sectional study. BMC Geriatr. 2019; 19(1): 255. https://doi.org/10.1186/ s12877-019-1274-0.

44. García-Mochón L, Peña-Longobardo LM, Del Río-Lozano M, Oliva-Moreno J, Larrañaga-Padilla I, García-Calvente M. Determinants of Burden and Satisfaction in Informal Caregivers: Two Sides of the Same Coin? The CUIDAR-SE Study. Int J Environ Res Public Health. 2019; 16(22): 4378. https://doi.org/10.3390/ijerph16224378.

45. Navarro Martínez M, Jiménez Navascués L, García Manzanares MC, de Perosanz Calleja M, Blanco Tobar E. Los enfermos de Alzheimer y sus cuidadores: intervenciones de enfermería [Alzheimer's patients and their caregivers: nursing interventions]. Gerokomos. 2018; 29(2): 79-82. Recuperado el 13 de febrero de 2021 de http://scielo. isciii.es/scielo.php?script=sci_arttext\&pid=S1 134-928X2018000200079\&lng=es\&t|$\mathrm{ng}=\mathrm{pt}$.

46. Wang T, Molassiotis A, Chung B, Tan JY. Unmet care needs of advanced cancer patients and their informal caregivers: a systematic review. BMC Palliat. Care. 2018; 17(1): 96. https://doi.org/10.1186/s12904-018-0346-9.

47. Ploeg J, Markle-Reid M, Valaitis R, McAiney C, Duggleby W, Bartholomew A, et al. Web-Based Interventions to Improve Mental Health, General Caregiving Outcomes, and General Health for Informal Caregivers of Adults With Chronic Conditions Living in the Community: Rapid Evidence Review. J Med Internet Res. 2017; 19(7): e263. https://doi.org/10.2196/jmir.7564.

48. Cranwell M, Gavine A, McSwiggan L, Kelly TB. What happens for informal caregivers during transition to increased levels of care for the person with dementia? A systematic review protocol. Syst Rev. 2018; 7(1): 91. https://doi.org/10.1186/s13643-0180755-0.

49. Regier NG, Hodgson NA, Gitlin LN Characteristics of Activities for Persons With Dementia at the Mild, Moderate, and Severe Stages. Gerontologist. 2017; 57(5): 987997. https://doi.org/10.1093/geront/gnw133.

50. Cheng HY, Chair SY, Chau J. Effectiveness of a strength-oriented psychoeducation on caregiving competence, problem-solving abilities, psychosocial outcomes and physical health among family caregiver of stroke survivors: A randomised controlled trial. Int J Nurs Stud. 2018; 87: 84-93. https://doi.org/10.1016/j.ijnurstu.2018.07.005. 
51. Ostwald SK, Godwin KM, Cron SG, Kelley CP, Hersch G, Davis S. Home-based psychoeducational and mailed information programs for stroke-caregiving dyads post-discharge: a randomized trial. Disabil Rehabil. 2014; 36(1): 55-62.

52. Verma PK, Walia TS, Chaudhury S, Srivastava S. Family psychoeducation with caregivers of schizophrenia patients: Impact on perceived quality of life. Ind Psychiatry J. 2019; 28(1): 19-23. https://doi.org/10.4103/ipj.ipj_2_19.

53. Joas E, Bäckman K, Karanti A, Sparding T, Colom F, Pålsson E, et al. Psychoeducation for bipolar disorder and risk of recurrence and hospitalization - a within-individual analysis using registry data. Psychol Med. 2020; 50(6): 1043-1049. https://doi. org/10.1017/S0033291719001053.

54. Cuevas-Cancino JJ, Moreno-Pérez NE. Psicoeducación: intervención de enfermería para el cuidado de la familia en su rol de cuidadora. Enferm Universitaria. 2017; 14(3): 207-218. https://doi.org/10.1016/j.reu.2017.06.003.

55. Turró Garriga O, Farrés Costa S, Pérez Terré A, Batlle Amat P. Evaluación del efecto del sentido de coherencia en la carga percibida y en la adherencia a un programa psicoeducativo para cuidadores informales de personas dependientes [Assessment of the sense of coherence in the perceived burden and in the adherence to a psycho-educational program for informal caregivers of dependent persons]. Rev Esp Geriatr Gerontol. 2018; 53(4): 196-201. https://doi.org/10.1016/j.regg.2017.12.002.

56. Titler MG, Visovatti MA, Shuman C, Ellis KR, Banerjee T, Dockham B, et al. Effectiveness of implementing a dyadic psychoeducational intervention for cancer patients and family caregivers. Support Care Cancer. 2017; 25(11): 3395-3406. https://doi. org/10.1007/s00520-017-3758-9.

57. Griffiths PC, Kovaleva M, Higgins M, Langston AH, Hepburn K. Tele-Savvy: An Online Program for Dementia Caregivers. Am J Alzheimers Dis Other Demen. 2018; 33(5): 269-276. https://doi.org/10.1177/1533317518755331.

58. Pihet S, Kipfer S. Coping with dementia caregiving: a mixed-methods study on feasibility and benefits of a psycho-educative group program. BMC Geriatr. 2018; 18(1): 209. https://doi.org/10.1186/s12877-018-0896-y.

59. Bonoso García RM, Del Pino Casado R. Intervenciones no farmacológicas para reducir la depresión, sobrecarga y ansiedad en personas cuidadoras de mayores con demencia: un metaanálisis. Metas Enferm. 2018;21(2): 20-32. https://doi.org/10.35667/ metasenf.2019.21.1003081191. 


\section{Referencias Bibliográficas}

60. Kim SK, Park M. Effectiveness of person-centered care on people with dementia: a systematic review and meta-analysis. Clin Interv Aging. 2017; 12: 381-397. https:// doi.org/10.2147/CIA.S117637.

61. Scales K, Zimmerman S, Miller SJ. Evidence-Based Non- pharmacological Practices to Address Behavioral and Psychological Symptoms of Dementia. Gerontologist. 2018; 58(suppl_1):S88-S102. https://doi.org/10.1093/geront/gnx167.

62. Agyemang-Duah W, Abdullah A, Mensah CM, Arthur-Holmes F, Addai B. Caring for older persons in rural and urban communities: perspectives of Ghanaian informal caregivers on their coping mechanisms. J Public Health (Berl.). 2020; 28: 729-736. https://doi.org/10.1007/s10389-019-01082-4.

63. Tang S-H, Chio O-I, Chang L-H, Mao H-F, Chen L-H, Yip P-K, et al. Caregiver active participation in psychoeducational intervention improved caregiving skills and competency. Geriatr Gerontol Int. 2018; 18(5): 750-757, doi:10.1111/ggi.13246.

64. Gilhooly KJ, Gilhooly MLM, Sullivan MP, Mclnyre A, Wilson L, Harding E, et al. A meta-review of stress, coping and interventions in dementia and dementia caregiving. BMC Geriatr. 2016; 16: 106. https://doi.org/10.1186/s12877-016-0280-8.

65. Petriwskyj A, Parker D, O'Dwyer S, Moyle W, Nucifora N. Interventions to build resilience in family caregivers of people living with dementia: a comprehensive systematic review. JBI Database SystemRev Implementation Rep. 2016; 14(6): 238-273. https://doi.org/10.11124/JBISRIR-2016-002555.

66. Garcia-Ptacek S, Dahlrup B, Edlund AK, Wijk H, Eriksdotter M. The caregiving phenomen on and caregiver participation in dementia. Scand J Caring Sci. 2019; 33: 255265. doi: $10.1111 /$ scs.12627.

67. Pérez Rodríguez M, Álvarez Gómez T, Martínez Badaló EJ, Valdivia Cañizares S, Borroto Carpio I, Pedraza Núñez H. El síndrome del cuidador en cuidadores principales de ancianos con demencia Alzhéimer. Gac Méd Espirit. 2017; 19(1): 38-50. Recuperado el 13 de febrero de 2021 de http://scielo.sld.cu/scielo.php?script=sci_arttext\&pi$\mathrm{d}=$ S1608-89212017000100007\&lng=es\&tIng=es.

68. González-Fraile E, Domínguez-Panchón Al, Berzosa P, Costas-González AB, Garrido-Jimenez I, Rufino-Ventura $D$, et al. Efficacy of a psychoeducational intervention in caregivers of people with intellectual disabilities: A randomized controlled trial (EDUCA-IV trial). Res Dev Disabil. 2019; 94: 103458. https://doi.org/10.1016/j. ridd.2019.103458. 
69. Ping Pang NT, Masiran R, Tan KA, Kassim A. Psychological mindedness as a mediator in the relationship between dysfunctional coping styles and depressive symptoms in caregivers of children with autism spectrum disorder. Perspect Psychiatr Care. 2020; 56(3): 649-656. https://doi.org/10.1111/ppc.12481.

70. Folkman S. Positive psychological states and coping with severe stress. Soc Sci Med. 1997; 45(8): 1207-1221. https://doi.org/10.1016/s0277-9536(97)00040-3.

71. Cheng ST, Zhang F. A comprehensive meta-review of systematic reviews and meta-analyses on nonpharmacological interventions for informal dementia caregivers. BMC Geriatr. 2020; 20(1): 137. https://doi.org/10.1186/s12877-020-01547-2.

72. Hopkinson MD, Reavell J, Lane DA, Mallikarjun P. Cognitive Behavioral Therapy for Depression, Anxiety, and Stress in Caregivers of Dementia Patients: A Systematic Review and Meta-Analysis. Gerontologist. 2019; 59(4): e343-e362. https://doi. org/10.1093/geront/gnx217.

73. Egan KJ, Pinto-Bruno ÁC, Bighelli I, Berg-Weger M, van Straten A, Albanese E, et al. Online Training and Support Programs Designed to Improve Mental Health and Reduce Burden Among Caregivers of People With Dementia: A Systematic Review. J Am Med Dir Assoc. 2018; 19(3): 200-206.e1. https://doi.org/10.1016/j.jamda.2017.10.023.

74. Teles S, Ferreira A, Seeher K, Fréel S, Paúl C. Online training and support program (iSupport) for informal dementia caregivers: protocol for an intervention study in Portugal. BMC Geriatr. 2020; 20(1): 10. https://doi.org/10.1186/s12877-019-1364-z.

75. Mehta KM, Gallagher-Thompson D, Varghese M, Loganathan S, Baruah U, Seeher $\mathrm{K}$, et al. iSupport, an online training and support program for caregivers of people with dementia: study protocol for a randomized controlled trial in India. Trials. 2018; 19(1): 271. https://doi.org/10.1186/s13063-018-2604-9.

76. Lappalainen P, Pakkala I, Nikander R. CareACT - internet-based intervention for enhancing the psychological well-being of elderly caregivers - a study protocol of a controlled trial. BMC Geriatr. 2019; 19(1): 72. https://doi.org/10.1186/s12877-0191071-9.

77. Roque F P, Ortiz K Z, Araújo , Bertolucci, PHF Eficácia de treinamento de estratégias comunicativas a cuidadores de pacientes com demência. Pró-Fono R Atual Cient. 2009; 21 (3): 225-230. https://dx.doi.org/10.1590/S0104-56872009000300008.

78. Perpiñá-Galvañ J, Orts-Beneito N, Fernández-Alcántara M, García-Sanjuán S, García-Caro MP, Cabañero-Martínez MJ. Level of Burden and Health-Related Quality of Life in Caregivers of Palliative Care Patients. Int J Environ Res Public Health. 2019; 16(23): 4806. https://doi.org/10.3390/ijerph16234806. 


\section{Referencias Bibliográficas}

79. Riffin C, Van Ness PH, Wolff JL, Fried T. Multifactorial Examination of Caregiver Burden in a National Sample of Family and Unpaid Caregivers. J Am Geriatr Soc. 2019; 67(2): 277-283. https://doi.org/10.1111/jgs.15664.

80. Jafari H, Ebrahimi A, Aghaei A, Khatony A. The relationship between care burden and quality of life in caregivers of hemodialysis patients. BMC Nephrol. 2018; 19(1): 321. https://doi.org/10.1186/s12882-018-1120-1.

81. Lin WC, Tsai CF, Wang SJ, Hwang JP, Fuh JL. Comparison of the burdens of family caregivers and foreign paid caregivers of the individuals with dementia. Int Psychogeriatr. 2012; 24(12): 1953-1961. https://doi.org/10.1017/S1041610212001354.

82. Ebert AR, Bernstein LE, Carney AK, Patrick JH. Emotional Well-being During the First Four Months of COVID-19 in the United States. J Adult Dev. 2020; , 1-8. Online ahead of print. https://doi.org/10.1007/s10804-020-09365-x.

83. Adejumo OA, lyawe IO, Akinbodewa AA, Abolarin OS, Alli EO. Burden, psychological well-being and quality of life of caregivers of end stage renal disease patients. Ghana Med J. 2019; 53(3): 190-196. https://doi.org/10.4314/gmj.v53i3.2.

84. Lin SY. 'Dementia-friendly communities' and being dementia friendly in health care settings. Curr Opin Psychiatry. 2017; 30(2): 145-150. https://doi.org/10.1097/ YCO.0000000000000304.

85. Ong HL, Vaingankar JA, Abdin E, Sambasivam R, Fauziana R, Tan ME, et al. Resilience and burden in caregivers of older adults: moderating and mediating effects of perceived social support. BMC Psychiatry. 2018; 18(1): 27. https://doi.org/10.1186/ s12888-018-1616-z.

86. Swartz K, Collins LG. Caregiver Care. Am Fam Physician. 2019; 99(11): 699-706. 


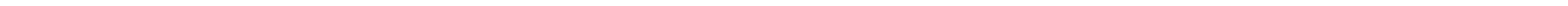


13. Anexos

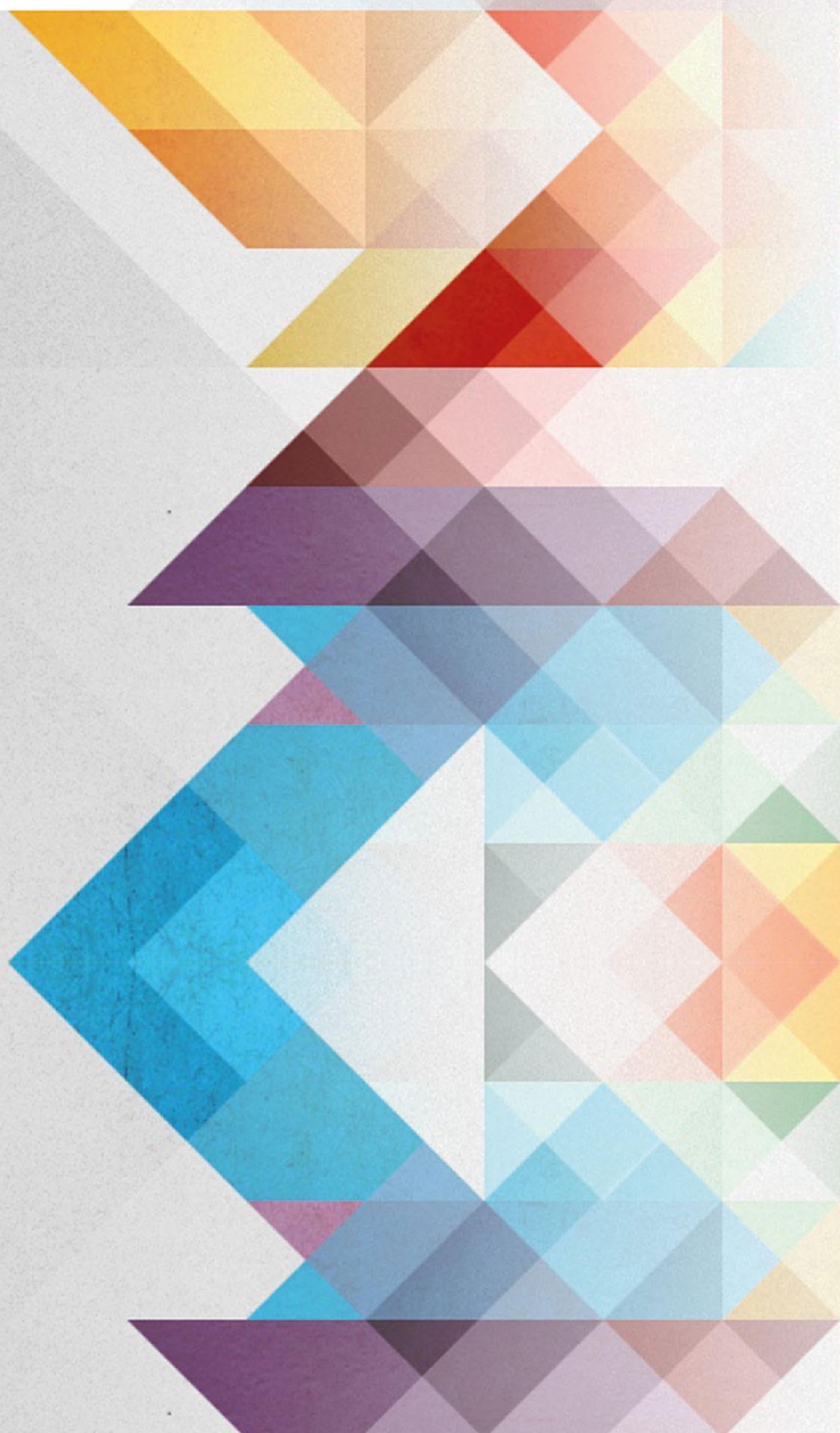


ANEXO 1:

Çarta de aprobación por el Comité Ético para la Investigación Clínica 



\section{ANEXO 2:}

Hoja de Consentimiento Informado para los cuidadores informales 
Investigador principal: Cindy E. Frías Torres

TÍTULO DEL PROYECTO:Evaluación de una intervención innovadora, informativa formativa y de apoyo social "INFOSA-DEM" dirigida a cuidadores informales de personas con demencia en relación a la sobrecarga, y el bienestar emocional.

Persona que sufre de demencia

Yo. , con DNI. declaro que he leído la Hoja de Información al paciente, de la que se me ha entregado una copia. Se me han explicado las características del estudio, así como los posibles beneficios y riesgos que puedo esperar, los derechos que puedo ejercitar, y las previsiones sobre el tratamiento de datos. He recibido suficiente información sobre el estudio.

Sé que se mantendrá en secreto mi identidad y que se identificarán mis muestras con un sistema de codificación. Soy libre de revocar mi consentimiento en cualquier momento y por cualquier motivo, sin tener que dar explicación y sin que repercuta negativamente sobre cualquier tratamiento médico presente o futuro.

Yo doy mi consentimiento para que se utilicen mis datos asociados como parte de este proyecto de investigación. Consiento en participar voluntariamente.

Fecha

Firma del paciente

Fecha

Firma representante legal (si procede)..

Nombre representante legal:

Relación con el paciente:

Cuidador informal (familiar u otro)

Yo. con DNI declaro que he leído la Hoja de Información al paciente, de la que se me ha entregado una copia. Se me han explicado las características del estudio, así como los posibles beneficios y riesgos que puedo esperar, los derechos que puedo ejercitar, y las previsiones sobre el tratamiento de datos. He recibido suficiente información sobre el estudio.

Sé que se mantendrá en secreto mi identidad y que se identificarán mis muestras con un sistema de codificación. Soy libre de revocar mi consentimiento en cualquier momento y por cualquier motivo, sin tener que dar explicación y sin que repercuta negativamente sobre cualquier tratamiento médico presente o futuro.

Yo doy mi consentimiento para que se utilicen los datos asociados como parte de este proyecto de investigación. Consiento en participar voluntariamente.

Fecha Firma del cuidador informal

Dirección Teléfono de contacto.

Constato que he explicado las características del proyecto de investigación y las condiciones de conservación que se aplicarán a la muestra y a los datos conservados. Nombre del Investigador o la persona designada para proporcionar la información: 


\section{ANEXO 3:}

Documento informativo sobre el

proyecto y el programa INFOSA-DEM 


\section{PROGRAMA “INFOSA DEM”: Evaluación de una intervención innovadora, informativa formativa y de apoyo social "INFOSA-DEM" dirigida a cuidadores informales de personas con demencia en relación a la sobrecarga, depresión y la ansiedad.}

\section{OBJETIVO}

Desarrollar, implementar y evaluar el impacto de una intervención innovadora informativa, formativa y de apoyo social "INFOSA-DEM", para cuidadores informales de padentes con demencia en el domicilio, en relación a la sobrecarga, depresión y la ansiedad, y consecuencias positivas del cuidado, soporte social percibido y mejores prácticas efectivas.

\section{¿A QUIÉN VA DIRIGIDO?}

Cuidadores informales (no remunerados) de pacientes mayores de 65 años con demencia que desarrollen su rol de cuidador en el domicilio. Dentro de esta población se excluirán aquellos candidatos que presenten las siguientes caracteristicas:

\section{- Cuidadores informales}

- Ser menor de 18 años.

- Tener una enfermedad fisica o mental invalidante.

- La existencia de una barrera idiomática que dificulte la comuncación, lectura y comprensión del castellano.

- Haber partidpado en grupos de soporte o intervenciones psicoeducativas en el último año.

\section{- Personas con demencia}

- Ser menor de 65 años.

- Tener una puntuación >24 MNSE y/o historia personal de trastornos psiquiátricos o sindrome de Korsakoff.

*Se considerará cuidador informal a la persona (familiar o no) que se encargue del cuidado de la persona con demencia, viva con el o al menos to visite 3 veces por semana.

\section{INTERVENCIÓN EDUCATIVA: “INFOSA DEM”}

El programa ha sido diseñado por profesionales de enfermeria, con el objetivo de proporcionar a los cuidadores ayuda personalizada en la adquisición de habilidades para el cuidado domiciliario de personas con demencia.

\section{Diseño de la intervención}

El programa constará de 5 sesiones grupales en grupos reducidos de 6 personas. La frecuencia de las sesiones será semanal con una duración aproximada de 90 minutos/sesión.

A los 3 y 6 meses de haber finalizado las sesiones, se realizará un seguimiento a los participantes que consistirá en la cumplimentación de cuestionarios, con el objetivo de evaluar el efecto de la intervención. 


\section{Temas a tratar}

- Información sobre la demencia

- Higiene corporal y problemas de eliminación

- Nutrición y medicación

- Estrategias de comunicación entre el cuidador informal y la persona con demencia

- Alteraciones de la conducta y trastorno del sueño

- Cuidar al cuidador

- Apoyo Social y Recursos de la comunidad

\section{RECLUTAMIENTO}

Se reclutarán un total de 160 cuidadores. De los candidatos seleccionados 80 recibirán la intervención educativa INFOSA-DEM y los 80 restantes formaran parte del grupo control.

\section{¿Cómo se realizará? ¿Quién se encargará de ello?}

El periodo de reclutamiento se realizará durante el año 2017. Pasado este periodo hasta el mes de junio, se continuarán comunicando al equipo investigador aquellos casos detectados que no han sido incluidos previamente, con el objetivo de cubrir cualquier necesidad que pueda surgir relacionada con el tamaño de la muestra.

\section{¿Qué hago ante un posible candidato?}

Ante la detección de un posible candidato, es preciso ponerse en contacto con los miembros del equipo investigador, a través de los datos de contacto que aparecen en la parte posterior. Independientemente del medio utilizado (via telefónica o correo electrónico), se deberá facilitar el nombre completo del paciente y del cuidador, seguido de un teléfono de contacto, junto con el nombre del centro de atención primaria de referencia del candidato. Para más información contactar con:

\section{Telf. 932275400 Ext 4421}

Cindy Frias: cfrias@clinic.ub.es

\section{PROGRAMA INFOSA-DEM}

Información, Formación y Apoyo Social al Cuidador de Personas con Demencia. Proyecto financiado por la Marató TV3. 
ANEXO 4:

Cuestionario de satisfacción 
PROGRAMA INFOSA-DEM: Evaluación de una intervención innovadora informativa y de apoyo social a los cuidadores de personas con demencia en el domicilio.

\section{CUESTIONARIO DE SATISFACCIÓN}

A continuación, le realizaremos unas preguntas en relación a la satisfacción que usted ha teniclo después de haber participado en la intervención psico-educativa INFOSA-DEM. Por fasor, responda cada pregunta marcando con un círculo la altemativa que mejor responde a su punto de vista. Cada respuesta va de $0-3$, donde $3=$ Totalmente de acuerdo y $0=$ Totalmente en desacuerdo.

\begin{tabular}{|c|c|c|c|c|c|}
\hline & & $\begin{array}{l}\text { Totalmente de } \\
\text { acuerdo }\end{array}$ & $\begin{array}{l}\text { Bastante de } \\
\text { acuerdo }\end{array}$ & $\begin{array}{l}\text { Poco de } \\
\text { acuerdo }\end{array}$ & $\begin{array}{l}\text { Totalmente en } \\
\text { desacuerdo }\end{array}$ \\
\hline 1 & El ambiente del grupo ha sido agradable. & 3 & 2 & 1 & 0 \\
\hline 3 & La información que he recibido sobre la enfermedad ha sido suficiente. & 3 & 2 & 1 & 0 \\
\hline 5 & $\begin{array}{l}\text { Ha sido suficiente la informacion que he recibido sobre como afrontar } \\
\text { las alteraciones conouctuales (desorientación, deambulacion...; de mi } \\
\text { iamiliar. }\end{array}$ & 3 & 2 & 1 & 0 \\
\hline 6 & A partir de ahora me resultarà más fäci! comunicarme con mi familiar. & 3 & 2 & 1 & 0 \\
\hline 8 & En general me serà mas fácil cuidar de mi familiar. & 3 & 2 & 1 & 0 \\
\hline 9 & $\begin{array}{l}\text { Ahora me resulta facil solicitar utilizar la ayuda disponible de } \\
\text { familiares y amigos. }\end{array}$ & 3 & 2 & 1 & 0 \\
\hline 10 & Ahora tengo más claro porque es importante cuidar de mi mismo. & 3 & 2 & 1 & 0 \\
\hline 11 & $\begin{array}{l}\text { Me ha resultaco de utilidad la informacion sobre los recursos sociales } \\
\text { disporibles. }\end{array}$ & 3 & 2 & 1 & 0 \\
\hline 12 & $\begin{array}{l}\text { Ahora me siento mejor informado(a) sobre aspectos legales, } \\
\text { económicos y comunitarios. }\end{array}$ & 3 & 2 & 1 & 0 \\
\hline 13 & Me siento mejor por haber compartido mi experiencia como cuidador a. & 3 & 2 & 1 & $\hat{0}$ \\
\hline 15 & $\begin{array}{l}\text { Las preguntas que he realizado o realizo otro cuidador a fueron } \\
\text { respondidas de forma clara. }\end{array}$ & 3 & 2 & 1 & 0 \\
\hline 16 & La persona que realizó la intervenciōn educatita se explicó claramente. & 3 & 2 & 1 & 0 \\
\hline 17 & Mie han sido suŕcientes el nímero de sesiones. & 3 & 2 & 1 & 0 \\
\hline 18 & La duración de las sesiones formatitas han sido adecuadas para mi. & 3 & 2 & 1 & 0 \\
\hline
\end{tabular}

PROGRAMA INFOSA-DEM

Mormación, Formacion y Apoyo Social ai cuidador de Personas con Demencia Provecto financiado por la Marato TV3 


\section{ANEXO 5:}

Tríptico Informativo sobre el proyecto y el programa INFOSA-DEM 


\section{PROGRAMA INFOSA-DEM}

Información, Formación y Apoyo Social a los Cuidadores de Personas con Demencia

INFOSA-DEM es un programa liderado por profesionales de enfermeria con el objetivo de proporcionar a los cuidadores ayuda personalizada en la adquisición de habilidades para el cuidado domiciliario de personas con demencia. Este programa combina la formación presencial y el uso de material audiovisual (TIC) como método útil de aprendizaje activo.

\section{¿A quién va dirigido?}

Curidadores familiares de personas con demencia que estén interesados en compartir su experiencia con otros cuidadores y adquirir nuevos conocimientos para el desarrollo del cuidado domiciliario.

\section{¿Quién lo imparte?}

Enfermeras del Hospital Clínic especialistas en el ámbito clínico de las demencias, con la colaboración de médicos y trabajadoras sociales.

\section{¿En qué consiste?}

El programa consta de 5 sesiones presenciales, de grupos reducidos y una duración aproximada de 90 minutos/sesión.

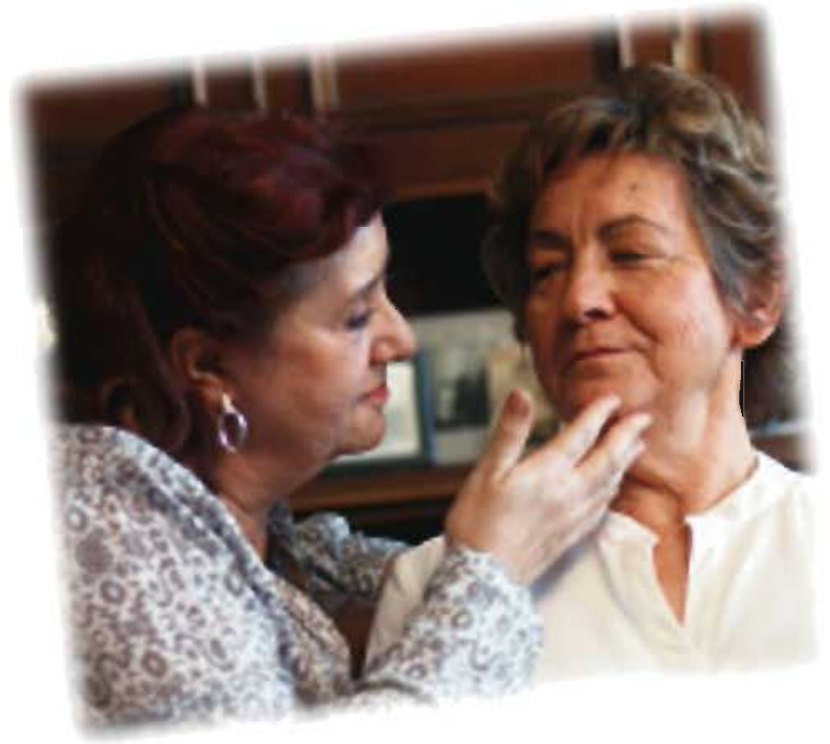

\section{¿Con quién debo contactar?}

Con su médico o enfermera de referencia del CAP/Hospital, o en el $n^{\circ}$ de teléfono 932275400 Ext. 4421. La participación en el programa deberá ser confirmada previamente a la realización de las sesiones.

\section{¿Dónde se realizará?}

Hospital Clinic de Barcelona. Centro Esther Koplowitz (Edificio CEK): C/Rosellón 149-153, 0 Hospital Clinic (L5)

\section{¿Cuándo se realizará?}

De Lunes a Viernes: Mañanas de 11:00 a 12:30 horas o Tardes de 17:30 a 19 horas 
ANEXO 6: Cuestionarios de recogida de la información para el cuidador y la Persona con demencia 
Participant ID:
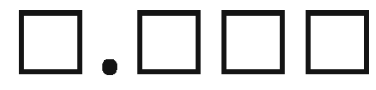

Visit: $1 \square 2 \square 3 \square$ TR $\square$

\section{Cuestionario INFOSA-DEM}

Parte A. incluye consentimiento informado e información sobre los criterios de inclusión.

(Cumplimentado por el investigador)

A1 Fecha nacimiento del participante:

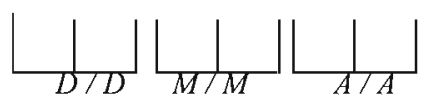

A2 Número ID participante*:

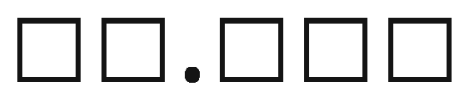

A3 $\square \quad$ Consentimiento recibido

Fecha:

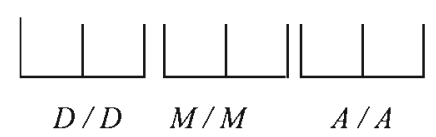

A4 $\square$

Visita 1 (Basal)

Fecha:

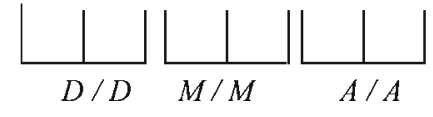

A5 $\square$

Visita TR (15d post-basal)

Fecha:

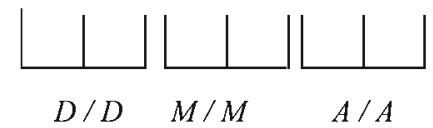

A6 $\square \quad$ Visita 2 (Fup 3m)

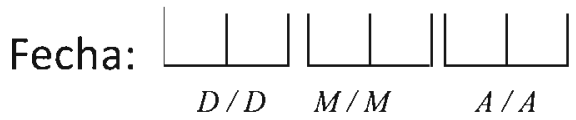

A7 $\square \quad$ Visita 2 (Fup 6m)

Fecha:

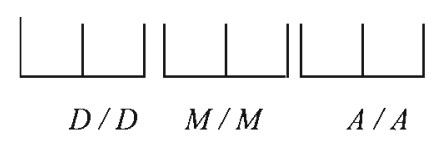

* El número de ID contiene 5 dígitos:

XX para el código de la institución y XXX para el número del paciente. 
Participant ID:

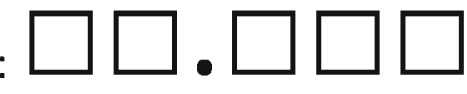

Visit: $1 \square 2 \square 3 \square$ TR $\square$

\section{Criterios inclusión de pacientes que reciben cuidados en el domicilio}

A8 No $\square$ Sí $\square \quad$ Diagnóstico de probable demencia establecido por un médico * * ( e.j. geriatra, médico especialista, médico generalista, neurólogo o un equipo especializado)

A9 No $\square$ Si $\square \quad$ Puntuación en el Mini-Mental State Examination (MMSE) $240<$

A10 No $\square$ Si $\square \quad$ Identificación del cuidador informal/persona de referencia que realice visitas al paciente al menos tres veces a la semana

A11 No $\square \quad$ Sí $\square \quad$ Vivir en el domicilio con apoyo de atención profesional

A12 No $\square$ Sí $\square \quad$ Consentimiento informado firmado

Todas las preguntas deben ser "SI"

\section{Criterios exclusión de pacientes que reciben cuidados en el domicilio}

A13 No $\square \quad$ Sí $\square \quad$ Paciente $<65$ años

A14 No $\square \quad$ Sí $\square \quad$ Paciente con diagnóstico psiquiátrico primario o Síndrome de Korsakoff

A15 No $\square$ Sí $\square \quad$ Paciente cuyo cuidador informal no puede ser identificado

A16 No $\square$ Sí $\square \quad$ Paciente cuyo cuidador informal presenta una enfermedad física o mental invalidante.

A17 No $\square$ Sí $\square \quad$ Paciente cuyo cuidador informal ha participado en grupos de soporte o intervenciones psicoeducativas en el último año.

Todas las preguntas deben ser "NO"

- En el caso de que la pregunta A17 sea positiva administrar paquete reducido 
Participant ID
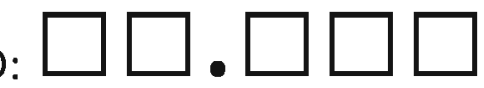

Visit: 1

$2 \square 3$

$3 \square \mathrm{TR} \square$

\section{Cuestionario INFOSA-DEM}

Parte A. incluye consentimiento informado e información sobre

los criterios de inclusión.

Información sobre el PACIENTE

(Cumplimentado por el investigador)

\section{Información demográfica básica}

P1 Sexo

$\square \quad$ Hombre

$\square \quad$ Mujer

P2 Edad

años

\section{Historia del paciente}

P3 Tipo de demencia:

$\begin{array}{ll}\square & \text { Demencia tipo Alzheimer (AD) } \\ \square & \text { AD con enfermedad cerebrovascular } \\ \square & \text { Demencia vascular } \\ \square & \text { Demencia Frontotemporal } \\ \square & \text { Demencia de Cuerpos de Lewy } \\ \square & \text { Desconocida } \\ \square & \text { Otros }\end{array}$

P4 Año de inicio de los síntomas de demencia:

$\square$ Desconocido

$\square \quad$ Conocido, si lo conoce por favor indíquela

P4.1 Año de inicio:

P4.1 Fecha del diagnóstico (si está disponible):

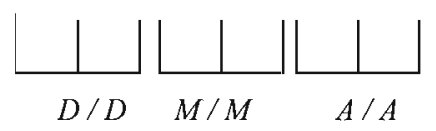


Participant ID: $\square \square . \square \square \square$ Visit: $1 \square 2 \square 3 \square$ TR $\square$

\section{P5. Índice de comorbilidad de Charlson}

\begin{tabular}{|c|c|}
\hline Condición de enfermedad* & Valor asignado a la enfermedad \\
\hline P5.1 $\square$ Infarto de miocardio & \multirow{10}{*}{1} \\
\hline P5.2 $\square$ Insuficiencia cardíaca & \\
\hline$\square$ Enfermedad arterial periférica & \\
\hline P5.4 $\square$ Enfermedad cerebrovascular & \\
\hline P5.5 $\square$ Demencia & \\
\hline P5.6 $\square$ Enfermedad respiratoria crónica & \\
\hline P5.7 $\square$ Enfermedad del tejido conectivo & \\
\hline P5.8 $\square$ Úlcera gastroduodenal & \\
\hline P5.9 $\square$ Hepatopatía crónica leve & \\
\hline P5.10 $\square$ Diabetis & \\
\hline P5.11 $\square$ Hemiplegia & \multirow{6}{*}{2} \\
\hline P5.12 $\square$ Insuficiencia renal crónica moderada/severa & \\
\hline P5.13 $\square$ Diabetes con lesión en órganos diana & \\
\hline P5.14 $\square$ Tumor o neoplasia sólida & \\
\hline P5.15 $\square$ Leucemia & \\
\hline P5.16 $\square$ Linfoma & \\
\hline P5.17 $\square$ Hepatopatía crónica moderada/severa & 3 \\
\hline P5.18 $\square$ Tumor o neoplasia sólida con metástasis & \multirow[b]{2}{*}{6} \\
\hline P5.19 $\square$ Sida definido & \\
\hline
\end{tabular}

Charlson ME, Pompei P, Ales K, MacKenzie CR. A new method of classifying prognostic comorbidity in longitudinal studies: development 
Participant ID: $\square \square$. $\square \square \square$ Visit: $1 \square 2 \square 3 \square$ TR $\square$

\title{
MMSE
}

P6 Evaluación

\author{
$\square \quad$ Evaluación completada, resultado fiable \\ $\square \quad$ Inaplicable/incapacidad para responder/negativa del paciente a \\ colaborar/falta de motivación \\ $\square \quad$ Inaplicable/incapacidad física para responder/incapacidad \\ cognitiva (ej. visual/discapacidad auditiva, afasia) \\ $\square \quad$ No se realizó la valoración, no se intentó completar la prueba
}

\section{Si existe una valoración reciente del test MMSE (menos de un mes) por favor, indique la puntuación total}

P7 puntuación disponible $|\quad|$ puntuación total

Voy a hacerle algunas preguntas y puede que tenga algunos problemas para resolver las preguntas. Por favor, trate de responder lo mejor que pueda.

\begin{tabular}{|l|r|r|}
\hline preguntas & \multicolumn{2}{l|}{ Puntuación } \\
\hline P8 (tiene 10 segundos para cada respuesta) & 1 punto x pregunta \\
\cline { 2 - 3 } P8.1 ¿En qué año estamos? ( aceptar la respuesta exacta) & 0 puntos & 1 punto \\
P8.2 ¿En qué estación estamos? (durante la última semana de la anterior & $\square$ & $\square$ \\
estación o la primera de la nueva estación acepte cualquiera de las & \\
dos) & \\
P8.3 ¿En que es mes del año estamos? (acepte como correcto el último día & \\
del mes anterior o el primero del mes actual) & \\
P8.4 ¿Qué fecha es hoy? (aceptar el anterior o posterior a la fecha) & \\
P8.5 ¿Qué día de la semana estamos? (aceptar solo la respuesta correcta) & $\square$ \\
\hline
\end{tabular}




\section{P9 (tiene 10 segundos para cada respuesta)}

P9.1 ¿En que país estamos? (acepte la respuesta exacta) P9.2 ¿En qué provincia ? (acepte la respuesta exacta solo) P9.3 ¿En qué ciudad o pueblo? (acepte solo la respuesta exacta) P9.4 Cuál es la dirección de su casa (acepte el nombre y el número de la casa o equivalente en área rurales)

\section{P9.5 ¿En qué lugar estamos? (acepte solo la respuesta exacta)}

P10 Diga « Le voy a nombrar tres objetos. Cuando termine, quiero que los repita. Recuerde lo que son porque voy a pedirle que los nombre una vez más en unos pocos minutos. (Repita a razón de 1 segundo)

\section{Peseta Caballo Manzana}

Repita estas 3 palabras hasta aprenderlas.

( 1 punto por cada respuesta correcta en el primer intento) Espere 20 segundos para la respuesta, si el sujeto no repite las 3 , repetir hasta que las aprenda cono máximo de 5 veces 8 pero solo puntúa el primer intento de respuesta)

\section{P11 Deletrear la palabra "Mundo" al revés}

(puede ayudar a la persona a deletrear la palabra mundo) Ahora dígala al revés. Si el sujeto no la puede deletrear ni con ayuda la puntuación es 0

\section{P12 ¿Recuerda las palabras que le he dicho antes?}

Puntuación. 1 punto por cada respuesta correcta, no importa el orden; espere 10 segundos

\section{P13 Mostrar un reloj, ¿que es esto?}

Puntuación: 1 punto por respuesta correcta. (espere 10 segundos)
1 punto x pregunta

\begin{tabular}{c|r}
\hline 0 puntos & 1 punto \\
$\square$ & $\square$ \\
$\square$ & $\square$ \\
$\square$ & $\square$ \\
$\square$ & $\square$ \\
$\square$ & \\
$\square$ & $\square$
\end{tabular}

0 punto

1 punto

2 punto

3 punto $\square$
0 punto $\square$

1 punto

2 punto $\square$

3 punto

4 punto

5 punto

0 punto

1 punto

2 punto

3 punto $\square$ 


\begin{tabular}{|c|c|c|}
\hline $\begin{array}{l}\text { P14 Repítelo con un bolígrafo } \\
\text { Puntuación: } 1 \text { punto por respuesta correcta, aceptar solo bolígrafo - } \\
\text { puntuación } 0 \text { para lápiz. espere } 10 \text { segundos }\end{array}$ & $\begin{array}{r}0 \text { punto } \\
\square\end{array}$ & $\begin{array}{r}1 \text { punto } \\
\square\end{array}$ \\
\hline $\begin{array}{l}\text { P15 Repita esta frase: “Ni sí, ni no, ni peros" } \\
\text { ( espere } 10 \text { segundos para responder . } 1 \text { punto para la respuesta exacta }\end{array}$ & $\begin{array}{r}0 \text { punto } \\
\square\end{array}$ & 1 punto \\
\hline $\begin{array}{l}\text { P16 Diga: Lea esto y haga lo que dice: } \\
\text { CIERRE LOS OJOS }\end{array}$ & $\begin{array}{r}0 \text { puntos } \\
\square\end{array}$ & 1 punto \\
\hline $\begin{array}{l}\text { P17 Escriba una frase } \\
\text { Diga: Escriba una frase en esta hoja. Espere } 30 \text { segundos }\end{array}$ & $\begin{array}{r}0 \text { puntos } \\
\square\end{array}$ & $\begin{array}{r}1 \text { punto } \\
\square\end{array}$ \\
\hline $\begin{array}{l}\text { P18 Copie este dibujo } \\
\text { Diga: copie este dibujo. Máximo de tiempo-1 minuto }\end{array}$ & $\begin{array}{r}0 \text { puntos } \\
\square\end{array}$ & $\begin{array}{r}1 \text { punto } \\
\square\end{array}$ \\
\hline \multicolumn{3}{|l|}{$\begin{array}{l}\text { P19 Coja este papel con la mano derecha, dóblelo y póngalo encima de la } \\
\text { mesa } \\
\text { Preguntar si el sujeto es diestro o zurdo. e j. Si el sujeto es diestro: tome } \\
\text { este papel con la mano izquierda. Decir: Tome este papel con la mano } \\
\text { derecha/izquierda dóblelo por la mitad una vez con las dos manos y } \\
\text { póngalo encima de la mesa: Espere } 30 \text { segundos. Puntuación } 1 \text { punto para } \\
\text { cada instrucción correctamente realizada }\end{array}$} \\
\hline & 0 puntos & 1 punto \\
\hline $\begin{array}{l}\text { P19.1 Toma el papel con la mano correcta } \\
\text { P19.2 Lo dobla por la mitad } \\
\text { P19.3 Lo pone encima de la mesa }\end{array}$ & $\begin{array}{l}\square \\
\square \\
\square\end{array}$ & $\begin{array}{l}\square \\
\square \\
\square\end{array}$ \\
\hline Total puntua & & \\
\hline
\end{tabular}




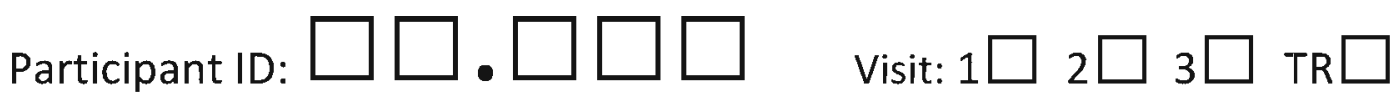

\section{P20. QOL-AD}

\section{P20.1 MOVILIDAD}

No tengo problemas para caminar.

Tengo algunos problemas para caminar

Tengo que estar en la cama

\section{P20.2 CUIDADO PERSONAL}

No tengo problemas con el cuidado personal.

Tengo algunos problemas para lavarme o vestirme solo

Soy incapaz de lavarme o vestirme solo.

P20.3 ACTIVIDADES de Todos los Días (ej. trabajar, estudiar, hacer tareas domésticas, actividades familiares o realizadas durante el tiempo libre)

Tengo algunos problemas para realizar mis actividades de todos los días.

No tengo problemas para realizar mis actividades de todos los días.

Soy incapaz de realizar mis actividades de todos los días.

\section{P20.4 Dolor/Malestar}

No tengo dolor ni malestar.

Tengo moderado dolor o malestar.

Tengo mucho dolor o malestar.

\section{P20.5 Ansiedad/Depresión}

No estoy ansioso/a ni deprimido/a.

Estoy moderadamente ansioso/a o deprimido/a.

Estoy muy ansioso/a o deprimido/a
Para ayudar a la gente a describir lo bueno o malo que es su estado de salud, hemos dibujado una escala parecida a un termómetro en el cual se marca con un 100 el mejor estado de salud que puede imaginarse, y con un 0 el peor estado de salud que puede imaginarse.

Por favor, dibuje una línea desde el cuadro que dice "su estado de salud hoy," hasta el punto en la escala que, en su opinión, indique lo bueno o malo que es su estado de saluden el día de hoy

P20.6 Total puntuación

\section{Su estado de salud hoy}

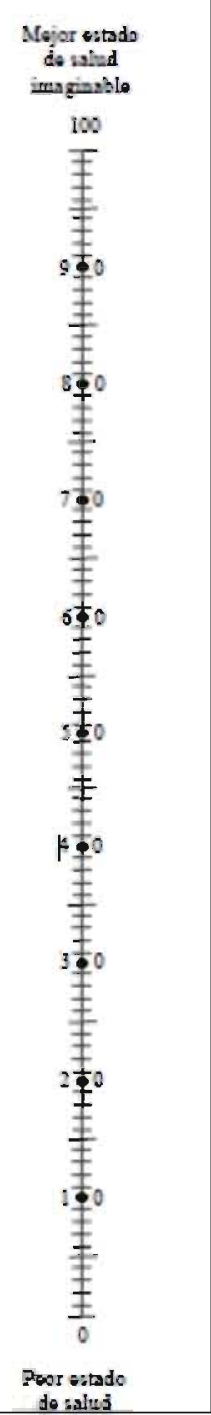

P21: Evaluación

Evaluación completada, resultado fiable

Inaplicable/incapacidad para responder/negativa del paciente a colaborar/falta de motivación

$\square \quad$ Inaplicable/incapacidad física para responder/incapacidad cognitiva (ej. visual/discapacidad auditiva, afasia)

$\square \quad$ No se realizó la valoración, no se intentó completar la prueba 
P22: Evaluación

Evaluación completada, resultado fiable

Inaplicable/incapacidad para responder/negativa del paciente a colaborar/falta de motivación

No se realizó la valoración, no se intentó completar la prueba

\section{P.23 Si existe una valoración reciente del test GDS (menos de un mes) por favor, indique la}

\section{fase en la que se encuentra el paciente}

$\square$ GDS 1: Ausencia de déficil cognitivo

$\square$ GDS 2: Déficit cognitivo muy leve

$\square$ GDS 3: Déficit cognitivo leve

$\square$ GDS 4: Déficit cognitivo moderado

$\square$ GDS 5: Déficit cognitivo moderadamente grave

$\square \quad$ GDS 6: Déficit cognitivo grave

$\square$ GDS 7: Déficit cognitivo muv grave

\begin{tabular}{|c|c|c|c|}
\hline Estadío & Fase clínica & Características FAST & Comentario \\
\hline GDS 1 & $\begin{array}{l}\text { Normal } \\
\text { MEC: } 30-35\end{array}$ & $\begin{array}{l}\text { Ausencia de déficit funcionales } \\
\text { objetivos o subjetivos. }\end{array}$ & No hay deterioro cognitivo subjetivo ni objetivo \\
\hline GDS 2 & $\begin{array}{l}\text { Normal para } \\
\text { su edad. } \\
\text { Olvido } \\
\text { MEC: } 25-30\end{array}$ & Déficit funcional subjetivo & $\begin{array}{l}\text { Quejas de perdida de memoria en ubicación de objetos, } \\
\text { nombres de personas, citas, etc. } \\
\text { No se objetiva déficit en el examen clínico ni en su medio } \\
\text { laboral o situaciones sociales. } \\
\text { Hay pleno conocimiento y valoración de la } \\
\text { sintomatología. }\end{array}$ \\
\hline GDS 3 & $\begin{array}{l}\text { Deterioro } \\
\text { límite } \\
\text { MEC: } 20-27\end{array}$ & $\begin{array}{l}\text { Déficit en tareas ocupacionales y } \\
\text { sociales complejas y que } \\
\text { generalmente lo observan familiares y } \\
\text { amigos }\end{array}$ & $\begin{array}{l}\text { Primeros defectos claros. Manifestación en una o más } \\
\text { de estas áreas: } \\
\text { - Haberse perdido en un lugar no familiar } \\
\text { - Evidencia de rendimiento laboral pobre } \\
\text { - Dificultad para recordar palabras y nombres } \\
\text { - tras la lectura retiene escaso material } \\
\text { - olvida la ubicación, pierde o coloca erróneamente } \\
\text { objetos de valor } \\
\text { - escasa capacidad para recordar a personas nuevas que } \\
\quad \text { ha conocido } \\
\text { El déficit de concentración es evidente para el clínico en } \\
\text { una entrevista exhaustiva. } \\
\text { La negación como mecanismo de defensa ,o el } \\
\text { desconocimiento de los defectos, empieza a }\end{array}$ \\
\hline
\end{tabular}


Participant ID:

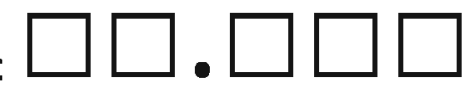

Visit: $1 \square 2 \square 3 \square$ TR $\square$

\begin{tabular}{|c|c|c|c|}
\hline & & & $\begin{array}{l}\text { manifestarse. } \\
\text { Los síntomas se acompañan de ansiedad leve moderada }\end{array}$ \\
\hline GDS 4 & $\begin{array}{l}\text { Alzheimer } \\
\text { leve } \\
\text { MEC: } 16-23\end{array}$ & $\begin{array}{l}\text { Déficits observables en tareas } \\
\text { complejas como el control de los } \\
\text { aspectos económicos personales o } \\
\text { planificación de comidas cuando hay } \\
\text { invitados }\end{array}$ & $\begin{array}{l}\text { Defectos manifiestos en: } \\
\text { - olvido de hechos cotidianos o recientes } \\
\text { - déficit en el recuerdo de su historia personal } \\
\text { - dificultad de concentración evidente en operaciones de } \\
\text { resta de } 7 \text { en } 7 \text {. } \\
\text { - incapacidad para planificar viajes, finanzas o } \\
\text { actividades complejas } \\
\text { - Labilidad afectiva } \\
\text { - Mecanismo de negación domina el cuadro } \\
\text { Frecuentemente no hay defectos en: } \\
\text { - orientación en tiempo y persona } \\
\text { - reconocimiento de caras y personas familiares } \\
\text { - capacidad de viajar a lugares conocidos }\end{array}$ \\
\hline GDS 5 & $\begin{array}{l}\text { Alzheimer } \\
\text { moderado } \\
\text { MEC: } 10-19\end{array}$ & $\begin{array}{l}\text { Decremento de la habilidad en } \\
\text { escoger la ropa adecuada en cada } \\
\text { estación del año o según las ocasiones }\end{array}$ & $\begin{array}{l}\text { Necesita asistencia en determinadas tareas, no en el aseo } \\
\text { ni en la comida, pero sí para elegir su ropa Es incapaz de } \\
\text { recordar aspectos importantes de su vida cotidiana } \\
\text { (dirección, teléfono, nombres de familiares) } \\
\text { Es frecuente cierta desorientación en tiempo o en } \\
\text { lugar Dificultad para contar en orden inverso desde } 40 \text { de } \\
4 \text { en } 4 \text {, o desde } 20 \text { de } 2 \text { en } 2 \\
\text { Sabe su nombre y generalmente el de su esposa e hijos }\end{array}$ \\
\hline$\overline{\text { GDS } 6}$ & $\begin{array}{l}\text { Alzheimer } \\
\text { moderada- } \\
\text { mente grave } \\
\text { MEC: } 0-12\end{array}$ & $\begin{array}{l}\text { Decremento en la habilidad para } \\
\text { vestirse, bañarse y lavarse; } \\
\text { específicamente, pueden identificarse } \\
5 \text { subestadios siguientes: } \\
\text { a) disminución de la habilidad de } \\
\text { vestirse solo } \\
\text { b) disminución de la habilidad para } \\
\text { bañarse solo } \\
\text { c) disminución de la habilidad para } \\
\text { lavarse y arreglarse solo } \\
\text { d) disminución de la continencia } \\
\text { urinaria e)disminución de la } \\
\text { continencia fecal }\end{array}$ & $\begin{array}{l}\text { Olvida a veces el nombre de su esposa de quien depende } \\
\text { para vivir Retiene algunos datos del } \\
\text { pasado Desorientación temporo espacial. } \\
\text { Dificultad para contar de } 10 \text { en } 10 \text { en orden inverso o } \\
\text { directo Puede necesitar asistencia para actividades de la } \\
\text { vida diaria } \\
\text { Puede presentar incontinencia Recuerda su nombre y } \\
\text { diferencia los familiares de los desconocidos Ritmo } \\
\text { diurno frecuentemente alterado } \\
\text { Presenta cambios de la personalidad y la afectividad } \\
\text { (delirio, síntomas obsesivos, ansiedad, agitación o } \\
\text { agresividad y abulia cognoscitiva) }\end{array}$ \\
\hline GDS 7 & $\begin{array}{l}\text { Alzheimer } \\
\text { grave } \\
\text { MEC: } 0\end{array}$ & $\begin{array}{l}\text { Pérdida del habla y la capacidad } \\
\text { motora Se especifican } 6 \text { subestadios: } \\
\text { a) capacidad de habla limitada } \\
\text { aproximadamente a } 6 \text { palabras } \\
\text { b) capacidad de habla limitada a una } \\
\text { única palabra } \\
\text { c) pérdida de la capacidad para } \\
\text { caminar solo sin ayuda } \\
\text { d) pérdida de la capacidad para } \\
\text { sentarse y levantarse sin ayuda } \\
\text { e) pérdida de la capacidad para } \\
\text { sonreir } \\
\text { f) pérdida de la capacidad para } \\
\text { mantener la cabeza erguida }\end{array}$ & $\begin{array}{l}\text { Perdida progresiva de todas las capacidades verbales } \\
\text { Incontinencia urinaria Necesidad de asistencia a la } \\
\text { higiene personal y alimentación } \\
\text { Pérdida de funciones psicomotoras como la deambulación } \\
\text { Con frecuencia se observan signos neurológicos }\end{array}$ \\
\hline
\end{tabular}


Participant ID: $\square \square . \square \square \square \quad$ Visit: $1 \square 2 \square$ 3 $\square$ TR 



\section{Cuestionario INFOSA-DEM}

\section{Parte A. incluye consentimiento informado e información sobre \\ los criterios de inclusión. \\ Información sobre el CUIDADOR INFORMAL}

(Cumplimentado por el investigador)

\section{Preguntas relacionadas con el proceso educativo \\ Cumplimentar por el/la cuidador/a principal/familiar más cercano}

C1. Durante el proceso de la enfermedad de la persona que cuida, ¿ha participado en algún taller o actividad formativa/informativa relacionada con el cuidado de la persona con demencia? Marque con una cruz una de las dos opciones.

No Si la respuesta es NO, pase a la pregunta C2.

$\square$ Sí Conteste a las preguntas que aparecen a continuación (C1.1, C1.2, C1.3 y C1.4)

C1.1 Indique el número de talleres formativos a los que ha asistido, relacionados con el cuidado de la persona con demencia.

№

C1.2 Seleccione, entre las opciones disponibles, los temas abordados en dichas sesiones formativas (puede seleccionar más de una opción).

C1.2.1. $\square$ Información sobre la demencia

C1.2.2. $\square$ Higiene corporal

C1.2.3. $\square$ Nutrición

C1.2.4. $\square$ Medicación

C1.2.5 $\square$ Estrategias de comunicación entre el cuidador informal y la persona con demencia

C1.2.6. $\square$ Alteraciones de la conducta

C1.2.7. $\square$ Cuidar al cuidador

C1.2.8. $\square$ Apoyo Social y Recursos de la comunidad

TC1.2.9. $\square$ Otros, por favor especificar

C1.3 Indique la Institución/organismo encargado de organizar dichas actividades formativas. Marque con una cruz las opciones que se ajusten a su situación (puede seleccionar más de una opción).

C1.3.1. $\square$ Hospital

C1.3.2 $\square$ Centro de Atención primaria (CAP)

C1.3.3 $\square$ Asociaciones pacientes/cuidadores

C1.3.4 $\square$ Centros de día

TC1.3.5 $\square$ Otros, por favor especificar

C1.4. Una vez finalizadas las sesiones formativas, has continuado el contacto con el resto de participantes del grupo. Marque con una cruz una de las dos opciones. $\square$ Sí $\square$ No 
C2. ¿Cree que los profesionales sanitarios de su centro de referencia, conocen las necesidades de información que usted tiene en relación al cuidado de la persona con demencia? Marque con una cruz la opción que se ajuste más a su situación.

$$
\square \text { Sí } \square \text { No }
$$

C3. ¿ Ha recibido información relacionada con el cuidado de la persona con demencia, por parte de los profesionales sanitarios? (p.ejemplo información sobre la enfermedad, cosas a tener en cuenta para los cuidados en domicilio, opciones de tratamiento, centros de día...).

$$
\begin{aligned}
& \text { No } \\
& \text { Sí }
\end{aligned}
$$

C3.1. ¿Qué profesionales sanitarios han sido los encargados de proporcionarle la información relacionada con el cuidado de la persona con demencia? Marque con una cruz las opciones que se ajusten a su situación (puede seleccionar más de una opción)
C3.1.1. $\square$ Medico de familia
C3.1.2 $\square$ Medico Especialista
C3.1.3 $\square$ Enfermera Atención primaria
C3.1.4 $\square$ Enfermera hospitalización/Consultas
C3.1.5 $\square$ Trabajador social
TC3.1.6 $\square \quad$ Otros, por favor especificar

C3.2 ¿Cómo ha recibido la información por parte de los profesionales sanitarios? Marque con una cruz las opciones que se ajusten a su situación (puede seleccionar más de una opción).
C3.2.1 $\square$ Folletos/guías
C3.2.2 $\square$ Información por escrito
C3.2.3 $\square$ Entrevista individual en la consulta
C3.2.4 $\square$ Sesiones grupales
C3.2.5 $\square$ Contenido audiovisual (videos, películas)
C3.2.6 $\square$ Enseñando cómo se realiza algo de forma práctica
TC3.2.7 $\square$ De otra manera, por favor especificar

C3.3. ¿Considera que el tiempo empleado por parte de los profesionales sanitarios en proporcionarle la información relacionada con el cuidado es el suficiente?

Sí $\square$ No

C3.4.¿Considera que la cantidad de información proporcionada por los profesionales sanitarios de su centro de referencia en relación al cuidado es adecuada para desarrollar el cuidado domiciliario?

प Sí

$\square \quad$ No TC3.4.1 por favor especificar

C3.5. ¿Considera que la información proporcionada ha sido de utilidad para el cuidado de la persona con demencia en su domícilio?

$\square$ Sí $\square$ No

C4. Durante el último año indique de manera aproximada, en cuantas ocasiones ha recibido información en relación al cuidado por parte de los profesionales sanitarios de su centro de referencia, Marque con una cruz la opción que se ajuste más a su situación.
$\square 1$
2
3
4 o más
Ninguna 
C4.1. Durante el último año ¿Qué profesionales sanitarios han sido los encargados de proporcionarle la información relacionada con el cuidado de la persona con demencia? Marque con una cruz las opciones que se ajusten a su situación (puede seleccionar más de una opción) C4.1.1. $\square$ Medico de familia

C4.1.2 $\square$ Medico Especialista

C4.1.3 $\square$ Enfermera Atención primaria

C4.1.4 $\square$ Enfermera hospitalización/Consultas

C4.1.5 $\square$ Trabajador social

TC4.1.6 $\square \quad$ Otros, por favor especificar

C5. Indique con que frecuencia los profesionales sanitarios de su centro de referencia, evalúan el aprendizaje/comprensión de la información que le han proporcionado/enseñado. Marque con una cruz la opción que se ajuste más a su situación.

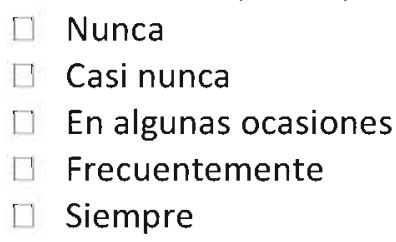

C6. Indique de qué forma los profesionales sanitarios de su centro de referencia, evalúan el aprendizaje/comprensión de la información que le han proporcionado/enseñado. Marque con una cruz las opciones que se ajusten más a su situación (puede seleccionar más de una opción). C6.1. $\square$ Cuestionarios/test

C6.2. $\square$ Preguntas/Verbalización del conocimiento adquirido

C6.3. $\square$ Realización de la técnica aprendida (ejemplos prácticos)

TC6.4. $\square$ Otros, por favor especificar

C7. ¿Conoce el documento de voluntades anticipadas?

$\square$ No Si la respuesta es No, ir directamente a la pregunta $\mathrm{C} 8$.

$\square$ Sí Conteste a las preguntas C7.1 y C7.2.

C7.1. ¿Ha recibido información sobre el documento de voluntades anticipadias por parte de los profesionales sanitarios? $\square$ Sí $\square \quad$ No

C7.2. ¿Conoce si la persona que cuida con demencia ha realizado el documento de voluntades anticipadas? $\quad \square$ Sí $\square$ No $\square$ No lo se

\section{Escala de Competencia para el Cuidado \\ Cumplimentar por el/la cuidador/a principal/familiar más cercano}

Las siguientes preguntas tratan sobre el grado en el que Ud. se siente capacitado para cuidar a un enfermo. Por favor, marque con un círculo el número que lo describe mejor.

\section{Cuánto Usted...}

$$
\text { Nada Solo Algo Mucho }
$$

C8. ¿Cree que ha aprendido a afrontar situaciones difíciles? $\begin{array}{llllll}0 & 1 & 2 & 3\end{array}$

$\begin{array}{lllll}\text { C9. ¿Siente que, en general, es un buen cuidador? } & 0 & 1 & 2 & 3\end{array}$

Pensando en todos los cambios diarios que Ud. pudiera enfrentar al cuidar a un enfermo, la labor que está realizando y la forma en que maneja las dificultades:

$\begin{array}{cccc}\text { Nada } & \begin{array}{c}\text { Solo } \\ \text { un poco }\end{array} & \text { Algo } & \text { Mucho } \\ 0 & 1 & 2 & 3 \\ 0 & 1 & 2 & 3\end{array}$

$\begin{array}{llllll}\text { C10. ¿Cómo de capacitado se siente para cuidar a un enfermo? } & 0 & 1 & 2 & 3 \\ \text { C11. ¿Cómo de seguro se siente en el cuidado del enfermo? } & 0 & 1 & 2 & 3\end{array}$


A continuación, hay unas preguntas referentes a los conocimientos que usted espera recibir sobre el cuidado y el tratamiento de la persona que cuida con demencia. Conteste cada pregunta marcando con un círculo la alternativa que mejor responde a su punto de vista. Para estas preguntas NO existen respuestas correctas o incorrectas, pero estamos interesados en conocer su opinión al respecto.

$\begin{array}{ccccc}\text { Totalmente } & \text { Bastante } & \text { Poco } & \text { Nada } & \text { No aplicable } \\ \text { de acuerdo } & \text { de acuerdo } & \text { de acuerdo } & \text { de acuerdo } & \text { en mi caso } \\ 1 & 2 & 3 & 4 & 0\end{array}$

\section{Espero recibir información sobre:}

C12. Síntomas relacionados con la enfermedad de la persona que cuido.

C13. Cuando y donde debo contactar, en el caso de que los síntomas de la persona que cuido empeoren.

C14. Las pruebas que serán realizadas a la persona que cuido.

C15. Cómo debe prepararse para las pruebas la persona que cuido (p.e. medicación, dieta).

C16. Cómo obtendré los resultados de las pruebas de la $\quad 1$ persona que cuido.

C17. Los diferentes tratamientos disponibles para la persona que cuido.

C18. Posibles complicaciones relacionadas con el tratamiento de la persona que cuido.

C19. Cómo puedo prevenir complicaciones derivadas de la enfermedad de la persona que cuido.

C20. Cómo puedo hacer para asegurarme que las necesidades de la persona que cuido están cubiertas (p.e. alimentación, higiene, eliminación).

C21. Qué tipo de ejercicio físico puede hacer la persona que cuido.

C22. Cómo favorecer el descanso de la persona que cuido.

C23. Qué tipo de dieta es la más adecuada para la persona que cuido.

C24. Cómo realizar el aseo de la persona que cuido (p.e. ducha, arreglarse, vestirse).

C25. Cómo la enfermedad o el tratamiento de la persona que cuido puede afectar a sus funciones corporales (p.e. comer, orinar, defecar) 
Totalmente Bastante Poco Nada No aplicable de acuerdo de acuerdo de acuerdo de acuerdo en mi caso

\section{Espero recibir información sobre:}

C26. Cómo la enfermedad de la persona que cuido puede afectar a sus funciones cognitivas (p.e. desorientación, pérdida de memoria, no reconocimiento de caras).

C27. Cómo manejar las alteraciones cognitivas que 1

puede presentar la persona que cuido (p.e. agitación, deambulación nocturna, agresividad).

C28. Cómo la enfermedad o el tratamiento de la persona que cuido puede afectar a la adaptación del 1 2 hogar. (p.e. instalación de barandas, plato de ducha, eliminación de alfombras)

C29. Dónde puedo conseguir las ayudas que necesita para el cuidado la persona que cuido (p.e. para 1 moverse, curar las heridas, comer).

C30. Qué tipo de sentimientos puede causarme la enfermedad y el tratamiento de la persona que cuido.

C31. Qué tipo de sentimientos puede causarle la enfermedad y el tratamiento a la persona que cuido.

C32. Con quien puedo hablar de los sentimientos sobre la enfermedad y el tratamiento de la persona que cuido.

C33.Cómo puedo aprovechar las experiencias de otros cuidadores en el manejo de la persona que cuido.

C34. Cómo la persona que cuido puede participar en la toma de decisiones acerca de su cuidado (p.e. voluntades anticipadas).

C35.Cómo la persona que cuido puede dar a conocer sus propias opiniones y puntos de vista.

C36. Qué derechos tiene la persona que cuido.

C37. Qué responsabilidad tengo respecto al cuidado.

C38. Cómo puedo contactar con la atención al usuario/cliente.

C39. Cómo la persona que cuido puede otorgar el

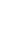
poder de ser representado legalmente en nombre de otra persona, para que ésta actúe en su nombre.

C40. Qué funciones tienen los diferentes profesionales que participan en el cuidado.

C41. Cómo se mantienen confidenciales los datos de la 


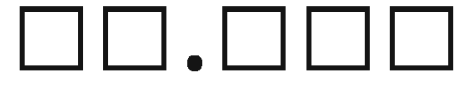

Totalmente de acuerdo
Visit: $1 \square 2 \square 3 \square$ TR $\square$

Bastante Poco Nada No aplicable de acuerdo de acuerdo de acuerdo en mi caso

\section{Espero recibir información sobre:}

C43. Cómo puedo tener acceso a la historia Clínica de la persona que cuido.

C44. Quien me puede informar acerca de los recursos sociales relacionados con la enfermedad o el tratamiento de la persona que cuido.

C45.Cómo puedo organizar el cuidado diario de la 1 persona que cuido.

C46. Cómo puedo compatibilizar el cuidado con mi vida laboral, social y aficiones.

C47. Cómo hacer partícipe a la familia y/o personas del entorno de la persona que cuido, de la enfermedad y su manejo.

C48. Cómo la persona que cuido puede conseguir una persona de apoyo si la necesita (p.e. acompañamiento, ayuda doméstica).

C49. Dónde conseguir otros recursos para el cuidado o tratamiento si fuera necesario.

C50. Cómo la persona que cuido puede obtener apoyo 1 espiritual.

C51. Asociaciones de pacientes/cuidadores y sus actividades.

C52. Cuidado y el coste de la persona que cuido.

C53. Ayudas económicas que la persona que cuido

C54. Información de seguros y coberturas de cursos de adaptación y su coste (p.e. centros de día, talleres de memoria).

C56.Coste de futuros cuidados domiciliarios y 1 residencias. 
A continuación, hay unas preguntas referentes a los conocimientos que usted ha recibido sobre el cuidado y el tratamiento de la persona que cuida con demencia. Conteste cada pregunta marcando con un círculo la alternativa que mejor responde a su punto de vista. Para estas preguntas NO existen respuestas correctas o incorrectas, pero estamos interesados en conocer su opinión al respecto.

$\begin{array}{ccccc}\text { Totalmente } & \text { Bastante } & \text { Poco } & \text { Nada } & \text { No aplicable } \\ \text { de acuerdo } & \text { de acuerdo } & \text { de acuerdo } & \text { de acuerdo } & \text { en mi caso } \\ 1 & 2 & 3 & 4 & 0\end{array}$

\section{Recibí información sobre:}

C58. Sintomas relacionados con la enfermedad de la 1 persona que cuido.

C59. Cuando y donde debo contactar, en el caso de que 1 los síntomas de la persona que cuido empeoren.

C60. Las pruebas que serán realizadas a la persona que cuido.

C61. Cómo debe prepararse para las pruebas la persona que cuido (p.e. medicación, dieta). persona que cuido.

C64. Posibles complicaciones relacionadas con el tratamiento de la persona que cuido.

C65. Cómo puedo prevenir complicaciones derivadas de la enfermedad de la persona que cuido.

C66. Cómo puedo hacer para asegurarme que las necesidades de la persona que cuido están cubiertas (p.e. alimentación, higiene, eliminación).

C67. Qué tipo de ejercicio físico puede hacer la persona que cuido.

C68. Cómo favorecer el descanso de la persona que cuido.

C69. Qué tipo de dieta es la más adecuada para la persona que cuido.

C70. Cómo realizar el aseo de la persona que cuido 


\section{Recibí información sobre:}

de acuerdo de acuerdo de acuerdo de acuerdo en mi caso

C72. Cómo la enfermedad de la persona que cuido puede afectar a sus funciones cognitivas (p.e. desorientación, pérdida de memoria, no reconocimiento de caras).

C73. Cómo manejar las alteraciones cognitivas que puede presentar la persona que cuido (p.e. agitación,

C74. Cómo la enfermedad o el tratamiento de la persona que cuido puede afectar a la adaptación del hogar. (p.e. instalación de barandas, plato de ducha, eliminación de alfombras)

C75. Dónde puedo conseguir las ayudas que necesita para el cuidado la persona que cuido (p.e. para moverse, curar las heridas, comer).

C76. Qué tipo de sentimientos puede causarme la enfermedad y el tratamiento de la persona que cuido.

C77. Qué tipo de sentimientos puede causarle la enfermedad y el tratamiento a la persona que cuido.

C78.Con quien puedo hablar de los sentimientos sobre la

C79.Cómo puedo aprovechar las experiencias de otros cuidadores en el manejo de la persona que cuido.

C80. Cómo la persona que cuido puede participar en la anticipadas).

C81.Cómo la persona que cuido puede dar a conocer sus propias opiniones y puntos de vista.

C82. Qué derechos tiene la persona que cuido.

C83. Qué responsabilidad tengo respecto al cuidado.

C84. Cómo puedo contactar con la atención al usuario/cliente.

C85. Cómo la persona que cuido puede otorgar el poder de ser representado legalmente en nombre de otra persona, para que ésta actúe en su nombre.

C86. Qué funciones tienen los diferentes profesionales que participan en el cuidado.

C87. Cómo se mantienen confidenciales los datos de la historia clínica de la persona que cuido. 


\section{Participant ID: $\square \square . \square \square \square$ Visit: $1 \square 2 \square$ 3 $\square$ TR $\square$ \\ Totalmente Bastante Poco Nada No aplicable de acuerdo de acuerdo de acuerdo de acuerdo en mi caso}

\section{Recibí información sobre:}

C89. Cómo puedo tener acceso a la historia Clínica de la 1 persona que cuido.

C90. Quien me puede informar acerca de los recursos sociales relacionados con la enfermedad 0 el 1 tratamiento de la persona que cuido.

C91.Cómo puedo organizar el cuidado diario de la persona que cuido.

C92. Cómo puedo compatibilizar el cuidado con mi vida laboral, social y aficiones.

C93. Cómo hacer partícipe a la familia y/o personas del entorno de la persona que cuido, de la enfermedad y su 1 manejo.

C94. Cómo la persona que cuido puede conseguir una persona de apoyo si la necesita (p.e. acompañamiento, ayuda doméstica).

C95. Dónde conseguir otros recursos para el cuidado o tratamiento si fuera necesario.

C96. Cómo la persona que cuido puede obtener apoyo espiritual.

C97. Asociaciones de pacientes/cuidadores y sus 1 actividades.

C98. Cuidado y el coste de la persona que cuido.

C99. Ayudas económicas que la persona que cuido 1 puede obtener a raiz de la enfermedad.

C100. Información de seguros y coberturas de tratamiento.

C101.Rehabilitación funcional, estimulación cognitiva, cursos de adaptación y su coste (p.e. centros de día, talleres de memoria).

C102.Coste de futuros cuidados domiciliarios y residencias.

C103. Coste de la medicación de la persona que cuido. 


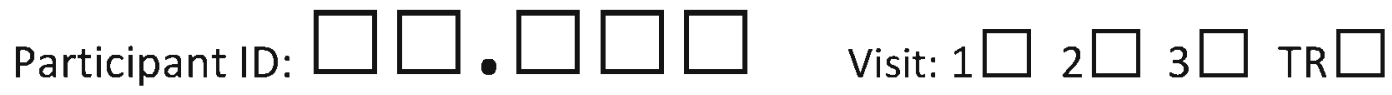

RUD- Cuidado en el entorno domiciliario

Datos demográficos del/la cuidador/a principal/familiar más cercano

Por favor, conteste las siguientes preguntas sobre su situación personal.

C124. Fecha de nacimiento $(d / d) /$ $(\mathrm{m} / \mathrm{m}) /$ $(a / a)$

TC.125 Edad años

C126. Sexo: $\square$ Hombre $\square$ Mujer

C127. Relación con la persona que cuida:

$\square$ Esposo/a $\square$ Hijo/a $\square$ Amigo/a $\square$ Otra

C128. Estado civil: $\square$ Casado/a o viviendo juntos $\square$ Nunca se casó $\square$ Divorciado/a o Separado/a $\square$ Viudo/a C129. ¿Vive Usted con el/la paciente? $\square$ Sí $\square$ No

\section{Tiempo del/de la cuidador/a principal o familiar más próximo}

TC130. En un día típico de cuidado del/de la paciente durante los últimos 30 días. ¿Cuánto tiempo dedicó al día a ayudar al/a la paciente en actividades como ir al lavabo, comer, vestirse y desvestirse, arreglarse, caminar y lavarse/bañarse horas al día

TC130.1. Durante los últimos 30 días, ¿cuántos días prestó estos servicios al/a la paciente? Días

TC131. En un día típico de cuidado del/de la paciente durante los últimos 30 días, ¿cuánto tiempo dedicó al día a ayudar al/a la paciente en actividades como comprar, preparar la comida, ocuparse de la casa, lavar la ropa, el transporte, tomar la medicación y gestionar temas financieros?

horas al día.

TC131.1. Durante los últimos 30 días, ¿cuántos días prestó estos servicios al/a la paciente? Días

TC132. En un día típico de cuidado del/de la paciente durante los últimos 30 días, ¿cuánto tiempo dedicó al día a vigilar (es decir, prevenir incidentes peligrosos) al/a la paciente?

horas al día.

TC132.1. Durante los últimos 30 días, ¿cuántos días prestó estos servicios al/a la paciente? Días

\section{Situación laboral del cuidador/a principal o familiar más próximo}

C133. ¿Realiza actualmente un trabajo remunerado?

$\square$ Sí si la respuesta es Sí, continúe contestando a las preguntas a partir de la pregunta TC 135

No si la respuesta es NO, conteste solamente la pregunta C134 y después vaya directamente al apartado utilización recursos sanitarios, pregunta C140

C134. ¿Por qué dejó de trabajar?

Nunca he trabajo

Por alcanzar la edad de jubilación

Jubilación anticipada (no deriva de enfermedad)

Despido

Problemas de salud propios

Para cuidar del/de la paciente

Otros 


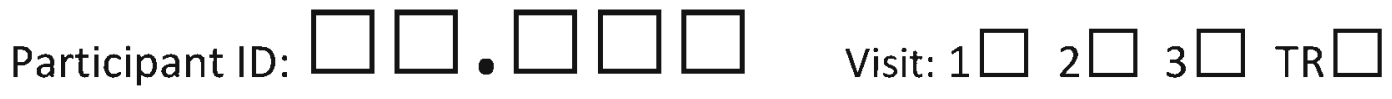

TC135. Durante los últimos 30 días, ¿cuántas horas de trabajo remunerado realiza en total a la semana (incluyendo las que realiza como cuidador)? horas/semana

C136. De este número de horas, ¿̇e le remunera una parte por cuidar al/a la paciente?

$\square$ No

$\square$ Si $\quad$ Si la respuesta es Sí:

TC136.1 ¿Cuántas horas por semana se le remuneran? horas/semana

C137. Durante los últimos 30 días, ¿ha tenido que reducir el número de horas que normalmente trabaja cada semana (reducción de jornada) debido a sus responsabilidades como cuidador/a?

$\square$ No

[ Sí Si la respuesta es Sí:

TC137.1 ¿Cuántas horas ha dejado de trabajar? horas/semana

Durante los últimos 30 días, indique en cuántas ocasiones sus responsabilidades como cuidador/a han afectado a su trabajo de alguna de estas formas:

TC138. Pérdida de un día completo de trabajo. número de veces

TC139. Pérdida de parte de un día de trabajo. número de veces

\section{Utilización de recursos sanitarios por el cuidador/a principal o familiar más próximo.}

C140. Durante los últimos 30 días ¿ha sido ingresado en un hospital (por más de 24 horas)?

$\square$ NO Si la respuesta en NO, pase a la pregunta C141

¿’í

TC140.1. Durante los últimos 30 días ¿cuántas veces ha sido hospitalizado/a? número de veces

C140.2. Para cada ingreso (durante los últimos 30 días), por favor, facilite el diagnóstico o el motivo del mismo.

\begin{tabular}{|l|l|l|}
\hline $\begin{array}{l}\text { 140.2.1. } \\
\text { № de ingresos }\end{array}$ & TC140.2.2. Diagnóstico general o motivo para el ingreso & $\begin{array}{l}\text { TC140.2.3. Código GDR } \\
\text { (si es posible) }\end{array}$ \\
\hline$\square 1$ & & \\
\hline$\square 2$ & & \\
\hline$\square 3$ & & \\
\hline$\square 4$ & & \\
\hline
\end{tabular}

C140.3. Por favor, indique el número total de noches pasadas en cada uno de los servicios hospitalarios (contando todas las hospitalizaciones durante los últimos 30 días).

\begin{tabular}{|l|l|}
\hline C140.3.1. Servicio hospitalario & TC140.3.2 № de noches \\
\hline C140.3.1.1 $\square$ Geriatría & TC140.3.2.1 \\
\hline C140.3.1.2 $\square$ Psiquiatría & TC140.3.2.2 \\
\hline C140.3.1.3 $\square$ Medicina interna & TC140.3.2.3 \\
\hline C140.3.1.4 $\square$ Cirugía & TC140.3.2.4 \\
\hline C140.3.1.5 $\square$ Otros (por favor, especifique) & TC140.3.2.5 \\
\hline
\end{tabular}




\section{Participant ID: $\square \square . \square \square \square$ Visit: $1 \square 2 \square 3 \square$ TR $\square$}

C141. En los últimos 30 días, ¿ha recibido asistencia en el servicio de urgencias de un hospital (durante menos de $24 \mathrm{~h})$ ?

$\square$ No

$\square$ Sí $\quad$ Si la respuesta es Sí:

TC141.1 ¿Cuántas veces? ___ veces

C142. Durante los últimos 30 días, ¿ha sido visitado/a, por un médico, un fisioterapia, un psicólogo u otros profesionales sanitarios?

$\square$ No

पSí Si la respuesta es Sí, Conteste a la siguiente tabla

C142.1 indique el número de visitas que ha recibido de cada uno de los profesionales sanitarios.

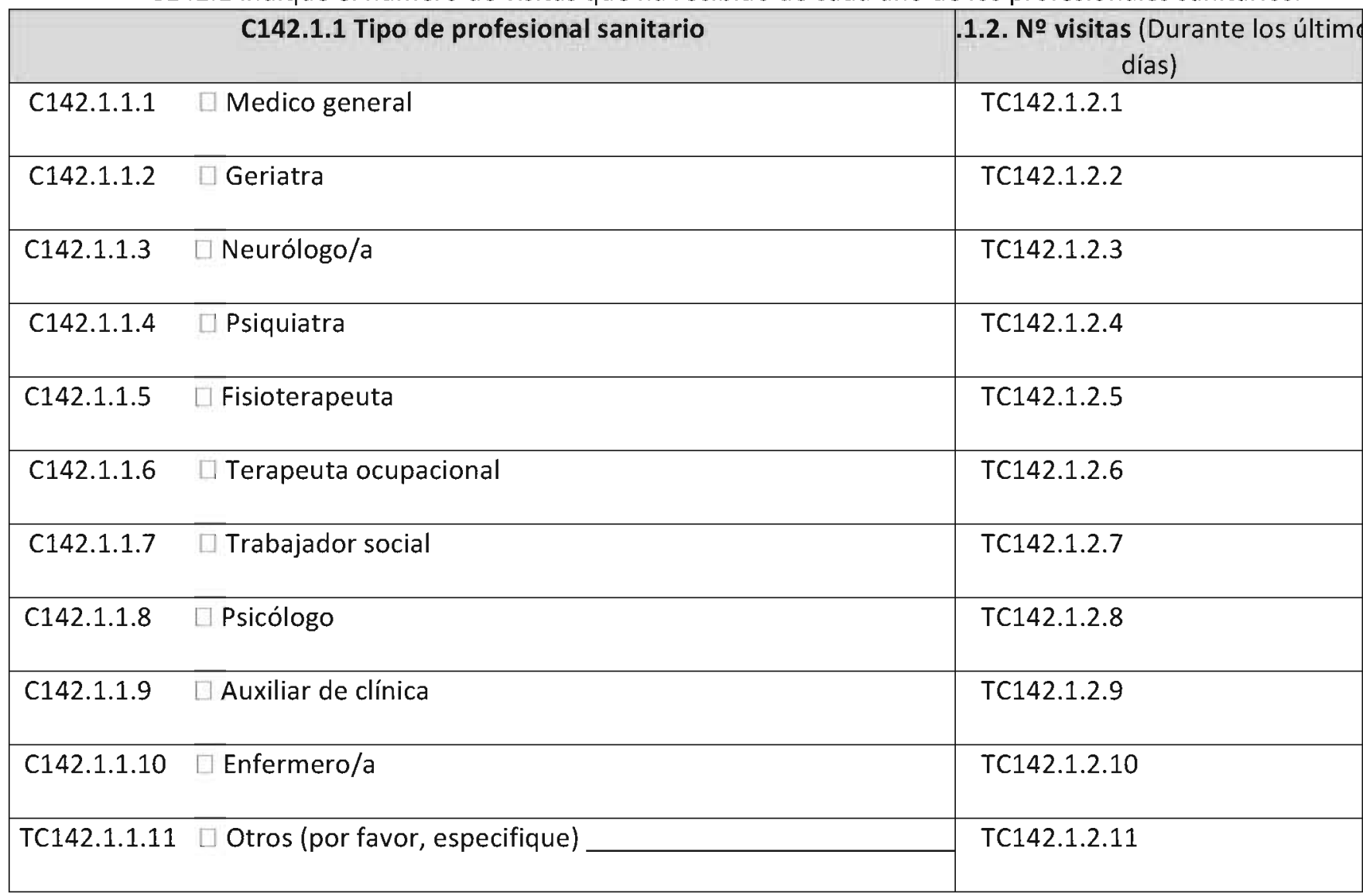

C143. De los servicios de la lista que aparece a continuación, por favor, especifique el número de veces que Usted recibió cada uno de estos servicios durante los últimos 30 días y el promedio de horas por visita.

\begin{tabular}{|c|c|c|}
\hline C143.1. Servicio & $\begin{array}{l}\text { TC143.2 No visitas } \\
\text { (últimos } 30 \text { dias) }\end{array}$ & $\begin{array}{l}\text { C } 143.3 \text { No horas } \\
\text { por visita }\end{array}$ \\
\hline $\begin{array}{l}\text { C143.1.1 Visita de un enfermero/a de Atención Primaria/ } \\
\text { Comunitaria }\end{array}$ & TC143.2.1 & TC143.3.1 \\
\hline $\begin{array}{l}\text { C143.1.2. } \\
\text { actividades personal de asistencia a domicilio (ayuda con las } \\
\text { Personal auxiliar de clínica o de geriatría }\end{array}$ & TC143.2.2 & TC143.3.2 \\
\hline C143.1.3. $\square$ Servicio de comidas a domicilio & TC143.2.3 & TC143.3.3 \\
\hline $\begin{array}{l}\text { C143.1.4. } \square \text { Transporte (financiado por sanidad pública o pagado } \\
\text { seguro privado) }\end{array}$ & TC143.2.4 & TC143.3.4 \\
\hline TC143.1.5. $\square$ Otros (por favor, especifique) & TC143.2.5 & TC143.3.5 \\
\hline
\end{tabular}




\section{Participant ID: $\square \square . \square \square \square$ Visit: $1 \square 2 \square$ 3 $\square$ TR $\square$}

C144. ¿Toma actualmente alguna medicación (con o sin receta médica)?

$\neg$ NO

$\square$ Sí Si la respuesta es Sí, complete la siguiente tabla

C144.1 Complete la siguiente tabla.

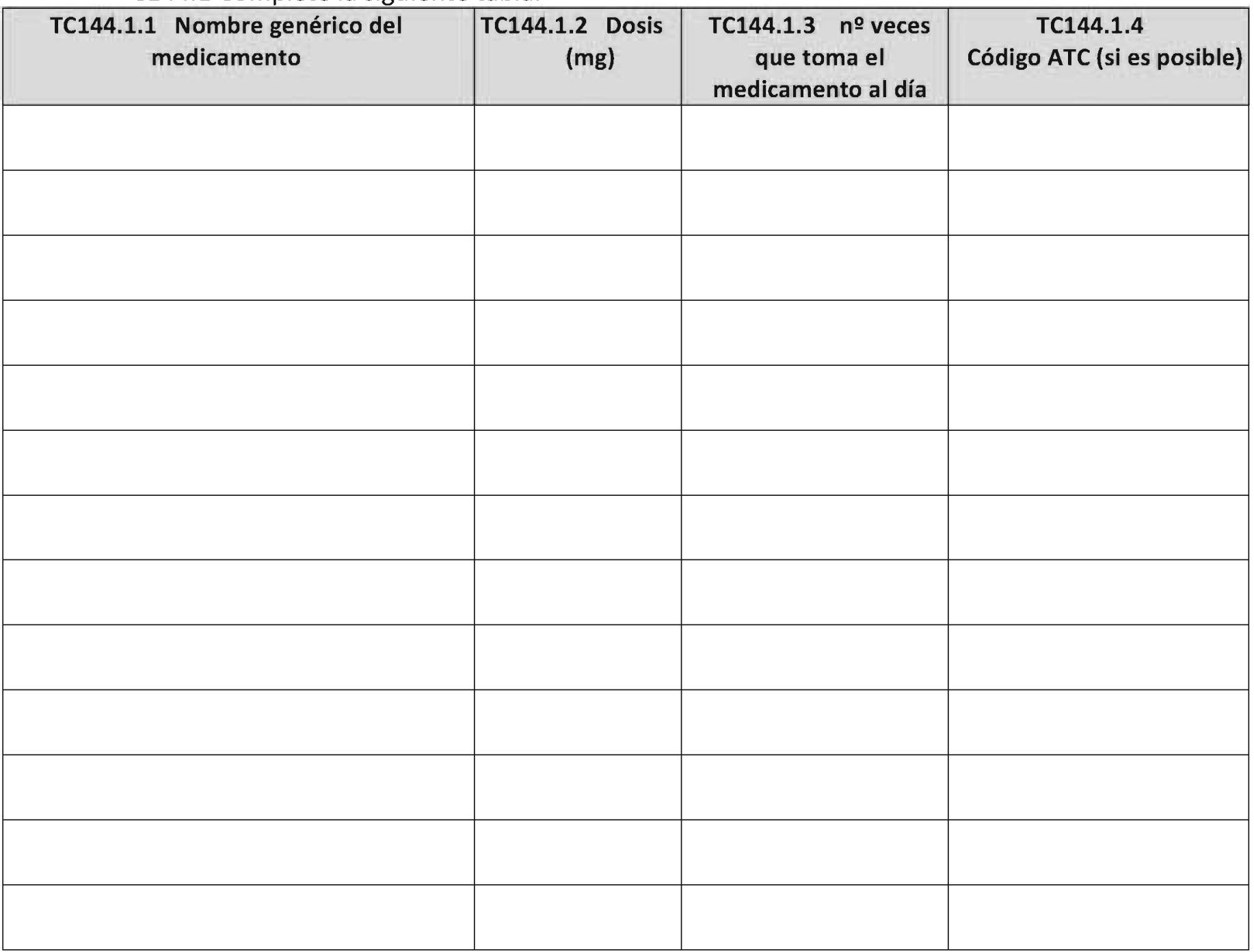

C145. En que proporción utiliza usted los recursos sociales y sanitarios (visitas profesionales, medicamentos, hospitalización...)
$\square 0 \%$
$\square 25 \%$
$\square 50 \%$
$\square 75 \%$
$\square 100 \%$

C146. ¿Considera que influye en la utilización de esos recursos y su situación de cuidador informal? 


\section{INSTRUMENTO DE EVALUACIÓN DE LA REACCIÓN DEL CUIDADOR INFORMAL FRENTE AL CUIDADO (CRA)}

Por favor señale las respuestas marcando una cruz:
1. Totalmente en desacuerdo
2. En desacuerdo
3. Indiferente
4. De acuerdo
5. Totalmente de acuerdo

C147. Me siento privilegiado de poder cuidad a . $\square 1 \quad \square 2 \quad \square 3 \quad \square 4 \quad \square 5$

C148. Otros han delegado el cuidado de en mí.

$\square 1 \square 2 \quad \square 3 \quad \square 4 \quad \square 5$

C149. Mis recursos económicos me permiten cubrir los gastos derivados del cuidado.

\section{$\square 1 \square 2 \quad \square 3 \quad \square 4 \quad \square 5$}

C150. Mis actividades están centradas en el cuidado de $\square 1 \quad \square 2 \quad \square 3 \quad \square 4 \quad \square \quad 5$

C151. Desde que cuido a parece que estoy siempre cansada.

$\square 1 \square 2 \quad \square 3 \quad \square 4 \quad \square 5$

C152. Es muy difícil conseguir ayuda de mi familia para cuidad a .$\square 1 \quad \square 2 \quad \square 3 \quad \square 4 \quad \square 5$

C153. Me molesta tener que cuidar a $\square 1 \square 2 \quad \square 3 \quad \square 4 \quad \square 5$

C154. Tengo que parar para descansar cuando realizo un trabajo. $\square 1 \quad \square 2 \quad \square 3 \quad \square 4 \quad \square 5$

C155. Realmente quiero cuidar a $\square 1 \quad \square 2 \quad \square 3 \quad \square 4 \quad \square 5$

C156. Mi salud ha empeorado desde que cuido a $\square 1 \quad \square 2 \quad \square 3 \quad \square 4 \quad \square 5$

C157. Visito menos a mis familiares y amigos desde que estoy cuidando a

\section{$\square 1 \square 2 \square 3 \quad \square 4 \quad \square 5$}

C158. Nunca seré capaz de dar tanto como yo he recibido de - $\square 1 \quad \square 2$

C159. Mi familia colabora en el cuidado de $\square 1 \square 2$ $\square 3 \quad \square 4 \quad \square 5$

C160. He eliminado cosas de mi vida cotidiana desde que cuido a . $\square 1 \quad \square 2 \quad \square 3 \quad \square 4$ 5

C161. Tengo la fortaleza física suficiente para cuidar a

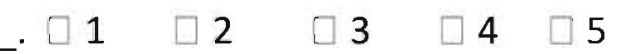
C162. Desde que cuido a , siento que mi familia me ha abandonado. $\square$

C163. Cuidar a me hace sentir bien.

$\square 1 \quad \square 2 \quad \square 3 \quad \square 4 \quad \square 5$

C164. Las constantes interrupciones hacen difícil encontrar tiempo para relajarme.

\section{$\square 1 \quad \square 2 \quad \square 3 \quad \square 4 \quad \square 5$}

C165. Tengo la salud necesaria para cuidar a $\square 1 \quad \square 2 \quad \square 3 \quad \square 4 \quad \square 5$

C166. Cuidar a es importante para mí.

$\square 1 \quad \square 2 \quad \square 3 \quad \square 4 \quad \square 5$

C167. Cuidar a ha supuesto una carga económica para la familia. $\quad \square$ 


\section{EUROQOL - 5 D}

Instrucciones:

Marque con una cruz $(\mathrm{X})$ la afirmación en cada sección que describa mejor su estado de salud en el día de hoy:

\section{C168. MOVILIDAD}

No tengo problemas para caminar.

Tengo algunos problemas para caminar.

Tengo que estar en la cama.

\section{C169. CUIDADO PERSONAL}

No tengo problemas con el cuidado personal.

Tengo algunos problemas para lavarme vestirme solo

Soy incapaz de lavarme o vestirme solo.

C170.ACTIVIDADES de Todos los Días (ej. trabajar, estudiar, hacer tareas domésticas, actividades familiares o realizadas durante el tiempo libre)

Tengo algunos problemas para realizar mis actividades de todos los días.

No tengo problemas para realizar mis actividades de todos los días.

Soy incapaz de realizar mis actividades de todos los días.

Para ayudar a la gente a describir lo bueno o malo que es su estado de salud, hemos dibujado una escala parecida a un termómetro en el cual se marca con un 100 el mejor estado de salud que puede imaginarse, y con un 0 el peor estado de salud que puede imaginarse.

Por favor, dibuje una línea desde el cuadro que dice "su estado de salud hoy," hasta el punto en la escala que, en su opinión, indique lo bueno o malo que es su estado de salud en el día de hoy.

Su estado de salud hoy
TC173.Total

puntuación

\section{C171.Dolor/Malestar}

No tengo dolor ni malestar.

Tengo moderado dolor o malestar.

Tengo mucho dolor o malestar.

\section{C172.Ansiedad/Depresión}

No estoy ansioso/a ni deprimido/a.

Estoy moderadamente ansioso/a o deprimido/a.

Estoy muy ansioso/a o deprimido/a.

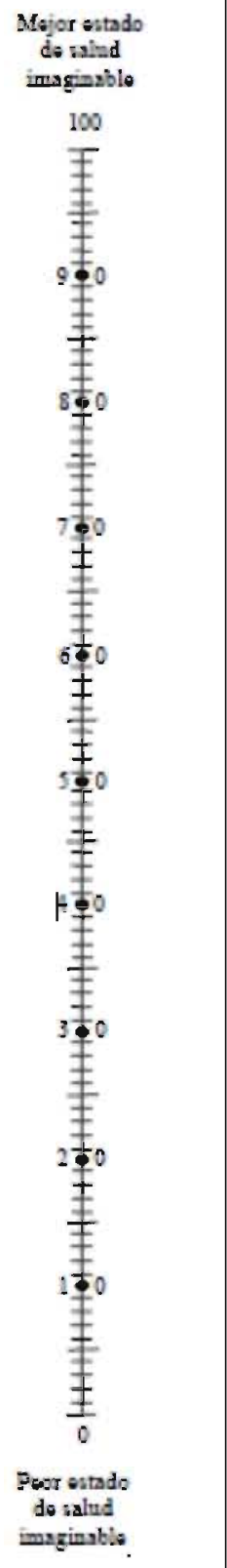




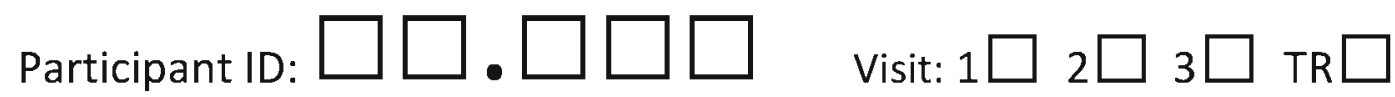

\section{Cuestionario DUKE-UNK}

\section{Instrucciones:}

En la siguiente lista se muestran algunas cosas que otras personas hacen por nosotros o nos proporcionan. Elija para cada una la respuesta que mejor refleje su situación, según los siguientes criterios:

\section{Por favor señale las respuestas marcando una cruz:}

1. Mucho menos de lo que deseo

2. Menos de lo que deseo

3. Ni mucho ni poco

4. Casi como deseo

5. Tanto como deseo

C174. Recibo visitas de mis amigos y familiares.

$\square 1 \quad \square 2 \quad \square 3 \quad \square 4 \quad \square 5$

C175. Recibo ayuda en asuntos relacionados con mi casa.

$\square 1 \quad \square 2 \quad \square 3 \quad \square 4 \quad \square 5$

C176. Recibo elogios o reconocimientos cuando hago bien mi trabajo. $\square 1 \quad \square 2 \quad \square 3 \quad \square 4 \quad \square 5$

C177. Cuento con personas que se ocupan de lo que me sucede. $\square 1 \quad \square 2 \quad \square 3 \quad \square 4 \quad \square 5$

C178. Recibo amor y afecto. $\quad \square 1 \quad \square 2 \quad \square 3 \quad \square 4 \quad \square 5$

C179. Tengo la posibilidad de hablar con alguien de mis problemas en $\quad \square 1 \quad \square 2 \quad \square 3 \quad \square 4 \quad \square 5$ el trabajo y/o en la casa.

C180. Tengo la posibilidad de hablar con alguien de mis problemas $\quad \square 1 \quad \square 2 \quad \square 3 \quad \square 4 \quad \square 5$ personales y familiares.

C181. Tengo la posibilidad de hablar con alguien de mis problemas económicos.

C182. Recibo invitaciones para distraerme y salir con otras personas. $\square 1 \quad \square 2 \quad \square 3 \quad \square 4 \quad \square 5$

C183. Recibo consejos útiles cuando me ocurre algún acontecimiento $\square 1 \quad \square 2 \quad \square 3 \quad \square 4 \quad \square 5$ Importante en mi vida.

C184. Recibo ayuda cuando estoy enfermo en cama. $\quad \square 1 \quad \square 2 \quad \square 3 \quad \square 4 \quad \square 5$ 


\section{Escala de sobrecarga del Cuidador de Zarit}

\section{Instrucciones:}

A continuación se presentan una lista de frases que reflejan cómo se sienten algunas personas cuando cuidan a otra persona. Después de leer cada frase, marque con una cruz $(X)$ en la casilla correspondiente, con qué frecuencia se siente usted de esa manera, escogiendo entre los siguientes criterios:

\section{Nunca 1.Casi nunca 2.A veces 3.Frecuentemente 4.Casi siempre}

C185.¿Tiene la sensación de que su familiar pide más ayuda de la que necesita?

$\square 0 \quad \square 1 \quad \square 2 \quad \square 3 \quad \square 4$

C186.¿Tiene la sensación de que, debido al tiempo que dedica a su familiar, no le queda suficiente tiempo para usted?

$$
\square 0 \quad \square 1 \quad \square 2 \quad \square 3 \quad \square 4
$$

C187.¿Se siente estresado/a por tener que ocuparse de su familiar e intentar cumplir con otras obligaciones familiares o laborales?

$$
\square 0 \quad \square 1 \quad \square 2 \quad \square 3 \quad \square 4
$$

C188.¿Se siente violento/a por el comportamiento que tiene su familiar con otras personas?

$$
\square 0 \quad \square 1 \quad \square 2 \quad \square 3 \quad \square 4
$$

C189.¿Se siente enfadado/a con su familiar cuando está con él/ella?

$$
\square 0 \quad \square 1 \quad \square 2 \quad \square 3 \quad \square 4
$$

C190.¿Cree que actualmente su relación con otros miembros de la familia o amigos se ve afectada negativamente por su familiar?

$$
\square 0 \quad \square 1 \quad \square 2 \quad \square 3 \quad \square 4
$$

C191.¿Le preocupa el futuro que le espera a su familiar?

$\square 0 \quad \square 1 \quad \square 2 \quad \square 3 \quad \square 4$

C192.¿Siente que su familiar depende de usted?

$\square 0 \quad \square 1 \quad \square 2 \quad \square 3 \quad \square 4$

C193.¿Se siente tenso/a cuando está con su familiar?
$\square 0$
$\square 1$
$\square 2$
$\square 3 \square 4$

C194.¿Siente que su salud se ha resentido debido a su implicación con su familiar?

$\square 0 \quad \square 1 \quad \square 2 \quad \square 3 \quad \square 4$

C195.¿Siente que no tiene tanta vida privada como quisiera a causa de su familiar?

$$
\square 0 \quad \square 1 \quad \square 2 \quad \square 3 \quad \square 4
$$

C196.¿Siente que su vida social se ha visto afectada por tener que ocuparse de su familiar?

$\square 0 \quad \square 1 \quad \square 2 \quad \square 3 \quad \square 4$


Participant ID:

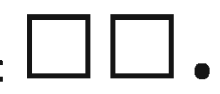

L

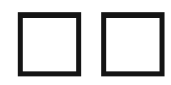

Visit: $1 \square 2 \square 3 \square$ TR $\square$

\section{Nunca 1.Casi nunca 2.A veces 3.Frecuentemente 4.Casi siempre}

C197.¿Se siente incómodo/a para invitar a sus amigos a casa, debido a su familiar?

$\square 0 \quad \square 1 \quad \square 2 \quad \square 3 \quad \square 4$

C198.¿Cree que su familiar espera que usted se ocupe de él/ella, como si fuera la única persona de quien pudiera depender?

$$
\square 0 \quad \square 1 \quad \square 2 \quad \square 3 \quad \square 4
$$

C199¿Siente que no tiene suficiente dinero para cuidar a su familiar además de sus otros gastos?

$$
\square 0 \square 1 \quad \square 2 \quad \square 3 \quad \square 4
$$

C200.¿Siente que será incapaz de cuidar a su familiar por mucho más tiempo?

$$
\square 0 \quad \square 1 \quad \square 2 \quad \square 3 \quad \square 4
$$

C201.¿Siente que ha perdido el control de su vida desde que empezó la enfermedad de su familiar?

$$
\square 0 \quad \square 1 \quad \square 2 \quad \square 3 \quad \square 4
$$

C202.¿Desearía simplemente dejar el cuidado de su familiar a otra persona?

$$
\square 0 \quad \square 1 \quad \square 2 \quad \square 3 \quad \square 4
$$

C203.¿Se siente inseguro/a sobre lo que debe hacer con su familiar?

$$
\square 0 \quad \square 1 \quad \square 2 \quad \square 3 \quad \square 4
$$

C204.¿Siente que debería hacer más por su familiar?

$$
\square 0 \quad \square 1 \quad \square 2 \quad \square 3 \quad \square 4
$$

C205.¿Cree que aún podría cuidar mejor a su familiar?

$$
\square 0 \quad \square 1 \quad \square 2 \quad \square 3 \quad \square 4
$$

C206. En general, ¿hasta qué punto siente que cuidar a su familiar es una carga para usted?

$\square 0 \quad \square 1 \quad \square 2 \quad \square 3 \quad \square 4$




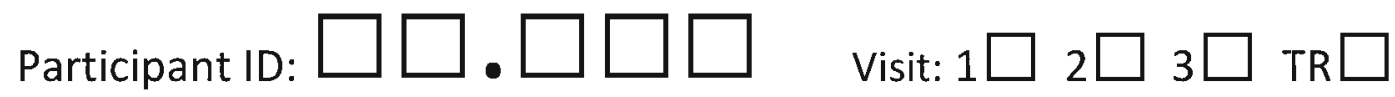

\section{Cuestionario de Salud General de Goldberg}

Por favor, lea esto cuidadosamente:

Nos gustaría saber si tiene algún problema médico y cómo ha estado su salud, en general, durante las últimas semanas. Por favor, conteste a TODAS las preguntas subrayando simplemente la respuesta que, a su juicio, puede aplicarse a usted. Recuerde que solo debe responder sobre los problemas recientes y los que tiene ahora, no sobre los que tuvo en el pasado. Es importante que intente contestar TODAS las preguntas.

Muchas gracias por su colaboración.

\section{ÚLTIMAMENTE:}

\begin{tabular}{|c|c|c|c|c|}
\hline $\begin{array}{l}\text { C207. ¿Ha podido concentrarse bien } \\
\text { en lo que hacía? }\end{array}$ & $\begin{array}{l}\text { Mejor que } \\
\text { lo habitual } \square\end{array}$ & $\begin{array}{l}\text { Igual que lo } \\
\text { Habitual } \square\end{array}$ & $\begin{array}{l}\text { Menos que lo } \\
\text { habitual } \square\end{array}$ & $\begin{array}{l}\text { Mucho menos que } \\
\text { lo habitual } \square\end{array}$ \\
\hline $\begin{array}{l}\text { C208. ¿Sus preocupaciones le } \\
\text { han hecho perder sueño? }\end{array}$ & $\begin{array}{l}\text { No, en } \\
\text { Absoluto } \square\end{array}$ & $\begin{array}{l}\text { No más que lo } \\
\text { habitual } \square\end{array}$ & $\begin{array}{l}\text { Algo más que lo } \\
\text { habitual } \square\end{array}$ & $\begin{array}{l}\text { Mucho más que lo } \\
\text { habitual } \square\end{array}$ \\
\hline $\begin{array}{l}\text { C209.¿Ha sentido que está } \\
\text { desempeñando un papel útil en la } \\
\text { vida? }\end{array}$ & $\begin{array}{l}\text { Más útil que lo } \\
\text { habitual } \square\end{array}$ & $\begin{array}{l}\text { Igual que lo habitual } \\
\square\end{array}$ & $\begin{array}{l}\text { Menos útil que } \\
\text { lo habitual } \\
\square\end{array}$ & $\begin{array}{l}\text { Mucho } \\
\text { menos útil que } \\
\text { lo habitual } \square\end{array}$ \\
\hline $\begin{array}{l}\text { C210. ¿Se ha sentido capaz de } \\
\text { tomar decisiones? }\end{array}$ & $\begin{array}{l}\text { Más útil que lo } \\
\text { habitual } \square\end{array}$ & $\begin{array}{l}\text { Igual que lo habitual } \\
\square\end{array}$ & $\begin{array}{l}\text { Menos que lo } \\
\text { habitual } \square\end{array}$ & $\begin{array}{l}\text { Mucho menos que } \\
\text { lo habitual } \\
\square\end{array}$ \\
\hline $\begin{array}{l}\text { C211. ¿Se ha notado } \\
\text { constantemente agobiado y en } \\
\text { tensión? }\end{array}$ & $\begin{array}{l}\text { No, en } \\
\text { absoluto } \\
\square\end{array}$ & $\begin{array}{l}\text { No más de lo } \\
\text { habitual } \quad \square\end{array}$ & $\begin{array}{l}\text { Algo más que } \\
\text { lo habitual } \square\end{array}$ & $\begin{array}{l}\text { Mucho más que lo } \\
\text { habitual } \square\end{array}$ \\
\hline $\begin{array}{l}\text { C212. ¿Ha tenido la sensación } \\
\text { de que no puede superar sus } \\
\text { dificultades? }\end{array}$ & $\begin{array}{l}\text { No, en } \\
\text { absoluto } \\
\square\end{array}$ & $\begin{array}{l}\text { No más de lo } \\
\text { habitual } \square\end{array}$ & $\begin{array}{l}\text { Algo más que lo } \\
\text { habitual } \square\end{array}$ & $\begin{array}{l}\text { Mucho mas que lo } \\
\text { habitual } \square\end{array}$ \\
\hline $\begin{array}{l}\text { C213. ¿Ha sido capaz de disfrutar } \\
\text { de sus actividades normales de } \\
\text { cada día? }\end{array}$ & $\begin{array}{l}\text { Más que lo } \\
\text { habitual } \square\end{array}$ & $\begin{array}{l}\text { Igual que lo } \\
\text { habitual } \square\end{array}$ & $\begin{array}{l}\text { Menos que lo } \\
\text { habitual } \square\end{array}$ & $\begin{array}{l}\text { Mucho menos que } \\
\text { lo habitual } \square\end{array}$ \\
\hline $\begin{array}{l}\text { C214. ¿Ha sido capaz de hace } \\
\text { frente adecuadamente a sus } \\
\text { problemas? }\end{array}$ & $\begin{array}{l}\text { Más capaz que } \\
\text { lo habitual } \square\end{array}$ & $\begin{array}{l}\text { Igual que lo } \\
\text { habitual } \square\end{array}$ & $\begin{array}{l}\text { Menos capaz que } \\
\text { lo habitual } \square\end{array}$ & $\begin{array}{l}\text { Mucho menos } \\
\text { capaz que lo } \\
\text { habitual } \square\end{array}$ \\
\hline $\begin{array}{l}\text { C215. ¿Se ha sentido poco feliz o } \\
\text { deprimido? }\end{array}$ & $\begin{array}{l}\text { NO, en } \\
\text { absoluto } \square\end{array}$ & $\begin{array}{l}\text { No más de lo } \\
\text { habitual } \square\end{array}$ & $\begin{array}{l}\text { Algo más que lo } \\
\text { habitual } \square\end{array}$ & $\begin{array}{l}\text { Mucho mas que lo } \\
\text { habitual } \square\end{array}$ \\
\hline $\begin{array}{l}\text { C216. ¿Ha perdido confianza en sí } \\
\text { mismo? }\end{array}$ & $\begin{array}{l}\text { No, en } \\
\text { absoluto } \square\end{array}$ & $\begin{array}{l}\text { No más de lo } \\
\text { habitual } \quad \square\end{array}$ & $\begin{array}{l}\text { Algo más que } \\
\text { lo habitual } \square\end{array}$ & $\begin{array}{l}\text { Mucho más que lo } \\
\text { habitual } \square\end{array}$ \\
\hline $\begin{array}{l}\text { C217. ¿Ha pensado que usted es } \\
\text { una persona que no vale para } \\
\text { nada? }\end{array}$ & $\begin{array}{l}\text { No, en } \\
\text { absoluto } \square\end{array}$ & $\begin{array}{l}\text { No más de lo } \\
\text { Habitual } \square\end{array}$ & $\begin{array}{l}\text { Algo más que lo } \\
\text { habitual } \square\end{array}$ & $\begin{array}{l}\text { Mucho más que lo } \\
\text { habitual } \square\end{array}$ \\
\hline $\begin{array}{l}\text { C218. ¿Se siente razonablemente } \\
\text { feliz considerando todas las } \\
\text { circunstancias? }\end{array}$ & $\begin{array}{l}\text { Más que lo } \\
\text { habitual } \square\end{array}$ & $\begin{array}{l}\text { Igual que lo } \\
\text { habitual } \square\end{array}$ & $\begin{array}{l}\text { Menos que lo } \\
\text { habitual } \square\end{array}$ & $\begin{array}{l}\text { Mucho menos que } \\
\text { lo habitual } \square\end{array}$ \\
\hline
\end{tabular}


Participant ID: $\square \square . \square \square \square$ Visit: $1 \square 2 \square 3 \square$ TR $\square$

\section{Pregunta para cuidadores informales/familiares sobre calidad de atención}

C219 ¿Cuál es su nivel de satisfacción en relación a los cuidados recibidos por parte del servicio de atención a las personas con demencia?

Muy insatisfecho/a

Insatisfecho/a

$\mathrm{Ni}$ satisfecho/a ni insatisfecho/a

Satisfecho/a

Muy satisfecho/a

TC219.1 Por favor detalle el tipo de servicio especifico de demencia

C219.2 Sobre todo, como de satisfecho esta de los servicios de demencia en general?

$\begin{array}{ll}\square & \text { Muy insatisfecho/a } \\ \square & \text { Insatisfecho/a } \\ \square & \text { Ni satisfecho/a ni insatisfecho/a } \\ \square & \text { Satisfecho/a } \\ \square & \text { Muy satisfecho/a }\end{array}$


L

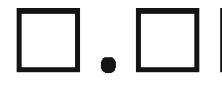

$\square \square$

Visit: $1 \square$

$2 \square 3 \square \operatorname{TR} \square$

\section{PREGUNTAS DIRIGIDAS AL CUIDADOR INFORMAL/FAMILIAR SOBRE LA PERSONA QUE CUIDA}

\section{Cuidador informal/familiar información de las visitas}

E1 Si el cuidador informal vive con el paciente con demencia marcar vivir juntos' Viven juntos. Ir a la pregunta E4

E2 Por favor indique el número de visitas en las últimas 2 semanas

$\square 1 \square 2 \square 3 \quad \square 4 \quad \square 5 \quad \square 6 \quad \square 7 \square 8 \quad \square 9 \square 10 \quad \square 11 \quad \square 12 \square 13 \quad \square 14 \square>14$ E2.1 En el caso de >14, ¿Cuántas? visitas

E3 ¿En general cuanto tiempo está en las visitas? horas

\section{Utilización de ayuda social por PARTE DEL PACIENTE}

E4 ¿Durante los últimos 30 días, ha ingresado en hospital (por menos de 24horas)?

$\square \quad$ NO. Si es No ir a la pregunta E5 $\square$ Sí

E4.1 Durante los últimos 30 días, ¿Cuántas veces ha estado hospitalizado? 


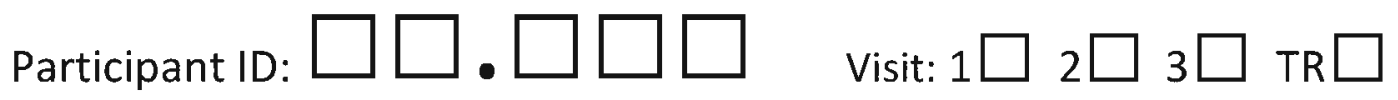

TE4.2 Por cada hospitalización (durante los últimos 30 días), por favor indique la razón de la hospitalización.

\begin{tabular}{|c|c|c|c|}
\hline \multicolumn{2}{|c|}{$\begin{array}{l}\text { TE4.2.1 } \\
\text { Número } \\
\text { Hospitalización }\end{array}$} & $\begin{array}{c}\text { TE4.2.2 } \\
\text { Diagnóstico o motivo hospitalización }\end{array}$ & \begin{tabular}{|r} 
TE4.2.3 \\
Código DRG \\
(si es posible)
\end{tabular} \\
\hline$\square$ & 1 & & $\perp \quad 1 \quad 1$ \\
\hline$\square$ & 2 & & $\mid$ \\
\hline$\square$ & 3 & & $\perp \quad 1 \quad 1$ \\
\hline$\square$ & 4 & & 1 \\
\hline
\end{tabular}

E4.3 Por favor especifique el número total de noches en cada unidad (para todas las hospitalizaciones de más de 30 días).

\begin{tabular}{|c|c|c|c|c|}
\hline E4.3.1 & \multicolumn{2}{|c|}{ Unidad } & \multicolumn{2}{|c|}{$\begin{array}{l}\text { E4.3.2 } \\
\text { Número de noches }\end{array}$} \\
\hline E20.3.1.1 & & Geriatria & $E 20.3 .2 .1$ & \\
\hline $\mathrm{E} 20.3 .1 .2$ & & Psiquiatria & $E 20.3 .2 .2$ & \\
\hline$E 20.3 .1 .3$ & $\square$ & Medicina General & $E 20.3 .2 .3$ & \\
\hline E20.3.1.4 & & Cirurgia & $E 20.3 .2 .4$ & \\
\hline TE20.3.1.5 & $\square$ & Otras (ej. por favor especificar) & $\mathrm{E} 20.3 .2 .5$ & \\
\hline
\end{tabular}

E5. ¿Durante los últimos $\mathbf{3 0}$ días, su familiar ha recibido atención en un Servicio de Urgencias (por menos de $\mathbf{2 4 h}$ )?

No, Si es No ir a la pregunta E6

Si $\quad$ E5.1 Si es Si, ¿Cuantas veces?

E6. ¿Su familiar ha sido trasladado por un evento grave a otro hospital?

No

Si E6.1. Si es Si, ¿Qué tipo de centro? 
E7. Durante los últimos $\mathbf{3 0}$ días, ¿̇su familiar ha recibido cuidados de doctores, fisioterapeuta, psicólogo o de otro profesional de cuidados?

No, $\quad$ Si es No ir a la pregunta E8

E7.1 En caso afirmativo, especificar el número de visitas para cada tipo de cuidado recibido.

\begin{tabular}{|lll|}
\hline & E7.1.1 \\
& Tipo de cuidado \\
E7.1.1.1 & $\square$ & Medicina General \\
\hline E7.1.1.2 & $\square$ & Geriatra \\
\hline E7.1.1.3 & $\square$ & Neurologo \\
\hline E7.1.1.4 & $\square$ & Psquiatra \\
\hline E7.1.1.5 & $\square$ & Fisioterapeuta \\
\hline E7.1.1.6 & $\square$ & Terapeuta ocupacional \\
\hline E7.1.1.7 & $\square$ & Trabajadora social \\
\hline E7.1.1.8 & $\square$ & Psicologo \\
\hline E7.1.1.9 & $\square$ & Auxiliar de clinica \\
\hline E7.1.1.10 & $\square$ & Enfermera \\
\hline TE7.1.1.11 & $\square$ & Otros (e.j. especialistata; por favor \\
& & especifique) \\
\hline
\end{tabular}

E7.1.2

Número de visitas durante los últimos $\mathbf{3 0}$

E7.1.2.1

E7.1.2.2

E7.1.2.3

E7.1.2.4

E7.1.2.5

E7.1.2.6

E7.1.2.7

E7.1.2.8

E7.1.2.9

E7.1.2.10

E7.1.2.11

E8. Para cada servicio de la lista inferior, especifique el servicio al que ha acudido durante los últimos 30 días, el número de veces, y la media de horas por visitas.

\begin{tabular}{|c|c|c|c|c|}
\hline E8.1 & & Servicio & $\begin{array}{l}\text { E8.2 } \\
\text { № de visitas en } \\
\text { los últimos } 30\end{array}$ & $\begin{array}{l}\text { E8.3 } \\
\text { № de horas por } \\
\text { visita }\end{array}$ \\
\hline E8.1.1 & $\square$ & Enfermera comunitaria & E8.2.1 & E8.3.1 1 \\
\hline E8.1.2 & $\square$ & $\begin{array}{l}\text { Profesional del cuidado en el hogar/ } \\
\text { auxiliar de clínica }\end{array}$ & E8.2.2 & E8.3.2 \\
\hline E8.1.3 & $\square$ & Comida a domicilio & E8.2.3 $\perp \perp$ & E8.3.3 \\
\hline E8.1.4 & $\square$ & Transporte (público/mutua privada) & E8.2.4 $\perp$ & E8.3.4 \\
\hline TE8.1.5 & $\square$ & Otros (especifique, por favor) & E8.2.5 $\perp$ & E8.3.5 \\
\hline
\end{tabular}




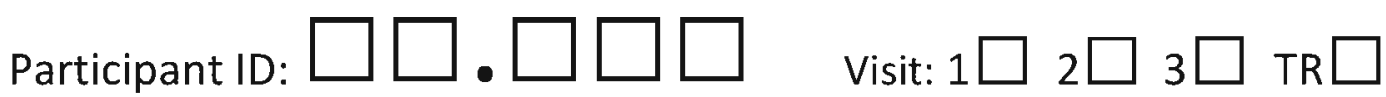

\section{CUESTIONARIO DE CALIDAD DE VIDA EN LA ENFERMEDAD DE ALHEIMER}

Versión para la familia

Las siguientes preguntas tratan sobre la calidad de vida de su familiar. Cuando piensa en la vida de su familiar, se tienen en cuenta varios aspectos, algunos de los cuales se detallan a continuación.

Piense en cada uno de los elementos mencionados y evalúe la calidad de vida actual de su familiar para cada uno seleccionando una de estas cuatro palabras: malo/a, regular, bueno/a, excelente. Evalúelos basándose en la vida de su familiar en la actualidad (es decir, durante las últimas semanas). Si tiene alguna pregunta sobre cualquiera de los elementos mencionados abajo, solicite ayuda a la persona que le ha entregado este formulario

\begin{tabular}{|c|c|c|c|c|c|}
\hline E9 & Salud física & $\square$ Malo/a & $\begin{array}{c}\square \\
\text { Regular }\end{array}$ & $\begin{array}{c}\square \\
\text { Bueno/a }\end{array}$ & $\square$ Excelente \\
\hline E10 & Energía & $\square$ Malo/a & $\begin{array}{c}\square \\
\text { Regular }\end{array}$ & $\begin{array}{c}\square \\
\text { Bueno/a }\end{array}$ & $\square$ Excelente \\
\hline E11 & Estado de ánimo & $\square$ Malo/a & $\begin{array}{c}\square \\
\text { Regular }\end{array}$ & $\begin{array}{c}\square \\
\text { Bueno/a }\end{array}$ & $\square$ Excelente \\
\hline E12 & Condiciones de vida & $\square$ Malo/a & $\begin{array}{c}\square \\
\text { Regular }\end{array}$ & $\begin{array}{c}\square \\
\text { Bueno/a }\end{array}$ & $\square$ Excelente \\
\hline E13 & Memoria & $\square$ Malo/a & $\begin{array}{c}\square \\
\text { Regular }\end{array}$ & $\begin{array}{c}\square \\
\text { Bueno/a }\end{array}$ & $\square$ Excelente \\
\hline E14 & Familia & $\square$ Malo/a & $\begin{array}{c}\square \\
\text { Regular }\end{array}$ & $\begin{array}{c}\square \\
\text { Bueno/a }\end{array}$ & $\square$ Excelente \\
\hline E15 & Matrimonio / Relación personal estrecha & $\square$ Malo/a & $\begin{array}{c}\square \\
\text { Regular }\end{array}$ & $\begin{array}{c}\square \\
\text { Bueno/a }\end{array}$ & $\square$ Excelente \\
\hline E16 & Vida social (amistades). & $\square$ Malo/a & $\begin{array}{c}\square \\
\text { Regular }\end{array}$ & $\begin{array}{c}\square \\
\text { Bueno/a }\end{array}$ & $\square$ Excelente \\
\hline E17 & Visión general de si mismo/a. & $\square$ Malo/a & $\begin{array}{l}\square \\
\text { Regular }\end{array}$ & $\begin{array}{c}\square \\
\text { Bueno/a }\end{array}$ & $\square$ Excelente \\
\hline E18 & Capacidad para realizar tareas en casa. & $\square$ Malo/a & $\begin{array}{r}\square \\
\text { Regular }\end{array}$ & $\begin{array}{c}\square \\
\text { Bueno/a }\end{array}$ & $\square$ Excelente \\
\hline E19 & Capacidad para hacer cosas por diversión & $\square$ Malo/a & $\begin{array}{c}\square \\
\text { Regular }\end{array}$ & $\begin{array}{c}\square \\
\text { Bueno/a }\end{array}$ & $\square$ Excelente \\
\hline E20 & Situación financiera & $\square$ Malo/a & $\begin{array}{r}\square \\
\text { Regular }\end{array}$ & $\begin{array}{c}\square \\
\text { Bueno/a }\end{array}$ & $\square$ Excelente \\
\hline E21 & La vida en general & $\square$ Malo/a & $\begin{array}{r}\square \\
\text { Regular }\end{array}$ & $\begin{array}{c}\square \\
\text { Bueno/a }\end{array}$ & $\square$ Excelente \\
\hline
\end{tabular}


Participant ID: $\square \square . \square \square \square$ Visit: $1 \square 2 \square 3 \square$ TR $\square$

\section{INDICE KATZ DE INDEPENDENCIA EN LAS ACTIVIDADES DE LA VIDA DIARIA}

Señale la descripción adecuada para cada una de las funciones que figuran en la lista siguiente. (La palabra "ayuda" significa supervisar, dar instrucciones o asistencia personal.)

E23 Lavarse - ya sea con una esponja, o sea en la bañera, o sea en la ducha.

No recibe ayuda, (entra y sale de la bañera por si mismo/a si la bañera es el medio de aseo habitual)

Recibe ayuda sólo para lavarse una parte del cuerpo (como la espalda o una pierna)

Recibe ayuda para lavarse más de una parte del cuerpo (o no se lava por si mismo/a)

E24 Vestirse - sacar la ropa de los armarios y de los cajones - incluyendo la ropa interior, las prendas exteriores y abrocharse botones, cremalleras, etc. (incluyendo tirantes si los lleva).

Saca la ropa y se viste completamente sin ayuda.

Saca la ropa y se viste sin ayuda excepto para atarse los cordones de los zapatos

Recibe ayuda para sacar la ropa o para vestirse, o se queda parcial o completamente sin vestir

E25 Ir al servicio - ir al servicio para orinar y hacer de vientre; limpiarse después por sí mismo/a, y arreglarse la ropa.

Se desplaza hasta el servicio, se limpia y se arregla la ropa sin ayuda (quizás usa un objeto de apoyo como un bastón, un andador o una silla de ruedas y posiblemente usa la cuña o la silla retrete por la noche, vaciándola por la mañana).

Recibe ayuda para desplazarse hasta el servicio, o para limpiarse o arreglarse la ropa después, o para usar la cuña o la silla retrete por la noche.

No va al servicio para hacer sus necesidades.

\section{E26 Movilidad.}

Se acuesta y se levanta de la cama así como de la silla sin ayuda (posiblemente usa un objeto de apoyo como un bastón o un andador).

Se acuesta o se levanta de la cama o de la silla con ayuda de alguien.

No se levanta de la cama.

\section{E27 Continencia.}

$\square \quad$ Controla totalmente la orina y las heces por si mismo/a.

Tiene "accidentes" ocasionales.

La supervisión le ayuda a controlar la orina o las heces; usa una sonda, o sufra incontinencia.

\section{E28 Alimentarse.}

Se alimenta sin ayuda.

Se alimenta solo/a pero recibe ayuda para cortar la carne o untar el pan con mantequilla.

Recibe ayuda para alimentarse, o se alimenta parcial o totalmente mediante sondas o líquidos intravenosos. 


\section{Participant ID: $\square \square . \square \square \square$ Visit: $1 \square$ 2 $\square 3 \square$ TR $\square$}

\section{INVENTARIO NEUROPSIQUIÁTRICO (NPI)}

Formule las siguientes preguntas teniendo en cuenta los cambios que hayan podido suceder. Marque

"sí" sólo si el síntoma se ha manifestado durante las últimas 4 semanas; de lo contrario, marque "no.

Por favor conteste con honestidad y con cuidado. Pida ayuda si tiene dudas en alguna pregunta.

\begin{tabular}{|c|c|}
\hline $\begin{array}{l}\text { E29 DELIRIOS } \\
\square \text { si } \\
\square \text { no }\end{array}$ & $\begin{array}{l}\text { ¿El/la paciente cree que otras personas le están robando o que planean } \\
\text { hacerle daño de un modo u otro? } \\
\qquad \text { E29.1 Gravedad: } \square 1 \square 2 \square 3 \quad \text { E29.2 Angustia: } \square 0 \square 1 \square 2 \square 3 \square 4 \square 5\end{array}$ \\
\hline $\begin{array}{l}\text { E30 ALUCINACIONES } \\
\square \text { si } \\
\square \text { no }\end{array}$ & $\begin{array}{l}\text { ¿El/la paciente actúa como si oyese voces? ¿Habla con personas que no están } \\
\text { presentes? } \\
\text { E30.1 Gravedad: } \square 1 \square 2 \square 3 \quad \text { E30.2 Angustia: } \square 0 \square 1 \square 2 \square 3 \square 4 \square 5 \\
\end{array}$ \\
\hline $\begin{array}{l}\text { E31AGITACIÓN O AGRESIVIDAD } \\
\qquad \text { si } \\
\square \text { no }\end{array}$ & $\begin{array}{l}\text { ¿EI/la paciente se muestra obstinado/a y se resiste a recibir ayuda de los } \\
\text { demás? } \\
\qquad \text { E31.1 Gravedad: } \square 1 \square 2 \square 3 \quad \text { E31.2Angustia: } \square 0 \square 1 \square 2 \square 3 \square 4 \square 5\end{array}$ \\
\hline $\begin{array}{l}\text { E32 DEPRESIÓN O DISFORIA } \\
\quad \square \text { si } \\
\square \text { no }\end{array}$ & E32.1 Gravedad: $\square 1 \square 2 \square 3 \quad$ E32.2Angustia: $\square 0 \square 1 \square 2 \square 3 \square 4 \square 5$ \\
\hline $\begin{array}{l}\text { E33 ANSIEDAD } \\
\square \text { si } \\
\square \text { no }\end{array}$ & $\begin{array}{l}\text { ¿Se altera el/la paciente cuando se separa de usted? ¿Muestra algún otro } \\
\text { signo de nerviosismo, como por ejemplo falta de aire, suspiros, incapacidad } \\
\text { de relajarse o sensación de estar demasiado tenso/a? } \\
\qquad \text { E33.1 Gravedad: } \square 1 \square 2 \square 3 \quad \text { E33.2Angustia: } \square 0 \square 1 \square 2 \square 3 \square 4 \square 5\end{array}$ \\
\hline $\begin{array}{l}\text { E34 EUFORIA } \\
\square \text { si } \\
\square \text { no }\end{array}$ & $\begin{array}{l}\text { ¿El/la paciente parece sentirse demasiado bien o actúa como si } \\
\text { estuviese excesivamente feliz? } \\
\text { E34.1 Gravedad: } \square 1 \square 2 \square 3 \quad \text { E35.2Angustia: } \square 0 \square 1 \square 2 \square 3 \square 4 \square 5\end{array}$ \\
\hline $\begin{array}{l}\text { E35 APATÍA O INDIFERENCIA } \\
\qquad \text { si } \\
\square \text { no }\end{array}$ & $\begin{array}{l}\text { ¿El/la paciente parece menos interesado/a en sus actividades habituales } \\
\text { y en las actividades y los planes de los demás? } \\
\text { E35.1 Gravedad: } \square 1 \square 2 \square 3 \quad \text { E35.2Angustia: } \square 0 \square 1 \square 2 \square 3 \square 4 \square 5\end{array}$ \\
\hline $\begin{array}{l}\text { E36 DESHINIBICIÓN } \\
\square \text { si } \\
\square \text { no }\end{array}$ & $\begin{array}{l}\text { ¿El/la paciente parece actuar de forma impulsiva? } \\
\text { Por ejemplo, ¿habla con desconocidos como si los conociera, o dice cosas que } \\
\text { pueden herir la sensibilidad de los demás? } \\
\text { E36.1 Gravedad: } \square 1 \square 2 \square 3 \quad \text { E36.2Angustia: } \square 0 \square 1 \square 2 \square 3 \square 4 \square 5\end{array}$ \\
\hline $\begin{array}{l}\text { E37 IRRITABILIDAD O LABILIDAD } \\
\square \text { si } \\
\square \text { no }\end{array}$ & $\begin{array}{l}\text { ¿El/la paciente se muestra impaciente y malhumorado/a? ¿Le cuesta } \\
\text { asimilar las demoras o esperar a que se produzcan las actividades que están } \\
\text { planeadas? } \\
\text { E37.1 Gravedad: } \square 1 \square 2 \square 3 \quad \text { E37.2Angustia: } \square 0 \square 1 \square 2 \square 3 \square 4 \square 5\end{array}$ \\
\hline $\begin{array}{l}\text { E38 } \quad \text { TRASTORNOS MOTORES } \\
\quad \square \text { si } \\
\square \text { no }\end{array}$ & $\begin{array}{l}\text { ¿El/la paciente realiza actividades repetitivas como caminar por la } \\
\text { Casa, manosear los botones, enrollar cuerdas u otros actos repetitivos? } \\
\quad \text { E38.1 Gravedad: } \square 1 \square 2 \square 3 \quad \text { E38.2Angustia: } \square 0 \square 1 \square 2 \square 3 \square 4 \square 5\end{array}$ \\
\hline $\begin{array}{l}\text { E39 CONDUCTAS NOCTURNAS } \\
\square \text { si } \\
\square \text { no }\end{array}$ & $\begin{array}{l}\text { ¿Le despierta el/la paciente durante la noche, se levanta demasiado pronto por } \\
\text { la mañana o echa cabezadas demasiado largas o frecuentes durante el día? } \\
\text { E39.1 Gravedad: } \square 1 \square 2 \square 3 \text { E39.2Angustia: } \square 0 \square 1 \square 2 \square 3 \square 4 \square 5\end{array}$ \\
\hline $\begin{array}{l}\text { E40 APETITO Y ALIMENTACIÓN } \\
\qquad \text { si } \\
\square \text { no }\end{array}$ & $\begin{array}{l}\text { ¿Ha perdido o ganado peso el/la paciente, o han cambiado sus gustos con } \\
\text { respecto a la comida? } \\
\text { E40.1 Gravedad: } \square 1 \square 2 \square 3 \text { E40.2Angustia: } \square 0 \square 1 \square 2 \square 3 \square 4 \square 5\end{array}$ \\
\hline
\end{tabular}




\section{INDICADORES DE CALIDAD DE VIDA}

\section{Estado nutricional}

E41 Ha sufrido el residente una rápida disminución o pérdida de peso $\geq 4 \%$ en el pasado año

$\square \mathrm{si}$

$\square$ no

E42 Contenciones físicas

\begin{tabular}{|c|c|c|c|c|c|c|c|}
\hline & & Nunca & $\begin{array}{l}\text { Menos } \\
\text { de } 1 \mathrm{x} \\
\text { semana }\end{array}$ & $\begin{array}{c} \pm 1 \text { a } 5 \text { a } \\
\text { la } \\
\text { semana }\end{array}$ & $\begin{array}{l} \pm 1 \text { al } \\
\text { día }\end{array}$ & $\begin{array}{l}\text { Más de } 1 \\
\text { al día }\end{array}$ & $\begin{array}{l}\text { No } \\
\text { aplicable }\end{array}$ \\
\hline$E 42.1$ & $\begin{array}{l}\text { Cinturón de contención (en } \\
\text { cama o silla) }\end{array}$ & $\square$ & $\square$ & $\square$ & $\square$ & $\square$ & $\square$ \\
\hline$E 42.2$ & $\begin{array}{l}\text { Silla (de ruedas) con una } \\
\text { mesa de bloqueo/Silla con } \\
\text { un tablero }\end{array}$ & $\square$ & $\square$ & $\square$ & $\square$ & $\square$ & $\square$ \\
\hline E42.3 & $\begin{array}{l}\text { Sillas (de ruedas) hondas } \\
\text { y/o tumbadas }\end{array}$ & $\square$ & $\square$ & $\square$ & $\square$ & $\square$ & $\square$ \\
\hline E42.4 & $\begin{array}{l}\text { Barandillas bilaterales de } \\
\text { cierre complete }\end{array}$ & $\square$ & $\square$ & $\square$ & $\square$ & $\square$ & $\square$ \\
\hline E42.5 & $\begin{array}{l}\text { Traje de dormir/Sábanas } \\
\text { ajustadas/ ceñidas }\end{array}$ & $\square$ & $\square$ & $\square$ & $\square$ & $\square$ & $\square$ \\
\hline E42.6 & Sistema de infrarrojos & $\square$ & $\square$ & $\square$ & $\square$ & $\square$ & $\square$ \\
\hline$E 42.7$ & Sistema de censores & $\square$ & $\square$ & $\square$ & $\square$ & $\square$ & $\square$ \\
\hline E42.8 & $\begin{array}{r}\text { Bloqueo de las puertas de } \\
\text { las puertas de los dormitorios }\end{array}$ & $\square$ & $\square$ & $\square$ & $\square$ & $\square$ & $\square$ \\
\hline
\end{tabular}

\section{Dolor}

(Marca el dolor más alto presente en los últimos 7 días)

E43 FRECUENCIA con la que el residente se queja o muestra evidencias de dolor
$\square$ Sin dolor., si es NO E44
$\square$ Inferior a dolor diario
$\square$ Dolor diario

E43.1 INTENSIDAD del dolor

$\square$ dolor leve

$\square$ dolor moderado

$\square$ Momentos en que el dolor es horrible o insoportable

E43.2 LOCALIZACIÓN DEL DOLOR (Si el dolor está presente, marca las localizaciones que haya padecido en los últimos 7 días)
E43.2.1 $\square$ Dolor de espalda
E43.2.2 $\square$ Dolor en los huesos
E43.2.3 $\square$ Dolor en el pecho al realizar las actividades cotidianas
E43.2.4 $\square$ Dolor de cabeza
E43.2.5 $\square$ Dolor en la cadera
E43.2.6 $\square$ Dolor en la incisión
E43.2.7 $\square$ Dolor en las articulaciones (distinto al de la cadera)
E43.2.8 $\square$ Dolor en tejidos blandos (ej. Lesión múscular)
E43.2.9 $\square$ Dolor estomacal 


\section{Úlceras por presión}

E 44 ¿Tiene el residente úlceras por presión?

$\square$ No, Si es NO continúe en la pregunta E45

$\square \mathrm{Si} . \quad$ Si es Si continúe las preguntas

\section{Clasificación de los estadios:}

Estadio 2 Perdida parcial del grosor (de la continuidad) de la piel que se manifiesta clínicamente como una abrasión, ampolla o depresión inflamada.

Estadio $3 \quad$ El grosor de la piel se pierde dejando al descubierto el tejido subcutáneo. Se presenta como una depresión profunda con o sin pérdida de los tejidos adyacentes.

Estadio 4 El grosor de la piel y el tejido subcutáneo se pierden dejando al descubierto músculo o hueso

E44.1 Por favor, indica la localización de la úlcera por presión

\begin{tabular}{|lll|l|ll|ll|lc|}
\hline \multicolumn{3}{|c|}{ E44.1.1 Localización } & \multicolumn{5}{c|}{ E44.1.2 Clasifcación } \\
\hline E44.1.1.1 & $\square$ & Sacro/espalda & E44.1.2.1 & $\square$ & 2 & $\square$ & 3 & $\square$ & 4 \\
\hline E44.1.1.2 & $\square$ & Codo & E44.1.2.2 & $\square$ & 2 & $\square$ & 3 & $\square$ & 4 \\
\hline E44.1.1.3 & $\square$ & Cadera & E44.1.2.3 & $\square$ & 2 & $\square$ & 3 & $\square$ & 4 \\
\hline E44.1.1.4 & $\square$ & Talón & E44.1.2.4 & $\square$ & 2 & $\square$ & 3 & $\square$ & 4 \\
\hline E44.1.1.5 & $\square$ & Rodilla & E44.1.2.5 & $\square$ & 2 & $\square$ & 3 & $\square$ & 4 \\
\hline E44.1.1.6 & $\square$ & Tobillo & E44.1.2.6 & $\square$ & 2 & $\square$ & 3 & $\square$ & 4 \\
\hline E44.1.1.7 & $\square$ & Omoplato & E44.1.2.7 & $\square$ & 2 & $\square$ & 3 & $\square$ & 4 \\
\hline TE44.1.1.8 & $\square$ & Otros: & E44.1.2.8 & $\square$ & 2 & $\square$ & 3 & $\square$ & 4 \\
\hline
\end{tabular}

\section{Caídas}

Se define caida como el desplazamiento no intencionado hacia el suelo o en un nivel inferior

E45. El residente ha sufrido al menos una caída en los últimos 3 meses

$\square$ No, Si es NO continúe en la pregunta E46

$\square$ Si. $\quad$ Si es Si continúe las preguntas

E45.1. Por favor indicar el número de caídas durante los últimos 3 meses caídas

E45.2. Sufrió el residente alguna lesión como consecuencia de la caída?

$$
\begin{aligned}
& \square \text { No } \\
& \square \mathrm{Si}
\end{aligned}
$$

E45.2.2 Si el residente se lesionó, sufrió alguna fractura como consecuencia de la caída?

$$
\begin{aligned}
& \square \text { No } \\
& \square \mathrm{Si}
\end{aligned}
$$

TE46 Por favor menciones algún evento relacionado con problemas de salud ocurrido en los últimos 3 meses y no mencionado anteriormente: 


\section{Participant ID: $\square \square$. $\square \square \square$ Visit: $1 \square$ 2 $\square$ 3 $\square$ TR}

\section{ESCALA CORNELL PARA LA DEPRESIÓN EN LA DEMENCIA}

La puntuación se obtiene a partir de la entrevista con el cuidador. La puntuación se basa en síntomas y signos que se hayan manifestado durante la semana previa a la entrevista. No se ha de puntuar si los síntomas son debidos a una discapacidad física o enfermedad

Puntuación

$$
\begin{aligned}
& A=\text { imposible de evaluar } \\
& 0=\text { ausencia } \\
& 1=\text { moderado/intermitente } \\
& 2=\text { severo }
\end{aligned}
$$

\begin{tabular}{|c|c|c|c|c|}
\hline E47 & Ansiedad: expresión ansionsa, rumiación preocupación & $\square \mathrm{A}$ & $\square 0$ & $\square$ \\
\hline E48 & Tristeza: expresión triste, voz triste, tendencia a llorar & $\square \mathrm{A}$ & $\square 0$ & $\square$ \\
\hline E49 & $\begin{array}{l}\text { Falta de capacidad de reacción delante de situaciones } \\
\text { agradables }\end{array}$ & $\square \mathrm{A}$ & $\square 0$ & \\
\hline 50 & Irritabilidad: se enfada fácilmente, irascible & $\square \mathrm{A}$ & $\square 0$ & $\square$ \\
\hline
\end{tabular}

\section{Signos relacionados con el estado de ánimo}

\section{Alteraciones del comportamiento}

E51 Agitación: intranquilidad, se retuerce las manos, se tira de los cabellos

$\begin{array}{llll}\square \mathrm{A} & \square 0 & \square 1 & \square 2 \\ \square \mathrm{A} & \square 0 & \square 1 & \square 2 \\ \square \mathrm{A} & \square 0 & \square 1 & \square 2 \\ \square \mathrm{A} & \square 0 & \square 1 & \square 2\end{array}$

E52 Enlentecimiento: movimientos lentos, habla lenta, reacciones enlentecidas

E53 Múltiples molestias físicas (puntuar "0" si sólo presente molestias gastrointestinales)

E54 Pérdida de interés: menos implicado en actividades cotidianas (puntuar sólo sí el cambio se ha producido de forma aguda. Por ejemplo: en menos de un mes)

\section{Signos físicos}

E55 Pérdida de apetito: come menos de lo normal

E56 Pérdida de peso: puntuar "2" si ha perdido más de $2 \mathrm{Kgr}$ en 1 mes

E57 Pérdida de energía: Fatiga fácil, incapaz de mantener ciertas actividades (puntuar sólo sí el cambio se ha producido de forma aguda. Por ejemplo: en menos de un mes)

\section{Funciones Cíclicas}

E58 Variaciones diurnas del humor: los síntomas empeoran por la mañana

E59 Dificultad para conciliar el sueño: se duerme más tarde de lo que es habitual en este paciente.

E60 Se despierta varias veces durante la noche

E61 Se despierta más pronto de lo que estaa acostumbrado

$\begin{array}{llll}\square \mathrm{A} & \square 0 & \square 1 & \square 2 \\ \square \mathrm{A} & \square 0 & \square 1 & \square 2 \\ \square \mathrm{A} & \square 0 & \square 1 & \square 2\end{array}$

\section{Alteraciones del contenido del pensamiento}

E62 Suicidio: piensa qué no vale la pena vivir, deseos de suicidio o tentativa de autolisis

E63 Baja autoestima: desprecio de sí mismo, sentimientos de culpa y sentimientos de fracaso

E64 Pesimismo: anticipación de lo peor que podría pasar 
Particicant to: $\square \square . \square \square \square \quad$ Vist: $1 \square 2 \square 3 \square$ TR $\square$ 


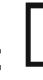

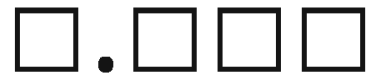

\section{Cuestionario INFOSA-DEM \\ Información sobre el PACIENTE. \\ SEGUIMIENTO \\ (Cumplimentado por el investigador)}

P20. QOL-AD

\section{P20.1 MOVILIDAD}

No tengo problemas para caminar.

Tengo algunos problemas para caminar

Tengo que estar en la cama

\section{P20.2 CUIDADO PERSONAL}

No tengo problemas con el cuidado personal.

Tengo algunos problemas para lavarme o vestirme solo

Soy incapaz de lavarme o vestirme solo.

P20.3 ACTIVIDADES de Todos los Días (ej. trabajar, estudiar, hacer tareas domésticas, actividades familiares o realizadas durante el tiempo libre)

Tengo algunos problemas para realizar mis actividades de todos los días.

No tengo problemas para realizar mis actividades de todos los dias.

Soy incapaz de realizar mis actividades de todos los días.

\section{P20.4 Dolor/Malestar}

No tengo dolor ni malestar.

Tengo moderado dolor o malestar.

Tengo mucho dolor o malestar.

\section{P20.5 Ansiedad/Depresión}

No estoy ansioso/a ni deprimido/a.

Estoy moderadamente ansioso/a o deprimido/a.

Estoy muy ansioso/a o deprimido/a
Para ayudar a la gente a describir lo bueno o malo que es su estado de salud, hemos dibujado una escala parecida a un termómetro en el cual se marca con un $100 \mathrm{el}$ mejor estado de salud que puede imaginarse, y con un 0 el peor estado de salud que puede imaginarse.

Por favor, dibuje una línea desde el cuadro que dice "su estado de salud hoy," hasta el punto en la escala que, en su opinión, indique lo bueno o malo que es su estado de saluden el día de hoy

P20.6 Total puntuación

\section{P21: Evaluación}

Evaluación completada, resultado fiable

Inaplicable/incapacidad para responder/negativa del paciente a colaborar/falta de motivación

Inaplicable/incapacidad física para responder/incapacidad cognitiva (ej. visual/discapacidad auditiva, afasia) 

Participant ID: $\square \square . \square \square \square$ visit: $1 \square$ 2 $\square$ 3 $\square$ TR $\square$

\section{Cuestionario INFOSA-DEM \\ Información sobre el CUIDADOR INFORMAL. SEGUIMIENTO}

(Cumplimentado por el investigador)

\section{Escala de Competencia para el Cuidado \\ Cumplimentar por el/la cuidador/a principal/familiar más cercano}

Las siguientes preguntas tratan sobre el grado en el que Ud. se siente capacitado para cuidar a un enfermo. Por favor, marque con un círculo el número que lo describe mejor.

Cuánto Usted...

Nada Solo Algo Mucho
un poco
C8. ¿Cree que ha aprendido a afrontar situaciones difíciles?
01
2
3
C9. ¿Siente que, en general, es un buen cuidador?
01
23

Pensando en todos los cambios diarios que Ud. pudiera enfrentar al cuidar a un enfermo, la labor que está realizando y la forma en que maneja las dificultades:

Nada Solo Algo Mucho

C10. ¿Cómo de capacitado se siente para cuidar a un enfermo? un poco

C11. ¿Cómo de seguro se siente en el cuidado del enfermo? $\quad 0 \quad \begin{array}{llll}1 & 2 & 3\end{array}$

\section{RUD- Cuidado en el entorno domiciliario}

Datos demográficos del/la cuidador/a principal/familiar más cercano

Por favor, conteste las siguientes preguntas sobre su situación personal.

C129. ¿Vive Usted con el/la paciente? $\square$ Sí $\square$ No

\section{Tiempo del/de la cuidador/a principal o familiar más próximo}

TC130. En un día típico de cuidado del/de la paciente durante los últimos 30 días. ¿Cuánto tiempo dedicó al día a ayudar al/a la paciente en actividades como ir al lavabo, comer, vestirse y desvestirse, arreglarse, caminar y lavarse/bañarse horas al día

TC130.1. Durante los últimos 30 días, ¿cuántos días prestó estos servicios al/a la paciente? Días

TC131. En un día típico de cuidado del/de la paciente durante los últimos 30 días, ¿cuánto tiempo dedicó al día a ayudar al/a la paciente en actividades como comprar, preparar la comida, ocuparse de la casa, lavar la ropa, el transporte, tomar la medicación y gestionar temas financieros? horas al día. 


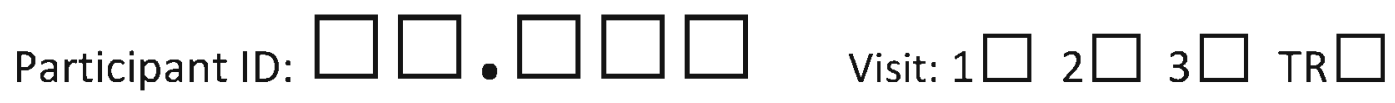

TC132. En un día típico de cuidado del/de la paciente durante los últimos 30 días, ¿cuánto tiempo dedicó al día a vigilar (es decir, prevenir incidentes peligrosos) al/a la paciente?

horas al día.

TC132.1. Durante los últimos 30 días, ¿cuántos días prestó estos servicios al/a la paciente? Días

\section{Situación laboral del cuidador/a principal o familiar más próximo}

C133. ¿Realiza actualmente un trabajo remunerado?

$\square$ Sí si la respuesta es Sí, continúe contestando a las preguntas a partir de la pregunta TC 135

No si la respuesta es NO, conteste solamente la pregunta C134 y después vaya directamente al apartado utilización recursos sanitarios, pregunta C140

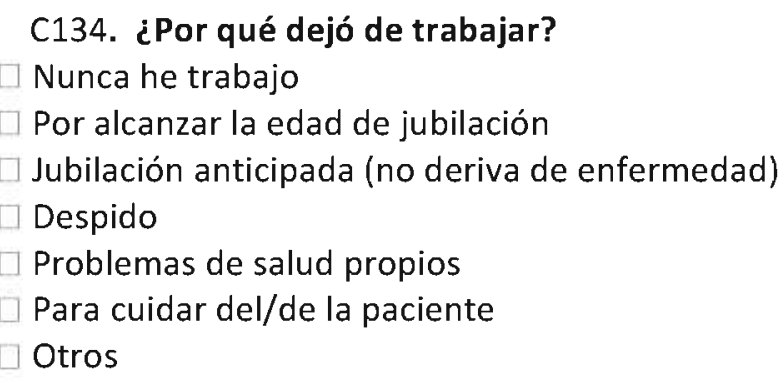

TC135. Durante los últimos 30 días, ¿cuántas horas de trabajo remunerado realiza en total a la semana (incluyendo las que realiza como cuidador)? horas/semana

C136. De este número de horas, ¿̇e le remunera una parte por cuidar al/a la paciente?

$\square$ No

$\square$ Sí Si la respuesta es Sí:

TC136.1 ¿Cuántas horas por semana se le remuneran? horas/semana

C137. Durante los últimos 30 días, ¿̇ha tenido que reducir el número de horas que normalmente trabaja cada semana (reducción de jornada) debido a sus responsabilidades como cuidador/a?

$\square$ No

$\square$ Sí $\quad$ Si la respuesta es Sí:

TC137.1 ¿Cuántas horas ha dejado de trabajar? horas/semana

Durante los últimos 30 días, indique en cuántas ocasiones sus responsabilidades como cuidador/a han afectado a su trabajo de alguna de estas formas:

TC138. Pérdida de un día completo de trabajo. número de veces

TC139. Pérdida de parte de un día de trabajo. número de veces

\section{Utilización de recursos sanitarios por el cuidador/a principal o familiar más próximo.}

C140. Durante los últimos 30 días cha sido ingresado en un hospital (por más de 24 horas)?

$\square$ NO Si la respuesta en NO, pase a la pregunta C141

$\square$ Sí

TC140.1. Durante los últimos 30 días ¿cuántas veces ha sido hospitalizado/a? número de veces 


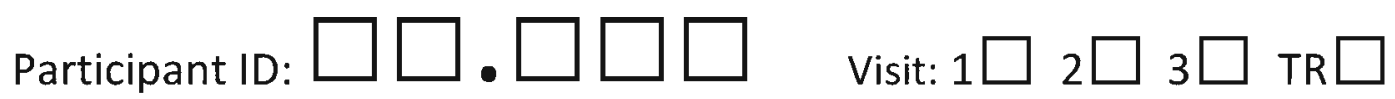

C140.2. Para cada ingreso (durante los últimos 30 días), por favor, facilite el diagnóstico o el motivo del mismo.

\begin{tabular}{|l|l|l|}
\hline $\begin{array}{l}\text { 140.2.1. } \\
\text { No de ingresos }\end{array}$ & TC140.2.2. Diagnóstico general o motivo para el ingreso & $\begin{array}{l}\text { TC140.2.3. Código GDR } \\
\text { (si es posible) }\end{array}$ \\
\hline$\square 1$ & & \\
\hline$\square 2$ & & \\
\hline$\square 3$ & & \\
\hline$\square 4$ & & \\
\hline
\end{tabular}

C140.3. Por favor, indique el número total de noches pasadas en cada uno de los servicios hospitalarios (contando todas las hospitalizaciones durante los últimos 30 dias).

\begin{tabular}{|l|l|}
\hline C140.3.1. Servicio hospitalario & TC140.3.2 № de noches \\
\hline C140.3.1.1 $\square$ Geriatría & TC140.3.2.1 \\
\hline C140.3.1. $\square \square$ Psiquiatría & TC140.3.2.2 \\
\hline C140.3.1. $3 \square$ Medicina interna & TC140.3.2.3 \\
\hline C140.3.1.4 $\square$ Cirugía & TC140.3.2.4 \\
\hline C140.3.1.5 $\square$ Otros (por favor, especifique) & TC140.3.2.5 \\
\hline
\end{tabular}

C141. En los últimos 30 días, cha recibido asistencia en el servicio de urgencias de un hospital (durante menos de $24 \mathrm{~h})$ ? $\quad$ DNo

¿Sí Si la respuesta es Sí:

TC141.1 ¿Cuántas veces? veces

C142. Durante los últimos 30 días, ¿̇ha sido visitado/a, por un médico, un fisioterapia, un psicólogo u otros profesionales sanitarios?

$\square$ No

$\square$ Sí Si la respuesta es Sí, Conteste a la siguiente tabla

C142.1 indique el número de visitas que ha recibido de cada uno de los profesionales sanitarios.

\begin{tabular}{|c|c|c|}
\hline & C142.1.1 Tipo de profesional sanitario & $\begin{array}{l}\text { 1.2. № visitas (Durante los últim } \\
\text { días) }\end{array}$ \\
\hline C142.1.1.1 & $\square$ Medico general & TC142.1.2.1 \\
\hline C142.1.1.2 & $\square$ Geriatra & TC142.1.2.2 \\
\hline C142.1.1.3 & $\square$ Neurólogo/a & TC142.1.2.3 \\
\hline C142.1.1.4 & $\square$ Psiquiatra & TC142.1.2.4 \\
\hline C142.1.1.5 & Fisioterapeuta & TC142.1.2.5 \\
\hline
\end{tabular}




\begin{tabular}{|c|c|c|}
\hline C142.1.1.6 & $\square$ Terapeuta ocupacional & TC142.1.2.6 \\
\hline C142.1.1.7 & $\square$ Trabajador social & TC142.1.2.7 \\
\hline C142.1.1.8 & $\square$ Psicólogo & TC142.1.2.8 \\
\hline C142.1.1.9 & $\square$ Auxiliar de clínica & TC142.1.2.9 \\
\hline C142.1.1.10 & $\square$ Enfermero/a & TC142.1.2.10 \\
\hline TC142.1.1.11 & $\square$ Otros (por favor, especifique) & TC142.1.2.11 \\
\hline
\end{tabular}

C143. De los servicios de la lista que aparece a continuación, por favor, especifique el número de veces que Usted recibió cada uno de estos servicios durante los últimos 30 días y el promedio de horas por visita.

\begin{tabular}{|l|l|l|}
\hline \multicolumn{1}{|c|}{ C143.1. Servicio } & $\begin{array}{l}\text { TC143.2 No visitas } \\
\text { (últimos 30 días) }\end{array}$ & $\begin{array}{c}\text { C143.3 № horas } \\
\text { por visita }\end{array}$ \\
\hline $\begin{array}{l}\text { C143.1. } \square \text { Visita de un enfermero/a de Atención Primaria/ } \\
\text { C143.1.2. } \square \text { Personal de asistencia a domicilio (ayuda con las } \\
\text { actividades personales e instrumentales de la vida diaria) / }\end{array}$ & TC143.2.1 & TC143.3.1 \\
\hline $\begin{array}{l}\text { Personal auxiliar de clínica o de geriatría } \\
\text { C143.1.3. } \square \text { Servicio de comidas a domicilio }\end{array}$ & TC143.3.2 \\
\hline $\begin{array}{l}\text { C143.1.4. } \square \text { Transporte (financiado por sanidad pública o pagado } \\
\text { SC143.1.5. } \square \text { Otros (por favor, especifique) }\end{array}$ & TC143.2.4 & TC143.3.4 \\
\hline \begin{tabular}{l} 
TC143.2.3 \\
\hline
\end{tabular} & TC143.2.5 & TC143.3.5 \\
\hline
\end{tabular}

C144. ¿Toma actualmente alguna medicación (con o sin receta médica)?

$\square$ NO

$\square$ Sí Si la respuesta es Sí, complete la siguiente tabla

C144.1 Complete la siguiente tabla.

\begin{tabular}{|c|c|c|c|}
\hline $\begin{array}{c}\text { TC144.1.1 Nombre genérico del } \\
\text { medicamento }\end{array}$ & $\begin{array}{c}\text { TC144.1.2 Dosis } \\
(\mathrm{mg})\end{array}$ & $\begin{array}{c}\text { TC144.1.3 no veces } \\
\text { que toma el } \\
\text { medicamento al día }\end{array}$ & $\begin{array}{c}\text { TC144.1.4 } \\
\text { Código ATC (si es posible) }\end{array}$ \\
\hline & & & \\
\hline
\end{tabular}


Participant ID: $\square \square . \square \square \square \quad$ Visit: $1 \square 2 \square 3 \square$ TR $\square$

\begin{tabular}{|l|l|l|l|}
\hline & & & \\
\hline & & & \\
\hline & & & \\
\hline & & & \\
\hline & & & \\
\hline & & & \\
\hline & & & \\
\hline & & & \\
\hline & & & \\
\hline & & & \\
\hline
\end{tabular}

C145. En que proporción utiliza usted los recursos sociales y sanitarios (visitas profesionales, medicamentos, hospitalización...)
$\square 0 \%$
$\square 25 \%$
$\square 50 \%$
$\square 75 \%$
$\square 100 \%$

C146. ¿Considera que influye en la utilización de esos recursos y su situación de cuidador informal?

$\square$ Sí $\quad \square$ NO 


\title{
INSTRUMENTO DE EVALUACIÓN DE LA REACCIÓN DEL CUIDADOR INFORMAL FRENTE AL CUIDADO (CRA)
}

\author{
Por favor señale las respuestas marcando una cruz: \\ 1. Totalmente en desacuerdo \\ 2. En desacuerdo \\ 3. Indiferente \\ 4. De acuerdo \\ 5. Totalmente de acuerdo
}

C147. Me siento privilegiado de poder cuidad a $\square 1 \square 2 \quad \square 3 \quad \square 4 \quad \square 5$ C148. Otros han delegado el cuidado de en mí. $\quad \square 1 \quad \square 2 \quad \square 3 \quad \square 4 \quad \square 5$

C149. Mis recursos económicos me permiten cubrir los gastos derivados del cuidado.

\section{$\square 1 \square 2 \quad \square 3 \quad \square 4 \quad \square 5$}

C150. Mis actividades están centradas en el cuidado de $\square 1 \quad \square 2 \quad \square \mathbf{3} \quad \square \mathbf{4} \quad \square \quad 5$

C151. Desde que cuido a parece que estoy siempre cansada.

$\square 1 \square 2 \quad \square 3 \quad \square 4 \quad \square 5$

C152. Es muy difícil conseguir ayuda de mi familia para cuidad a .$\square 1 \square 2 \quad \square 3 \quad \square 4 \quad \square 5$

C153. Me molesta tener que cuidar a $\square 1 \quad \square 2 \quad \square 3 \quad \square 4 \quad \square 5$

C154. Tengo que parar para descansar cuando realizo un trabajo. $\square 1 \quad \square 2 \quad \square 3 \quad \square 4 \quad \square 5$ C155. Realmente quiero cuidar a $\square 1 \quad \square 2 \quad \square 3 \quad \square 4 \quad \square 5$ C156. Mi salud ha empeorado desde que cuido a $\square 1 \quad \square 2 \quad \square 3 \quad \square 4 \quad \square 5$

C157. Visito menos a mis familiares y amigos desde que estoy cuidando a

\section{$\square 1 \square 2 \square 3 \quad \square 4 \quad \square 5$}

C158. Nunca seré capaz de dar tanto como yo he recibido de . $\square 1 \quad \square 2 \quad \square 3 \quad \square 4 \quad \square 5$ C159. Mi familia colabora en el cuidado de __ $\quad . \quad \square 1 \quad \square 2 \quad \square 3 \quad \square 4 \quad \square 5$ C160. He eliminado cosas de mi vida cotidiana desde que cuido a . $\square 1 \quad \square 2 \quad \square 3 \quad \square 4$ 5

C161. Tengo la fortaleza física suficiente para cuidar a . $\square 1 \quad \square 2 \quad \square 3 \quad \square 4 \quad \square 5$ C162. Desde que cuido a , siento que mi familia me ha abandonado.

$\square 1 \square 2 \quad \square 3 \quad \square 4 \quad \square 5$

C163. Cuidar a me hace sentir bien.

$\square 1 \quad \square 2 \quad \square 3 \quad \square 4 \quad \square 5$

C164. Las constantes interrupciones hacen difícil encontrar tiempo para relajarme.

$\square 1 \quad \square 2 \quad \square 3 \quad \square 4 \quad \square 5$

C165. Tengo la salud necesaria para cuidar a $\begin{array}{lllll}\square 1 & \square 2 & \square 3 & \square 4 & \square 5 \\ \square 1 & \square 2 & \square 3 & \square 4 & \square 5\end{array}$ C166. Cuidar a es importante para mí. ha supuesto una carga económica para la familia. $\quad \square$

$\square 1 \quad \square 2 \quad \square 3 \quad \square 4$




\section{EUROQOL - 5 D}

\section{Instrucciones:}

Marque con una cruz $(X)$ la afirmación en cada sección que describa mejor su estado de salud en el día de hoy:

\section{C168. MOVILIDAD}

No tengo problemas para caminar.

Tengo algunos problemas para caminar.

Tengo que estar en la cama.

\section{C169. CUIDADO PERSONAL}

No tengo problemas con el cuidado personal.

Tengo algunos problemas para lavarme vestirme solo

Soy incapaz de lavarme o vestirme solo.

C170.ACTIVIDADES de Todos los Días (ej. trabajar, estudiar, hacer tareas domésticas, actividades familiares o realizadas durante el tiempo libre)

Tengo algunos problemas para realizar mis actividades de todos los días.

No tengo problemas para realizar mis actividades de todos los días.

Soy incapaz de realizar mis actividades de todos los días.

\section{C171.Dolor/Malestar}

No tengo dolor ni malestar.

Tengo moderado dolor o malestar.

Tengo mucho dolor o malestar.
Para ayudar a la gente a describir lo bueno o malo que es su estado de salud, hemos dibujado una escala parecida a un termómetro en el cual se marca con un 100 el mejor estado de salud que puede imaginarse, y con un 0 el peor estado de salud que puede imaginarse.

Por favor, dibuje una línea desde el cuadro que dice "su estado de salud hoy," hasta el punto en la escala que, en su opinión, indique lo bueno o malo que es su estado de salud en el día de hoy.

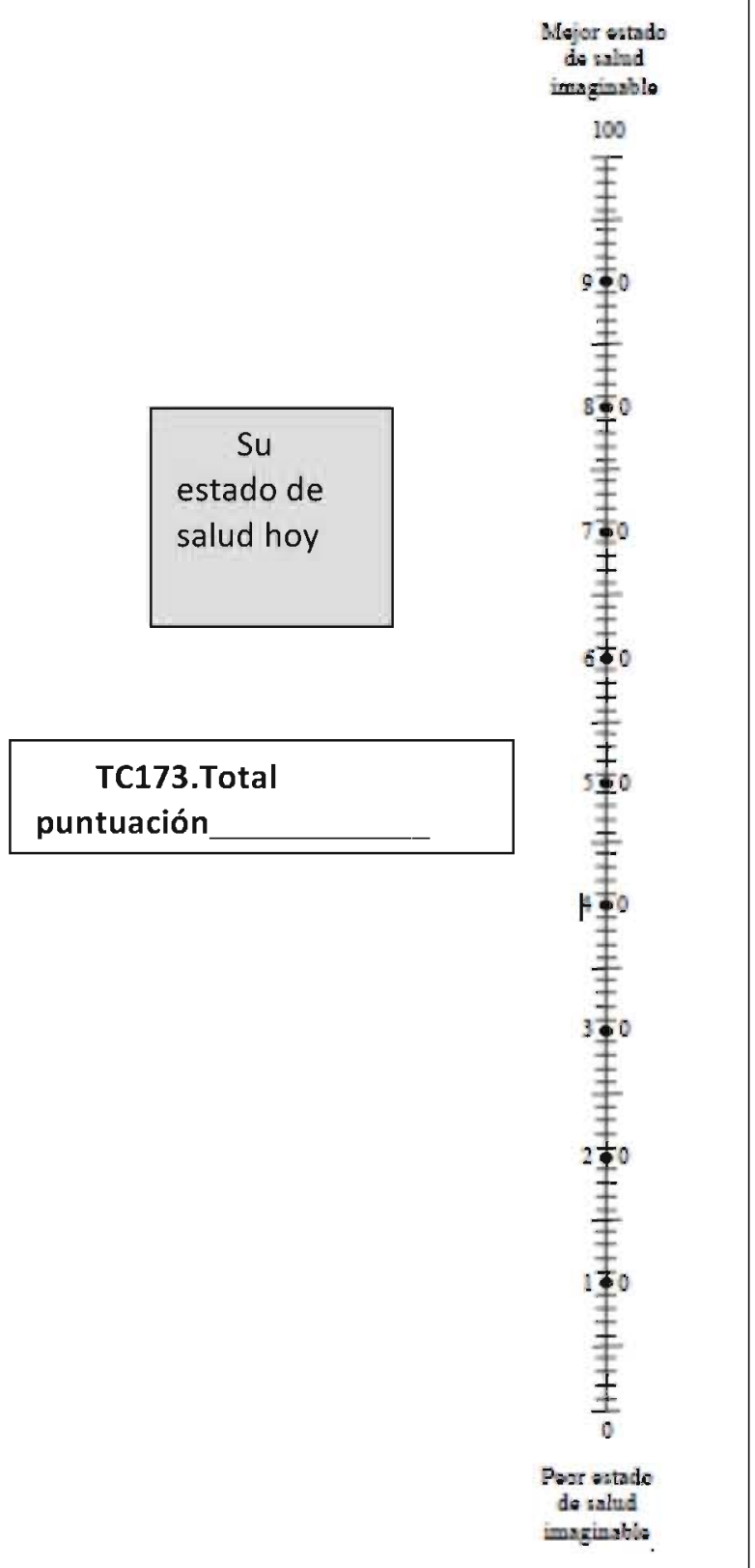




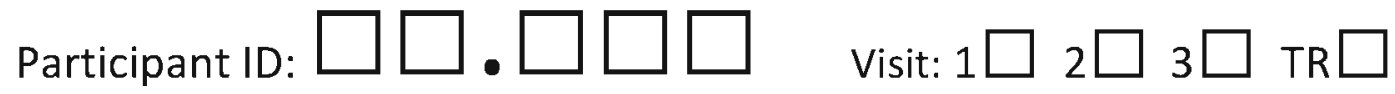

\section{Cuestionario DUKE-UNK}

\section{Instrucciones:}

En la siguiente lista se muestran algunas cosas que otras personas hacen por nosotros o nos proporcionan. Elija para cada una la respuesta que mejor refleje su situación, según los siguientes criterios:

Por favor señale las respuestas marcando una cruz:

1. Mucho menos de lo que deseo

2. Menos de lo que deseo

3. Ni mucho ni poco

4. Casi como deseo

5. Tanto como deseo

C174. Recibo visitas de mis amigos y familiares.

$\square 1 \square 2 \quad \square 3 \quad \square 4 \quad \square 5$

C175. Recibo ayuda en asuntos relacionados con mi casa.

$\square 1 \square 2 \quad \square 3 \quad \square 4 \quad \square 5$

C176. Recibo elogios o reconocimientos cuando hago bien mi trabajo. $\square 1 \quad \square 2 \square 3 \quad \square 4 \quad \square 5$

C177. Cuento con personas que se ocupan de lo que me sucede. $\quad \square 1 \quad \square 2 \quad \square 3 \quad \square 4 \quad \square 5$

C178. Recibo amor y afecto. $\quad \square 1 \quad \square 2 \quad \square 3 \quad \square 4 \quad \square 5$

C179. Tengo la posibilidad de hablar con alguien de mis problemas en $\quad \square 1 \quad \square 2 \quad \square 3 \quad \square 4 \quad \square 5$ el trabajo y/o en la casa.

C180. Tengo la posibilidad de hablar con alguien de mis problemas $\quad \square 1 \quad \square 2 \quad \square 3 \quad \square 4 \quad \square 5$ personales y familiares.

C181. Tengo la posibilidad de hablar con alguien de mis problemas económicos.

$1 \square 2 \quad \square 3 \quad \square 4 \quad \square 5$

C182. Recibo invitaciones para distraerme y salir con otras personas. $\square 1 \quad \square 2 \quad \square \mathbf{3} \square \mathbf{4} \square 5$

C183. Recibo consejos útiles cuando me ocurre algún acontecimiento $\square 1 \quad \square 2 \quad \square 3 \quad \square 4 \quad \square 5$ Importante en mi vida.

C184. Recibo ayuda cuando estoy enfermo en cama. $\quad \square 1 \quad \square 2 \quad \square 3 \quad \square 4 \quad \square 5$ 


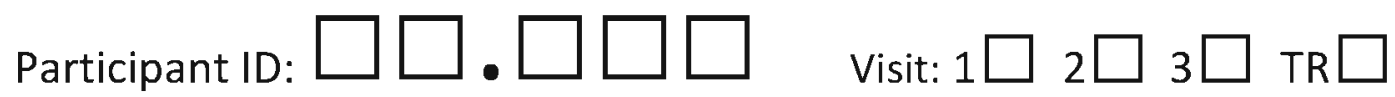

0.Nunca 1.Casi nunca 2.A veces 3.Frecuentemente 4.Casi siempre

C197.¿Se siente incómodo/a para invitar a sus amigos a casa, debido a su familiar?

$\square 0 \quad \square 1 \quad \square 2 \quad \square 3 \quad \square 4$

C198.¿Cree que su familiar espera que usted se ocupe de él/ella, como si fuera la única persona de quien pudiera depender?

$\square 0 \quad \square 1 \quad \square 2 \quad \square 3 \quad \square 4$

C199¿Siente que no tiene suficiente dinero para cuidar a su familiar además de sus otros gastos?

$\square 0 \quad \square 1 \quad \square 2 \quad \square 3 \quad \square 4$

C200.¿Siente que será incapaz de cuidar a su familiar por mucho más tiempo?

$\square 0 \quad \square 1 \quad \square 2 \quad \square 3 \quad \square 4$

C201.¿Siente que ha perdido el control de su vida desde que empezó la enfermedad de su familiar?

$\square 0 \quad \square 1 \quad \square 2 \quad \square 3 \quad \square 4$

C202.¿Desearía simplemente dejar el cuidado de su familiar a otra persona?

$\square 0 \quad \square 1 \quad \square 2 \quad \square 3 \quad \square 4$

C203.¿Se siente inseguro/a sobre lo que debe hacer con su familiar?

$\square 0 \quad \square 1 \quad \square 2 \quad \square 3 \quad \square 4$

C204.¿Siente que debería hacer más por su familiar?

$\square 0 \quad \square 1 \quad \square 2 \quad \square 3 \quad \square 4$

C205.¿Cree que aún podría cuidar mejor a su familiar?

$\square 0 \quad \square 1 \quad \square 2 \quad \square 3 \quad \square 4$

C206. En general, ¿hasta qué punto siente que cuidar a su familiar es una carga para usted?

$\square 0 \quad \square 1 \quad \square 2 \quad \square \mathbf{3} \quad \square \mathbf{4}$




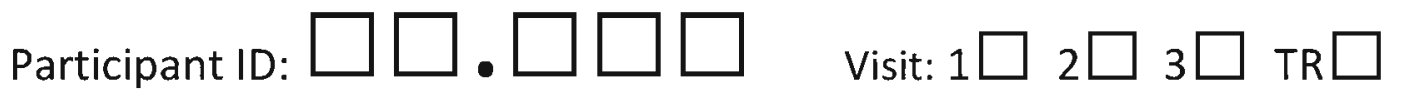

\section{Cuestionario de Salud General de Goldberg}

Por favor, lea esto cuidadosamente:

Nos gustaría saber si tiene algún problema médico y cómo ha estado su salud, en general, durante las últimas semanas. Por favor, conteste a TODAS las preguntas subrayando simplemente la respuesta que, a su juicio, puede aplicarse a usted. Recuerde que solo debe responder sobre los problemas recientes y los que tiene ahora, no sobre los que tuvo en el pasado. Es importante que intente contestar TODAS las preguntas.

Muchas gracias por su colaboración.

ÚLTIMAMENTE:

\begin{tabular}{|c|c|c|c|c|}
\hline $\begin{array}{l}\text { C207. ¿Ha podido concentrarse bien } \\
\text { en lo que hacía? }\end{array}$ & $\begin{array}{l}\text { Mejor que } \\
\text { lo habitual } \square\end{array}$ & $\begin{array}{l}\text { Igual que lo } \\
\text { Habitual } \square\end{array}$ & $\begin{array}{l}\text { Menos que lo } \\
\text { habitual } \square\end{array}$ & $\begin{array}{l}\text { Mucho menos que } \\
\text { lo habitual } \square\end{array}$ \\
\hline $\begin{array}{l}\text { C208. ¿Sus preocupaciones le } \\
\text { han hecho perder sueño? }\end{array}$ & $\begin{array}{l}\text { No, en } \\
\text { Absoluto } \square\end{array}$ & $\begin{array}{l}\text { No más que lo } \\
\text { habitual } \square\end{array}$ & $\begin{array}{l}\text { Algo más que lo } \\
\text { habitual } \square\end{array}$ & $\begin{array}{l}\text { Mucho más que lo } \\
\text { habitual } \square\end{array}$ \\
\hline $\begin{array}{l}\text { C209.¿Ha sentido que está } \\
\text { desempeñando un papel útil en la } \\
\text { vida? }\end{array}$ & $\begin{array}{l}\text { Más útil que lo } \\
\text { habitual } \square\end{array}$ & $\begin{array}{l}\text { Igual que lo habitual } \\
\square\end{array}$ & $\begin{array}{l}\text { Menos útil que } \\
\text { lo habitual } \\
\square\end{array}$ & $\begin{array}{l}\text { Mucho } \\
\text { menos útil que } \\
\text { lo habitual } \square\end{array}$ \\
\hline $\begin{array}{l}\text { C210. ¿Se ha sentido capaz de } \\
\text { tomar decisiones? }\end{array}$ & $\begin{array}{l}\text { Más útil que lo } \\
\text { habitual } \square\end{array}$ & $\begin{array}{l}\text { Igual que lo habitual } \\
\square\end{array}$ & $\begin{array}{l}\text { Menos que lo } \\
\text { habitual } \square\end{array}$ & $\begin{array}{l}\text { Mucho menos que } \\
\text { lo habitual } \\
\square\end{array}$ \\
\hline $\begin{array}{l}\text { C211. ¿Se ha notado } \\
\text { constantemente agobiado y en } \\
\text { tensión? }\end{array}$ & $\begin{array}{l}\text { No, en } \\
\text { absoluto } \\
\square\end{array}$ & $\begin{array}{l}\text { No más de lo } \\
\text { habitual } \square\end{array}$ & $\begin{array}{l}\text { Algo más que } \\
\text { lo habitual } \square\end{array}$ & $\begin{array}{l}\text { Mucho más que lo } \\
\text { habitual } \square\end{array}$ \\
\hline $\begin{array}{l}\text { C212. ¿Ha tenido la sensación } \\
\text { de que no puede superar sus } \\
\text { dificultades? }\end{array}$ & $\begin{array}{l}\text { No, en } \\
\text { absoluto } \\
\square\end{array}$ & $\begin{array}{l}\text { No más de lo } \\
\text { habitual } \square\end{array}$ & $\begin{array}{l}\text { Algo más que lo } \\
\text { habitual } \square\end{array}$ & $\begin{array}{l}\text { Mucho mas que lo } \\
\text { habitual } \square\end{array}$ \\
\hline $\begin{array}{l}\text { C213. ¿Ha sido capaz de disfrutar } \\
\text { de sus actividades normales de } \\
\text { cada día? }\end{array}$ & $\begin{array}{l}\text { Más que lo } \\
\text { habitual } \square\end{array}$ & $\begin{array}{l}\text { Igual que lo } \\
\text { habitual } \square\end{array}$ & $\begin{array}{l}\text { Menos que lo } \\
\text { habitual } \square\end{array}$ & $\begin{array}{l}\text { Mucho menos que } \\
\text { lo habitual } \square\end{array}$ \\
\hline $\begin{array}{l}\text { C214. ¿Ha sido capaz de hace } \\
\text { frente adecuadamente a sus } \\
\text { problemas? }\end{array}$ & $\begin{array}{l}\text { Más capaz que } \\
\text { lo habitual } \square\end{array}$ & $\begin{array}{l}\text { Igual que lo } \\
\text { habitual } \square\end{array}$ & $\begin{array}{l}\text { Menos capaz que } \\
\text { lo habitual } \square\end{array}$ & $\begin{array}{l}\text { Mucho menos } \\
\text { capaz que lo } \\
\text { habitual } \square\end{array}$ \\
\hline $\begin{array}{l}\text { C215. ¿Se ha sentido poco feliz o } \\
\text { deprimido? }\end{array}$ & $\begin{array}{l}\text { NO, en } \\
\text { absoluto } \square\end{array}$ & $\begin{array}{l}\text { No más de lo } \\
\text { habitual } \square\end{array}$ & $\begin{array}{l}\text { Algo más que lo } \\
\text { habitual } \square\end{array}$ & $\begin{array}{l}\text { Mucho mas que lo } \\
\text { habitual } \square\end{array}$ \\
\hline $\begin{array}{l}\text { C216. ¿Ha perdido confianza en sí } \\
\text { mismo? }\end{array}$ & $\begin{array}{l}\text { No, en } \\
\text { absoluto } \square\end{array}$ & $\begin{array}{l}\text { No más de lo } \\
\text { habitual } \quad \square\end{array}$ & $\begin{array}{l}\text { Algo más que } \\
\text { lo habitual } \square\end{array}$ & $\begin{array}{l}\text { Mucho más que lo } \\
\text { habitual } \square\end{array}$ \\
\hline $\begin{array}{l}\text { C217. ¿Ha pensado que usted es } \\
\text { una persona que no vale para } \\
\text { nada? }\end{array}$ & $\begin{array}{l}\text { No, en } \\
\text { absoluto } \square\end{array}$ & $\begin{array}{l}\text { No más de lo } \\
\text { Habitual } \square\end{array}$ & $\begin{array}{l}\text { Algo más que lo } \\
\text { habitual } \square\end{array}$ & $\begin{array}{l}\text { Mucho más que lo } \\
\text { habitual } \square\end{array}$ \\
\hline $\begin{array}{l}\text { C218. ¿Se siente razonablemente } \\
\text { feliz considerando todas las } \\
\text { circunstancias? }\end{array}$ & $\begin{array}{l}\text { Más que lo } \\
\text { habitual } \square\end{array}$ & $\begin{array}{l}\text { Igual que lo } \\
\text { habitual } \square\end{array}$ & $\begin{array}{l}\text { Menos que lo } \\
\text { habitual } \square\end{array}$ & $\begin{array}{l}\text { Mucho menos que } \\
\text { lo habitual } \square\end{array}$ \\
\hline
\end{tabular}


Participant ID:

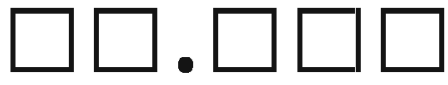

Visit: $1 \square 2 \square 3$

$3 \square$ TR $\square$

\section{Pregunta para cuidadores informales/familiares sobre calidad de atención}

C219 ¿Cuál es su nivel de satisfacción en relación a los cuidados recibidos por parte del servicio de atención a las personas con demencia?

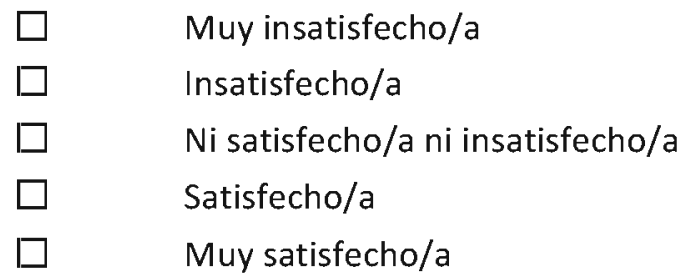

TC219.1 Por favor detalle el tipo de servicio especifico de demencia

C219.2 Sobre todo, como de satisfecho esta de los servicios de demencia en general?

$\begin{array}{ll}\square & \text { Muy insatisfecho/a } \\ \square & \text { Insatisfecho/a } \\ \square & \text { Ni satisfecho/a ni insatisfecho/a } \\ \square & \text { Satisfecho/a } \\ \square & \text { Muy satisfecho/a }\end{array}$




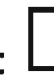

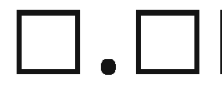

$\square \square$

Visit: 1

$2 \square 3 \square$ $T R \square$

\section{PREGUNTAS DIRIGIDAS AL CUIDADOR INFORMAL/FAMILIAR SOBRE LA PERSONA QUE CUIDA}

\section{Cuidador informal/familiar información de las visitas}

E1 Si el cuidador informal vive con el paciente con demencia marcar vivir juntos' Viven juntos. Ir a la pregunta E4

E2 Por favor indique el número de visitas en las últimas 2 semanas

$\square 1 \quad \square 2 \square 3 \quad \square 4 \quad \square 5 \quad \square 6 \quad \square 7 \quad \square 8 \quad \square 9 \square 10 \quad \square 11 \quad \square 12 \square 13 \quad \square 14 \quad \square>14$ E2.1 En el caso de >14, ¿Cuántas? visitas

E3 ¿En general cuanto tiempo está en las visitas? horas

Utilización de ayuda social por PARTE DEL PACIENTE

E4 ¿Durante los últimos 30 días, ha ingresado en hospital (por menos de 24horas)? $\begin{array}{ll}\square & \text { NO. Si es No ir a la pregunta E5 } \\ \square \quad \text { Sí }\end{array}$

E4.1 Durante los últimos 30 días, ¿Cuántas veces ha estado hospitalizado? 


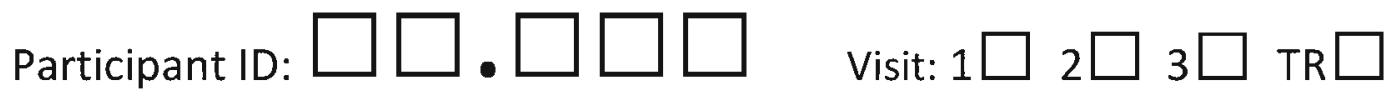

TE4.2 Por cada hospitalización (durante los últimos 30 días), por favor indique la razón de la hospitalización.

\begin{tabular}{|c|c|c|c|}
\hline \multicolumn{2}{|c|}{$\begin{array}{l}\text { TE4.2.1 } \\
\text { Número } \\
\text { Hospitalización }\end{array}$} & $\begin{array}{c}\text { TE4.2.2 } \\
\text { Diagnóstico o motivo hospitalización }\end{array}$ & \begin{tabular}{|c|} 
TE4.2.3 \\
Código DRG \\
(si es posible)
\end{tabular} \\
\hline$\square$ & 1 & & $1 \quad 1 \quad 1$ \\
\hline$\square$ & 2 & & \\
\hline$\square$ & 3 & & $\perp|1|$ \\
\hline$\square$ & 4 & & \\
\hline
\end{tabular}

E4.3 Por favor especifique el número total de noches en cada unidad (para todas las hospitalizaciones de más de 30 días).

\begin{tabular}{|c|c|c|c|c|}
\hline E4.3.1 & \multicolumn{2}{|c|}{ Unidad } & \multicolumn{2}{|c|}{$\begin{array}{l}\text { E4.3.2 } \\
\text { Número de noches }\end{array}$} \\
\hline E20.3.1.1 & & Geriatria & E20.3.2.1 & \\
\hline$E 20.3 .1 .2$ & & Psiquiatria & $E 20.3 .2 .2$ & \\
\hline E20.3.1.3 & $\square$ & Medicina General & $E 20.3 .2 .3$ & \\
\hline$E 20.3 .1 .4$ & $\square$ & Cirurgia & $E 20.3 .2 .4$ & \\
\hline TE20.3.1.5 & & Otras (ej. por favor especificar) & E20.3.2.5 & \\
\hline
\end{tabular}

E5. ¿Durante los últimos $\mathbf{3 0}$ días, su familiar ha recibido atención en un Servicio de Urgencias (por menos de 24h)?
$\square \quad$ No, Si es No ir a la pregunta E6
$\square \mathrm{Si}$
E5.1 Si es Si, ¿Cuantas veces?

E6. ¿Su familiar ha sido trasladado por un evento grave a otro hospital?
$\square \quad$ No
$\square \quad \mathrm{Si} \quad$ E6.1. Si es Si, ¿Qué tipo de centro? 
Participant ID: $\square \square . \square \square \square$ Visit: $1 \square$ 2 $\square$ 3 $\square$ TR $\square$

E7. Durante los últimos $\mathbf{3 0}$ días, ¿su familiar ha recibido cuidados de doctores, fisioterapeuta, psicólogo o de otro profesional de cuidados?

No, $\quad$ Si es No ir a la pregunta E8

Si $\quad$ E7.1 En caso afirmativo, especificar el número de visitas para cada tipo de cuidado recibido.

\begin{tabular}{|c|c|c|c|c|}
\hline \multicolumn{3}{|c|}{$\begin{array}{c}\text { E7.1.1 } \\
\text { Tipo de cuidado }\end{array}$} & \multicolumn{2}{|c|}{$\begin{array}{l}\text { Número de visitas } \\
\text { durante los } \\
\text { últimos } 30\end{array}$} \\
\hline E7.1.1.1 & $\square$ & Medicina General & E7.1.2.1 & \\
\hline E7.1.1.2 & $\square$ & Geriatra & E7.1.2.2 & \\
\hline E7.1.1.3 & $\square$ & Neurologo & E7.1.2.3 & \\
\hline E7.1.1.4 & $\square$ & Psquiatra & E7.1.2.4 & \\
\hline E7.1.1.5 & $\square$ & Fisioterapeuta & E7.1.2.5 & \\
\hline E7.1.1.6 & $\square$ & Terapeuta ocupacional & E7.1.2.6 & \\
\hline E7.1.1.7 & $\square$ & Trabajadora social & E7.1.2.7 & \\
\hline E7.1.1.8 & $\square$ & Psicologo & E7.1.2.8 & \\
\hline E7.1.1.9 & $\square$ & Auxiliar de clinica & E7.1.2.9 & \\
\hline E7.1.1.10 & $\square$ & Enfermera & E7.1.2.10 & \\
\hline \multirow[t]{2}{*}{ TE7.1.1.11 } & $\square$ & $\begin{array}{l}\text { Otros (e.j. especialistata; por favor } \\
\text { especifique) }\end{array}$ & & \\
\hline & & & E7.1.2.11 & $\perp$ \\
\hline
\end{tabular}

E8. Para cada servicio de la lista inferior, especifique el servicio al que ha acudido durante los últimos 30 días, el número de veces, y la media de horas por visitas.

\begin{tabular}{|c|c|c|c|c|}
\hline E8.1 & & Servicio & $\begin{array}{l}\text { E8.2 } \\
\text { № de visitas en } \\
\text { los últimos } 30\end{array}$ & $\begin{array}{l}\text { E8.3 } \\
\text { № de horas por } \\
\text { visita }\end{array}$ \\
\hline E8.1.1 & $\square$ & Enfermera comunitaria & E8.2.1 & E8.3.1 \\
\hline E8.1.2 & $\square$ & $\begin{array}{l}\text { Profesional del cuidado en el hogar/ } \\
\text { auxiliar de clínica }\end{array}$ & E8.2.2 & $E 8.3 .2 \perp \quad \mid$ \\
\hline E8.1.3 & $\square$ & Comida a domicilio & E8.2.3 $\perp ل$ & E8.3.3 \\
\hline E8.1.4 & $\square$ & Transporte (público/mutua privada) & E8.2.4 ᄂ $\perp$ & E8.3.4 $\perp ل \perp$ \\
\hline TE8.1.5 & $\square$ & Otros (especifique, por favor) & E8.2.5 & E8.3.5 $\perp ل$ \\
\hline
\end{tabular}


Participant ID: $\square \square . \square \square \square$ Visit: $1 \square$ 2 $\square$ 3 $\square$ TR $\square$

E7. Durante los últimos $\mathbf{3 0}$ días, ¿su familiar ha recibido cuidados de doctores, fisioterapeuta, psicólogo o de otro profesional de cuidados?

No, $\quad$ Si es No ir a la pregunta E8

Si $\quad$ E7.1 En caso afirmativo, especificar el número de visitas para cada tipo de cuidado recibido.

\begin{tabular}{|c|c|c|c|c|}
\hline \multicolumn{3}{|c|}{$\begin{array}{c}\text { E7.1.1 } \\
\text { Tipo de cuidado }\end{array}$} & \multicolumn{2}{|c|}{$\begin{array}{l}\text { Número de visitas } \\
\text { durante los } \\
\text { últimos } 30\end{array}$} \\
\hline E7.1.1.1 & $\square$ & Medicina General & E7.1.2.1 & \\
\hline E7.1.1.2 & $\square$ & Geriatra & E7.1.2.2 & \\
\hline E7.1.1.3 & $\square$ & Neurologo & E7.1.2.3 & \\
\hline E7.1.1.4 & $\square$ & Psquiatra & E7.1.2.4 & \\
\hline E7.1.1.5 & $\square$ & Fisioterapeuta & E7.1.2.5 & \\
\hline E7.1.1.6 & $\square$ & Terapeuta ocupacional & E7.1.2.6 & \\
\hline E7.1.1.7 & $\square$ & Trabajadora social & E7.1.2.7 & \\
\hline E7.1.1.8 & $\square$ & Psicologo & E7.1.2.8 & \\
\hline E7.1.1.9 & $\square$ & Auxiliar de clinica & E7.1.2.9 & \\
\hline E7.1.1.10 & $\square$ & Enfermera & E7.1.2.10 & \\
\hline \multirow[t]{2}{*}{ TE7.1.1.11 } & $\square$ & $\begin{array}{l}\text { Otros (e.j. especialistata; por favor } \\
\text { especifique) }\end{array}$ & & \\
\hline & & & E7.1.2.11 & $\perp$ \\
\hline
\end{tabular}

E8. Para cada servicio de la lista inferior, especifique el servicio al que ha acudido durante los últimos 30 días, el número de veces, y la media de horas por visitas.

\begin{tabular}{|c|c|c|c|c|}
\hline E8.1 & & Servicio & $\begin{array}{l}\text { E8.2 } \\
\text { № de visitas en } \\
\text { los últimos } 30\end{array}$ & $\begin{array}{l}\text { E8.3 } \\
\text { № de horas por } \\
\text { visita }\end{array}$ \\
\hline E8.1.1 & $\square$ & Enfermera comunitaria & E8.2.1 & E8.3.1 \\
\hline E8.1.2 & $\square$ & $\begin{array}{l}\text { Profesional del cuidado en el hogar/ } \\
\text { auxiliar de clínica }\end{array}$ & E8.2.2 & $E 8.3 .2 \perp \quad \mid$ \\
\hline E8.1.3 & $\square$ & Comida a domicilio & E8.2.3 $\perp ل$ & E8.3.3 \\
\hline E8.1.4 & $\square$ & Transporte (público/mutua privada) & E8.2.4 ᄂ $\perp$ & E8.3.4 $\perp ل \perp$ \\
\hline TE8.1.5 & $\square$ & Otros (especifique, por favor) & E8.2.5 & E8.3.5 $\perp ل$ \\
\hline
\end{tabular}




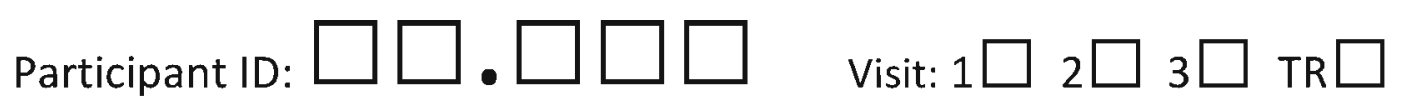

CUESTIONARIO DE CALIDAD DE VIDA EN LA ENFERMEDAD DE ALHEIMER

Versión para la familia

Las siguientes preguntas tratan sobre la calidad de vida de su familiar. Cuando piensa en la vida de su familiar, se tienen en cuenta varios aspectos, algunos de los cuales se detallan a continuación.

Piense en cada uno de los elementos mencionados y evalúe la calidad de vida actual de su familiar para cada uno seleccionando una de estas cuatro palabras: malo/a, regular, bueno/a, excelente. Evalúelos basándose en la vida de su familiar en la actualidad (es decir, durante las últimas semanas). Si tiene alguna pregunta sobre cualquiera de los elementos mencionados abajo, solicite ayuda a la persona que le ha entregado este formulario

\begin{tabular}{|c|c|c|c|c|c|}
\hline \multicolumn{6}{|c|}{ Administrar instrucciones al entrevistador. } \\
\hline & Salud física & $\square$ Malo/a & $\begin{array}{c}\square \\
\text { Regular }\end{array}$ & $\begin{array}{c}\square \\
\text { Bueno/a }\end{array}$ & $\square$ Excelente \\
\hline E10 & Energía & $\square$ Malo/a & $\begin{array}{c}\square \\
\text { Regular }\end{array}$ & $\begin{array}{c}\square \\
\text { Bueno/a }\end{array}$ & $\square$ Excelente \\
\hline E11 & Estado de ánimo & $\square$ Malo/a & $\begin{array}{c}\square \\
\text { Regular }\end{array}$ & $\begin{array}{c}\square \\
\text { Bueno/a }\end{array}$ & $\square$ Excelente \\
\hline E12 & Condiciones de vida & $\square$ Malo/a & $\begin{array}{c}\square \\
\text { Regular }\end{array}$ & $\begin{array}{c}\square \\
\text { Bueno/a }\end{array}$ & $\square$ Excelente \\
\hline E13 & Memoria & $\square$ Malo/a & $\begin{array}{c}\square \\
\text { Regular }\end{array}$ & $\begin{array}{c}\square \\
\text { Bueno/a }\end{array}$ & $\square$ Excelente \\
\hline E14 & Familia & $\square$ Malo/a & $\begin{array}{c}\square \\
\text { Regular }\end{array}$ & $\begin{array}{c}\square \\
\text { Bueno/a }\end{array}$ & $\square$ Excelente \\
\hline E15 & Matrimonio / Relación personal estrecha & $\square$ Malo/a & $\begin{array}{c}\square \\
\text { Regular }\end{array}$ & $\begin{array}{c}\square \\
\text { Bueno/a }\end{array}$ & $\square$ Excelente \\
\hline E16 & Vida social (amistades). & $\square$ Malo/a & $\begin{array}{c}\square \\
\text { Regular }\end{array}$ & $\begin{array}{c}\square \\
\text { Bueno/a }\end{array}$ & $\square$ Excelente \\
\hline E17 & Visión general de sí mismo/a. & $\square$ Malo/a & $\stackrel{\square}{\square}$ & $\begin{array}{c}\square \\
\text { Bueno/a }\end{array}$ & $\square$ Excelente \\
\hline E18 & Capacidad para realizar tareas en casa. & $\square$ Malo/a & $\begin{array}{r}\square \\
\text { Regular }\end{array}$ & $\begin{array}{c}\square \\
\text { Bueno/a }\end{array}$ & $\square$ Excelente \\
\hline E19 & Capacidad para hacer cosas por diversión & $\square$ Malo/a & $\begin{array}{c}\square \\
\text { Regular }\end{array}$ & $\begin{array}{c}\square \\
\text { Bueno/a }\end{array}$ & $\square$ Excelente \\
\hline E20 & Situación financiera & $\square$ Malo/a & $\begin{array}{r}\square \\
\text { Regular }\end{array}$ & $\begin{array}{c}\square \\
\text { Bueno/a }\end{array}$ & $\square$ Excelente \\
\hline E21 & La vida en general & $\square$ Malo/a & $\begin{array}{r}\square \\
\text { Regular }\end{array}$ & $\begin{array}{c}\square \\
\text { Bueno/a }\end{array}$ & $\square$ Excelente \\
\hline
\end{tabular}


Participant ID: $\square \square . \square \square \square$ Visit: $1 \square 2 \square 3 \square$ TR $\square$

\section{INDICE KATZ DE INDEPENDENCIA EN LAS ACTIVIDADES DE LA VIDA DIARIA}

Señale la descripción adecuada para cada una de las funciones que figuran en la lista siguiente. (La palabra "ayuda" significa supervisar, dar instrucciones o asistencia personal.)

E23 Lavarse - ya sea con una esponja, o sea en la bañera, o sea en la ducha.

No recibe ayuda, (entra y sale de la bañera por si mismo/a si la bañera es el medio de aseo habitual)

Recibe ayuda sólo para lavarse una parte del cuerpo (como la espalda o una pierna)

Recibe ayuda para lavarse más de una parte del cuerpo (o no se lava por si mismo/a)

E24 Vestirse - sacar la ropa de los armarios y de los cajones - incluyendo la ropa interior, las prendas exteriores y abrocharse botones, cremalleras, etc. (incluyendo tirantes si los lleva).

Saca la ropa y se viste completamente sin ayuda.

Saca la ropa y se viste sin ayuda excepto para atarse los cordones de los zapatos

Recibe ayuda para sacar la ropa o para vestirse, o se queda parcial o completamente sin vestir

E25 Ir al servicio - ir al servicio para orinar y hacer de vientre; limpiarse después por sí mismo/a, y arreglarse la ropa.

Se desplaza hasta el servicio, se limpia y se arregla la ropa sin ayuda (quizás usa un objeto de apoyo como un bastón, un andador o una silla de ruedas y posiblemente usa la cuña o la silla retrete por la noche, vaciándola por la mañana).

Recibe ayuda para desplazarse hasta el servicio, o para limpiarse o arreglarse la ropa después, o para usar la cuña o la silla retrete por la noche.

No va al servicio para hacer sus necesidades.

\section{E26 Movilidad.}

Se acuesta y se levanta de la cama así como de la silla sin ayuda (posiblemente usa un objeto de apoyo como un bastón o un andador).

Se acuesta o se levanta de la cama o de la silla con ayuda de alguien.

No se levanta de la cama.

\section{E27 Continencia.}

$\square \quad$ Controla totalmente la orina y las heces por si mismo/a.

Tiene "accidentes" ocasionales.

La supervisión le ayuda a controlar la orina o las heces; usa una sonda, o sufra incontinencia.

\section{E28 Alimentarse.}

Se alimenta sin ayuda.

Se alimenta solo/a pero recibe ayuda para cortar la carne o untar el pan con mantequilla.

Recibe ayuda para alimentarse, o se alimenta parcial o totalmente mediante sondas o líquidos intravenosos. 


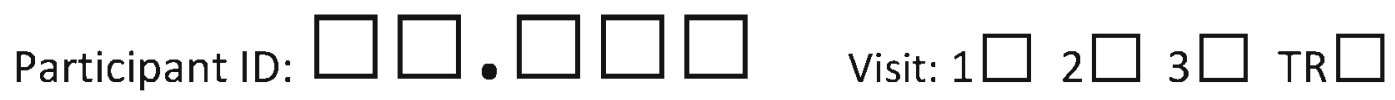

\section{INVENTARIO NEUROPSIQUIÁTRICO (NPI)}

Formule las siguientes preguntas teniendo en cuenta los cambios que hayan podido suceder. Marque

"sí" sólo si el síntoma se ha manifestado durante las últimas 4 semanas; de lo contrario, marque "no.

Por favor conteste con honestidad y con cuidado. Pida ayuda si tiene dudas en alguna pregunta.

\begin{tabular}{|c|c|}
\hline $\begin{array}{l}\text { E29 DELIRIOS } \\
\square \text { si } \\
\square \text { no }\end{array}$ & $\begin{array}{l}\text { ¿El/la paciente cree que otras personas le están robando o que planean } \\
\text { hacerle daño de un modo u otro? } \\
\qquad \text { E29.1 Gravedad: } \square 1 \square 2 \square 3 \quad \text { E29.2 Angustia: } \square 0 \square 1 \square 2 \square 3 \square 4 \square 5\end{array}$ \\
\hline $\begin{array}{l}\text { E30 ALUCINACIONES } \\
\square \text { si } \\
\square \text { no }\end{array}$ & $\begin{array}{l}\text { ¿El/la paciente actúa como si oyese voces? ¿ Habla con personas que no están } \\
\text { presentes? } \\
\quad \text { E30.1 Gravedad: } \square 1 \square 2 \square 3 \quad \text { E30.2 Angustia: } \square 0 \square 1 \square 2 \square 3 \square 4 \square 5\end{array}$ \\
\hline $\begin{array}{l}\text { E31AGITACIÓN O AGRESIVIDAD } \\
\qquad \text { si } \\
\square \text { no }\end{array}$ & $\begin{array}{l}\text { ¿El/la paciente se muestra obstinado/a y se resiste a recibir ayuda de los } \\
\text { demás? } \\
\qquad \text { E31.1 Gravedad: } \square 1 \square 2 \square 3 \quad \text { E31.2Angustia: } \square 0 \square 1 \square 2 \square 3 \square 4 \square 5\end{array}$ \\
\hline $\begin{array}{l}\text { E32 DEPRESIÓN O DISFORIA } \\
\square \text { si } \\
\square \text { no }\end{array}$ & $\begin{array}{l}\text { ¿El/la paciente actúa como si estuviese triste o desanimado/a? ¿Llora? } \\
\text { E32.1 Gravedad: } \square 1 \square 2 \square 3 \quad \text { E32.2Angustia: } \square 0 \square 1 \square 2 \square 3 \square 4 \square 5\end{array}$ \\
\hline $\begin{array}{l}\text { E33 ANSIEDAD } \\
\square \text { si } \\
\square \text { no }\end{array}$ & $\begin{array}{l}\text { ¿Se altera el/la paciente cuando se separa de usted? ¿Muestra algún otro } \\
\text { signo de nerviosismo, como por ejemplo falta de aire, suspiros, incapacidad } \\
\text { de relajarse o sensación de estar demasiado tenso/a? } \\
\qquad \text { E33.1 Gravedad: } \square 1 \square 2 \square 3 \quad \text { E33.2Angustia: } \square 0 \square 1 \square 2 \square 3 \square 4 \square 5\end{array}$ \\
\hline $\begin{array}{l}\text { E34 EUFORIA } \\
\quad \square \text { si } \\
\square \text { no }\end{array}$ & $\begin{array}{l}\text { ¿El/la paciente parece sentirse demasiado bien o actúa como si } \\
\text { estuviese excesivamente feliz? } \\
\text { E34.1 Gravedad: } \square 1 \square 2 \square 3 \quad \text { E35.2Angustia: } \square 0 \square 1 \square 2 \square 3 \square 4 \square 5\end{array}$ \\
\hline $\begin{array}{l}\text { E35 APATÍA O INDIFERENCIA } \\
\quad \square \text { si } \\
\square \text { no }\end{array}$ & $\begin{array}{l}\text { ¿El/la paciente parece menos interesado/a en sus actividades habituales } \\
\text { y en las actividades y los planes de los demás? } \\
\text { E35.1 Gravedad: } \square 1 \square 2 \square 3 \quad \text { E35.2Angustia: } \square 0 \square 1 \square 2 \square 3 \square 4 \square 5\end{array}$ \\
\hline $\begin{array}{l}\text { E36 DESHINIBICIÓN } \\
\square \text { si } \\
\square \text { no }\end{array}$ & $\begin{array}{l}\text { ¿EI/la paciente parece actuar de forma impulsiva? } \\
\text { Por ejemplo, ¿habla con desconocidos como si los conociera, o dice cosas que } \\
\text { pueden herir la sensibilidad de los demás? } \\
\text { E36.1 Gravedad: } \square 1 \square 2 \square 3 \quad \text { E36.2Angustia: } \square 0 \square 1 \square 2 \square 3 \square 4 \square 5\end{array}$ \\
\hline $\begin{array}{l}\text { E37 IRRITABILIDAD O LABILIDAD } \\
\square \text { si } \\
\square \text { no }\end{array}$ & $\begin{array}{l}\text { ¿El/la paciente se muestra impaciente y malhumorado/a? ¿Le cuesta } \\
\text { asimilar las demoras o esperar a que se produzcan las actividades que están } \\
\text { planeadas? } \\
\text { E37.1 Gravedad: } \square 1 \square 2 \square 3 \quad \text { E37.2Angustia: } \square 0 \square 1 \square 2 \square 3 \square 4 \square 5\end{array}$ \\
\hline $\begin{array}{l}\text { E38 TRASTORNOS MOTORES } \\
\quad \square \text { si } \\
\square \text { no }\end{array}$ & $\begin{array}{l}\text { ¿EI/la paciente realiza actividades repetitivas como caminar por la } \\
\text { casa, manosear los botones, enrollar cuerdas u otros actos repetitivos? } \\
\text { E38.1 Gravedad: } \square 1 \square 2 \square 3 \quad \text { E38.2Angustia: } \square 0 \square 1 \square 2 \square 3 \square 4 \square 5\end{array}$ \\
\hline $\begin{array}{l}\text { E39 CONDUCTAS NOCTURNAS } \\
\square \text { si } \\
\square \text { no }\end{array}$ & $\begin{array}{l}\text { ¿Le despierta el/la paciente durante la noche, se levanta demasiado pronto por } \\
\text { la mañana o echa cabezadas demasiado largas o frecuentes durante el día? } \\
\text { E39.1 Gravedad: } \square 1 \square 2 \square 3 \text { E39.2Angustia: } \square 0 \square 1 \square 2 \square 3 \square 4 \square 5\end{array}$ \\
\hline $\begin{array}{l}\text { E40 APETITO Y ALIMENTACIÓN } \\
\square \text { si } \\
\square \text { no }\end{array}$ & $\begin{array}{l}\text { ¿Ha perdido o ganado peso el/la paciente, o han cambiado sus gustos con } \\
\text { respecto a la comida? } \\
\text { E40.1 Gravedad: } \square 1 \square 2 \square 3 \text { E40.2Angustia: } \square 0 \square 1 \square 2 \square 3 \square 4 \square 5\end{array}$ \\
\hline
\end{tabular}




\section{INDICADORES DE CALIDAD DE VIDA}

\section{Estado nutricional}

E41 Ha sufrido el residente una rápida disminución o pérdida de peso $\geq 4 \%$ en el pasado año $\square$ si

$\square$ no

E42 Contenciones físicas

\begin{tabular}{|c|c|c|c|c|c|c|c|}
\hline & & Nunca & $\begin{array}{l}\text { Menos } \\
\text { de } 1 \mathrm{x} \\
\text { semana }\end{array}$ & $\begin{array}{l} \pm 1 \text { a } 5 \text { a } \\
\text { la } \\
\text { semana }\end{array}$ & $\begin{array}{l} \pm 1 \text { al } \\
\text { día }\end{array}$ & $\begin{array}{l}\text { Más de } 1 \\
\text { al día }\end{array}$ & $\begin{array}{l}\text { No } \\
\text { aplicable }\end{array}$ \\
\hline E42.1 & $\begin{array}{l}\text { Cinturón de contención (en } \\
\text { cama o silla) }\end{array}$ & $\square$ & $\square$ & $\square$ & $\square$ & $\square$ & $\square$ \\
\hline E42.2 & $\begin{array}{l}\text { Silla (de ruedas) con una } \\
\text { mesa de bloqueo/Silla con } \\
\text { un tablero }\end{array}$ & $\square$ & $\square$ & $\square$ & $\square$ & $\square$ & $\square$ \\
\hline$E 42.3$ & $\begin{array}{l}\text { Sillas (de ruedas) hondas } \\
\text { y/o tumbadas }\end{array}$ & $\square$ & $\square$ & $\square$ & $\square$ & $\square$ & $\square$ \\
\hline E42.4 & $\begin{array}{l}\text { Barandillas bilaterales de } \\
\text { cierre complete }\end{array}$ & $\square$ & $\square$ & $\bar{\square}$ & $\square$ & $\bar{\square}$ & $\square$ \\
\hline$E 42.5$ & $\begin{array}{l}\text { Traje de dormir/ Sábanas } \\
\text { ajustadas/ ceñidas }\end{array}$ & $\square$ & $\square$ & $\square$ & $\square$ & $\square$ & $\square$ \\
\hline E42.6 & Sistema de infrarrojos & $\square$ & $\square$ & $\square$ & $\square$ & $\square$ & $\square$ \\
\hline E42.7 & Sistema de censores & $\square$ & $\square$ & $\square$ & $\square$ & $\square$ & $\square$ \\
\hline E42.8 & $\begin{array}{l}\text { Bloqueo de las puertas de } \\
\text { las puertas de los dormitorios }\end{array}$ & $\square$ & $\square$ & $\square$ & $\square$ & $\square$ & $\square$ \\
\hline
\end{tabular}

\section{Dolor}

(Marca el dolor más alto presente en los últimos 7 días)

E43 FRECUENCIA con la que el residente se queja o muestra evidencias de dolor
$\square$ Sin dolor., si es NO E44
$\square$ Inferior a dolor diario
$\square$ Dolor diario

E43.1 INTENSIDAD del dolor

$\square$ dolor leve

$\square$ dolor moderado

$\square$ Momentos en que el dolor es horrible o insoportable

E43.2 LOCALIZACIÓN DEL DOLOR (Si el dolor está presente, marca las localizaciones que haya padecido en los últimos 7 días)
E43.2.1 $\square$ Dolor de espalda
E43.2.2 $\square$ Dolor en los huesos
E43.2.3 $\square$ Dolor en el pecho al realizar las actividades cotidianas
E43.2.4 $\square$ Dolor de cabeza
E43.2.5 $\square$ Dolor en la cadera
E43.2.6 $\square$ Dolor en la incisión
E43.2.7 $\square$ Dolor en las articulaciones (distinto al de la cadera)
E43.2.8 $\square$ Dolor en tejidos blandos (ej. Lesión múscular)
E43.2.9 $\square$ Dolor estomacal 


\section{Úlceras por presión}

E 44 ¿Tiene el residente úlceras por presión?

$\square$ No, Si es NO continúe en la pregunta E45

$\square$ Si. Si es Si continúe las preguntas

\section{Clasificación de los estadios:}

Estadio 2 Perdida parcial del grosor (de la continuidad) de la piel que se manifiesta clínicamente como una abrasión, ampolla o depresión inflamada.

Estadio 3 El grosor de la piel se pierde dejando al descubierto el tejido subcutáneo. Se presenta como una depresión profunda con o sin pérdida de los tejidos adyacentes.

Estadio 4 El grosor de la piel y el tejido subcutáneo se pierden dejando al descubierto músculo o hueso

E44.1 Por favor, indica la localización de la úlcera por presión

\begin{tabular}{|cc|c|l|ll|ll|lc|}
\hline \multicolumn{3}{|c|}{ E44.1.1 Localización } & \multicolumn{5}{c|}{ E44.1.2 Clasifcación } \\
\hline E44.1.1.1 & $\square$ & Sacro/espalda & E44.1.2.1 & $\square$ & 2 & $\square$ & 3 & $\square$ & 4 \\
\hline E44.1.1.2 & $\square$ & Codo & E44.1.2.2 & $\square$ & 2 & $\square$ & 3 & $\square$ & 4 \\
\hline E44.1.1.3 & $\square$ & Cadera & E44.1.2.3 & $\square$ & 2 & $\square$ & 3 & $\square$ & 4 \\
\hline E44.1.1.4 & $\square$ & Talón & E44.1.2.4 & $\square$ & 2 & $\square$ & 3 & $\square$ & 4 \\
\hline E44.1.1.5 & $\square$ & Rodilla & E44.1.2.5 & $\square$ & 2 & $\square$ & 3 & $\square$ & 4 \\
\hline E44.1.1.6 & $\square$ & Tobillo & E44.1.2.6 & $\square$ & 2 & $\square$ & 3 & $\square$ & 4 \\
\hline E44.1.1.7 & $\square$ & Omoplato & E44.1.2.7 & $\square$ & 2 & $\square$ & 3 & $\square$ & 4 \\
\hline TE44.1.1.8 & $\square$ & Otros: & E44.1.2.8 & $\square$ & 2 & $\square$ & 3 & $\square$ & 4 \\
\hline
\end{tabular}

\section{Caídas}

Se define caída como el desplazamiento no intencionado hacia el suelo o en un nivel inferior

E45. El residente ha sufrido al menos una caída en los últimos 3 meses

$\square$ No, Si es NO continúe en la pregunta E46

$\square \mathrm{Si} . \quad$ Si es Si continúe las preguntas

E45.1. Por favor indicar el número de caídas durante los últimos 3 meses caídas

E45.2. Sufrió el residente alguna lesión como consecuencia de la caída?
$\square$ No
$\square \mathrm{Si}$

E45.2.2 Si el residente se lesionó, sufrió alguna fractura como consecuencia de la caída?

$\square$ No

$\square \mathrm{Si}$

TE46 Por favor menciones algún evento relacionado con problemas de salud ocurrido en los últimos 3 meses y no mencionado anteriormente: 


\section{ANEXO 7:}

Portada de los vídeos explicativos para el soporte tecnológico de las sesiones psicoeducativas 

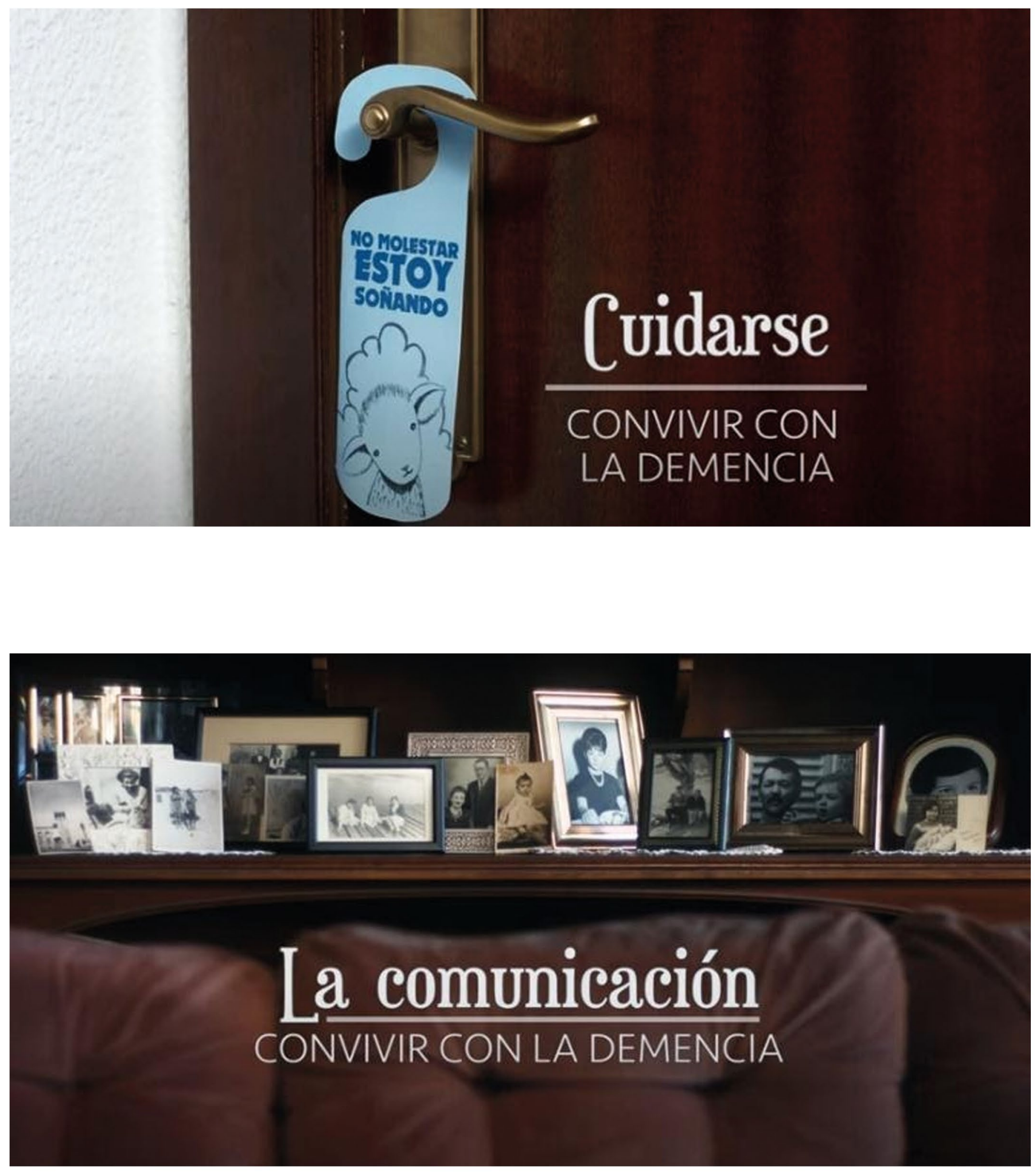
ANEXO 8:

Portada de las sesiones

psicoeducativas del

programa INFOSA-DEM 

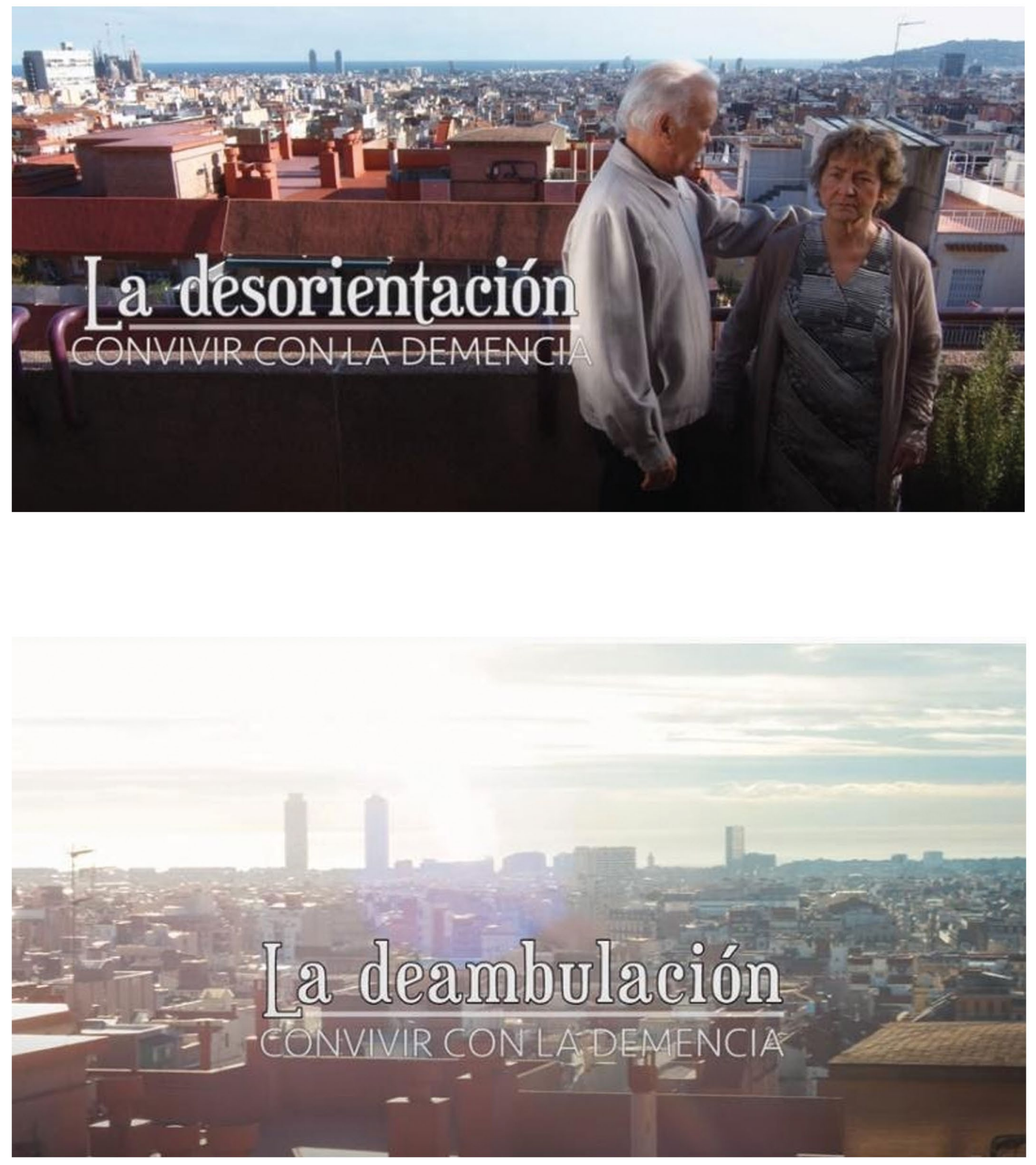
ANEXO 9:

Guía práctica de elaboración propia para el cuidador informal 


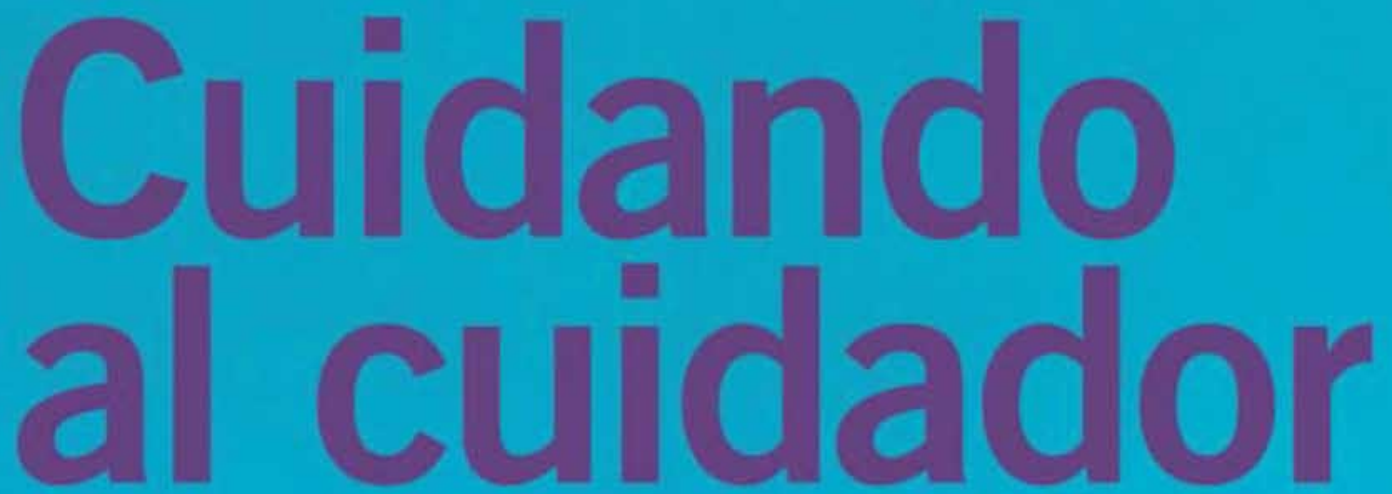

\section{de personas con Demencia}
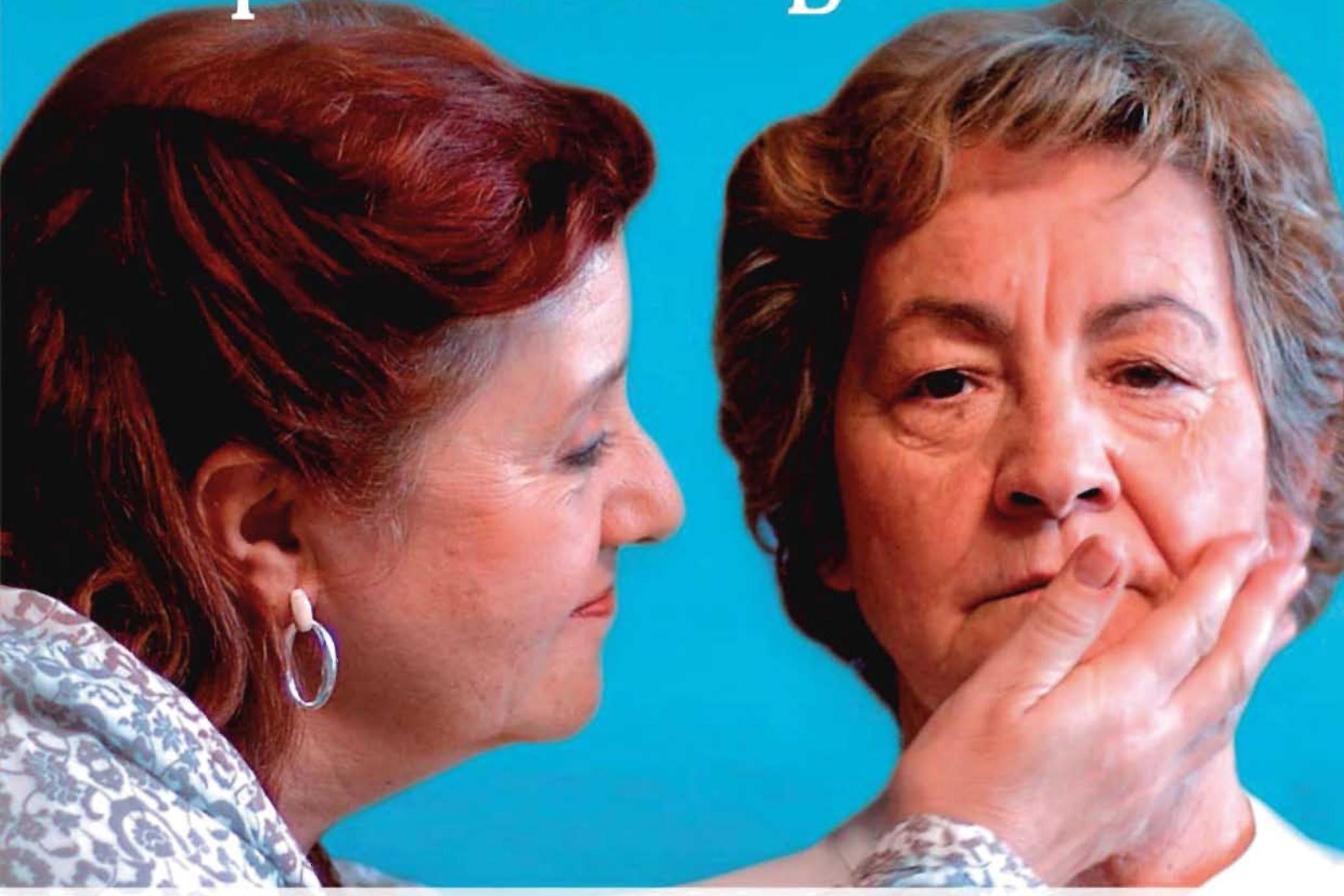

\section{GUÍA PRÁCTICA} Recomendaciones para el cuidador

Zabalegui A, Risco E, Canalias M, Galisteo M, Frías CE, García-Pascual M.

Programa INFOSA-DEM Información, Formación y Apoyo Social al cuidador de personas con Demencia

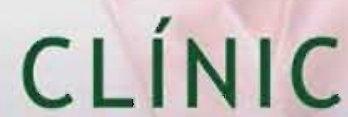

B ARCELONA

Hospital Universitari 

Programa INFOSA-DEM

Información, Formación y Apoyo Social

al cuidador de personas con Demencia

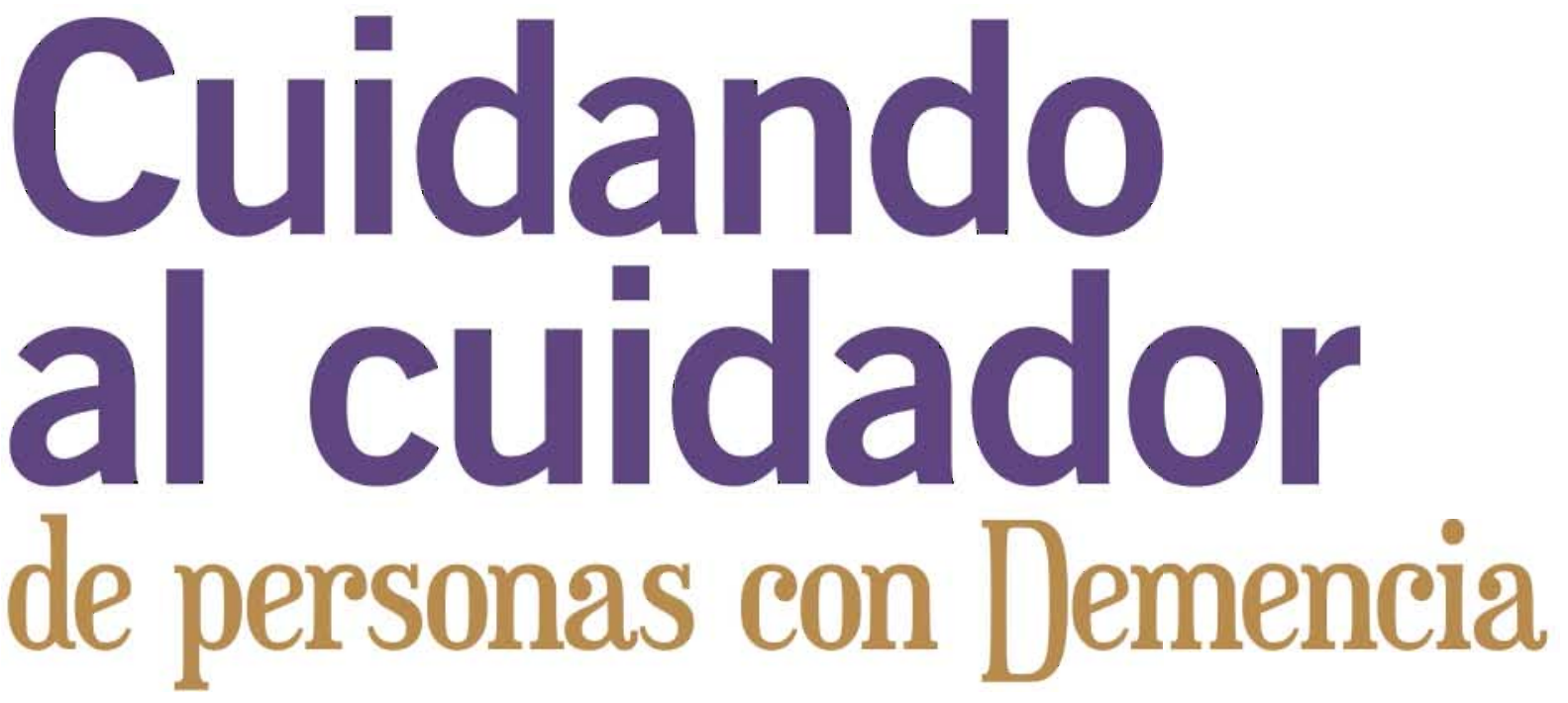

\section{GUÍA PRÁCTICA \\ Recomendaciones para el cuildador}

Zabalegui A, Risco E, Canalias M, Galisteo M, Frías CE, García-Pascual M. Montoro M, Puy N, Navarro M, Roura S, Blat E, Segarra R, Vilares P, Cabrera E.

Financiado por La Marató de TV3. Expediente 20144410.

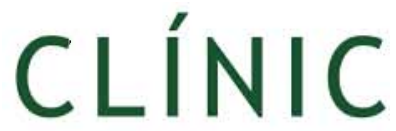

B A R C E L O N A

La Marató 
(c) Cuidando al cuidador de personas con demencia. Guía práctica y recomendaciones para el cuidador. Edita: HosPITAL CLINIC DE BARCELONA

Financiado por La Marató de TV3, Expediente 20144410. IP: Zabalegui A.

Autores: Zabalegui A, Risco E, Canalias M, Galisteo M, Frias CE, Garcia-Pascual $M$.

Colaboradores: Montoro M, Puy N, Navarro M, Roura S, Blat E, Segarra R, Vilares P, Cabrera E.

(c) Fotografias

Foto de portada: fotograma extraldo del VIDEO "La COMUNICACIÓN" Del programa InfOSA-DEM, 2016.

Interior: Marina Garcia, @ freeImages.com (bolleria, pag. 21); DominIC Morel, @FreeIMAges.com (Toallas, pag. 24);

Pascal Montsma, @freeimages.com (ducha, pag. 24); Carlos Paes, @freeimages.com (cepllo de dientes, pag. 26); Tamas Nép, @ areeimages.com (oreja, PÁg. 26); LAS Fotografias de LAS pÁGinas $6-7,11,14-15,22,27,30,31,32,33,34,35$, $36,37,38-39,41,42$ Y 46 SON FOTOGRAMAS EXTRAIDOS DE LOS VIDEOS DEL PROGRAMA INFOSA-DEM, 2016; LAS FOTOGRAFIAS DE LAS PAGINAS 20, 21, 25, 26, Y 31 SON FOtOGRAMAS EXTRAIDOS DE LOS VIDEOS DEL PROGRAMA INFOSA, 2012.

Diseño gráfico

Jordi Rabascall MadRID (Estudi Puche S. L.)

Depósito legal: B-12203-2016

Primera edición: junio de 2016

Impresión

El Tafaner

c/ Pere II de Queralt, 2

43420 Santa Coloma de Queralt

\section{(C) (1)(9) Esta obra está bajo una licencia de Creative Commons Reconocimiento- (CC)}




\section{Índice}

Presentación. Cuidando al cuidador de personas con demencia ...... 5

Cuidando al cuidador

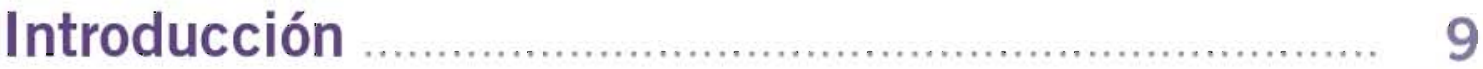

Cuidando al cuidador ......................................... 10

Como controlar la sobrecarga ................................. 12

Decálogo del cuidador ....................................... 13

Practicar una actitud positiva ................................. 13

Cuidando a la persona con demencia

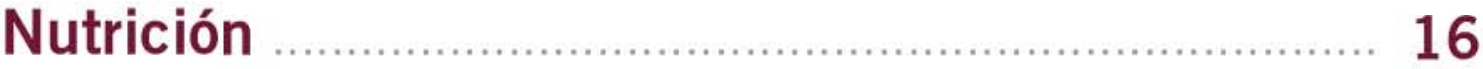

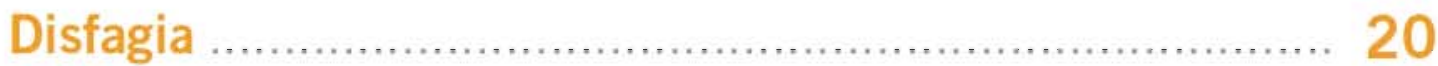

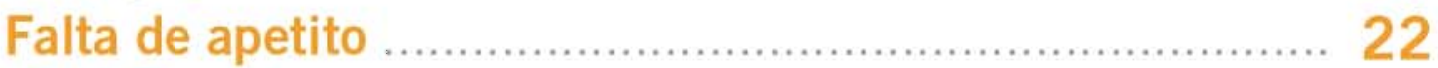

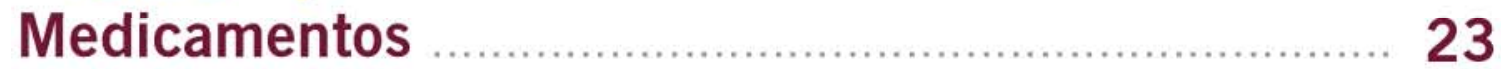

Higiene personal …....................................... 24

Vestido

Alteraciones en la eliminación ............................ 28

Incontinencia urinaria ............................................... 28

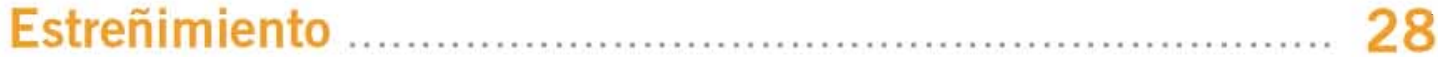

Diarrea ……

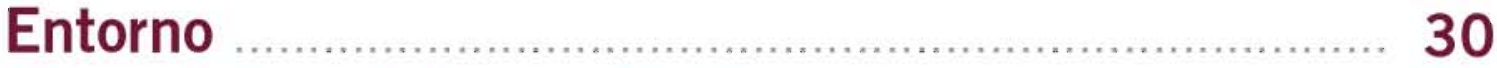

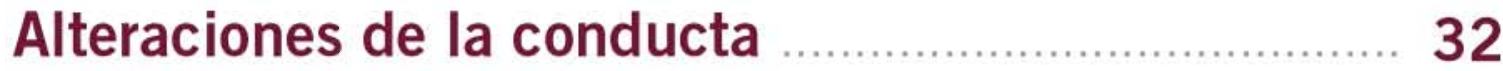

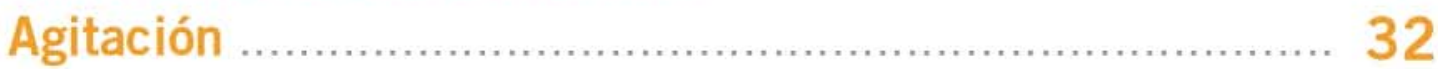

Palabras o acciones repetitivas .................................... 33

Delirios o alucinaciones ............................................. 34

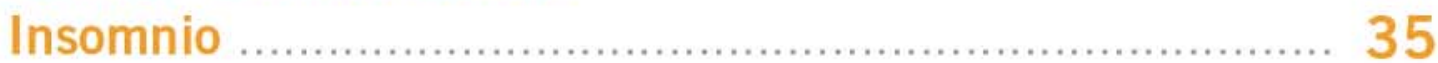

Deambulación o vagabundeo ……………………......... 36

La comunicación …......................................... 40

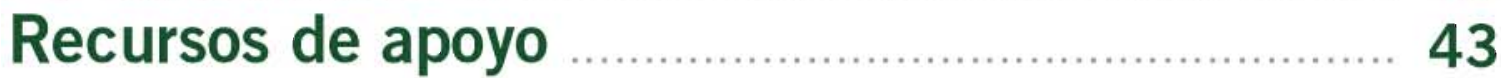

Direcciones de interés .................................................... 51

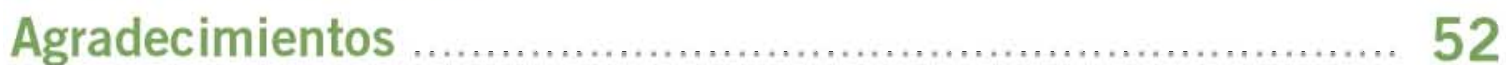





\section{Cuidando al cuidador de personas con demencia}

La demencia es un síndrome clínico que se caracteriza por el deterioro de la capacidad cognitiva. Este deterioro altera el desempeño de las actividades cotidianas. La memoria es la capacidad que más a menudo se pierde con la demencia. También resultan afectadas otras facultades mentales como el lenguaje, la orientación, la resolución de problemas y el juicio.

El deterioro puede originar depresión, aislamiento, alteraciones de la conducta, insomnio y desinhibición. La demencia es crónica y por lo general progresiva. Por ello, es una de las principales causas de discapacidad y dependencia entre los adultos mayores a nivel mundial.

El cuidado de personas con demencia supone una tarea importante a nivel familiar, ya que, por lo general el cuidado es asumido por algún miembro de la familia que se convierte en el cuidador principal. En algunos casos, los cuidadores no reciben la información suficiente y adecuada para el manejo de la persona con demencia en el domicilio, lo que puede generar sensación de sobrecarga, alteraciones en el estado de ánimo e incluso otro tipo de enfermedades en el propio cuidador.

A partir de lo anterior, se crea el programa INFOSA-DEM (Información, Formación y Apoyo Social al cuidador de personas con Demencia) dirigido a cuidadores principales de personas con demencia, con el fin de mejorar en el cuidador los conocimientos de la enfermedad, las habilidades y fomentar el auto-cuidado.

INFOSA-DEM bajo el lema "Cuidando al cuidador de personas con demencia», desarrolla esta guía práctica de recomendaciones para el cuidado integral, basadas en el marco de buenas prácticas de enfermería, en temas de importancia para la demencia como la nutrición, la higiene, el entorno, las alteraciones de la conducta, la comunicación y los recursos de apoyo.

Si usted es uno de los muchos cuidadores o cuidadoras que se enfrenta diariamente al cuidado de personas con demencia y se esfuerza para brindar la mejor atención, este es el programa que necesita para informarse, comprender y hacer más llevadera la tarea de cuidar.

Recuerde que no está solo y que estamos aquí para ayudarle. 


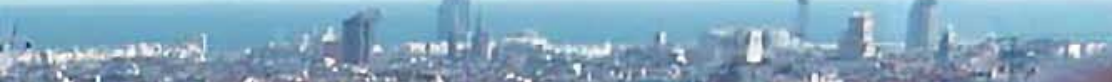

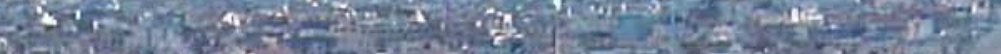

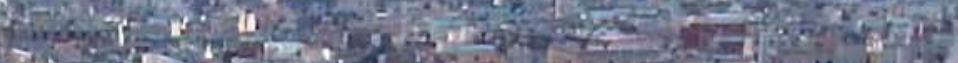

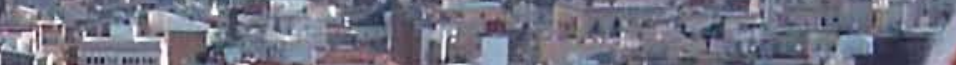

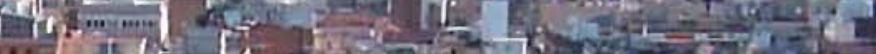

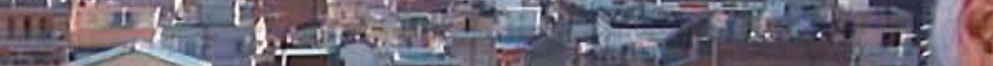

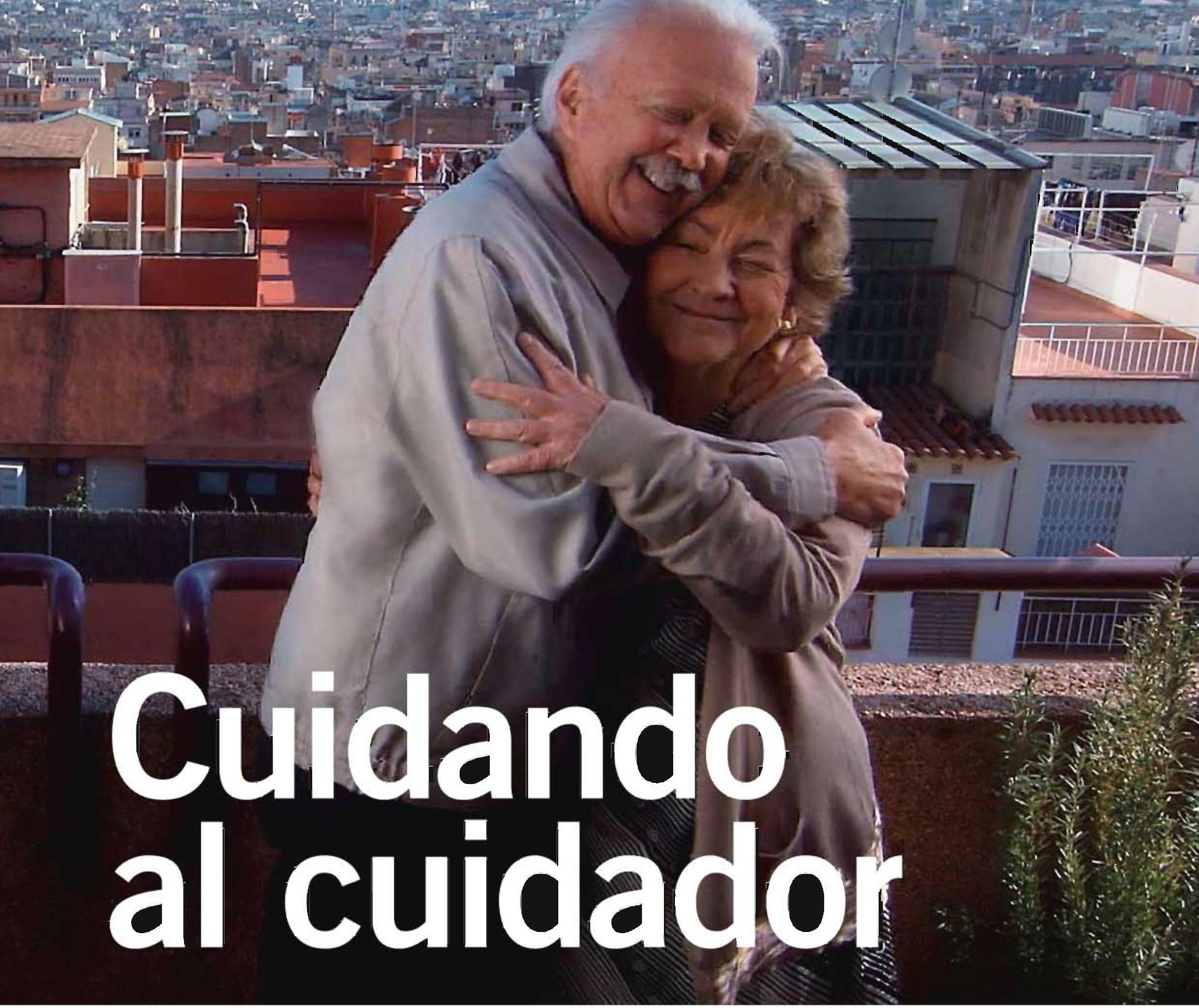

"Ayúdame a ser tan autónoma como sea capaz" 



\section{Introducción}

El cuidado en el domicilio de personas con demencia es una tarea que genera cambios en el núcleo familiar, al ser la familia el principal proveedor de cuidado. Esta situación requiere implicación y esfuerzo.

Cuidar es una labor importante y representa un desafío. Para poder superar el desafío, son necesarios conocimientos y habilidades específicas para afrontar los problemas que surgen como consecuencia del desarrollo de la enfermedad y del nivel de dependencia de la persona afectada.

Cuidar a una persona con demencia significa ser una fuente de apoyo emocional para una variedad de actividades que incluyen, por ejemplo, la organización de las actividades de la vida diaria, la administración de medicamentos, la higiene personal, las tareas del hogar, la reorientación respecto a la persona, espacio y tiempo, etc. Cuidar genera emociones y sentimientos positivos en el cuidador; no obstante, el cuidado puede suponer renunciar a actividades personales.

Por otra parte, algunos síntomas de la demencia pueden generar en el cuidador principal sensación de impotencia, sentimientos de culpa, soledad, preocupación o tristeza, dando lugar incluso al deterioro de la propia salud por la elevada demanda de cuidados del familiar o ser querido.

Por ello, es importante contar con apoyo profesional y una guía orientativa que proporcione al cuidador información específica sobre cómo realizar el cuidado de personas con demencia y prepararle para la toma de decisiones.

Ésta es una guía de apoyo con la que pretendemos asesorarle en aspectos que facilitarán su labor de cuidador, y ofrecerle respuestas en aspectos concretos, además de recordarle que no debe descuidar su propia salud. La guía no sustituye el consejo de los profesionales de su centro de referencia, ellos le indicarán sobre el tratamiento de la persona con demencia.

Esta guía está hecha para usted, por enfermeras del Hospital Clínic de Barcelona expertas en el cuidado de personas con demencia, porque creemos que cuidar no es tarea fácil, y queremos ayudarle.

«Si tú no estás bien, ellos tampoco»

Adelaida Zabalegui, RN, PhD

Directora de Enfermería Hospital Clínic de Barcelona 


\section{Cuidando al cuidador}

La demencia genera discapacidad y dependencia. El tipo de demencia más común es la enfermedad de Alzheimer. El deterioro cerebral progresivo conduce a pérdida de la memoria, dificultad para razonar, problemas en la comunicación con los demás y problemas para atender la propia persona, provocando variaciones súbitas en el estado de ánimo e incluso en la personalidad y la conducta, alterando la convivencia normal de la persona con demencia.

La tarea de cuidar implica conocer, desarrollar habilidades y actividades que mantengan o mejoren los síntomas. Por ello, el cuidador o cuidadora trata de ofrecer una atención completa, que supla las necesidades de la persona con demencia dentro de la medida de lo posible.

Es importante que como cuidador se enorgullezca del trabajo que realiza, y que también busque el apoyo de otras personas que le ayuden a cuidar de su familiar, con el fin de tomar un respiro en sus deberes cotidianos. Quizá le sea imposible tomar unas vacaciones prolongadas, pero es muy importante que programe algún tiempo de relajación, por ejemplo, un breve paseo, un rato para descansar tranquilamente en el propio hogar, visitar amistades, etc. Es importante que atienda su propia salud, para evitar la sobrecarga y la aparición de distintos trastornos.

\section{¿Qué debería tener presente un cuidador?}

- Mantener una dieta equilibrada.

- Descanso nocturno entre 7-8 horas diarias.

- Atender a las molestias persistentes.

- Asistir a grupos de apoyo. Personas con más experiencia le brindarán respaldo emocional y sugerencias para facilitar la tarea.

- Buscar información sobre recursos disponibles en la comunidad. 
Es importante realzar su fortaleza física, su capacidad para encontrar soluciones y la energía necesaria para sus labores de cuidar. Si se cuida adecuadamente, estará en mejores condiciones físicas y emocionales para cuidar a su familiar. Esté alerta ante los síntomas de sobrecarga.

\section{¿Cuáles son los síntomas de sobrecarga en el cuidador?}

- Rechazo de la propia sintomatología.

- Ansiedad y preocupación excesiva por el futuro.

- Depresión (desesperanza/impotencia).

- Irritabilidad ante pequeñas cosas.

- Enojo en momentos inoportunos.

- Dificultad para concentrarse.

- Aislamiento social.

- Insomnio o cansancio excesivo.

- Otros problemas de salud (por ejemplo, hipertensión arterial)

\section{Recuerde que nuestro objetivo es cuidar al cuidador de personas con demencia.}




\section{Como controlar la sobrecarơa}

\section{Pasos a seguir para aliviar la sobrecarga}

- Dedíquese unos 15-20 minutos al día para reposar y despejar la mente, tome las cosas con calma y paciencia, aleje pensamientos que puedan provocar ansiedad e inquietud. ¿Qué tal usar técnicas de Yoga, Mindfulness o Thai-Chi?

- Dedique una parte de su día a alguna actividad de ocio: leer, coser, cultivar un jardín, ver su programa favorito.

- Priorice citas y compromisos diarios, use calendarios y agendas.

- Límite el número de tareas al día para evitar agotamiento y sobrecarga.

- Haga algún ejercicio físico, disminuirá la ansiedad, aumentará su energía y conservará su salud. Camine algún día a la semana o haga un paseo en bicicleta.

- Realice controles médicos, para poder llevar un control de su propia salud.

- Busque ayuda, mantenga los lazos de amistad y las relaciones familiares. Únase a grupos de apoyo para compartir experiencias.

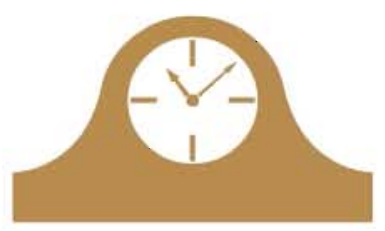

Repose 20 min.

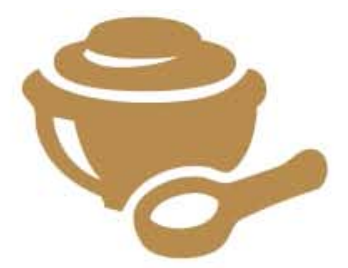

Actividad de ocio

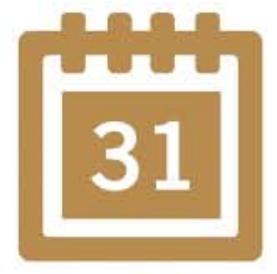

Planifique

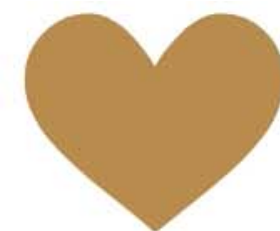

Haga ejercicio

- Realice actividades que le proporcionen satisfacción personal.

- Conserve su sentido del humor y sonría, la risa es excelente para la salud física y mental. Busque libros y películas que sean alegres y humorísticos. Incluso en los peores días suceden cosas graciosas.

- Reconozca y valore sus propios méritos, como cuidador de una persona con demencia es una gran labor la que está realizando.

- Como cuidador ha cambiado y desarrollado habilidades. iDese un aplauso por ese crecimiento!

\section{Es esencial mantener un estilo de vida saludable a nivel físico y mental, de otra manera, no podrá estar en las mejores condiciones para cuidar.}




\section{Decálogo del cuidador}

\section{Buscar apoyo} en los profesionales.

4. Ser sincero consigo mismo y con los demás.

5. Cuidarse física y mentalmente.

8. Ser un amigo incondicional para la persona a la que se cuida.
2. Aceptar la situación de cuidador.

3. Contactar con grupos de apoyo.

6. Tener paciencia.

7. No auto-exigirse demasiado. NO existe el cuidador perfecto.

9. Aceptar la ayuda que ofrecen familiares, amigos y vecinos.

10. Planificar y programar las propias actividades.

\section{Practicar una actitud positiva}

\section{Recuerde}

- Identificar pensamientos negativos y reemplazarlos con mensajes positivos:

$\checkmark$ "estoy haciendo lo mejor que puedo"

$\checkmark$ "algunas cosas están fuera de mi control"

$\checkmark$ "a veces, sólo tengo que hacer lo que funciona en este momento"

- El pensamiento positivo facilita el cuidado y promueve una buena salud mental, refuércese así mismo en todo momento: «es imposible que todo sea perfecto en mi situación, en realidad, estoy haciendo un gran esfuerzo».

- Con una actitud mental más positiva, tendrá mejores recursos para manejar los desafíos que se presenten en su camino como cuidador.

\section{Es necesario identificar sentimientos y emociones para poder ejercer el rol de cuidador.}




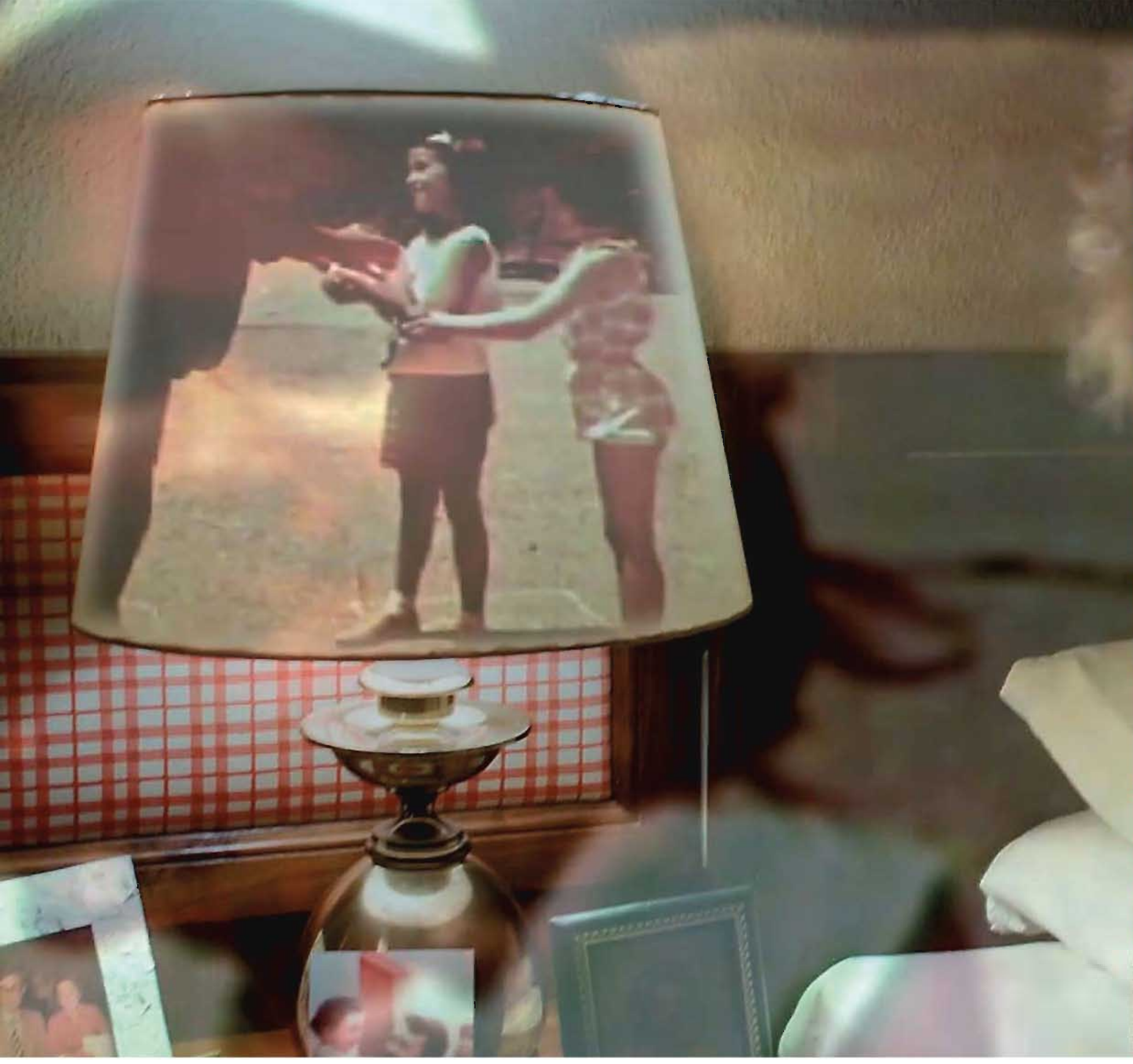




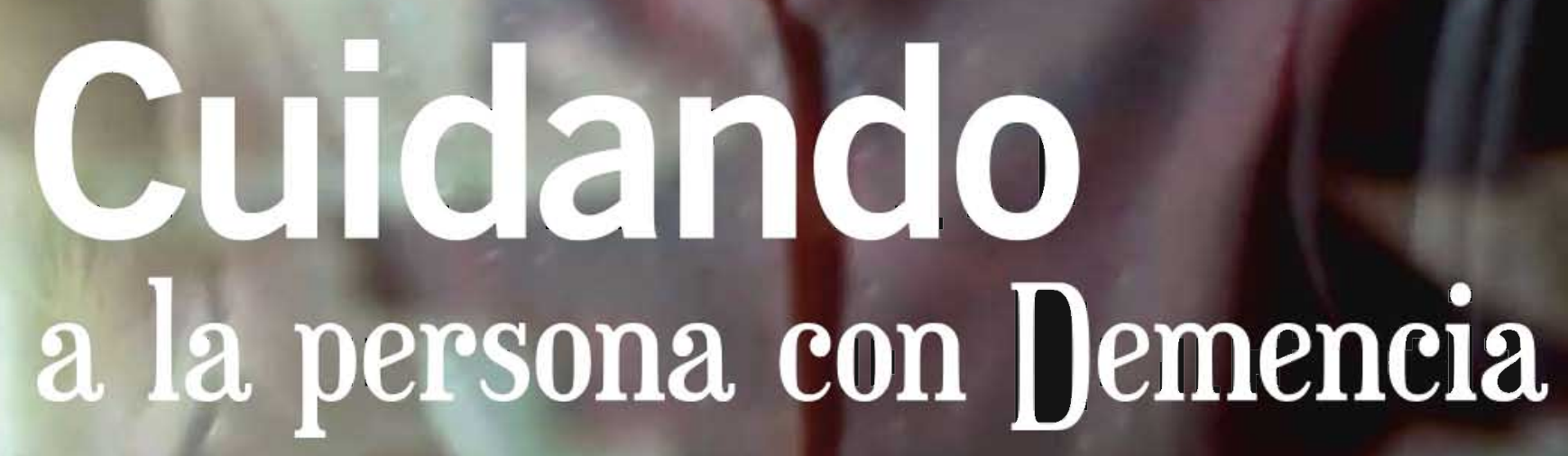

"Trata de entender las razones por las que actúo" 


\section{Nutrición}

Es necesario garantizar y promover que la persona con demencia se alimente bien y que beba suficientes líquidos. Suelen olvidarse de comer y beber. Para complicar más las cosas, es posible que padezca de problemas dentales 0 que algunos medicamentos le reduzcan el apetito 0 hagan que se le altere el gusto.

Para una alimentación saludable se recomienda un equilibrio entre todos los grupos de alimentos, que asegure un buen aporte de nutrientes, a partir de una dieta variada, agradable y de cantidad suficiente.

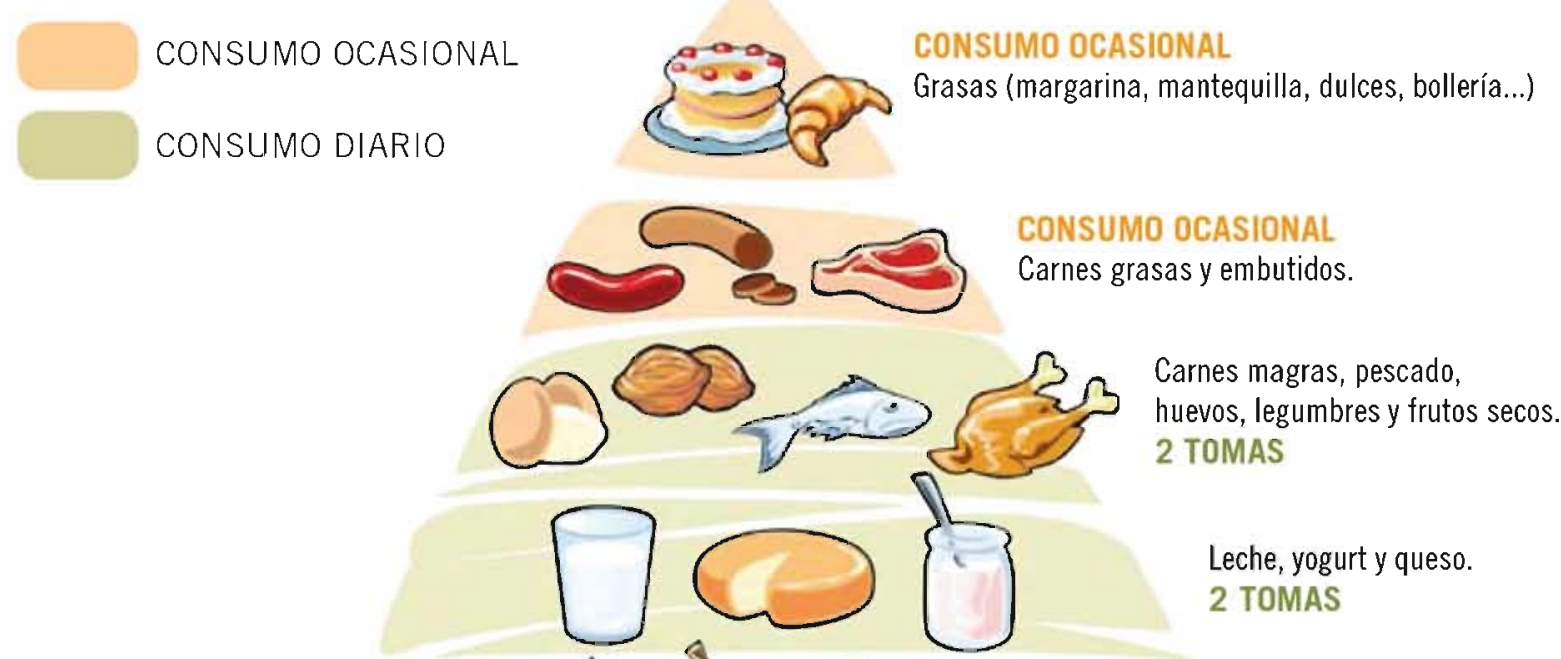

Vedituas ythatilas
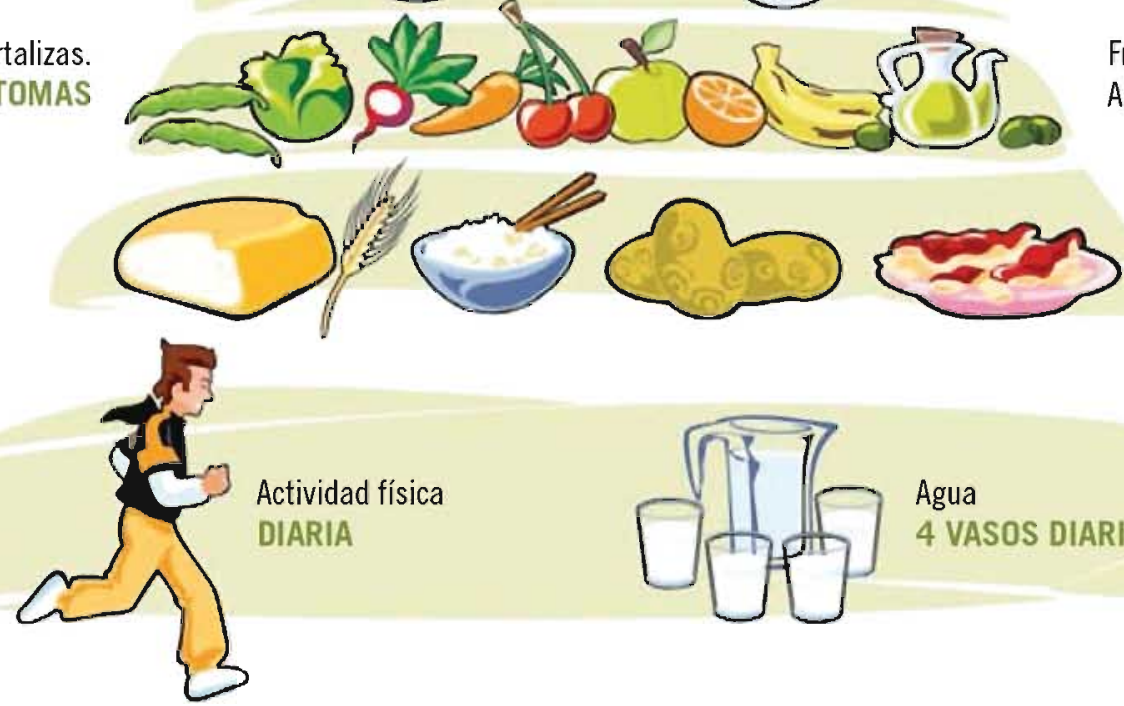

Frutas 2-3 PIEZAS

Aceite de oliva para cocinary aliñar.

Pan, cereales, cereales integrados, arroz, pasta, patatas $y$ harinas. 4-6 TOMAS

\section{Una mala alimentación causará pérdida de peso,} irritabilidad, insomnio, incontinencia y desorientación. 


\section{Recomendaciones para facilitar la alimentación}

- Establecer un horario para las comidas y meriendas (desayuno, media mañana, comida, merienda y cena).

- Haga que sea un momento especial. Ponga flores o sintonice música suave.

- Haga los cortes necesarios y añada condimentos. Estimule la autonomía y pruebe el uso de un tazón para niños si hay dificultades para manipular los vasos. Ayude cuando sea indispensable.

- No sirva comidas o líquidos humeantes o extremadamente calientes.

- Prepare los platos en función de las necesidades, sírvale comidas blandas. Por ejemplo, hamburguesas, croquetas o tortilla.

- Si se le olvida masticar o tragar, pruebe a manipular su mentón para que mastique, o acaríciele suavemente la garganta para estimularle a tragar.

- No sea repetitivo o le critique cuando se manche o no quiera seguir comiendo, así evitará aumentar su malestar o crear tensiones.

- Dé instrucciones simples y fáciles de entender. Por ejemplo, «levanta el tenedor y come despacio, ahora llévalo a tu boca».

- Tenga paciencia, no apresure a comer más rápido.

- Comer en buena postura, procurar que la persona esté sentada o lo más incorporada posible.

- Siéntese a la mesa y coma con su ser querido en la medida de lo posible, con frecuencia imitan sus acciones, y además será más agradable.

- Si hay exceso de peso, retire alimentos de alto contenido calórico. Por el contrario, ponga a mano frutas, verduras y otras meriendas de bajo contenido calórico.

- Si hay pérdida de peso, sírvale meriendas nutritivas entre las comidas principales.

- Use suplementos vitamínicos, bajo la recomendación de un médico y controle su uso.

- Limite o elimine las comidas con mucha sal o dulce, sobre todo si tiene un problema de salud crónico.

- Si la persona parece siempre tener hambre, sirva porciones más pequeñas de comida a intervalos más frecuentes.

- Evite la presencia de grumos, espinas y huesos.

- Si existe dificultad para deglutir líquidos, utilice espesantes. También puede tomar agua gelificada o gelatinas.

- La buena hidratación es tan importante como una buena higiene general.

- Cuando la persona está encamada, debemos aportar con más razón una dieta con alto contenido en proteínas para evitar la aparición de úlceras por presión. 


\section{Recomendaciones especiales}

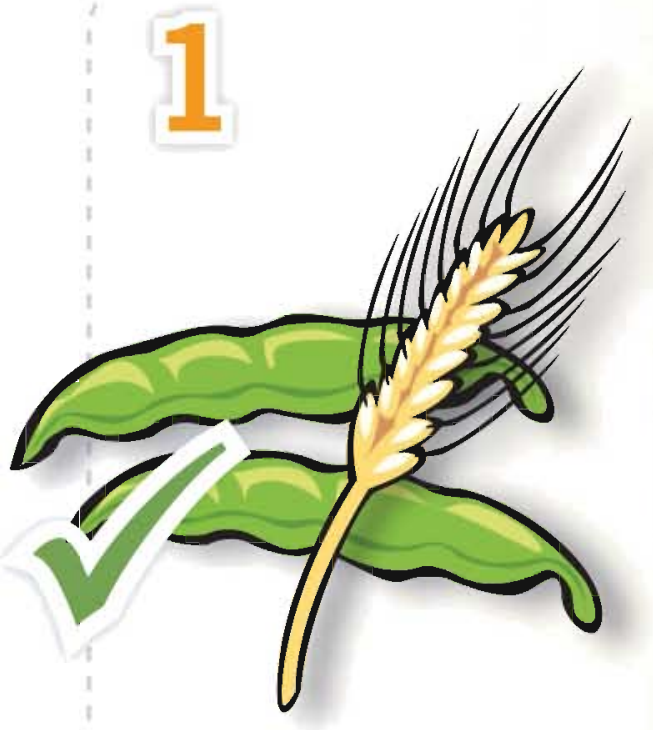

\section{Estreñimiento}

- Aumente el consumo de alimentos ricos en fibra como verduras, frutas con piel, legumbres y cereales integrales.

- Aliñar los alimentos con aceite.

- Aumentar la ingesta de líquidos: agua, infusiones, zumos, caldos.

- Realizar ejercicio físico, o realice masajes en el abdomen suavemente de forma circular con la yema de los dedos en la zona por debajo del ombligo para estimular el peristaltismo intestinal.

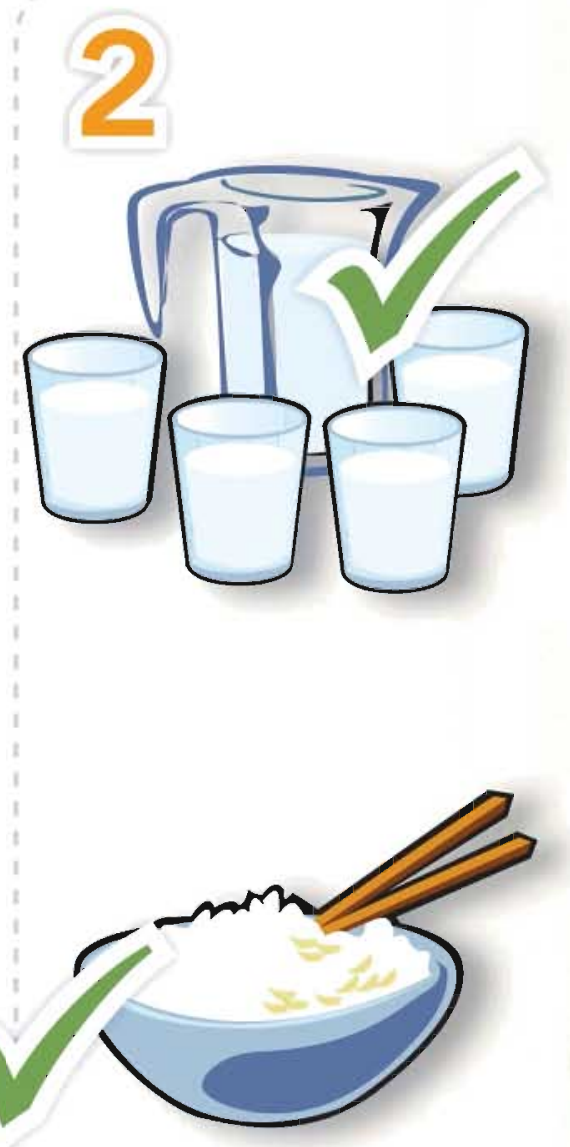

\section{Diarrea}

- Aumentar los líquidos para evitar la deshidratación, se recomienda la ingesta de pequeños sorbos de agua, infusiones y agua de arroz durante todo el día.

- Alimentos preferentes: arroz, patata hervida, pescado blanco, pollo a la plancha, pan tostado, jamón cocido, manzana o pera sin piel al horno o cocida, dulce de membrillo.

- Formas de cocción de los alimentos: hervidos, al vapor y asados.
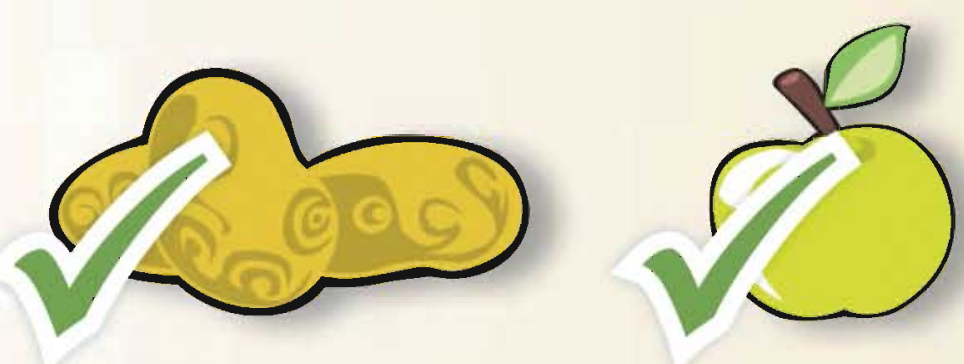


\section{Hipertensión arterial}

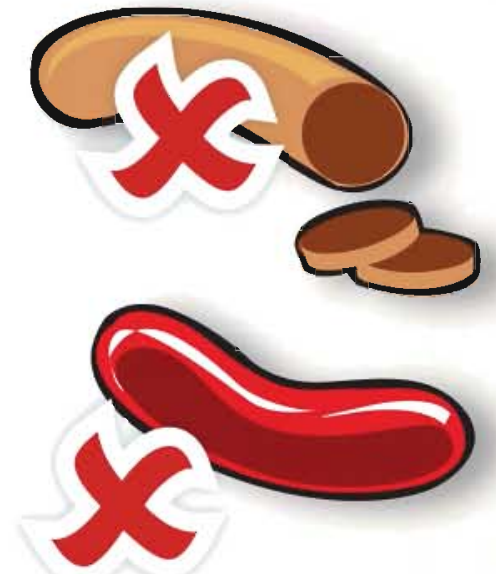

- Disminuir el consumo de sal y evitar poner el salero en la mesa.

- Condimentar con perejil, hierbas aromáticas, cebolla o limón.

- No beber agua mineral con gas, gaseosas o refrescos.

- Reducir el consumo de queso curado.

- Evitar las conservas, embutidos y aperitivos.

- Evitar las comidas precocinadas.

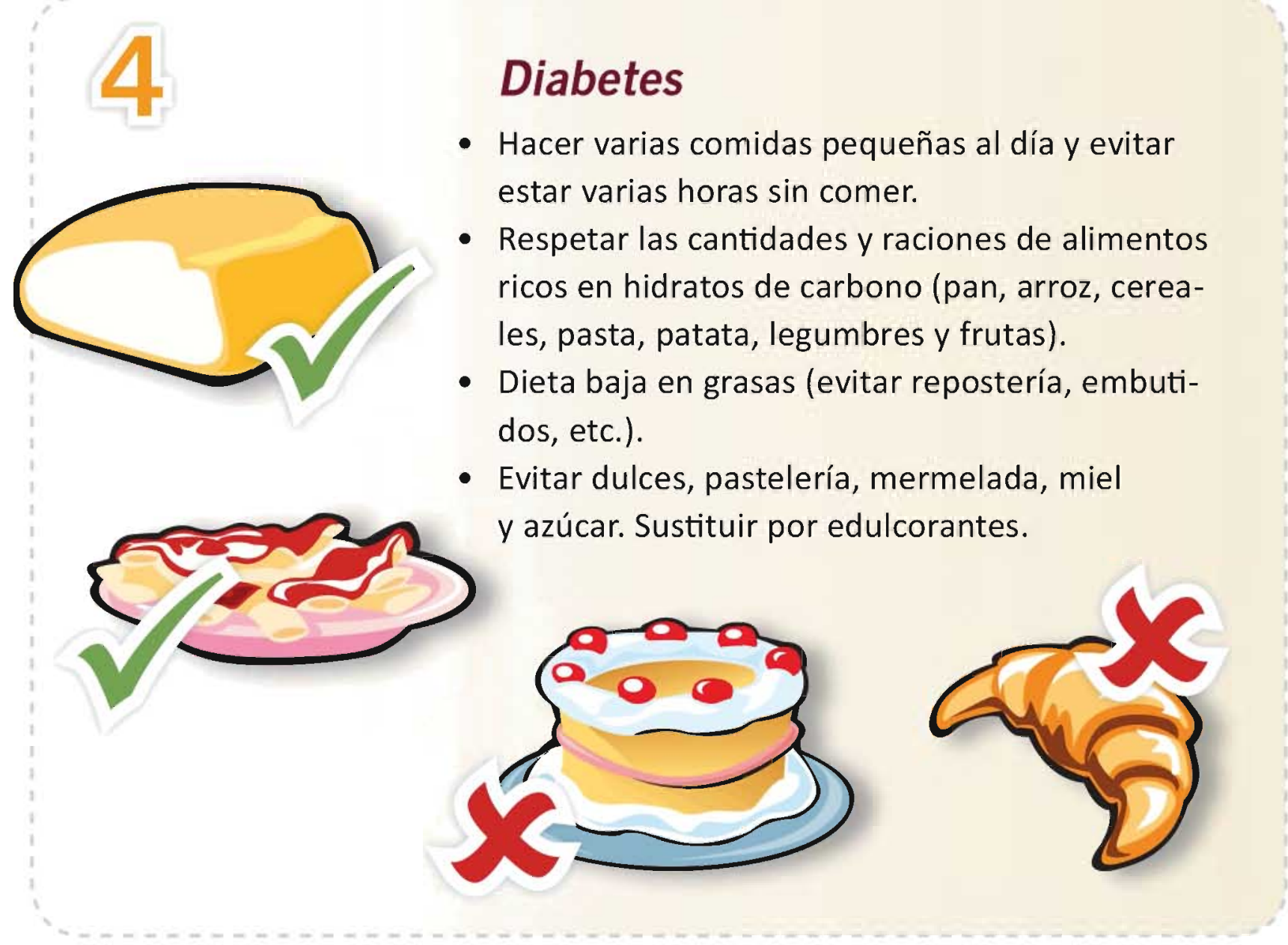




\section{Disfagia}

La disfagia es la alteración o dificultad para tragar o deglutir los alimentos sólidos y líquidos e incluso la saliva. Puede provocar atragantamientos, desnutrición o deshidratación así como infecciones respiratorias.

A medida que avanza la enfermedad las personas con demencia pueden presentar esta alteración.
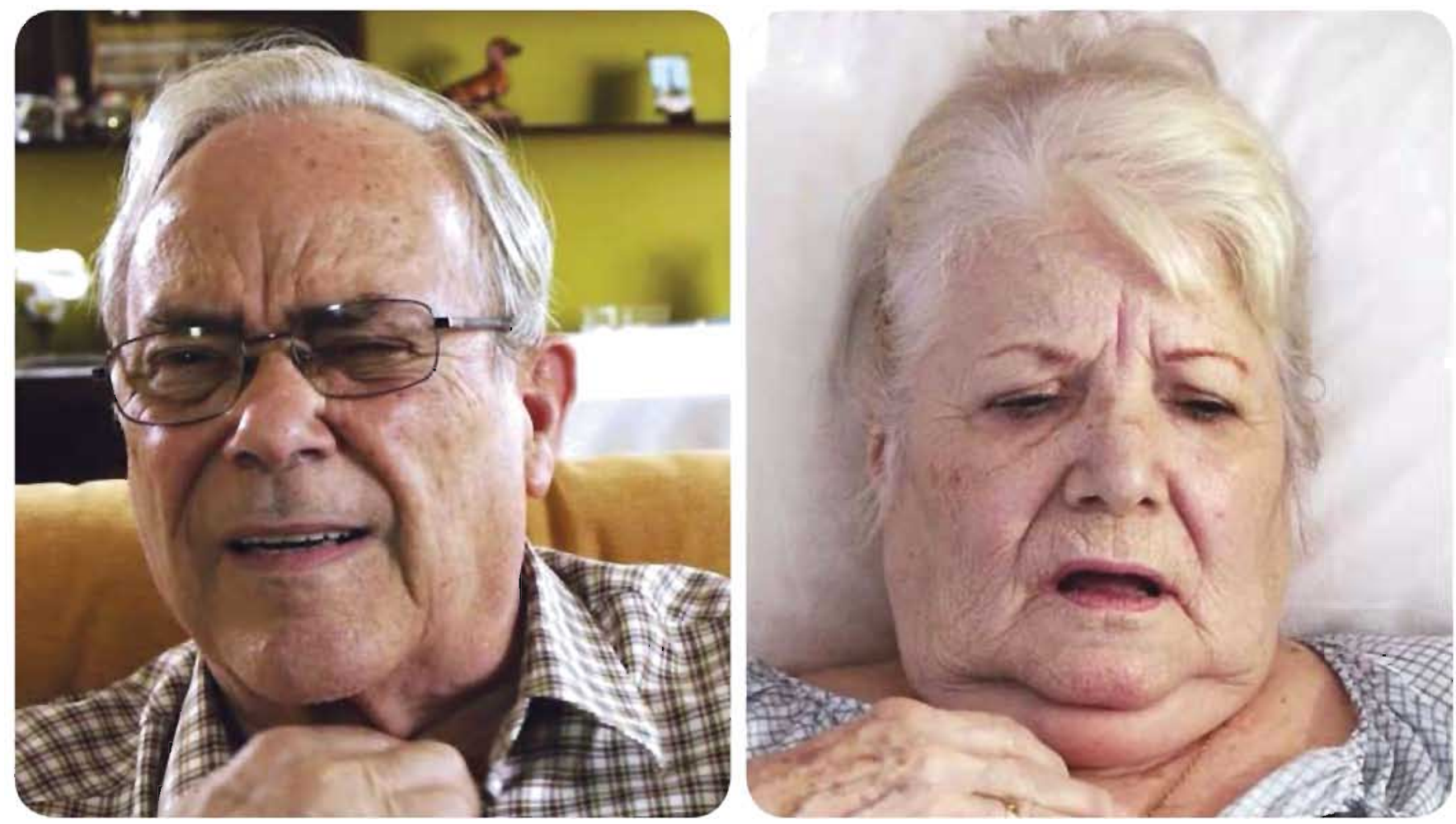

Signos y síntomas para identificar la disfagia

- Rechazo de ciertos alimentos que antes tomaba de manera habitual por miedo atragantamiento.

- Atragantamiento y babeo.

- Necesidad de tragar más de una vez para poder tomar un mismo bocado.

- Cambio en la voz coincidiendo con las comidas y acompañado de tos y/o carraspeo, sobre todo al ingerir líquidos.

- Comer despacio y mantener la comida en la boca.

- Desinterés por comer, ya que supone un gran esfuerzo. 


\section{Recomendaciones}

- Evite alimentos pegajosos (pan de molde, bizcochos, magdalenas), secos (tostadas), de doble textura (sopa con pasta) y fruta con semillas (kiwis).

- Triture los alimentos para conseguir una textura homogénea sin grumos, pepitas ni filamentos.

- Use salsas para conseguir texturas más suaves (bechamel, mayonesa, tomate).

- Adáptela consistencia de los líquidos, utilice preparados como la gelatina o agua espesada.

- Prepare la mesa con pocos cubiertos y de fácil manejo. Podemos usar ayudas técnicas para facilitar la actividad, como por ejemplo, engrosadores del mango de los cubiertos, vasos con asas, platos con reborde. Estos materiales los podemos encontrar en lugares especializados y en ortopedias.

- Durante las comidas procure que la persona esté sentada o lo más incorporada posible y mantenerla incorporada de 30-60 minutos tras la comida. Acostarle mu y pronto podría ocasionar reflujo.

- Es importante que pueda comer de forma autónoma, pero siempre ha de observarle o vigilarle atentamente.

- Nunca utilice jeringas o pajitas. Se recomienda utilizar cucharas pequeñas, ya que la ligera presión que ejerce sobre la base de la lengua favorece el reflejo de deglución.

- Aconséjele que no hable mientras come.

- Dele tiempo a que pueda tragar y deglutir, proporcionándole volúmenes pequeños.

- Recuérdele que cuando trague debe tener la barbilla inclinada hacia el pecho, para proteger el paso de los alimentos a la vía respiratoria. Si usted le da de comer facilitará la posición si se sitúa enfrente de la persona y ligeramente por debajo.
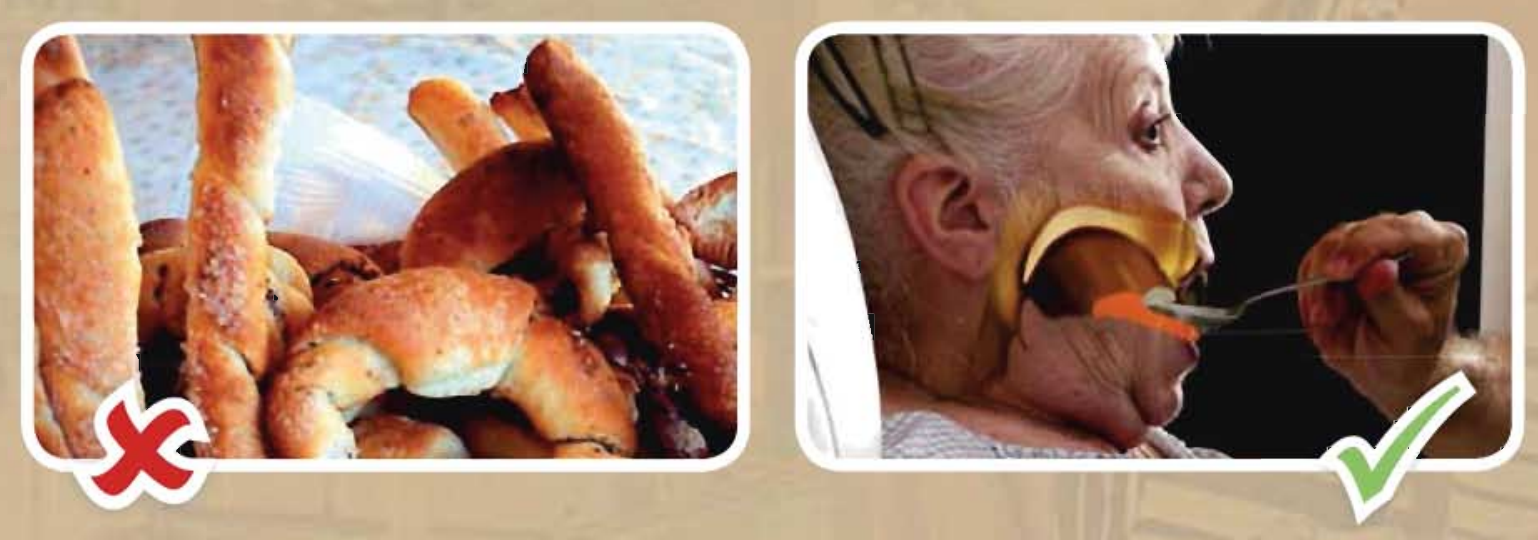


\section{Falta de apetito}

Las personas con demencia pueden presentar falta de apetito a medida que avanza la enfermedad.

\section{Algunas causas de la falta de apetito}

- No reconoce la comida. Los platos de colores o una vajilla brillante pueden ayudar a lograr mayor contraste.

- Problemas con la dentadura. Es importante realizar visitas regulares al dentista.

- La medicación. Algunos medicamentos pueden interferir en el apetito. Si nota algún cambio es importante consultarlo al médico.

- Falta de ejercicio. La falta de actividad física puede contribuir a la falta de apetito. Ejercicios sencillos como caminar o lavar los platos, doblar la ropa pueden ayudar.

- Pérdida del sentido del olfato y del gusto. La persona con demencia puede que no reconozca, el olor y sabor de los alimentos. Las especias pueden ser de gran ayuda realzando el sabor de la comida.

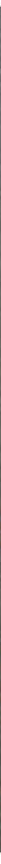

\section{Una alimentación equilibrada y un buen estado nutricional influirán en el estado de salud de la persona con demencia.}




\section{Medicamentos}

Dependiendo de la evolución de la enfermedad, la persona con demencia necesitará más o menos medicamentos. La medicación tendrá un efecto diferente que dependerá del peso, de la edad y de los síntomas que se presenten; a veces es necesario que su médico modifique las dosis.

Por lo general, en las personas mayores se pautan dosis más pequeñas, ya que el medicamento permanece más tiempo en el organismo.

\section{Recomendaciones generales para asegurar que la administración de los medicamentos se hagan de forma segura y eficaz}

- Conozca el nombre del medicamento, funciones, forma de aplicación, dosis y número de tomas al día. Teniendo en cuenta la duración del tratamiento y si es necesario la adopción de precauciones especiales.

- Guarde los medicamentos en un lugar seguro, manteniendo las condiciones de conservación y evitando que sean de fácil acceso para la persona a quien se cuida.

- Tenga presente la fecha de caducidad.

- Cumpla los horarios de administración. Asocie la toma de medicamentos con las comidas o con alguna actividad cotidiana para que no se le olvide. Explíquele antes de cada toma de que medicamento se trata y recuérdele que es para su recuperación y/o bienestar.

- El farmacéutico o el equipo de profesionales pueden asesorarle en la organización y planificación de la toma de la medicación. En la medida de lo posible, haga partícipe a la persona a quien cuida de la organización de la medicación, bajo su vigilancia.

\section{Como cuidador puede ayudarle a tomar el medicamento} en el momento adecuado para mantener su buena salud. 


\section{Higiene personal}

Las personas con demencia muchas veces olvidan los hábitos higiénicos, como cepillarse los dientes, arreglarse, bañarse y cambiarse de ropa periódicamente.

Desde la infancia se nos ha enseñado que éstas son actividades estrictamente privadas y personales; el hecho de que los desvistamos y duchemos puede asustarles, humillarles o avergonzarles. En consecuencia, la hora del baño suele provocar angustia al cuidador y al ser querido.
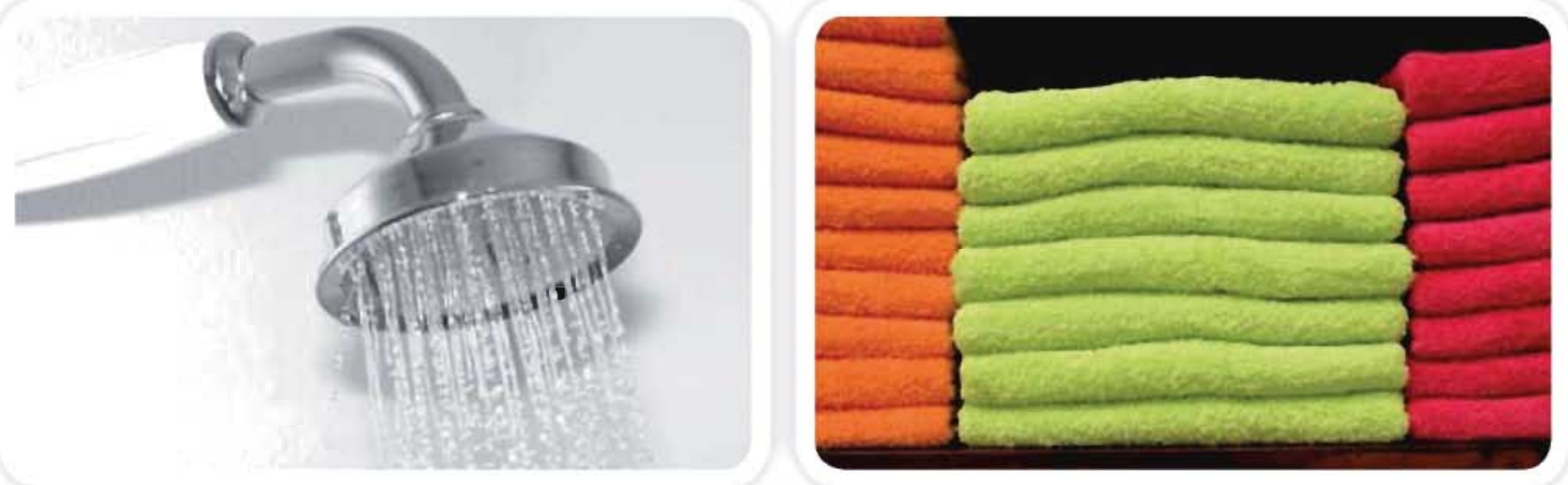

\section{Recomendaciones generales}

- Recuérdele antiguos hábitos de higiene.

- No es necesario bañarle todos los días, a veces basta con una ducha 2-3 veces por semana. El resto de días puede probar a asearle con una toalla o paño húmedo. Sin embargo, es necesario limpiar la zona genital y anal de forma diaria.

- Aseo diario de la cavidad bucal y del resto de la cara.

- Mantenga su intimidad. Cúbrale el cuerpo con una toalla siempre que sea posible. Tenga listas toallas, una bata de casa o la ropa limpia para cuando termine el baño.

- Tenga en cuenta otros factores como la temperatura ambiental y del agua, así como la adecuada iluminación, alfombrillas anti-deslizantes, agarradoras para sostenerse y los asientos para la bañera o la ducha. Recuerde que las personas con demencia suelen tener temor a caerse. Asegúrese de que se sienta seguro en la ducha o la bañera. 


\section{Más recomendaciones}

- Explique en todo momento qué se va a hacer.

- Facilite y enseñe la correcta utilización de utensilios de aseo.

- Mantenga condiciones adecuadas (iluminación, limpieza, accesibilidad, comodidad, temperatura, geles neutros, champús que no irriten la piel, etc.)

- Mantenga la autonomía siempre que sea posible y ayude solo en lo necesario.

- Cree rutinas, para facilitar la asociación de determinados acontecimientos con la llegada del aseo.

- Respete su intimidad.

- Si es posible, utilice una silla con un orificio para facilitar la higiene genital. Otra opción es utilizar una silla de plástico y pedirle que se mantenga de pie el tiempo necesario para realizar la higiene genital y anal.
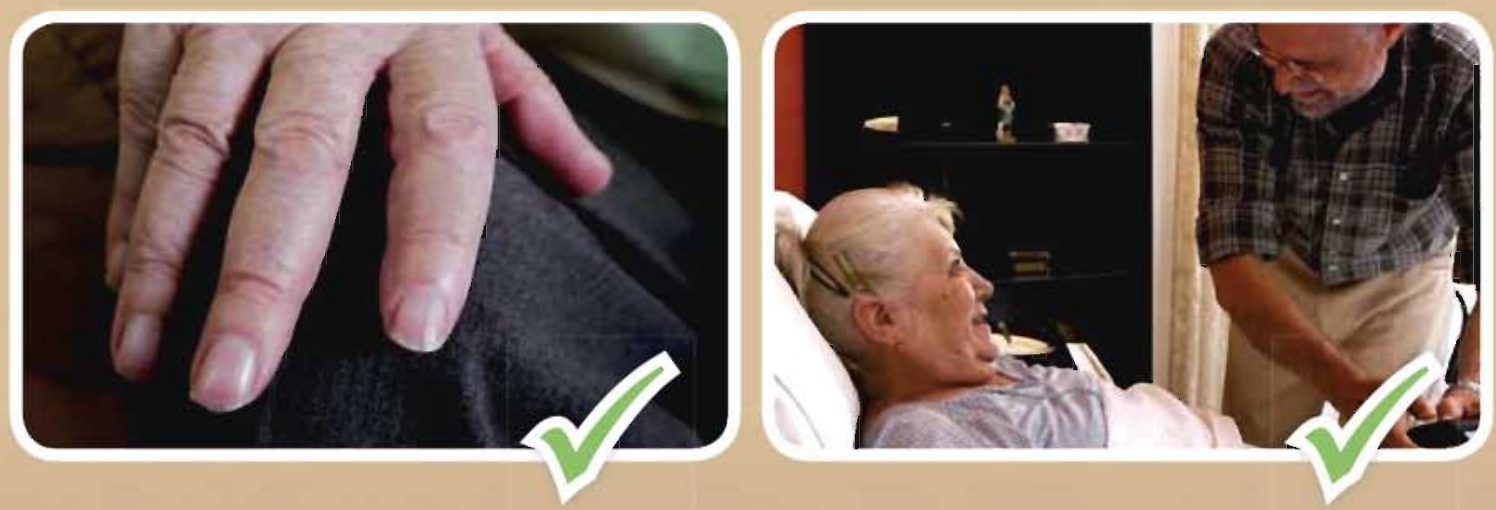

- Mantenga las uñas de manos y pies limpias para evitar infecciones graves, sobre todo en caso de personas con diabetes.

- Utilice jabón neutro y evite el uso de alcohol y polvos de talco, ya que producen deshidratación de la piel.

- Seque correctamente la piel para evitar erosiones y la aparición de infecciones debido a la humedad, teniendo especial cuidado con las zonas de pliegues.

- Para finalizar hidrate la piel con crema hidratante. Puede realizar un masaje para activar la circulación. 


\section{Vestido}

Algunas personas con demencia tienen dificultades para vestirse. Para mayor comodidad es aconsejable elegir ropa suelta y cómoda con cremalleras, cinturilla de goma 0 broches fáciles de abrir y cerrar, con un mínimo de botones o velcro.

Con el fin de facilitar el proceso de vestirse y estimular su capacidad de independencia, entréguele las prendas una por una, en el mismo orden en el que se tiene que vestir. Saque del dormitorio la ropa sucia, y no discuta si insiste en ponerse otra vez la misma ropa. Es práctico tener prendas que combinen fácilmente.

Evite los cordones de los zapatos. Le recomendamos el uso del calzado que recoja el pie. Prescinda de zapatos tipo chanclas o zuecos.

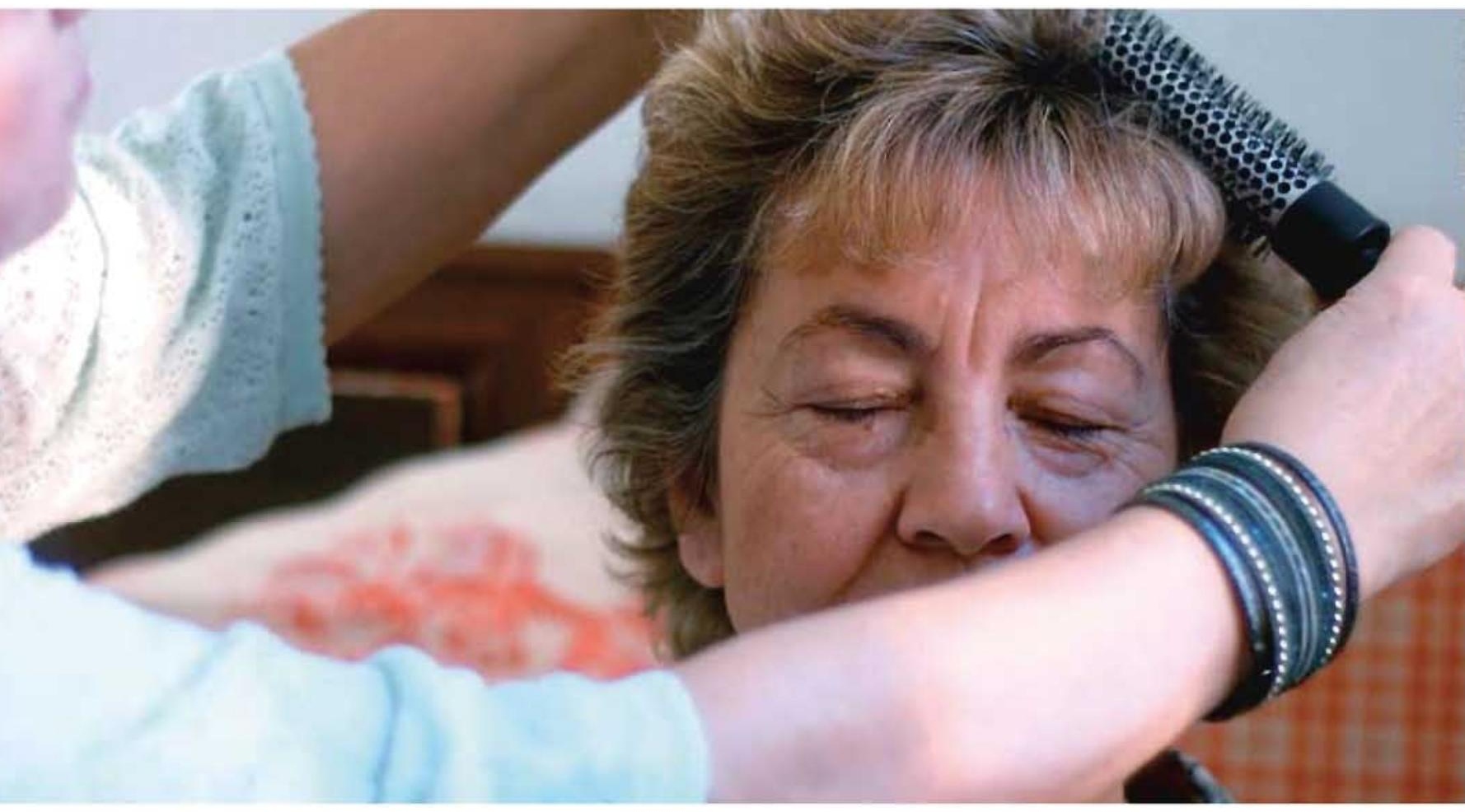

\section{Si la persona con demencia está bien aseada y vestida, él y usted se sentirán mucho mejor.}




\section{Alteraciones en la eliminación}

\section{Incontinencia Urinaria}

La pérdida del control de esfínteres es frecuente en las etapas avanzadas de la demencia. Si ocurre un escape de orina, mantenga una postura comprensiva y de apoyo, que ayude a conservar la dignidad y a reducir al mínimo sentimientos de vergüenza.

\section{Recomendaciones}

- Programe un horario establecido para ir al baño. Pruebe a recordarle que vaya al baño cada dos horas, o ayúdelo a ir.

- Asegúrese de que ingiera suficiente líquido, para que no se deshidrate. No obstante, evite bebidas con efectos diuréticos (café, té, refrescos de cola y cervezas).

- Reduzca la ingestión de líquidos por la noche, sobre todo antes de ir a dormir.

- Ponga carteles para indicar la puerta del baño.

- Durante la noche puede dejar en el dormitorio un orinal de fácil acceso, que podrá adquirir en cualquier tienda de suministros médicos o proporcione una luz adecuada por la noche que indique el camino hacia el lavabo.

- Utilice ropa fácil de quitar y de lavar, con elástico o velcro en la cintura.

- Observe la presencia de claves no verbales que señalen la necesidad de orinar, como intranquilidad, ademán de sujetarse, etc.

\section{Estreñimiento}

Los síntomas de estreñimiento son heces duras y secas, con dificultad y falta de expulsión en más de 2 días, acompañadas de dolor. La disminución de la movilidad y el escaso aporte de líquidos, son factores claves para sufrir estreñimiento.

Es importante la cantidad y el tipo de líquidos ingeridos a lo largo del día, con especial atención al consumo de cafeína y alcohol, ya que son alimentos con efecto diurético que promueven el endurecimiento de las heces por la pérdida de agua. Tenga en cuenta la cantidad de alimentos y fibra dietética ingerida habitualmente. 


\section{Recomendaciones}

- Controle la frecuencia de ir al baño.

- Debe ingerir unos 1500-2000 ml de líquidos al día. Anímelo a beber frecuentemente.

Intente identificar las posibles causas de la incontinencia fecal y urinaria, vigile la higiene tras cada deposición y recurra a cualquier ayuda para minimizar las consecuencias de la incontinencia, recuerde que la enfermera puede ayudarle.

- Asegúrese de un consumo diario de alimentos con fibra (pan integral, fruta, verduras, legumbres).

- Puede tomar una cucharada de aceite de oliva en ayunas.

- En el momento de la necesidad de defecar, respete la intimidad y favorezca su confort.

- Debe realizar, en la medida de lo posible, ejercicio físico. Si la persona no puede moverse, realice masajes abdominales siguiendo la dirección de las agujas del reloj. La frecuencia, intensidad y duración de los ejercicios debe ajustarse a la tolerancia de la persona con demencia.

\section{Diarrea}

Los síntomas son eliminación de heces de aspecto acuoso, que puede acompañarse de dolor abdominal, náuseas y/o vómitos.

En ocasiones el cuadro se agrava y la persona puede presentar sangrado y diarreas continuas durante más de una semana, con fiebre o vómitos que impiden la ingesta de líquidos. Ante esta situación debe consultar a profesionales expertos.

\section{Recomendaciones}

- Iniciar una dieta blanda (pasta, arroz, purés).

- Introduzca alimentos astringentes como arroz, zanahoria, manzana, plátanos, tomate crudo y/o pescado blanco cocido (no en caldo).

- Asegurar el aporte de líquidos con el fin de evitar la deshidratación. Dé infusiones, zumos naturales, agua de forma frecuente y en poca cantidad.

- Evite líquidos muy fríos o muy calientes ya que estimulan el movimiento intestinal.

- Higiene adecuada, con especial atención en la limpieza de la zona perianal, ya que podría estar irritada.

- Consulte con el profesional sanitario si fuese necesario el uso de medicamentos y/o si se agrava la situación. 


\section{Entorno}

En el entorno de la persona con demencia es necesario realizar algunas modificaciones, sin realizar cambios bruscos de decoración, de lo contrario, la persona puede confundirse y desorientarse hasta el punto de no identificar el medio como su propio hogar y sentirse desubicado.

Ellos son especialmente sensibles al ambiente que se encuentra a su alrededor. El entorno debe ser sencillo, seguro, y facilitar la autonomía. Las adaptaciones deben hacerse de forma gradual y acorde a las necesidades.

Para facilitar la orientación, es importante indicar en la puerta de cada habitación con un dibujo apropiado o con palabras reconocibles en mayúsculas (por ejemplo, baño con el dibujo de una bañera o el inodoro, un cartel donde ponga comedor...).
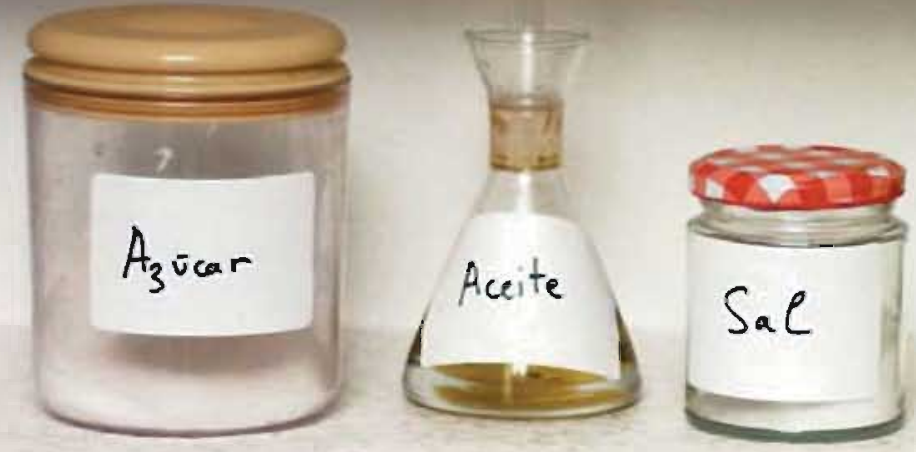

\section{Recomendaciones en la cocina}

La cocina puede convertirse en una de las estancias más peligrosas de la casa, sería conveniente.

- Utilizar vajillas y vasos irrompibles, de colores, para visualizarlos mejor y con manteles antideslizantes.

- Guardar en un lugar seguro utensilios punzantes o peligrosos (cuchillos, cerillas, tóxicos, etc.).

- Evitar el uso de taburetes o escaleras.

- Señalizar mediante dibujos o palabras escritas el contenido de los armarios. 


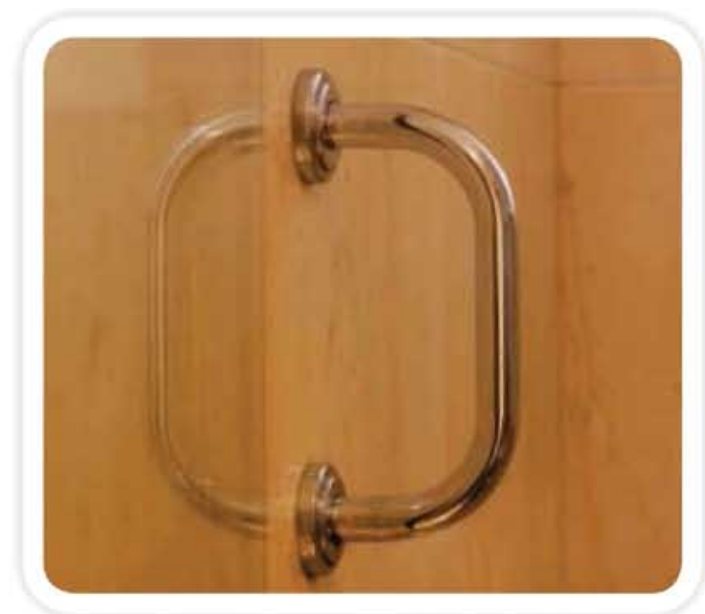

\section{Recomendaciones en el baño}

El baño necesita más adaptaciones para conseguir que sea un lugar seguro y facilite la autonomía.

- Sustituir la bañera por plato de ducha, colocar un asiento y agarraderas y suelo antideslizante para evitar resbalones y caídas.

- La puerta del baño no debe tener
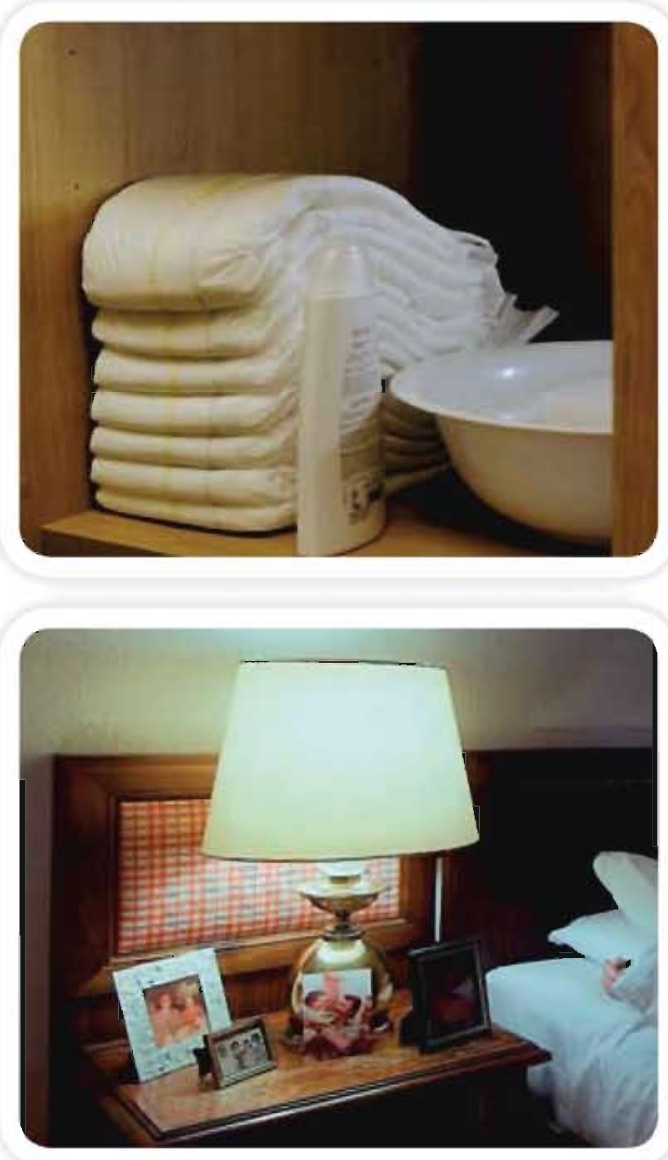
pestillo, es mejor poner una puerta corredera o que la puerta se abra hacia fuera.

- Utilizar temperatura del agua con un máximo $37^{\circ} \mathrm{C}$, para evitar quemaduras, recuerde que en la persona con demencia puede verse reducida la sensibilidad.

- Los productos de limpieza deben de estar en un lugar seguro.

\section{Recomendaciones en el dormitorio}

En el dormitorio pueden ocurrir más caídas, por mala iluminación, barreras o traslados.

- Tener interruptores de luz cerca de la cama, mantener encendida una luz tenue toda la noche para que sepa el camino hacia el baño.

- Indique mediante dibujos o palabras escritas el contenido de los cajones

- Retire alfombras y objetos que puedan ser un obstáculo. Los espejos se pueden retirar o tapar. 


\section{Alteraciones de la conducta}

Entre las mayores dificultades para cuidar a un ser querido con demencia están los cambios que suelen presentarse en la personalidad y la conducta.

La mejor forma de enfrentarlas es desplegar la creatividad, flexibilidad, la paciencia y la compasión. Es importante que no se dé por aludido y que mantenga el sentido del humor.

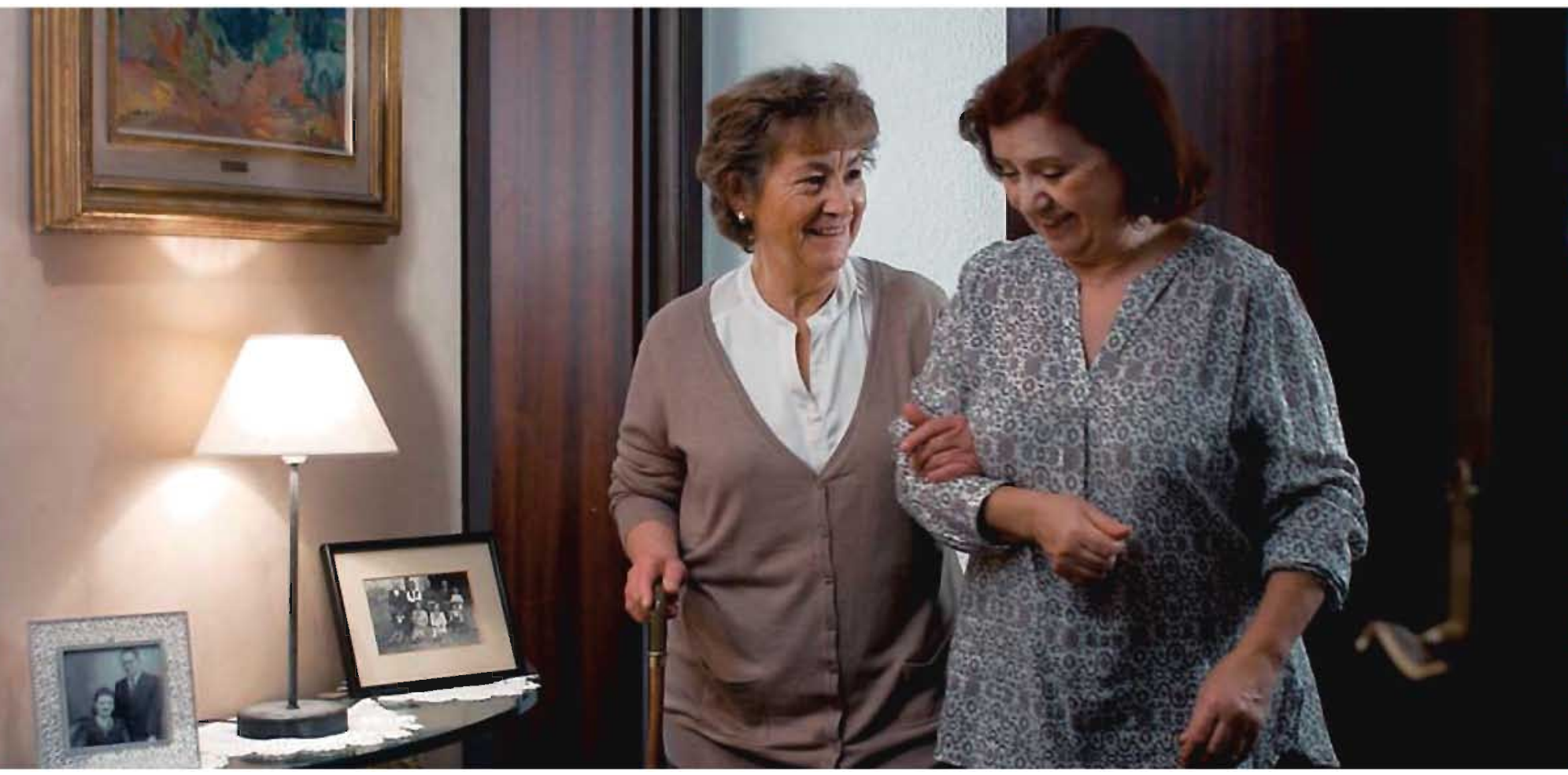

\section{Agitación}

La agitación son conductas asociadas a la demencia, entre ellas la irritabilidad, el insomnio y la agresividad verbal o física.

Si bien no siempre existen, pueden ser fluctuantes, es decir a veces aparecen para luego mejorar con la progresión de la enfermedad y pueden deberse a numerosas causas (factores del ambiente, el miedo y la fatiga).

Lo más frecuente es que la agitación se presente cuando la persona con demencia piense que se le está privando de su capacidad de auto-gestión, de su autonomía. 


\section{Recomendaciones para evitar agitaciones}

- Reducir el consumo de cafeína y de dulces.

- Reducir el ruido ambiental, el desorden de las cosas y el número de personas que le puedan agobiar.

- Mantenga un ambiente estable y rutinas fijas. Ponga siempre objetos muebles en el mismo sitio. Las fotografías y otros objetos conocidos contribuyen a crear una sensación de seguridad y pueden facilitar los recuerdos agradables.

- Pruebe a calmar la agitación mediante caricias suaves, música tranquila, la lectura y las caminatas. Háblele siempre con voz suave y reconfortante. No intente razonar con él/ella cuando se muestre agitado.

- Mantenga fuera del alcance objetos peligrosos.

- Permítale que se ocupe tanto como sea posible de su propia atención, estimule su independencia y su capacidad de auto-cuidado.

- Distráigale con una merienda o alguna actividad. Permítale olvidar el incidente que provocó el problema.

\section{Palabras o acciones repetitivas}

Las personas con demencia suelen repetir una y otra vez determinada palabra, afirmación, pregunta o actividad. Este tipo de conducta es por lo general inofensivo, pero puede provocar irritación o estrés al cuidador. Puede deberse a la ansiedad, al aburrimiento, al temor o a factores del ambiente.

\section{Recomendaciones para manejar un comportamiento repetitivo}

- Cree sentimientos de seguridad y bienestar, mediante la palabra y el contacto físico.

- Pruebe a distraerle.

- No le reproche que acaba de hacer la misma pregunta.

- No explique planes cuando él/ella esté en estado de confusión hasta justamente antes del momento de ejecutarlos.

- Elimine la ansiedad y la incertidumbre sobre hechos futuros. Ponga un cartel en la mesa o la cocina donde diga que «La comida es a las 13:30» o "María vendrá a las 20:00».

- Aprenda a interpretar ciertas conductas. El estado de agitación o el tirarse de la ropa, por ejemplo, pueden indicar la necesidad de ir al baño. 


\section{Delirios o alucinaciones}

En la medida en que avance la demencia pueden presentarse alucinaciones (ver o escuchar cosas que en realidad no existen) e ideas delirantes (creencias falsas). Es muy desconcertante comprobar que nuestro ser querido de un momento a otro se torna suspicaz, celoso o propenso a hacer acusaciones. Recuerde que lo que él/ella siente, es muy real desde su punto de vista.

Lo mejor es no discutir ni rebatir lo que diga. Estas conductas también son parte de la demencia, no lo tome como algo personal.

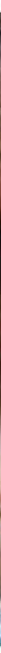

\section{Recomendaciones para el manejo de los delirios o las alucinaciones}

- Si está en estado de confusión e insiste en que "le falta dinero»", guárdale una pequeña suma de dinero en el bolsillo o en el bolso, para que pueda verlo.

- Ayúdele a buscar el objeto "perdido», y después intente distraerlo con otra actividad. Trate de descubrir donde esconde las cosas que después cree «perdidas». Evite toda discusión.

- Explique a los demás familiares y asistentes domésticos que las acusaciones y sospechas son parte de la enfermedad.

- Emplee medios no verbales para fortalecer la sensación de seguridad, como una suave caricia o un abrazo. Puede decirle, "Veo que eso te asusta; quédate a mi lado, no dejaré que te pase nada malo".

- Hágale saber, de manera sencilla y calmada, que los demás no ven ni escuchan tales cosas, pero evite toda discusión y no trate de convencerle de que su percepción es errónea.

- Mantenga la habitación bien iluminada para reducir sombras.

- Si se agravaran estos síntomas, consulte a profesionales expertos. 


\section{Insomnio}

La ansiedad, la agitación, la desorientación y otras conductas problemáticas en las personas con demencia suelen agravarse al final del día y a veces se mantienen durante toda la noche.

El insomnio, es una conducta conocida como agitación vespertina, que se debe a una combinación de factores, como el cansancio después de los sucesos de la jornada, y a los cambios en el reloj biológico que confunde el día y la noche.

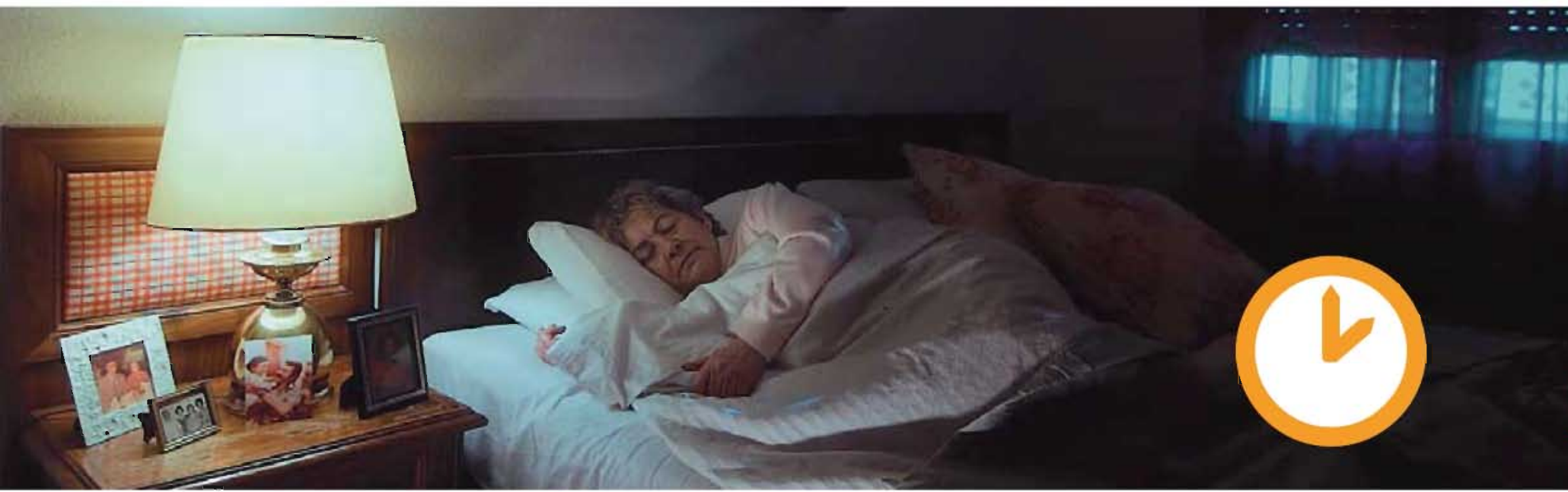

\section{Recomendaciones para el manejo del insomnio}

- Incremente las actividades diurnas. No estimule la inactividad y las siestas durante el día.

- Programe comidas más pequeñas a lo largo del día, incluida una merienda ligera antes de dormir.

- Trate que las horas de la tarde sean tranquilas y calmadas. Pruebe con música tranquila.

- Consultar al médico sobre la posibilidad de medicamentos para dormir. Teniendo en cuenta que la medicación para dormir y los tranquilizantes tal vez resuelvan un problema y creen otro; quizás duerma de noche, pero esté más confundido al día siguiente.

- Es esencial que el cuidador, duerma lo suficiente. Si las actividades nocturnas de su ser querido le impiden dormir, considere la posibilidad de pedirle a alguna amistad o familiar que lo cuide durante la noche. Es conveniente hacer una siesta durante el día. 


\section{Deambulación o vagabundeo}

\section{La deambulación es una conducta que suele aparecer en la etapa intermedia de la enfermedad.}

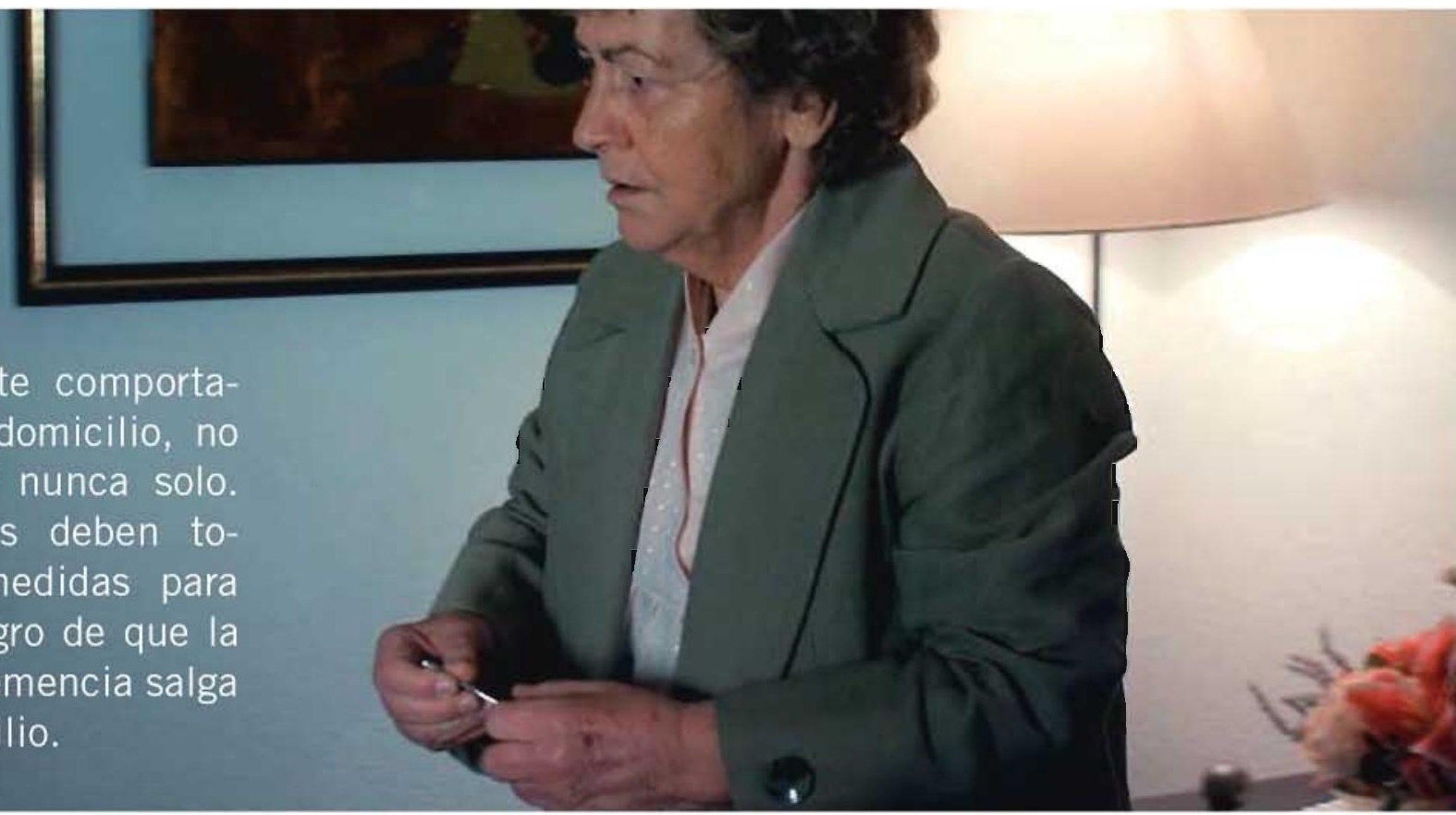

\section{CAUSAS DE LA DEAMBULACIÓN}

- Confusión. Al estar desorientado no se da cuenta que está en casa, y sale dispuesto a «encontrarla». Se encuentra en un lugar desconocido para él.

- Delirios. Piensa cosas que no son reales en su presente y puede estar tratando de cumplir una responsabilidad del pasado, tal como ir a trabajar o ir a buscar a un hijo.

- Intentos de escapar de una amenaza real o percibida. Las personas con demencia pueden sentirse asustados por un hogar ruidoso, un visitante extraño o incluso por la creencia de que su cuidador está tratando de hacerle daño.

- Nerviosismo, está más ansioso, algunas veces la ansiedad y el nerviosismo son efectos secundarios de algún medicamento, consulte con un profesional si la conducta persiste.

- Inquietud, por la falta de ejercicio y otras estimulaciones.

- Búsqueda de algo, ya sea una persona, un lugar o un artículo personal que haya perdido. 


\section{Recomendaciones para el manejo de la deambulación}

- Realizar ejercicios periódicos para reducir a la ansiedad.

- Obtener un brazalete de identificación médica. Asegúrese de que lo use en todo momento, a menudo se venden en farmacias. Existen otras opciones como localizadores GPS, tipo reloj o llavero.

- Brinde un lugar despejado y seguro para caminar.

- Dele algo repetitivo que hacer.

- Guarde en un lugar seguro algunos artículos esenciales, como el abrigo, la cartera o las gafas.

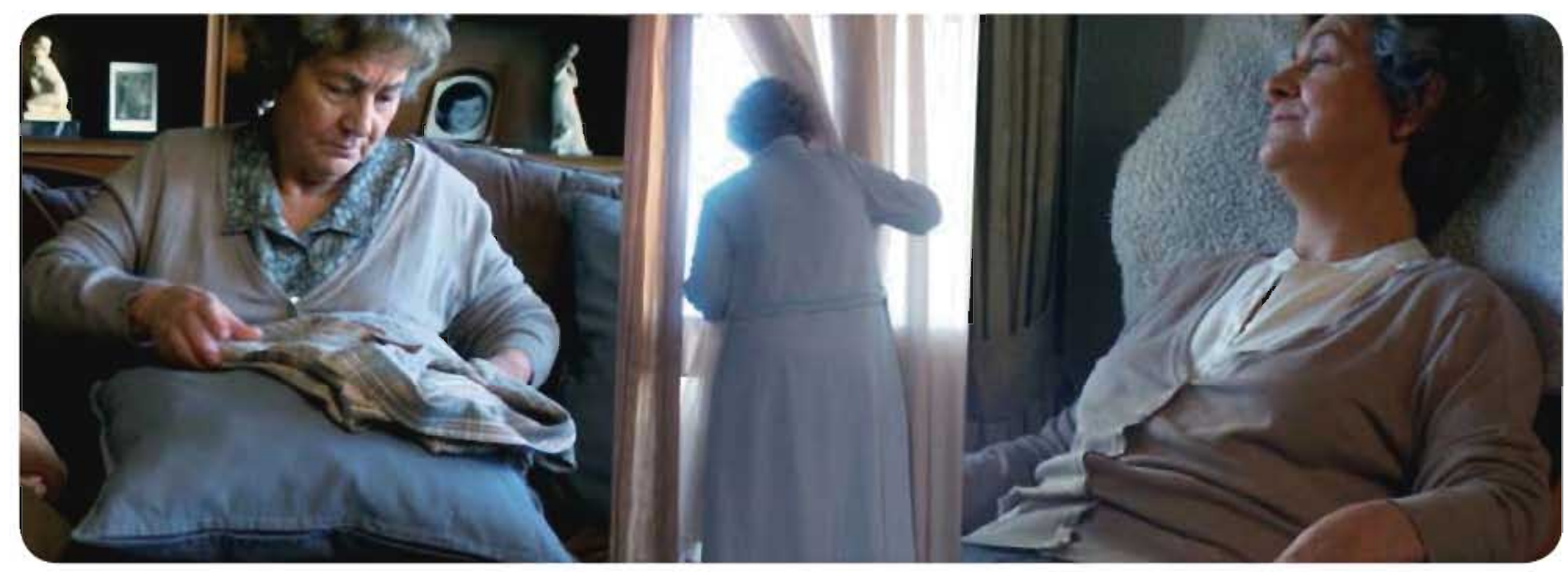

- Tenga las puertas que conducen al exterior cerradas, y mantener las llaves en un lugar seguro, donde no tenga acceso a ellas.

- Instalar dispositivos de seguridad en las ventanas.

- Instale timbres o alarmas que suenen cuando se abra una puerta que conduce al exterior.

- Avise a sus vecinos que su familiar es una persona con demencia y pídales que le avisen si ven que está solo en la calle.

- Pruebe a usar barreras para ocultar las puertas. También puede que funcione la señal de «Pare» o de «No pasar».

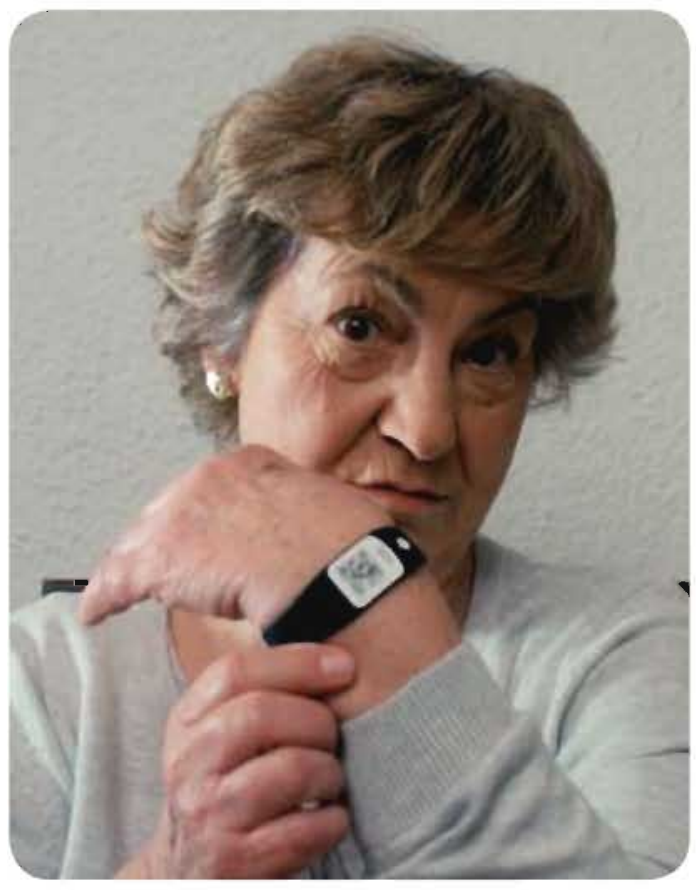




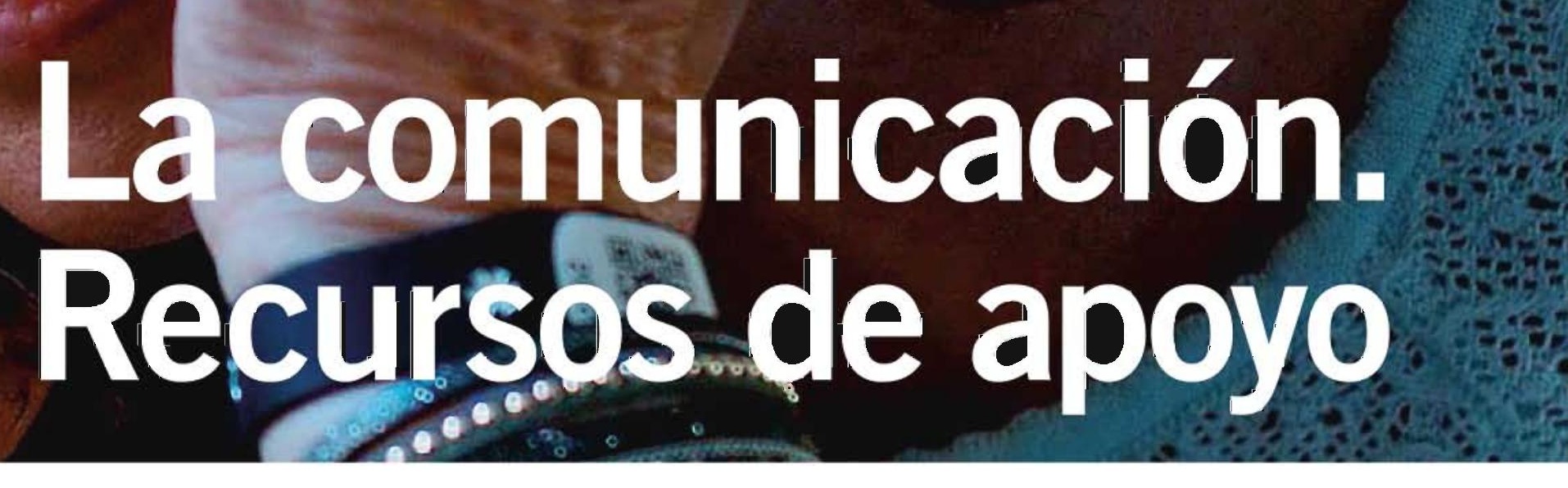
"Por favor, no discutas mis percepciones" 


\section{La comunicación}

\section{Recomendaciones generales para mantener una comunicación fluida con la persona que se cuida}

- Crear un ambiente positivo para la interacción.

- Háblele de manera agradable y respetuosa.

- Aproveche la expresión del rostro, el tono de voz y el contacto físico para comunicarse y muestre sus sentimientos de cariño.

- Captar la atención del paciente.

- Háblele por su nombre, identifíquese y recuérdele su relación o parentesco, utilice señales no verbales.

- Mantenga el contacto visual.

- Expresar claramente lo que queremos decir.

- Hable lentamente.

- Trate de no alzar la voz, hable con un tono de voz algo más grave.

- Diga los nombres de las personas y lugares.

- Haga preguntas sencillas que puedan responderse, de una en una. Las mejores son las que puedan responderse con un Sío un No.

- No haga preguntas demasiado largas, ni presente numerosas opciones al mismo tiempo. Pregunte, por ejemplo: «¿Quieres ponerte la camisa blanca o la camisa azul?».

- Muestre las dos alternativas. Los estímulos y recordatorios visuales contribuyen a aclarar la pregunta y a guiar la respuesta.

- Emplee instrucciones sencillas.

Recuerde que, debemos escuchar con los

oídos, los ojos y el corazón. Tenga en cuenta el lenguaje

corporal y responda en consecuencia. 



\section{Comunicación cuidador-profesionales de la salud}

\section{Es importante una buena comunicación entre el cuidador informal y los profesionales de la salud, para crear una relación terapéutica que contribuya a la calidad de la atención, bienestar de la persona y busque solucionar problemas.}

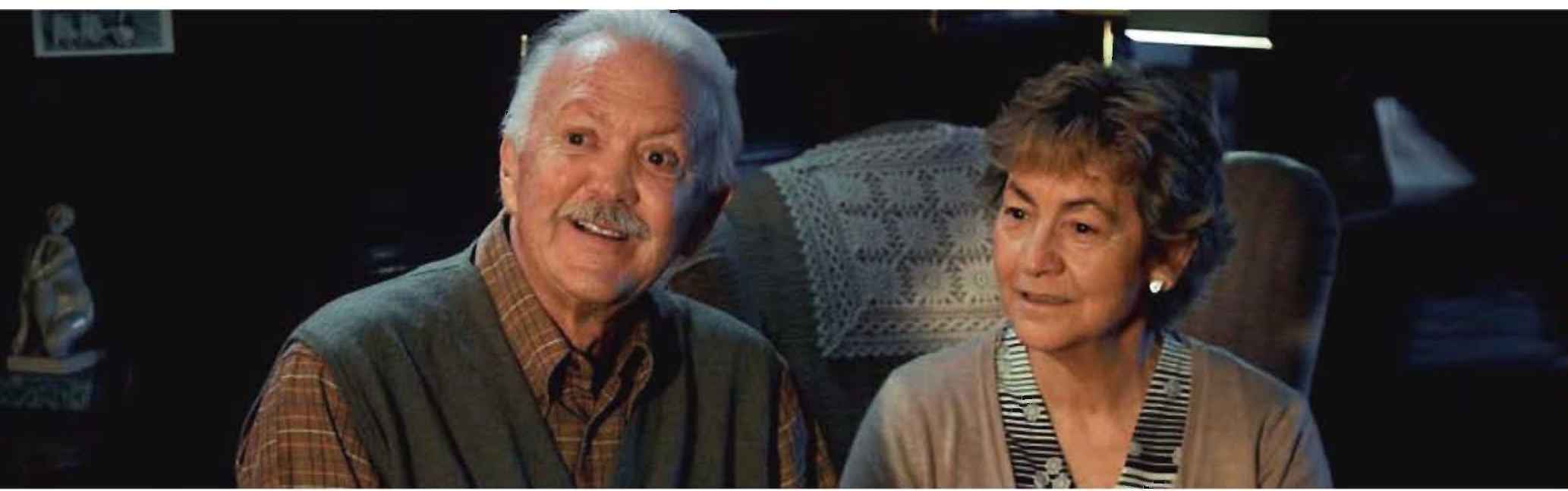

La demencia exige un nivel de cuidado más complejo cuanto más evolucione la enfermedad. Gracias a la educación y la utilización de apoyos disponibles, las familias pueden aprender nuevas capacidades para ajustarse a las exigencias del cuidado.

Resulta esencial que los cuidadores dediquen el tiempo necesario a prepararse física y emocionalmente. El apoyo y la ayuda de otras personas serán muy importantes a lo largo de los meses o años de su trabajo como cuidador/a, no lo olvide y pida ayuda.

Los cuidadores deben informarse con respecto al cuidado a largo plazo, y también deben conocer las posibilidades de ayuda en la comunidad.

La opción de cuidar en el domicilio, en una clínica especializada o en una residencia permanente, depende de las posibilidades de la familia y de las necesidades de la persona con demencia. Se está avanzando rápidamente en la investigación sobre las causas y el tratamiento de la demencia. Todos confiamos en que algún día se logre encontrar la manera de postergar, curar e incluso evitar estas enfermedades.

\section{No olvide que, como profesionales estamos dispuestos a ayudarle, porque nuestro objetivo es cuidar al cuidador de personas con demencia.}




\section{Recursos de apoyo}

\section{El cuidado de personas con demencia repercute a nivel familiar y a nivel social. Por ello, los recursos sociales son un complemento junto con otras intervenciones para procurar el máximo bienestar de la persona con demencia y de su familia.}

El trabajador social es el profesional que puede valorar su situación y asesorarle cuando así lo precise. Entre los diferentes recursos sociales que se encuentran en la comunidad, existen los de titularidad privada, los de titularidad pública y los de titularidad mixta o concertada.

Para tener acceso a los recursos tanto mixtos como públicos es necesario tener la Ley de Dependencia tramitada.

\section{¿Qué es la Ley de Dependencia?}

Es la Ley 39/2006 del actual Sistema para la Autonomía y Atención a la Dependencia, que enmarca el conjunto de servicios y prestaciones destinados a la promoción de la autonomía personal, así como a la protección y atención a las personas, a través de servicios públicos y privados concertados debidamente acreditados.

La ley reconoce la necesidad de protección de aquellos colectivos que presenten disminuida su capacidad de autonomía personal, como es el caso de personas con demencia quienes tienen derecho a que se les reconozca su situación de dependencia.

\section{¿Cómo funciona?}

Para poder acceder a los beneficios de la ley, es necesario.

- Reconocimiento del grado: Es el primer paso para poder acceder a las ayudas técnicas y prestaciones económicas reconocidas en la Ley de Dependencia. Se valoran tres grados (I, II, III) en función de una escala que mide las capacidades de la persona para poder desarrollar las Actividades Básicas de la Vida Diaria (ABVD).

- Plan Individualizado de Atención (PIA): Una vez reconocido el grado de dependencia, se ha de elaborar el plan que se realizará junto con los trabajadores 
sociales de los servicios sociales de su zona, para determinar qué prestaciones o ayudas corresponden a las necesidades y la situación actual de la persona con dependencia.

- Acceso a las prestaciones: Entre las prestaciones están el acceso a determinados servicios tanto públicos como concertados de la red de servicios sociales (centros de día, residencias, atención domiciliaria...). Estas prestaciones tienen prioridad y cuando no son posibles se valoran las prestaciones económicas.

- Prestaciones económicas: Se encuentran las vinculadas a la adquisición de un determinado servicio y las prestaciones del cuidado en el entorno familiar y de apoyo a las personas cuidadoras no profesionales. Todo ello, dependerá tanto de la situación personal (su grado de dependencia, renta y patrimonio) como de la situación familiar y la disponibilidad de recursos en el entorno.

Puede encontrar toda la información y la solicitud para iniciar el trámite en la web http://web.gencat.cat/es/tramits/ introduciendo la palabra "dependencia» en el buscador. Así mismo, las solicitudes se pueden entregar directamente en los Centros de Servicios Sociales.

\section{$-\cdots$ Red de Servicios Sociales}

\section{Servicios Sociales Básicos}

Están distribuidos por los diferentes barrios de Barcelona y se asignan según el domicilio donde reside la persona con dependencia. Se pueden solicitar diferentes ayudas siempre y cuando se cumplan los requisitos de acceso.

- Reconocimiento del grado: Es el primer paso para poder acceder a las ayudas técnicas y prestaciones económicas reconocidas en la Ley de Dependencia. Se valoran tres grados $(\mathrm{I}, \mathrm{II}, \mathrm{III})$ en función de una escala que mide las capacidades de la persona para poder desarrollar las Actividades Básicas de la Vida Diaria (ABVD).

- Servicio de ayuda a domicilio: Para completar el nivel de autonomía de la persona con demencia y favorecer que permanezca en su entorno habitual. El 
servicio es prestado por trabajadores familiares, formados para ayudar en la asistencia personal (higiene, alimentación....) y del hogar (compra...) excluyendo los servicios de limpieza general.

- Servicio de Teleasistencia: Aparato anexo al teléfono fijo, que conecta con una centralita del Ayuntamiento para dar respuesta ante situaciones de emergencia cuando la persona está sola o el cuidador no profesional es mayor de 75 años. El usuario lleva un colgante o reloj pulsera con el que puede activar un botón para solicitar ayuda ante una caída o una situación de emergencia. No es adecuado para personas con una demencia avanzada.

- Sistema inteligente de monitorización de alertas personales (SIMAP): Sistema de alerta para la localización de personas con deterioro cognitivo leve que se realiza a través de la red de telefonía móvil y de un dispositivo GPS. Es imprescindible que haya un familiar o persona de referencia.

\section{Servicios Sociales Especializados}

\section{Están distribuidos por los diferentes barrios de Barcelona y se asignan según el domicilio donde reside la persona con dependencia. Se pueden solicitar diferentes ayudas siempre y cuando se cumplan los requisitos de acceso.}

- Centros de día: Servicios de atención diurnos (9 a 17h) para personas de más de 65 años con el fin de complementar la atención propia del entorno familiar. Se presta atención social y sanitaria para personas que requieren supervisión y cierta ayuda para las Actividades Básicas de la Vida Diaria (ABVD).

- Residencias asistidas: Servicios de atención integral que ofrecen alojamiento temporal o permanente para personas mayores de 65 años con falta de autonomía para las ABVD y que precisan atención y supervisión intensiva. Ofrecen un conjunto de servicios: médicos, enfermería, fisioterapia, terapia ocupacional y trabajo social.

- Grupos de apoyo para cuidadores no profesionales: Facilita espacios de encuentro entre personas cuidadoras con la finalidad de compartir experiencias, expresar sentimientos, emociones y preocupaciones de la tarea de cuidar. Estos espacios grupales facilitan el apoyo mutuo y la prevención de la sobrecarga del cuidador principal. 
- Formación para cuidadores no profesionales: Se ofrecen conocimientos básicos sobre el manejo de la persona con dependencia (alimentación, curas, higiene, movilización...) para mejorar tanto la realización del cuidado como la calidad de vida del propio cuidador.

\section{Otros recursos}

- Programa adaptación funcional del hogar: El centro de vida independiente (CVI) junto con el Ayuntamiento de Barcelona ofrecen un programa para personas mayores de 65 años con falta de autonomía para las ABVD con la finalidad de instalar adaptaciones en el hogar (pasamanos, rampas...) y mejorar la movilidad de la persona con dependencia y facilitar la realización de las funciones del cuidador principal. Se priorizan las personas que viven solas o con un cuidador no profesional mayor de 75 años y según criterios económicos.

- Programa Respir para personas mayores: La Diputación junto con el Ayuntamiento de Barcelona ofrecen un programa de apoyo a familias que tienen a su cargo una persona mayor de 65 años con cierto grado de dependencia. Ofrecen estancias residenciales temporales con una duración máxima de dos meses al año con la finalidad de ofrecer un descanso al cuidador principal y mejorar la calidad de vida.

\section{Para ambos programas debe consultar los requisitos de acceso en los servicios sociales.}




\section{$-\multimap$ Recursos de los Equipos de Atención Primaria de Salud}

\section{Servicios Sociales Básicos}

Están distribuidos por los diferentes barrios de Barcelona y se asignan según el domicilio donde reside la persona con dependencia. Se pueden solicitar diferentes ayudas siempre y cuando se cumplan los requisitos de acceso.

- Centros Socio-sanitarios: Hay diferentes unidades específicas para personas con demencia que suelen intervenir en fases avanzadas. Algunas de estas unidades se han especializado en el manejo de síntomas conductuales o psicológicos y otras en el control de problemas de salud recurrentes. Incluyen la atención a personas con demencia avanzada o con algún otro trastorno cognitivo de tipo crónico.

Debe solicitar más información a su médico de familia 0 al trabajador social de los equipos de atención primaria de salud, encargados de valorar su indicación.

- Tarjeta Sanitaria Cuida'm: Es una tarjeta sanitaria de atención especial que sirve para identificar a las personas que, por su estado de salud o por sus características específicas, necesitan una atención más adaptada a sus necesidades. La finalidad es poder ofrecer una mejor atención en los centros de salud siempre que su situación clínica lo permita.

Debe solicitar más información a su médico de familia, quien es el encargado de valorar su indicación. 
- Poderes notariales preventivos: Se realizan mediante un notario y en escritura pública. La persona que tiene sus facultades mentales aún preservadas, designa a un responsable para la toma de decisiones sobre sus bienes y patrimonio cuando ésta ya no pueda decir por sí misma. También puede acotar cuando se extingue el poder. El notario da fe de la capacidad de la persona para poder realizar el trámite.

- Proceso de modificación de la capacidad: Procedimiento legal por vía judicial para proteger a la persona que no tiene las capacidades físicas o mentales suficientes para autogobernarse. El juez dictamina a través de resolución judicial el contenido de la medida (parcial o total) y designa un tutor/representante legal que suele ser un familiar o bien una Fundación Tutelar.

\section{Es aconsejable para ambos procesos pedir asesoramiento legal antes de realizar el trámite.}

- Documento de Voluntades Anticipadas (DVA) o testamento vital: Documento donde la persona, que tiene sus facultades mentales aún preservadas, expresa el tratamiento médico que desea recibir o no, en caso de que un día la enfermedad lo incapacite para expresar o decidir su voluntad. Está dirigido al equipo sanitario responsable y se puede designar una persona representante para tomar esas decisiones. Se realiza ante notario o con tres testigos, dos de los cuales no pueden tener una relación de parentesco hasta segundo grado, ni estar vinculados por relación patrimonial.

Para redactar el contenido es aconsejable pedir asesoramiento con su médico de familia.

\section{Puede tener más información en las Unidades de Atención} al Usuario del Hospital 0 acuda al Equipo de Atención Primaria de Salud y a los Centros de servicios Sociales para mayor información. 


\section{$-\multimap$ Apoyo en la Web}

- www.alzheimercatalunya.org

Ofrecen acompañamiento, asesoría e información a personas con demencia y a sus familiares.

- www.afab-bcn.org

Ofrecen apoyo y grupos de ayuda a los cuidadores y asesoría jurídica.

- www.fundacioace.com

Ofrecen centros de día y «unidades de memoria». Pueden descargarse libros y cuadernos de ejercicios.

- www.sen.es

Acceso al grupo de estudio de la conducta y la demencia de la sociedad española de neurología.

\section{- $\multimap$ Recursos literarios}

- Tengo Alzheimer. que puedo hacer

Alzheimer Catalunya Fundación en colaboración con Janssen-Cilag.

Pensado para las personas que quieren acercarse a su enfermedad de manera activa desde el inicio.

- La memoria está en los besos

M. Boada Rovira. Barcelona 2002. Ed Mayo.

Historias personales de personas que sufren Alzheimer.

- Cuando el día tiene 36 horas Nancy L. Mace, Peter V. Rabins. Editorial Pax.

Una guía para cuidar de enfermos con pérdida de memoria, demencia senil y Alzheimer.

- Alzheimer. Manual de instrucciones

N.Acarín. 2010. Ed. RBA.

Incluye historias reales de pacientes y un conjunto de recomendaciones y consejos para los cuidadores. 



\section{Direcciones de interés}

Unidad de Geriatría del Hospital Clínic de Barcelona

Dirección: c/Villarroel, 170 (08036) Barcelona

Teléfono: 932275400

www.hospitalclinic.org

Instituto Clínic de Neurociencias (ICN): Unidad de Alzheimer y otros trastornos cognitivos

Hospital Clínic de Barcelona

Dirección: c/Villarroel, 170 (08036) Barcelona

Teléfono: 932275400

Programa forumclínic

www.forumclinic.org

Emergencias

Teléfono: 112 (único para toda España y Europa)

CatSalut Respon

Teléfono: 061

Departament de Treball, Afers Socials

i Família de la Generalitat de Catalunya

Teléfono: 934831000

Atención Ciudadana de la Generalitat de Catalunya

Teléfono: 012

Servicios Sociales de Barcelona

Para programar una visita llamar al teléfono: 936197311

De lunes a viernes de 9 a $14 \mathrm{~h}$ y martes y jueves de 16 a $19 \mathrm{~h}$ 


\section{Agradecimientos}

Dedicamos esta guía a todos los cuidadores que han participado desinteresadamente en la elaboración y producción del programa INFOSA-DEM.

Queremos agradecer a La Marató de TV3 la financiación de este proyecto.

Por otra parte, queremos agradecer especialmente la colaboración de profesionales del Hospital Clínic de Barcelona: Dr. Albert Lladó, adjunto de la Unidad de Alzheimer y otros trastornos cognitivos, a Soledad Barreiro, enfermera del Hospital de Día de enfermedades neurodegenerativas, a Mar Guillén y Silvia Carrasco, enfermeras del servicio de Geriatría, al Dr. Ferran Masanés, adjunto del Servicio de Medicina Interna y a la Dra. Imma Grau del departamento de comunicación. También queremos agradecer a Susana Torres, Trabajadora Social del Centro de Atención Primaria Casanova. Gracias por vuestra generosidad, capacidad creativa y compromiso profesional con el cuidado de los cuidadores de personas con demencia.

Finalmente reconocemos el gran trabajo realizado por Carme Puche y Jordi Rabascall y demás personas colaboradoras de Estudi Puche y los actores Alzira Gómez, Teresa Urroz y Pedro Cánovas, ya que sin su trabajo no hubiese sido posible la producción de este documento. 


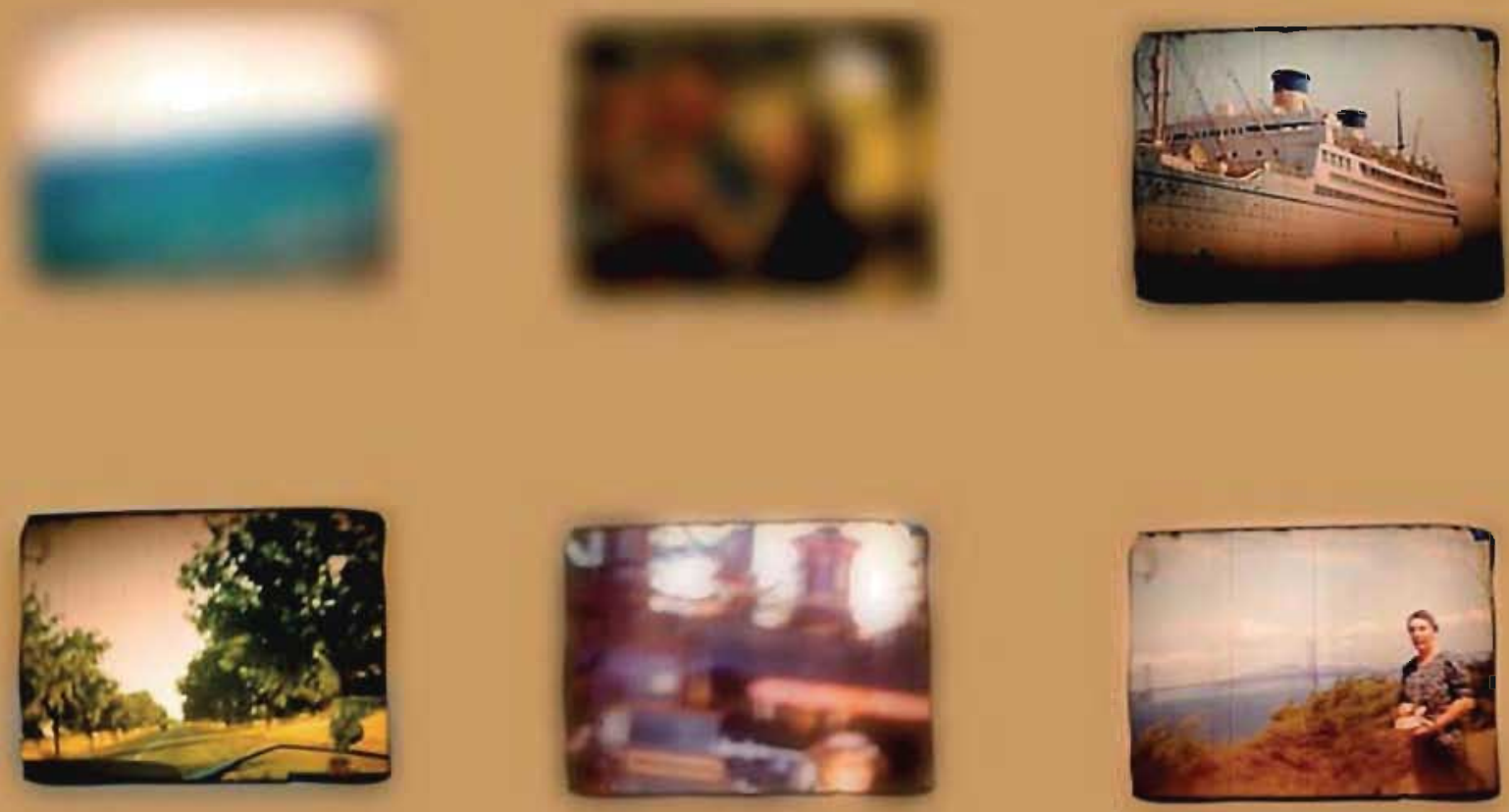

"La demencia es un espacio y un tiempo diferentes que hay que comprender con paciencia.

Porque puede haber perdido sus recuerdos, pero sus sentimientos siguen intactos".

\section{Cuídate para poder cuidarme. No dejes de hacer lo que te guste.}



ANEXO 10: Dictamen favorable 
DICTAMEN DEL COMITÉ DE ÉTICA DE LA INVESTIGACIÓN CON MEDICAMENTOS

NEUS RIBA GARCIA, Secretario del Comité de Ética de la Investigación con medicamentos del Hospital Clínic de Barcelona

Certifica:

Que este Comité ha evaluado la propuesta del promotor, para que se realice el estudio:

CÓDIGO:

DOCUMENTOS CON VERSIONES:

\begin{tabular}{|l|l|l|}
\hline Tipo & Subtipo & Versión \\
\hline Protocolo & & V2. 02/08/2018 \\
\hline Hoja Información de Paciente & & Versión 2. 04/09/2018 \\
\hline
\end{tabular}

TÍTULO: Evaluación de una intervención innovadora, informativa formativa y de apoyo social "INFOSA-DEM" dirigida a cuidadores informales de personas con demencia en relación a la sobrecarga, depresión y la ansiedad.

PROMOTOR:

INVESTIGADOR PRINCIPAL: CINDY E. FRIAS TORRES; ADELAIDA ZABALEGU!

y considera que, teniendo en cuenta la respuesta a las aclaraciones solicitadas (si las hubiera), y que:

- Se cumplen los requisitos necesarios de idoneidad del protocolo en relación con los objetivos del estudio y están justificados los riesgos y molestias previsibles.

- La capacidad del investigador y los medios disponibles son apropiados para llevar a cabo el estudio.

- Que se han evaluado la compensaciones económicas previstas (cuando las haya) y su posible interferencia con el respeto a los postulados éticos y se consideran adecuadas.

- Que dicho estudio se ajusta a las normas éticas esenciales y criterios deontológicos que rigen en este centro.

- Que dicho estudio cumple con las obligaciones establecidas por la normativa de investigación y confidencialidad que le son aplicables.

- Que dicho estudio se incluye en una de las líneas de investigación biomédica acreditadas en este centro, cumpliendo los requisitos necesarios, y que es viable en todos sus términos.

Este CEIm acepta que dicho estudio sea realizado, debiendo ser comunicado a dicho Comité Ético todo cambio en el protocolo o acontecimiento adverso grave.

y hace constar que: 
10 En la reunión celebrada el día 26/07/2018, acta 15/2018 se decidió emitir el informe correspondiente al estudio de referencia.

2ㅇ El CElm del Hospital Clínic i Provincial, tanto en su composición como en sus PNTs, cumple con las normas de BPC (CPMP/ICH/135/95)

3은 Listado de miembros:

\section{Presidente:}

- BEGOÑA GÓMEZ PÉREZ (Farmacéutica Hospitalaria, HCB)

\section{Vicepresidente:}

- JOAQUIM FORÉS I VIÑETA (Médico Traumatólogo, HCB)

\section{Secretario:}

- NEUS RIBA GARCIA (Médico Farmacólogo Clínico, HCB)

\section{Vocales:}

- ITZIAR DE LECUONA (Jurista, Observatorio de Bioética y Derecho, UB)

- MONTSERRAT GONZALEZ CREUS (Trabajadora Social, Servicio de Atención al Usuario, $\mathrm{HCB})$

- JOSE RIOS GUILLERMO (Estadístico. Plataforma de Estadística Médica. IDIBAPS)

- OCTAVI SANCHEZ LOPEZ (Representante de los pacientes)

- MARIA JESÚS BERTRAN LUENGO (Médico Epidemiólogo, HCB)

- JOAQUÍN SÁEZ PEÑATARO (Médico Farmacólogo Clínico, HCB)

- SERGIO AMARO DELGADO (Médico Neurólogo, HCB)

- JULIO DELGADO GONZÁLEZ (Médico Hematólogo, HCB)

- EDUARD GUASCH I CASANY (Médico Cardiólogo, HCB)

- VIRGINIA HERNANDEZ GEA (Médico Hepatólogo, HCB)

- NURIA SOLER BLANCO (Farmacéutica Hospitalaria, HCB)

- MARINA ROVIRA ILLAMOLA (Farmacéutico Atención Primaria, CAP Eixample)

- JOSE LUIS BLANCO ARÉVALO (Médico Medicina Interna, HCB)

- MIIRIAM MIÉNDEZ GARCÍA (Abogada, HCB)

- MERCÈ VIDAL FLOR (Enfermera, HCB)

En el caso de que se evalúe algún proyecto del que un miembro sea investigador/colaborador, este se ausentará de la reunión durante la discusión del proyecto.

Para que conste donde proceda, y a petición del promotor,<smiles></smiles>

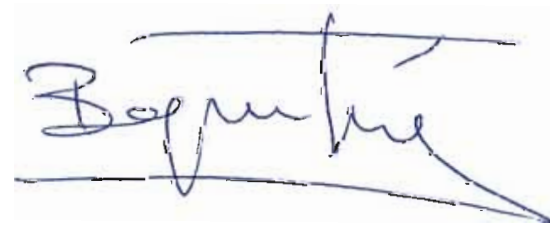

Barcelona, a 13 de septiembre de 2018 

ANEXO 11:

Sesiones 


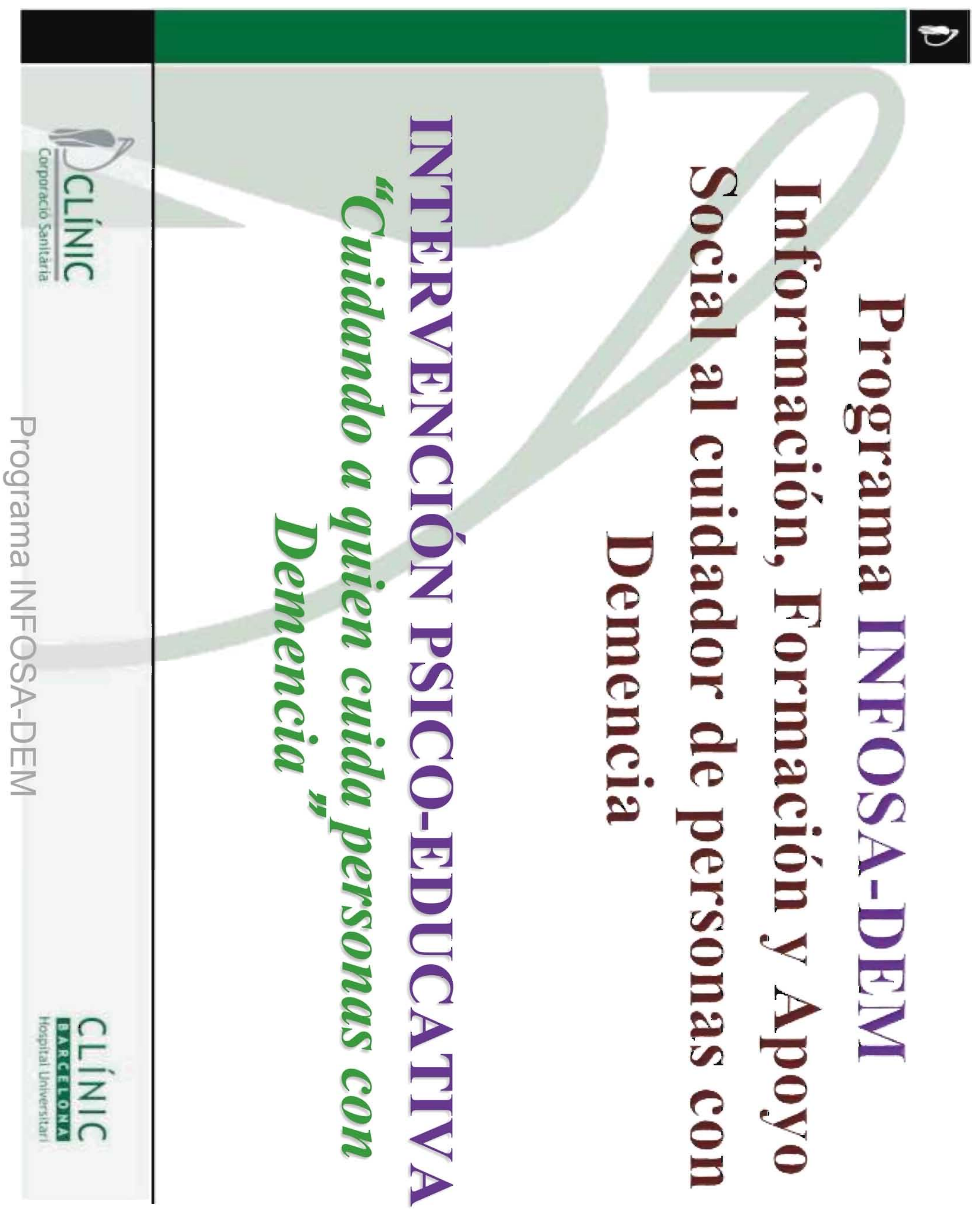




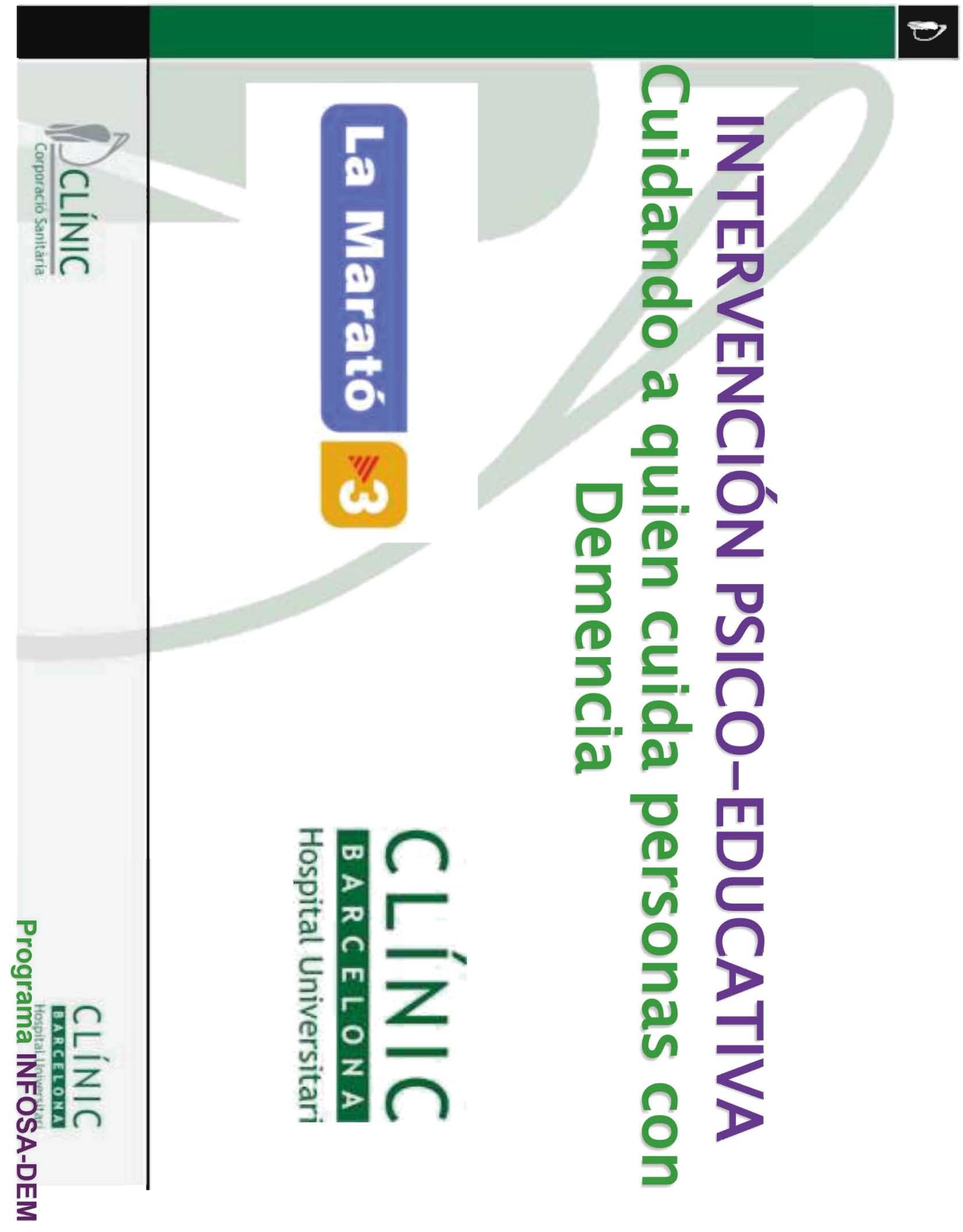




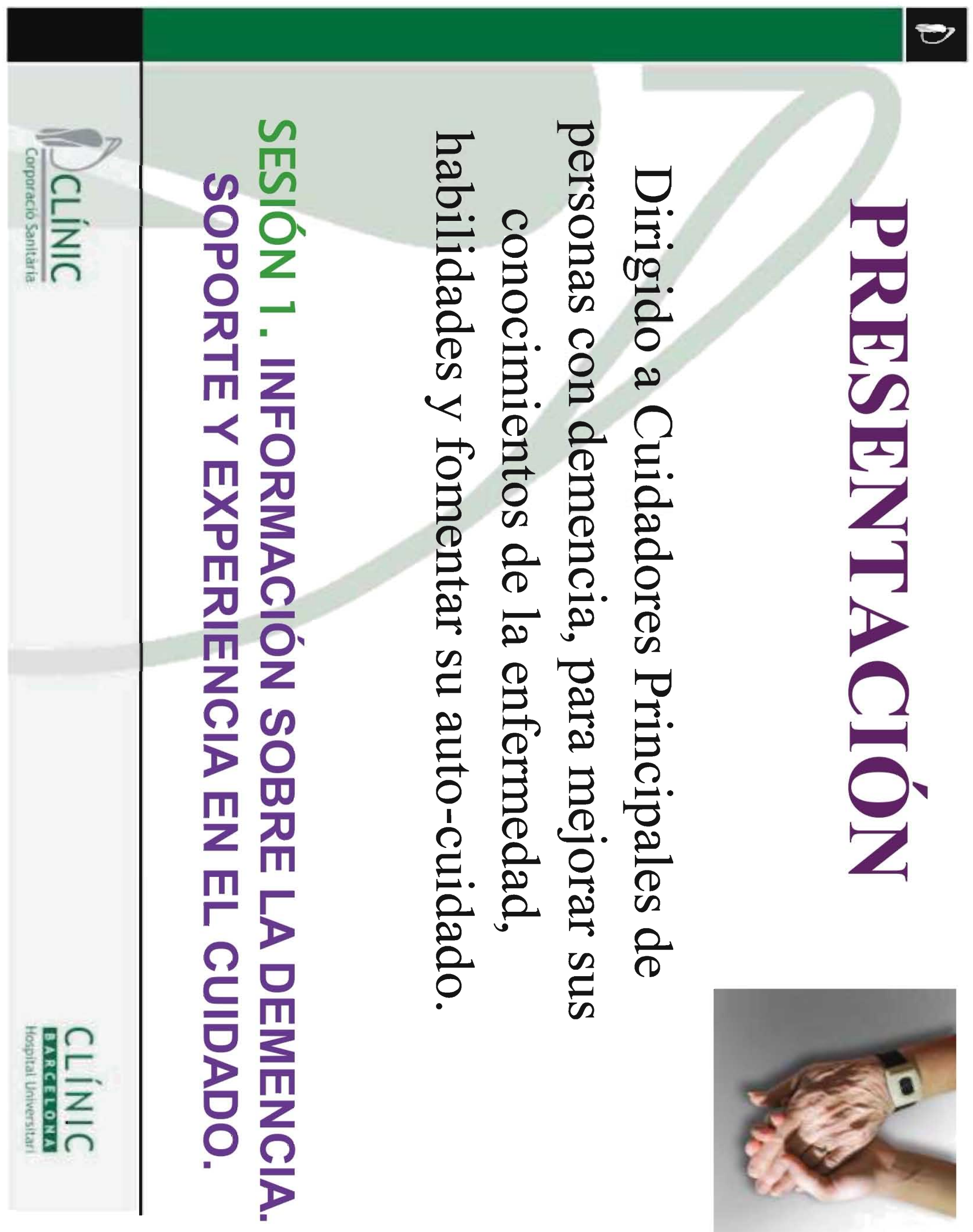




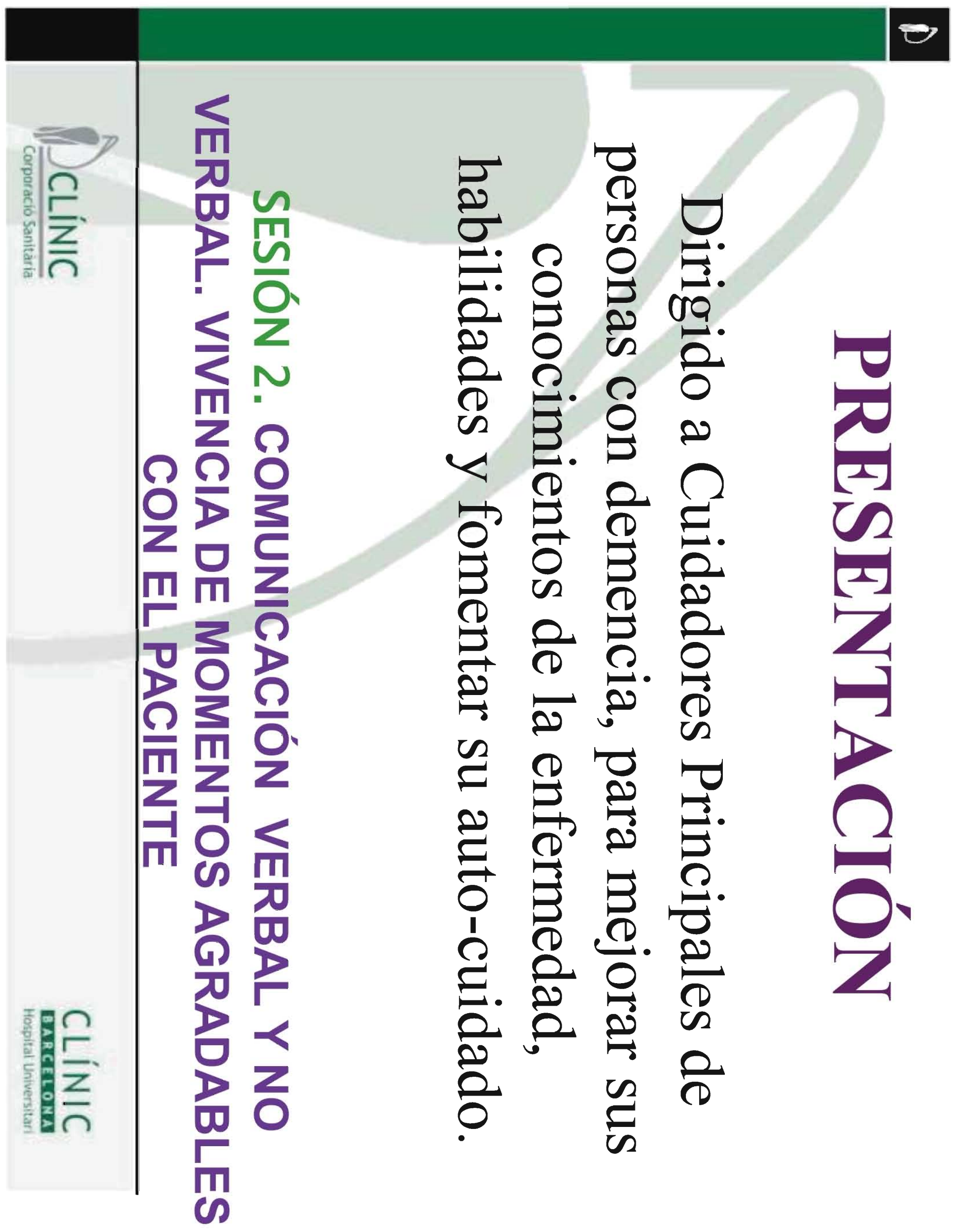




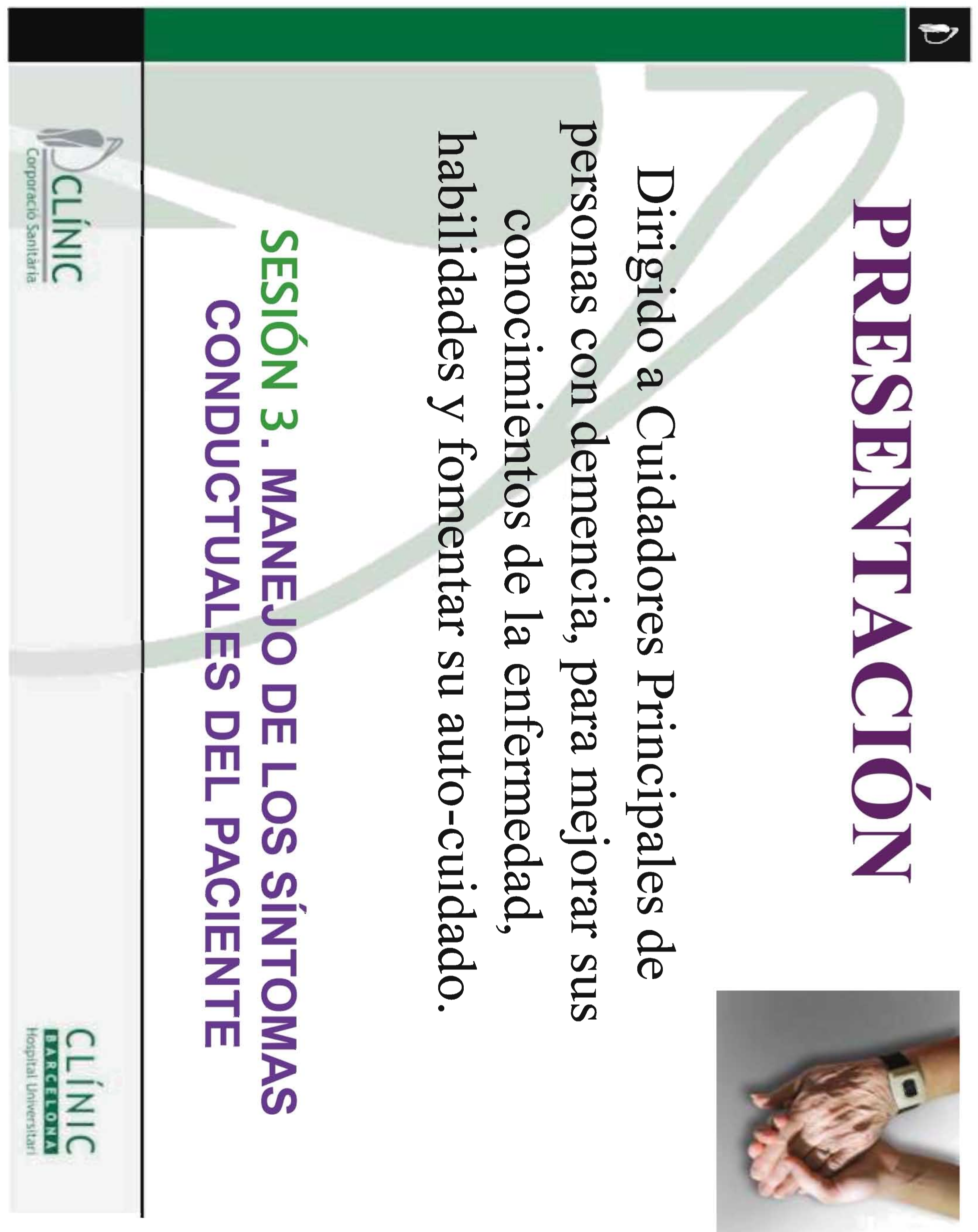




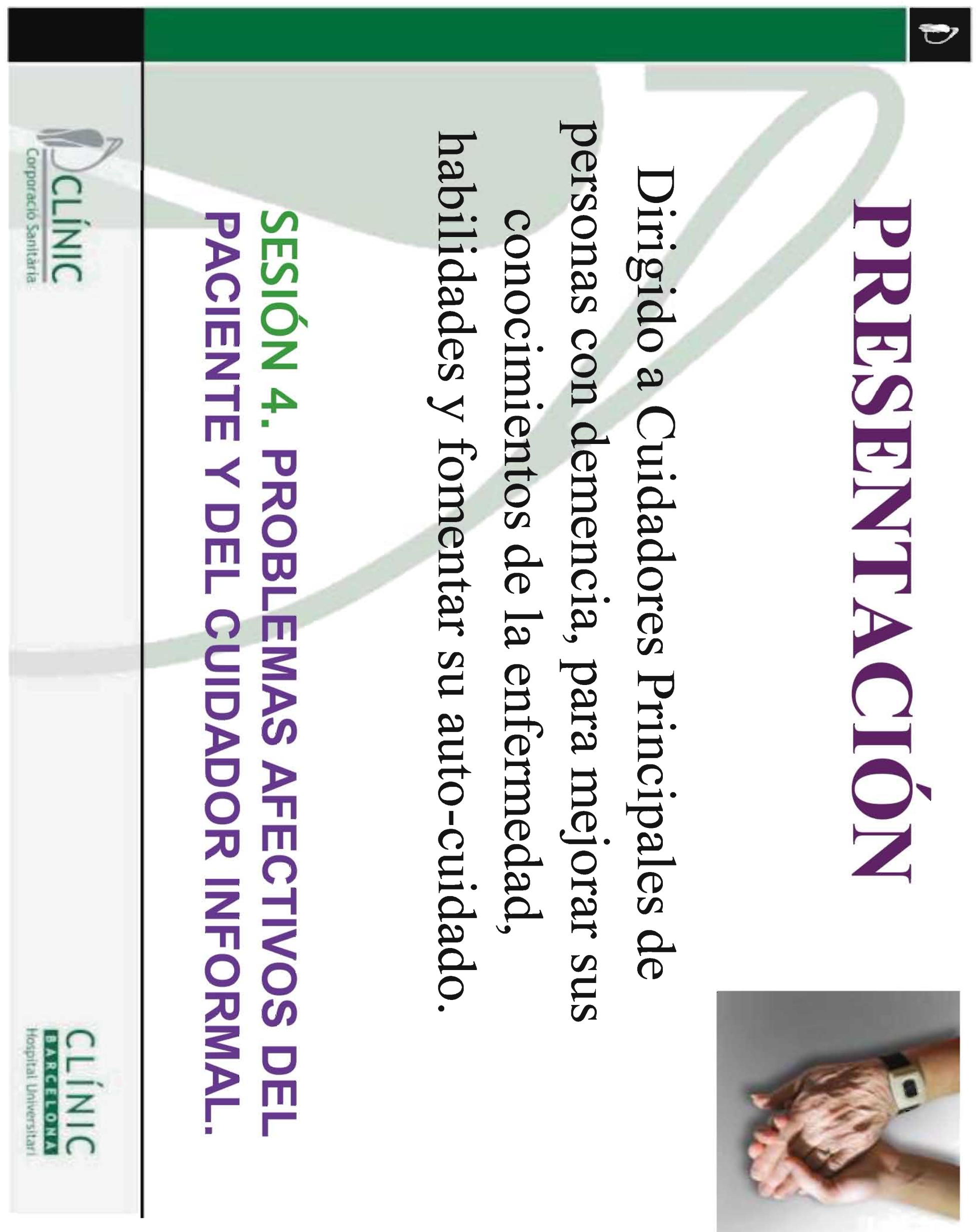




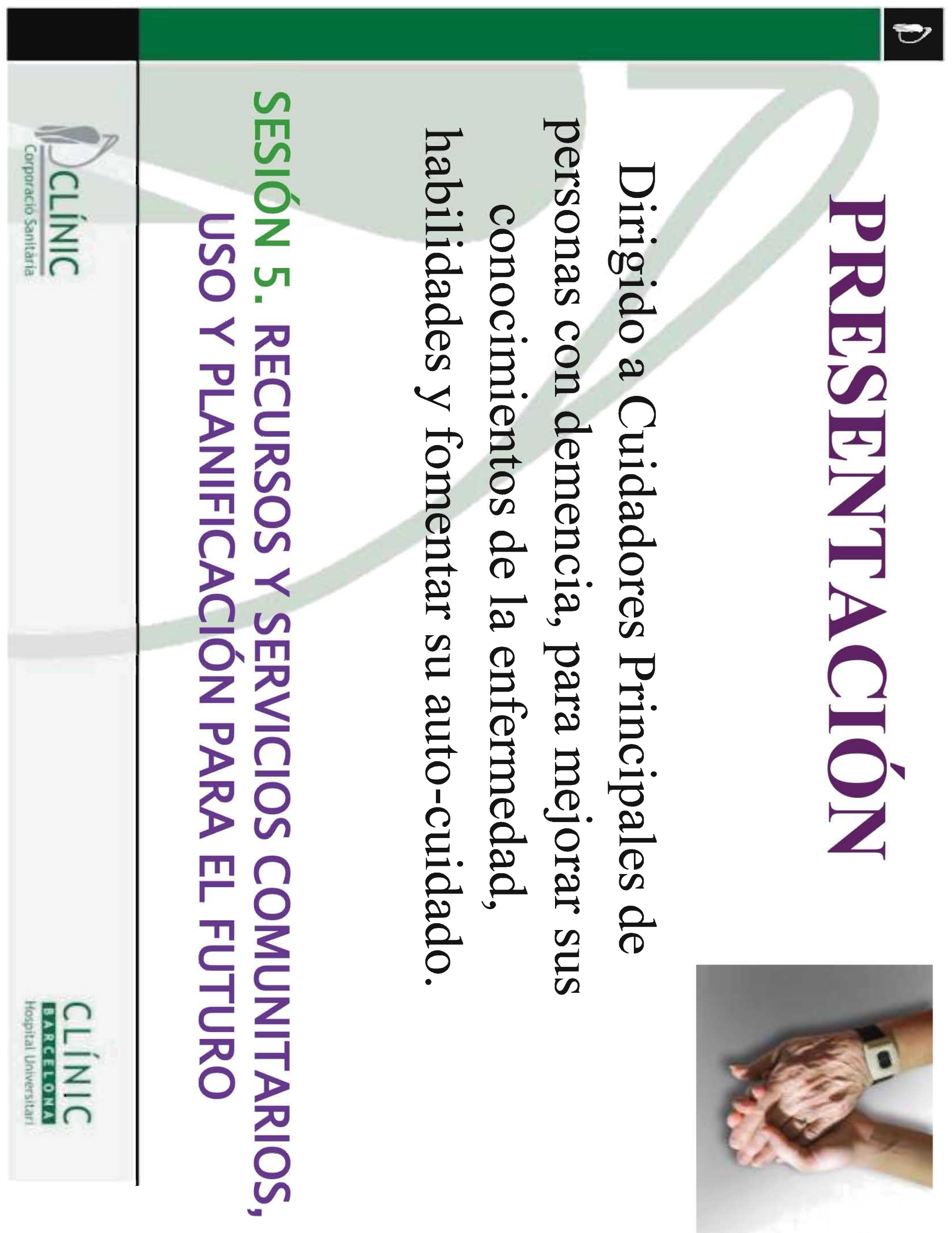


ANEXO 12:

Autorización de coautores 


\section{UNIVERITAT \\ JAUME I}

Escola de Doctorat · ED

Adelaida Zabalegui como coautora doy mi autorización a Cindy E. Frías Torres, para la presentación de las siguientes publicaciones como parte de su tesis doctoral.

Relación de publicaciones:

- Effectiveness of a psychoeducational intervention for caregivers of People With Dementia with regard to burden, anxiety and depression: A systematic review. J Adv Nurs. 2020;76(3):787-802. https://doi.org/10.111/jan.14286.

- INFOSA-DEM: programa dirigido a figuras cuidadoras de personas con demencia. Metas Enferm. 2020; 23(4):16-24. https://doi.org/10.35667/ MetasEnf.2019.23.1003081581.

- Psychoeducational intervention on burden and emotional well-being addressed to informal caregivers of people with dementia. Psychogeriatrics. 2020. https://doi:10.1111/psyg.12616.

- Caregivers' role in Dementia. The impact on their quality of life. Life 2020, 10(11), 251; https://doi.org/10.3390/life 10110251.

Asimismo, renuncio a poder utilizar estas publicaciones como parte de otra tesis doctoral.

Y para que conste firmo el presente documento,

Barcelona, 20 de octubre de 2020

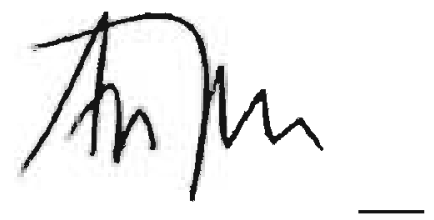

Todo ello, atendiendo al artículo 23 de la Normativa de los Estudios de Doctorado, regulados por el RD 99/2011, en la Universitat Jaume I (Aprobada por el Consejo de Gobierno núm. 19 de 26 de Enero de 2012, modificada por el Consejo de Gobierno núm. 29 de 27 de Noviembre de 2012 y con posterior modificación por el Consejo de Gobierno núm. 37 de 25 de Julio de 2013): "(...)

"Aquellas tesis doctorales que opten por la incorporación de articulos (compendio de publicaciones) deben de ajustarse, en la medida de lo posible, a la siguiente estructura: -Introducción/objetivos - Un capitulo por articulo incorporado - Discusión general de los resultados - Conclusiones. -Aceptación de los coautores de que el doctorando presente el trabajo como tesis y renuncia expresa de estos a presentarlo como parte de otra tesis doctoral." 


\section{UNIVERSITAT \\ JAUME I}

\section{Escola de Doctorat · ED}

Ana Rodriguez como coautora doy mi autorización a Cindy E. Frías Torres, para la presentación de las siguientes publicaciones como parte de su tesis doctoral.

Relación de publicaciones:

- INFOSA-DEM: programa dirigido a figuras cuidadoras de personas con demencia. Metas Enferm. 2020; 23(4):16-24. https://doi.org/10.35667/ MetasEnf.2019.23.1003081581.

Asimismo, renuncio a poder utilizar estas publicaciones como parte de otra tesis doctoral.

Y para que conste firmo el presente documento,

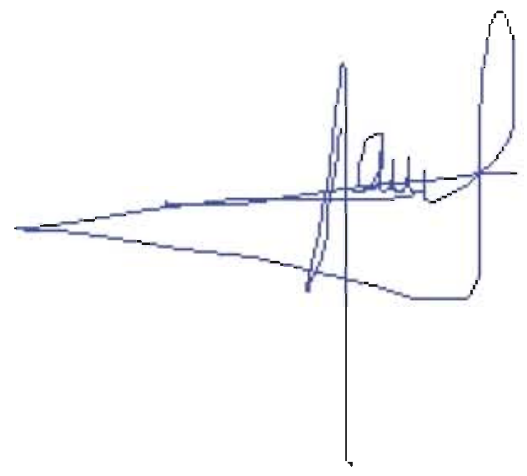

Barcelona, 20 de octubre de 2020

Todo ello, atendiendo al artículo 23 de la Normativa de los Estudios de Doctorado, regulados por el RD 99/2011, en la Universitat Jaume I (Aprobada por el Consejo de Gobierno núm. 19 de 26 de Enero de 2012, modificada por el Consejo de Gobierno núm. 29 de 27 de Noviembre de 2012 y con posterior modificación por el Consejo de Gobierno núm. 37 de 25 de Julio de 2013):

$$
\text { "(...) }
$$

"Aquellas tesis doctorales que opten por la incorporación de articulos (compendio de publicaciones) deben de ajustarse, en la medida de lo posible, a la siguiente estructura: -Introducción/objetivos - Un capítulo por articulo incorporado - Discusión general de los resultados - Conclusiones. -Aceptación de los coautores de que el doctorando presente el trabajo como tesis y renuncia expresa de estos a presentarlo como parte de otra tesis doctoral." 


\section{U. I UNIVERSITAT}

Escola de Doctorat - ED

Ester Cabrera como coautora doy mi autorización a Cindy E. Frías Torres, para la presentación de las siguientes publicaciones como parte de su tesis doctoral.

Relación de publicaciones:

- Caregivers' role in Dementia. The impact on their quality of life. Life 2020, 10(11), 251; https://doi.org/10.3390/life10110251.

Asimismo, renuncio a poder utilizar estas publicaciones como parte de otra tesis doctoral.

Y para que conste firmo el presente documento,

Barcelona, 13 de diciembre de 2020

\section{Dra. Esther Cabrera Torres \\ Escola Superior de Ciències de la Salut \\ TecnoCampus \\ Directora de la Càtedra Envelliment i Qualitat de vida}

Todo ello, atendiendo al artículo 23 de la Normativa de los Estudios de Doctorado, regulados por el RD 99/2011, en la Universitat Jaume I (Aprobada por el Consejo de Gobierno núm. 19 de 26 de Enero de 2012, modificada por el Consejo de Gobierno núm. 29 de 27 de Noviembre de 2012 y con posterior modificación por el Consejo de Gobierno núm. 37 de 25 de Julio de 2013):

"(...)

"Aquellas tesis doctorales que opten por la incorporación de articulos (compendio de publicaciones) deben de ajustarse, en la medida de lo posible, a la siguiente estructura: -Introducción/objetivos - Un capítulo por articulo incorporado - Discusión general de los resultados - Conclusiones. -Aceptación de los coautores de que el doctorando presente el trabajo como tesis y renuncia expresa de estos a presentarlo como parte de otra tesis doctoral." 


\section{UNIVERSITAT JAUME I}

\section{Escola de Doctorat · ED}

Ester Risco como coautora doy mi autorización a Cindy E. Frías Torres, para la presentación de las siguientes publicaciones como parte de su tesis doctoral.

Relación de publicaciones:

- Effectiveness of a psychoeducational intervention for caregivers of People With Dementia with regard to burden, anxiety and depression: A systematic review. $J$ Adv Nurs. 2020;76(3):787-802. https://doi.org/10.111/jan.14286.

- INFOSA-DEM: programa dirigido a figuras cuidadoras de personas con demencia. Metas Enferm.2020;23(4):16-24. https://doi.org/10.35667/; MetasEnf.2019.23.1003081581.

- Psychoeducational intervention on burden and emotional well-being addressed to informal caregivers of people with dementia. Psychogeriatrics. 2020. https:ll. doi:10.11111psyg. 12616 .

Asimismo, renuncio a poder utilizar estas publicaciones como parte de otra tesis doctoral.

Y para que conste firmo el presente documento,

Barcelona, 20 de octubre de 2020

(FIRMA)

Todo ello, atendiendo al artículo 23 de la Normativa de los Estudios de Doctorado, regulados por el RD 99/2011, en , la Universitat Jaume I (Aprobada por el Consejo de Gobierno núm. 19 de 26 de Enero de 2012, modificada por el Consejo de Gobierno núm. 29 de 27 de Noviembre de 2012 y con posterior modificación por el Consejo de Gobierno núm. 37 de 25 de Julio de 2013):

$$
\text { "(...) }
$$

"Aquellas tesis doctorales que opten por la incorporación de articulos (compendio de publicaciones) deben de $l$ ajustarse, en la medida de lo posible, a la siguiente estructura: -Introducción/objetivos - Un capítulo por artículo" incorporado - Discusión general de los resultados - Conclusiones. -Aceptación de los coautores de que el doctorando presente el trabajo como tesis y renuncia expresa de estos a presentarlo como parte de otra tesis doctoral." 


\section{I UNIVERSITAT JAUME I}

\section{Escola de Doctorat - ED}

Estela Solbes como coautora doy mi autorización a Cindy E. Frías Torres, para la presentación de las siguientes publicaciones como parte de su tesis doctoral.

Relación de publicaciones:

- INFOSA-DEM: programa dirigido a figuras cuidadoras de personas con demencia. Metas Enferm. 2020; 23(4):16-24. https://doi.org/10.35667/ MetasEnf.2019.23.1003081581.

Asimismo, renuncio a poder utilizar estas publicaciones como parte de otra tesis doctoral.

Y para que conste firmo el presente documento,

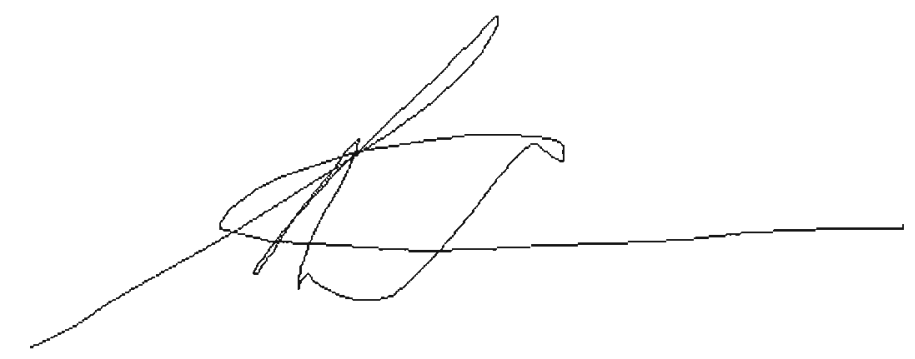

Barcelona, 21 de Octubre de 2020

Todo ello, atendiendo al artículo 23 de la Normativa de los Estudios de Doctorado, regulados por el RD 99/2011, en la Universitat Jaume I (Aprobada por el Consejo de Gobierno núm. 19 de 26 de Enero de 2012, modificada por el Consejo de Gobierno núm. 29 de 27 de Noviembre de 2012 y con posterior modificación por el Consejo de Gobierno núm. 37 de 25 de Julio de 2013):

"(...)

"Aquellas tesis doctorales que opten por la incorporación de articulos (compendio de publicaciones) deben de ajustarse, en la medida de lo posible, a la siguiente estructura: -Introducción/objetivos - Un capitulo por articulo incorporado - Discusión general de los resultados - Conclusiones. Aceptación de los coautores de que el doctorando presente el trabajo como tesis y renuncia expresa de estos a presentarlo como parte de otra tesis doctoral." 


\section{U. I UNIVERSITAT}

\section{Escola de Doctorat · ED}

Elisabeth Calvo como coautora doy mi autorización a Cindy E. Frías Torres, para la presentación de las siguientes publicaciones como parte de su tesis doctoral.

Relación de publicaciones:

- INFOSA-DEM: programa dirigido a figuras cuidadoras de personas con demencia. Metas Enferm. 2020; 23(4):16-24. https://doi.org/10.35667/ MetasEnf.2019.23.1003081581.

Asimismo, renuncio a poder utilizar estas publicaciones como parte de otra tesis doctoral.

Y para que conste firmo el presente documento,
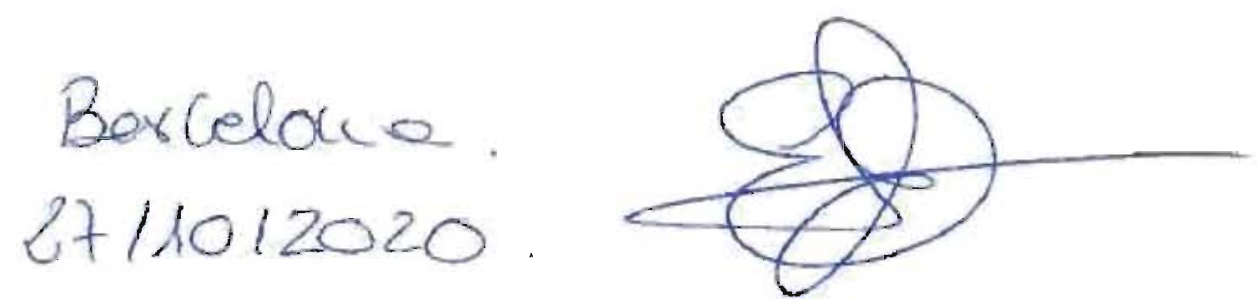

Todo ello, atendiendo al artículo 23 de la Normativa de los Estudios de Doctorado, regulados por el RD 99/2011, en la Universitat Jaume I (Aprobada por el Consejo de Gobierno núm. 19 de 26 de Enero de 2012, modificada por el Consejo de Gobierno núm. 29 de 27 de Noviembre de 2012 y con posterior modificación por el Consejo de Gobierno núm. 37 de 25 de Julio de 2013):

$$
\text { "(...) }
$$

"Aquellas tesis doctorales que opten por la incorporación de articulos (compendio de publicaciones) deben de ajustarse, en la medida de lo posible, a la siguiente estructura: -Introducción/objetivos - Un capítulo por articulo incorporado - Discusión general de los resultados - Conclusiones. -Aceptación de los coaulores de que el doctorando presente el trabajo como tesis y renuncia expresa de estos a presentarlo como parte de otra tesis doctoral." 


\section{UNIVERSITAT JAUME I}

\section{Escola de Doctorat · ED}

Irene Torrero como coautora doy mi autorización a Cindy E. Frías Torres, para la presentación de las siguientes publicaciones como parte de su tesis doctoral.

Relación de publicaciones:

- INFOSA-DEM: programa dirigido a figuras cuidadoras de personas con demencia. Metas Enferm. 2020; 23(4):16-24. https://doi.org/10.35667/ MetasEnf.2019.23.1003081581.

Asimismo, renuncio a poder utilizar estas publicaciones como parte de otra tesis doctoral.

Y para que conste firmo el presente documento,

Barcelona, 20 de octubre de 2020

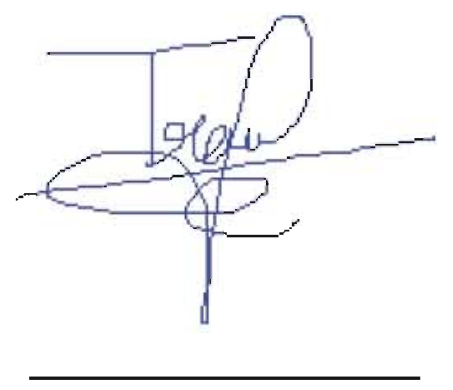

Todo ello, atendiendo al artículo 23 de la Normativa de los Estudios de Doctorado, regulados por el RD 99/2011, en la Universitat Jaume I (Aprobada por el Consejo de Gobierno núm. 19 de 26 de Enero de 2012, modificada por el Consejo de Gobierno núm. 29 de 27 de Noviembre de 2012 y con posterior modificación por el Consejo de Gobierno núm. 37 de 25 de Julio de 2013):

$$
\text { “(...) }
$$

"Aquellas tesis doctorales que opten por la incorporación de articulos (compendio de publicaciones) deben de ajustarse, en la medida de lo posible, a la siguiente estructura: -Introducción/objetivos - Un capitulo por articulo incorporado - Discusión general de los resultados - Conclusiones. -Aceptación de los coautores de que el doctorando presente el trabajo como tesis y renuncia expresa de estos a presentarlo como parte de otra tesis doctoral." 


\section{UNIVERSITAT \\ JAUME I}

\section{Escola de Doctorat · ED}

Marta García-Pascual como coautora doy mi autorización a Cindy E. Frías Torres, para la presentación de las siguientes publicaciones como parte de su tesis doctoral.

Relación de publicaciones:

- Effectiveness of a psychoeducational intervention for caregivers of People With Dementia with regard to burden, anxiety and depression: A systematic review. $J$ Adv Nurs. 2020;76(3):787-802. https://doi.org/10.111/jan.14286.

- INFOSA-DEM: programa dirigido a figuras cuidadoras de personas con demencia. Metas Enferm. 2020; 23(4):16-24. https://doi.org/10.35667/ MetasEnf.2019.23.1003081581.

Asimismo, renuncio a poder utilizar estas publicaciones como parte de otra tesis doctoral.

Y para que conste firmo el presente documento,

Barcelona, 20 de octubre de 2020

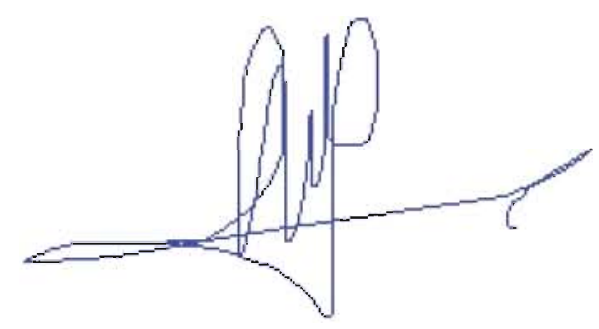

Todo ello, atendiendo al artículo 23 de la Normativa de los Estudios de Doctorado, regulados por el RD 99/2011, en la Universitat Jaume I (Aprobada por el Consejo de Gobierno núm. 19 de 26 de Enero de 2012, modificada por el Consejo de Gobierno núm. 29 de 27 de Noviembre de 2012 y con posterior modificación por el Consejo de Gobierno núm. 37 de 25 de Julio de 2013):

$$
\text { “(...) }
$$

"Aquellas tesis doctorales que opten por la incorporación de articulos (compendio de publicaciones) deben de ajustarse, en la medida de lo posible, a la siguiente estructura: -Introducción/objetivos - Un capítulo por artículo incorporado - Discusión general de los resultados - Conclusiones. -Aceptación de los coautores de que el doctorando presente el trabajo como tesis y renuncia expresa de estos a presentarlo como parte de otra tesis doctoral." 


\section{I UNIVERSITAT JAUME I}

\section{Escola de Doctorat · ED}

Mercedes Montoro como coautora doy mi autorización a Cindy E. Frías Torres, para la presentación de las siguientes publicaciones como parte de su tesis doctoral.

Relación de publicaciones:

- Effectiveness of a psychoeducational intervention for caregivers of People With Dementia with regard to burden, anxiety and depression: A systematic review. $J$ Adv Nurs. 2020;76(3):787-802. https://doi.org/10.111/jan.14286.

Asimismo, renuncio a poder utilizar estas publicaciones como parte de otra tesis doctoral.

Y para que conste firmo el presente documento,

Barcelona, 20 de octubre de 2020

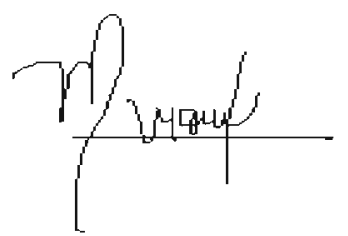

Todo ello, atendiendo al artículo 23 de la Normativa de los Estudios de Doctorado, regulados por el RD 99/2011, en la Universitat Jaume I (Aprobada por el Consejo de Gobierno núm. 19 de 26 de Enero de 2012, modificada por el Consejo de Gobierno núm. 29 de 27 de Noviembre de 2012 y con posterior modificación por el Consejo de Gobierno núm. 37 de 25 de Julio de 2013):

$$
\text { "(...) }
$$

"Aquellas tesis doctorales que opten por la incorporación de artículos (compendio de publicaciones) deben de ajustarse, en la medida de lo posible, a la siguiente estructura: -Introducción/objetivos - Un capítulo por articulo incorporado - Discusión general de los resultados - Conclusiones. -Aceptación de los coautores de que el doctorando presente el trabajo como tesis y renuncia expresa de estos a presentarlo como parte de otra tesis doctoral." 


\section{I UNIVERSITAT JAUME I}

\section{Escola de Doctorat - ED}

Nuria Ribas como coautora doy mi autorización a Cindy E. Frías Torres, para la presentación de las siguientes publicaciones como parte de su tesis doctoral.

Relación de publicaciones:

- Effectiveness of a psychoeducational intervention for caregivers of People With Dementia with regard to burden, anxiety and depression: A systematic review. J Adv Nurs. 2020;76(3):787-802. https://doi.org/10.111/jan.14286.

Asimismo, renuncio a poder utilizar estas publicaciones como parte de otra tesis doctoral.

Y para que conste firmo el presente documento,

Barcelona, 20 de octubre de 2020

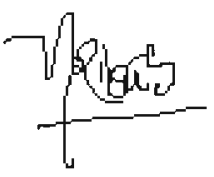

Todo ello, atendiendo al artículo 23 de la Normativa de los Estudios de Doctorado, regulados por el RD 99/2011, en la Universitat Jaume I (Aprobada por el Consejo de Gobierno núm. 19 de 26 de Enero de 2012, modificada por el Consejo de Gobierno núm. 29 de 27 de Noviembre de 2012 y con posterior modificación por el Consejo de Gobierno núm. 37 de 25 de Julio de 2013):

$$
\text { "(..) }
$$

"Aquellas tesis doctorales que opten por la incorporación de artículos (compendio de publicaciones) deben de ajustarse, en la medida de lo posible, a la siguiente estructura: -Introducción/objetivos - Un capitulo por articulo incorporado - Discusión general de los resultados - Conclusiones. -Aceptación de los coautores de que el doctorando presente el trabajo como tesis y renuncia expresa de estos a presentarlo como parte de otra tesis doctoral." 


\section{UNIVERSITAT JAUME I}

\section{Escola de Doctorat · ED}

Teresa Jordi como coautora doy mi autorización a Cindy E. Frías Torres, para la presentación de las siguientes publicaciones como parte de su tesis doctoral.

Relación de publicaciones:

- INFOSA-DEM: programa dirigido a figuras cuidadoras de personas con demencia. Metas Enferm. 2020; 23(4):16-24. https://doi.org/10.35667/ MetasEnf.2019.23.1003081581.

Asimismo, renuncio a poder utilizar estas publicaciones como parte de otra tesis doctoral.

Y para que conste firmo el presente documento,

Barcelona, 20 de octubre de 2020

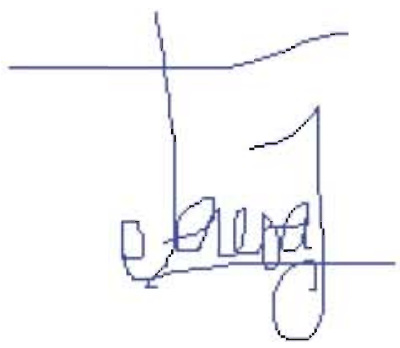

Todo ello, atendiendo al artículo 23 de la Normativa de los Estudios de Doctorado, regulados por el RD 99/2011, en la Universitat Jaume I (Aprobada por el Consejo de Gobierno núm. 19 de 26 de Enero de 2012, modificada por el Consejo de Gobierno núm. 29 de 27 de Noviembre de 2012 y con posterior modificación por el Consejo de Gobierno núm. 37 de 25 de Julio de 2013):

$$
\text { "(...) }
$$

"Aquellas tesis doctorales que opten por la incorporación de articulos (compendio de publicaciones) deben de ajustarse, en la medida de lo posible, a la siguiente estructura: -Introducción/objetivos - Un capitulo por articulo incorporado - Discusión general de los resultados - Conclusiones. -Aceptación de los coautores de que el doctorando presente el trabajo como tesis y renuncia expresa de estos a presentarlo como parte de otra tesis doctoral." 
ANEXO 13:

Premios de investigación al

Estudio INFOSA-DEM 


\section{$M^{a}$ del Pilar Serrano Gallardo Directora de la revista Metas de Enfermería}

\section{CERTIFICA}

Que Dña. Cindy E. Frías Torres, con DNI Y1366428N, ha participado en el XXI Certamen de Premios de Investigación de la Revista Metas de Enfermería con el trabajo titulado "Evaluación de una intervención innovadora, formativa y de apoyo social "INFOSA-DEM" dirigida a cuidadores informales de personas con demencia en relación a la sobrecarga y el bienestar emocional", designado por el Jurado como ganador del Primer Accésit.

Lo que firmo en Madrid, a 20 de diciembre del año 2019 para que conste a efectos de la interesada.

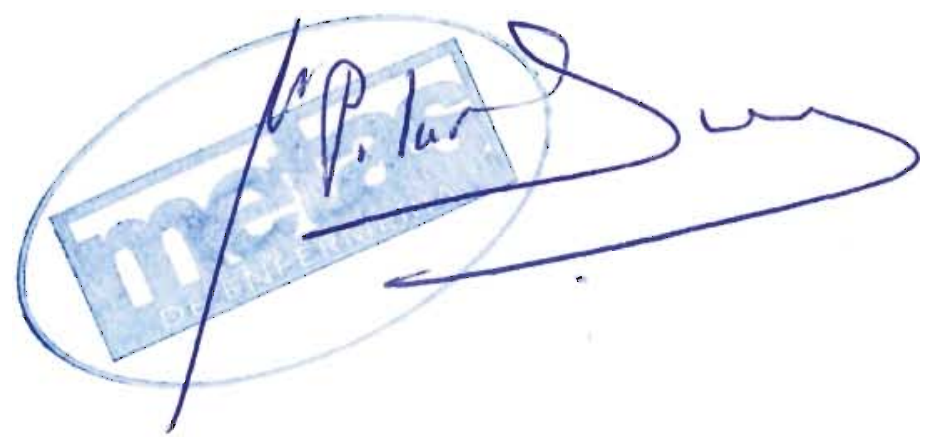

ISSN: 1138-7262

Depósito Legal: M-43015-1997 
Evaluación de una intervención formativa y de apoyo social "INFOSA-DEM» dirigida a cuidadores informales de personas con demencia en relación con la sobrecarga y el bienestar emocional
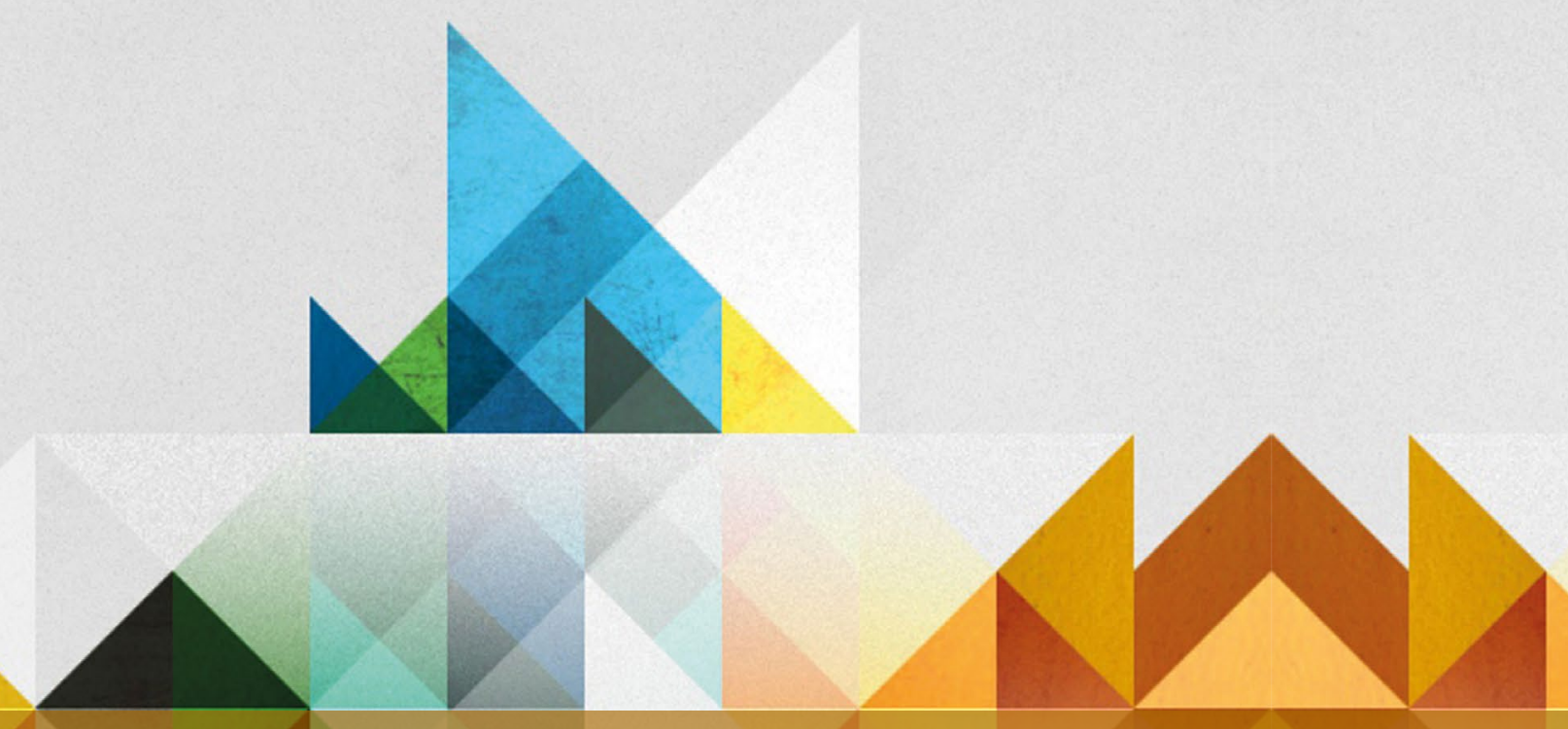

TESIS DOCTORAL

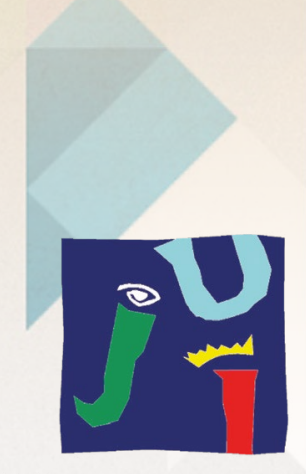

UNIVERSITAT

JAUME•I
Autora:

Doctoranda Cindy E. Frías Torres Directora de la tesis: Adelaida Zabalegui Yárnoz 